\title{
Fish Populations of the Wild \& Scenic Missouri River, Montana
}

BY: RODNEY K. BERG

Fisheries BIOLOGIST

Ecological Services Division

Montana Department of Fish, Wildlife \& Parks
STATE DOCUMENTS COLLECTION

\section{FEB 131990}

MONTANA STATE LIBRARY

1515 E. Gth AVE.

HELENA, MONTANA 59620

Federal Aid to Fish \& WildLife Restoration Project FW-3-R JOB $1-A$ JUNE 1981

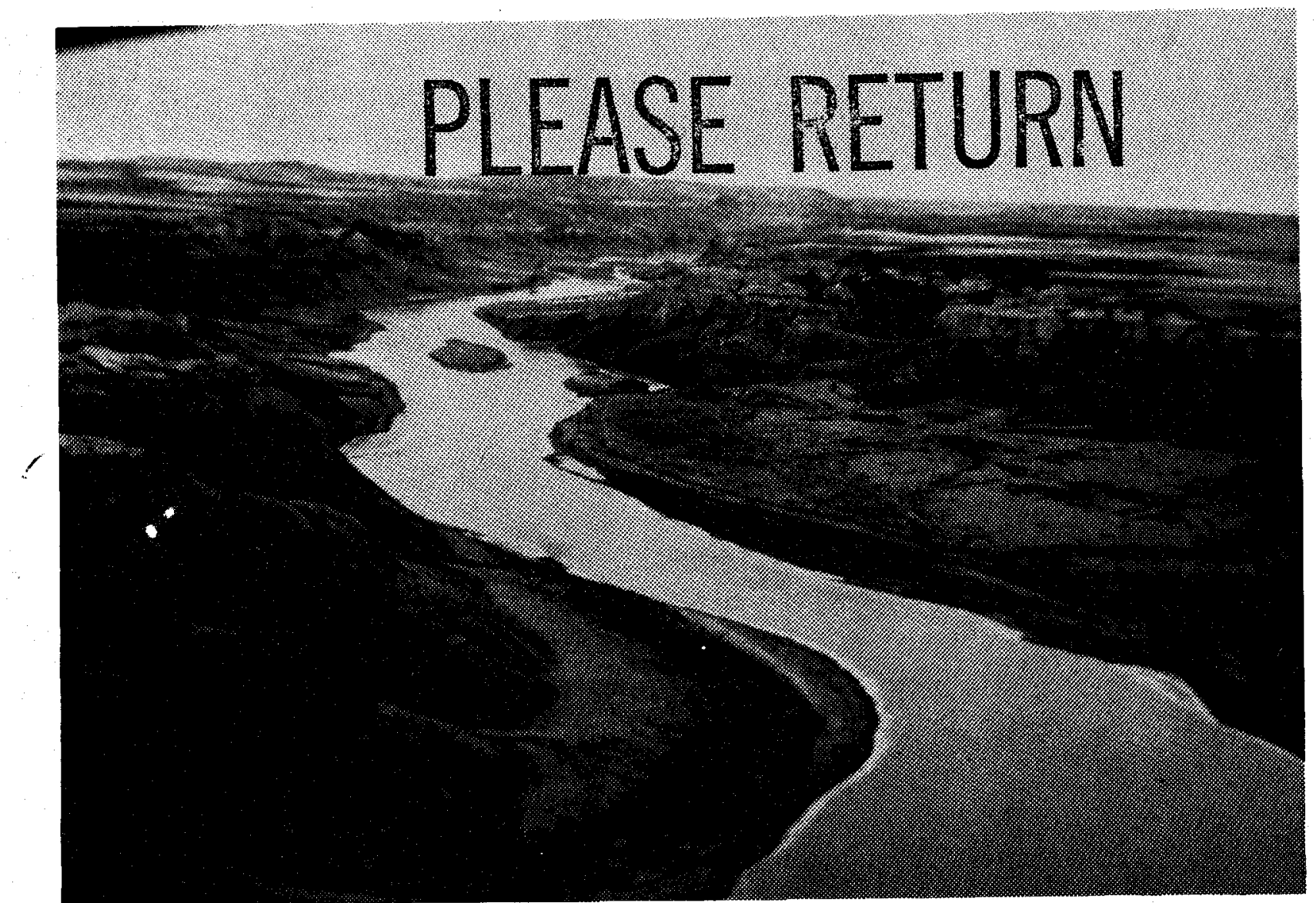




$$
\begin{aligned}
& \text { WAY }-7900 \\
& \text { abs : : - } \\
& \text { JIIL } 81007 \\
& \text { DEC - }-108
\end{aligned}
$$$$
\begin{aligned}
& \text { MONTANA STATE LIBRARY } \\
& \text { S 333.952 F2tp c.1 Berg }
\end{aligned}
$$$$
\text { S 333.952 F2fp c. } 1 \text { Berg }
$$$$
\text { Fish populations of the wild \& scenic Mi }
$$

DEc - 0 ingo

FEV 111190

AfR 1909

FEB $21200 \%$

JAN! $: 2004$

AP? $80 \% 4$

JUN 142004

10262007 


\section{PREFACE}

The Missouri River from Fort Benton to Fred Robinson Bridge (US Highway $191)$ was designated a component of the National Wild and Scenic River System in October 1976. This 240-kilometer (149-mile) segment is the only major portion of the Missouri River to be protected and preserved in its natura 1, free-flowing state.

Today, floaters enjoy scenic vistas which remain much as first described by Lewis and Clark in 1805-1806. The Missouri River was the major waterway route to the Rocky Mountain west from the time of Lewis and Clark until the coming of the railroads in the late $1800^{\prime} \mathrm{s}$.

The Blackfeet, Assiniboine, and Cree held dominion over the river area for many years. At the riverside trading posts of Fort Lewis, Benton, McKenzie, and Piegan, fur trade flourished for a brief period. Steamboats plied the shallow waters as far as Fort Benton, bringing gold seekers and materials for an expanding economy. The exceptionally scenic White Rocks area along the river contains landmarks that recall those days of long ago. LaBarge Rock, Hole-in-the-Wa11, Dark Butte, Citadel Rock - the names ring with the excitement and romance of this period of westward expansion.

Later, homesteaders found the Missouri River valley too harsh an environment to pursue their livelihood. The frame and log dwellings they left behind are present-day reminders of dreams that were not to be.

The river's free-flowing nature, protected by its designation to the National Wild and Scenic System, has preserved not only scenery, solitude, and recreational opportunities, but it has also preserved a precious and rare ecological community. A study of a portion of this community is described in the pages of this report. 
TABLE OF CONTENTS

Page

PREFACE ......................... . . . . . . .

LIST OF TABLES .................... . . . . . .

LIST OF FIGURES ..................... . . . . . . . . . . . . . .

ABSTRACT .............................. 1

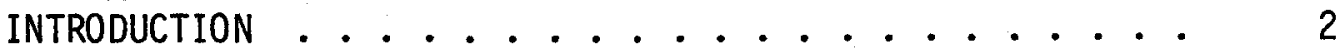

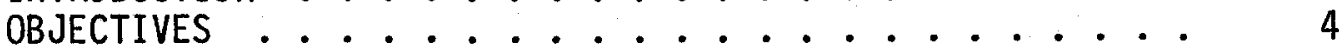

TECHNIQUES ................... 5

Water Temperature ........... . . 5

Water Quality ............... 5

Macroinvertebrates............. 5

Larval Fish ................ . 5

Adult Fish ................... . . . . 7

Boom-Suspended Electrofishing Apparatus . . . 7

Mobile Electrofishing Apparatus . . . . . . 9

Gill Nets............... . . 9

Baited Hoop Nets ............ 10

Frame Traps .............. 12

Seines ................. . . . 13

Fish Sample Processing and Tagging .... . 13

Age and Growth ............. 14

Creel Census and Creel Survey ......... 15

Paddlefish Creel Census .......... 15

Missouri River Creel Survey ......... 16

FINDINGS - AQUATIC HABITAT PARAMETERS . . . . . . . . 16

Drainage Area and Stream Discharge ........ 16

Stream Gradient and Velocity ......... 17

Water Temperature ............. 17

Water Quality ............... 21

FINDINGS - MACROINVERTEBRATES . . . . . . . . . 27

Missouri River............... . . . 27

Ephemeroptera (Mayflies) . . . . . . . 27

Plecoptera (Stonefijes) .......... 29

Trichoptera (Caddisflies) . . . . . . . 29

Diptera (Trueflies)........... . 29

Other Macroinvertebrate Orders . . . . . 36

Discussion .............. 36

Marias and Judith Rivers ........... . 40

FINDINGS - LARVAL FISH ................ . . . . 40

Spatial Distribution........... . . 40

Missouri River ............. . . 40

Marias River ............. 45

Temporal Abundance............. . . 45

FINDINGS - ADULT FISH POPULATIONS . . . . . . . . . 46

Species Distribution, Relative Abundance and Size
Composition . . . . . . . . . . . . . . 46

Spawning Migrations, Spawning Periods and Fish

Movements ................ 56

Paddlefish Spawning Migrations . . . . . . . 56 
Page

Spawning Periods of Fish in the Missouri River River Mainstem ............... 75 Seasonal Migrations of Fish in the Missouri River Mainstem . . . . . ...... 75 Movements of Fish as Indicated by Tag Returns : 78 Sauger. ............ . . 78 Channel Catfish............. . . . 91 Shovelnose Sturgeon ............ 93 Blue Suckers. . . . . . . . . . . . . 94 Smallmouth and Bigmouth Buffalo ..... 95 Other Species.............. . 95 Discussion ................ . 95

Marias River Spawning Migrations . . . . . . 96 Sauger and Shovelnose Sturgeon. . . . . . 96 Size at Maturity ............ . 99 Size-Frequency Distributions . . . . . . . . 100 Channel Catfish and Other Species..... 103

Age Teton and Judith River Spawning Migrations . . 105

Age and Growth ................ 106

Paddlefish .................... . . . 106

Shovelnose Sturgeon ............... . . . 108

Channel Catfish ............... 112

Sauger .................. . . . 116

Blue Sucker ............... . . . 119

Smallmouth Buffalo.............. 124

Bigmouth Buffalo ................. . . 125

Freshwater Drum . . . . . . . . . . . . 129

Other Species ................. . . . . 131

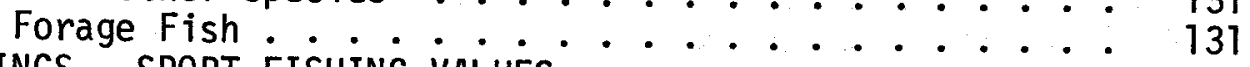

FINDINGS - SPORT FISHING VALUES
Paddlefish Creel Census .............. 134

Background ..................... . . . . . . 134

Cree] Period and Coverage . . . . . . . . 137

Fishing Pressure and Harvest . . . . . . . . . 137

Angler Residency ................. . . . . 139

Size and Sex Composition of Harvested Paddlefish 139

Age Structure of Harvested Paddlefish ... . 144

Paddlefish Tagging.............. 144

Discussion ................... . . . 144

Missouri River Creel Survey . . . . . . . . . . . . . . . . . 145

Angler Harvest as Indicated by Tag Returns . . . . 145

Fishing Seasons and Cree] Limits ........... 148

POTENTIAL AND EXISTING ENVIRONMENTAL PROBLEMS

Water Quality Degradation.............. . 149

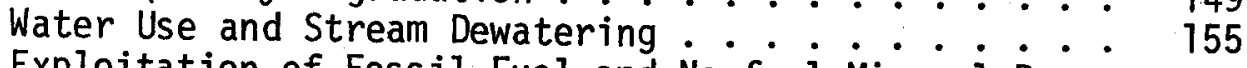

Exploitation of Fossit Fuel and Nonfuel Minera $\dot{\mathrm{Re}} \dot{\mathrm{B}}$

sources.................. 155

Potential Hydropower Dams . . . . . . . . . . . . . . . . . 156

MANAGEMENT RECOMMENDATIONS .....................

LITERATURE CITED . . . . . . . . . . . . . . . . . . . . . . 163

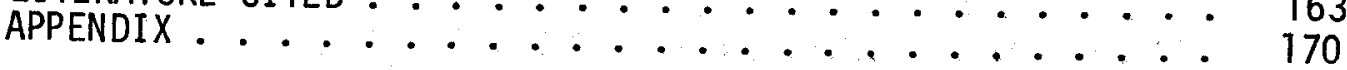




\section{LIST OF TABLES}

Table

Page

1 Stream gradients of the middle Missouri River from Morony Dam to Fort Peck Reservoir. Confluence of the Missouri River with the normal flood pool of Fort Peck Reservoir is kilometer 0.0........................

2. Water quality measurements at six stations on the mainstem of the middle Missouri River, 1978-79...........

3 Percent composition (by order) and average number of subordinal taxa (in parentheses) of the aquatic macroinvertebrate community in the middle Missouri River, late October through mid-September, 1976-77...........

4 Longitudinal distribution, relative abundance and frequency of occurrence (in parentheses) of aquatic macroinvertebrates in the middle Missouri River, late October through mid-September 1976-77

5 A simplified schematic assemblage of the most common aquatic macroinvertebrates sampled at five sites on the middle Missouri River, late October through mid-September 1976-77.

6 Taxonomic composition of the aquatic macroinvertebrate community in the lower Marias and Judith rivers, 1977-78. Asterisk (*) indicates the presence of a taxon at the sample site.....................

7 Taxonomic composition and relative abundance (mean densities) of fish larvae sampled in the middle Missouri and lower Marias rivers, late May through mid-August 1978 . . . . . .

8 Fish species recorded for the middle Missouri River drainage in Montana between Morony and Fort Peck Dams (family, scientific, and common names

9. Longitudinal distribution of fish species sampled in the middle Missouri River during the period from 1976 through 1979

10 Catch rate summary for electrofishing surveys conducted on the middle Missouri River from 1976 through 1979, expressed as number of fish sampled per electrofishing hour. . . . .

11 Catch rate summary for experimental gi11 net surveys conducted on the middle Missouri River in 1976 and 1977, expressed as number of fish captured per overnight net set . 
Table

12 Catch rate summary for baited hoop net surveys conducted on the middle Missouri River from 1977 through 1979, expressed as number of fish captured per net-day ..........

13 Number of paddlefish counted in electrofishing survey runs on the middle Missouri River in 1977............

14 Number of paddlefish counted in electrofishing survey runs on the middle Missouri River in 1978...........

15 Number of paddlefish counted in electrofishing survey runs on the middle Missouri River in 1979...........

16 Date of capture, sex and size paddlefish tagged at spawning sites on the middle Missouri River in 1978 and 1979 ...

17 Movement of tagged fish in the middle Missouri River study area during the inventory period from October 1, 1975 through

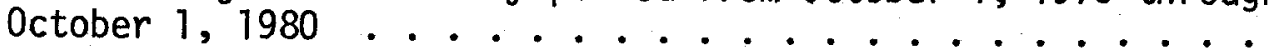

18 Spawning condition of several fish species sampled in the lower Marias River during the spring/summer spawning periods from 1976 through 1979 . . . . . . . . . .

19 Age structure and observed growth of male and female paddlefish sampled in the middle Missouri River in 1977 and 1978. The number of fish sampled is shown in parentheses.

20 Observed growth of paddlefish sampled from the middle Missouri River in 1977 and 1978 compared to observed growth in other waters. Mean lengths are an average for male and female paddlefish combined, unless otherwise noted. The number of fish sampled is shown in parentheses . . . . . .

21 Age-frequency of shovelnose sturgeon sampled from the middle Missouri River in 1978 and 1979 with mean fork length, weight and condition factor $\left(K_{T L}\right)$ of each age class .........

22. Age-frequency of channel catfish sampled from the middle Missouri River in 1978 with mean length, weight and condition factor $\left(K_{\mathrm{TL}}\right)$ of each age class ..........

23 Observed growth of channel catfish sampled from the middle Missouri River in 1978 compared to observed growth in other waters. The number of fish sampled is shown in parentheses

24 Calculated length at the end of each year of 1 ife and average growth of channel catfish sampled from the middle Missouri River in 1978 (Monastyrsky logarithmic method) . 
Table

Page

25 Calculated growth of channel catfish sampled from the middle Missouri River in 1978 compared to calculated growth in other waters . . . . . . . . . . . . .

26 Age-frequency of sauger sampled from the middle Missouri River in 1978 and 1979 with mean length, weight and condition factor $\left(K_{T L}\right)$ of each age class .........

27 Observed growth of sauger sampled from the middle Missouri River in 1978 and 1979 compared to observed growth in other Montana streams. The number of fish sampled is shown in parentheses

28 Mean monthly condition factors $\left(K_{T l}\right)$ of sauger sampled from the middle Missouri River in 4978 and 1979 .....

29 Calculated length at the end of each year of 1 ife and average growth of sauger sampled from the middle Missouri River in 1978 and 1979 (Monastyrsky logarithmic method) .

30 Comparison of grand average calculated lengths of sauger at the end of each year of life using a logarithmic method (Monastyrsky) and three 1 inear methods. Calculations are based on 735 sauger sampled from the middle Missouri River

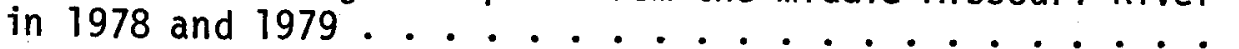

31 Calculated growth of sauger sampled from the middle Missouri River in 1978 and 1979 compared to calculated growth in other northern waters

32 Age-frequency of blue suckers sampled from the middle Missouri River in 1978 and 1979 with mean length, weight and condition factor $\left(K_{T L}\right)$ of each age class ........

33 Length-frequency distribution of blue suckers sampled on the middle Missouri River in 1978 and $1979 . . . . . . .$.

34 Mean monthly condition factors $\left(K_{T L}\right)$ of blue suckers sampled from the middle Missouri River in 1978 and 1979 .

35 Age-frequency of smallmouth buffalo sampled from the middle Missouri River in 1978 and 1979 with mean length, weight and condition factor $\left(K_{T L}\right)$ of each age class . . . 124

36 Mean monthly condition factors $\left(K_{T I}\right)$ of smallmouth buffalo sampled from the middle Missouri Rtver in 1978 and 1979 . . 125

37 Calculated length at the end of each year of 1 ife and average growth of smalimouth buffalo sampled from the middle Missouri River in 1978 and 1979 (Monastyrsky logarithmic method) : . 
38 Calculated growth of smallmouth buffalo sampled from the the middle Missouri River in 1978 and 1979 compared to calculated growth in other waters .............

39 Age-frequency of bigmouth buffalo sampled from the middle Missouri River in 1978 and 1979 with mean length, weight and condition factor $\left(K_{T L}\right)$ of each age class .........

40 Calculated length at the end of each year of 1 ife and average growth of bigmouth buffalo sampled from the middle Missouri River in 1978 and 1979 (Monastyrsky logarithmic method). .

41 Calculated growth of bigmouth buffalo sampled from the middle Missouri River in 1978 and 1979 compared to calculated growth in other waters

42 Age-frequency of freshwater drum sampled from the middle Missouri River in 1979 with mean length, weight and condition factor $\left(K_{T L}\right)$ of each age class .............

43 Calculated length at the end of each year of life and average growth of freshwater drum sampled from the middle Missouri River in 1979 (Monastyrsky logarithmic method) . . . . . .

44 Calculated growth of freshwater drum sampled from the middle Missouri River in 1979 compared to calculate growth in the Salt River, Missouri

45 Ages of several miscellaneous fish species sampled from the middle Missouri River in 1978 and 1979 . . . . . . . .

46 Longitudinal distribution of forage fish species sampled in the middle Missouri River during the period from 1976 through 1980

47 Estimates of fishermen, fishing pressure, total catch and harvest, and success rates during the spring snagging season on the paddlefish fishery above Fort Peck Reservoir, April 15 to June 12, 1977 ...............

48 A summary of fishing pressure, paddlefish harvest and harvest rates during the spring snagging seasons on the paddlefish fishery above Fort Peck Reservoir, 1973-75 and 1977

49 Angler residence for 761 fishermen interviewed during the paddlefish creel census period in 1977 . . . . . . . .

50. Size of paddlefish harvested in the Missouri River above Fort Peck Reservoir during the spring of 1977 
Table

Page

51 A summary of size data from paddlefish harvested in the Missouri River above Fort Peck Reservoir during eight spring snagging seasons, 1965 to 1977 .......... 142

52 A summary of paddlefish tagging and fisherman tag returns in the Missouri River above Fort Peck Reservoir, 1973 to 1977 • 142

53 A summary of creel census survey data collected in three subreaches of the middle Missouri River during the spring

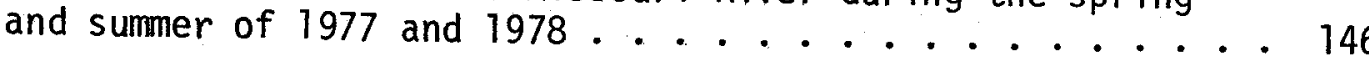

54 Summary of tagged fish returned (i.e., harvested) by anglers in the middle Missouri River from October 1, 1975 through October 1, 1980.

55 A summary of water quality problems in the middle Missouri River drainage (adopted from inventories conducted by the Water Quality Bureau, Montana Department of Health and Environmental Sciences - Kaiser and Botz 1975, Garvin and Botz 1975

56. An evaluation of ten potential hydropower dam sites on the mainstem of the middle Missouri River between Fort Benton and Morony Dam (US Water and Power Resources Service appraisal study, September, 1980).

\section{APPENDIX}

1 River distance chart for the middle Missouri River study area ................... 170

2 Daily maximum and minimum water temperatures (degrees $F$ ) for the Missouri River near Morony Dam during 1977 . . . . . . . 171

3 Daily maximum and minimum water temperatures (degrees F) for the Missouri River at Fort Benton during 1976 . . . . . . 172

4 Daily maximum and minimum water temperatures (degrees F) for the Missouri River at Fort Benton during 1977....... . 173

5 Daily maximum and minimum water temperatures (degrees $F$ ) for the Missouri River at Fort Benton during 1978.......

6 Daily maximum and minimum water temperatures (degrees $F$ ) for the Missouri River at Fort Benton during 1979 ......

7 Daily maximum and minimum water temperatures (degrees F) for the Missouri River near Coal Banks Landing during 1976. .

8 Daily maximum and minimum water temperatures (degrees F) for the Missouri River near Coal Banks Landing during 1977 . . 
Table

Page

9 Daily maximum and minimum water temperatures (degrees $F$ ) for the Missouri River near Coal Banks Landing during 1978...

10 Daily maximum and minimum water temperatures (degrees F) for the Missouri River near Coal Banks Landing during 1979 . . .

11 Daily maximum and minimum water temperatures (degrees F) for the Missouri River near Robinson Bridge during 1976

12 Daily maximum and minimum water temperatures (degrees F) for the Missouri River near Robinson Bridge during 1977

13 Daily maximum and minimum water temperatures (degrees F) for the Missouri River near Robinson Bridge during 1978 . . . .

14 Daily maximum and minimum water temperatures (degrees $F$ ) for the Missouri River near Robinson Bridge during 1979 . ...

15 Daily maximum and minimum water temperatures (degrees F) for the Marias River near the mouth during 1977 . . . . .

16. Daily maximum and minimum water temperatures (degrees F) for the Marias River near the mouth during 1978 ........

17 Daily maximum and minimum water temperatures (degrees $F$ ) for the Marias River near the mouth during 1979

18 Numbers of aquatic macroinvertebrates collected (per sample period) at the Morony Dam site, late October, 1976, through

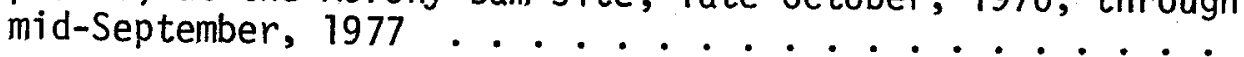

19 Numbers of aquatic macroinvertebrates collected (per sample period) at the Fort Benton site, late October, 1976, through mid-September, 1977 ..................

20 Numbers of aquatic macroinvertebrates collected (per sample period) at the Coal Banks Landing site, late October, 1976, through mid-September, 1977 ............

21 Numbers of aquatic macroinvertebrates collected (per sample period) at the Judith Landing site, late October, 1976, through mid-September, 1977 ............... 193

22 Numbers of aquatic macroinvertebrates collected (per sample period) at the Robinson Bridge site, late October, 1976, through mid-September, 1977

23 Numbers of aquatic macroinvertebrates collected (per sample date) in the lower Marias and Judith rivers, 1977 and 1978 .

24 Numbers of larval fish collected (per sample) in the middle Missouri and lower Marias rivers, late May through midAugust, 1978 
Table

Page

25 Legal description of boundaries of eleven fishery study sections on the mainstem of the middle Missouri River . . . 203

26 Species composition, number, and size of fish sampled by e lectrofishing in the Morony Dam study section, 1976 through

27 Species composition, number, and size of fish sampled by electrofishing in the Carter Ferry study section, 1976 through

28 Species composition, number, and size of fish sampled by electrofishing in the Fort Benton study section, 1976 through

29 Species composition, number, and size of fish sampled by electrofishing in the Loma Ferry study section, 1976 through

30 Species composition, number, and size of fish sampled by electrofishing in the Coal Banks Landing study section, 1976 through 1979

31 Species composition, number, and size of fish sampled by electrofishing in the Hole-in-the-Wall study section 1976 through 1979

32 Species composition, number, and size of fish sampled by electrofishing in the Judith Landing study section, 1976 through 1979

33 Species composition, number, and size of fish sampled by electrofishing in the Stafford Ferry study section, 1976 through 1979

34 Species composition, number and size of fish sampled by electrofishing in the Cow Island study section, 1976 through

35 Species composition, number, and size of fish sampled by electrofishing in the Robinson Bridge study section, 1976 through 1979

36 Species composition, number, and size of fish sampled by electrofishing in the Turkey Joe study section, 1976 through

37 Species composition, number, and size of fish sampled by experimental gill netting in the Carter Ferry study section, 
Table

Page

38 Species composition, number, and size of fish sampled by experimental gill netting in the Fort Benton study section,

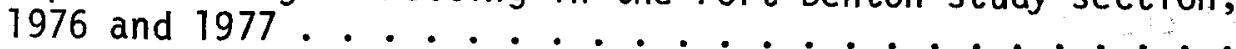

39 Species composition, number, and sizes of fish sampled by experimental gill netting in the Loma Ferry study section,

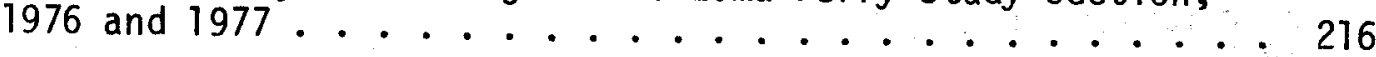

40 Species composition, number, and size of fish sampled by experimental gill netting in the Coal Banks Landing study section, 1976 and 1977

41 Species composition, number, and size of fish sampled by experimental gill netting in the Hole-in-the-Wall study section, 1976 and 1977

42 Species composition, number, and size of fish sampled by experimental gill netting in the Judith Landing study section,

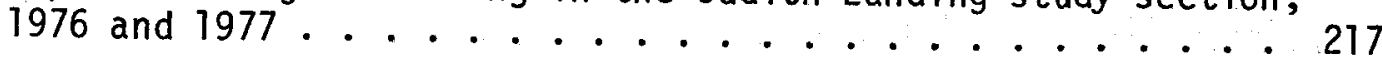

43 Species composition, number, and size of fish sampled by experimental gill netting in the Stafford Ferry study section,

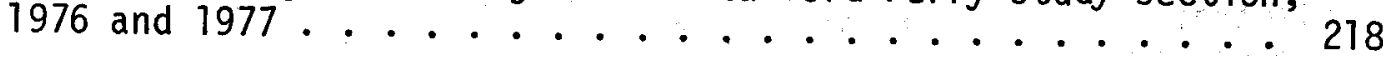

44 Species composition, number, and size of fish sampled by experimental gill netting in the Cow Island study section, 1976 and 1977

45 Species composition, number, and size of fish sampled by experimental gill netting in the Robinson Bridge study section,

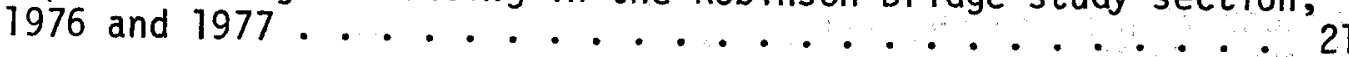

46 Species composition, number, and size of fish sampled by experimental gill netting in the Turkey Joe study section,

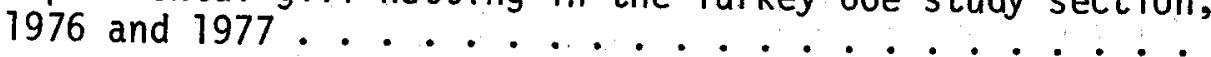

47 Species composition, number, and size of fish sampled with baited hoop nets at the Turkey Joe study site, 1977 through 1979

48 Species composition, number, and size of fish sampled with baited hoop nets at the Two Calf Island study site, 1979

49 Species composition, number, and size of fish sampled with baited hoop nets at the Judith Landing study site, 1977 . . . 221

50 Species composition, number, and size of fish sampled with baited hoop nets at the Loma Ferry study site, 1978 . . . . 221

51 Species composition, number, and size of fish sampled with baited hoop nets in the lower Marias River study section, 1978 and 1979 
Table

Page

52 Species composition, number, and size of fish sampled with baited hoop nets in the lower Teton River study section, 1978

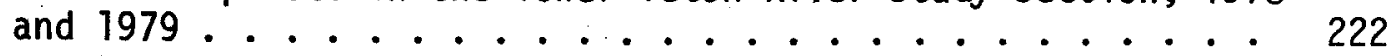

53. Numbers of fish sampled by electrofishing a 4-km study section of the lower Maris River during the spring/summer spawning migration periods from 1976 through 1979.

223

54 Numbers of sauger sampled by frame trapping in the lower Marias River during the spring/summer migration periods from 1976 through 1978, with catch per unit effort statistics . . 225

55 Numbers of fish sampled with baited hoop nets in the lower Marias River during three time periods in 1978 and 1979, with catch per unit effort statistics . . . . . . . . . 226

56 Summary of forage fish surveys conducted on the middle Missouri River from 1976 through 1979, showing location, date of collection, and habitat sampled.

227

$x i i$ 


\section{LIST OF FIGURES}

Figure

Page

1 Map of the middle Missouri River drainage showing locations of eleven study sections established on the mainstem of the river (study sections are marked with arrows).......

2 Macroinvertebrate samples were collected with a rectangular framed kick net positioned on the stream bottom ......

3 A $0.5 \mathrm{~m}$ diameter larval fish net was used to collect drifting

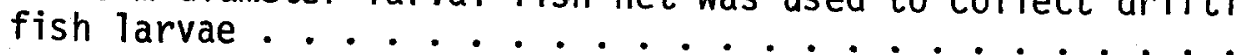

4 Boom suspended electrofishing apparatus mounted on a $6.7 \mathrm{~m}$ aluminum boat was used for sampling fish populations in the

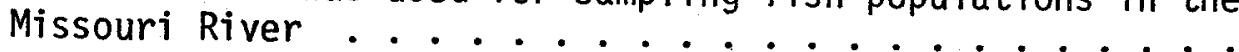

5 Baited hoop nets were used to sample channel catfish in the Missouri, Marias and Teton rivers...........

6 Spawning migrations of sauger in the lower Marias River were monitored with frame traps .......... 12

7 Longitudinal profile of the Missouri River from Morony Dam to Fort Peck Reservoir ..............

8 Diversity of the aquatic macroinvertebrate community was least at Morony Dam and greatest at Judith Landing and

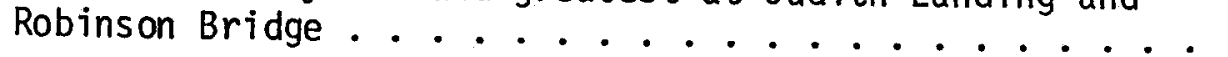

9 Paddlefish prolarvae were sampled on July 12-13, 1978, on the Missouri River at Coal Banks Landing and Little Sandy Creek..............................

10 Temporal abundance of larval fish sampled in three subreaches of the Missouri River and at one site on the lower Marias River, early June through late July, 1978....

11 Decrease in average size (mean total length) of six fish species at downstream study sites on the middle Missouri River.................

12 Photograph of a paddlefish in the field of the positive electrodes ahead of the boat ...........

13 Photograph of a paddlefish in the field of the negative

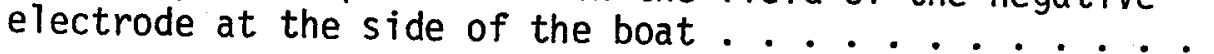

14 Number of paddlefish observed at various localities along the Missouri River in electrofishing survey runs made during the migration period in 1977 ......... 
Figure

15 Relationship between the total number of paddlefish counted in electrofishing surveys and discharge of the Missouri River at Virgelle in $1977 \ldots . . . . .$.

16 Relationship between the total number of paddlefish counted in electrofishing surveys and discharge of the Missouri River at Virgelle in $1978 . . . . . . . .$.

17 Relationship between the total number of paddlefish counted in electrofishing surveys and discharge of the Missouri River at Virgelle in 1979..............

18 Number of paddlefish observed at various localities along the Missouri River in electrofishing census runs made during the migration period in 1978 ..........

19 Number of paddlefish observed at various localities along the Missouri River in electrofishing survey runs made during the migration period in 1979

20 Number of paddlefish counted in electrofishing surveys above Cow Island compared to discharge of the Missouri River at

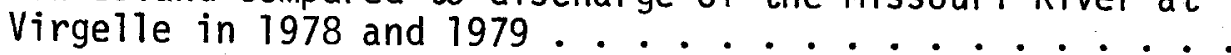

21 Observed spawning chronology of eighteen fish species sampled in the middle Missouri River from 1976 through 1979 . . . .

22 Relation of water temperature and discharge to spawning of sauger and shovelnose sturgeon in the lower Marias River from 1976 through 1979 ..............

23 A comparison of the length-frequency distributions of shovelnose sturgeon sampled in the lower Marias and middle Missouri rivers (Montana), Chippewa River (Wisconsin), Mississippi River (Iowa), and Missouri River (South Dakota)....

24 A comparison of the weight-frequency distribution of shoveinose sturgeon sampled in the lower Marias and Tongue rivers, Montana...............

25 Cross-sections of the anterior pectoral fin rays of shovelnose sturgeon were studied for age and growth determination

26 Cross-sections of the pectoral spines of channel catfish were studied for age and growth determination . . . . . .

27 Weight-frequency and sex composition of 231 paddlefish harvested in the Missouri River above Fort Peck Reservoir during the spring of 1977 


\section{APPENDIX}

Figure

Page

1 Fish species identification chart for Missouri River fisherman survey

2 "Voluntary" (top) and "interview" (bottom) fisherman survey forms used in Missouri River fisherman survey 
A fishery inventory and planning study was conducted on a 333-kilometer $(\mathrm{km})$ reach of the mainstem of the middle Missouri River between Morony Dam and Fort Peck Reservoir and on the lower reaches of its principal tributaries, the Marias, Teton, and Judith rivers. The study was made during a five-year period from 0ctober 1, 1975, through September 30, 1980. Physical, chemical, and biological characteristics of the waters of importance, or potential importance, to the recreational fishery of the study area were determined.

A total of 92,568 fish were sampled in the mainstem and 8,720 in tributaries. Longitudinal distribution, relative abundance, and size composition of the fish populations were determined. A total of 53 species representing 14 families of fish occur in the study area. Sauger, walleye, channel catfish, shovelnose sturgeon, paddlefish, northern pike, and burbot were the most common game fish species collected. Common nongame species included goldeye, carp, freshwater drum, stonecat, mottled sculpin, and a variety of suckers and minnows. Movements of several important fish species were evaluated by electrofishing catch rate and tag return data. Age and growth studies of eight important fish species indicated growth in the middle Missouri River generally equals or exceeds growth in other waters.

Seasonal spawning migrations of shove Inose sturgeon, sauger, bigmouth and smallmouth buffalo, and blue suckers in the Missouri River and from the Missouri River into major tributaries were identified and monitored. The annual spawning migration of paddlefish from Fort Peck Reservoir into the Missouri River was studied, and nine critical spawning sites were identified. Significant movements of paddlefish to the spawning sites did not occur until flow in the Missouri River at the Virgelle gage station exceeded 396 meters ${ }^{3}$ / second $\left(\mathrm{m}^{3} / \mathrm{sec}\right)\left[14,000 \mathrm{feet}^{3} / \mathrm{sec}\right.$ (cfs)].

Aquatic macroinvertebrates, larval fish, and forage fish were studied in the Missouri River and in the lower reaches of major tributaries. Water temperature was monitored at four sites on the Missouri River and at one site on the lower Marias River. Water chemistry was studied at six stations on the Missouri River. In 1977, a paddlefish creel census was conducted in a 23-km segment of the Missouri River between Robinson Bridge and Fort Peck Reservoir. An estimated 1,625 anglers fished 2,526 man-days and harvested 666 paddlefish weighing 15.96 metric tons. A partial creel survey of the Missouri River from Morony Dam to Fort Peck Reservoir revealed an excellent sport fishery exists for sauger, shovelnose sturgeon, channel catfish, and several other species. Returns of tagged fish by anglers indicated relatively light harvest rates for most species.

Assessment of human-related activities affecting the aquatic resource indicates water quality degradation and stream dewatering are problems in portions of the study area. Increased exploitation of fossil fuels and nonfuel mineral resources could lead to future environmental problems. Potential dams on the Missouri River near Fort Benton represent the greatest single threat to the aquatic resources of the study area. 


\section{INTRODUCTION}

A basic inventory is essential in formulating management plans for maintaining and utilizing a fishery. Seldom is this information complete for an entire area or drainage. The middle Missouri River in Montana supports a significant fishery, and prior to this study, basic data on the aquatic resources of this area were lacking.

The aquatic resources of Montana are threatened by an expanding population. Human activities encroach on the aquatic habitat at an alarming rate. These activities on the floodplain, streambanks, and headwaters have altered many streams beyond the point where they can naturally adjust.

Because of the increasing human demand for Montana's limited water supplies for industrial, agricultural, and domestic uses, development of the middle Missouri River appears likely. Projects which remove or impound substantial amounts of stream flow may alter the existing flow regimes and associated aquatic communities. For these reasons the Montana Department of Fish, Wildlife and Parks (DFWP) initiated this study on October 1, 1975. Without basic inventory data on the aquatic resources of the middle Missouri River, little could be done to evaluate conflicting resource demands and minimize adverse impacts on the resource.

A 333-km (207-mile) reach of the mainstem of the middle Missouri River was included in the fisheries inventory. This reach extends from Morony Dam near Great Falls to the headwaters of Fort Peck Reservoir near Landusky. Eleven study sections were established in the reach (Figure 1). In addition, the lower reaches of the Marias, Teton, and Judith rivers were studied. The Marias River entering from the north (including its tributary, the Teton River) and the Judith River from the south are the principal tributaries to the Missouri River in the study area.

The Missouri is the nation's longest river. The $333-\mathrm{km}$ reach covered by this study represents the last major free-flowing portion of the $3,982-\mathrm{km}$ river. From Three Forks to Great Falls, the Missouri is characterized by several dams and intensive bottomland cultivation. From Fort Peck to its junction with the Mississippi River, the Missouri has been substantially altered with channel pilings, flood walls, dams, and reservoirs, all of which have impaired the river's natural values.

The land contiguous to the Missouri River in the study area has retained most of its primitive characteristics. It consists primarily of rolling plains, interrupted by isolated areas of mountain uplift (Missouri River Joint Study 1963). The gorge-like river valley, which lies 150 to 300 meters (m) below the average elevation of the adjacent upland plains, is comprised largely of spectacular, varied, and highly scenic badlands and breaks, ranging from 3 to $16 \mathrm{~km}$ in width.

Because of its extraordinary historical, recreational, scenic, and natural values, a $240-\mathrm{km}$ segment of the Missouri River in the study area from Fort Benton to Robinson Bridge has been designated as part of the National Wild and Scenic Rivers System (US Congress 1975a). This inclusion, signed into law on 0ctober 13, 1976, affords considerable protection for the last major free-flowing portion of the Missouri River. Under provisions 


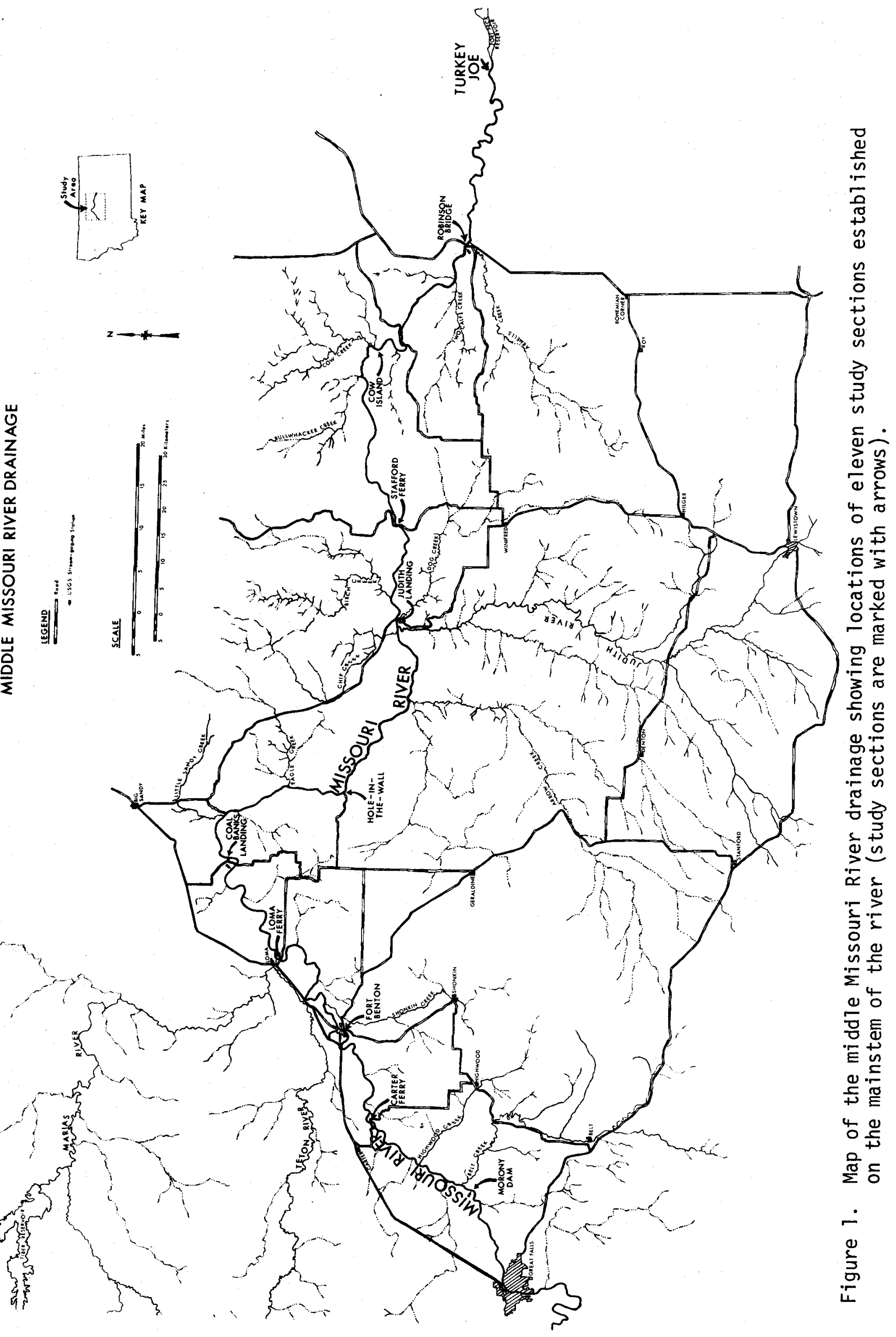


of the legislation, no dams may be built on any of the protected waters and specific protective regulations will be imposed on any new commercial development in designated areas surrounding the protected waters (US Congress 1975b). The law does allow minor diversion and pumping of water from the protected area for agricultural uses. Private landowners in the area can continue with traditional grazing, farming, recreational, and residential uses.

\section{OBJECTIVES}

The long-range objective of the study was to follow the inventory procedures developed on the Smith River (Wipperman 1973) and the upper Yellowstone and Shields rivers(Berg 1975) and use the resulting data to prepare recommendations for aquatic resource management on the middle Missouri River. Specific objectives were:

1. To conduct baseline surveys of resident fish populations in 11 study sections on the mainstem of the middle Missouri River,

2. To identify and monitor spawning migrations of paddlefish, shovelnose sturgeon, and sauger in the Missouri River and the lower reaches of the Marias, Judith, and Teton rivers,

3. To tag key fish species with individually numbered tags to determine angler harvest and monitor movement patterns,

4. To determine age and growth of paddlefish, shovelnose sturgeon, sauger, channel catfish, blue sucker, bigmouth and smallmouth buffalo, and freshwater drum in the middle Missouri River,

5. To determine location, seasonality, and success of spawning of important fish species in the middle Missouri River by sampling for larval fish at eight stations on the mainstem of the river and at one station near the mouth of the Marias River,

6. To inventory the aquatic macroinvertebrate community at five stations on the mainstem of the middle Missouri River and at one station each near the mouths of the Marias and Judith rivers,

7. To maintain thermograph stations on the Missouri and Marias rivers to monitor water temperatures,

8. To monitor water chemistry (quality) parameters at six stations on the mainstem of the middle Missouri River,

9. To conduct a partial creel survey on the sport fishery of the middle Missouri River between Morony Dam and Fort Peck Reservoir,

10. To conduct a creel census on the paddlefish fishery between Robinson Bridge and Fort Peck Reservoir, and

11. To identify immediate and future problems affecting the aquatic resources in the study area and recommend solutions to alleviate these problems. 
All objectives stated above were accomplished. Findings are presented in the appropriate sections of this completion report.

\section{TECHNIQUES}

\section{Water Temperature}

Thirty-day continuous recording thermographs were used to monitor water temperature regimes. The recorder box was positioned on the streambank as far above the high water mark as possible. A thermocouple lead, varying in length from 8 to $23 \mathrm{~m}$, was extended into the water through flexible, plastic sewer pipe.

Water Quality

A limited amount of water chemistry (quality) monitoring was conducted during this study. Samples were collected by the DFWP, and laboratory analyses were made by the Water Quality Bureau of the Montana Department of Health and Environmental Sciences. Standard Methods for the Examination of Water and Wastewater were followed (APHA 1975).

\section{Macroinvertebrates}

Aquatic macroinvertebrate samples were taken using a rectangular framed $20 \times 45$ centimeters $(\mathrm{cm})$, conical net kick sampler with fine mesh (300 micron) pores (Figure 2). The net was positioned on the streambed so the current flowed into it. Macroinvertebrates were washed into the net by an operator standing in front of the net kicking into the substrate. A variety of habitat types (cobble, gravel, sand, mud, submerged vegetation, etc.) were sampled at each station to obtain a representative sample. Samples were transferred to jars containing an identifying label and preserved with 10 percent formaldehyde.

In the laboratory, the samples were washed on a US Series No. 30 screen. Material retained by the screen was transferred to an enamel sorting pan where the aquatic macroinvertebrates were separated from vegetation and bottom materials. Separation of macroinvertebrates was accomplished by picking each sample twice. Macroinvertebrates were identified to the lowest taxon practical using keys by Ward and Whipple (1959), Pennak (1953), Brown (1972), and Roemhild (1976). Al1 macroinvertebrate identifications, except chironomids, were verified by Dr. George Roemhild, Montana State University. Chironomids were identified by Dick Oswald, Montana State University.

\section{Larval Fish}

Larval fish were sampled with a $0.5 \mathrm{~m}$ diameter by $1.6 \mathrm{~m}$ long Nitex plankton net $(0.75 \mathrm{mi} 71$ imeter $(\mathrm{mm})$ mesh) fitted with a threaded ring sewn at the distal end to accommodate a wide mouth, pint mason jar as the collecting bucket (Figure 3 ). The net was fished in a stationary position immediately below the surface of the water in main channel border areas of the river. The net was anchored in position in the current by a $4 \mathrm{~m}$ length of rope. The volume of water filtered was measured with a Price type-AA current meter positioned at the center of the net orifice. The net was fished for a measured period of time, usually 30 to 60 minutes. 


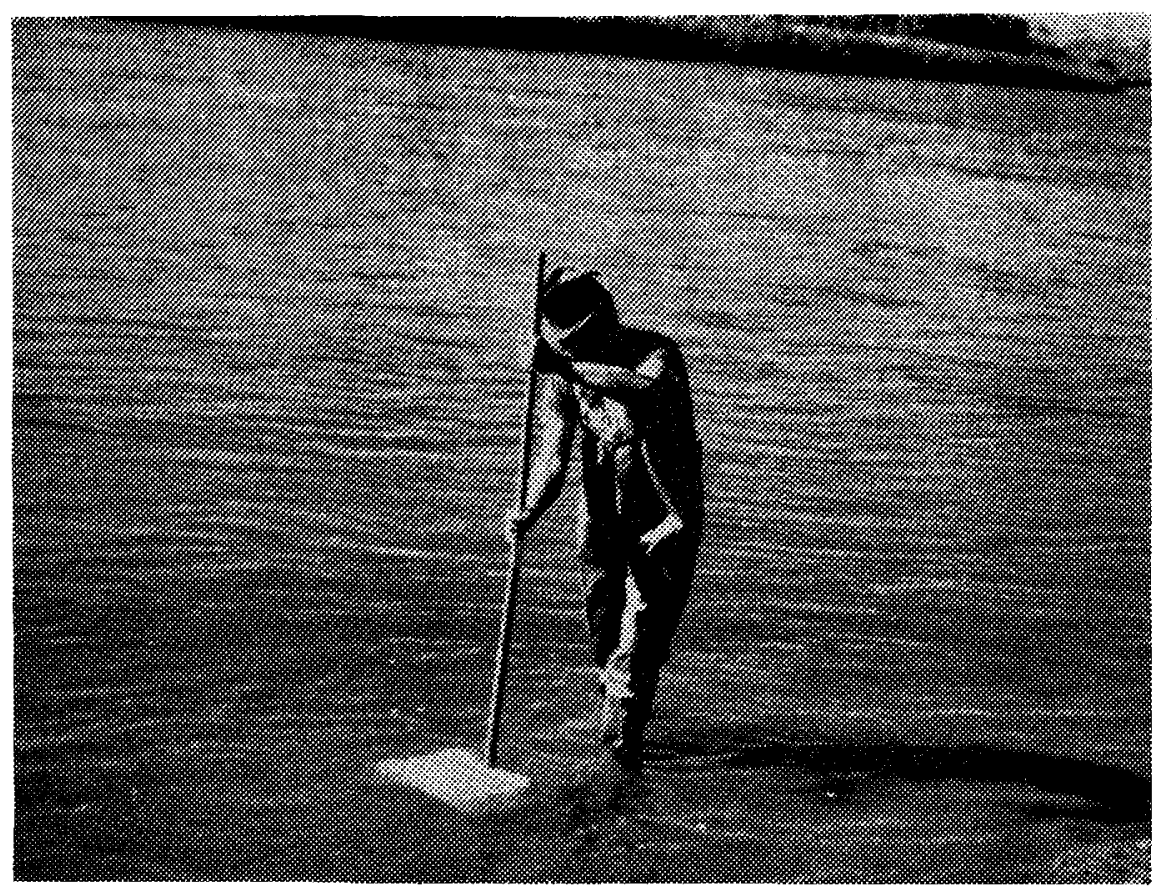

Figure 2. Macroinvertebrate samples were collected with a rectangular framed kick net positioned on the stream bottom.

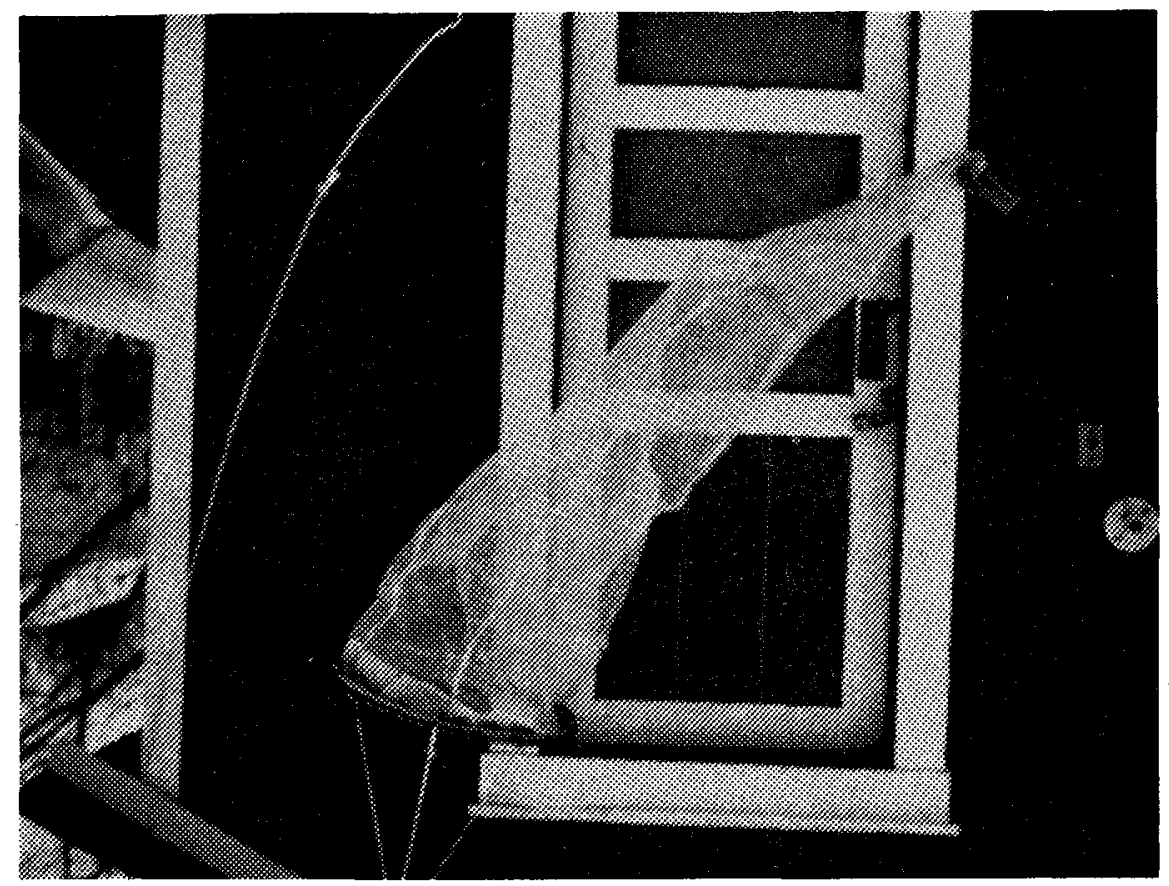

Figure 3. A $0.5 \mathrm{~m}$ diameter larval fish net was used to collect drifting fish larvae. 
On some occasions the net was fished for less than 30 minutes because of excessive amounts of debris collecting in the nets. The samples were usually collected during the dusk-to-dawn hours of the day at two week intervals.

After the net was retrieved from the river, its contents were thoroughly washed into the collecting jar. All samples were preserved in a 10 percent solution of formaldehyde colored with phloxine-B dye. In the laboratory, the samples were washed on a US Series No. 30 screen. Material retained by the screen was transferred to an enamel sorting pan where the larval fish were extracted. The ploxine-B dye was a deep pink coloring agent which penetrated the fish larvae and aided in separating them from aquatic vegetation and debris. Larvae were identified to the lowest taxon practical using keys by Hogue et al. (1976) and May and Gasaway (1967). For purposes of this study, larval fish were defined as those fish exhibiting undeveloped pectoral, anal, and dorsal fin rays, essentially as suggested by May and Gasaway (1967).

\section{Adult Fish}

The middle Missouri River is a substantially larger stream than the Smith or upper Yellowstone River drainages where the previous inventory and planning investigations were conducted. The Missouri has a greater diversity of aquatic habitat types and a larger variety of fish species than the aforementioned drainages. Natural turbidity, deep water, and deceptive current velocities present problems for survey operations in many areas.

Because of these problems, many of the fish population sampling procedures developed during the previous inventory and planning studies could not be used on the Missouri River. A basic objective of this study was to become familiar with proven sampling methods on large rivers and develop sampling equipment and techniques adaptable to the Missouri River. The following fishery sampling gear and methods were tested and used during the study.

\section{Boom-Suspended Electrofishing Apparatus}

Alternating or direct current shockers with ellectrodes suspended from fixed booms have been relatively successful for sampling fish populations in large rivers such as the lower Yellowstone River in Montana (Peterman and Haddix 1975), the Missouri River in Nebraska (Morris 1965, Stuckey 1973), the Missouri River in Missouri (Robinson 1973 and 1977), and other large rivers (FAO 1975).

A boom shocker was constructed for use on the middle Missouri River. Basic design of the boom shocker was adapted largely from boom shockers used in Wisconsin (Novotny and Priegel 1974) with specific modifications similar to those used on the lower Yellowstone River in Montana (Peterman 1978).

The electrofishing apparatus was mounted on a $6.7 \mathrm{~m}(22 \mathrm{ft}$.) semi-vee aluminum boat powered by a 245 horsepower (hp) inboard jet (Figure 4). An aluminum boat offers the advantage of simple, reliable grounding of all electrical equipment by the physical attachment of the equipment to the boat (Novotny and Priegel 1974). A metal railing was constructed around the front deck of the boat for safety and to facilitate collection of stunned 


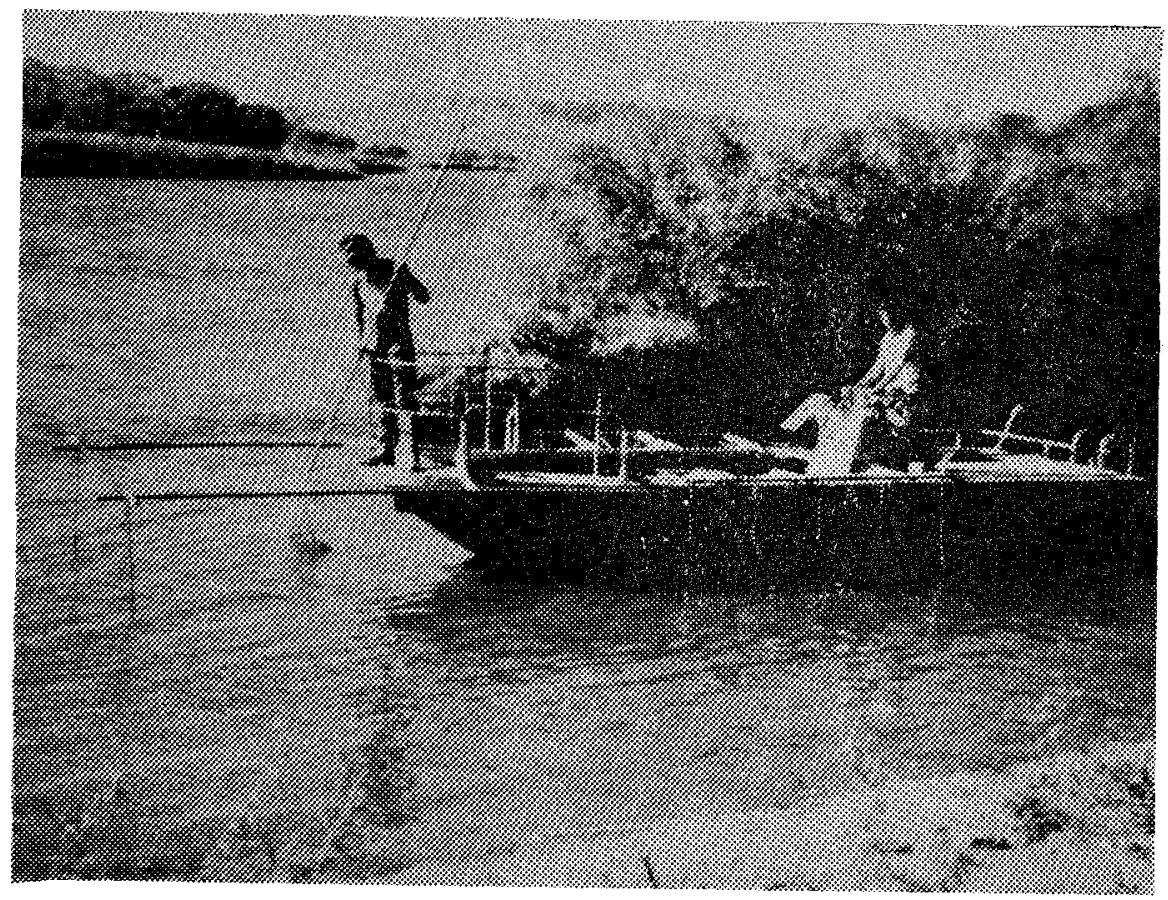

Figure 4. Boom suspended electrofishing apparatus mounted on a $6.7 \mathrm{~m}$ aluminum boat was used for sampling fish populations in the Missouri River.

fish with dip nets.

The electrode system of the boat consisted of positive and negative arrays. Since the boat was intended primarily for operation with direct current, the electrode configurations were designed specifically for this operating mode. However, the electrode system was also adequate for operation in the alternating current mode.

The positive electrode system consisted of two anodes suspended from fiberglass booms approximately $1.8 \mathrm{~m}(6 \mathrm{ft}$.) ahead of the bow of the boat. The booms were spread $2.1 \mathrm{~m}$ ( $7 \mathrm{ft}$.) apart and were adjustable for height by means of pin-locked adjustments. Each anode consisted of either (1) a spherical electrode, $38.1 \mathrm{~cm}$ (15 in.) in diameter, constructed from 1.0 $\mathrm{cm}$ (3/8 in.) diameter copper tubing or (2) an array of 12 to 15 "dropper" electrodes clipped to a $0.9 \mathrm{~m}$ ( $3 \mathrm{ft}$.) diameter aluminum support ring. The support ring provided mechanical support and an electrical connection for the droppers which actually carried the current into the water. Individual "droppers" consisted of $15.2 \mathrm{~cm}$ ( 6 in.) lengths of $1.6 \mathrm{~cm}(5 / 8$ in.) diameter stainless steel tubing supported by a $45.7 \mathrm{~cm}$ (18 in.) length of heavy gauge insulated copper wire with a 20-amp test clip to attach to the support ring. By moving a sleeve of insulating material $(1.6 \mathrm{~cm}$ [5/8 in.] diameter auto wire loom), exposure of the stainless steel "droppers" could be adjusted for waters of varying conductivity.

The negative electrode system consisted of two cathode arrays, one mounted on each side of the boat. Each array consisted of a set of five $1.2 \mathrm{~m}$ (4 ft.) lengths of $1.9 \mathrm{~cm}(3 / 4 \mathrm{in.})$ diameter flexible conduit supported 
by a 2.4-m ( $8 \mathrm{ft}$.$) length of fiberglass boom. Each length of conduit was$ fastened to the support boom by a chain and rubber insulator. The top of each length of conduit was insulated with electrical tape to reduce an unnecessary electrical field near the surface of the water.

Power was supplied to the positive and negative electrodes through 1.3 $\mathrm{cm}(1 / 2$ in.) diameter metal conduit and watertight junction boxes. Industrial duty electronic plugs and receptacles (screw-in type) provided positive watertight connections between junction boxes, electrodes, and power source.

The power source for the electrofishing system was a 2,500-watt, 230volt ( $60 \mathrm{~Hz}$. single phase) alternating current generator. A Coffelt Model VVP-15 rectifying unit was used to change the aiternating current to various forms of pulsed or continuous direct current. Output from the rectifying units could be varied from 0 to 600 volts and from 0 to 25 amps. Pulse frequency was adjustable from 20 to 200 pulses per second and pulse width from 20 to 80 percent. Meters were used to monitor all voltages, current output, frequency and pulse width.

Most of the aquatic habitat of the Missouri River in the study area consisted of deep mainstem areas with a few large side channels and backwaters. The boom-suspended electrofishing apparatus was the most effective technique for sampling these areas. Other procedures such as mobile electrofishing apparatus, gill nets, hoop nets, frame traps, and seining were effective only in restricted habitat areas such as shorelines, quiet pools, backwaters, and small side channels.

\section{Mobile Electrofishing Apparatus}

A mobile electrode apparatus was used for sampling fish populations in the lower Marias River and in shallow, restricted side channel and backwater areas of the Missouri River. Maneuverability of the relatively small mobile unit in these confined habitat areas proved highly advantageous.

The mobile electrofishing unit consisted of a $4.3 \mathrm{~m}$ (14 ft.) fiberglass boat containing a hand-held mobile positive electrode, a stationary negative electrode (fastened to the bottom of the boat) and a portable 2,500-watt, 115-volt (60 Hz. single phase) alternating current generator. A Fisher Model FS- 103 rectifying unit was used to change the alternating current to various forms of pulsed or continuous direct current. The direct current output was adjustable from 0 to 500 volts. A $40 \mathrm{hp}$ jet outboard was used for mobility in deep water areas where the electrofishing boat coula not be maneuvered by hand.

\section{Gi11 Nets}

Fish were also captured with standard experimental sinking nylon gill nets $1.8 \times 38.1 \mathrm{~m}(6 \times 125 \mathrm{ft}$.) with graduated mesh size from 1.9 to $5.1 \mathrm{~cm}$ ( $3 / 4$ to 2 in.) square measure. Overnight stationary sets with these nets in areas of the river with little or no current, generally produced good catches of a wide variety of fish species. Stationary gill net sets in areas of the river with any significant amount of current were largely unsuccessful because the nets usually became badly fouled with debris and, in some cases, were washed downstream by the current. 
In some main channel areas of the Missouri River with moderate current, heavy-duty, large-mesh sinking nylon gill nets were drifted perpendicular to the current in an attempt to capture fish. These nets were $2.4 \mathrm{~m}$ ( $8 \mathrm{ft}$.) deep and varied in length from 15.2 to $45.7 \mathrm{~m}$ (50 to $150 \mathrm{ft}$.). The nets could be drifted only in areas of the river relatively free from snags and with sufficient current to carry the nets. In many areas, the current was too swift for drifting the nets.

Drifting gill nets with $7.6 \mathrm{~cm}$ (3 in.) square measure mesh was effective and fairly selective for sampling shovelnose sturgeon and blue suckers. Paddlefish were taken readily by drifting gill nets with $12.7 \mathrm{~cm}$ ( 5 in.) square measure mesh in the Missouri River below Robinson Bridge. The 12.7 $\mathrm{cm}$ mesh appeared to be exclusively selective for paddlefish.

\section{Baited Hoop Nets}

Baited hoop nets were used to sample channel catfish in the study area. The nets were constructed of $3.2 \mathrm{~cm}(1.25$ in.) square mesh, tarred, nylon netting on a matched set of four $0.8 \mathrm{~m}(2.5 \mathrm{ft}$.$) diameter wood hoops with$ an overall length of $2.0 \mathrm{~m}$ (Figure 5 ). This type of hoop net had been used successfully by commercial fishermen to capture channel catfish in the Missouri and Mississippi rivers (Ragland and Robinson 1972, Helms 1973). The nets were fairly selective for channel catfish although a few other species were occasionally taken.

The hoop nets were set in the river with the open throat facing downstream. A bait bag containing from $\frac{1}{2}$ to 1 kilogram $(\mathrm{kg})$ of rotten cheese was attached to the bottom of the rear hoop inside the net. The bait bags were constructed from rubber tire inner tubes perforated as much as possible to help feed the bait. A weight of from 20 to $50 \mathrm{~kg}$ was attached to the rear of the net. This weight anchored the hoop net on the streambottom. The exact amount of weight required to anchor the net depended on the force of the current. A second weight of about $2 \mathrm{~kg}$ was attached to the bottom of the front hoop to keep the net stretched in position on the streambottom. A 3 to $6 \mathrm{~m}$ nylon line with a buoy was attached to the top of the front hoop to mark the location of the set.

The most important element in sampling for channel catfish in large rivers is to locate the specific site for the net. The lack of success in capturing catfish is usually due to net location rather than to inefficiency of the hoop net or bait.

Net location varies to some extent with the seasonal distribution of channel catfish. From about mid-March through mid-June, a substantial number of catfish were found in side channels of the Missouri River in pools near undercut banks. A limited number of sets were made in these areas during spring. However, it was generally impractical to set hoop nets in the Missouri River during spring because of the great amount of debris carried by the river. As stream flow levels rose, the nets often became badly fouled with debris and, in some cases, were washed downstream by the current.

The best results in sampling for channel catfish in the Missouri River were obtained during the period from mid-June through late October. Most of the channel catfish were found in deep pools in main channel areas in or near the thalweg during this time period. The nets were placed on stable 


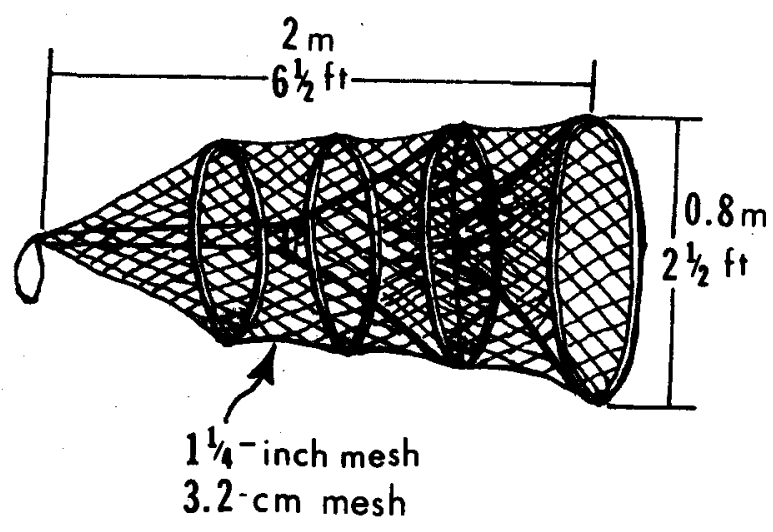

Figure 5. Baited hoop nets were used to sample channel catfish in the Missouri, Marias, and Teton rivers. 
gravel or sand and gravel substrate at the head of the larger pools in water at least $1.5 \mathrm{~m}$ ( $5 \mathrm{ft}$.) deep. Nets placed on unstable substrate, such as sand or mud, usually resulted in poor catches and often became partially buried and were difficult to retrieve. To facilitate feeding out of the bait the nets were placed in areas with current velocity as swift as possible without washing away the nets.

The first nets set in each section were left in the water for 48 to 72 hours to allow sufficient time for the bait to feed out. The nets were then raised and data on the catch recorded. After the first set, the nets were checked approximately once every 48 hours. Information on the time of setting and raising, correct to the nearest five minutes was recorded for each net.

\section{Frame Traps}

Spawning migrations of sauger and other species were monitored on the lower Marias River with $0.9 \mathrm{~m}$ ( $3 \mathrm{ft}$.) high by $1.2 \mathrm{~m}$ ( $4 \mathrm{ft}$.) long frame traps (Figure 6). The traps were constructed from $2.5 \mathrm{~cm}$ (1 in.) square mesh fence wire and $1.3 \mathrm{~cm}\left(\frac{1}{2}\right.$ in.) diameter reinforcing rod material. Similar traps were used successfully by Posewitz (1963) to capture fish in the middle Missouri River and the lower reaches of its tributaries.

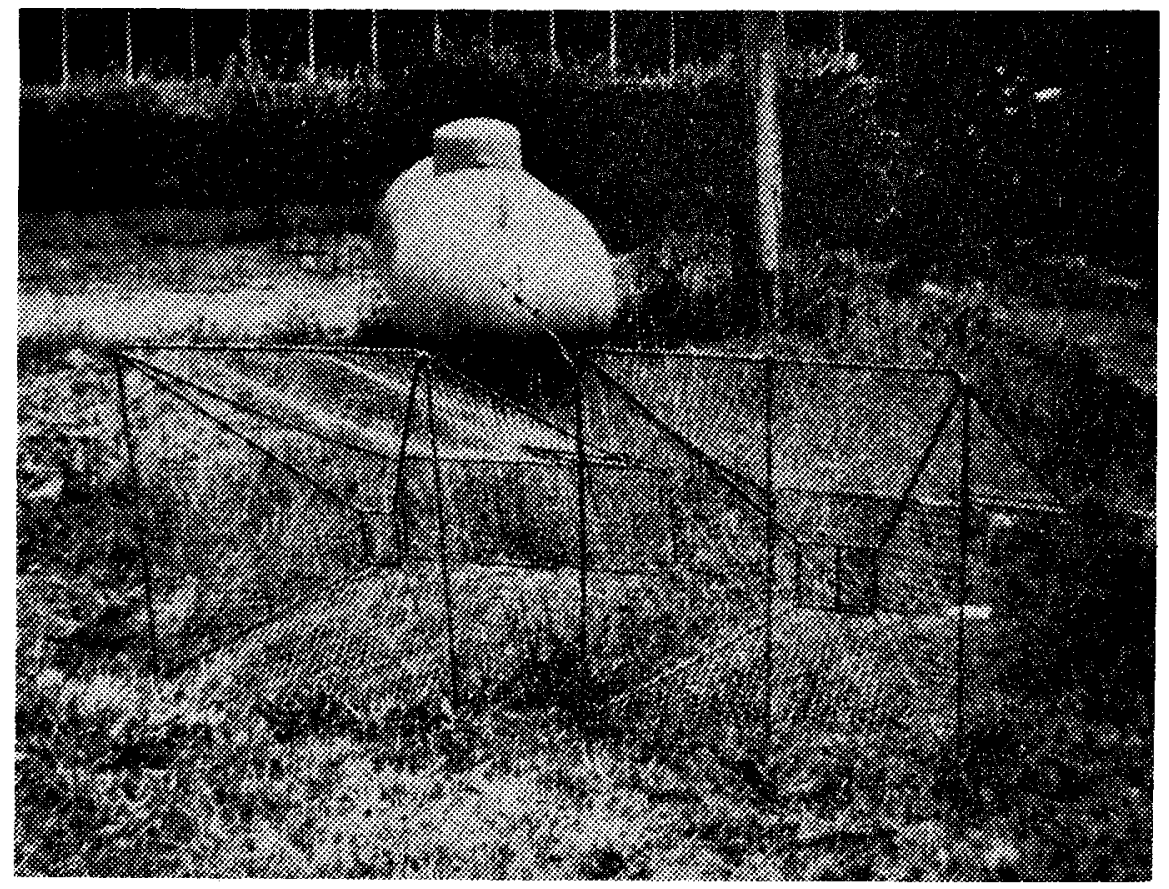

Figure 6. Spawning migrations of sauger in the lower Marias River were monitored with frame traps. 
The frame traps were set in the river with the open throat facing downstream. One or two lead nets, 0.9 to $1.8 \mathrm{~m}$ (3 to $6 \mathrm{ft}$.) high, with $2.5 \mathrm{~cm}$ ( 1 in.) square mesh and from 3 to $15 \mathrm{~m}$ long, were stretched at various angles downstream from the trap. The angle depended on the force of the current.

The frame traps were successful for sampling a substantial number of migrating adult game fish, especially sauger, during their spawning seasons. Posewitz (1962) believed the traps were selective for adult sauger in the lower Marias River. Selectivity toward adults was probably due to the relatively large square mesh $2.5 \mathrm{~cm}$ (1 in.) of the traps and leads. Ricker (1971) reported that underwater frame traps are selective by species, and have been selective for the larger fish of a size class above the minimum imposed by the physical dimensions of the net. Traps and leads of a mesh size smaller than $2.5 \mathrm{~cm}$ cannot be fished effectively in the Missouri River because they impede streamflow, trap debris, and are washed out much more easily than the large mesh.

\section{Seines}

Forage fish samples were collected with $15.2 \times 1.2 \mathrm{~m}(25 \times 4 \mathrm{ft}$. beach seines with 6.4 and $3.2 \mathrm{~mm}(1 / 4$ and $1 / 8 \mathrm{in.})$ square mesh. The seine was operated by two persons and worked in as many different habitat types as the current and bottom characteristics allowed. Most of the seining sites were confined areas, such as backwaters and side channels, where the presence of forage fish was anticipated. Some forage fish were also taken in selected unconfined portions of the open river, such as shoreline and shallow riffle areas. Fish collected were identified and associated habitat types were recorded.

\section{Fish Sample Processing and Tagging}

Fish captured by the various techniques were anesthetized with MS-222, measured to the nearest millimeter in total length, and weighed to the nearest 10 grams $(\mathrm{g})$. In addition, paddlefish and shovelnose sturgeon were measured to the nearest millimeter in fork length. Sex and spawning condition (gravid, ripe, or spawned) were recorded for fish captured during their spawning season. All fish were released near the capture site.

In addition to the above, several fish species were marked with individually numbered tags. Tag return data were used to provide an indication of angler harvest rates and to determine movement patterns of individual fish, particularly spawners, and establish their home ranges.

Individually numbered, plastic, cinch-up spaghetti tags, anchored through the base of the adipose fin, were used to mark channel catfish. Shovelnose sturgeon were tagged with individually numbered, monel, wing band tags clipped over the anterior rays of the pectoral fin or with individually numbered, plastic, cinch-up spaghetti tags inserted through the posterior portion of the fleshy keel at the base of the dorsal fin. All other game fish species and several nongame species, including blue suckers, bigmouth buffalo, smallmouth buffalo, and freshwater drum were tagged with individually numbered Floy T-tags inserted near the base of the dorsal fin. Information signs were placed at accessible points along the river in an effort to encourage anglers to provide information about tagged fish in their creel. 
Age and Growth

Scales or other structures were taken from certain fish species for age and growth determination. Scale samples were taken regularly from sauger, blue suckers, bigmouth and smallmouth buffalo, and freshwater drum. Small numbers of scales were also collected from walleye, northern pike, rainbow and brown trout, and mountain whitefish. The scale samples were imprinted on an acetate slide, and the imprints were projected at $44 \mathrm{X}$ on a Norwest nmi 90 microfiche reader. Annuli were identified and ages assigned following criteria in Tesch (1971) and Lagler (1956).

Annuli measurements in millimeters for back calculations were made from the center of the focus of each scale along the central radius to the anterior edge of the scale. Calculations of length at previous annuli for fish 0 to 10 years old were made at the Montana State University computer center using a modified version of FIRE I, a fisheries statistics program. This program employs the Dahl Lea, Rosa Lea, and corrected Rosa Lea linear back calculation equations and the Monastyrsky logarithmic equation (Tesch 1971). FIRE I was also used to summarize empirical data concerning length, weight, percent composition, and condition factors of assigned age groups. It also calculated length-weight and length-scale radi $i$ relationships. Condition factors $\left(K_{T L}\right)$ were calculated by the forumula:

$$
K_{T L}=\frac{W \times 105}{L 3}
$$

Dentarys (lower jaws) were collected from a number of angler harvested paddlefish during creel census surveys conducted on the Missouri River in the Slippery Ann area. The dentarys were placed in chlorine bleach for several days to remove the flesh and then dried in an oven set at 50 degrees centigrade $(C)$. The dentarys were then cut into thin cross sections, 30 to 40 micra thick, with a jeweler's saw. Because of the greater thickness of the dentary at the point where it bends mesially, cross sections were made in this area (the caudio mesiad) to provide the widest area for counting growth rings. The sections were smoothed on garnet paper and immersed in glycerin prior to being examined under a $30 x$ stereoscope. Annuli were then counted in the manner described by Adams (1942).

Pectoral spines were collected from channel catfish for age and growth determination. The spines were sectioned with a small power saw apparatus similar to that described by Witt (1961). Sections of the spines were made just distal to the basal groove as suggested by sneed (1951). The sections were sanded to less than $0.05 \mathrm{~mm}$ in thickness and emersed in a dilute solution of hydrochloric acid for partial decalcification. The sections were then washed in tap water and placed in glycerin between two microscope slides. The mounted sections were projected at $44 \mathrm{X}$ on a Norwest nmi 90 microfiche reader for age and growth determinations.

The magnified spine sections clearly showed narrow transparent bands separated by wider, opaque bands. The narrow, transparent bands were deposited by slower winter growth and were considered annuli. Measurements were made in millimeters from the center of the lumen to each annulus and to the edge of the spine section along the axis of the longest anterior lobe as suggested by Sneed (1951). The articulating process of each spine was sectioned, wetted with xylene and viewed with reflected light under a binocular microscope. Under reflected light the annuli appeared as narrow, dark banks. These sections were used to check ages assigned to spine sections taken distad 
to the basal groove as suggested by Ragland and Robinson (1972). The sections made through the articulating process retained all annual marks, while sections made through the spine distad to the basal groove were missing annuli due to enlargement of the spine lumen. Age and growth calculations were made using methods previously described for scaled fish.

Pectoral fin rays of shovelnose sturgeon were sectioned and examined for age determination. Three sections of each ray were made, beginning approximately $12 \mathrm{~mm}$ distad from the articulation and proceeding proximally toward the articulation. Roussow (1957) and Cuerrier (1951) sectioned shovelnose sturgeon pectoral rays $13 \mathrm{~mm}$ or closer to the base. Zweiacker (1967) made the first sections $20 \mathrm{~mm}$ from the base and proceeded proximally. The shovelnose sturgeon pectoral sections were then prepared and mounted as described above for channel catfish. The cross section of the marginal anterior ray of the pectoral fin was used to age the sturgeon. Annuli apppeared as narrow, translucent, single or banded 7 ines. No attempt was made to back calculate shovelnose sturgeon lengths at previous annuli because of their old age and the close compaction of their annuli.

Complete decalcification, microtome sectioning and mounting with Giensa stain proved unsatisfactory for viewing annuli on channel catfish and shovelnose sturgeon pectoral cross sections. This process tended to obliterate the annuli.

Creel Census and Creel Survey

\section{Paddlefish Creel Census}

A creel census study was conducted on the paddlefish fishery on the Missouri River immediately upstream from Fort Peck Reservoir during the spring of 1977. The creel census method was adapted largely from Needham (1973). Based on field tests of various creel census methods, Needham selected this technique because it was the most reliable one for the Missouri River study area.

Creel census data were collected on as many days as possible throughout the entire spring paddlefish snagging season. Weekends and holidays received much heavier fishing pressure than weekdays. Therefore, a larger proportion of weekends and holidays were creel censused than weekdays. Estimates of fisherman pressure and catch on noncensus days were based on data from preceding and following census days. In addition, some information on pressure and harvest on noncensus days was provided by US Fish and Wildlife Service personnel stationed on the Charles M. Russell National Wildlife Range, which borders the study area and by DFWP wardens.

As many anglers as possible were interviewed after completing their fishing day. On most days, the absolute number of fishermen and their harvest could be determined. Data recorded on angler interviews included angler residency, length of trip, estimated time spent fishing, method of fishing (bank or boat), number of paddlefish caught, and number of paddlefish kept.

As much of the creel as practical was measured to the nearest centimeter in length, fork length, and eye-to-fork length. Weights were determined to the nearest $0.5 \mathrm{~kg}$ with a Chatillon Model $100 \mathrm{~A}$ straight spring scale. Sex was determined by weight, body configuration, presence of tubercules and examination of the gonads and urogenital pore. 
A number of paddlefish in good condition which were caught by anglers who did not wish to keep them, were tagged and released near the capture site. The tags used were individually numbered, monel, poultry bands anchored around the dentary (lower jaw) near its symphysis. Tag returns provided information on angler harvest rates and movements.

\section{Missouri River Creel Survey}

An angler creel survey was conducted during 1977 and 1978 on the sport fishery which exists on the Missouri River from Great Falls to Fort Peck Reservoir. This survey was a partial census in which interviews of fishermen were used to obtain estimates of angling data. The survey technique, formulated with the assistance of George Holton, Fisheries Division, DFWP, used a fish species identification chart and postcard-sized angler survey forms (Appendix Figures 1 and 2).

The angler survey forms were of two different types - "voluntary" and "interview." The "voluntary" survey form relied on voluntary compliance in answering the survey and returning the postpaid card. "Voluntary" forms were distributed to parties of anglers by personnel from the Bureau of Land Management (BLM), Lewistown, and Northwestern University, Evanston, Illinois, during the course of their recreational use surveys on the river.

With the "interview" survey form, partial trip data were obtained during interviews with individual anglers. The "interview" form was recorded in duplicate, with the original copy retained by the census taker and the carbon copy given to the angler. Upon completion of his/her fishing trip, the angler voluntarily recorded complete trip data and returned the postpaid carbon copy of the "interview" form. As many interviews as possible were obtained during the course of the research, such as electrofishing and gill netting on the river. In addition, a number of days, especially weekends and holidays, were devoted exclusively to collecting creel survey data.

Data recorded on the angler survey forms included residency, party size, length of trip, estimated time spent fishing, type of fishing (bank or boat), method of fishing (setline, angling, or snagging), type of lure used, and number and kind of fish kept and released.

\section{FINDINGS - AQUATIC HABITAT PARAMETERS}

Drainage Area and Stream Discharge

The drainage area of the middle Missouri River increases from 60,326 $\mathrm{km}^{2}$ to $106,156 \mathrm{~km}^{2}$ or by about 76 percent, between Morony Dam and Robinson Bridge (United States Geological Survey 1979). However, due to the semiarid climate, the increase in mean annual streamflow is only about 17 percent. The climate is characterized by moderately low rainfal1, a dry atmosphere, hot summers, cold winters, and a large proportion of sunny days (Gieseker 1931). Precipitation averages about $33 \mathrm{~cm}$ (13 in.) annually, of which about $22 \mathrm{~cm}$ falls during May through September (Misssouri River Joint Study 1963).

Streamflow regimes are monitored by the US Geological Survey (USGS) at Morony Dam, Fort Benton, Coal Banks Landing, and Robinson Bridge. Mean annual discharge for a 22-year period of record at Morony Dam, an 88-year period of record at Fort Benton, a 43-year period of record at Coal Banks 
Landing, and a 44-year period of record at Robinson Bridge were $7.12 \mathrm{~km} 3 / \mathrm{y}$ $(5,776,000 \mathrm{AF} / \mathrm{y}), 6.95 \mathrm{~km} / \mathrm{y}(5,636,000 \mathrm{AF} / \mathrm{y}), 7.70 \mathrm{~km} 3 / \mathrm{y}(6,242,000 \mathrm{AF} / \mathrm{y})$, and $8.35 \mathrm{~km} 3 / \mathrm{y}(6,775,000 \mathrm{AF} / \mathrm{y})$ respectively (USGS 1979). The maximum flows recorded at the four stations, respectively, were $2,040 \mathrm{~m} 3 / \mathrm{sec}(72,000 \mathrm{cfs})$ on June $10,1964,3,960 \mathrm{~m}^{3} / \mathrm{sec}(140,000 \mathrm{cfs})$ on June $6,1908,3,460 \mathrm{~m}^{3} / \mathrm{sec}$ $(122,000 \mathrm{cfs})$ on June 5,1953 , and $3,880 \mathrm{~m} / \mathrm{sec}(137,000 \mathrm{cfs})$ on June $6,1953$. The recorded minimums were $0.028 \mathrm{~m}^{3} / \mathrm{sec}$ (1 cfs) on Apri1 16, 1962, at Morony Dam in response to a power plant shutdown, $9.06 \mathrm{~m}^{3} / \mathrm{sec}(320 \mathrm{cfs})$ on July 5 , 1936, at Fort Benton, $18.1 \mathrm{~m} 3 / \mathrm{sec}$ (638 cfs) on July 5, 1936, at Coal Banks Landing and $31.7 \mathrm{~m} / \mathrm{sec}(1,120 \mathrm{cfs})$ on July 8,1936 at Robinson Bridge. The present day flow regimens are not natural because of regulation and storage at several dams in the drainage upstream from the study area.

Stream Gradient and Velocity

The Missouri River enters the study area immediately below Morony Dam at an elevation of $856.2 \mathrm{~m}(2,809 \mathrm{ft}.) \mathrm{ms} 1$, dropping $167.6 \mathrm{~m}$ (550 ft.) to an elevation of $688.5 \mathrm{~m}$ (2259 ft.) ms 1 at Robinson Bridge. Stream gradient averages $0.57 \mathrm{~m} / \mathrm{km}(3.0 \mathrm{ft} . / \mathrm{mi}$.) and varies from over $1.9 \mathrm{~m} / \mathrm{km}(10 \mathrm{ft} . / \mathrm{mi})$. in the extreme upper reaches to less than $0.4 \mathrm{~m} / \mathrm{km}(2 \mathrm{ft} . / \mathrm{mi}$.$) in some sections$ (Table 1). A longitudinal profile from Morony Dam to Fort Peck Reservoir is shown in Figure 7. Stream gradients were determined by measurements taken from USGS topographic maps $(1: 24,000$ scale). A river distance chart, also taken from the topographic map, is presented in Appendix Table 1.

Velocity is closely associated with stream width, discharge, and gradient. Mean velocities range from about 1.1 to $0.6 \mathrm{~m} / \mathrm{sec}(3.5$ to $2.0 \mathrm{ft} . / \mathrm{sec}$.) at a discharge of $169.9 \mathrm{~m}^{3} / \mathrm{sec}$ (600 cfs) (USDI 1975).

Water Temperature

Water temperatures were monitored during the ice-free period by continuous recording thermograph stations located on the Missouri River at Morony Dam, Fort Benton, Coal Banks Landing, and Robinson Bridge and on the Marias River $5.1 \mathrm{~m}$ upstream from the mouth. The daily maximum and minimum water temperatures recorded at each station from 1976 through 1979 are shown in Appendix Tables 2 through 17. The Coal Banks Landing station was operated by the USGS. The others were maintained by the DFWP.

Each year, at the five stations, water temperature warmed progressively from late March through early June. The highest annual water temperatures were achieved from early June through mid-August. The highest temperatures recorded at the Morony Dam, Fort Benton, Coal Banks Landing, and Robinson Bridge stations during the study period were $20.0,26.1,26.7$, and $26.7 \mathrm{C}$ $(68,79,80$, and $80 \mathrm{~F})$, respectively. The highest temperature recorded on the Marias River was $28.9 \mathrm{C}(84 \mathrm{~F})$.

Water temperatures were monitored from 1976 through 1979 at Fort Benton, Coal Banks Landing, and Robinson Bridge. The Marias River was monitored from 1977 through 1979, and Morony Dam was monitored only in 1977.

Water temperature at the Coal Banks Landing and Robinson Bridge stations from late July through early November 1976 averaged 0.22 and $0.17 \mathrm{C}(0.4$ and $0.3 \mathrm{~F})$ degrees higher, respectively, than the Fort Benton station. The mean diurnal differences between the average maximum and average minimum water temperatures were $2.52,2.26$ and $1.26 \mathrm{C}(4.53,4.07$ and $2.26 \mathrm{~F})$ degrees for the Fort Benton, Coal Banks Landing, and Robinson Bridge stations, respectively. 
Table 1. Stream gradients of the middle Missouri River from Morony Dam to Fort Peck Reservoir. Confluence of the Missouri River with the normal flood pool of Fort Peck Reservoir is kilometer 0.0 .

\begin{tabular}{|c|c|c|c|c|}
\hline $\begin{array}{l}\text { River } \\
\text { Ki lometer }\end{array}$ & $\begin{array}{l}\text { Approximate } \\
\text { Location } \\
\end{array}$ & $\begin{array}{l}\text { Elevation } \\
\text { (meters, ms l) }\end{array}$ & $\begin{array}{l}\text { Gradient } \\
(\mathrm{m} / \mathrm{km})\end{array}$ & $\begin{array}{l}\text { Gradient } \\
(\mathrm{ft} / \mathrm{mi})\end{array}$ \\
\hline $\begin{array}{l}333.1 \\
331.9 \\
330.2 \\
326.8 \\
323.7 \\
316.2 \\
309.2 \\
304.3 \\
297.7 \\
289.5 \\
282.2 \\
270.9 \\
261.5 \\
254.9 \\
240.4 \\
225.3 \\
203.7 \\
188.7 \\
173.0 \\
158.8 \\
148.2 \\
133.5 \\
113.3 \\
90.6 \\
65.6 \\
37.3 \\
0.0\end{array}$ & $\begin{array}{l}\text { Morony Dam } \\
\text { Belt Creek } \\
\text { Highwood Creek } \\
\text { Carter Ferry } \\
\text { Fort Benton } \\
\text { Marias River } \\
\text { Little Sandy Creek } \\
\text { Hole-in-the-Wall } \\
\text { Judith River } \\
\text { Stafford Ferry } \\
\text { Cow Island } \\
\text { Robinson Bridge } \\
\text { Fort Peck Reservoir }\end{array}$ & $\begin{array}{l}856.2 \\
853.4 \\
847.3 \\
841.2 \\
835.2 \\
829.1 \\
823.0 \\
816.9 \\
810.8 \\
804.7 \\
798.6 \\
792.5 \\
786.4 \\
780.3 \\
774.2 \\
768.1 \\
762.0 \\
755.9 \\
749.8 \\
743.7 \\
737.6 \\
731.5 \\
719.3 \\
707.1 \\
694.9 \\
688.5 \\
684.6\end{array}$ & $\begin{array}{l}- \\
3.11 \\
3.54 \\
1.77 \\
2.05 \\
0.79 \\
0.88 \\
1.21 \\
0.92 \\
0.75 \\
0.84 \\
0.54 \\
0.65 \\
0.92 \\
0.42 \\
0.40 \\
0.28 \\
0.40 \\
0.39 \\
0.44 \\
0.57 \\
0.42 \\
0.60 \\
0.53 \\
0.49 \\
0.39 \\
0.16\end{array}$ & $\begin{array}{r}- \\
16.41 \\
18.69 \\
9.34 \\
10.81 \\
4.19 \\
4.66 \\
6.41 \\
4.88 \\
3.95 \\
4.45 \\
2.84 \\
3.41 \\
4.88 \\
2.20 \\
2.13 \\
1.49 \\
2.13 \\
2.05 \\
2.30 \\
3.01 \\
2.20 \\
3.17 \\
2.82 \\
2.59 \\
2.08 \\
0.83\end{array}$ \\
\hline
\end{tabular}




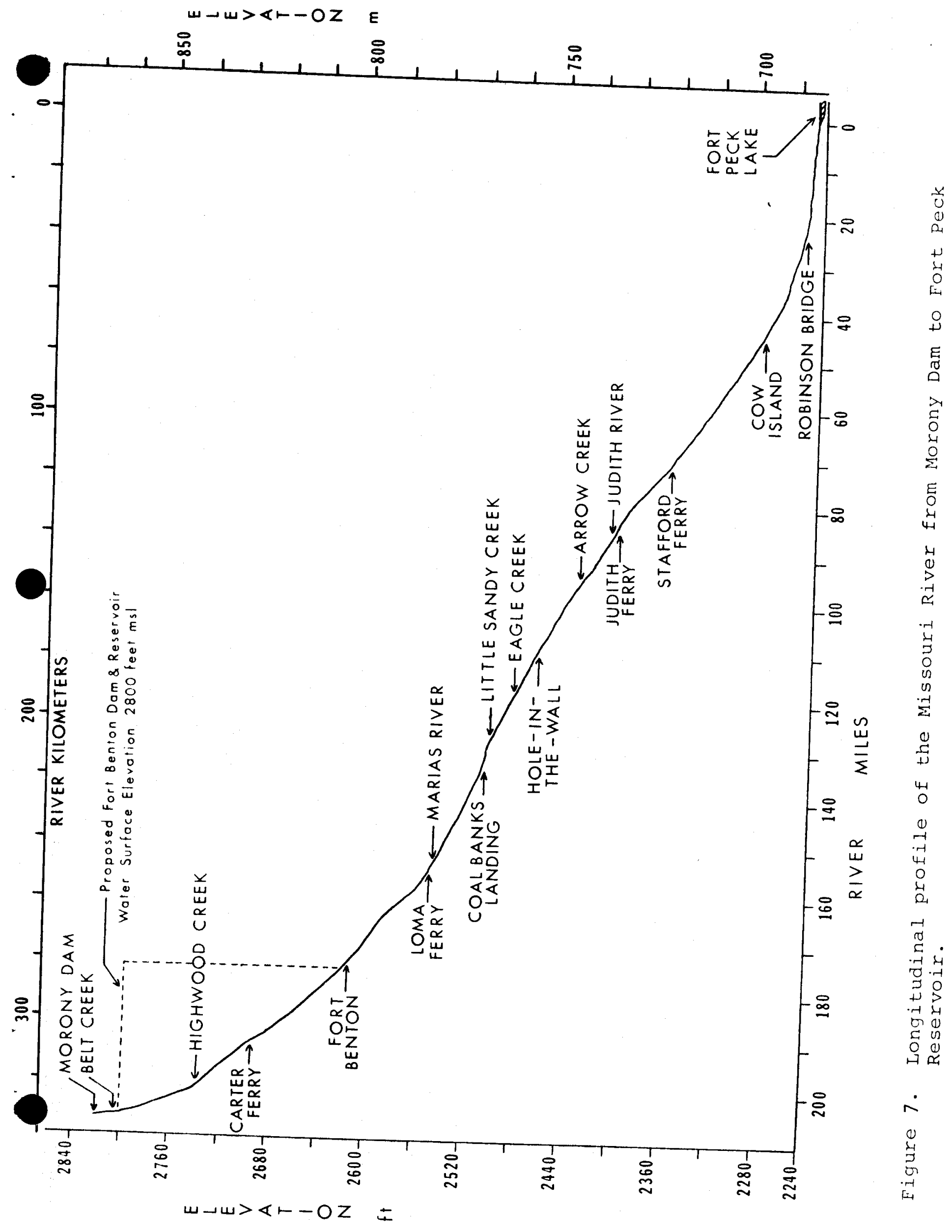


In 1977, water temperatures at the Coal Banks Landing and Robinson Bridge stations from mid-April through early November averaged 1.2 and 1.0 $C(2.1$ and $1.8 \mathrm{~F})$ degrees higher, respectively, than the Fort Benton station. At the Morony Dam station during 1977, a shorter period of record was available than for the other three Missouri River stations. However, during a period of record from early June through early September, 1977 , water temperature at the Morony Dam station averaged $3.7 \mathrm{C}(6.7 \mathrm{~F})$ degrees lower than the Fort Benton station. During 1977, the mean diurnal differences between the average maximum and average minimum water temperatures were $2.83,2.71,2.44$, and $2.14 \mathrm{C}(5.10,4.87,4.39$, and $3.86 \mathrm{~F})$ degrees for the Morony Dam, Fort Benton, Coal Banks Landing, and Robinson Bridge stations, respectively.

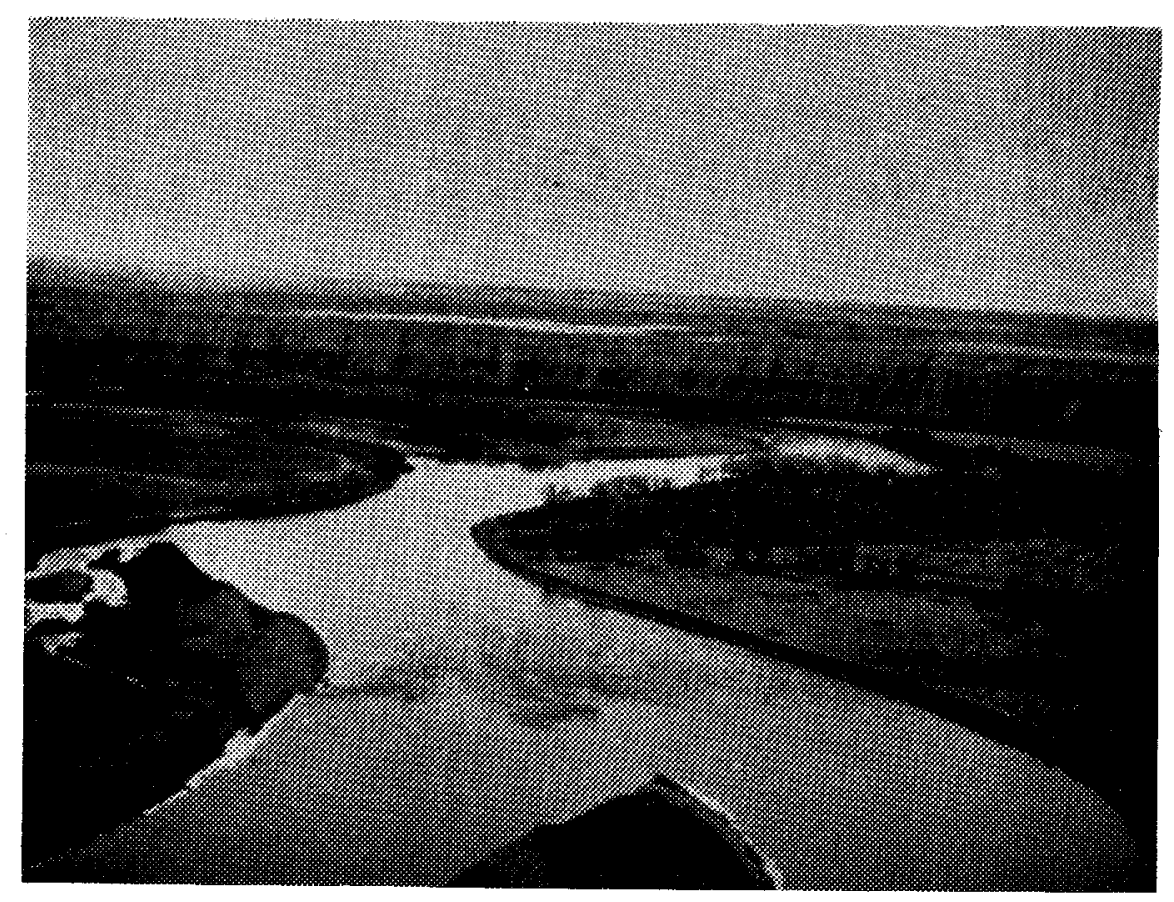

In 1978, water temperatures at the Coal Banks Landing and Robinson Bridge stations from late April through mid-October averaged 0.2 and $1.7 \mathrm{C}$ $(0.4$ and $3.1 \mathrm{~F})$ degrees higher, respectively, than the Fort Benton station. During the same period of record in 1979, water temperatures at the Coal Banks Landing and Robinson Bridge stations averaged $0.3 \mathrm{C}(0.5 \mathrm{~F})$ degrees lower and $0.9 \mathrm{C}(1.6 \mathrm{~F})$ degrees higher, respectively, then the Fort Benton station. The colder water temperatures in 1979 at the Coal Banks Landing and Robinson Bridge stations are due to relatively cooler water temperatures of the Marias River in 1979. The mean diurnal differences between the average maximum and average minimum water temperatures at the Fort Benton, Coal Banks Landing, and Robinson Bridge stations, respectively were 2.13, 1.59 , and $1.56 \mathrm{C}(3.83,2.87$, and $2.81 \mathrm{~F})$ degrees in 1978 and 2.38, 1.98, and $1.51 \mathrm{C}(4.28,3.57$, and $2.72 \mathrm{~F})$ degrees in 1979 .

The Marias River enters the Missouri River between the Fort Benton and Coal Banks Landing stations. The average temperature of the Marias River from 1ate April through mid-October was 16.8, 16.6, and 16.0 C (62.2, 61.9 , and $60.9 \mathrm{~F}$ ) in 1977, 1978, and 1979, respectively. By comparison 
the water temperature of the Missouri River upstream from the Marias River at Fort Benton averaged 15.5, 15.6, and $17.2 \mathrm{C}(59.8,60.0$, and $63.1 \mathrm{~F})$ during the same periods in 1977, 1978, and 1979, respectively. The Marias River had a warming influence on the Missouri River in 1977 and 1978 and a cooling influence in 1979. The reversal in 1979 was due to abnormally large amounts of cold water being released from the bottom of Tiber Reservoir. The Marias River normally has a warming influence on the Missouri River during the ice-free period. The mean diurnal difference between the average maximum and average minimum water temperature is greater on the Marias River than on the Missouri River. The diurnal difference was 4.12, 4.07, and $2.97 \mathrm{C}(7.42,7.33$, and $5.35 \mathrm{~F})$ degrees in 1977, 1978, and 1979, respectively. By comparison the diurnal difference on the Missouri River at Fort Benton was $2.71,2.13$, and $2.38 \mathrm{C}(4.87,3.83$, and $4.28 \mathrm{~F})$ degrees in the same years.

Water Quality

Basic water quality parameters were monitored at six stations on the middle Missouri River during 1978 and 1979. The stations were located at Ulm (above Great Falls), below Morony Dam, at Fort Benton, at Coal Banks Landing, at Judith Landing, and at Robinson Bridge. The latter five stations were study sites for aquatic macroinvertebrates and fish.

Sampling "runs" were made during four periods:

(1) Jow flow, warm water - early August 1978,

(2) low flow, cool water - middle October 1978,

(3) after ice-out, prior to spring runoff - early April 1979, and

(4) near the peak of spring runoff - middle June 1979.

Stream flow in the Missouri River was near normal in 1978 and 1979. Therefore, the water quality findings should be representative of average conditions. Results of the water quality analyses are shown in Table 2 .

In general, chemical constituent values progressively increased downstream at the six stations. Concentrations of most of the major ions, including calcium, magnesium, sodium, bicarbonate, and sulfate, were moderately high at all stations during all sampling periods. In general, the Missouri River contains two or three times more total dissolved solids than "average" river water as described by Livingstone (1963). However, the concentrations of two major ions, chloride and carbonate, were near normal on the Missouri River when compared to other rivers.

Reid (1961) developed the following classification scheme for potential biological productivity based on calcium ion concentration:

$\mathrm{Ca}^{++}$concentration

Less than $0.50 \mathrm{me} / 1$

$0.50-1.25 \mathrm{me} / 1$

Greater than $1.25 \mathrm{me} / 1$
Potential biological productivity

Poor

Medium

Rich

Calcium ion concentrations of the Missouri River during our sampling ranged from 1.796 to $3.942 \mathrm{me} / 1$. Therefore, by these criteria, the potentia] biological productivity of the Missouri River in the study area is very good. 


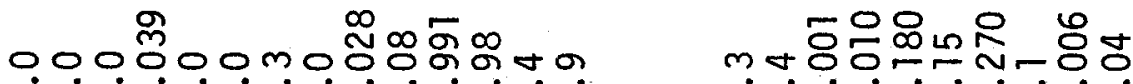
نூ

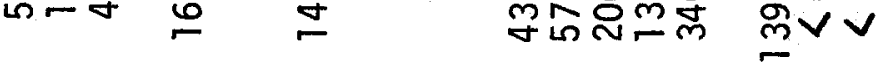

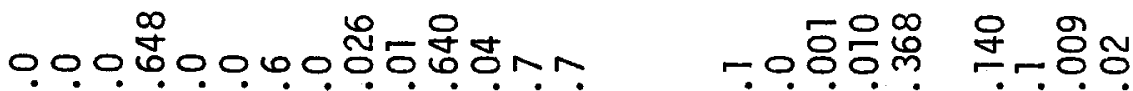

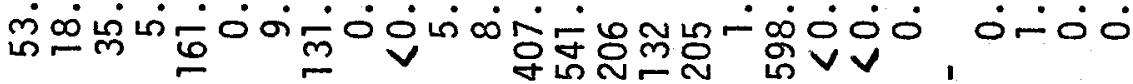

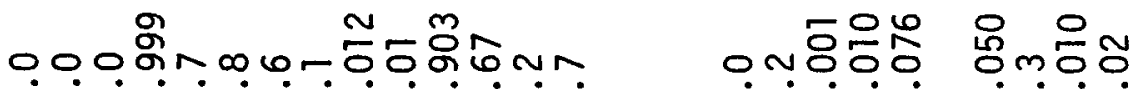
近官

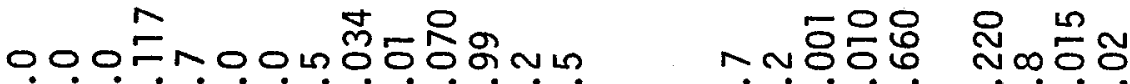

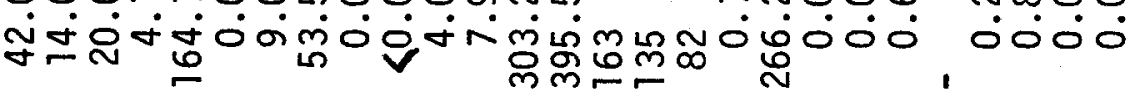

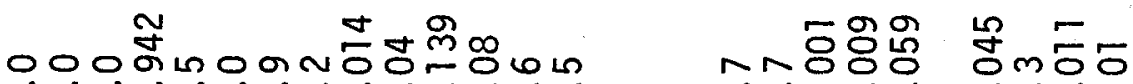
ஏற㇒冋்

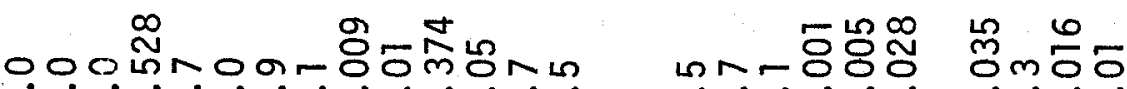

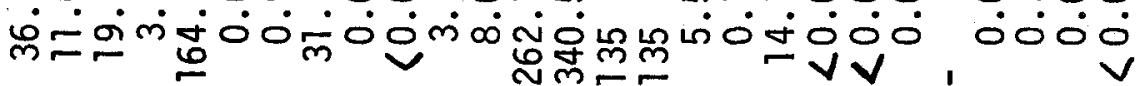




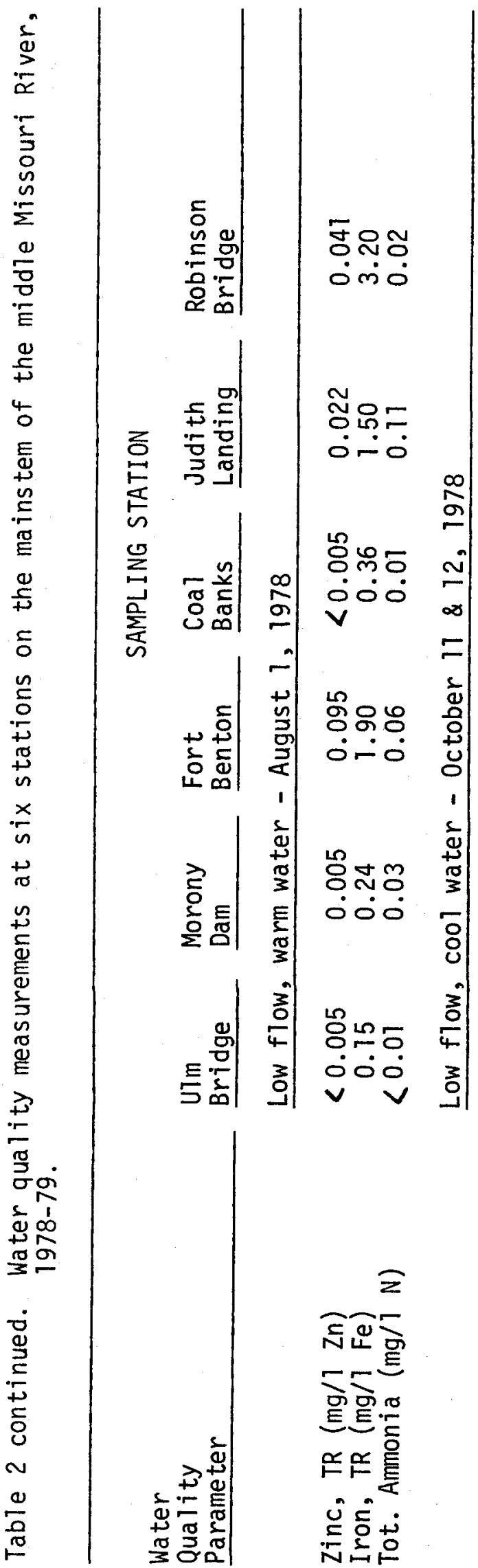

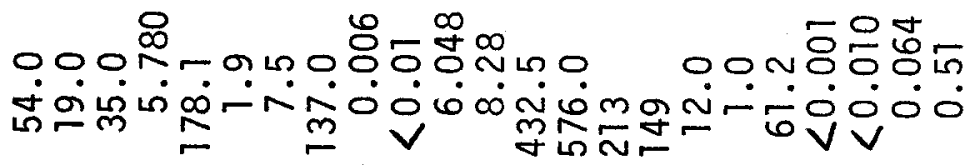

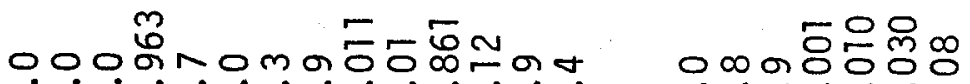
迥宁

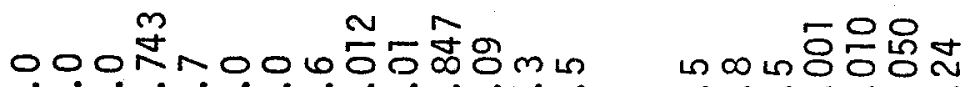
逐过

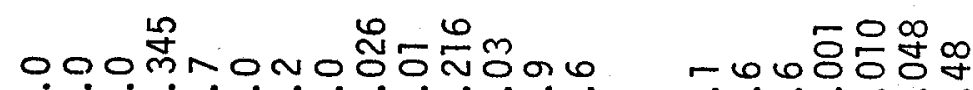
ம்மீه

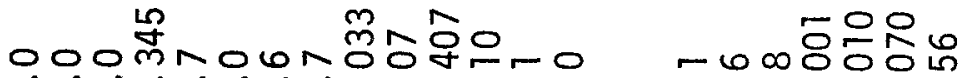

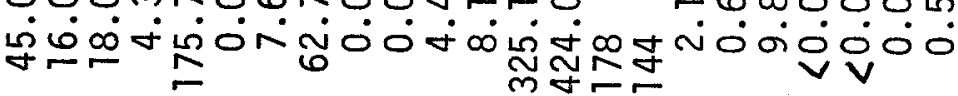
$000 \frac{1}{4}+0 \infty \pi$ 㟧 醮 


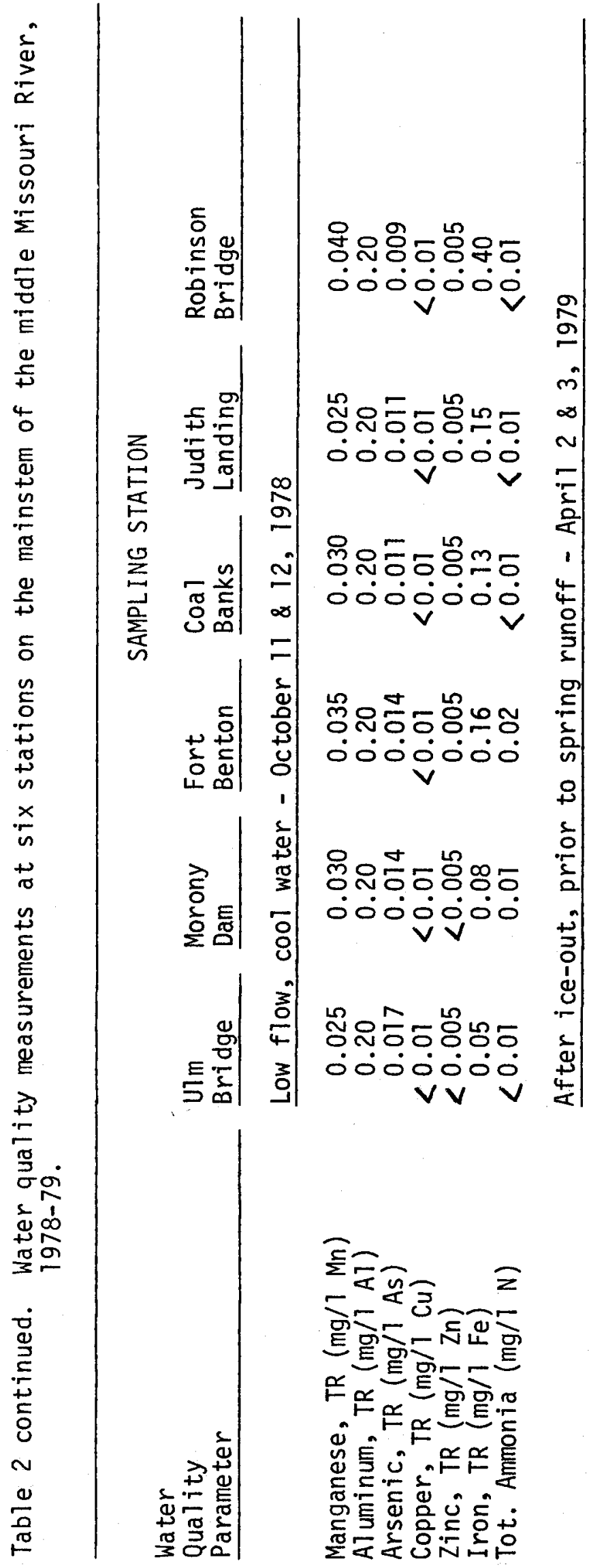

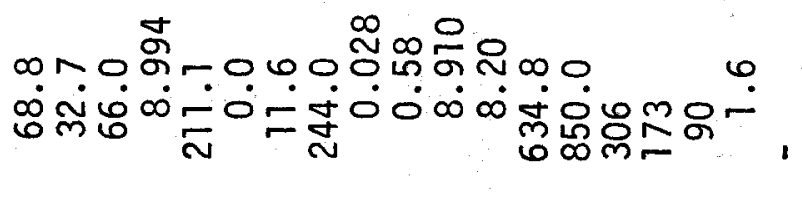

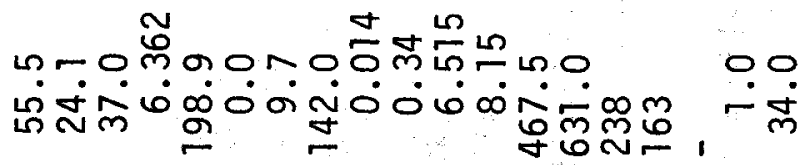

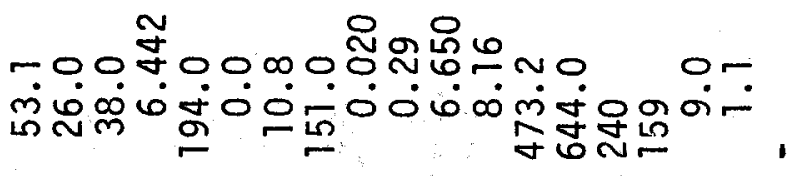

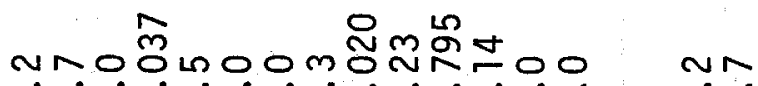

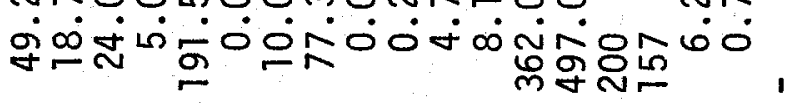

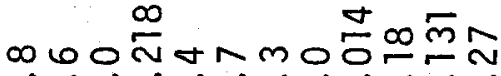

min்

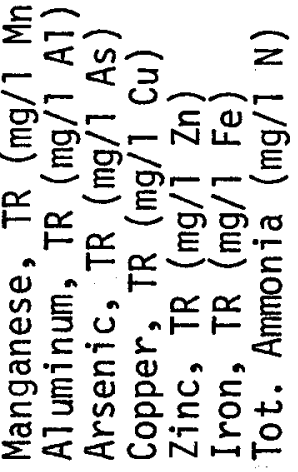

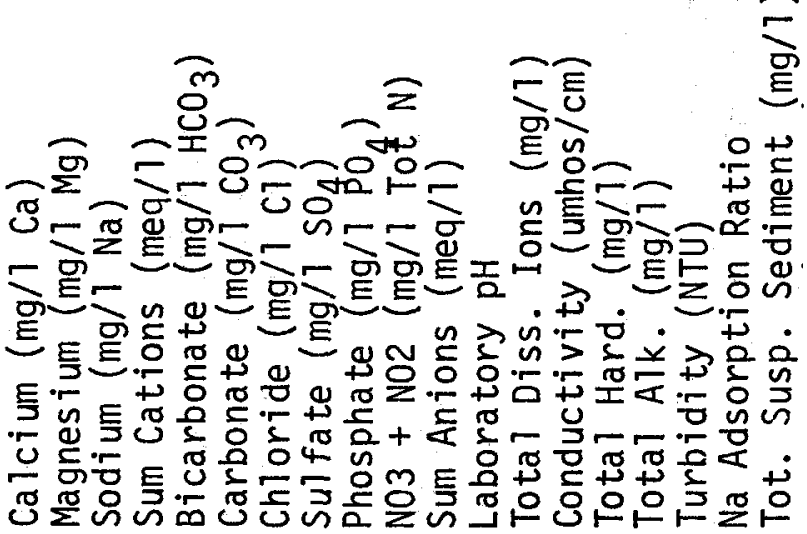




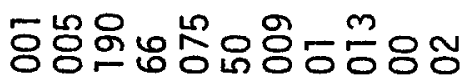

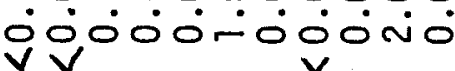

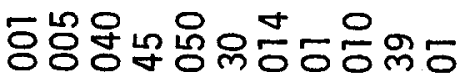
نं00000ं000

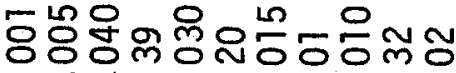
ऽं00ं000்000

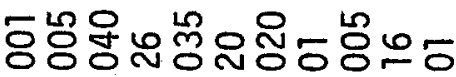
00000000000 VV VVV

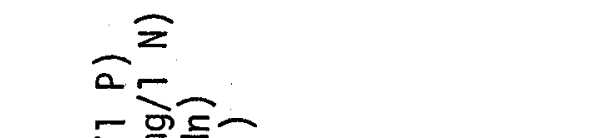

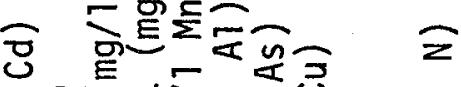
-ล

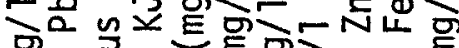
E一 को

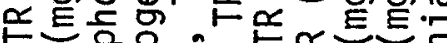

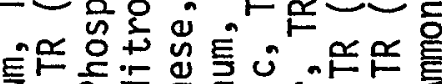

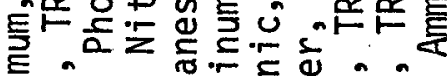

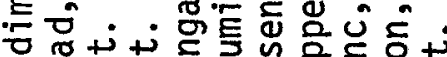
r \& 0 으의

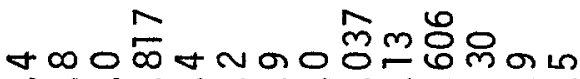
ம்

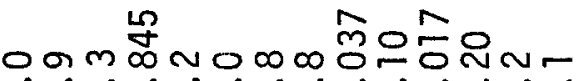

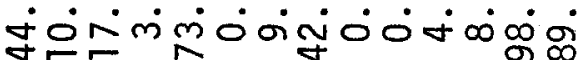

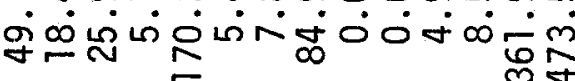

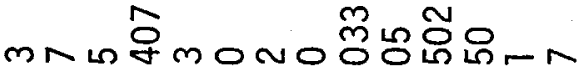
gं大் ம்

ヘ

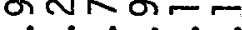

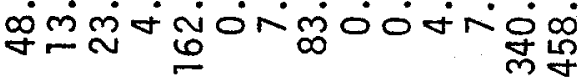

F⿻一 \&

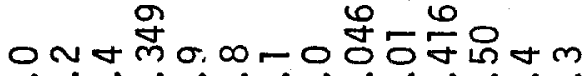

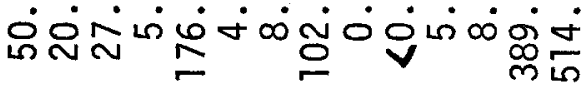

m+a은

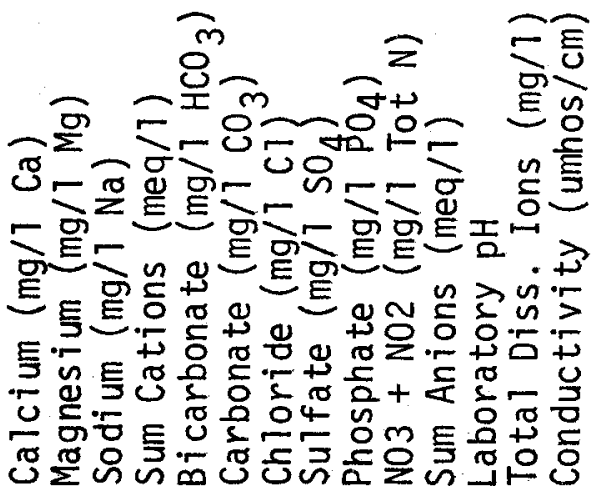




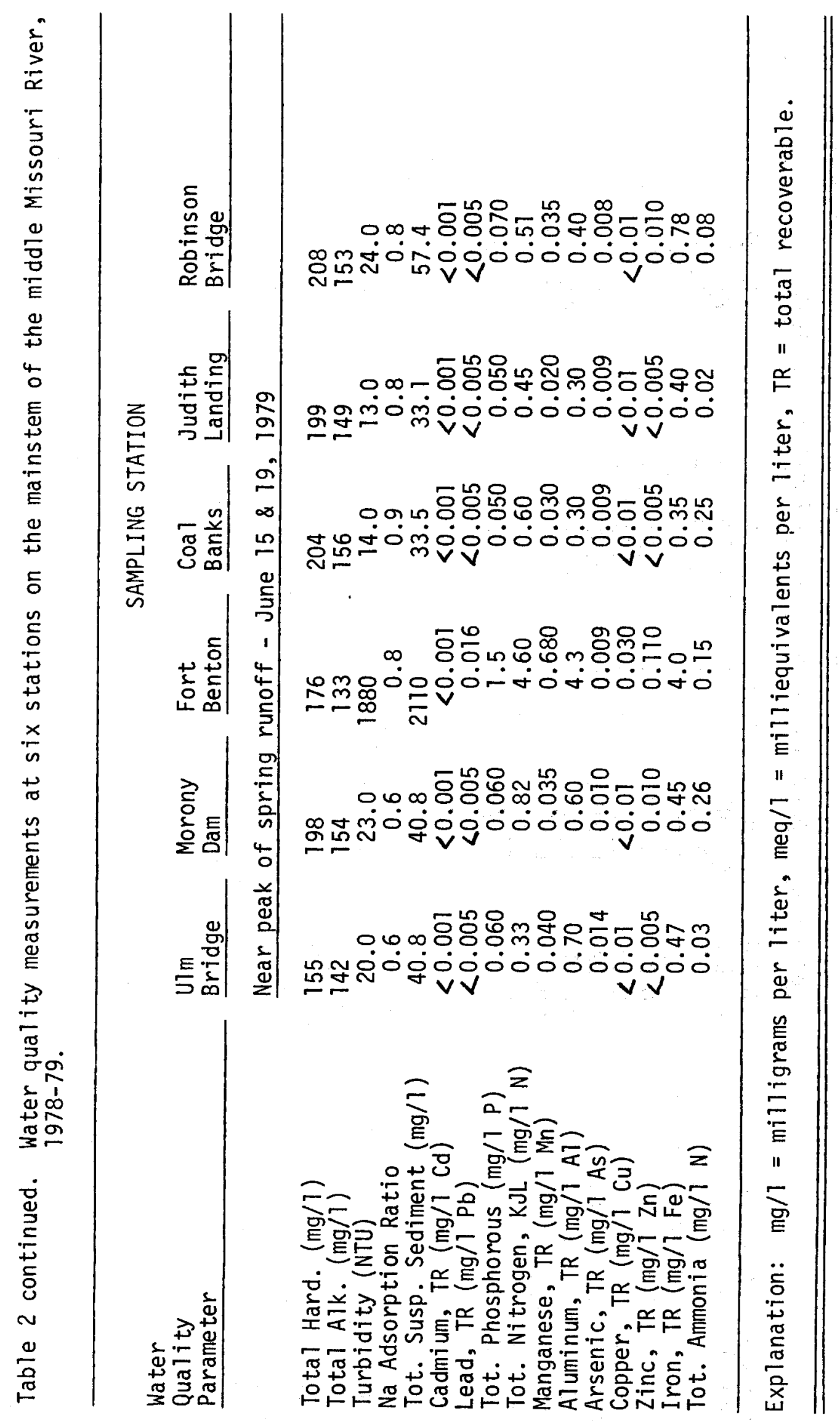


Inorganic nitrogen and phosphorous are generally recognized as having an influence on primary production in streams and lakes (Sawyer 1948, Chu 1942, Curry and Wilson 1955). Organic nitrogen, amino acids, and ammonia may inhibit biological growth whereas nitrates and phosphates stimulate phytoplankton (Chu 1942, Sawyer 1948). Nuisance growth of algae in flowing waters usually does not occur until total soluble inorganic nitrogen exceeds $0.35 \mathrm{mg} / 1$ and total phosphorous (as P) exceeds $0.05 \mathrm{mg} / 1$. Both nitrogen and phosphorus must exceed these amounts for problems to develop. No clear conclusion can be made about the limiting nutrient for productivity in the middle Missouri River (Loren Bahls, Montana Department of Health and Environmental Sciences, personal communication).

During the winter of 1978-79, a major sewage pipeline break occurred on the Missouri River at Great Falls. It appears that the consequences of this break may be reflected to some extent in the relatively higher nitrogen concentration levels in early April and mid-June, 1979, at the five stations below Great Falls. However, the nitrogen concentrations were still generally below the maximum suggested permissible levels.

Even before the pipeline break, some nitrogen enrichment of the Missouri River was observed in the Great Falls area between U1m and Morony Dam. A slight increase in nitrates, nitrites, and total nitrogen was evident in early August and mid-October, 1978, at the Morony Dam station immediately below Great Falls. However, the increase was not significant, and nitrogen levels were below the maximum suggested permissible levels.

Concentrations of trace elements and heavy metals (copper, lead, zinc, etc.) were within acceptable limits for all six stations. Concentrations of aluminum, zinc, and iron increased significantly following heavy rainstorms and during spring runoff, while the concentrations of other trace elements did not increase significantly.

\section{FINDINGS - MACROINVERTEBRATES}

Missouri River

Aquatic macroinvertebrate sampling was conducted at five study sites on the middle Missouri River from late October, 1976, through mid-September, 1977. The sites were located at Morony Dam, Fort Benton, Coal Banks Landing, Judith Landing, and Robinson Bridge. The Morony Dam, Fort Benton, and Coal Banks Landing sites were sampled on eight occasions at approximately six-week intervals. Because of channel ice, the Judith Landing and Robinson Bridge sites were sampled on seven and six occasions, respectively.

A total of 59,135 macroinvertebrates, representing 13 orders and at least 40 families, was collected during the study. The number of macroinvertebrates collected per kick sample ranged from 62 to 9,200 (Appendix Tables 18-22). Diptera, Ephemeroptera, Trichoptera and Plecoptera comprised $37,32,18$, and 2 percent of the macroinvertebrates collected, respectively. (Table 3 ). The average number of subordinal taxa ranged from 18.4 at Robinson Bridge to 24.7 at Fort Benton.

\section{Ephemeroptera (Mayflies)}

The numerical percentage of mayflies, averaging all sampling dates, ranged from 19 percent at Fort Benton to 52 percent at Robinson Bridge (Table 3). Mayflies were the most common order at Judith Landing and Robinson Bridge. There were approximately twice as many mayflies at the Judith Landing and 


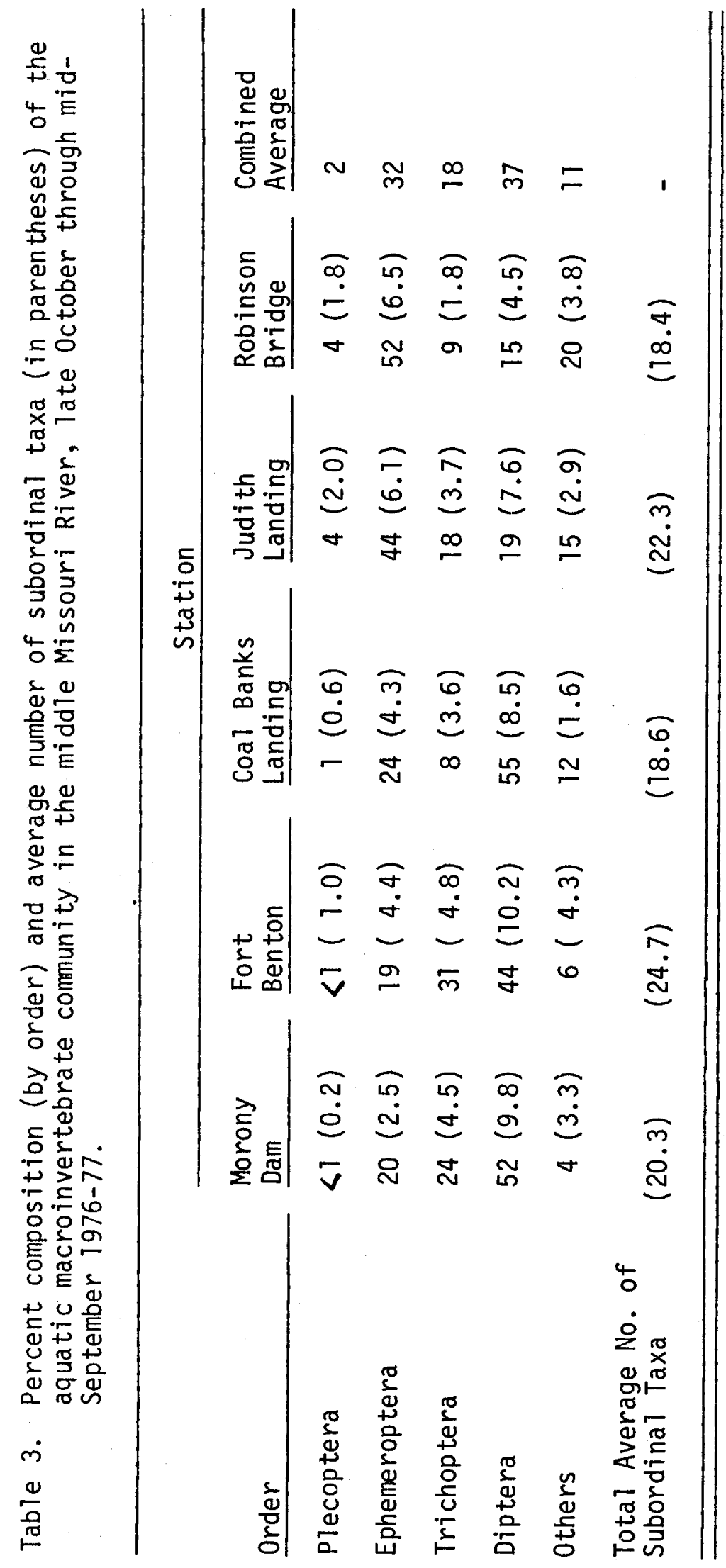


Robinson Bridge sites as there were at the upper three sampling sites. The lower two sampling sites, Judith Landing and Robinson Bridge, also exhibited the greatest mayfly diversity, with 9 and 11 genera, respectively (Table 4).

A total of 13 mayfly genera were collected in the study area. Tricorythodes, Ephemerelza, Rhithrogena, Stenonema, Heptagenia, and Baetis were the most common and widely distributed genera. Traverezza and Ephoron were not common in the kick samples; however, large numbers of these species were observed emerging from the river as adults during summer 1977 at the lower three sampling sites. Hornung and Pollard (1978) also found underrepresentation of Traverezla in kick samples. They concluded that Traverelza was not effectively sampled by the kick technique because of $i$ ts close attachment to the substrate. Ephoron, a burrowing mayfly, is also difficult to dislodge from the substrate and collect in kick samples (Merritt and Cummins 1978). The occurrence of Baetisca at Coal Banks Landing was an anomaly, probably the result of drift from the Marias River where it is common.

\section{Plecoptera (Stoneflies)}

The numerical percentage of stoneflies, averaging all sampling dates, ranged from less than 1 percent at Morony Dam and Fort Benton to 4 percent at Judith Landing and Robinson Bridge (Table 3). Stoneflies were similar to mayflies in being significantly more abundant at Judith Landing and Robinson Bridge than the upper three sampling sites. The Judith Landing and Robinson Bridge sites also exhibited the greatest stonefly diversity with five and four genera, respectively (Table 4).

A total of five stonefly genera were collected in the study area. Isoperia, the most widely distributed genus, was common at all sites except Morony Dam. Isogenus was collected at all sites except Morony Dam; however, it was common only at Judith Landing. The remaining three stonefly genera were rare.

\section{Trichoptera (Caddisflies)}

The numerical percentage of caddisflies, averaging a17 sampling dates, ranged from 8 percent at Coal Banks Landing to 31 percent at Fort Benton (Table 3). Caddisflies were significantly more abundant at Morony Dam and Fort Benton than the lower three sampling sites. The Morony Dam site exhibited the greatest caddisfly diversity with eight genera (Table 4 ).

Nine caddisfly genera were collected in the study area. Hydropsyche was the most abundant and widely distributed genus, followed by Chermatopsyche, Brachycentrus, and oecetis. Hydroptila was sampled regularly from Morony Dam to Coal Banks Landing. Leuchotrichia, Psychomyia, and Amiocentrus were rare, found only at Morony Dam. The occurrence of Heliopsyche at Coal Banks Landing was an anomaly, probably the result of drift from the Marias River where it is common.

\section{Diptera (Trueflies)}

The numerical percentage of trueflies, averaging all sampling dates, ranged from 15 percent at Robinson Bridge to 55 percent at Coal Banks Landing (Table 3). Trueflies were numerically the most common order at Morony Dam, Fort Benton, and Coal Banks Landing. There was more than a twofold increase 


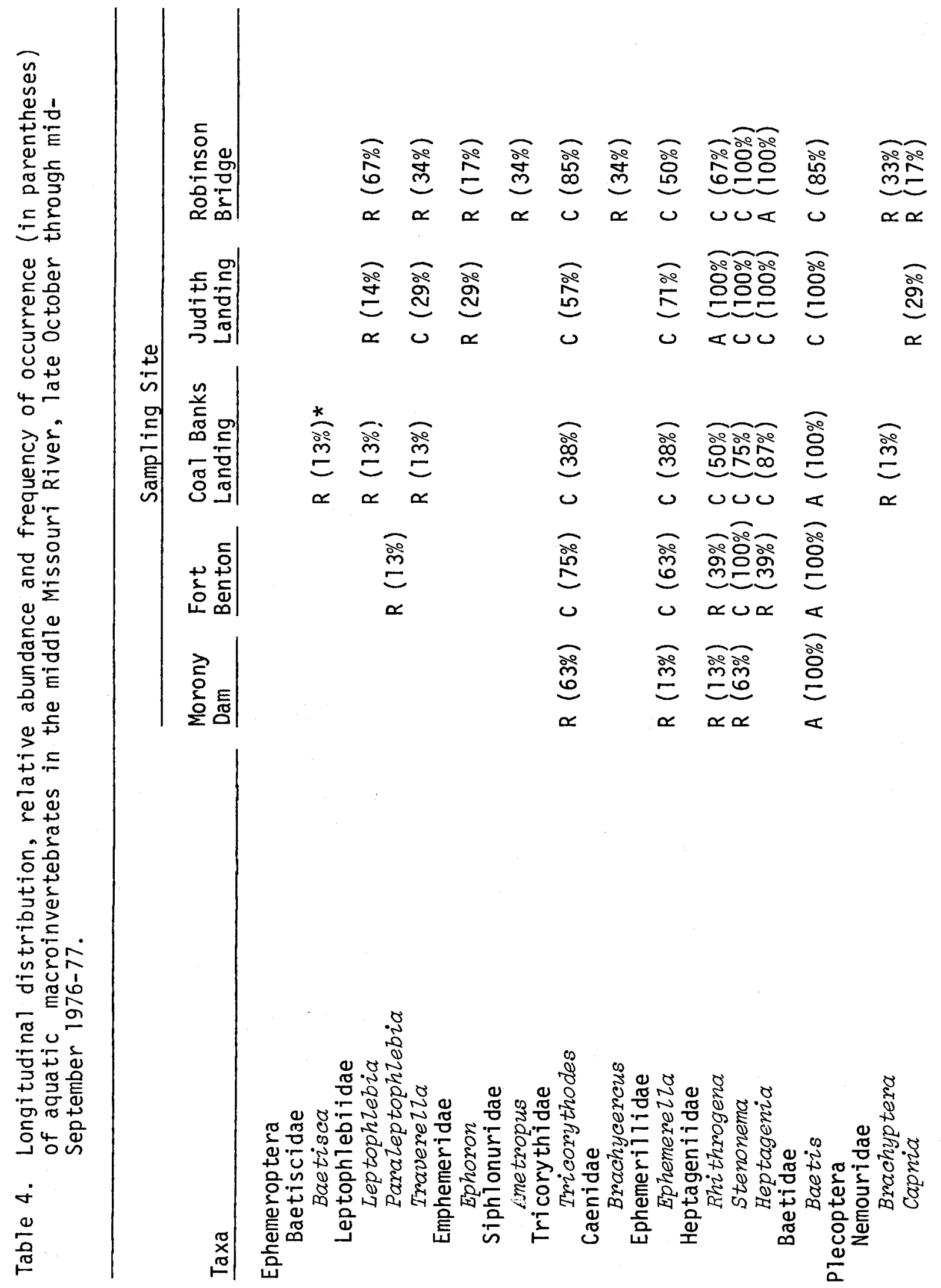




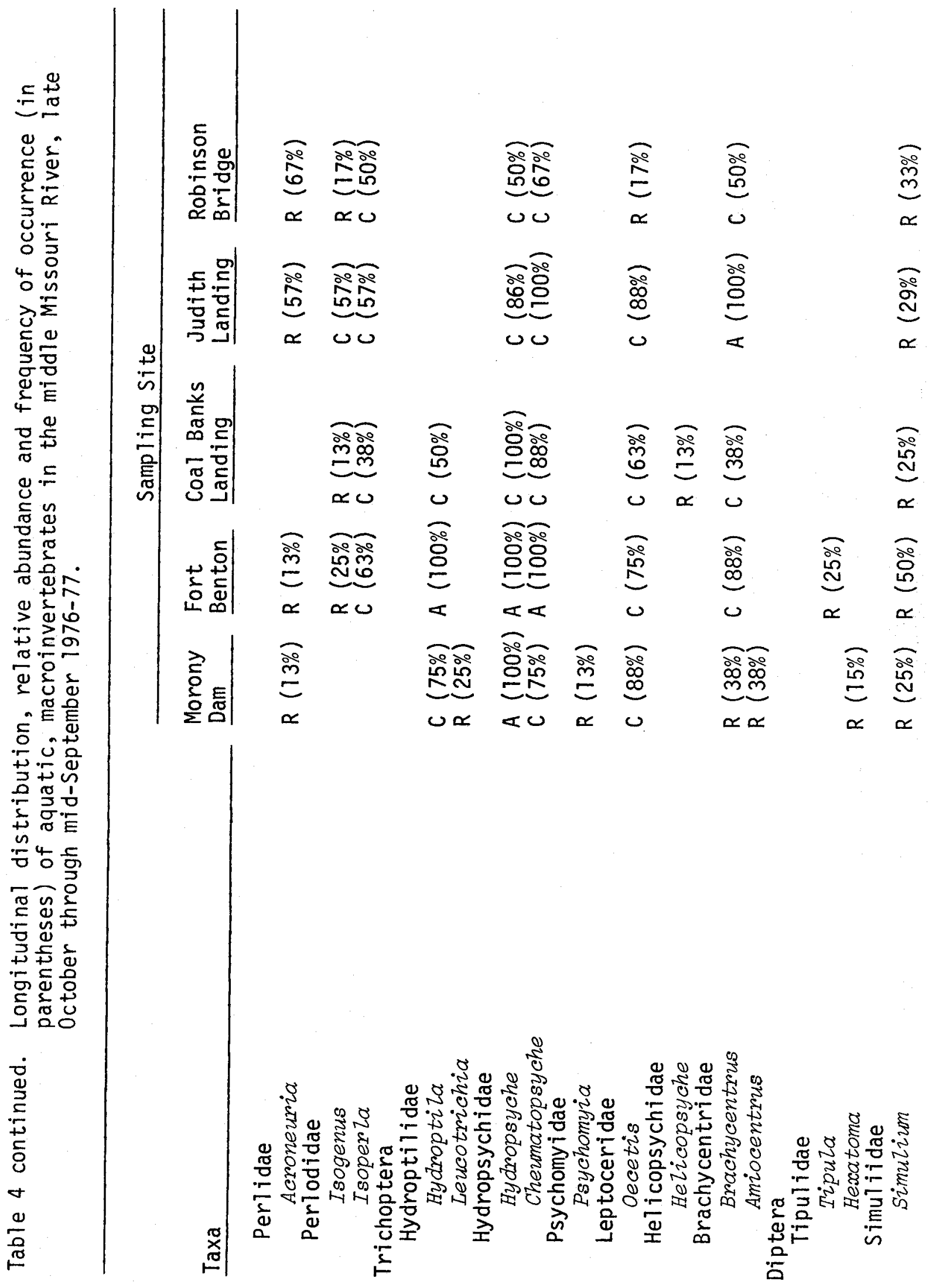




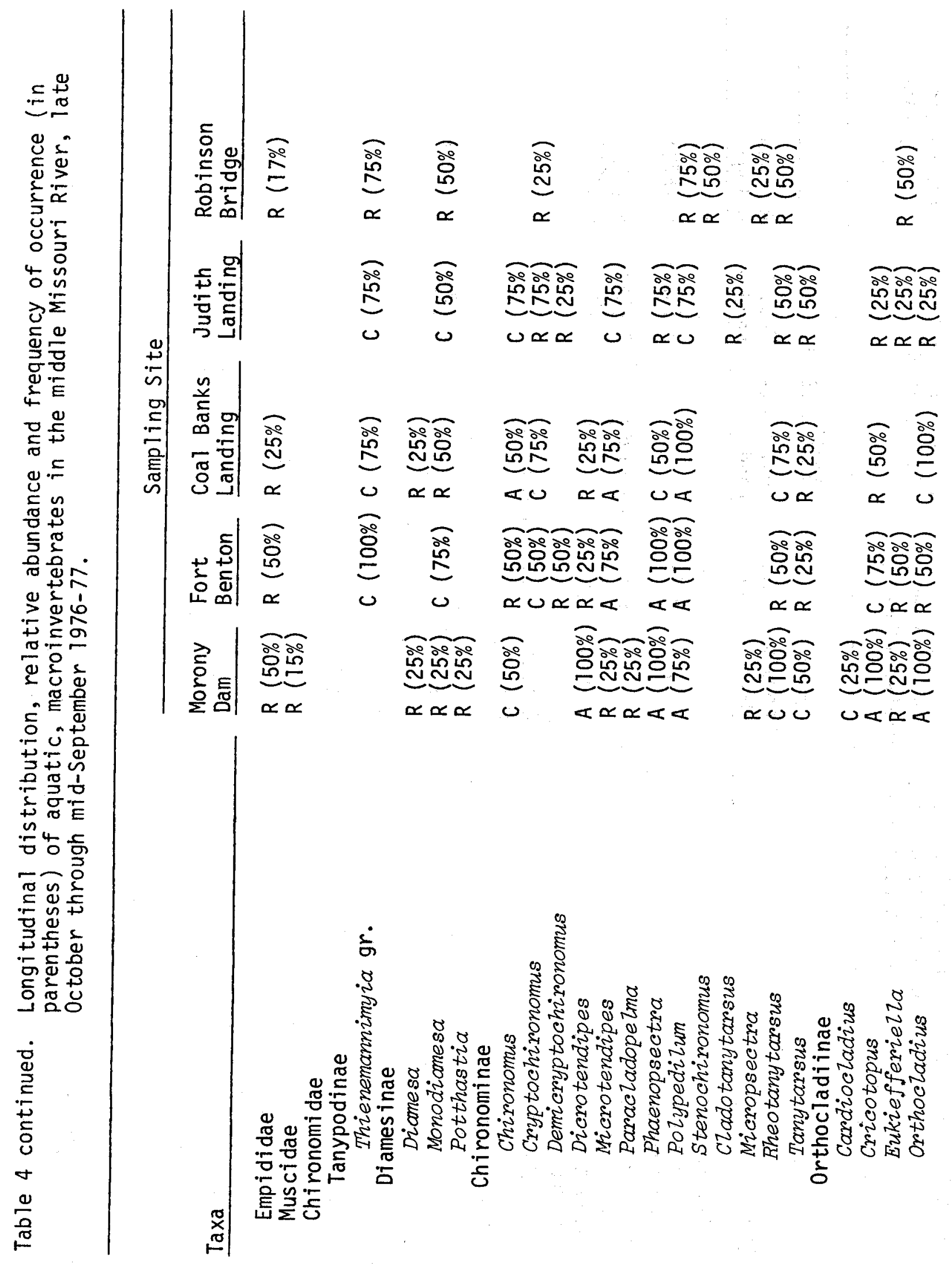



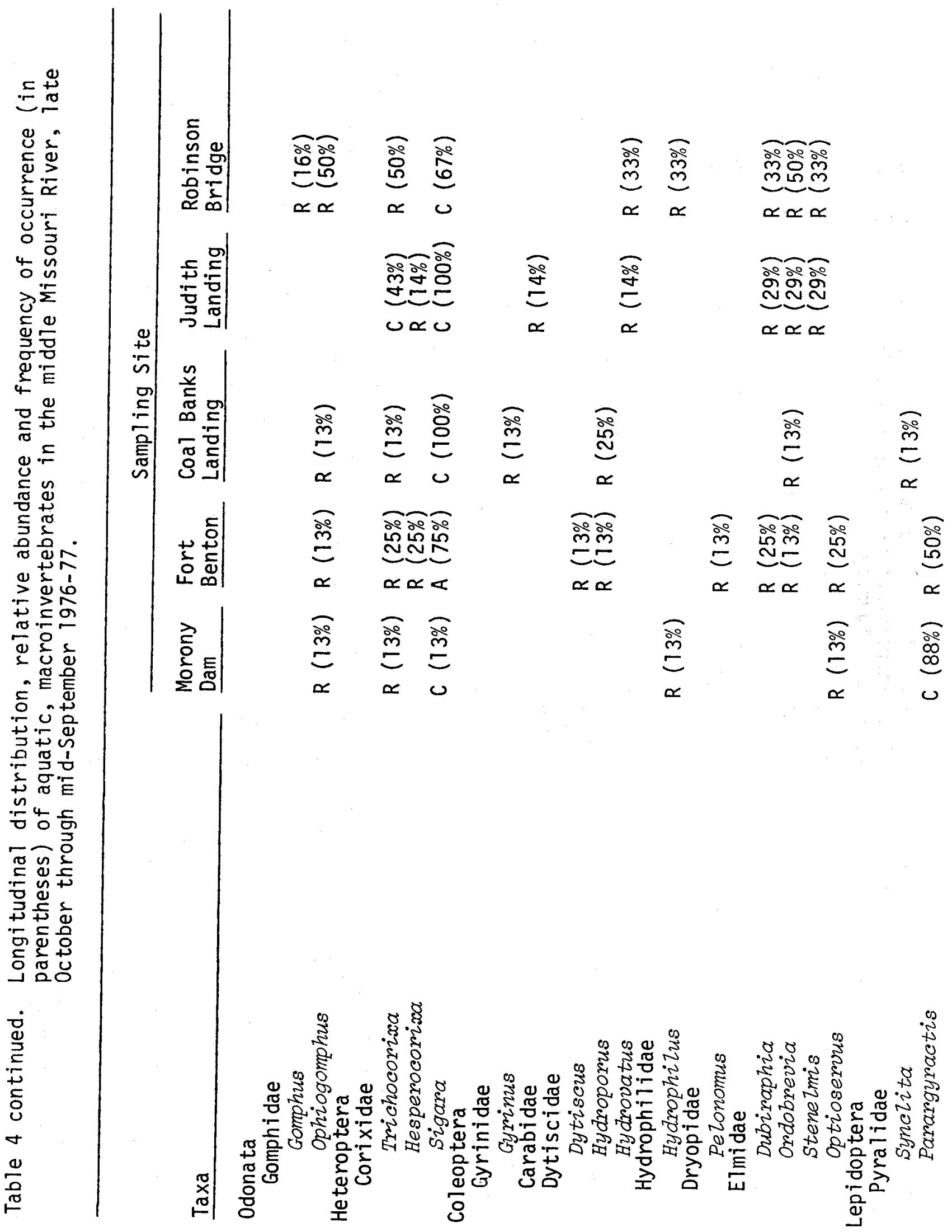


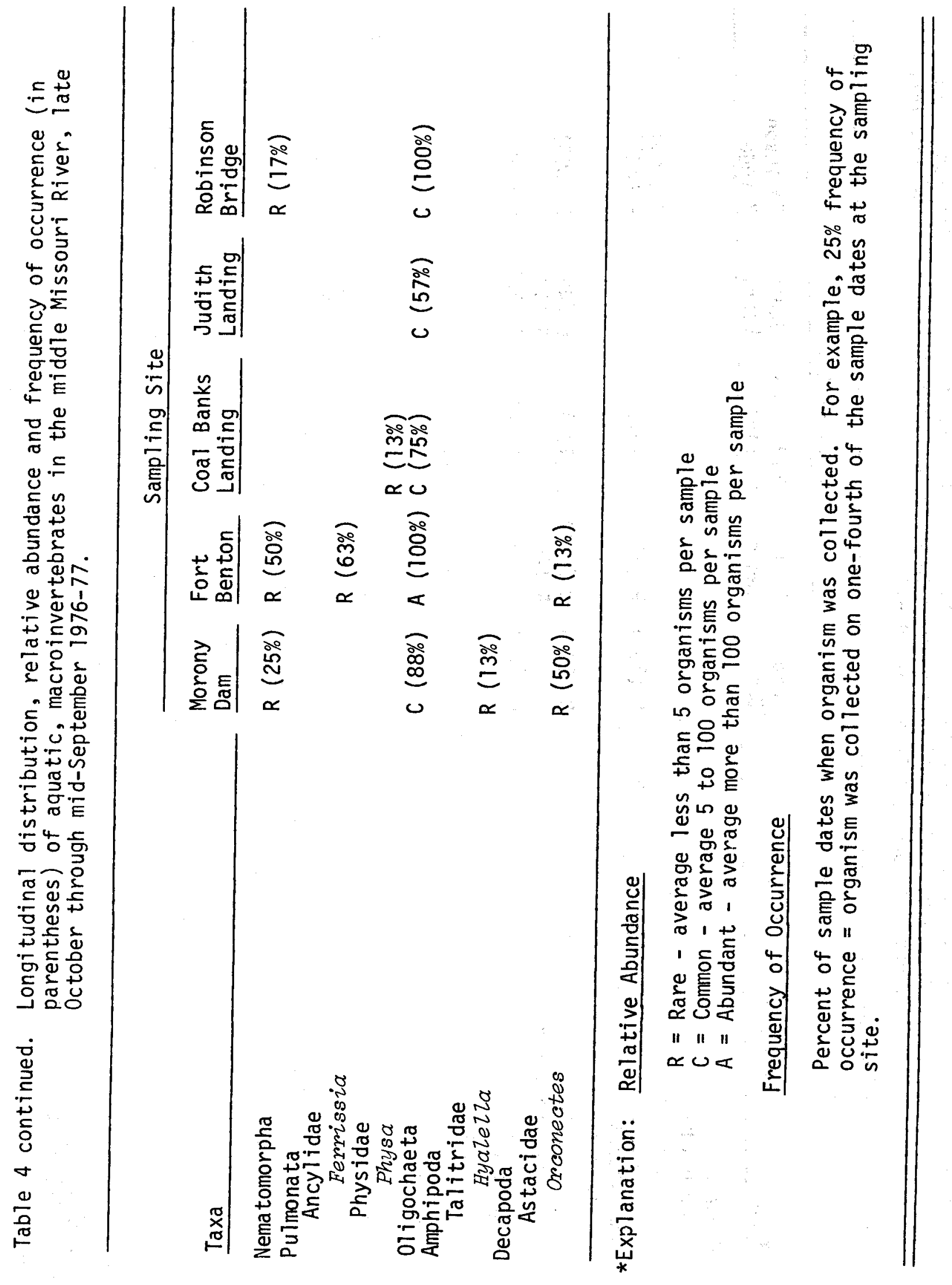




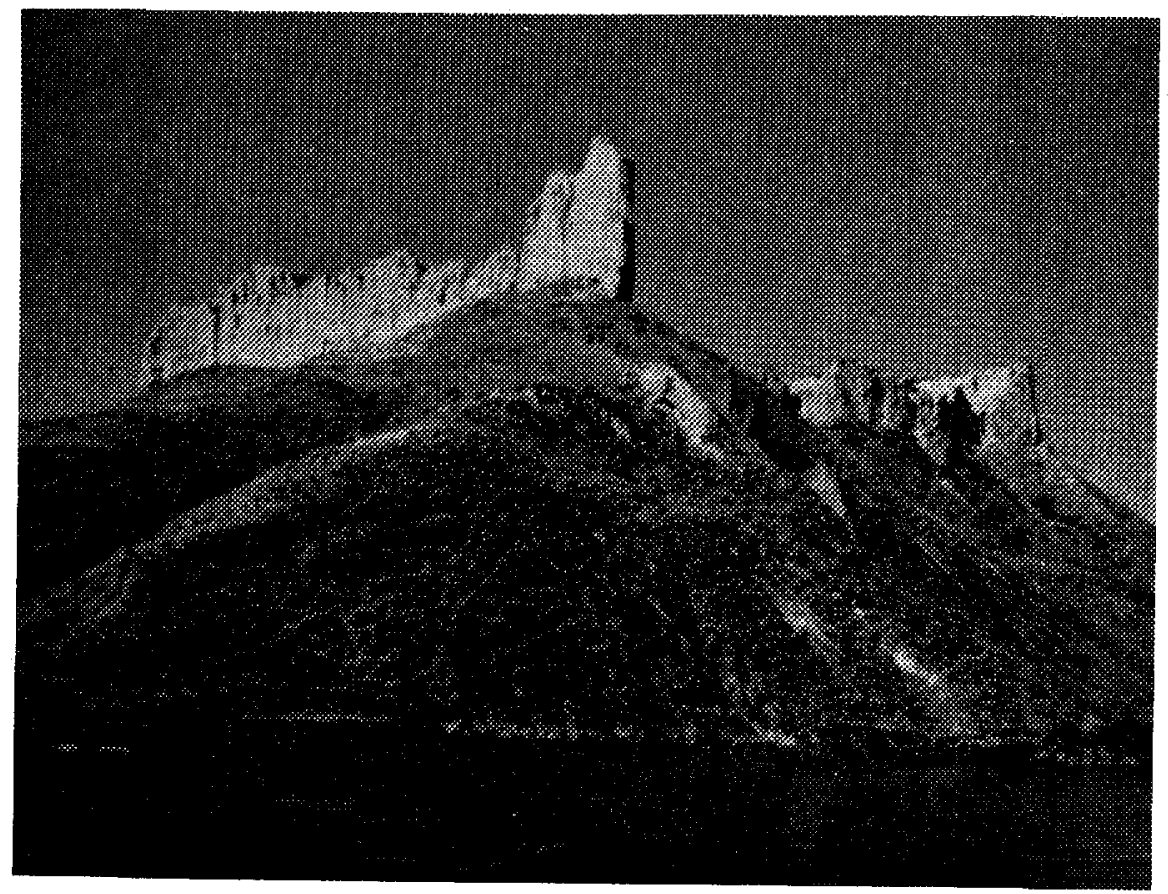

in trueflies at these three sites compared to Judith Landing and Robinson Bridge. The Morony Dam site exhibited the greatest truefly diversity with 20 subordinal taxa (Table 4). Robinson Bridge exhibited the least diversity with 10 subordinal taxa. However, truefly diversity (particularly chironomid diversity) was probably underestimated at Robinson Bridge because of sampling problems.

Twenty-six subordinal taxa of trueflies were collected in the study area. Chironomus, Microtendipes, Phaenopsectra, Polypedizum, and Rheotanytarsus were the most common and widely distributed genera. Potthastia, Paracladopelma, Micropsectra, Cardiocladius, Hexatoma and Muscidae were collected only at Morony Dam. In contrast, Thienemannimyia gr. and Cryptochironomus were sampled regularly at all sites except Morony Dam.

Sixteen of the 21 subordinal taxa of trueflies collected in the study area were from the Chironomidae family. At Morony Dam, Cricotopus, Orthocladius, and to a lesser extent, Phaenopsectra, and Dicrotendipes were clearly the predominant chironomids. At Fort Benton, a notable change in chironomids occurred, and Microtendipes, Phaenopsectra, Polypedizum, and Thienemannimyia gr. were the most common taxa. This chironomid fauna essentially persisted throughout the lower three study sites. However, the attenuation of chironomids below Coal Banks Landing was apparent.

The chironomid fauna at the five sites sampled in this study is typical of large western Montana rivers on the east slope of the Continental Divide (Richard Oswald, Montana State University, personal communication). The change in the taxonomic composition of chironomids between Morony Dam and the four stations downstream is probably related to water temperature. Water temperature at Morony Dam from early June through early September, 1977, averaged 3 to $5 \mathrm{C}$ degrees cooler than the downstream study sites. Several possible effects of the cooler water temperature at Morony Dam were observed: 
(1) Diamesa were present in large numbers at Morony Dam in June and virtually absent from the downstream stations. Diamesa is a coldwater form which emerges in early spring from most streams.

(2) Potthastia, another coldwater form, was found only at the Morony Dam site.

(3) Orthocladiinae dominated over Chironominae during the cooler months at Morony Dam, while Chironominae dominated at the lower four study sites. Orthocladiinae typically dominate over Chironominae in cooler water and vice-versa in warmer water (Richard Oswald, Montana State University, personal communication).

(4) The two dominant Chironominae at Morony Dam, Dicrotendipes and Phaenopsectra, prefer cool water.

(5) Polypedizum, a warmwater form, was very common at the lower study sites throughout the spring and summer, but significant numbers were not observed at Morony Dam until August.

(6) The Thienemannimyia group, which prefers warmwater was totally absent from the Morony Dam site.

\section{Other Macroinvertebrate Orders}

The longitudinal distribution, relative abundance and frequency of occurrence for the remaining orders of macroinvertebrates sampled in the Missouri River are shown in Table 4. Two heteropterans (Sigara and Trichocorixa), a coleopteran family (Elmidae), and the order 0ligochae ta were collected at all five sampling sites. The crayfish, Orconectes, was sampled regularly at Morony Dam and occasionally at Fort Benton.

\section{Discussion}

The structure of the aquatic macroinvertebrate community at Morony Dam was relatively simple compared to the four downstream study sites (Figure 8). Macroinvertebrate diversity increased progressively in a downstream direction. The Judith Landing and Robinson Bridge sites had the greatest diversity and the most "stable" community structure (Table $5)$.

A possible explanation for the community change between Morony Dam and the downstream sites is the apparent scarcity of good substrate for macroinvertebrate production at Morony Dam. At the Morony Dam sampling site, most of the substrate was comprised of flat rocks and bedrock. Hynes (1970) concluded that substrate is a major factor influencing distribution and abundance of aquatic macroinvertebrates.

The series of hydropower dams immediately upstream from the Morony Dam sampling site may also have an effect on the macroinvertebrate community. The dams may act as barriers to natural colonization (drift) of the macroinvertebrates.

Also, diurnal fluctuations of stage height in the river below the hydropower dams are more severe at the Morony Dam sampling site than at the downstream sites. This fluctuation could disrupt the macroinvertebrate 


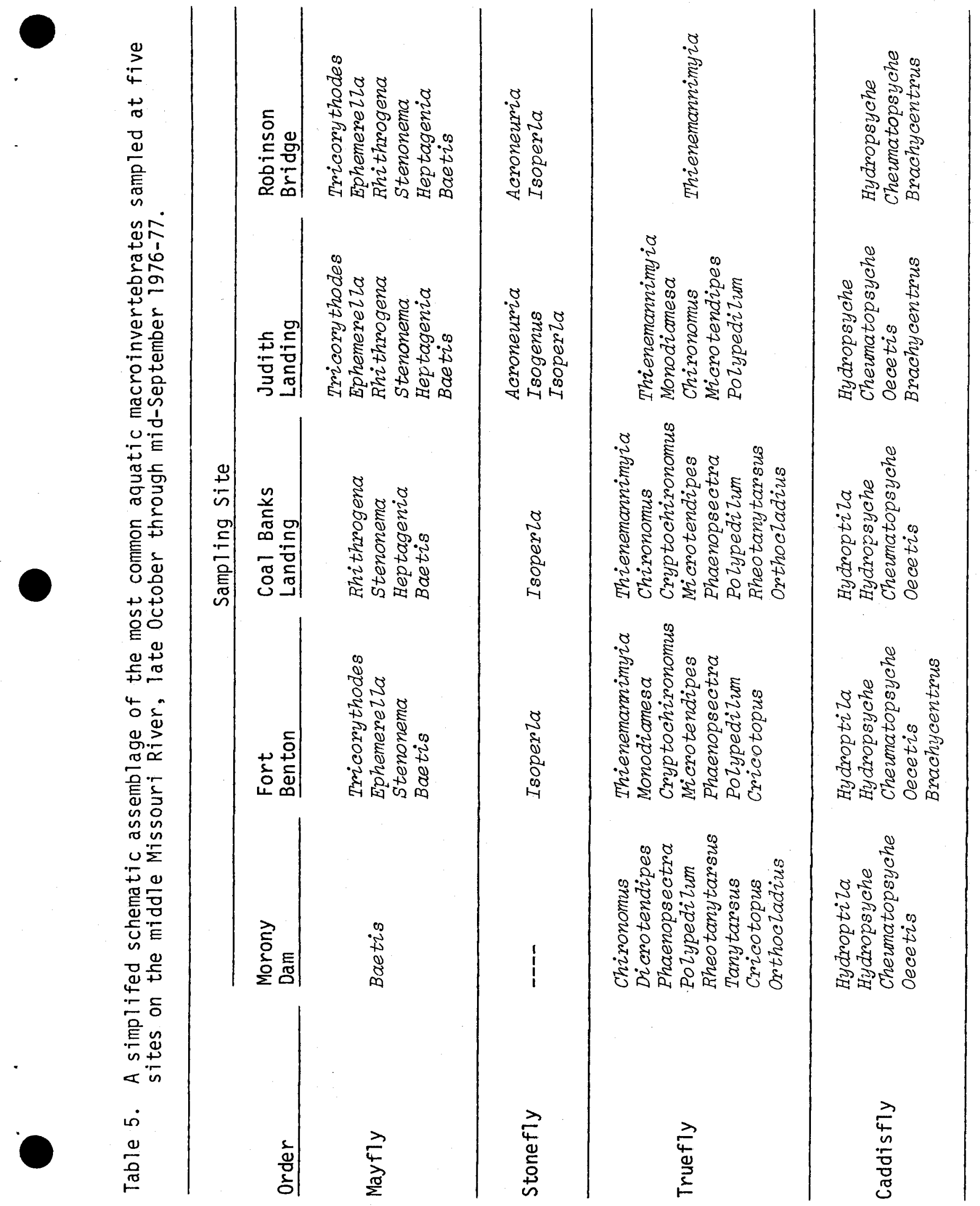




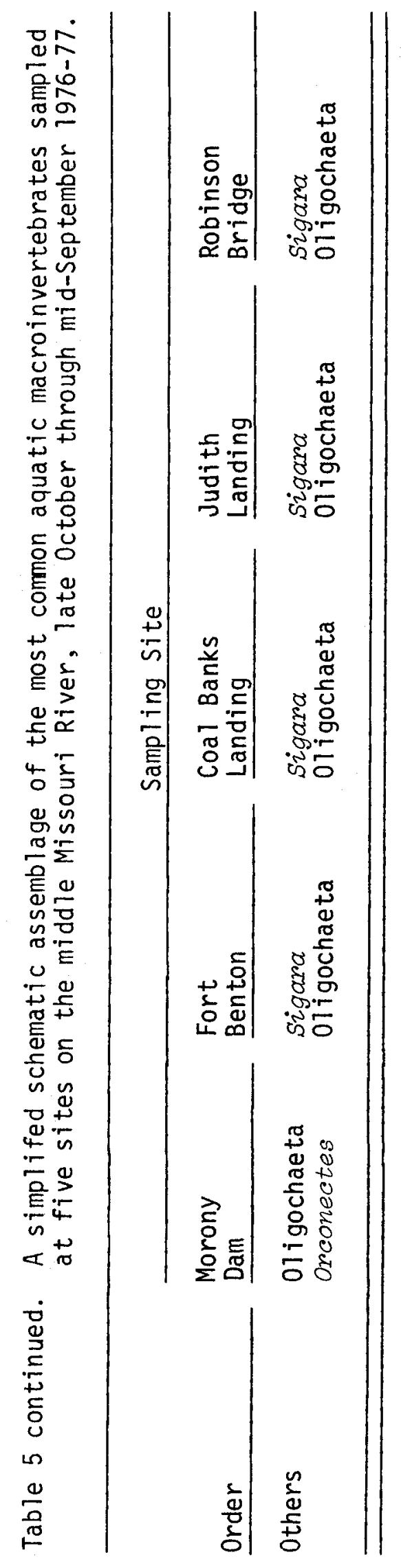




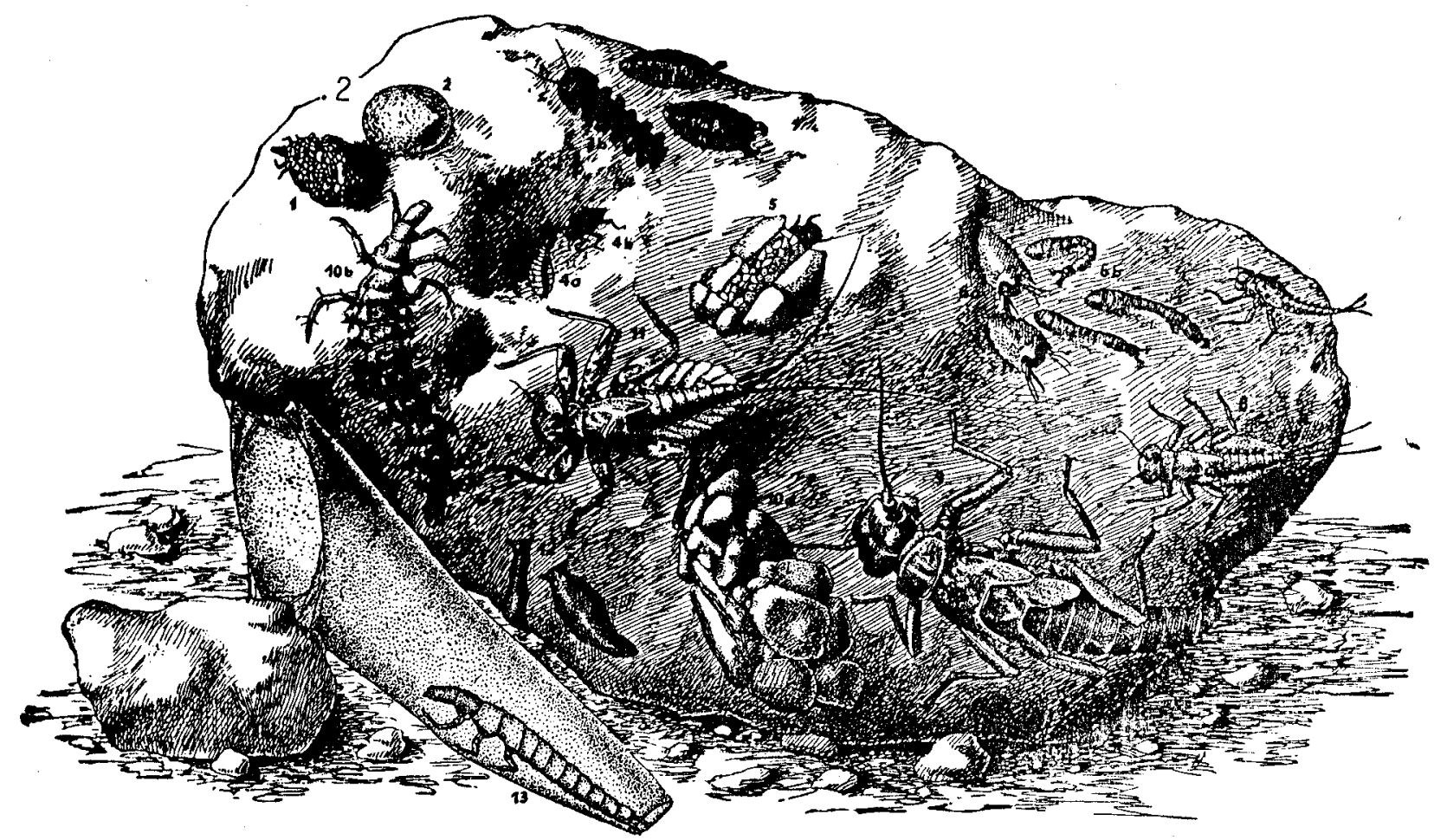

Figure 8. Diversity of the aquatic macroinvertebrate community was least at Morony Dam and greatest at Judith Landing and Robinson Bridge.

community.

Baetis, chironomids, and Hydropsyche were the predominant macroinvertebrate taxa collected at the Morony Dam site. As an average for a 11 sampling dates combined, these taxa accounted for 83 percent of the macroinvertebrates collected at the Morony Dam site. In contrast, these taxa accounted for only 47 percent of the macroinvertebrates collected at the downstream sites. Baetis, chironomids, and Hydropsyche, because of their great variety of species, are generally considered very adaptable to wide changes in the normal physical and chemical conditions in a lotic system (Merritt and Cummins 1978). Stoneflies, which have a narrower environmental tolerance, were essentialiy absent from the Morony Dam site, and mayflies were found only in limited numbers. Although the aquatic macroinvertebrate community at the Morony Dam site was not as diverse as the downstream sites, the relative abundance of macroinvertebrates appeared to be similar to the downstream sites.

With a few important differences, the aquatic macroinvertebrate community of this Missouri River study area exhibited a striking resemblance to that of the Yellowstone River between Huntley and Glendive (Schwehr 1977). Considering the mayflies, stoneflies, and caddisflies only, both rivers contained a diverse mayfly taxa in contrast to a rather 1 imited diversity of stonefly and caddisfly taxa. The mayfly diversity was slightly higher on the Yellowstone River, while stoneflies and caddisflies were slightly more diverse on the Missouri. Dominant subordinal taxa were essentialiy the same in both 
rivers.

The largest number and greatest diversity of mayflies on the Yellowstone River occurred in the cold-water/warm-water transitional zone (Schwehr 1977). This was attributed to overlap of cold-water and warm-water forms. In' contrast, the largest number and greatest diversity of mayflies on the middle Missouri River occurred downstream from the cold-water/warm-water transitional zone. Since the Yellowstone River exists in a natural free-flowing state, its macroinvertebrate community is probably a model for large rivers within its physiographic range. The flow regime of the middle Missouri River has been altered by upstream impoundments. This alteration has probably had some influence on the aquatic macroinvertebrate community of the river.

Marias and Judith Rivers

Aquatic macroinvertebrate sampling was conducted at study sites near the mouths of the Marias and Judith rivers in 1977 and 1978. The Marias River was sampled four times, and the Judith River was sampled three times (Appendix Table 23).

The lower Marias and Judith rivers had relatively diverse mayfly taxa, moderate caddisfly and truefly compositions, and a meager stonefly representation (Table 6). This composition is typical of western rivers. The mayfly, Baetisca, was sampled regularly in the lower Marias, but it was rare in the Missouri and apparentiy absent from the Judith River.

In general, the aquatic macroinvertebrate community of the Marias River is very similar to the Tongue River, a tributary of the Yellowstone River (Newell 1976). The Marias and Tongue rivers are both greatiy influenced by large water impoundments. The truefly, Atherix, was sampled regularly in the Judith River but never in the Marias River. Similarly, Newell (1976) did not find Atherix in the Tongue River.

\section{FINDINGS - LARVAL FISH}

Larval fish were sampled at eight study sites on the mainstem of the Missouri River and at one study site on the lower Marias River near its mouth. Samples were collected from late May through late August, 1978, to determine timing and location of successful hatching and emergence of important fish species. The mainstem Missouri River sampling sites were located at Carter Ferry, Fort Benton, Coal Banks Landing, Little Sandy Creek, Judith Landing, Stafford Ferry, Cow Island, and Robinson Bridge (Figure 1).

A total of 6,141 larvae were collected in 53 samples from the Missouri River, and 966 larvae were taken in 11 samples from the Marias River (Appendix Table 24). The larval taxa sampled represented common adult fish known to occur in the study area.

Spatial Distribution

\section{Missouri River}

Catostominae (suckers) accounted for 86 percent of the fish larvae sampled at the mainstem Missouri River sites and were the predominant group sampled at all sites except Robinson Bridge (Table 7). The Ictiobinael Cyprinidae group (buffalo, carpsucker and minnows) was the only other major 
Table 6. Taxonomic composition of the aquatic macroinvertebrate community in the lower Marias and Judi th rivers, 1977-78. Asterisk (*) indicates the presence of a taxon at the sample site.

\begin{tabular}{|c|c|c|}
\hline Taxa & Marias River & Judith River \\
\hline \multicolumn{3}{|l|}{$\begin{array}{c}\text { Ephemeroptera } \\
\text { Baetiscidae }\end{array}$} \\
\hline Baetiscidae & & \\
\hline \multirow{2}{*}{\multicolumn{3}{|c|}{ Leptophlebiidae }} \\
\hline & & \\
\hline $\begin{array}{l}\text { Leptophlebia } \\
\text { Traverezla }\end{array}$ & $\star$ & * \\
\hline Ephemeridae & & \\
\hline Ephemera & * & \\
\hline Hexagenia & * & \\
\hline \multirow{2}{*}{\multicolumn{3}{|c|}{ Siphlonuridae }} \\
\hline & & \\
\hline Isonychia & * & \\
\hline \multicolumn{3}{|l|}{ Tricorythidae } \\
\hline \multicolumn{3}{|l|}{$\begin{array}{l}\text { Tricory,thodes } \\
\text { Ephemere } 11 \text { idae }\end{array}$} \\
\hline Ephemere ila & * & * \\
\hline \multicolumn{3}{|l|}{ Hep tagen i idae } \\
\hline Rhithrogena & * & * \\
\hline Stenonema & * & * \\
\hline Heptagenia & & * \\
\hline \multicolumn{3}{|l|}{ Baetidae } \\
\hline Pseudoctoeon & * & \\
\hline \multicolumn{3}{|l|}{ Plecoptera } \\
\hline \multicolumn{3}{|l|}{ Nemouridae } \\
\hline Brachyptera & & * \\
\hline \multicolumn{3}{|l|}{ Perl idae } \\
\hline Acroneuria & * & \\
\hline \multirow{2}{*}{\multicolumn{3}{|c|}{ Perlodidae }} \\
\hline & & * \\
\hline Isoperla & * & * \\
\hline \multicolumn{3}{|l|}{$\begin{array}{l}\text { Trichoptera } \\
\text { Hydroptilidae }\end{array}$} \\
\hline Hydrop tila & $\star$ & * \\
\hline \multicolumn{3}{|l|}{ Hydropsychidae } \\
\hline Hydropsyche & * & * \\
\hline Chermatopsyche & * & * \\
\hline \multicolumn{3}{|l|}{ Lep toceridae } \\
\hline \multicolumn{3}{|l|}{$\begin{array}{l}\text { Oecetis } \\
\text { Heliconsvchidae }\end{array}$} \\
\hline $\begin{array}{l}\text { Helicopsychidae } \\
\text { Helicopsyche }\end{array}$ & * & \\
\hline $\begin{array}{l}\text { Helzopsyche } \\
\text { Brachycentridae }\end{array}$ & & \\
\hline Brachycentrus & * & * \\
\hline \multicolumn{3}{|l|}{ Diptera } \\
\hline Hexatoma & & * \\
\hline
\end{tabular}


Table 6 continued. Taxonomic composition of the aquatic macroinvertebrate community in the lower Marias and Judith Rivers, 197778. Asterisk (*) indicates the presence of a taxon at the sample site.

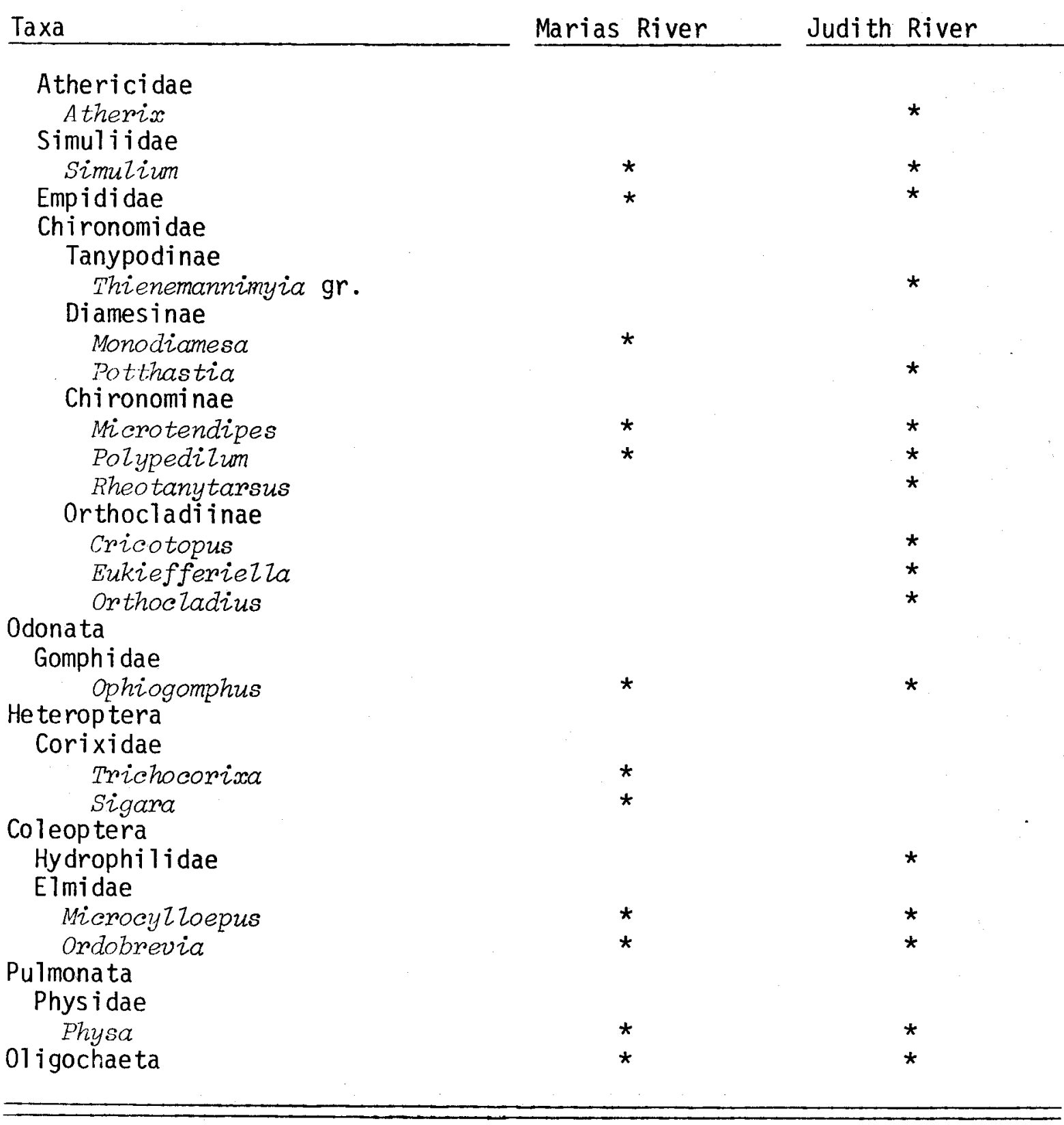




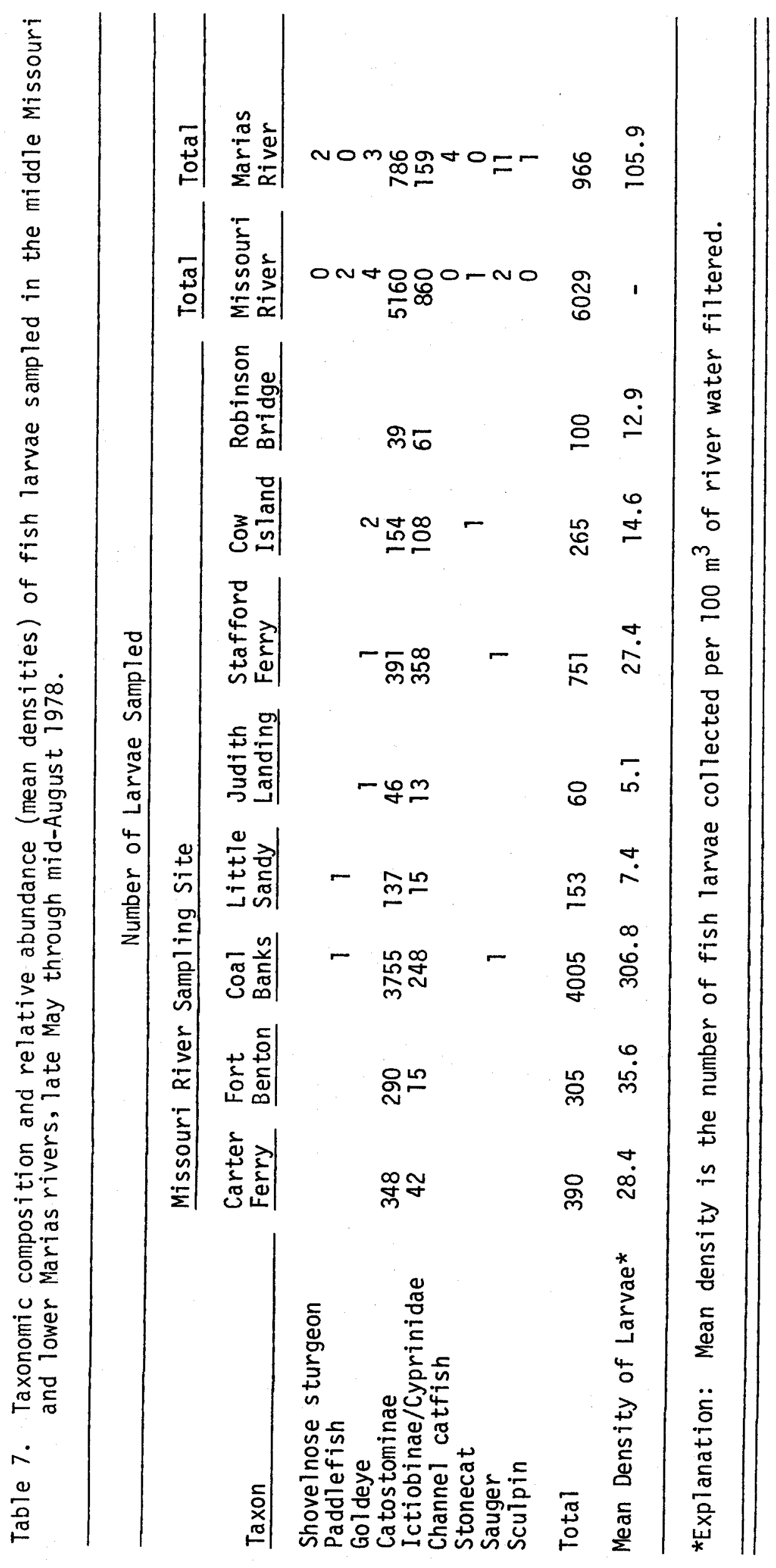


group collected. This group comprised a substantial portion of the Tarvae sampled at the lower three study sites. Ictiobinae/Cyprinidae accounted for 61 percent of the larvae sampled at Robinson Bridge.

Two paddlefish prolarvae (Figure 9) were collected in the Missouri River in 1978, one at Coal Banks Landing and one at Little Sandy Creek. The specimens were collected late at night, July 12, and the early morning, July 13 at each site, respectively. This finding confirms that paddlefish spawn successfully in the Missouri River at least as far upstream as Coal Banks Landing. Paddlefish larvae have also been sampled in the Yellowstone and Milk rivers, Montana (Russ Penkal and Kent Gilge, DFWP, personal communication).

Goldeye was a very common fish in the study area, but very few goldeye larvae were sampled, and those found were sampled only at the three lower study sites. The scarcity of goldeye is probably related to their preference for calm waters for spawning and incubation (Scott and Crossman 1973). Larval fish samples were collected in the Missouri River only at sites where current velocity was sufficient enough to stretch out the sampling net. Calm water, which probably was preferred by goldeye for spawning, was not sampled.

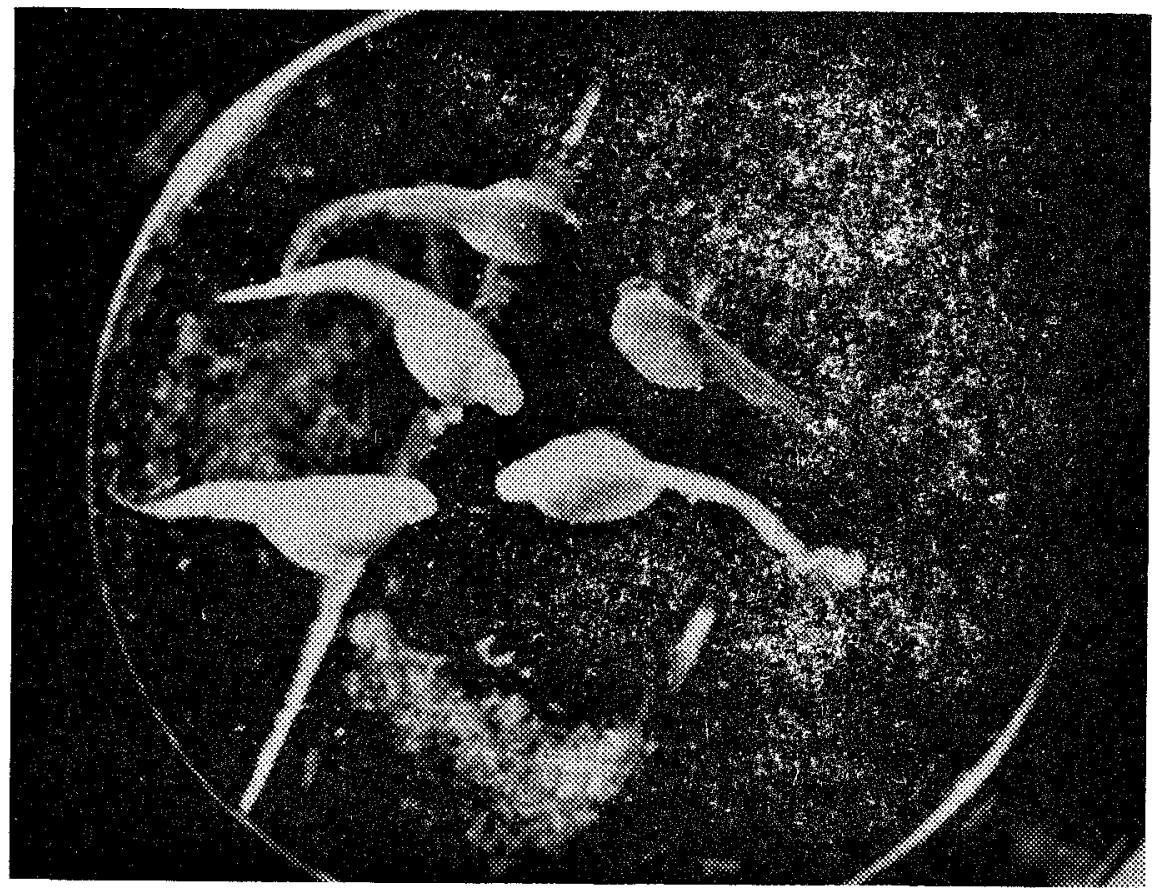

Figure 9. Paddlefish prolarvae were sampled on July 12-13, 1978, on the Missouri River at Coal Banks Landing and Little Sandy Creek. 
The scarcity of sauger in the larval fish collections was probably related to time of sampling. Based on examination of the spawning condition of adult sauger, it is believed that the peak of spawning occurred in late April and early May, 1978. Assuming an incubation period of 13 to 21 days as described by Nelson (1968), most of the larval sauger probably emerged by the end of May. Intensive sampling for larval fish on the Missouri was not initiated until early June. Most larval sauger probably had emerged prior to this time. The two larval sauger which were collected on the Missouri River in 1978 were taken on June 13 and 15 at Coal Banks Landing and Stafford Ferry, respectively.

The greatest density of larval fish in 1978, for all sampling dates combined, was found at the Coal Banks Landing site. Mean density at this site was 306.8 larval fish/100 $\mathrm{m}^{3}$ of water filtered (Table 7 ). Mean densities at the remaining seven sites ranged from 5.1 larvae/100 $\mathrm{m}^{3}$ at Judith Landing to 35.6 larvae $/ 100 \mathrm{~m}^{3}$ at Fort Benton. Densities at the latter sites were similar to averages reported for the Missouri River below Gavins Point Dam in South Dakota (Kallemeyn and Novotny 1977).

\section{Marias River}

Taxonomic composition of larval fish in the Marias River in 1978 was similar to the Missouri River. Catostominae and Ictiobinae/Cyprinidae accounted for 81 and 17 percent, respectively, of the larvae sampled in the Marias (Table 7). The mean density of larval fish taken at the Marias River sampling site was 105.9 larvae/100 $\mathrm{m}^{3}$.

Two shovelnose sturgeon prolarvae were collected in the Marias River on June 19, 1978. These were the first shovelnose sturgeon larvae ever collected in the Missouri River drainage above Fort Peck Dam, indicating that successful reproduction of shovelnose sturgeon occurs in the lower Marias River.

Very few goldeye larvae were sampled on the Marias River. The scarcity is probably related to sampling techniques previously described for goldeye in the Missouri River.

One channel catfish aelvin was sampled on the Marias River June 19, and three were collected July 28, 1978. This finding confirms that channel catfish spawn successfully in the lower Marias River.

Eleven sauger larvae were sampled on the lower Marias River June 1 and 2, 1978. Most larval sauger in the Marias River probably emerged prior to sampling.

\section{Tempora 1 Abundance}

To facilitate interpretation of temporal abundance data for larval fish, the Missouri River was divided into three subreaches:

(1) Subreach 1 included the Carter Ferry and Fort Benton sampling sites,

(2) Subreach 2 included the Coal Banks Landing, Little Sandy Creek, and Judith Landing sampling sites, and

(3) Subreach 3 included the Stafford Ferry, Cow Island, and Robinson 


\section{Bridge sampling sites.}

Two different peaks in temporal abundance of larval fish were observed in 1978. In Subreaches 1 and 2, peak densities were observed from late May through June, while in Subreach 3 the peak occurred in July (Figure 10). The relatively early peak densities of larval fish in the upper subreaches were related to the dominance of Catostominae (suckers) in the larval fish samples collected in the upper river. The later peak in Subreach 3 was due to the large number of Ictiobinae/Cyprinidae (buffalo, carpsuckers, and minnows) larvae which were sampled in the lower river. Brown (1971) indicated that Catostominae spawn earlier and prefer swifter water for spawning then Ictiobinae/Cyprinidae which prefer slow, protected water. The former habitat is common in Subreaches 1 and 2 while the latter is prevalent in Subreach 3.

The greatest density of larval fish on the Marias River in 1978 was observed in early June (Figure 10). However, the Marias was not sampled frequently enough to determine if this was the actual peak in abundance of larval fish.

\section{FINDINGS - ADULT FISH POPULATIONS}

\section{Species Distribution, Relative Abundance and Size Compasition}

Fifty-three species representing 14 families of fish occur in the middle Missouri River drainage between Morony and Fort Peck dams (Table 8). Fortytwo species are found in the mainstem of the Missouri River from Morony Dam to Fort Peck Reservoir. Known distribution of the remaining 11 species is limited to Fort Peck Reservoir or tributaries of the middle Missouri River. It is possible that some of the latter species occur as transients in the mainstem.

Longitudinal distribution of fish species sampled in the Missouri River during the inventory period, 1976 through 1979, is shown in Table 9. Sauger, burbot, white sucker, longnose sucker, shorthead redhorse, river carpsucker, carp, goldeye, freshwater drum, emerald shiner, western silvery minnow, and longnose dace were the most widely distributed fish species. They were abundant throughout the 333-km length of the study area. Northern pike and walleye were also distributed throughout the study area, but not as abundantly as the former species. Mountain whitefish, rainbow trout, brown trout, mountain suckers, and mottled sculpin were mast common in the upstream study sections with only an occasional specimen found in the lower reaches. Shovelnose sturgeon, flathead chubs, blue suckers, smalimouth buffalo, bigmouth buffalo, and channel catfish were common in the Missouri River below the confluence of the Marias River but generally uncommon above the Marias. However, blue suckers and buffalo were common in the Missouri River upstream from the Marias River during their spawning period. Paddlefish were found seasonally in the Missouri River from Fort Peck Reservoir upstream to the confluence of the Marias River. They occurred primarily during Apri1, May, and June when they migrated upstream from Fort Peck Reservoir into the Missouri River to spawn. Most paddlefish return to Fort Peck Reservoir following high water in June. It is not known if any paddlefish reside in the Missouri River throughout the year.

In 11 study sections on the middle Missouri River a total of 92,568 fish representing 41 species were sampled. The primary objective of the surveys was to determine species distribution, relative abundance, and size 


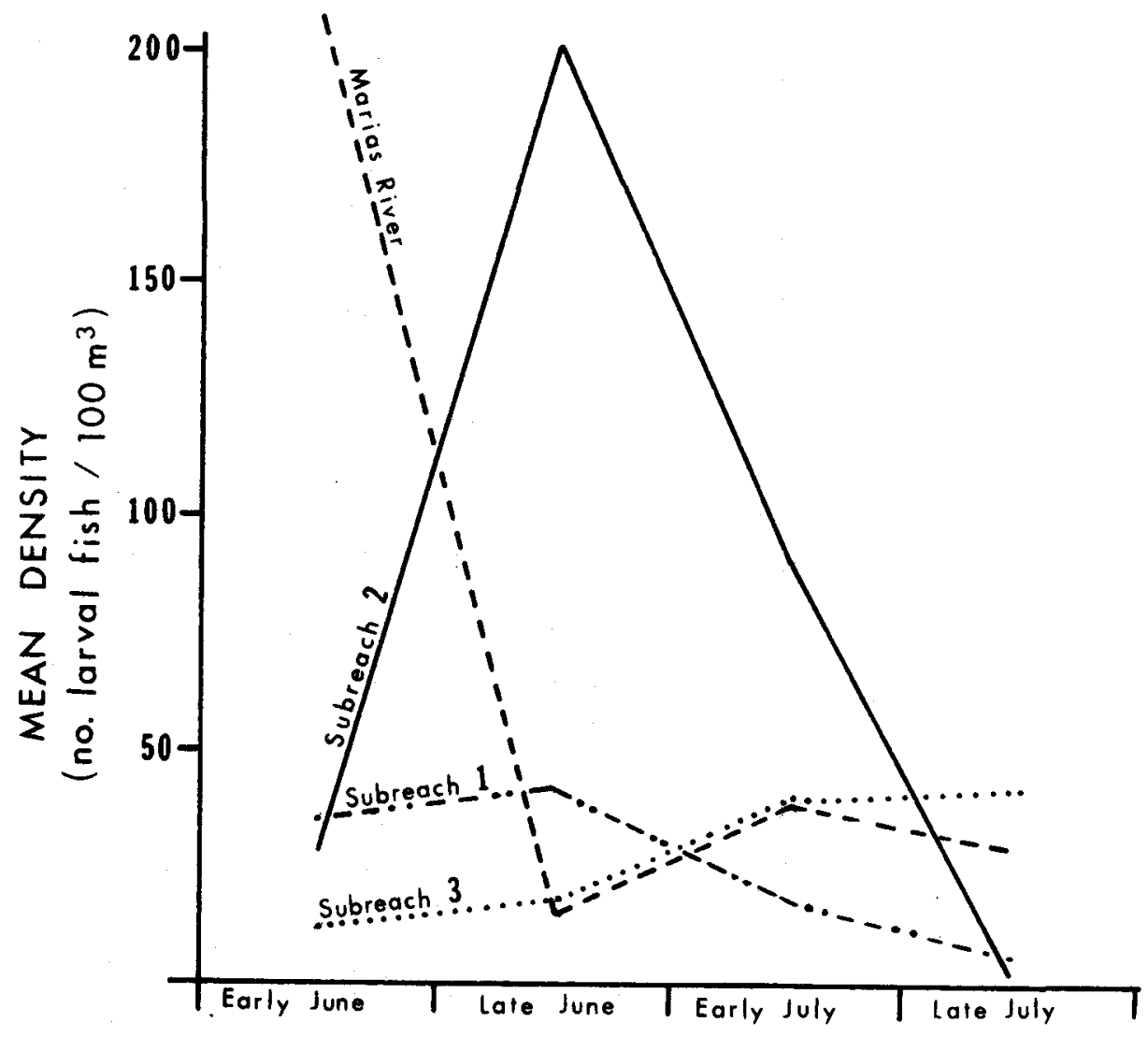

Figure 10. Temporal abundance of larval fish sampled in three subreaches of the Missouri River and at one site on the lower Marias River, early June through late July, 1978. 
Table 8. Fish species recorded for the middle Missouri River drainage in Montana between Morony and Fort Peck Dams (family, scientific, and common names).

ACIPENSERIDAE (Sturgeon family)

Scaphirhynchus albus - Pallid sturgeon

Scaphirhynchus platorynchus - Shovelnose sturgeon

POLYODONTIDAE (Paddlefish family)

Polyodon spathula - Paddlefish

HIODONTIDAE (Mooneye family)

Hiodon alosoides - Goldeye

SALMONIDAE (Trout family)

Prosopium wizliamsoni - Mountain whitefish

Onocorhynchus kisutch - Coho salmon*

Onocorhynchus nerka - Kokanee*

Salmo clarkii - Cutthroat trout*

Salmo gairdneri - Rainbow trout

Salmo trutta - Brown trout

Salvelinus fontinalis - Brook trout

Salvelinus namaycush - Lake trout*

ESOCIDAE (Pike family)

Esox Zucius - Northern pike

CYPRINIDAE (Minnow family)

Cyprinus carpio - Carp

Carassius auratus - Goldfish

Notemigonus crysoleucas - Golden shiner*

Phoxinus eos - Northern redbelly dace*

Phoxinus neogaeus - Finescale dace*

Hybopsis gracilis - Flathead chub

Hybopsis gelida - Sturgeon chub

Hybopsis meeki - Sicklefin chub

Couesius plumbeus - Lake chub

Notropis atherinoides - Emerald shiner

Hybognathus hankinsoni - Brassy minnow

Hybognathus placitus - Plains minnow

Hybognathus argyritis - Western silvery minnow

Pimephales promelas - Fathead minnow

Rhinichyths cataractae - Longnose dace

CATOSTOMIDAE (Sucker famity)

Carpoides carpio - River carpsucker

Cycleptus elongatus - Blue sucker

Ictiobus bubalus - Smallmouth buffalo

Ictiobus cyprinelzus - Bigmouth buffalo

Moxostoma macrolepidotum - Shorthead redhorse

Catostomus catostomus - Longnose sucker

Catostomus commersoni - White sucker

Catostomus platyrhynchus - Mountain sucker 
Table 8 continued. Fish species recorded for the middle Missouri River drainage in Montana between Morony and Fort Peck Dams (family, scientific, and common names).

ICTALURIDAE (Catfish family)

Ictalurus melas - Black bullhead

Ictalurus punctatus - Channel catfish

Noturus flavus - Stonecat

GADIDAE (Codfish family)

Lota Zota -Burbot

GASTEROSTEIDAE (Stickleback family)

Culaea inconstans - Brook stickleback*

CENTRARCHIDAE (Sunfish family)

Lepomis macrochirus - Bluegill*

Lepomis gibbosus - Pumpkinseed

Micropterus dolomieui - Smallmouth bass

Micropterus salmoides - Largemouth bass*

Pomoxis annularis - White crappie

Pomoxis nigromaculatus - Black crappie*

PERCIDAE (Perch family)

Perea flavescens - Yellow perch

Stizostedion canadense - Sauger

Stizostedion vitreum - Walleye

Etheostoma exile - Iowa darter

SCIAENIDAE (Drum famity)

Aplodinotus grunniens - Freshwater drum

COTTIDAE (Sculpin family)

Cottus bairdi - Mottled sculpin

*Known distribution is limited to Fort Peck Reservoir or tributaries to the middle Missouri River. 


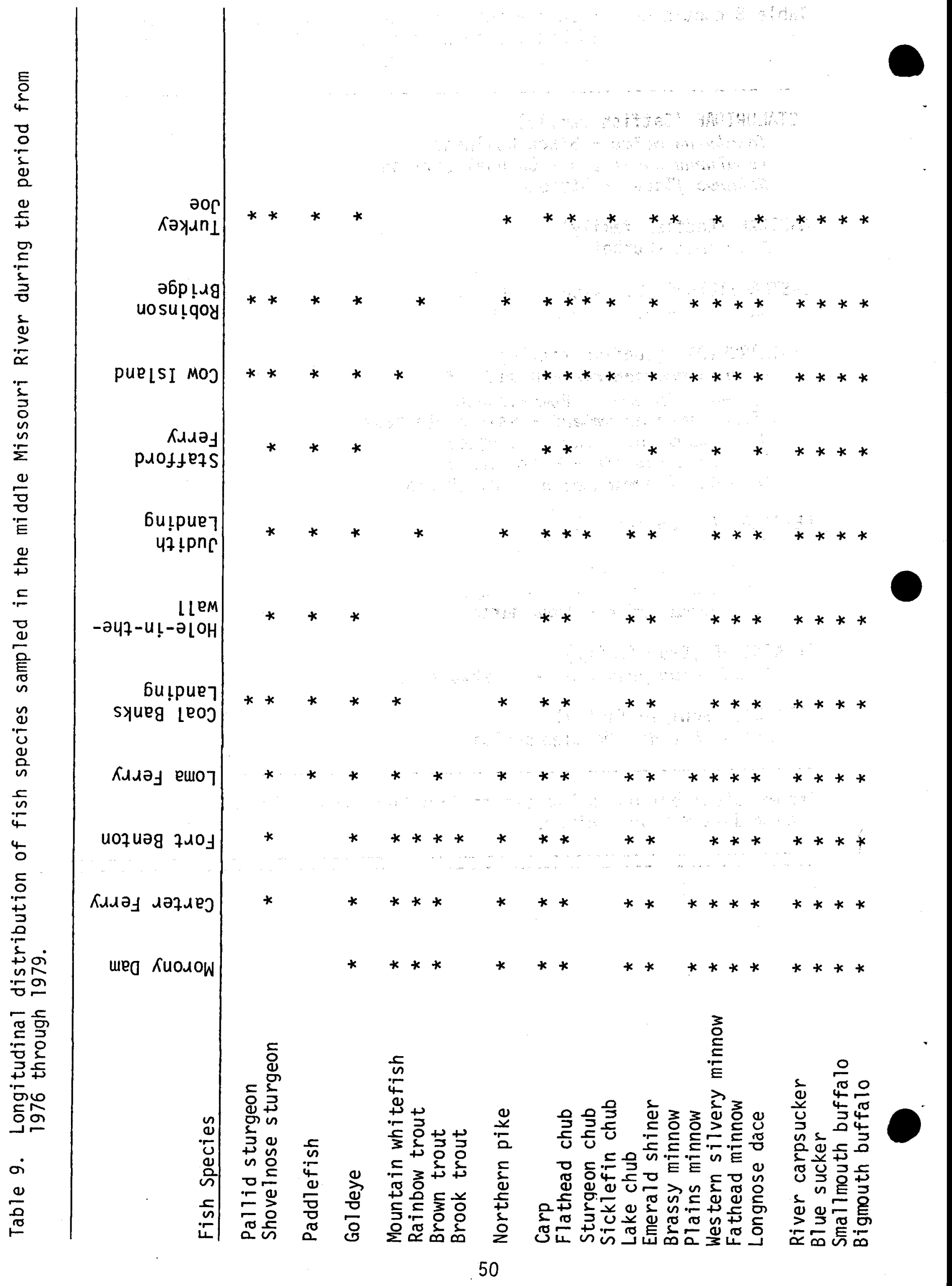




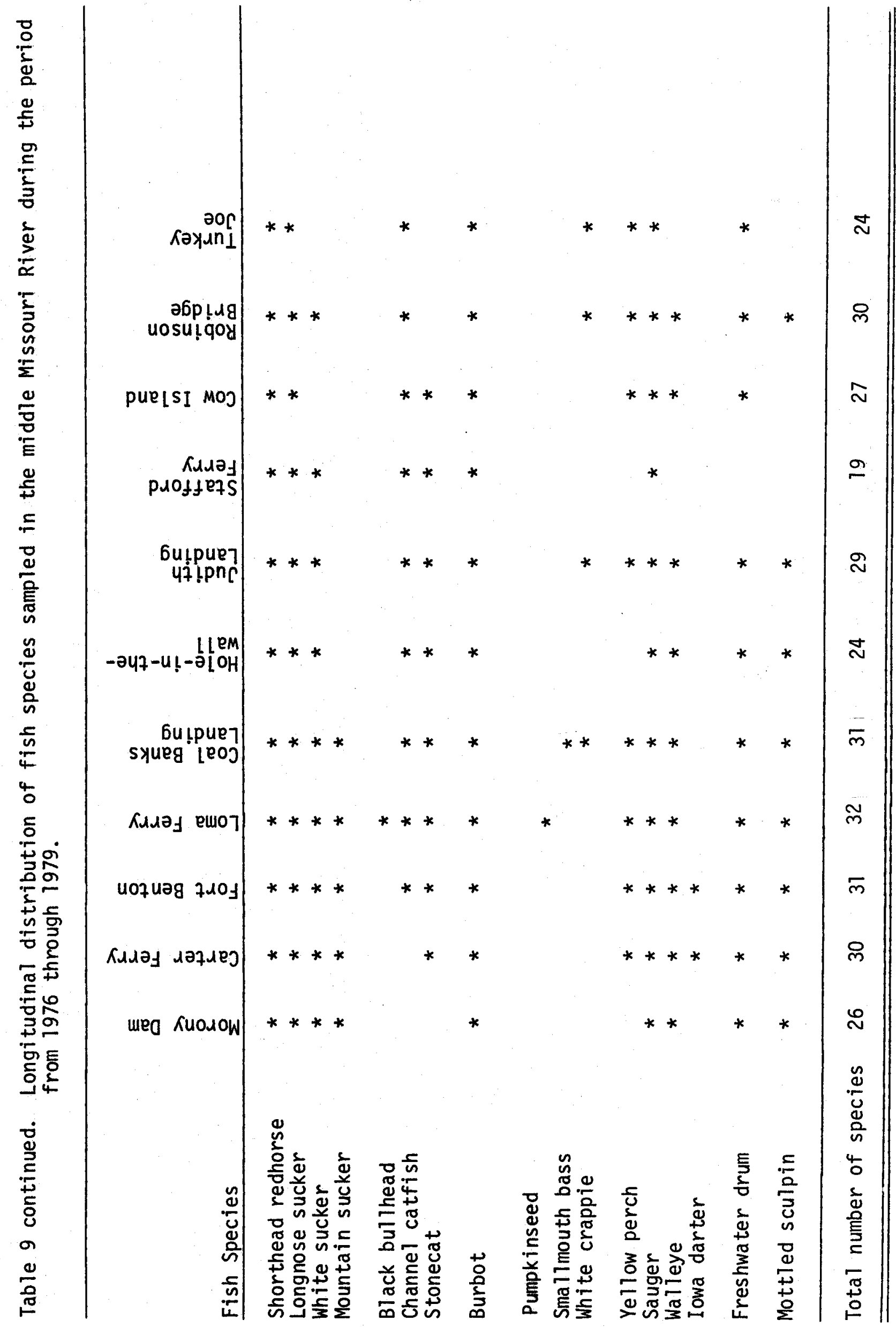


composition. The study sections were located near Morony Dam, Carter Ferry, Fort Benton, Loma Ferry, Coal Banks Landing, Hole-in-the-Wa11, Judith Landing, Stafford Ferry, Cow Island, Robinson Bridge, and Turkey Joe (Figure 1). Exact descriptions of the study section boundaries are given in Appendix Table 25 .

Catch rate summaries for electrofishing and gill net surveys are presented in Tables 10 and 11 , respectively. The catch rate summaries provide an indication of species composition in each study section and allow for a general comparison of relative abundance of fish populations between study sections. Total catch, average size, and size range for individual species sampled in each study section by electrofishing and gill netting are shown in Appendix Tables 26 through 46.

Electrofishing surveys indicated that sauger was the most common game fish species in the Missouri River. The greatest densities of sauger were found in the Missouri River above the confluence of the Marias River. During the four-year inventory, an average of 11.0 sauger per electrofishing hour were sampled in the Missouri River above the Marias, and 2.1 sauger per hour were collected below the Marias (Table 10). In the Morony Dam section, the uppermost study area, an average of 20.1 sauger per electrofishing hour were sampled. This was more than twice the catch rate observed for sauger in any of the remaining 10 study sections.

Shovelnose sturgeon and burbot were also common game fish, averaging 1.2 and 0.2 fish per electrofishing hour, respectively, for the 11 study sections. Walleye, northern pike, channel catfish, and the four salmonid species found in the Missouri River all averaged 0.1 or fewer fish per electrofishing hour. Northern pike, burbot, and channel catfish do not respond as well to electrofishing as the other game fish species. Therefore, densities indicated for these species in the electrofishing surveys are an underestimate of their actual relative abundance and cannot be used for comparison.

Excluding forage species (minnows, dace, sculpin, etc.), goldeye, shorthead redhorse, and longnose suckers were the most common nongame species. For the 11 study sections combined, an average of 18.8 goldeye, 9.2 shorthead redhorse, and 6.2 longnose suckers per electrofishing hour were sampled. Carp, river carpsucker, blue sucker, smalimouth buffalo, freshwater drum, and white sucker averaged $3.1,1.2,0.8,0.5,0.4$, and 0.4 fish per electrofishing hour, respectively. The remaining nongame fish species all averaged 0.1 or fewer fish per electrofishing hour.

Channel catfish are a common and important game fish in the Missouri River. However, they respond poorly to many kinds of sampling techniques. Boom shocking, gill netting, frame trapping, and seining all failed to produce a sufficient sample of channel catfish. Other researchers have also reported problems sampling channel catfish in main channel areas of large rivers (Haddix and Estes 1976, Schmulbach 1974). However, good success has been reported by researchers in the states of Missouri (Ragland and Robinson 1972) and lowa (Helms 1973) sampling for channel catfish in large rivers with baited hoop nets.

Channel catfish were sampled with baited hoop nets at six sites in the study area during the four-year inventory period. Four of the study sites were located on the mainstem of the Missouri at Turkey Joe, Two Calf Is land, Judith Landing, and Loma Ferry. These study sites are 3, 45, 136, and 248 


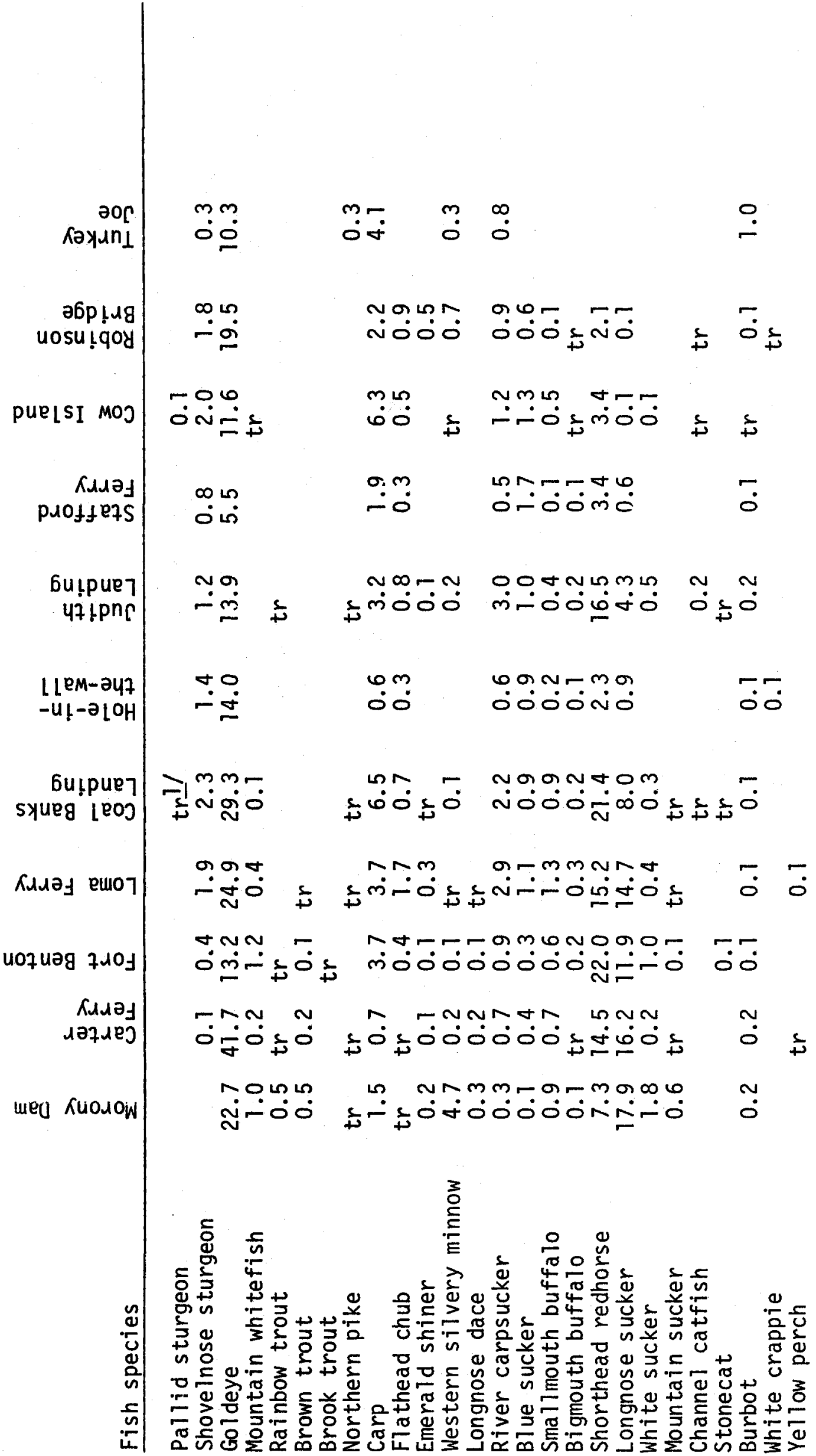




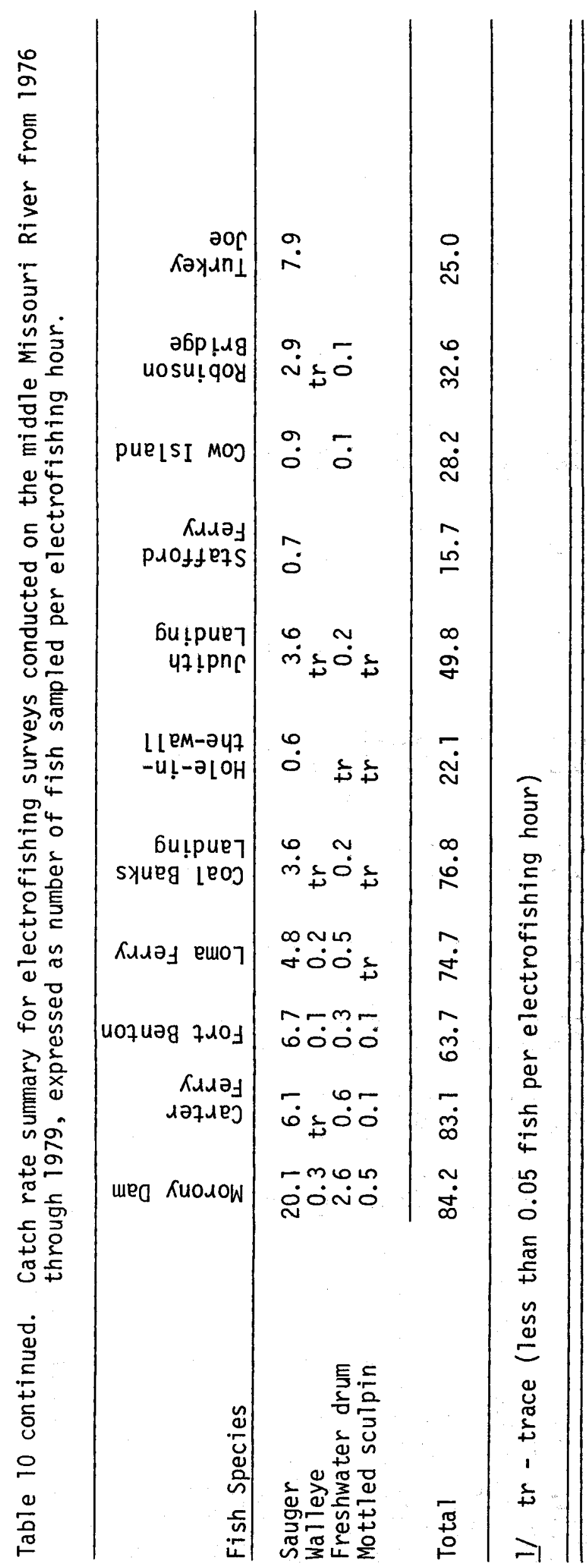


(†乙) әос

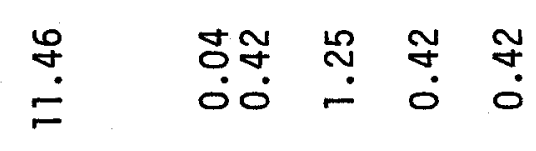

m

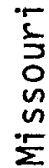

$\stackrel{0}{\frac{0}{0}}$

导

$\stackrel{4}{+5}$

5

प

幽

$+$

马

동 돔

ज

बे

$\stackrel{2}{2}$

is

$\stackrel{0}{0}$

Кәуג山!

(c) $ә 6 p ! 4 g$ uosutqoy

(t) puelsI

MOJ

(t) Kus.j

puoffezs

(6) bu!pue7

47 !pn

(t) LLEM

$-247-4 !-\partial \mathrm{LOH}$

(6) Gu!̣pue 7 syueg [eoJ

$=\frac{1}{3}$

ธᄄ口

苾

递穴

ㄴ. 4

爻高

ธํㅡㄹ

(IL) Kudzy emo 7

(2L) voquәg

710

(b) אuivコ 1ә74leJ

空喿

压

를

जิ

$\Phi$

x

บิ

ชั

$\pi(0)$ weg

సั

오 응용워영 ஸ

오 오

응 융요용 - 0 0 0 0 iñ

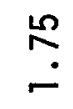

$\dot{0} \sim$

ํำ

○ं

$\stackrel{n}{n}$

ํำ

$\circ \sigma^{\circ}$

00

융

공요

षलं

8

$\stackrel{8}{\circ}$

ஜேテ

$\approx 010$

Lกㅠ. F

$\begin{array}{lll}\stackrel{0}{n} & 0 \\ & 0\end{array}$

ำ 웅

in

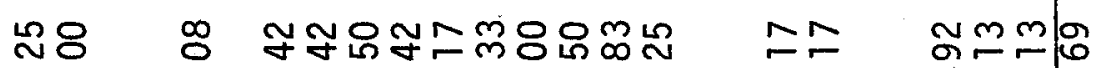

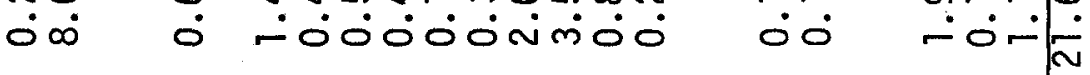

$\begin{array}{lll}\stackrel{n}{0} & 0 & \text { 유뉴 } \\ 0 & 0 & 000\end{array}$

$\stackrel{\sim}{\sim} \quad \stackrel{\sim}{\sim}$

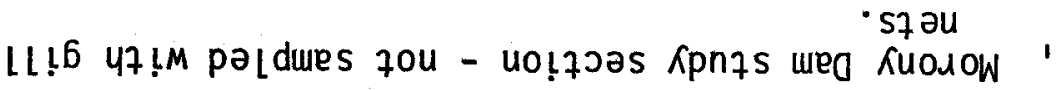

든 $\frac{0}{4}$

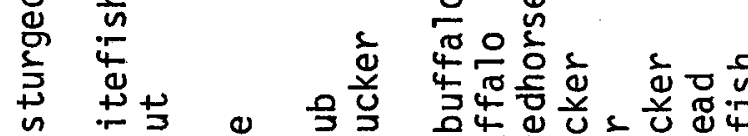

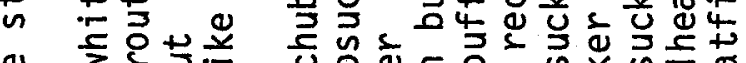

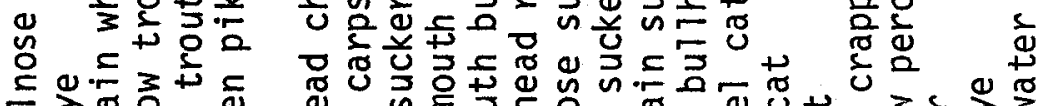

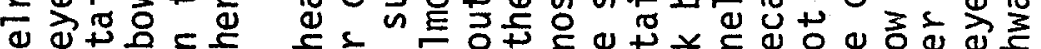

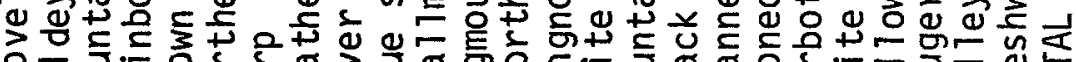


$\mathrm{km}$ upstream from Fort Peck Reservoir, respectively. The remaining two study sites were located on the Marias River 1 to $10 \mathrm{~km}$ upstream from the mouth and on the Teton River 1 to $2 \mathrm{~km}$ upstream from the mouth. Sampling for channel catfish with baited hoop nets was conducted during the months of June through September.

A total of 2,049 channel catfish and 119 fish of other species were captured in 313 net-days at the six study sites. A net-day represents one baited hoop net fished for a 24-hour period. Catch rates for channel catfish were consistently higher at the Turkey Joe study site than at the other sampling sites. The catch rate at Turkey Joe averaged 10.0 channel catfish per net-day (Table 12). Catch rates at the Two Calf Island, Judith Landing, Loma Ferry, Marias River, and Teton River study sites averaged 3.0, 1.1, 0.2, 0.8 and 1.0 channel catfish per net-day, respectively.

The catch data can be used to make a general comparison of relative abundance of channel catfish between study sites. However, since the baited hoop nets are selective for channel catfish, the catch rates cannot be used to determine relative abundance of other species. Total catch, average size, and size range of channel catfish and other species sampled in hoop nets at the six study sites during the inventory period are shown in Appendix Tables 47 through 52 .

The average size (mean total length) of a number of fish species was larger in the upper study sections than in the lower sections (Figure 11). This phenomenon can be explained largely by the upstream migration of mature adults before or after spawning, and the downstream drift of emergent larval fish into the lower study sections following spawning. Gardner and Berg (1981) found the most important rearing areas for several fish species in the Missouri River in this study area were in downstream sites. The larger number of subadult fish rearing in the downstream study sites accounts for the smaller average size of fish in these areas. Graham and Penkal (1978) observed that sauger in the upper section of the lower Yellowstone River had a larger average length than those in the lower section. They attributed this to a general upstream migration of mature sauger after spawning.

Spawning Migrations, Spawning Periods \& Fish Movements

\section{Paddlefish Spawning Migrations}

Paddlefish are native to Montana and are found in both the Yellowstone and Missouri River drainages. Significant numbers of paddlefish are found seasonally in the lower Yellowstone River and in the Missouri River in the dredge cut complex below Fort Peck Dam. Another paddlefish population inhabits Fort Peck Reservoir. A portion of this population seasonally migrates upstream from Fort Peck Reservoir into the present study area to spawn.

The paddlefish was formerly abundant throughout much of the Mississippi/ Missouri River System but has undergone a drastic decline since 1900 (Pflieger 1975, Rehwinkel 1975, Vasetskiy 1971). A combination of destructive influences, including overharvest and loss of habitat in some areas, has contributed to this decline. Only six major, self-sustaining populations of paddlefish remain in the United States today, including the population in this study area (Berg 1980).

The annual migration of paddlefish from Fort Peck Reservoir into the Missouri River was studied during 1977, 1978, and 1979. The main objectives 
Table 12. Catch rate summary for baited hoop net surveys conducted on the middle Missouri River from 1977 through 1979, expressed as number of fish captured per net-day.

\section{STUDY SITE}

\begin{tabular}{|c|c|c|c|c|c|c|}
\hline $\begin{array}{l}\text { Fish } \\
\text { Species }\end{array}$ & $\begin{array}{l}\text { Turkey } \\
\text { Joe (196) I/ }\end{array}$ & $\begin{array}{l}\text { Two Calf } \\
\text { Island (2) }\end{array}$ & $\begin{array}{l}\text { Judith } \\
\text { Landing (28) }\end{array}$ & $\begin{array}{l}\text { Loma } \\
\text { Ferry (33) }\end{array}$ & $\begin{array}{l}\text { Marias } \\
\text { River (34) } \\
\end{array}$ & $\begin{array}{l}\text { Teton } \\
\text { River (20) }\end{array}$ \\
\hline $\begin{array}{l}\text { Channel } \\
\text { catfish }\end{array}$ & 10.0 & 3.0 & 1.1 & 0.2 & 0.8 & 1.0 \\
\hline $\begin{array}{l}\text { Shovelnose } \\
\text { sturqeon }\end{array}$ & & & $\operatorname{tr}$ & & 0.4 & \\
\hline $\begin{array}{l}\text { Sauger } \\
\text { Northern } \\
\text { pike }\end{array}$ & 0.1 & & 0.1 & 0.1 & $\begin{array}{l}0.2 \\
\operatorname{tr}\end{array}$ & 0.3 \\
\hline Burbot & $\operatorname{tr} \underline{2}$ & & & & 0.1 & \\
\hline Goldeye & tr & & $\operatorname{tr}$ & & 0.1 & 0.1 \\
\hline Carp & $\operatorname{tr}$ & & & $\operatorname{tr}$ & & \\
\hline $\begin{array}{l}\text { Freshwater } \\
\text { drum }\end{array}$ & $\operatorname{tr}$ & & & & & \\
\hline $\begin{array}{l}\text { Smal lmouth } \\
\text { buffa to }\end{array}$ & $\operatorname{tr}$ & & & & & \\
\hline $\begin{array}{l}\text { Shorthead } \\
\text { redhorse }\end{array}$ & $\operatorname{tr}$ & & $\operatorname{tr}$ & 0.2 & 0.1 & 0.1 \\
\hline $\begin{array}{l}\text { Longnose } \\
\text { sucker }\end{array}$ & & & & 0.1 & 0.1 & \\
\hline $\begin{array}{l}\text { White } \\
\text { sucker }\end{array}$ & & & & & 0.2 & \\
\hline $\begin{array}{l}\text { River carp- } \\
\text { sucker }\end{array}$ & $\operatorname{tr}$ & & & & 0.1 & 0.3 \\
\hline $\begin{array}{l}\text { Flathead } \\
\text { chub }\end{array}$ & & & & & & 0.1 \\
\hline Total & 10.2 & 3.0 & 1.3 & 0.6 & 2.1 & 1.7 \\
\hline
\end{tabular}

$1 /$ Number of net-days sampled at the study site.

2) tr - trace (less than $0.05 \mathrm{fish} /$ net-day). 

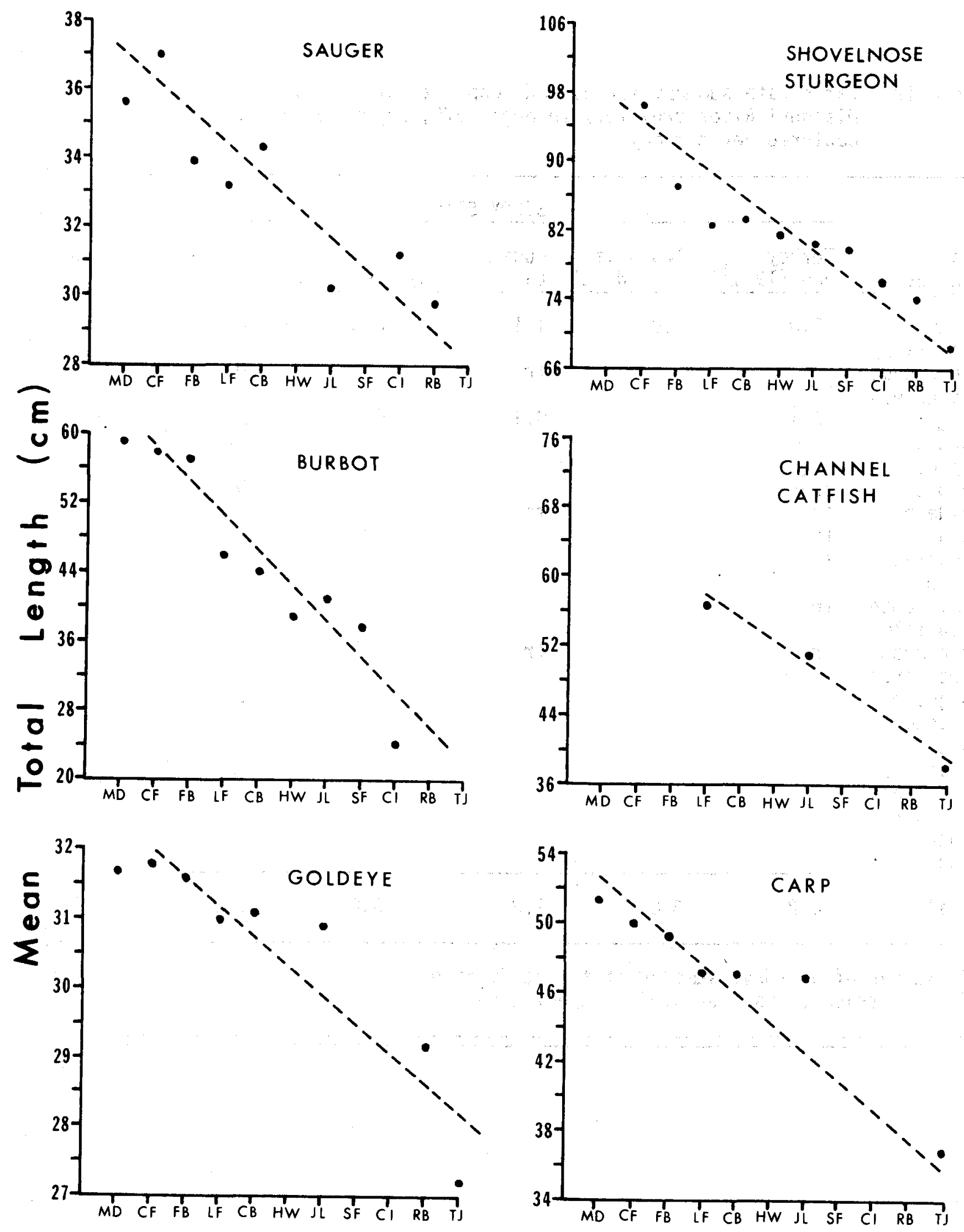

Figure 11. Decrease in average size (mean total length) of six fish species at downstream study sites on the middle Missouri River. Study section abbreviations are: $M D=$ Morony Dam, $\mathrm{CF}=$ Carter Ferry, $\mathrm{FB}=$ Fort Benton, $\mathrm{LF}=$ Loma Ferry, $\mathrm{CB}=$ Coal Banks Landing, $\mathrm{HW}=\mathrm{Hole}-\mathrm{in}-$ the-Wa $17 . \mathrm{JL}=$ Judith Landing, $S F=$ Stafford Ferry, CI = COW Is Iand, $R B=$ Robinson Bridge, and $\mathrm{TJ}=$ Turkey Joe. 
were to monitor the migration to determine timing of the run, relative abundance of paddlefish involved in the run, and extent of their upstream movements.

The migration was monitored by sampling with boom suspended electrofishing apparatus. Survey counts were made by tabulating all paddlefish observed by the boat operator and dip netter during the electrofishing operation (Figures 12 and 13). Since the effective field of the boom shocker did not cover the entire width of the river, the survey counts are a sample of the spawning run, not a complete census.

A direct current of 6 to 8 amps and 120 volts pulsed at 120 to 160 pulses per second with a pulse width of 40 to 50 percent was sufficient to make the survey counts. The effective field of the boom shocker at this setting was 15 to 20 meters. More than a thousand paddlefish were counted in three years with the electrical field at this setting, and no paddlefish mortality was observed. Paddlefish were considerably less vulnerable to electrofishing mortality at these settings than other game fish species such as sauger, walleye, mounta in whitefish, and trout. Only two known paddlefish electrofishing mortalities occurred during the entire three years, and these occurred at the inception of the study when the current was allowed to exceed 10 amps and 200 volts. The electrofishing census technique was a very safe and effective method for monitoring the paddlefish migration in the Missouri River.

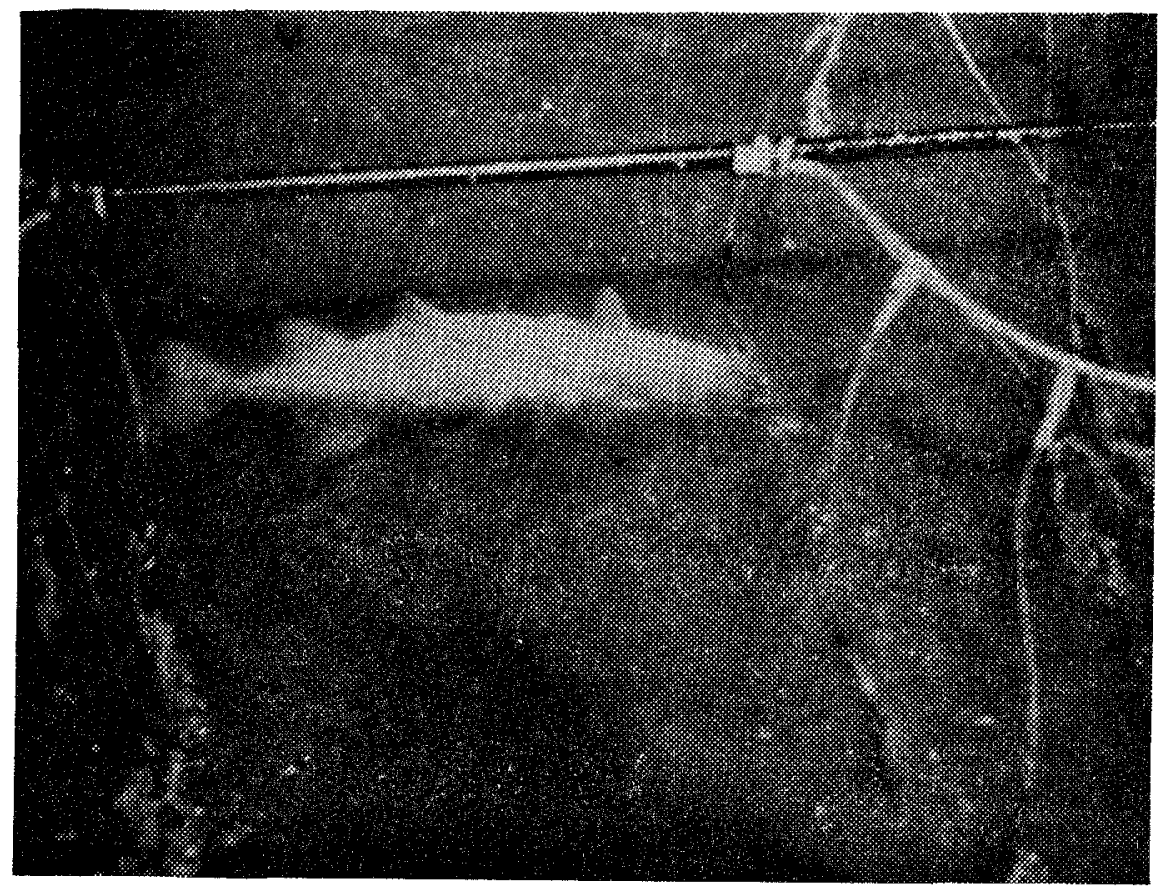

Figure 12. Photograph of a paddlefish in the field of the positive electrodes ahead of the boat. 


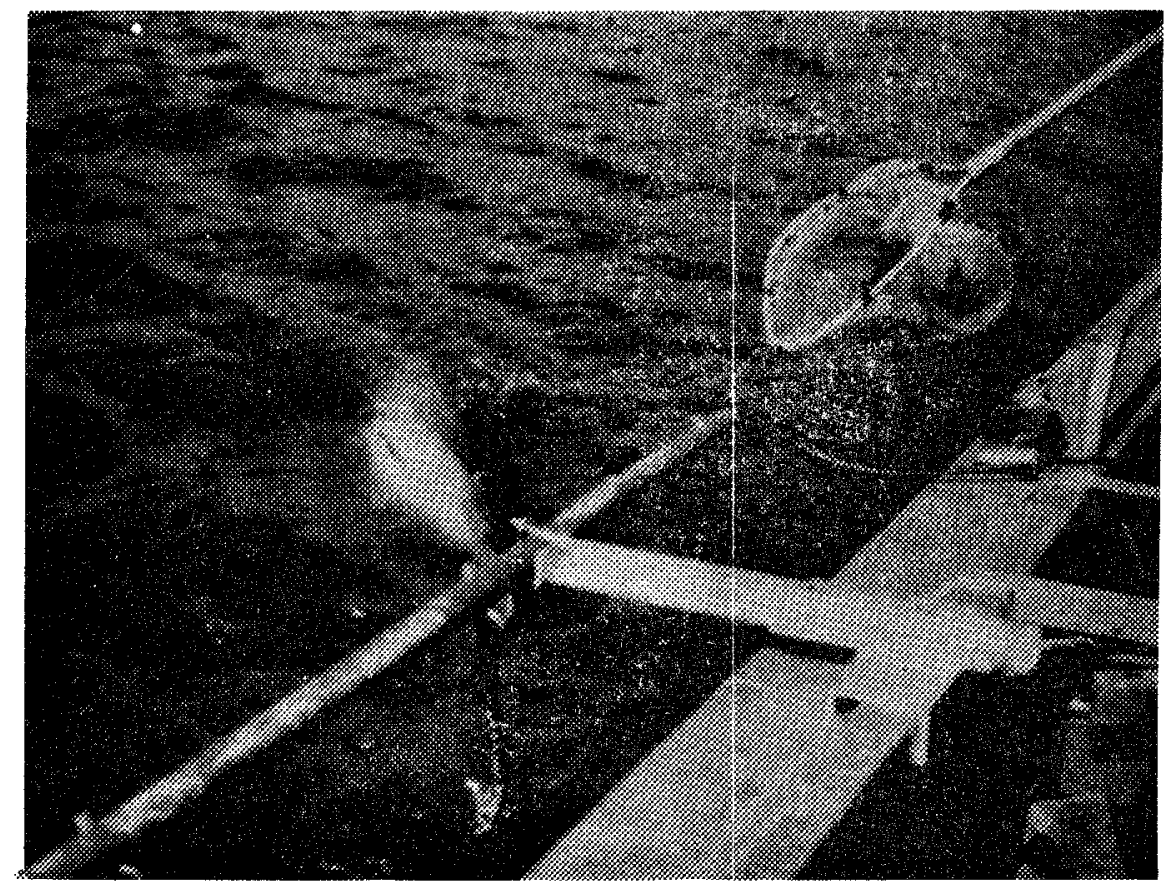

Figure 13. Photograph of a paddlefish in the field of the negative electrode at the side of the boat.

Twelve electrofishing survey runs were made during a 119-day period from Apri1 6 to August 2, 1977 (Table 13). The most paddlefish observed in a survey run was 63 on May 19. Nearly all paddlefish counted during the 1977 migration period were observed in the lower $37 \mathrm{~km}$ of the Missouri River between Robinson Bridge and Fort Peck Reservoir (Figure 14). The farthest documented upstream movement was one paddlefish observed $42 \mathrm{~km}$ upstream from Fort Peck Reservoir on June 18.

Flow was well below normal in the Missouri River during the 1977 migration period. Peak flow was about $221 \mathrm{~m}^{3} / \mathrm{sec}$ (7800 cfs) from early to mid-May at the Virgelle gage station. Because of the low flows, the paddlefish migration was severely reduced. A relatively small number of fish was involved in the run, and the extent of their upstream movements was minimal. Some paddlefish remained in the lower $37 \mathrm{~km}$ of the Missouri River during JuTy, August, and September (Figure 15). These fish were probably waiting for sufficient flow to make an extended migration, but this flow was not achieved in 1977. Since there is no known suitable spawning substrate in the lower $37 \mathrm{~km}$ of the river, it is likely that spawning success in 1977 was very poor. 


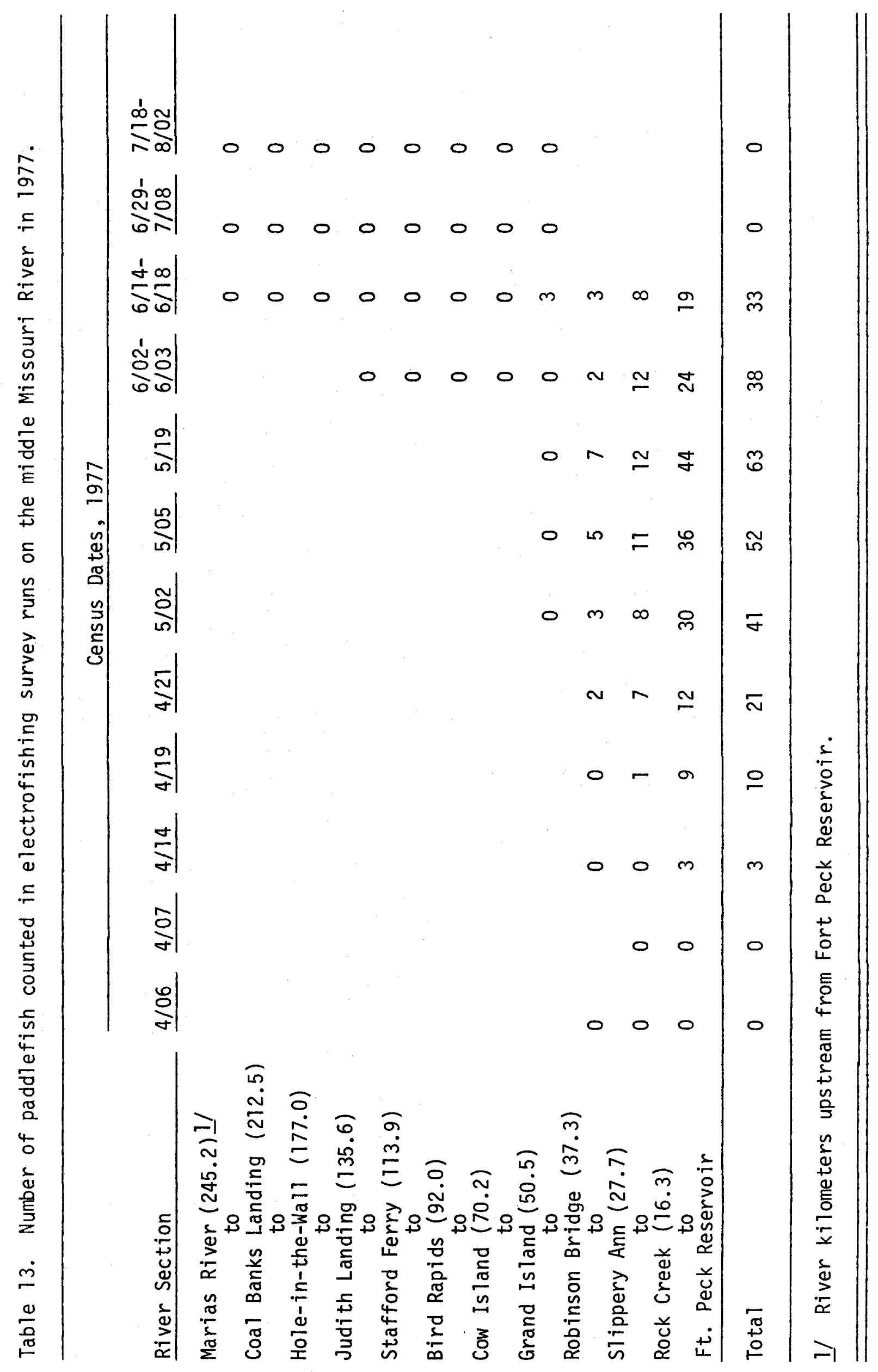




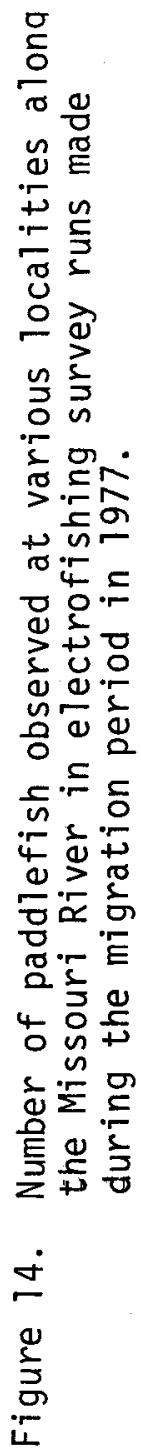

$N$

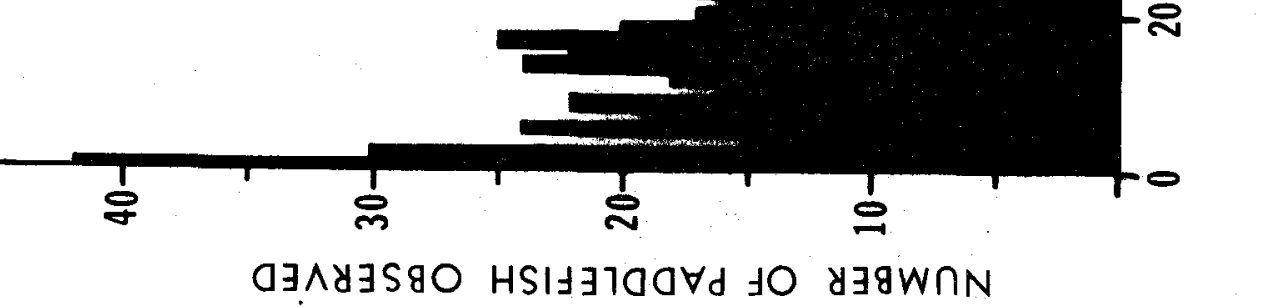




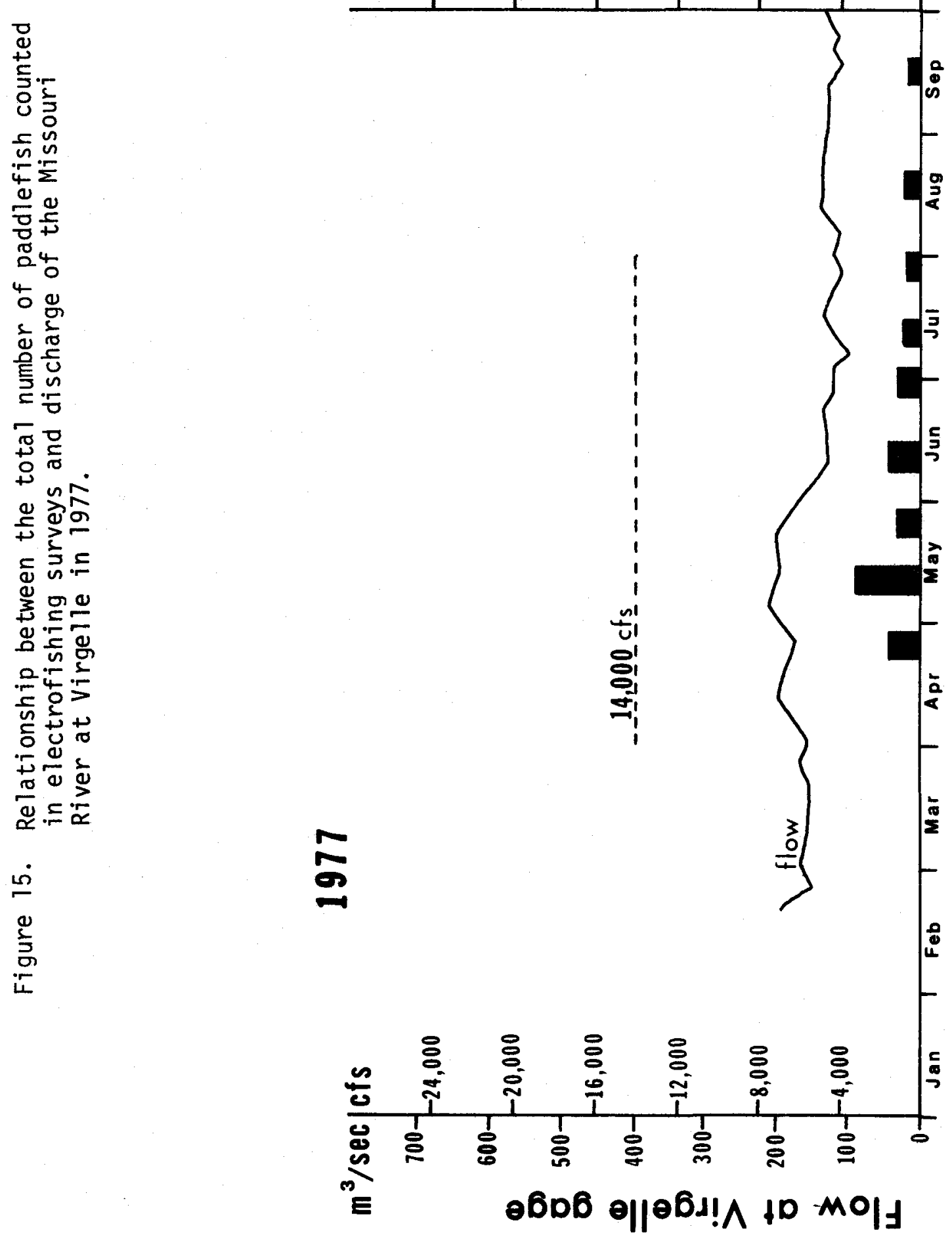


In 1978, flow in the Missouri River was about normal during the migration period, and a substantial number of paddlefish were found upstream from Robinson Bridge (Table 14). Six electrofishing survey runs were made during a 128-day period from April 26 through August 21. The most paddlefish observed was 244 in a survey run from May 10 through 14. The farthest documented upstream movement was two paddlefish observed $241 \mathrm{~km}$ upstream from Fort Peck Reservoir (about $3 \mathrm{~km}$ below the mouth of the Marias River) on June 13, 1978.

Table 14. Number of paddlefish counted in electrofishing survey runs on the middle Missouri River in 1978.

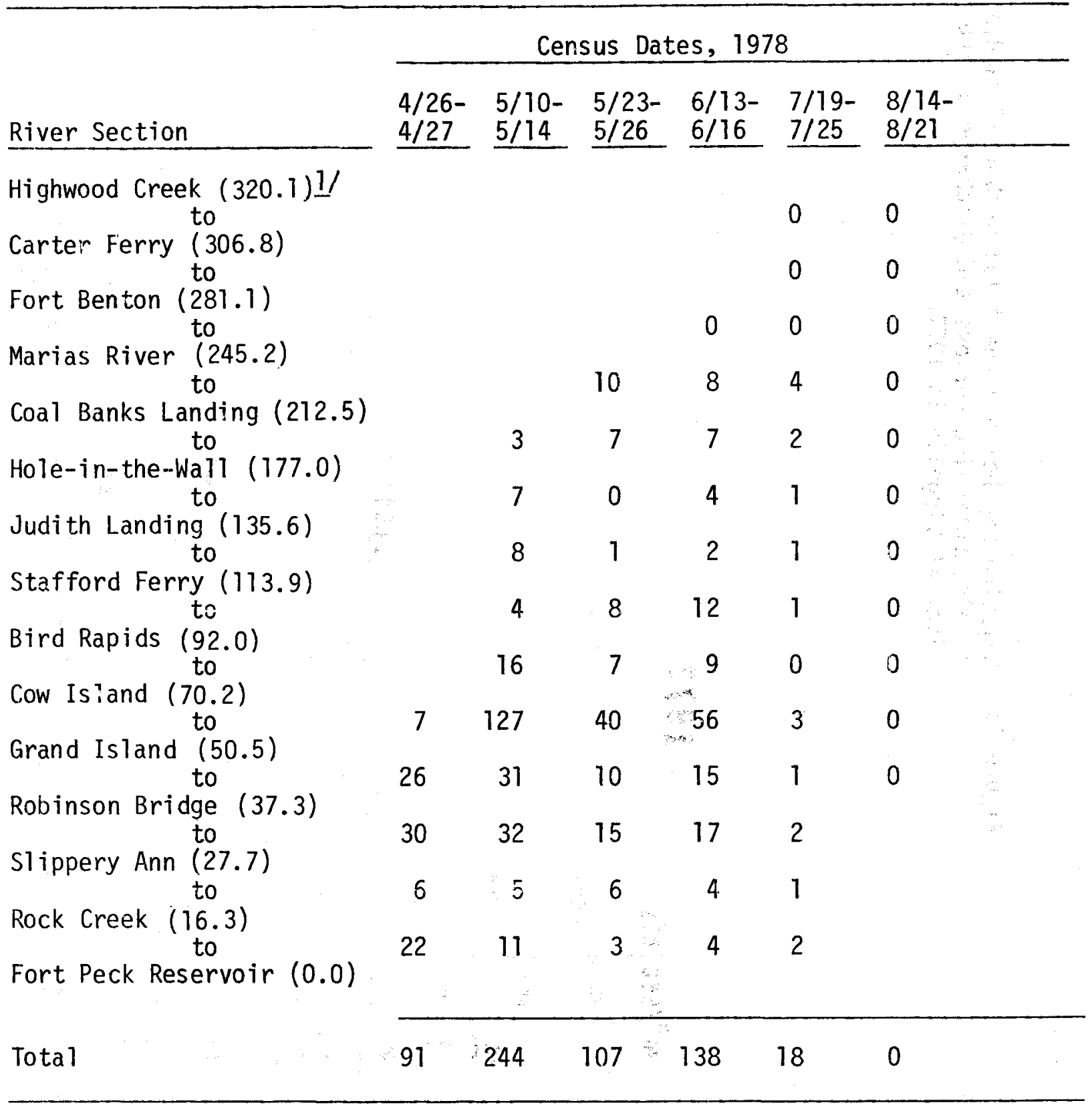

1/ River kilometers upstream from Fort Peck Reservoir. 
A significant migration did not develop in 1978 until flow at the Virgelle gage station exceeded $396 \mathrm{~m}^{3} / \mathrm{sec}(14,000 \mathrm{cfs})$. A flow of this magnitude was achieved during the first week of May, and a substantial increase of paddlefish was observed shortly thereafter in a suryey count made from May 10 through 14 (Figure 16). Flow exceeded $396 \mathrm{~m}^{3} / \mathrm{sec}$ for 50 consecutive days, May 4 through June 22, and paddlefish survey counts remained high throughout this time period. In late June, flow was reduced to slightly less than $396 \mathrm{~m}^{3} / \mathrm{sec}$, and most of the paddlefish returned to Fort Peck Reservoir. During the first three weeks of July, flow recovered to a level again exceeding $396 \mathrm{~m}^{3} / \mathrm{sec}$. However, there was no parallel recovery of the paddlefish run during this time period. Most of the paddlefish probably spawned before the flow reduction in late June. However, since flow at the Virgelle gage usually exceeds $396 \mathrm{~m}^{3} / \mathrm{sec}$ through early July, the paddlefish spawning season may have been slightly shortened.

On May 23, 1978, an abnormally heavy rainstorm in the Highwood Mountains caused flooding in Arrow Creek, a tributary entering the Missouri River $154 \mathrm{~km}$ upstream from Fort Peck Reservoir. As a result of the flood a large amount of logs, tree branches, grass, and other organic debris was washed into the Missouri River and carried in suspension in the thalweg. Many migrant paddlefish in the Missouri River between the mouth of Arrow Creek and Fort Peck Reservoir encountered this debris, and it apparently clogged their mouths and gill rakers, weakening the fish. As a result, many paddlefish were forced downstream into Fort Peck Reservoir. On May 24, 1978, Bob Watts, a DFWP biologist from Lewistown, observed about 1000 to 1500 paddlefish in the Missouri River below Robinson Bridge drifting downstream near the surface of the water (Needham 1978). The fish were apparently under stress and exhausted from contending with debris.

As a result of this event, the abundance of migrant paddlefish in the Missouri River was temporarily reduced during late May and early June (Figure 16). However, by mid-June a significant recovery of the run was observed. The run probably would not have recovered if flows had not remained above $396 \mathrm{~m}^{3} / \mathrm{sec}$.

In 1979, five electrofishing survey runs were made on the Missouri River during a 60-day period from May 15 through July 13 (Table 15). Flow in the Missouri River in 1979 reached a near normal peak, but the duration of time during which flow exceeded $396 \mathrm{~m} / \mathrm{sec}$ at the Virgelle gage station was greatly reduced, compared to 1978 . Flow exceeded $396 \mathrm{~m}^{3} / \mathrm{sec}$ at Virgelle for oniy 23 consecutive days, May 18 through June 9. By comparison flow exceeded this amount for 50 consecutive days in 1978. As an average for a 39-year period of record from 1940 through 1978, flow at the Virgelle gage exceeded $396 \mathrm{~m} / \mathrm{sec}(14,000 \mathrm{cfs})$ for 48 consecutive days, May 19 through July 5 (USGS 1980).

Because of the shortened 1979 spring runoff period, the main portion of the spawning migration occurred during a more confined time period than in 1978 (Figures 16 and 17). A substantial movement of migrant paddlefish into the Missouri was observed shortly after flows surpassed $396 \mathrm{~m} 3 / \mathrm{sec}$ on May 18 at the Virgelle gage. Three hundred and thirty-seven paddlefish were counted in the river during a survey run made from May 26 through June 6 (Table 15). This was the highest paddlefish count made during the threeyear study period, and it coincided with the peak flow observed in 1979 (Figure 17). On June 10, 1979, flow declined to less than $396 \mathrm{~m} 3 / \mathrm{sec}$, and most of the paddlefish returned to Fort Peck Reservoir. Only 70 paddlefish 
Table 15. Number of paddlefish counted in electrofishing survey runs on the middle Missouri River in 1979.

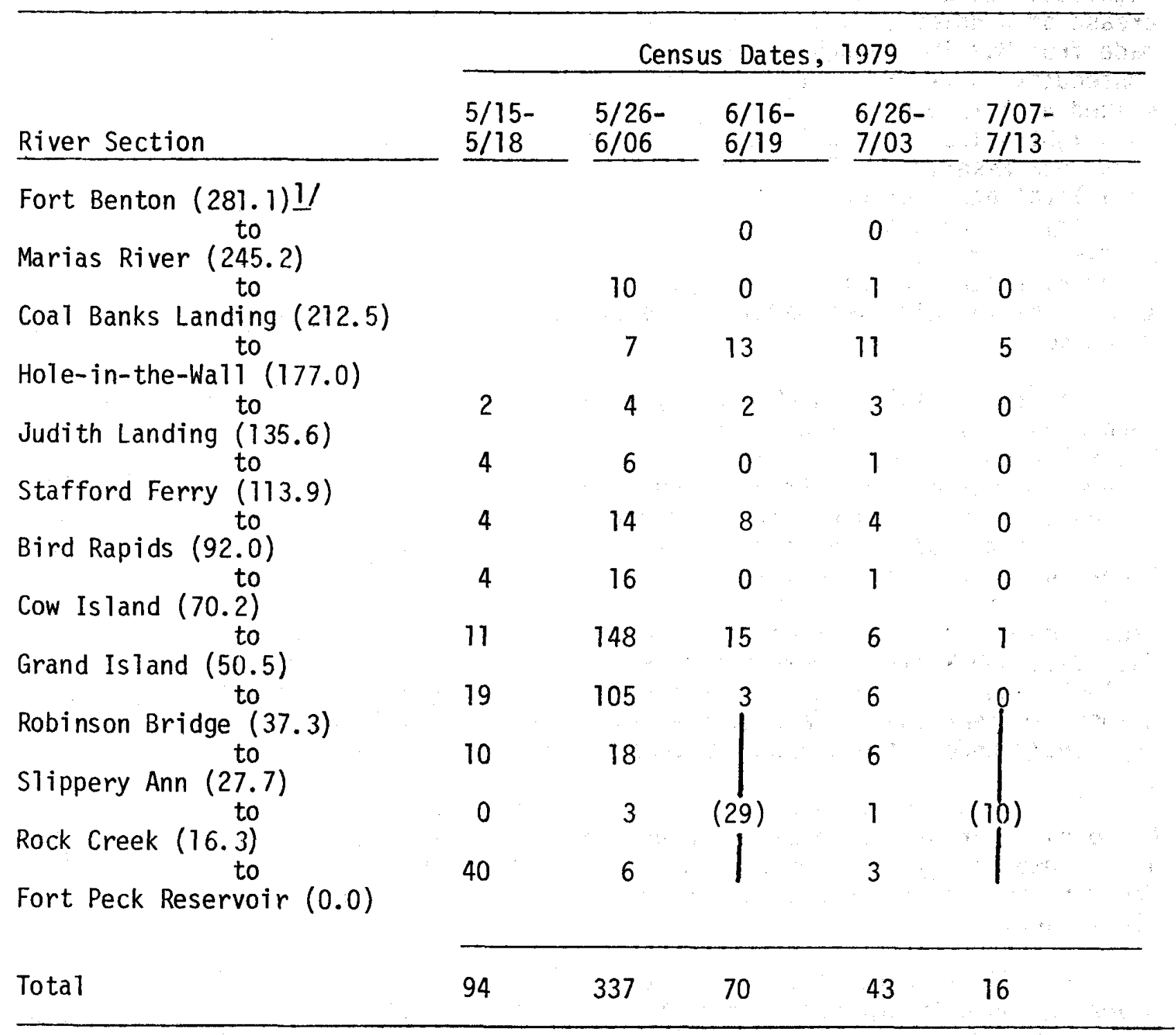

I/ River kilometers upstream from Fort Peck Reservoir. 

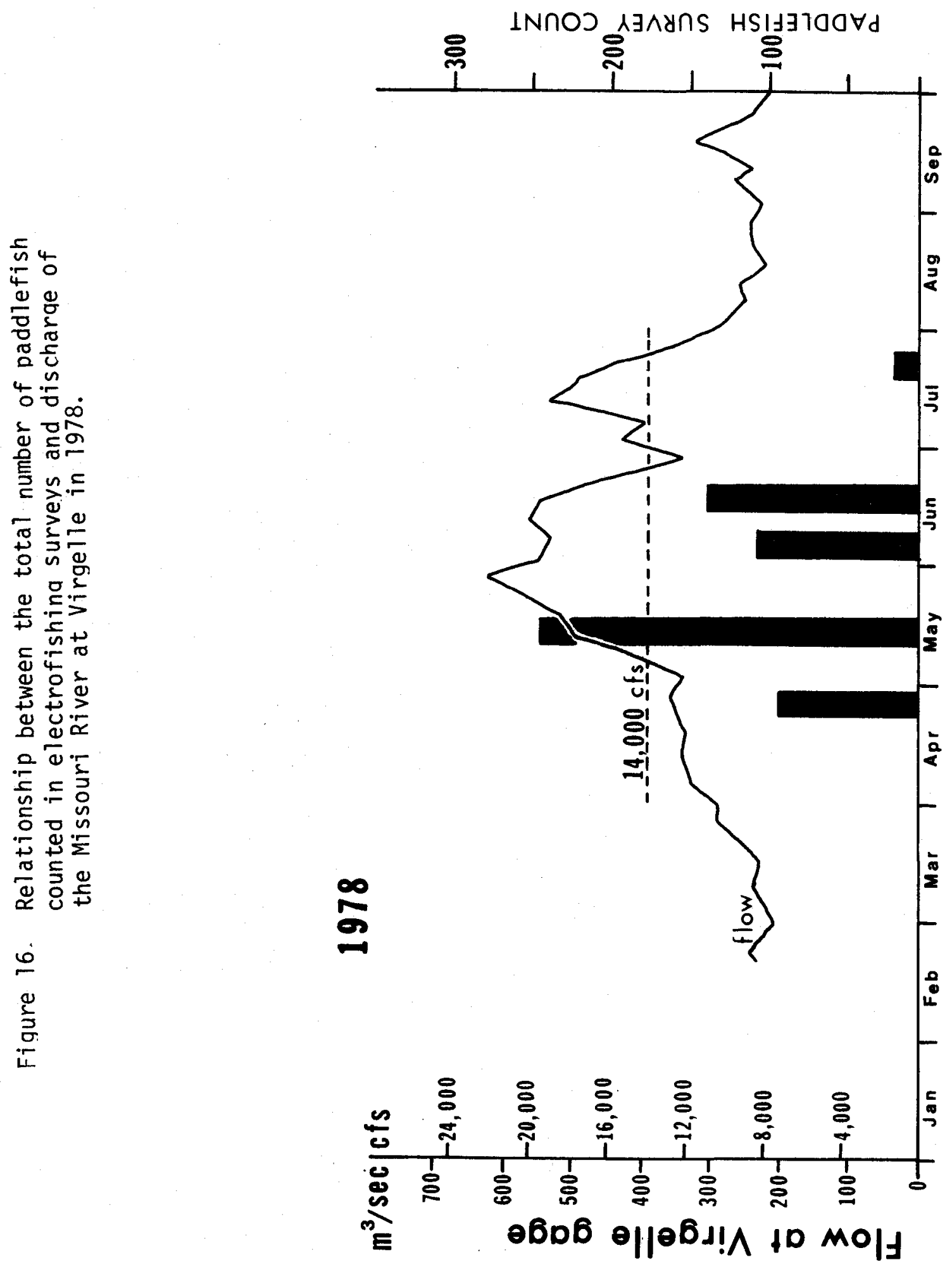

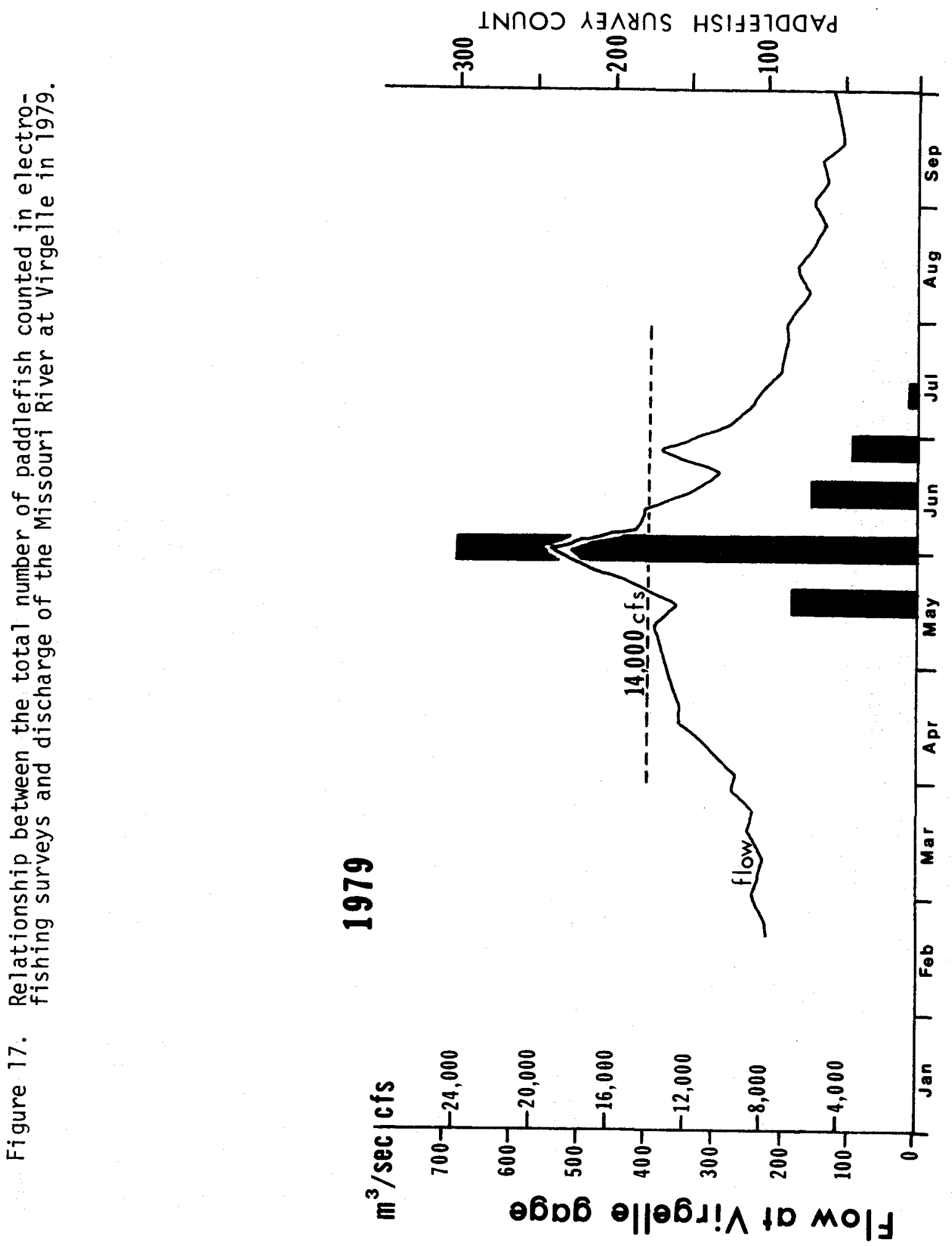
were observed in a survey count conducted from June 16 to 19 , and 49 of these were found in the lower $37 \mathrm{~km}$ of river below Robinson Bridge. Documentation gathered during these studies indicates most paddlefish spawn in the Missouri River from early June through early July. Therefore, it is possible that a portion of the paddlefish in the 1979 run did not spawn before the flow declined in mid-June. If so, reproductive success of paddlefish in 1979 may have been poorer than average.

The farthest documented upstream movement of paddlefish in 1979 was seven paddlefish observed near Three Islands, a site located $233 \mathrm{~km}$ upstream from Fort Peck Reservoir. Six paddlefish were counted at Three Islands on June 5-6 and one on June 27.

Concentrations of paddlefish were observed at certain localities along the Missouri River during the migration periods in 1978 and 1979 (Figures 18 and 19). Ten areas of particular importance are:

1. Slippery Ann- Robinson Bridge area - river kilometers 29 to 37

2. Upper and Lower Two Calf Islands area - river kilometers 45 to 50

3. Cow Is land - Powerplant Ferry area - river kilometers 56 to 71

4. Bullwhacker Creek area - river kilometers 78 to 79

5. Dauphine Rapids area - river kilometers 113 to 116

6. Holmes Rapids area - river kilometers 129 to 132

7. Deadmans Rapids area - river kilometers 137 to 142

8. Little Sandy Creek area - river kilometers 195 to 211

9. Virgelle Ferry - Boggs Island area - river kilometers 216 to 222

10. Three Islands area - river kilometers 233 to 235.

Although these ten areas encompassed only $64 \mathrm{~km}$, or 19 percent, of the 333-km reach of free-flowing Missouri River between Morony Dam and Fort Peck Reservoir, they contained 87 percent of the migrant paddlefish observed during the electrofishing survey counts. It is very significant that the paddlefish observed in 1979 inhabited the same ten sites that were occupied in 1978. The recurrent use emphasizes the importance of these sites as paddlefish habitat.

The Slippery Ann - Robinson Bridge area does not appear to contain gravel bars suitable for paddlefish spawning. However, the site is important as a "staging" area for paddlefish which inhabit the area prior to or following extended migrations to upstream spawning areas.

The remaining nine paddlefish concentration areas are important spawning sites. The following evidence was gathered during the study to support this conclusion:

1. All nine sites contained extensive silt-free gravel bars of a type described by Purkett (1961) as being suitable for paddlefish spawning.

2. Numerous paddlefish were observed in electrofishing survey counts conducted at the nine sites in both 1978 and 1979. The total number of paddlefish observed at the sites ranged from 10 at the Bullwhacker Creek site to 411 at the Cow Island - Powerplant Ferry site.

3. The paddlefish were observed at the nine sites during their known spawning period. 
Figure 18. Number of paddlefish observed at various localities along the Missouri River in electrofishing census runs made during the migration period in 1978.

$$
\text { i }
$$

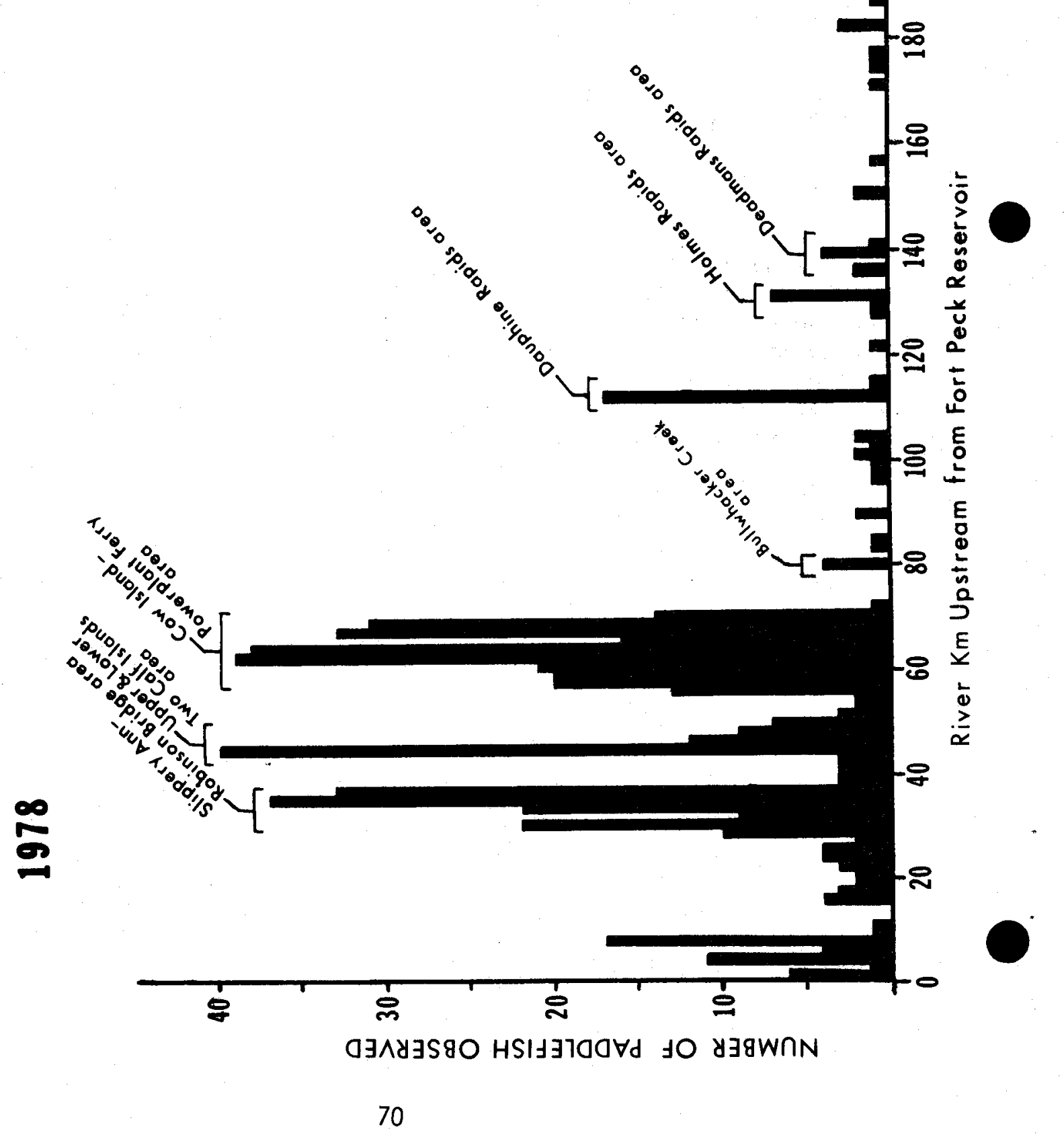




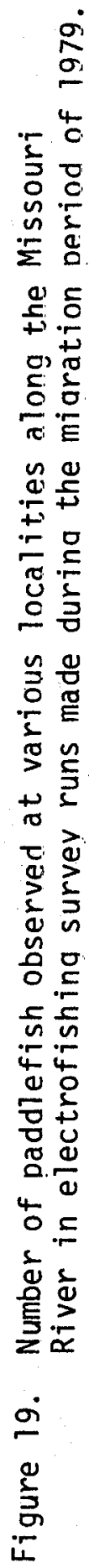

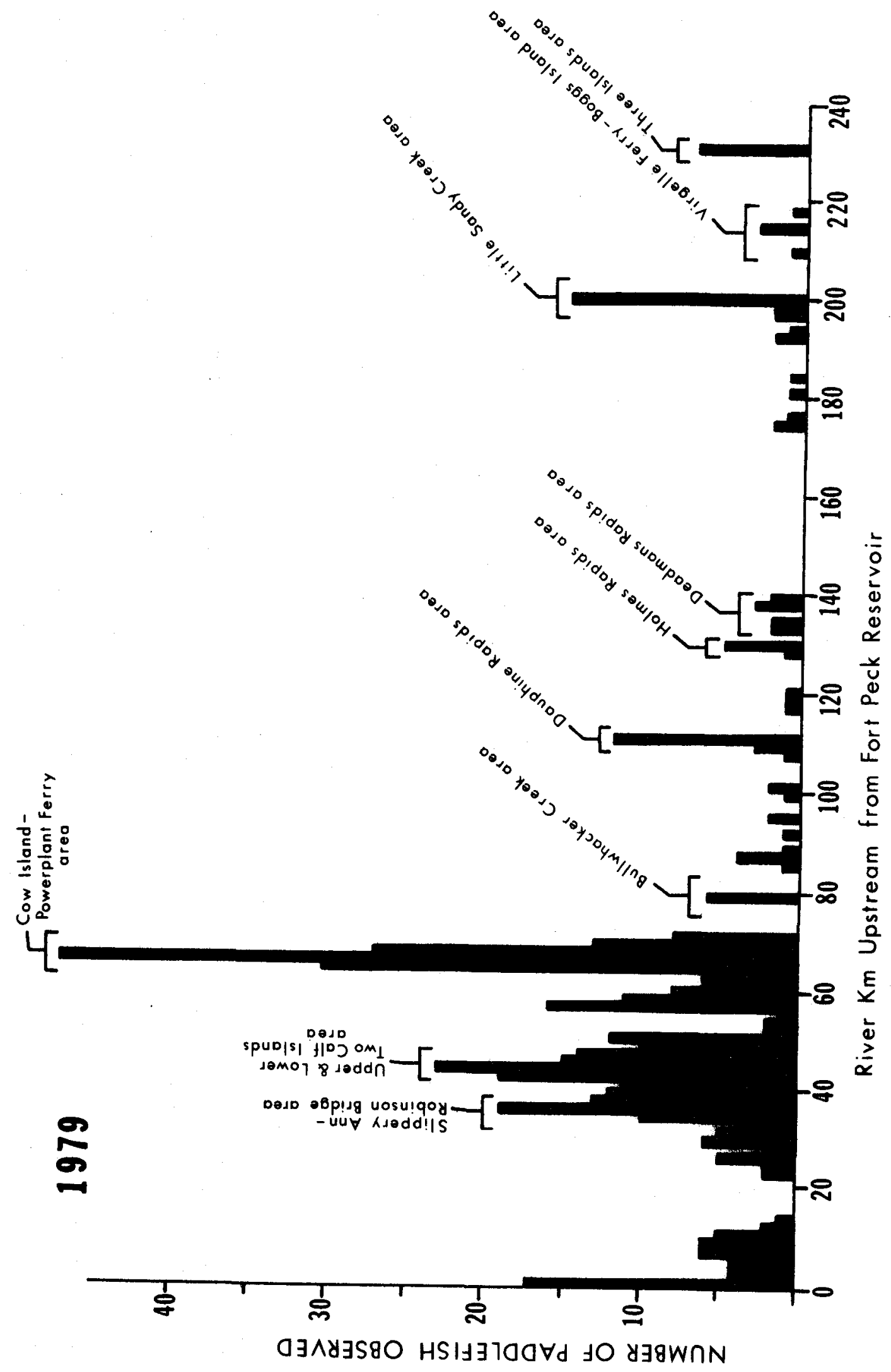


4. Sexually mature paddlefish were captured, tagged, and released in five of the nine sites, including Little Sandy Creek, Holmes Rapids, Dauphine Rapids, Cow Is land - Powerplant Ferry, and Upper and Lower Two Calf Islands (Table 16).

5. Spawning activity, as described for paddlefish on the Osage River by Purkett (1961), was observed at four of the nine sites. Purkett indicated most paddlefish spawning activity occurred underwater, but the spawning behavior also involved appearances on the surface of the water. Spawning paddlefish visible at the surface agitated the caudal fin several times, then disappeared after a few seconds. Specific spawning sites were tentatively identifed on the Osage River by observing paddlefish which continued to surface in one place. When the river level declined, Purkett found attached eggs and newly hatched larvae in these areas. Spawning activity was observed on May 23 and June 14, 1978, at the Little Sandy Creek site, on June 15 and June 27, 1978, at the Dauphine Rapids site, on June 16, 1979, at the Cow Island Powerplant Ferry site, and on June 17, 1979, at the Upper and Lower Two Calf Islands site.

6. Two paddlefish prolarvae were collected on the Missouri River in 1978, one at Coal Banks Landing on July 12 and one at Little Sandy Creek on July 13. This finding confirms that paddlefish spawn successfully in the farthest upstream spawning sites which have been identified.

7. An incubating paddlefish egg was collected at the Dauphine Rapids spawning site on June 12, 1979. Identification of this egg was confirmed at the TVA fish repository in Norris, Tennessee. The egg was developed to the 55-hour embryo stage as described by Ballard and Needham (1964). Thus, the egg was spawned at the site on June $10,1979$.

Numbers of paddlefish observed at the nine spawning sites do not necessarily indicate the relative importance of the sites for spawning. For example, the largest numbers of paddlefish in electrofishing surveys were observed in the Cow Island - Powerplant Ferry area. While the concentration of paddlefish in this area was probably related in part to suitability of the site for spawning, it was also apparent that physical characteristics of the river in the vicinity of Cow Island (shallow, swift water) acted as a partial barrier to upstream passage of paddlefish. Large concentrations of paddlefish were often found in a $16-\mathrm{km}$ section of river located immediately below Cow Island. Significant movements of paddlefish to the seven spawning sites located upstream from Cow Island did not occur until flow at the Virgelle gage station exceeded $396 \mathrm{~m}^{3} / \mathrm{sec}(14,000 \mathrm{cfs})$ (Figure 20). Since most of the spawning areas are located upstream from Cow Island, flow should be maintained in excess of $396 \mathrm{~m} / \mathrm{sec}$ whenever possible during the spawning period to allow passage past the island.

In summary, the nine paddlefish spawning sites and the "staging" area below Robinson Bridge are critical habitat areas for the Missouri River Fort Peck Reservoir paddlefish population. Efforts must be made to protect the sites so paddlefish use can continue undiminished. These efforts are particularly important because of the tenuous status of paddlefish in the United States today. 


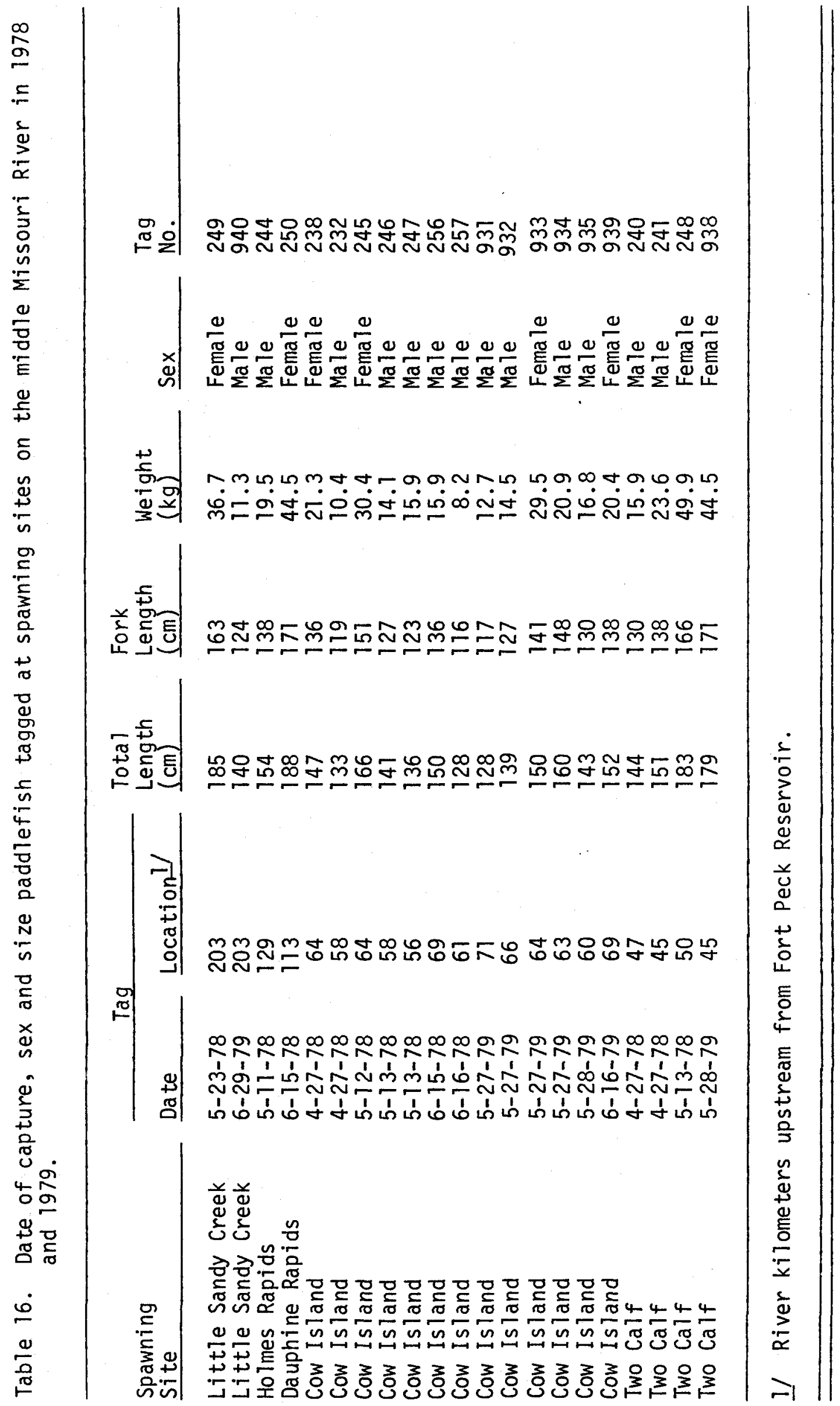



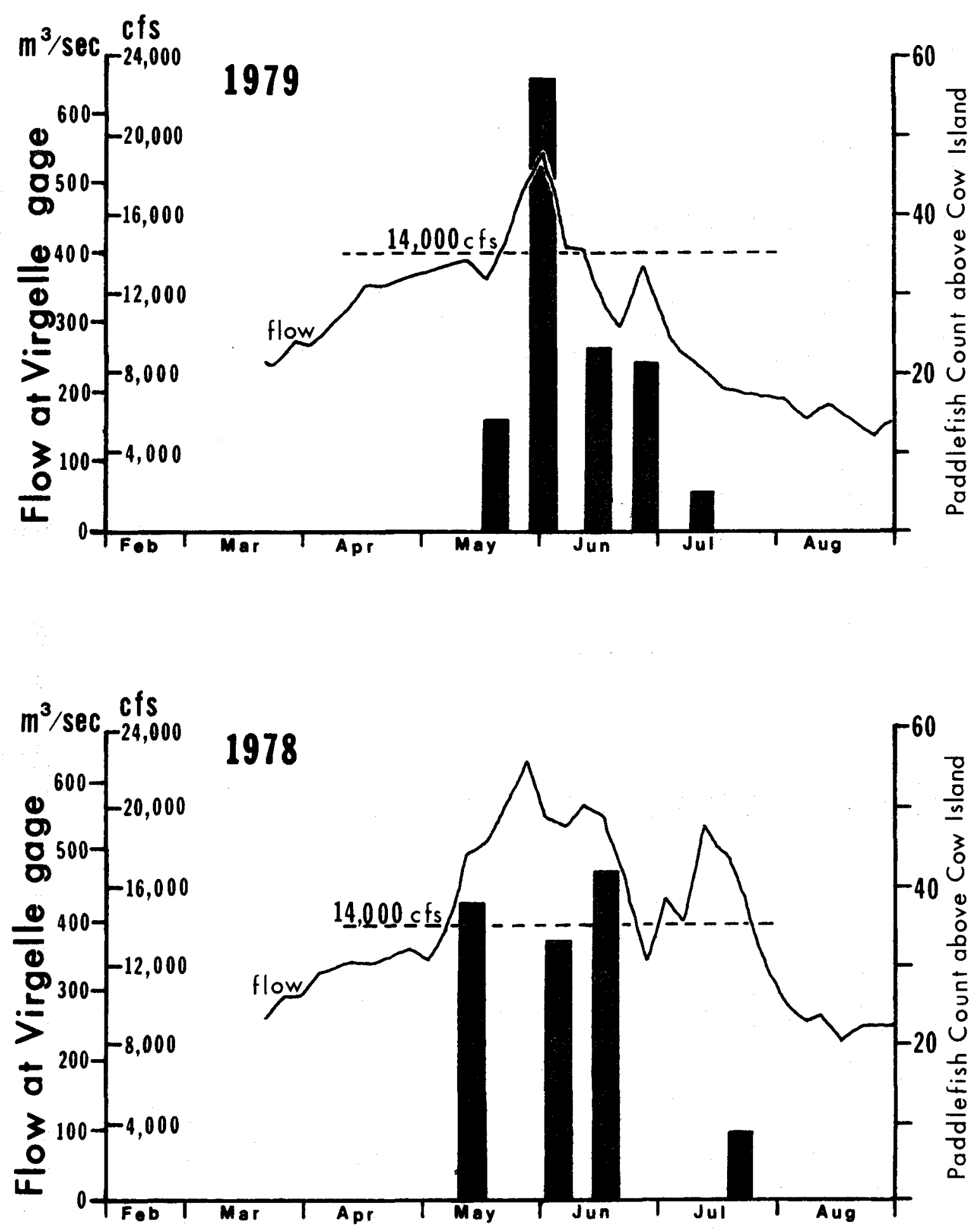

Figure 20. Number of paddlefish counted in electrofishing surveys above Cow Island compared to discharge of the Missouri River at Virgelle in 1978 and 1979. 
Spawning Periods of Fish in the Missouri River Mainstem

Spawning periods were determined for 18 fish species in the mainstem of the middle Missouri River. The spawning period was defined as the time between the first observation of a spent or partly spent female to the last observation of a ripe female. Larval fish collections were used to aid in determining the spawning period for some species. Spawning chronology of the 18 fish species is illustrated in Figure 21. The spawning periods represent a four-year composite for the inventory period, 1976 through 1979.

Walleye, sauger, northern pike, goldeye, and longnose sucker were relatively early spawners; all began spawning in April. Walleye spawning peaked in late April. Sauger, northern pike, goldeye, and Catostominae (suckers and redhorse) spawned primarily in May, while shovelnose sturgeon, paddlefish, and Ictiobinae/Cyprinidae (river carpsucker, buffalo, and minnows) spawned primarily in June and early July. Channel catfish spawning peaked during the first three weeks of July.

Seasonal Migrations of Fish in the Missouri River Mainstem

Information on seasonal migrations of common fish species in the study area was provided by electrofishing catch rates. Electrofishing data indicated shovelnose sturgeon made a significant seasonal spawning movement from the lower portion of the middle Missouri River into the Coal Banks Landing and Loma Ferry study sections. The shovelnose sturgeon spawning period in the Missouri River extends from late May through early July. From 1976 through 1979, an average of 0.9 shovelnose sturgeon per electrofishing hour was sampled in the Coal Banks Landing and Loma Ferry study sections in early May. During the peak of the shovelnose sturgeon spawning period in early June, the catch rate increased to an average of 2.2 sturgeon per electrofishing hour in these study sections. By late June the catch rate decreased to 0.9 sturgeon per electrofishing hour, probably indicating that many of the fish had spawned and dispersed back downstream.

It is not known if shovelnose sturgeon actually spawn in the Coal Banks Landing and Loma Ferry study sections or if this is a staging area for sturgeon which spawn in the Marias River. Shovelnose sturgeon prolarvae have been collected in the lower Marias River, indicating that successful reproduction occurs there. While shovelnose sturgeon spawning has not been verified in the mainstem of the middle Missouri River, the presence of substantial numbers of ripe male and female sturgeon in the Coal Banks Landing and Loma Ferry study sections during the spawning period suggests that some spawning could occur in the mainstem. The Coal Banks Landing and Loma Ferry study sections contain significant amounts of silt-free gravel bars. Although little is known about the spawning habits of shovelnose sturgeon, Pflieger (1975) indicated they evidently spawn in the open channels of large rivers, in a strong current, and over gravelly bottoms. Morris et al. (1974) also indicated that shovelnose sturgeon spawn over gravel, and they have been observed moving upstream prior to spawning, sometimes for considerable distances.

One of the most substantial fish movement patterns observed in the middle Missouri River was the seasonal migration of sauger from the lower river into the reach between Fort Benton and Morony Dam. Sauger movement into the upper portion of the river occurred during the spring and summer. 


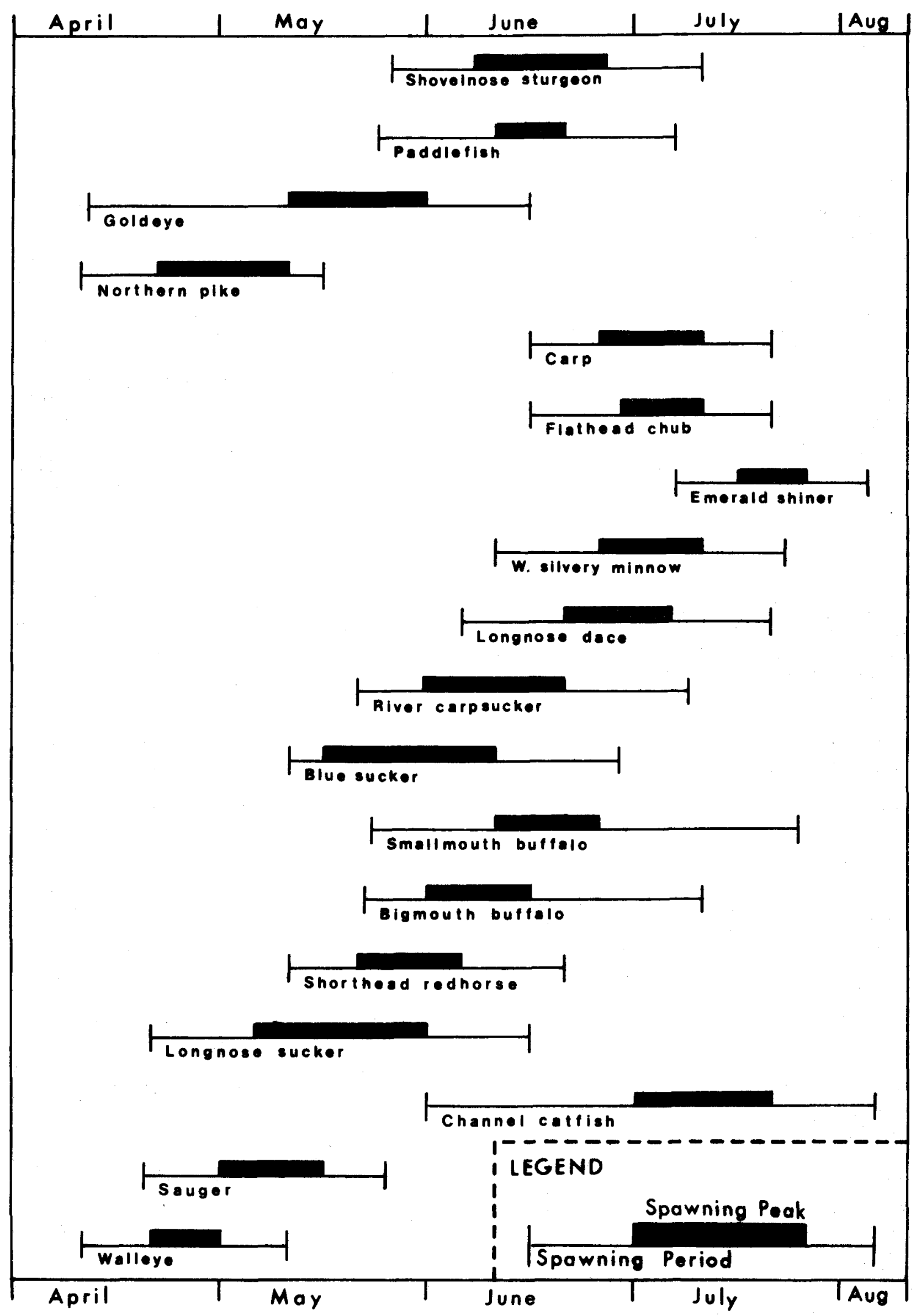

Figure 21. Observed spawning chronology of eighteen fish species sampled in the middle Missouri River from 1976 through 1979. 
The catch rate of sauger in the upper river gradually increased prior to, during, and following the spawning period which peaked in early May. The early spring movements of sauger were related to spawning, while movements later in the summer were probably related to feeding.

The increased concentration of sauger was particularly evident in the Morony Dam study section where the catch rate increased from an average of 0.2 sauger per electrofishing hour in late March to 12.0 sauger per hour during the spawning period in May. The catch rate continued to gradually increase to a peak of 28.8 sauger per hour in August, and then it decreased to an average of 9.5 sauger per hour in 0ctober. The catch rates represent a composite average for the period from 1976 through 1979.

In the Carter Ferry study section, located between Morony Dam and Fort Benton, the catch rate increased from an average of 0.6 sauger per hour in late March to 10.0 sauger per hour during the spawning period in May. In August, the catch rate reached a peak of 18.7 sauger per hour. By late October, the catch rate decreased to 7.5 sauger per hour, indicating that many of the fish had dispersed back downstream.

Sauger movement trends in the Fort Benton study section were similar to those observed in the Morony Dam and Carter Ferry sections, but seasonal changes were less pronounced. Catch rates in the Fort Benton study section were 2.5 sauger per electrofishing hour in late March, 7.5 sauger per hour during the spawning period in May, 9.9 sauger per hour in August, and 9.5 sauger per hour in October.

The reach of Missouri River between Morony Dam and Fort Benton is obviously critical sauger habitat. Large numbers of sauger in a ripe spawning condition are found in this area during the spring spawning period. In addition, a spawning run of sauger from the Missouri River occurs in lower Belt Creek, a tributary which enters the Missouri River 1.9 kilometers below Morony Dam (Posewitz 1963 and Al Wipperman, DFWP, personal communication). Forage fish, which comprise the principal portion of the sauger diet, are very abundant in the Missouri River between Morony Dam and Fort Benton. Several important forage species, including longnose dace, mottled sculpin, mounta in suckers, and juvenile shorthead redhorse and longnose suckers are significantly more abundant upstream from Fort Benton than in downstream areas (Table 10). Tag return evidence indicates that sauger using the Missouri River upstream from Fort Benton come from areas as far downstream as the headwaters of Fort Peck Reservoir, a distance of approximately $280 \mathrm{~km}$. Sauger movements indicated by tag returns will be discussed in greater detail in the next section of this report.

In summary, the Missouri River from Morony Dam to Fort Benton provides food production and spawning sites for sauger from as far downstream as Fort Peck Reservoir. Protection of this critical habitat area is essential.

Electrofishing data also indicated that blue suckers, smallmouth buffalo, and bigmouth buffalo made significant seasonal movements from the lower portions of the river into upstream areas. Large numbers of blue suckers and buffalo were found during their spawning period in the Coal Banks Landing, Loma Ferry, and Fort Benton study sections, and some were found seasonally as far upstream as the Morony Dam study section. The seasonal movement of blue suckers and buffalo was evidently related to spawning since most of the fish dispersed back downstream shortly after the spawning period. 
Several additional species of fish, including goldeye, river carpsuckers, shorthead redhorse and others, made extensive seasonal movements. However, electrofishing data were not adequate to evaluate movement patterns of these species.

Movements of Fish as Indicated by Tag Returns

A total of 8165 fish of 17 species were marked with individually numbered tags during the period, October 1, 1975 through October 1, 1980 . of this total, 6992 fish were tagged in the mainstem of the Missouri River from Morony Dam to Fort Peck Reservoir, and 1001, 131, and 41 were tagged in the lower Marias, Teton, and Judith rivers, respectively. The species tagged included 3950 sauger, 1926 channel catfish, 814 shovelnose sturgeon, 423 blue suckers, 287 smallmouth buffalo, 216 freshwater drum, 169 burbot, 131 mountain whitefish, 97 bigmouth buffa10, 40 walleye, 40 northern pike, 28 brown trout, 21 white crappie, 18 rainbow trout, 2 brook trout, 2 yellow perch, and 1 pallid sturgeon.

Of the 8165 fish tagged, 276 were recaptured in subsequent research surveys or by anglers (Table 17). The recaptures included 168 sauger, 66 channel catfish, 12 shovelnose sturgeon, 6 blue suckers, 6 smallmouth buffalo, 6 walleye, 3 northern pike, 3 burbot, 2 freshwater drum, 2 brown trout, 1 bigmouth buffalo, and 1 mountain whitefish. The recaptures provided significant information about movement patterns of several species.

\section{Sauger}

Tag return data indicated that sauger moved considerable distances in the Missouri River and its tributaries. Of 168 sauger recaptured, 127 ( 76 percent) moved $1 \mathrm{~km}$ or more from the site where they were tagged. Distances moved by individual fish ranged from 1 to $295 \mathrm{~km}$ upstream and from 1 to $246 \mathrm{~km}$ downstream (Table 17). The tag return data indicate that sauger move throughout the entire river from Morony Dam to Fort Peck Reservoir.

Other researchers have also reported extensive movements of sauger in rivers. Graham et al. (1979) found numerous sauger which moved more than $100 \mathrm{~km}$ upstream or downstream in the lower Yellowstone River, Montana. The maximum distances moved in the lower Yellowstone were $417 \mathrm{~km}$ downstream and $269 \mathrm{~km}$ upstream. Posewitz (1963) observed sauger movements of up to $87 \mathrm{~km}$ upstream and $32 \mathrm{~km}$ downstream in the lower Marias River, Montana. Morris (1969) reported downstream movements of up to $124 \mathrm{~km}$ below the stilling basin of Gavins Point Dam on the Missouri River, Nebraska.

A seasonal migration of sauger from the lower portion of the middle Missouri River into the reach between Fort Benton and Morony Dam was described in the previous section of this report. Numerous recaptures of individually tagged sauger provided additional evidence of this movement pattern. Twenty-nine sauger tagged upstream from Fort Benton were subsequently recaptured downstream from Fort Benton. Most of the recaptured fish were tagged upstream from Fort Benton during spring and summer (mid-April through mid-September). Most of the downstream recoveries were made in the late fall or early spring.

Nineteen sauger tagged downstream from Fort Benton were recaptured in the Missouri River upstream from Fort Benton. Most of these fish were tagged downstream in the late fall or early spring, and most of the recoveries 


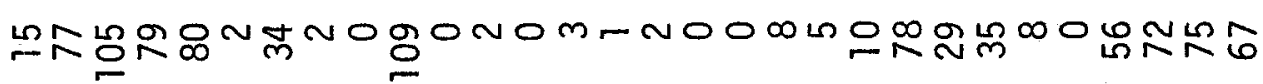

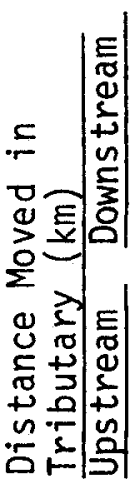

$m$

$\stackrel{\llcorner}{\circ}$

N

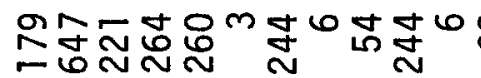

$\sim$

$m-$

$\infty \sim$

ํํำ

LกN

$N \quad N \quad N \quad \infty \quad \infty$

NNMNNODLL

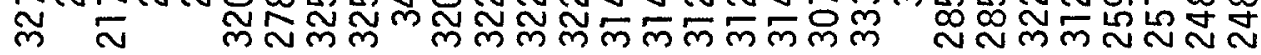

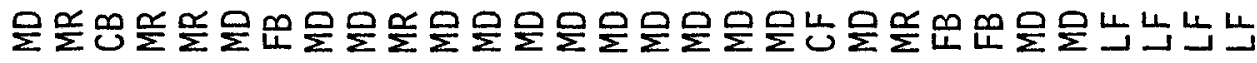

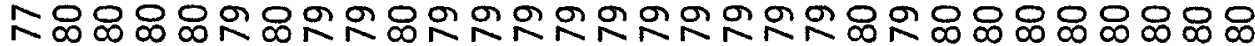

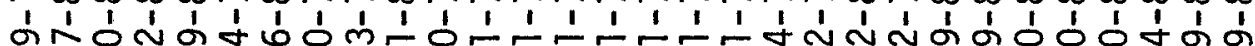

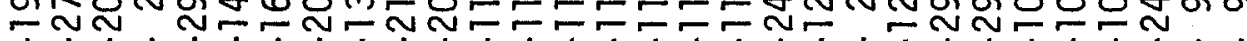

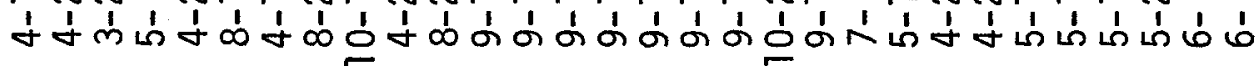

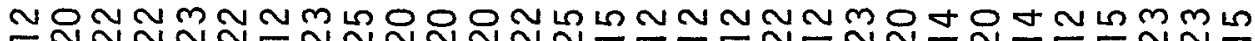
m

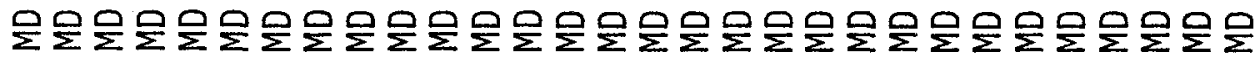

cos 山́丶 N⿴囗十 آم 


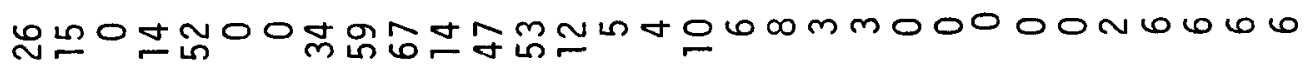

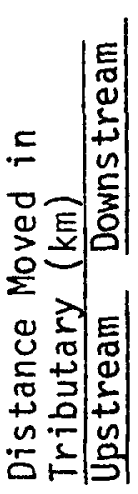

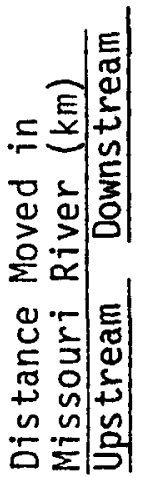

$\omega m$

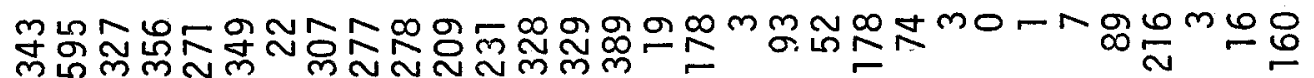

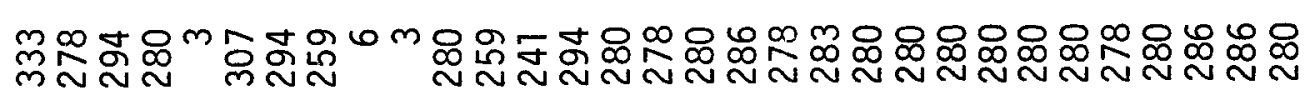
올

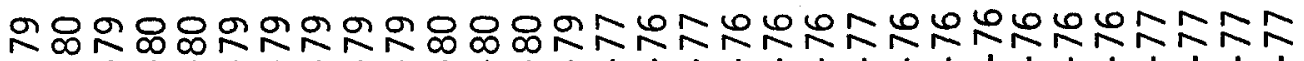

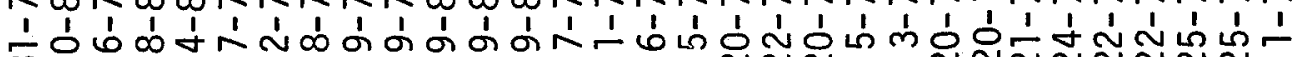

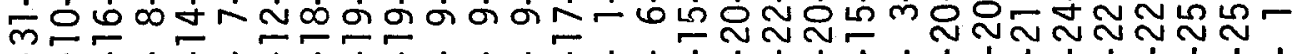

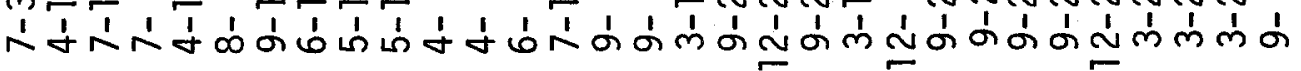

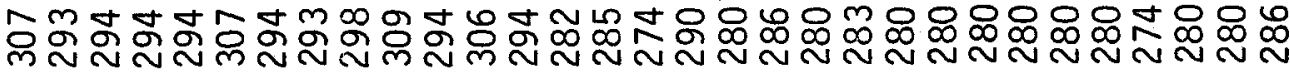

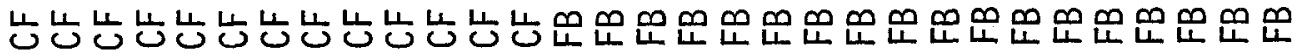

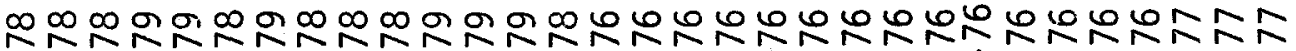

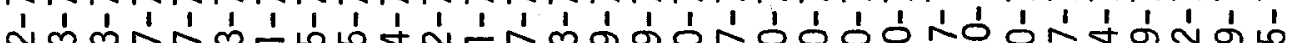

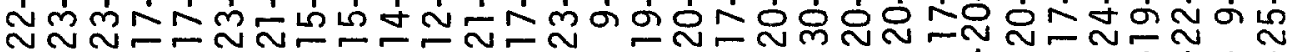
d́ 
mmmgू

$\infty 6 \pm$

จ

I

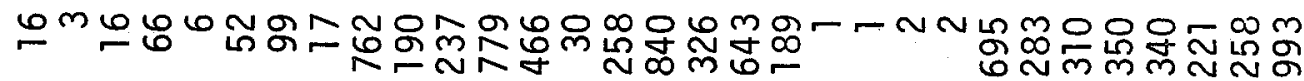

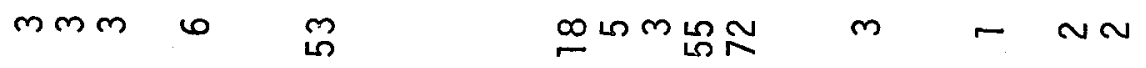

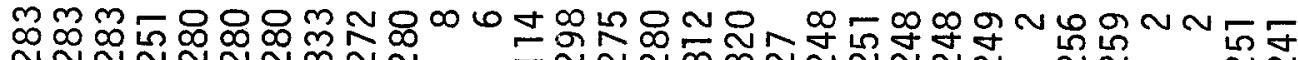

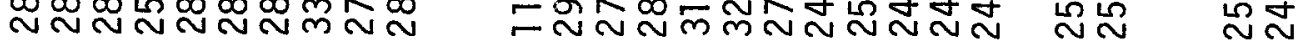

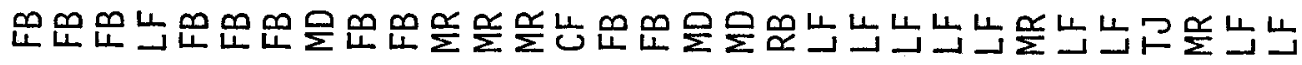

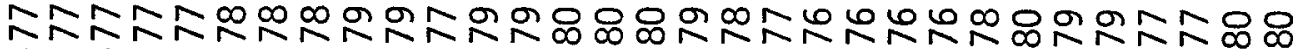

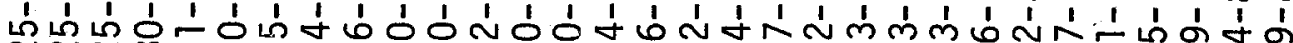
NNN

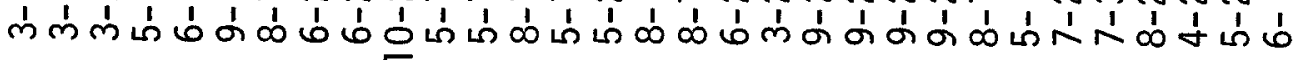

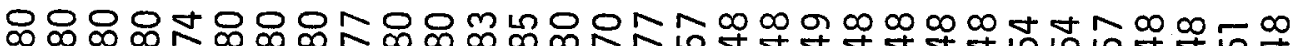

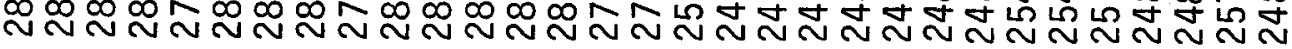

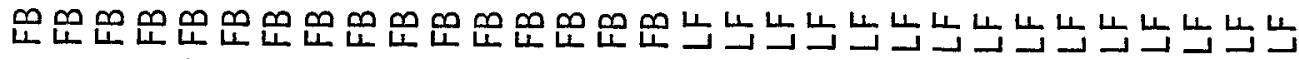

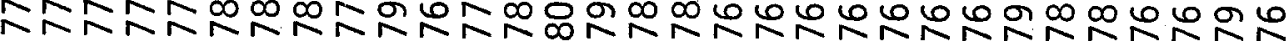
ด่ ḿ่m 


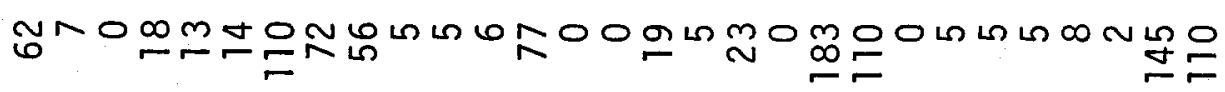

$\infty$

$\infty \quad$ w

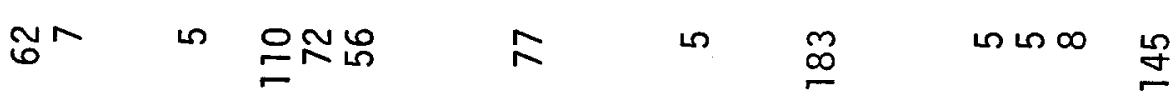

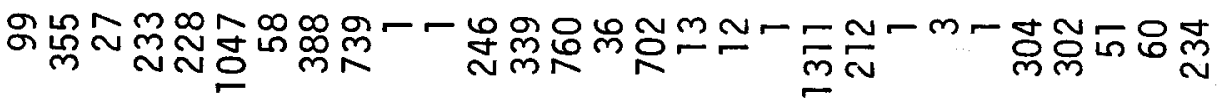

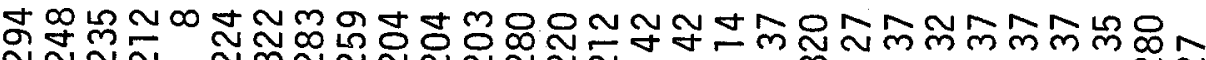

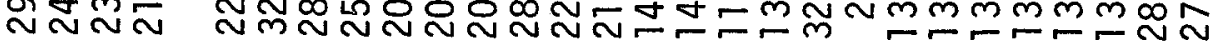

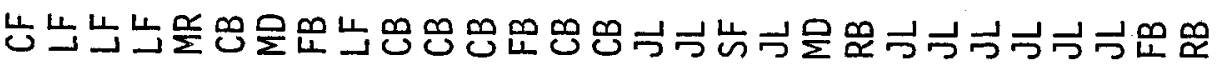

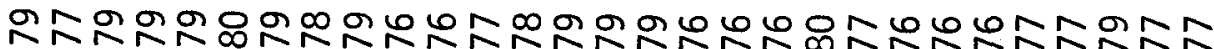

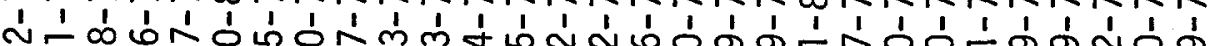

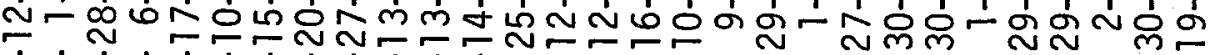

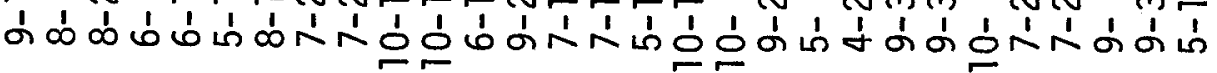

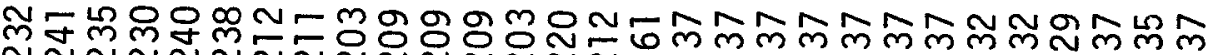

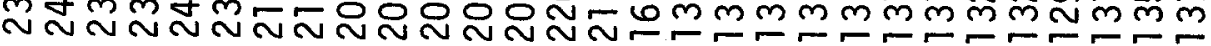

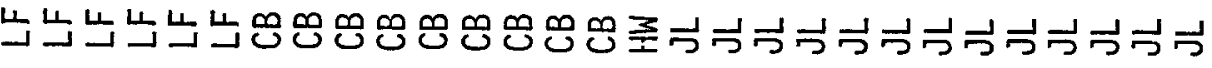

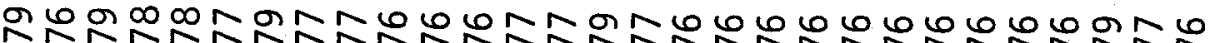

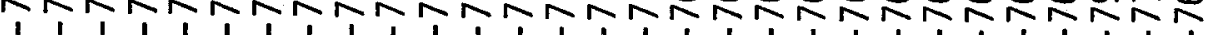

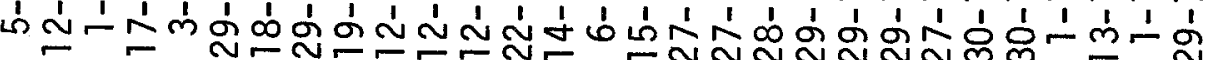
b́ 


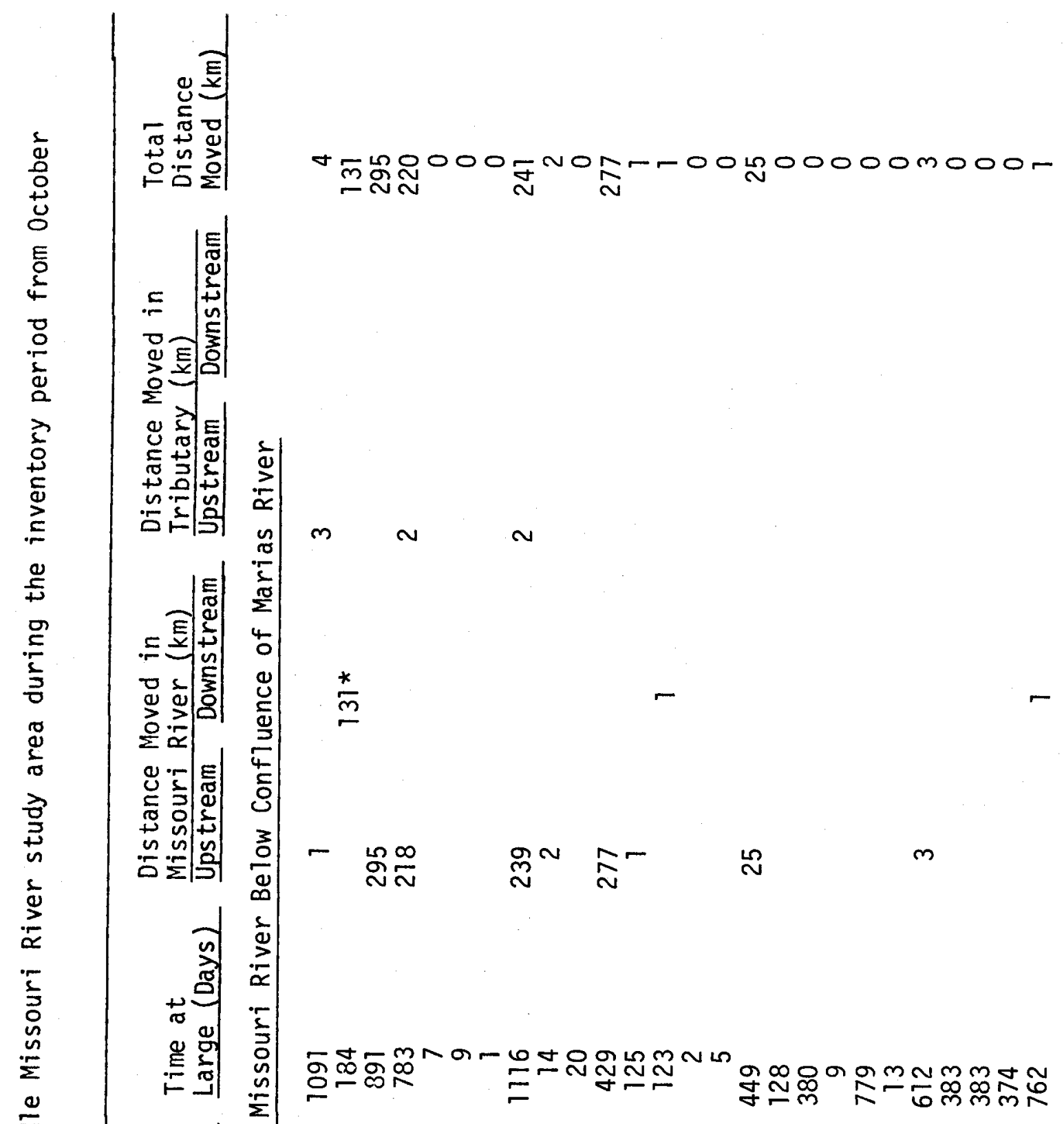

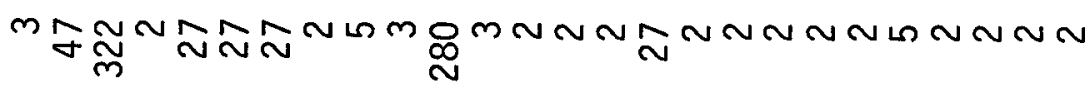

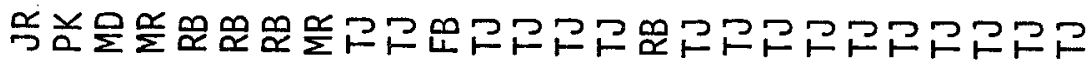

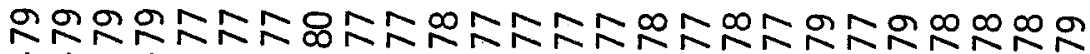
1 1 1 늠 б.

4

芒保

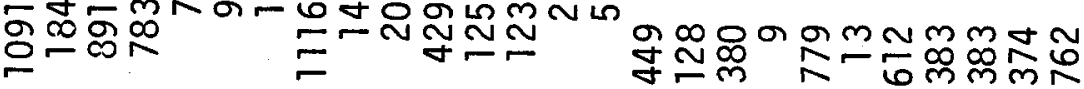

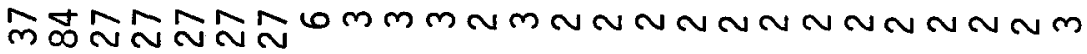

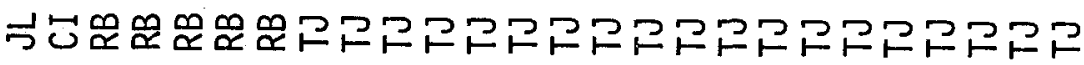
LRANANANANANANANANANANANAN

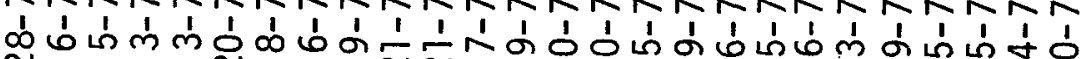

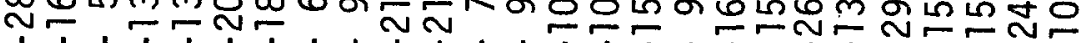

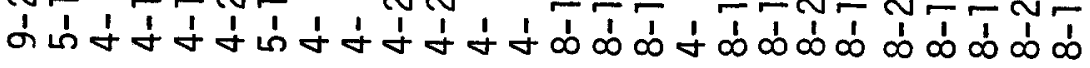




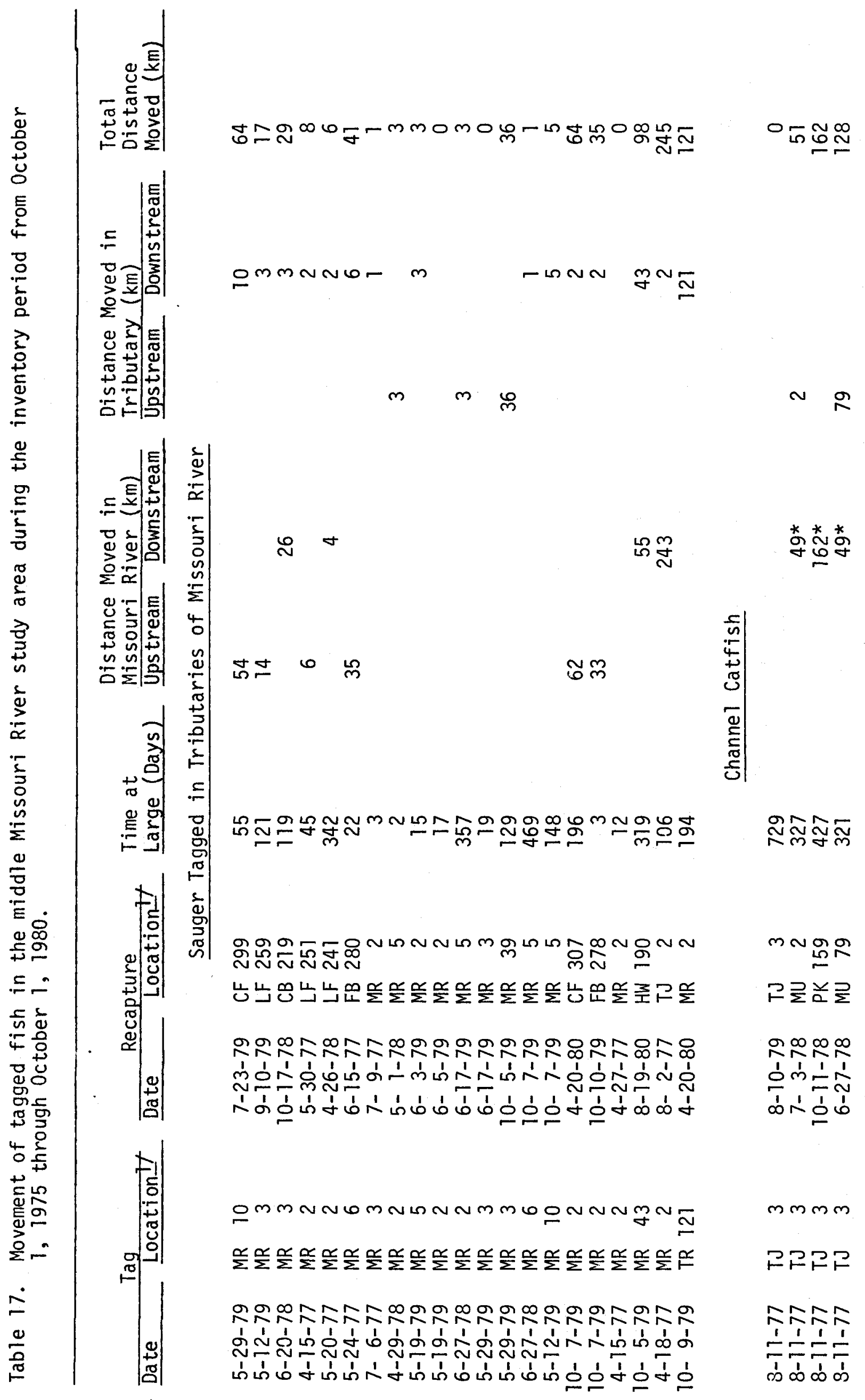




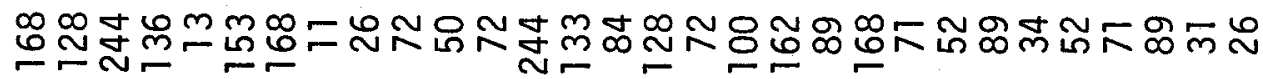

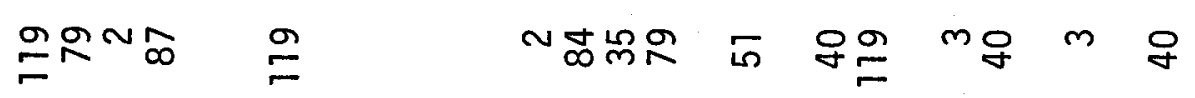

$\varepsilon E$

$\therefore \geq$

○<

$\stackrel{4}{3}$ 웅

을

Q E

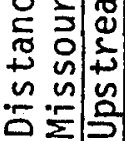

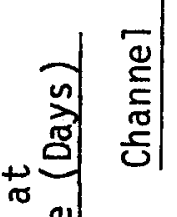

$\stackrel{E}{=} \frac{1}{\sigma}$

$\stackrel{0}{0}$

뭄

E

용

至

.

ᄃs

जิ

40

궁

思

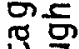

$4 \frac{2}{5}$

芒的

$\overline{\frac{0}{2}} \frac{10}{2}$

Eั on

$\sum_{0}^{\infty}$

$\sum$ m

$\frac{1}{10}$

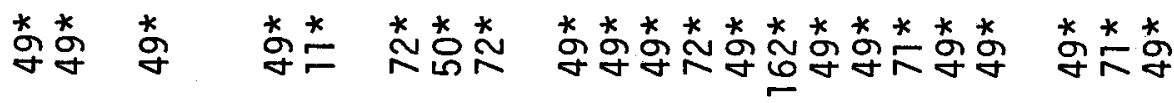

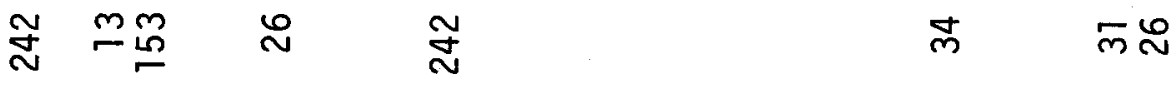

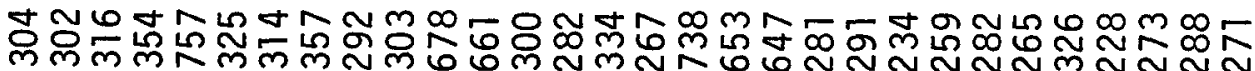

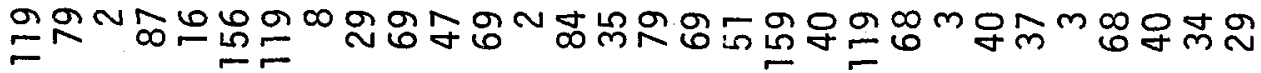

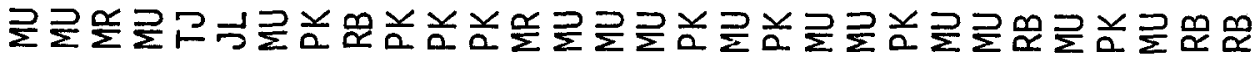

뮴 1'́l't 1 '

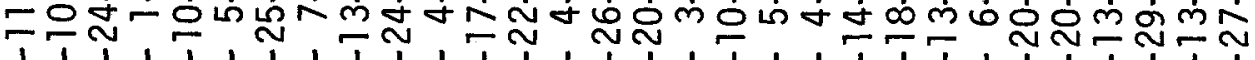

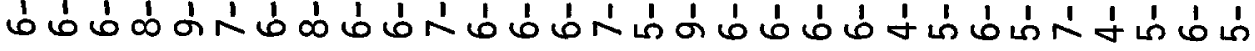

Мmmm

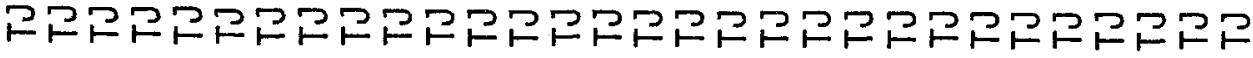

NANANANANANANANANANANNANANANAN !́⿴囗十丁

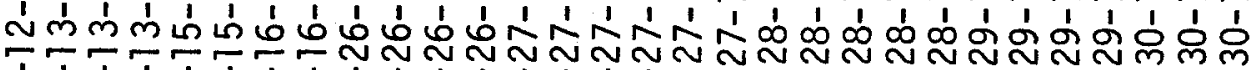
ळ 


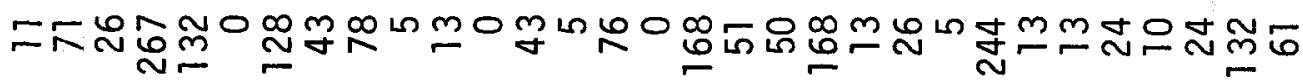

$m$

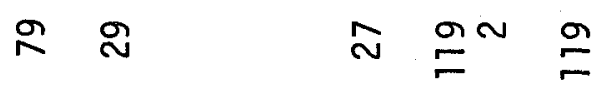

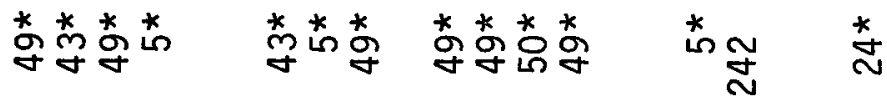

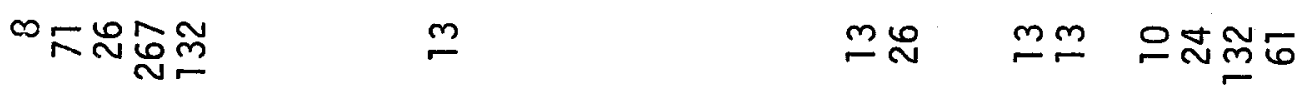

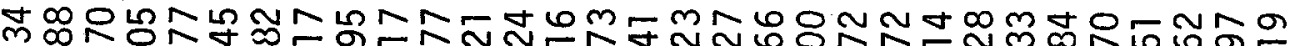

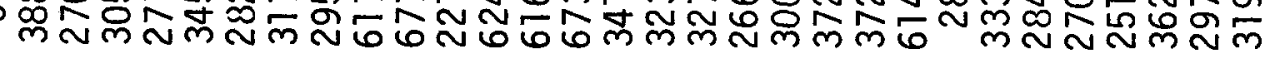

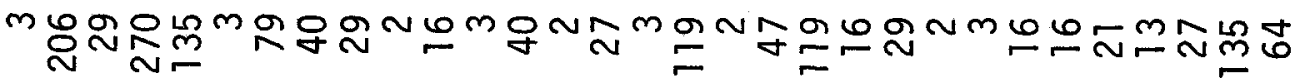

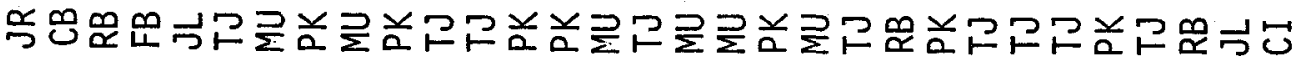

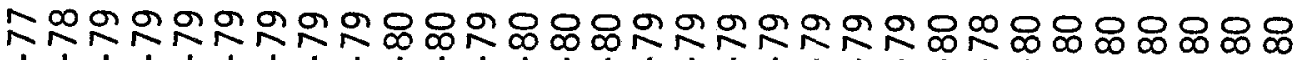

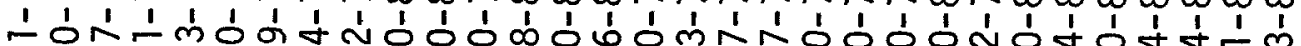

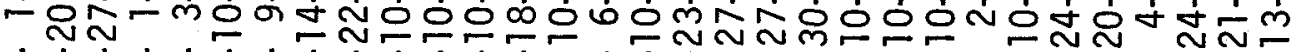

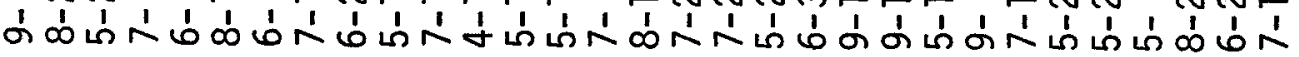

$\mathbb{N} \mathrm{m} m \mathrm{mmmmmmmmmmmmmmmmmmmNmmmmmmm}$ -

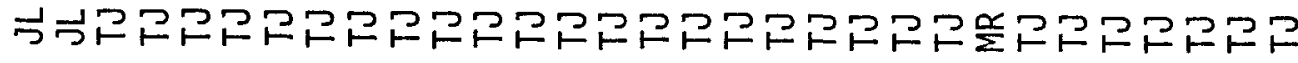

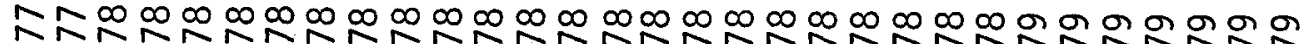

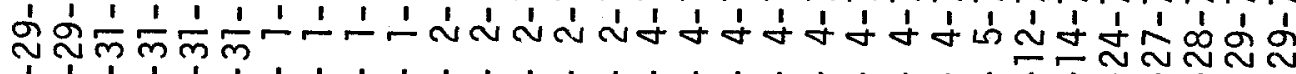

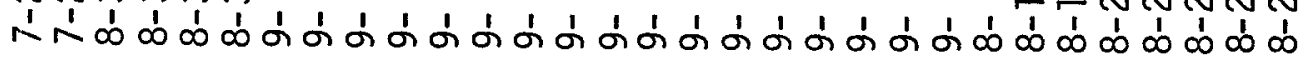




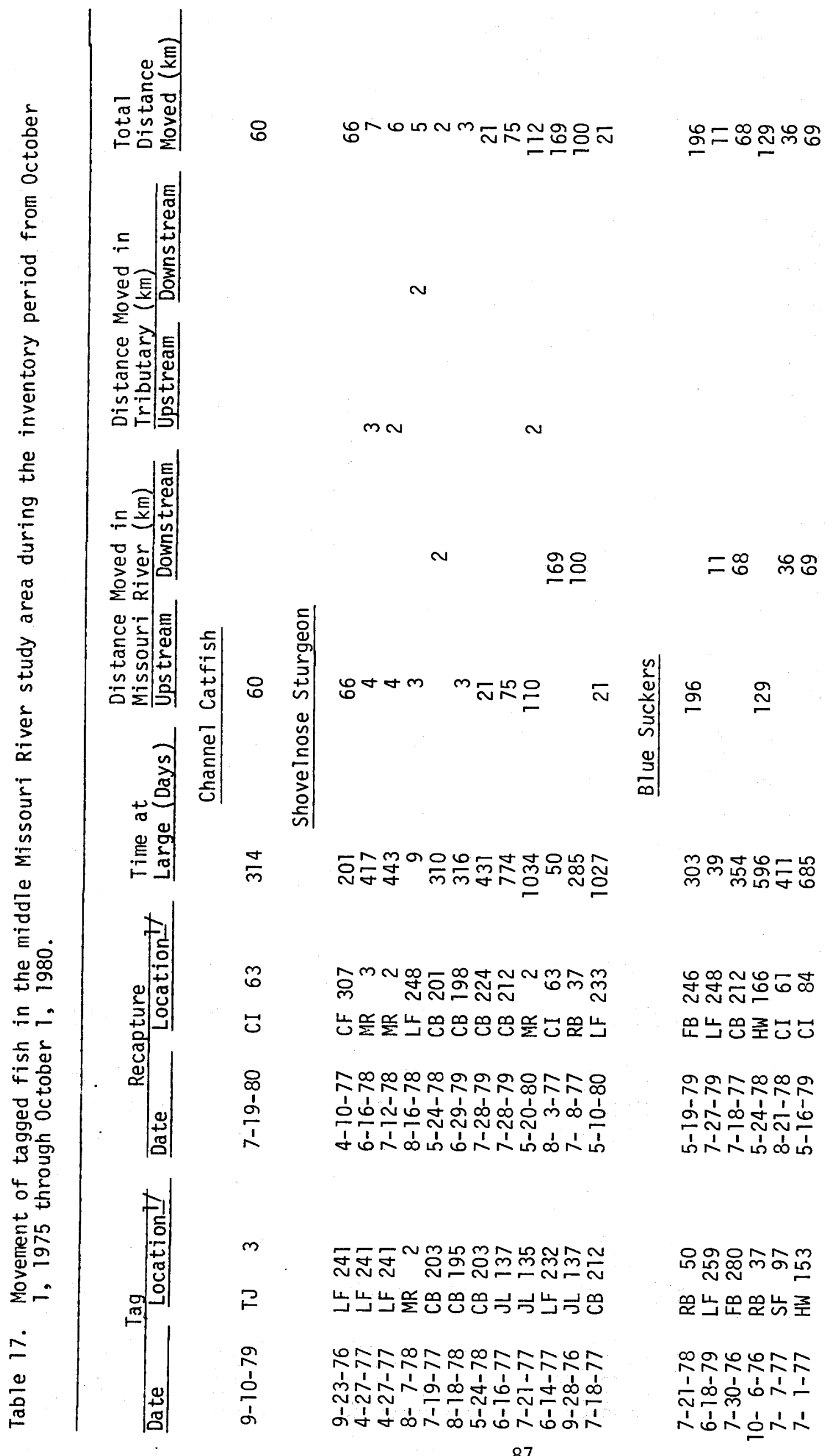




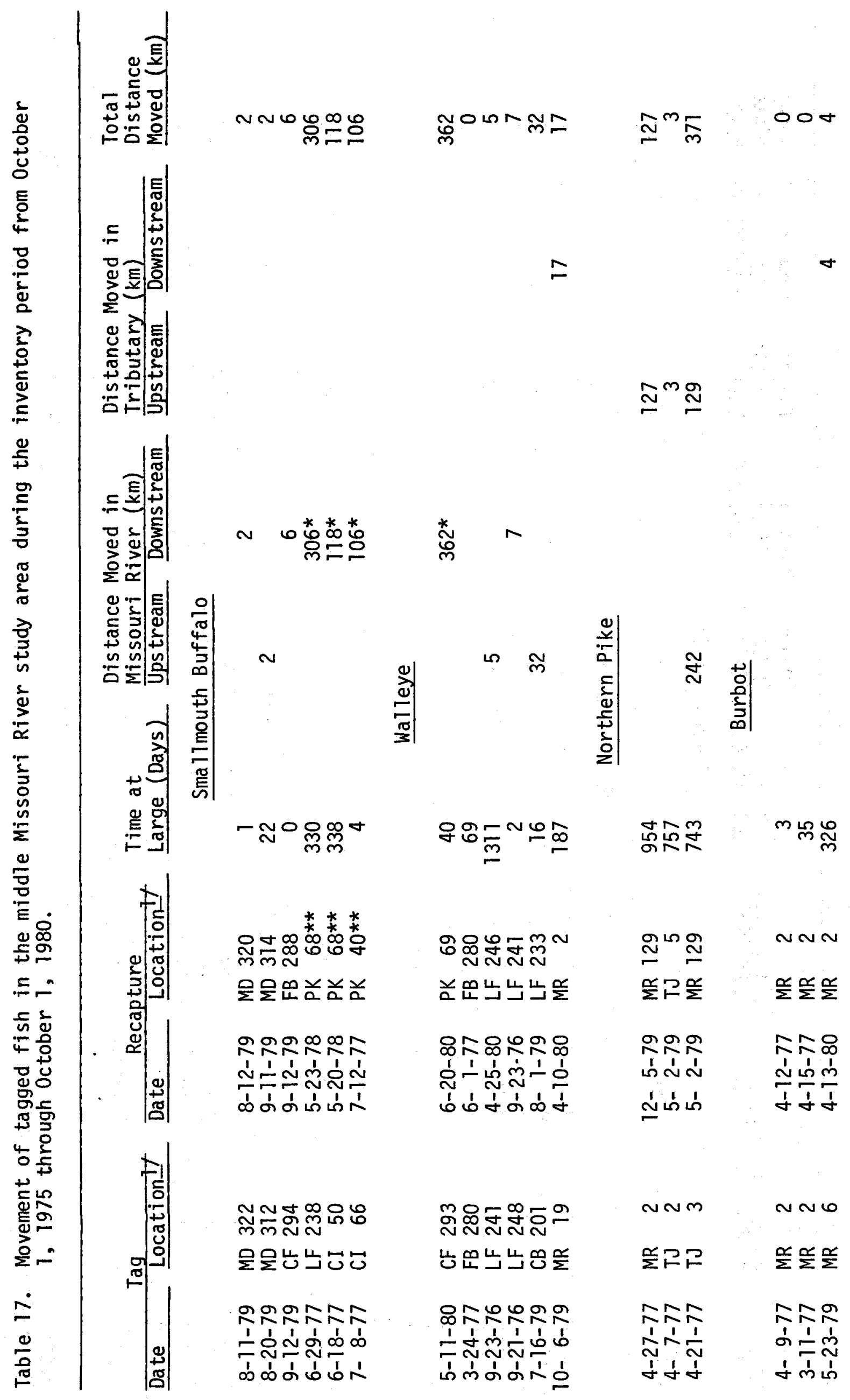




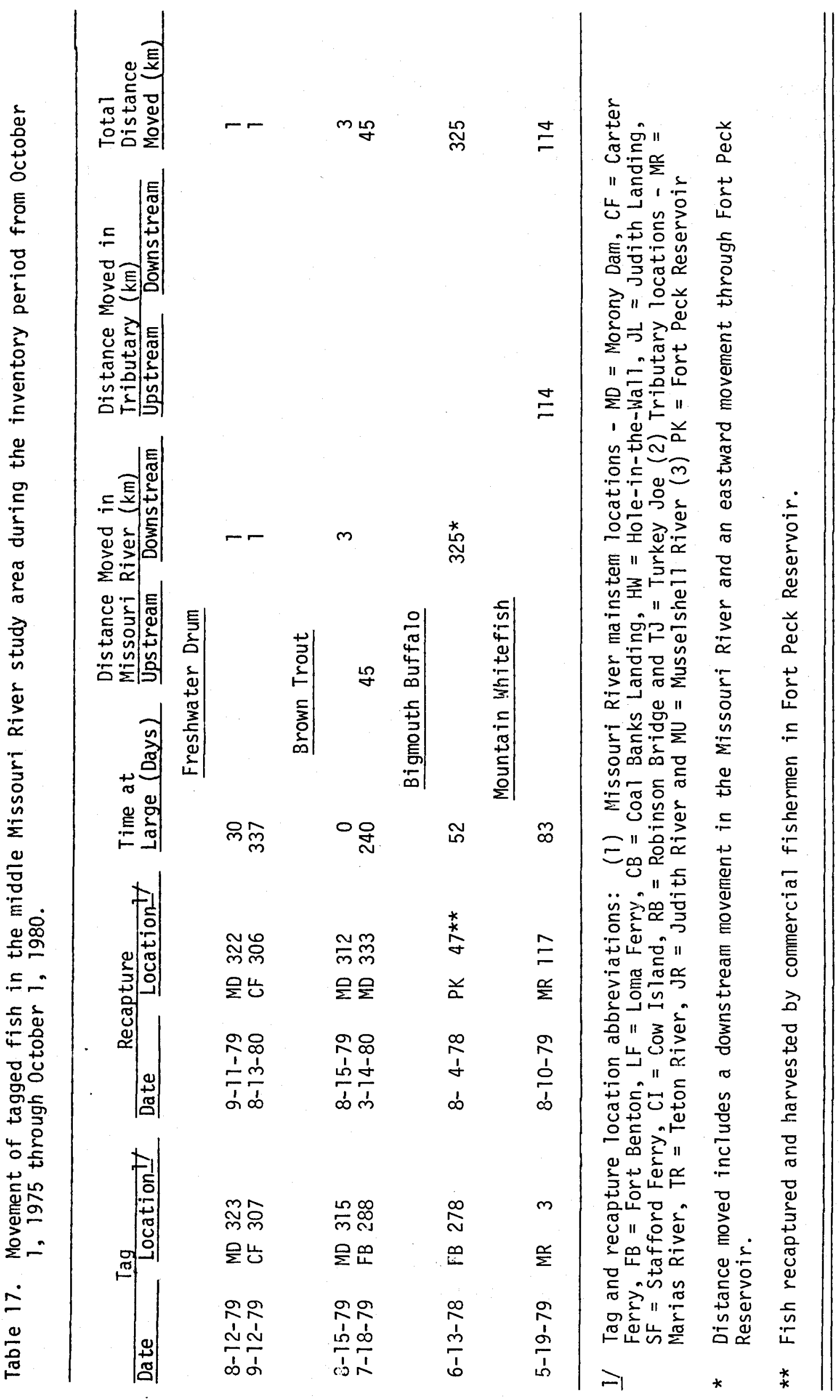


were made upstream in the spring and summer. Some of the sauger recaptured upstream from Fort Benton had been tagged in the Missouri River near the headwaters of Fort Peck Reservoir. Several of these fish moved upstream for distances of more than $200 \mathrm{~km}$. In summary, the tag return evidence verifies that sauger using the Missouri River upstream from Fort Benton for spawning and feeding come from areas throughout the Missouri between Fort Benton and Fort Peck Reservoir, a distance of approximately $280 \mathrm{~km}$.

Another significant movement pattern for a portion of the sauger residing seasonally in the Missouri River upstream from Fort Benton was their migration downstream in the Missouri River and upstream into the lower Marias River. Eleven sauger tagged in the Missouri River upstream from Fort Benton in July and August were recaptured the following spring in the lower Marias River. These fish moved 35 to $80 \mathrm{~km}$ downstream in the Missouri River and then several kilometers upstream in the lower Marias River to spawn. The recaptures were made in the lower Marias River during the spawning period in April and May. Two sauger tagged in the lower Marias River during the spring spawning period were recaptured in the Missouri River upstream from Fort Benton after the spawning period in June and July. These fish moved several kilometers downstream in the Marias River and 35 to $55 \mathrm{~km}$ upstream in the Missouri River. Three additional sauger tagged in the lower Marias River were recaptured in the Missouri River between the confluence of the Marias River and Fort Benton. These fish moved several kilometers downstream in the Marias River and 6 to $33 \mathrm{~km}$ upstream in the Missouri River to the recapture sites.

Sauger residing in the Missouri River below the confluence of the Marias River also use the Marias for spawning. Three sauger tagged in the Missouri below the Marias prior to the spawning period were recaptured in the lower Marias River during the spawning period. These fish moved 5 to $239 \mathrm{~km}$ upstream in the Missouri River and several kilometers upstream in the Marias River. Four sauger tagged in the lower Marias River during the spawning period were recaptured in the Missouri River below the confluence of the Marias River after the spawning period. These fish moved several kilometers downstream in the Marias River and 4 to $243 \mathrm{~km}$ downstream in the Missouri.

Tag returns reveal that sauger from the Missouri River which enter the lower Marias River for spawning come from anywhere in the immediate vicinity of the confluence of the Marias River to at least as far as $243 \mathrm{~km}$ downstream and $80 \mathrm{~km}$ upstream. This evidence indicates that sauger residing throughout the Missouri from Morony Dam to Fort Peck Reservoir use the lower Marias River for spawning. Spawning success of sauger in the lower Marias River has been confirmed by collecting larval sauger in $\frac{1}{2}-$ meter plankton nets.

As mentioned previously, electrofishing surveys also indicate that sauger from the Missouri River use the lower Judith and Teton rivers and the Missouri River upstream from Fort Benton for spawning. Larval sauger have not been collected from these sites, but the presence of large numbers of ripe sauger in these areas during the spawning period indicates that they are spawning sites.

In summary, movements of sauger in the middle Missouri River are extensive, and several intricate migration patterns have been identified. The migration patterns include: 
1. A sesaonal spawning and feeding migration of sauger from areas in the Missouri River downstream from Fort Benton into the reach of river between Fort Benton and Morony Dam. This is, by far, the most significant migration pattern of sauger. It involves a large portion of the sauger population of the Missouri River from Morony Dam to Fort Peck Reservoir and is probably vital to its survival.

2. A seasonal spawning migration of sauger from areas in the Missouri River above the confluence of the Marias River into the lower Marias River.

3. A seasonal spawning migration of sauger from areas in the Missouri River below the confluence of the Marias River into the lower Marias River.

4. A seasonal spawning migration of sauger from areas in the Missouri and Marias rivers into the lower Teton River.

5. A seasonal spawning migration of sauger from areas in the Missouri River into the lower Judith River.

The latter four movement patterns involve migrations of sauger between the mainstem of the Missouri River and its tributaries. These migrations are collectively significant, and are important in maintaining the sauger population in the mainstem of the middle Missouri River. However, the tributary spawning migrations do not appear to be as important as the mainstem spawning migration into the Missouri River upstream from Fort Benton. The tributary migrations involve smaller numbers of fish, and the migrations appear to be related only to spawning. The mainstem migration involves significantly more fish, and the migration appears to be related to both spawning and feeding.

Channel catfish

Movement data for channel catfish were provided by 66 recaptures of tagged fish in the study area. Ninety-four percent of the recaptured channel catfish moved one kilometer or more from the site where they were tagged. Distances moved by individual fish ranged from 5 to 267 $\mathrm{km}$ (Table 17). Other researchers have also reported extensive movements of channel catfish in large rivers. Elser et a 1. (1977) observed channel catfish movements ranging from 1 to $333 \mathrm{~km}$ in the lower Yellows tone and Tongue rivers, Montana. Hubley (1963) reported channel catfish movements of up to $344 \mathrm{~km}$ upstream and $275 \mathrm{~km}$ downstream in the upper Mississippi River.

The largest numbers of channel catfish in the Missouri River are found in a $37-\mathrm{km}$ reach of the river between Robinson Bridge and Fort Peck Reservoir. Channel catfish normally residing in this area apparently move long distances during the spawning period. A total of 1792 channel catfish were tagged in the Missouri River at the Turkey Joe study site about $3 \mathrm{~km}$ upstream from Fort Peck Reservoir. Most of the fish were tagged at Turkey Joe in August and September following the channel catfish spawning period. Sixty-three channel catfish tagged at Turkey Joe were recaptured in subsequent research surveys or by anglers. Most recaptures were made in succeeding years during the channel catfish migration and spawning period from late May through early August. 
Channel catfish recaptured during the migration and spawning period exhibited extensive and divergent movement patterns. Six percent of the catfish tagged at Turkey Joe were recaptured at the release site, 30 percent were recaptured upstream in the mainstem of the Missouri River, 35 percent moved eastward through the headwaters of Fort Peck Reservoir and upstream into the Musselshell River where they were recaptured, 25 percent were recaptured in Fort Peck Reservoir, and 3 percent moved upstream in the Missouri River and were recaptured in the lower Marias River. Since many of the tag returns were provided by anglers, the percentages could reflect some bias if fishing pressure was not equally distributed at the recovery sites. However, observations of anglers made during the study period suggest that fishing pressure was fairly eveniy distributed, and bias was probably negligible. Therefore, the recaptured catfish should provide an accurate appraisal of general migration tendencies of the population.

Channel catfish recaptured in the mainstem of the Missouri River upstream from the Turkey Joe study site moved from 10 to $267 \mathrm{~km}$. The fish which moved $267 \mathrm{~km}$ was tagged at the Turkey Joe site on August 31, 1978, and was recaptured during the spawning period at Fort Benton, July 1, 1979. Several other channel catfish moved more than $100 \mathrm{~km}$ in the mainstem. The data indicate that channel catfish in the Turkey Joe area migrate throughout the Missouri River between Fort Benton and Fort Peck Reservoir.

Another significant movement pattern identified for channel catfish residing at Turkey Joe was a seasonal spawning migration upstream through the Missouri River and into the lower Marias River. One channel catfish tagged at Turkey Joe on August 13, 1977, was recaptured 316 days 1ater on June 24, 1978, in the lower Marias River. Another catfish tagged on August 27, 1977, was recaptured 300 days later on June 22, 1978, in the lower Marias River. Each of these fish moved $242 \mathrm{~km}$ upstream from the tag site at Turkey Joe to the confluence of the Marias River, and then $2 \mathrm{~km}$ up the Marias River to the recapture site. One channel catfish tagged during the spawning period in the lower Marias River on August 5, 1978, was recaptured at Turkey Joe, September 2, 1978. This fish moved 244 kilometers downstream ( $2 \mathrm{~km}$ in the Marias and 242 in the Missouri) in 28 days. The data indicate that channel catfish using the lower Marias River for spawning come from areas throughout the entire length of the Missouri River downstream from its confluence with the Marias River, a distance of approximately $245 \mathrm{~km}$.

Another significant movement pattern identified for channel catfish residing at Turkey Joe was a seasonal spawning migration eastward through the headwaters of Fort Peck Reservoir and into the lower Musselshell River. Twenty-two channel catfish tagged at Turkey Joe from mid-August through early September were recaptured in subsequent years in the Musselshell River from late May through early August. To spawn, these fish moved $3 \mathrm{~km}$ downstream in the Missouri River, $46 \mathrm{~km}$ eastward through Fort Peck Reservoir and upstream into the lower Musselshell River. Channel catfish were recaptured in the Musselshell River at distances ranging from 2 to $119 \mathrm{~km}$ upstream from the mouth. An irrigation diversion dam on the Musselshell River near the town of Musselshel1, $119 \mathrm{~km}$ upstream from the mouth, blocks further movement of the migrant channel catfish. Five channel catfish tagged at Turkey Joe were caught immediately below this diversion dam by anglers. These fish each moved a distance of $168 \mathrm{~km}$. Recapture data indicate that channel catfish in the Turkey Joe area migrate to areas of the lower Musselshell River from the diversion dam to the mouth. Weidenheft 


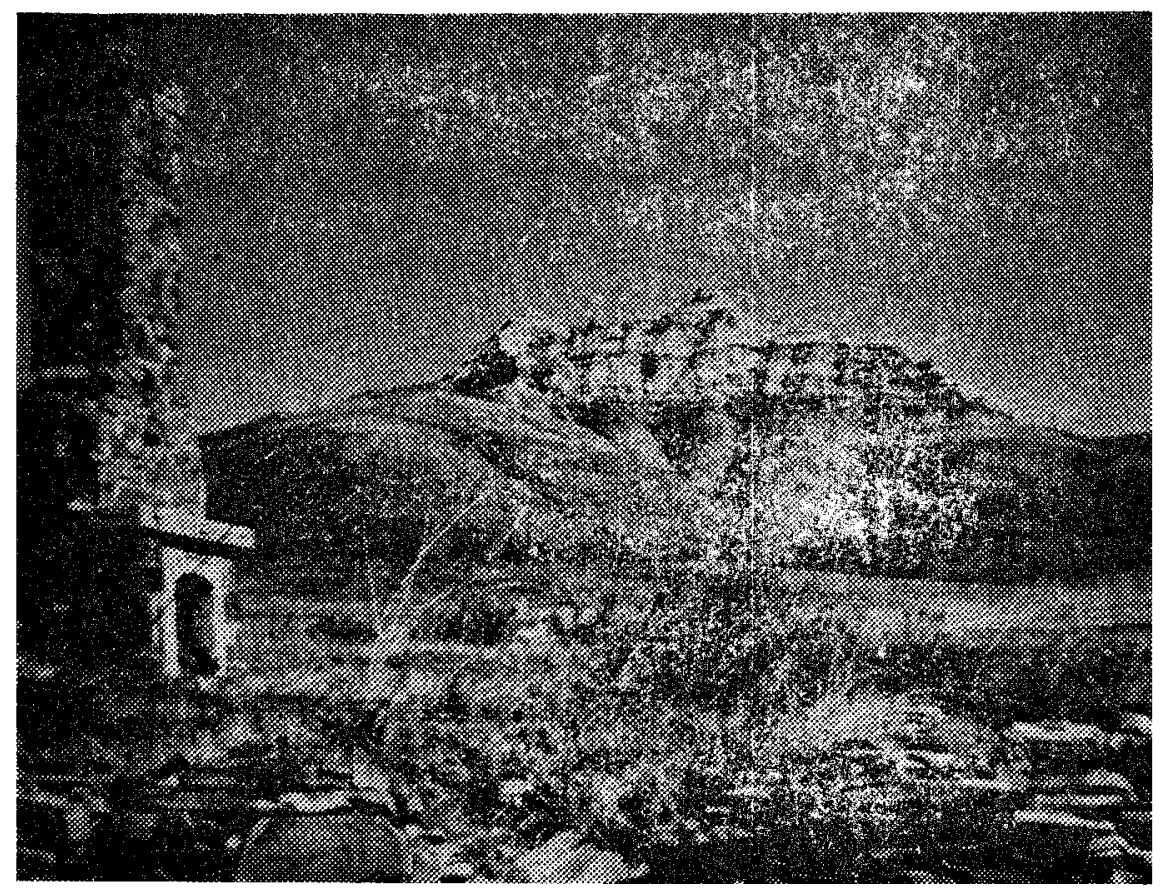

(1980) indicated that the peak of channel catfish spawning activity in the lower Musselshell River probably occurs from late May through midJune. Every effort should be made to keep the lower $119 \mathrm{~km}$ of the Musselshell River free from barriers, so the channel catfish spawning migration in this river can continue undiminished.

Sixteen channel catfish tagged at Turkey Joe were recaptured in Fort Peck Reservoir. These fish moved $3 \mathrm{~km}$ downstream in the Missouri River and 8 to $159 \mathrm{~km}$ eastward through Fort Peck Reservoir to the recovery sites. Fort Peck Reservoir is about $199 \mathrm{~km}$ in length from the dam to its confluence with the Missouri River near Turkey Joe. Tag return evidence indicates that channel catfish in the Turkey Joe area migrate into Fort Peck Reservoir at least as far eastward as the mouth of Crooked Creek, a site located $40 \mathrm{~km}$ from Fort Peck Dam. Most channel catfish were recaptured in Fort Peck Reservoir following or prior to the spawning period.

\section{Shavelnose Sturgeon}

Movement data for shovelnose sturgeon were provided by 12 recaptures of tagged fish in the study area. All of the recaptured fish moved from the site where they were tagged. Distances moved ranged from 3 to $112 \mathrm{~km}$ upstream and from 2 to $169 \mathrm{~km}$ downstream (Table 17). Other researchers have also reported significant movements of shovelnose sturgeon in rivers. Schmulbach (1974) observed shovelnose sturgeon movements of up to $533.6 \mathrm{~km}$ downstream in the lower Missouri River. Christenson (1975) reported shovelnose sturgeon movements of up to $19 \mathrm{~km}$ upstream and $17 \mathrm{~km}$ downstream in the Red Cedar River, Wisonsin. Helms (1974a) found the maximum distance moved 
by shovelnose sturgeon in the upper Mississippi River, Iowa, was $193 \mathrm{~km}$ ups tream. Moos (1978) reported a shovelnose sturgeon which moved $250 \mathrm{~km}$ downstream in the lower Missouri River, South Dakota and Nebraska.

Recaptures of shovelnose sturgeon in the study area provided evidence of the importance of the lower Marias River as a spawning area for shovelnose sturgeon. One shovelnose sturgeon tagged in the Missouri River $4 \mathrm{~km}$ below the mouth of the Marias River on Apri1 27, 1977, was recaptured 417 days later on June 16, 1978, during the spawning period in the Marias River $3 \mathrm{~km}$ upstream from its confluence with the Missouri. Another shovelnose sturgeon tagged in the Missouri River $4 \mathrm{~km}$ below the mouth of the Marias River on April 27, 1977, was recaptured 443 days later on July 12, 1978, in the Marias River, $2 \mathrm{~km}$ upstream from the mouth. One shovelnose sturgeon tagged $2 \mathrm{~km}$ upstream from the mouth of the Marias River on August 7 , 1978, was recaptured nine days later in the Missouri River, $3 \mathrm{~km}$ upstream from its confluence with the Marias River. The maximum distance moved by a shovelnose sturgeon using the lower Marias River for spawning was a fish tagged immediately below Judith Landing on July 21,1977 . This fish was recaptured 1034 days later during the spawning period in the lower Marias River, $2 \mathrm{~km}$ upstream from the mouth. This fish moved $112 \mathrm{~km}$ from the tag site to the recapture site. It appears that shovelnose sturgeon from the Missouri River using the lower Marias River for spawning come from anywhere in the immediate vicinity of the confluence to at least as far as $110 \mathrm{~km}$ downs tream.

It also appears that shovelnose sturgeon use the Missouri River upstream from Fort Benton for spawning. Electrofishing evidence indicates that shovelnose sturgeon begin to move into this area in mid-April, and numbers peak during the June spawning period. One shovelnose sturgeon tagged in the Missouri River just below the confluence of the Marias River on September 23, 1976, was recaptured Apri1 10, 1977, at Carter Ferry. This fish moved $66 \mathrm{~km}$ upstream in 201 days. Presently, there are no barriers in the Missouri River to inhibit any of the shovelnose sturgeon migration routes which have been identified.

\section{Blue Suckers}

Electrofishing evidence indicates that blue suckers make extensive seasonal movements in the Missouri River. One blue sucker tagged near Robinson Bridge on July 21, 1978, was recaptured during the spawning period on May 19, 1979, just upstream from Fort Benton, a movement of $196 \mathrm{~km}$ upstream (Table 17). One blue sucker tagged near Robinson Bridge on October 6, 1976, was recaptured during the spawning period near Holein-the-Wall on May 24, 1978, a movement of $129 \mathrm{~km}$ upstream. Electrofishing surveys indicate that blue suckers migrate during the spawning period at least as far upstream as the mouth of Highwood Creek, $320 \mathrm{~km}$ ups tream from Fort Peck Reservoir. 
Smallmouth and Bigmouth Buffalo

Smallmouth and bigmouth buffalo are common and important fish species in the middle Missouri River. They comprise a significant portion of the commercial fishery which exists in Fort Peck Reservoir. Three smallmouth buffalo and one bigmouth buffalo tagged in the middle Missouri River were subsequently recaptured and harvested in Fort Peck Reservoir by commercial fishermen (Table 17). These fish moved for distances which ranged from 106 to $325 \mathrm{~km}$ from the tag site to the harvest site.

Electrofishing and tag return evidence indicates that smallmouth and bigmouth buffalo move considerable distances in the Missouri River between Morony Dam and Fort Peck Reservoir, particularly during their spawning periods. One bigmouth buffalo tagged on June 13, 1978, while spawning in a backwater near Fort Benton was harvested 52 days 7ater by commercial fishermen in Fort Peck Reservoir. This fish moved $278 \mathrm{~km}$ downstream in the Missouri River and $47 \mathrm{~km}$ eastward through Fort Peck Reservoir to the harvest site. One smallmouth buffalo tagged on June 29, 1977, while spawning in a backwater near Loma Ferry was harvested 330 days later by commercial fishermen in Fort Peck Reservoir. This fish moved $238 \mathrm{~km}$ downstream in the Missouri River and $68 \mathrm{~km}$ eastward through Fort Peck Reservoir to the harvest site. Electrofishing surveys indicate that large numbers of bigmouth and smallmouth buffalo are found seasonally in the Missouri River during the spawning period as far upstream as Horseshoe Falls, $5 \mathrm{~km}$ below Morony Dam.

\section{Other Species}

Limited information on movements of walleye, northern pike, burbot, freshwater drum, brown trout, and mounta in whitefish was provided by recaptures of tagged fish (Table 17). One walleye tagged near Carter Ferry on May 11, 1980, was recaptured 10 days 1ater by an angler in Fort Peck Reservoir. This walleye was a large female which apparently spawned in the Carter Ferry area. The fish moved $293 \mathrm{~km}$ downstream in the Missouri River and $69 \mathrm{~km}$ eastward through Fort Peck Reservoir to the harvest site. Electrofishing data indicate walleye spawn in the Missouri River at least as far upstream as Horseshoe Falls, $5 \mathrm{~km}$ below Morony Dam. Most wall eye found in the Missouri River are probably seasonal migrants from Fort Peck Reservoir.

One northern pike tagged $3 \mathrm{~km}$ upstream from Fort Peck Reservoir on April 21, 1977, was recaptured in the Marias River below Tiber Dam on May 2, 1979. This movement of $371 \mathrm{~km}$ was the greatest distance moved by any tagged fish in the study area during the inventory period. Another northern pike tagged near the mouth of the Marias River on Apri] 27, 1977, was recaptured on December 5, 1979, in the Marias River at Tiber Dam, a movement of $127 \mathrm{~km}$. Many of the northern pike in the Missouri River are probably seasonal migrants from Fort Peck Reservoir. Northern pike are found seasonally in the Missouri River as far upstream as the Big Eddy, $7 \mathrm{~km}$ below Morony Dam.

\section{Discussion}

Migration patterns of numerous fish species have been identified in the middle Missouri River and its tributaries. Presently, there are no barriers in the mainstem of the Missouri River between Morony Dam and Fort Peck Reservoir to block any of the migration routes which have been 
identified. The migration routes are undoubtedly important to the survival of several fish species which inhabit Fort Peck Reservoir, the Missouri River, and its tributaries. Every effort must be made to keep the Missouri River free from barriers so the spawning, feeding, and other migration movements can continue undiminished.

\section{Marias River Spawning Migrations}

The lower $4 \mathrm{~km}$ of the Marias River was sampled regularly by electrofishing during the spring/summer of 1976, 1977, 1978, and 1979 to monitor spawning runs of fish from the Missouri River. In addition, frame traps were operated in the lower $2 \mathrm{~km}$ of the Marias River during the spawning periods in 1976, 1977 and 1978, and baited hoop nets were used in the same reach in 1978 and 1979 . Electrofishing was generally effective to monitor migrations of all species in the Marias River except channel catfish. Frame traps were mostly selective for sauger and walleye, and baited hoop nets were almost exclusively selective for channel catfish.

The lower Marias River was sampled prior to and following the spawning runs to determine the size and abundance of resident fish species. Fish captured in the lower Marias River during the spawning season were assumed to be from the Missouri River if they were in a ripe spawning condition and obviously overabundant for the habitat present. Also, some fish captured in the lower Marias River had tags attached from fish population study sections on the mainstem of the Missouri River, which confirmed their origin.

Sampling efforts on the lower Marias River during the spring/summer migration periods were limited. Since only selected days during the migration periods were sampled, spawning numbers presented in this report represent only a portion of the runs and do not necessarily reflect their magnitude. Also, the study section surveyed on the lower Marias represents only a small portion of the total spawning area available. Significant numbers of migrant fish move upstream in the Marias River to spawning areas located upstream from the study section. Evidence of this was provided by angler tag returns and by limited sampling conducted in the upstream areas.

The game fish species which most heavily used the lower Marias River for spawning were sauger, shovelnose sturgeon, and channel catfish. River carpsucker, shorthead redhorse, longnose sucker, and goldeye were the most abundant nongame spawning migrants found in the lower Marias. Migrant blue suckers and bigmouth and smallmouth buffalo also made significant use of the lower Marias River for spawning, but they were less abundant than the preceding nongame species. Results of electrofishing, frame trapping, and baited hoop netting surveys conducted on the lower Marias River during the spring/summer spawning migration periods from 1976 through 1979 are presented in Appendix Tables 53, 54, and 55.

\section{Sauger and Shovelnose Sturgeon}

The relation of water temperature and discharge to sauger and shovelnose sturgeon spawning in the lower Marias River during each of the four survey years is shown in Figure 22. The spawning periods shown on the graph were defined as the time between the first observation of a spent or partly spent female to the last observation of a ripe female. The peak of spawning was judged by a combination of a large number of spawring migrants and a high percentage of ripe females among the migrants. Abnormal flow, water temperature, or ice conditions altered sauger and shovelnose sturgeon 

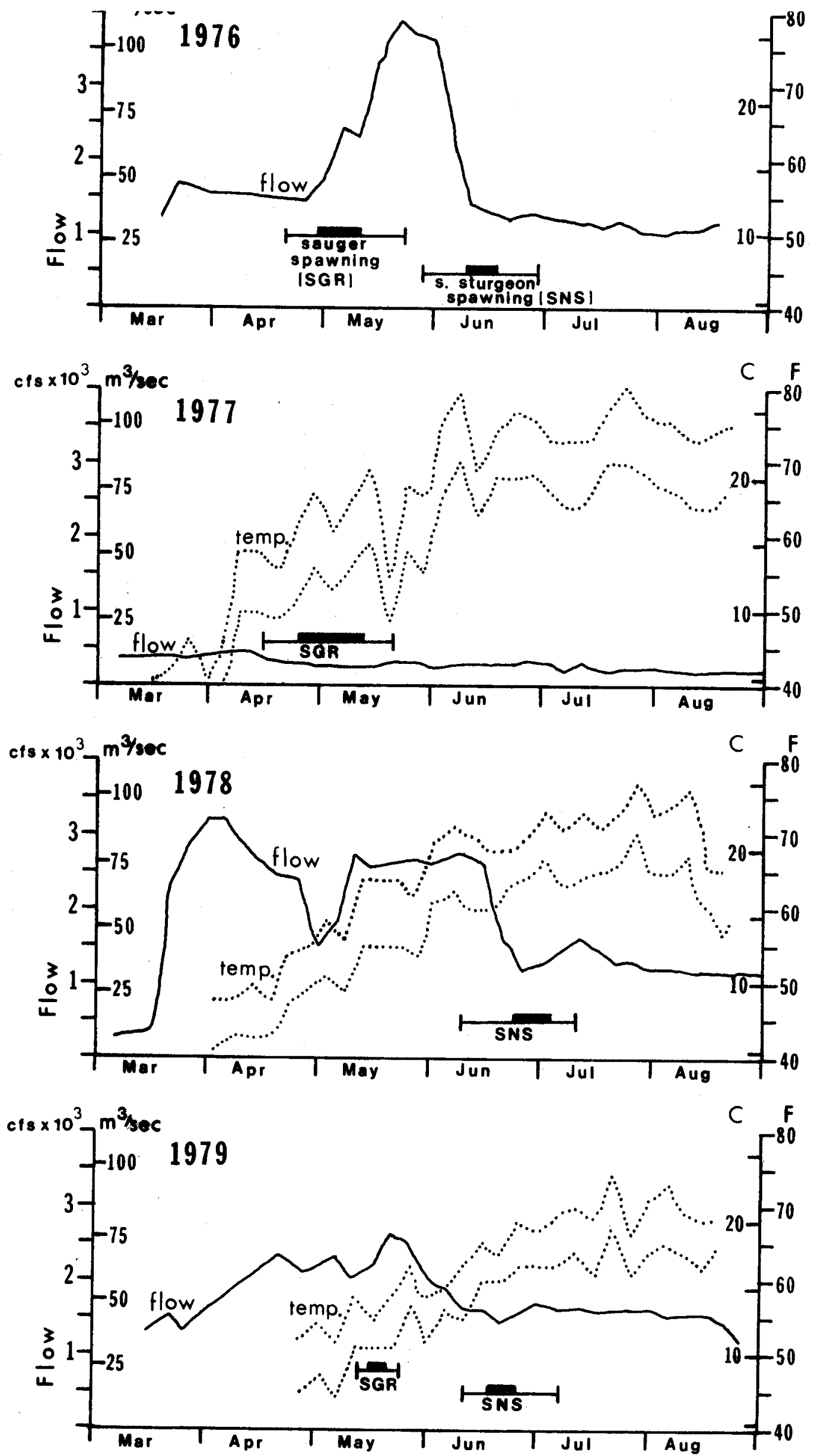

Figure 22. Relation of water temperature and discharge to spawning of sauger and shovelnose sturgeon in the lower Marias River from 1976 through 1979. 
spawning in each year except 1976.

In 1976, the magnitude of flow in the lower Marias River during the spring/summer migration period was near normal. However, the runoff peaked slightly sooner than normal in mid-May rather than early June. Water temperature was not measured continuously, but spot measurements revealed near average temperature conditions. The sauger spawning period extended from April 20 to May 22 and peaked from April 29 to May 10. The shove1nose sturgeon spawning period extended from May 27 to June 28 and peaked from June 9 to 17 . Since flow, water temperature, and other physical conditions were near normal during the spring/summer period in 1976, the observed spawning periods and peaks should also be considered as typical for the lower Marias River.

In 1977, water temperature in the lower Marias during the spring/ summer period was significantly higher than normal, and flow was considerably below normal. As a result of the above normal water temperature, sauger spawning in 1977 occurred slightly earlier than normal. Partly spent female sauger were sampled on April 15, the earliest spawning date observed during the four-year inventory period. The sauger spawning period in 1977 extended from Apri1 15 to May 20 and peaked from Apri1 25 to May 12. Migrant sauger in the lower Marias River were significantly less abundant in 1977 than 1976. In 1976, an average of 1.00 sauger per trap-day was sampled in frame traps during the migration period compared to 0.48 sauger per trap-day in 1977.

The shovelnose sturgeon spawning run in 1977 was even more severely depressed than the sauger run. An average of 15.0 shovelnose sturgeon per electrofishing-kilometer was sampled in 1976 during the peak of the spawning run compared to only 2.3 shovelnose sturgeon per electrofishing-kilometer in 1977. Flow in the lower Marias River in 1977 during the sauger and shoveinose sturgeon spawning periods ranged from 7.9 to $11.3 \mathrm{~m} / \mathrm{sec}$ (280 to $400 \mathrm{cfs}$ ), and was obviously well below the minimum flow required to sustain good spawning runs.

In 1978, flow and water temperatures of the lower Marias River during the spring/summer period were near normal. However, a more severe than normal ice break up occurred in the Missouri River in March, 1978. As a result, it appeared that many fish in the Missouri River were displaced downstream into the lower portion of the river or Fort Peck Reservoir. Consequently, the sauger run in the lower Marias River was severely reduced in 1978. An average of only 0.02 sauger per trap-day was sampled during the migration period. However, 11 sauger larvae were sampled with a plankton net on the lower Marias River on June 1 and 2, 1978, indicating that some successful reproduction did occur. Assuming an incubation period of 13 to 21 days as described by Nelson (1968), spawning occurred between May 11 and 20.

Shovelnose sturgeon spawning in the lower Marias River in 1978 occurred significantly later than normal. This may have been the result of substantial downstream displacement of shovelnose related to the severe ice break up, and the long distance of the migration route back upstream to the Marias River. The sturgeon spawning period in the lower Marias River extended from June 9 to July 10 and peaked from June 23 to July 3 . An average of 6.3 shovelnose sturgeon per electrofishing-kilometer were sampled during the peak of the spawning run. Two shovelnose sturgeon prolarvae were sampled with a plankton net on the lower Marias River on June 
19, 1978. Assuming an incubation period of one week as estimated by Brown (1971), spawning occurred about June 12.

Severe ice break ups such as the one observed in 1978 occur periodically. It is significant to note that even though this ice break up resulted in substantial downstream displacement of fish, native resident species, such as the shovelnose sturgeon and sauger, were able to move back upstream and spawn successfully in the lower Marias River.

In 1979, flow in the lower Marias River during the spring/summer migration period was near normal, but water temperature was significantiy below normal. The cooler-than-average water temperature was due to large amounts of cold water being released from Tiber Reservoir. As a result of the depressed water temperature, sauger and shovelnose sturgeon spawning occurred later than usual. The sauger spawning period extended from May 12 to May 23 and peaked from May 12 to 19. A Tarval sauger was sampled with a plankton net on the lower Marias River on May 28, 1979. Assuming an incubation period of 13 to 21 days as described by Nelson (1968), spawning occurred between May 7 and 15 . The shovelnose sturgeon spawning period in 1979 extended from June 10 to July 6 and peaked from June 17 to 21 . An average of 12.7 shovelnose sturgeon per electrofishing-kilometer were sampled during the peak of the spawning run.

The inception of sauger spawning on the lower Marias River in 1977 occurred when mean water temperature reached $11.7 \mathrm{C}(53 \mathrm{~F})$. In 1978 and 1979 initial spawning was observed at $12.2 \mathrm{C}(54 \mathrm{~F})$. Elser et a1. (1977) reported sauger spawning on the Lower Tongue River, Montana, in a temperature range of 9.4 to $12.2 \mathrm{C}(49$ to $54 \mathrm{~F})$. Peterman and Haddix (1975) observed sauger spawning on the mainstem of the lower Yellowstone between May 16 and 24, 1974, when water temperatures were 7.2 to $11.1 \mathrm{C}$ ( 45 to $52 \mathrm{~F}$ ). Brown (1971) indicated sauger spawning usually occurs in Montana when water temperatures reach about $10.0 \mathrm{C}(50 \mathrm{~F})$.

Shovelnose sturgeon spawning in the lower Marias River was observed at mean water temperatures ranging from 15.0 to $22.8 \mathrm{C}$ (59 to $73 \mathrm{~F}$ ), but peak spawning occurred at 16.1 to $20.6 \mathrm{C}(61$ to $69 \mathrm{~F})$. The optimum temperature range for spawning of shovelnose sturgeon on the lower Tongue River, Montana, was 17.2 to $21.7 \mathrm{C}(63$ to $71 \mathrm{~F})$ (Elser et a1. 1977). In the Powder River, Montana, the peak of the shovelnose sturgeon run occurred at $16.1 \mathrm{C}(61 \mathrm{~F})$; however, these fish were not considered ripe (Rehwinkel et al. 1976). Christenson (1975) reported shovelnose sturgeon spawning in the Red Cedar River, Wisconsin, at temperatures between 19.4 and 21.1 C $(67$ and $70 \mathrm{~F})$. Brown (1971) stated that shovelnose sturgeon usually spawn in Montana at temperatures between 15.6 and $21.1 \mathrm{C}(60$ and $70 \mathrm{~F})$.

\section{Size at Maturity}

Sauger found in the lower Marias River during the migration period were usually mature at sizes larger than 270 to $280 \mathrm{~mm}(10.6$ to $11.0 \mathrm{in}$.). The smallest mature sauger sampled on the lower Marias River was a $259 \mathrm{~mm}$ ripe male. However, most sauger smaller than $270 \mathrm{~mm}$ were immature. Female sauger appeared to reach maturity at about the same size as males. The smallest mature female sauger sampled on the lower Marias River was a 274 $\mathrm{mm}$ specimen. Brown (1971) indicated that sauger reach maturity at lengths of 229 to $305 \mathrm{~mm}$. 
Male shovelnose sturgeon found in the lower Marias River during the migration period were usually mature at a smaller size than females. The minimum fork lengths of ripe male and female sturgeon sampled in the lower Marias during the inventory period were 546 and $709 \mathrm{~mm}(21.5$ and 27.9 in.), respectively. Elser et a1. (1977) reported minimum lengths of ripe male and female shovelnose on the lower Tongue River of 523 and $688 \mathrm{~mm}$ (20.6 and 27.1 in.), respectively. Other researchers have also reported male shovelnose maturing at a smaller size than females (Christenson 1975, Helms 1974, Monson and Greenbank 1947, Barnickol and Starrett 1951).

Size-Frequency Distributions

The length-frequency distribution of shovelnose sturgeon sampled during the spawning period in the lower Marias River was compared to the lengthfrequency distribution of shoveinose sturgeon sampled during the spawning and nonspawning periods in the mainstem of the middle Missouri River (Figure 23). The average size of shovelnose sturgeon sampled in the lower Marias River was significantly larger than the average size of sturgeon collected from the Missouri River mainstem. Also, the length distribution was wider for the Missouri River sample than for the Marias River sample. Sturgeon smaller than $550 \mathrm{~mm}$, which are usually immature, were rarely found in the Marias River but were common in the Missouri River mainstem. These data indicate that the lower Marias River shovelnose sturgeon were a migrant spawning population. Peterman and Haddix (1975) and Rehwinkel et al. (1976) found migrant populations of shovelnose sturgeon from the lower Yellowstone River spawning in the lower Tongue and Powder rivers, respectively. The average size of sturgeon found in the tributaries was larger than the average size of sturgeon sampled in the mainstem of the Yellowstone. This was attributed to the tributary sturgeon being spawning populations.

The length-frequency distribution of shovelnose sturgeon sampled in the middle Missouri and Marias rivers was also compared to the lengthfrequency distribution of shovelnose sturgeon sampled in the Missouri River in South Dakota (Moos 1978), the Mississippi River in Iowa (He1ms 1973), and the Chippewa River in Wiscons in (Christenson 1975) (Figure 23). Shovelnose sturgeon in the middle Missouri/Marias River study area were significantly larger than those sampled in the other rivers. In fact, the mean fork lengths of shovelnose sturgeon sampled in the middle Missouri and Marias rivers were about equivalent to the maximum fork lengths attained in the abovementioned study areas.

The weight-frequency distribution of migrant shovelnose sturgeon sampled in the lower Marias River during this study was very similar to the weight-frequency distribution reported for migrant shovelnose sturgeon in the lower Tongue River, Montana (Peterman and Haddix 1974, Elser et a1. 1977) (Figure 24). Of the shovelnose sturgeon sampled during the spawning period on the lower Tongue River in 1975 and 1976, 22.6 percent exceeded $2.7 \mathrm{~kg}(6 \mathrm{lb}), 7.2$ percent exceeded $3.6 \mathrm{~kg}(8 \mathrm{lb})$, and 1.7 percent exceeded $4.5 \mathrm{~kg}$ (10 lb). On the lower Marias River from 1976 through 1979, 29 percent of the shovelnose sturgeon sampled during the spawning period exceeded $2.7 \mathrm{~kg}, 8$ percent exceeded $3.6 \mathrm{~kg}$, and 2 percent exceeded $4.5 \mathrm{~kg}$. The average size of sturgeon sampled on the Marias River was $2.43 \mathrm{~kg}(5.36 \mathrm{lb})$ compared to $2.41 \mathrm{~kg}(5.31 \mathrm{lb})$ on the Tongue River. A sample of shovelnose sturgeon migrating from the Yellows tone River into the lower Powder River, Montana, averaged $2.42 \mathrm{~kg}$ (5.33 lb) (Rehwinkel et a1. 1976). 


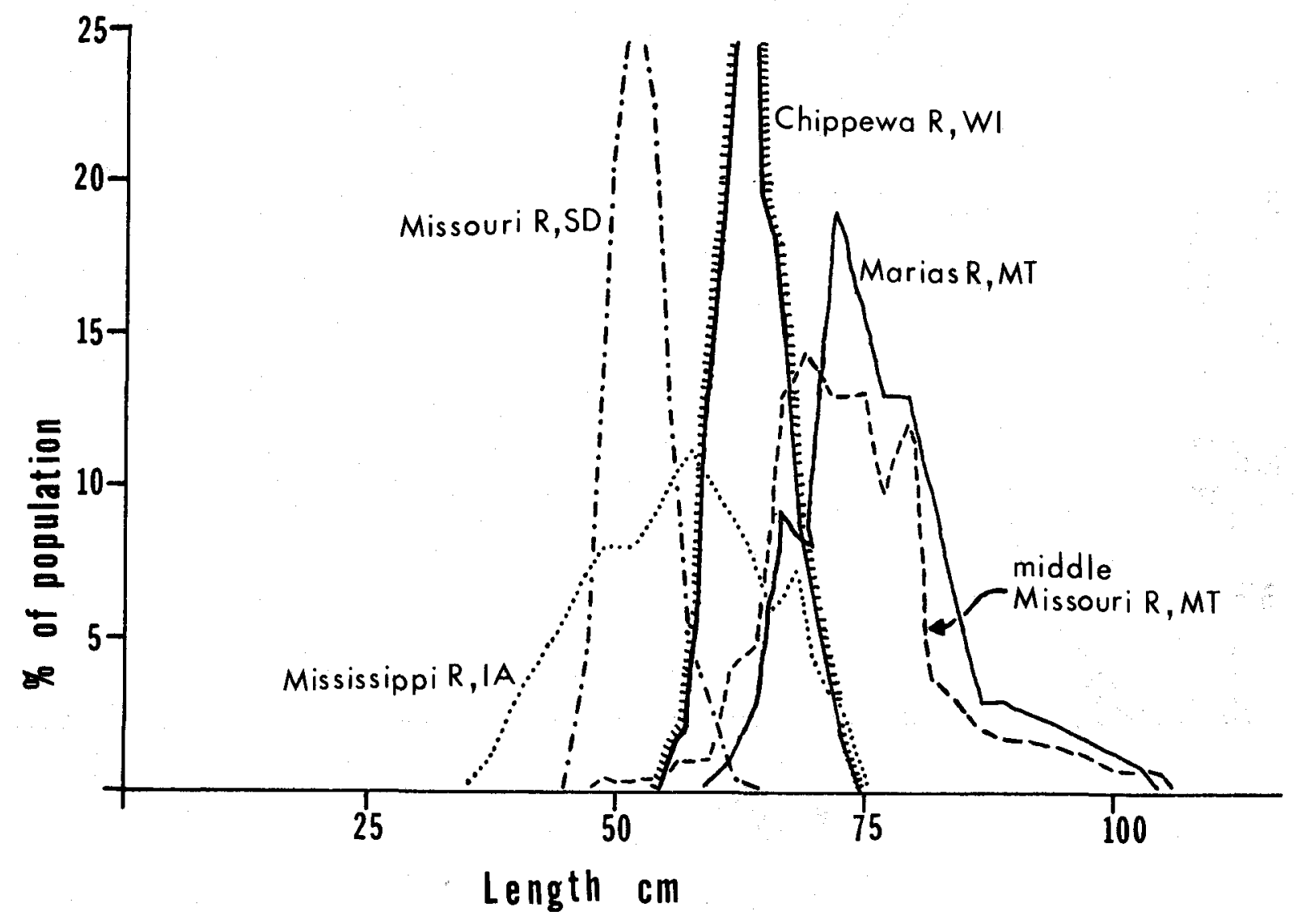

Fiqure 23. A comparison of the lenath-frequency distributions of shovelnose sturgeon sampled in the lower Marias and middle Missouri rivers (Montana), Chippewa River (Wisconsin), Mississippi River (Iowa), and Missouri River (South Dakota). 


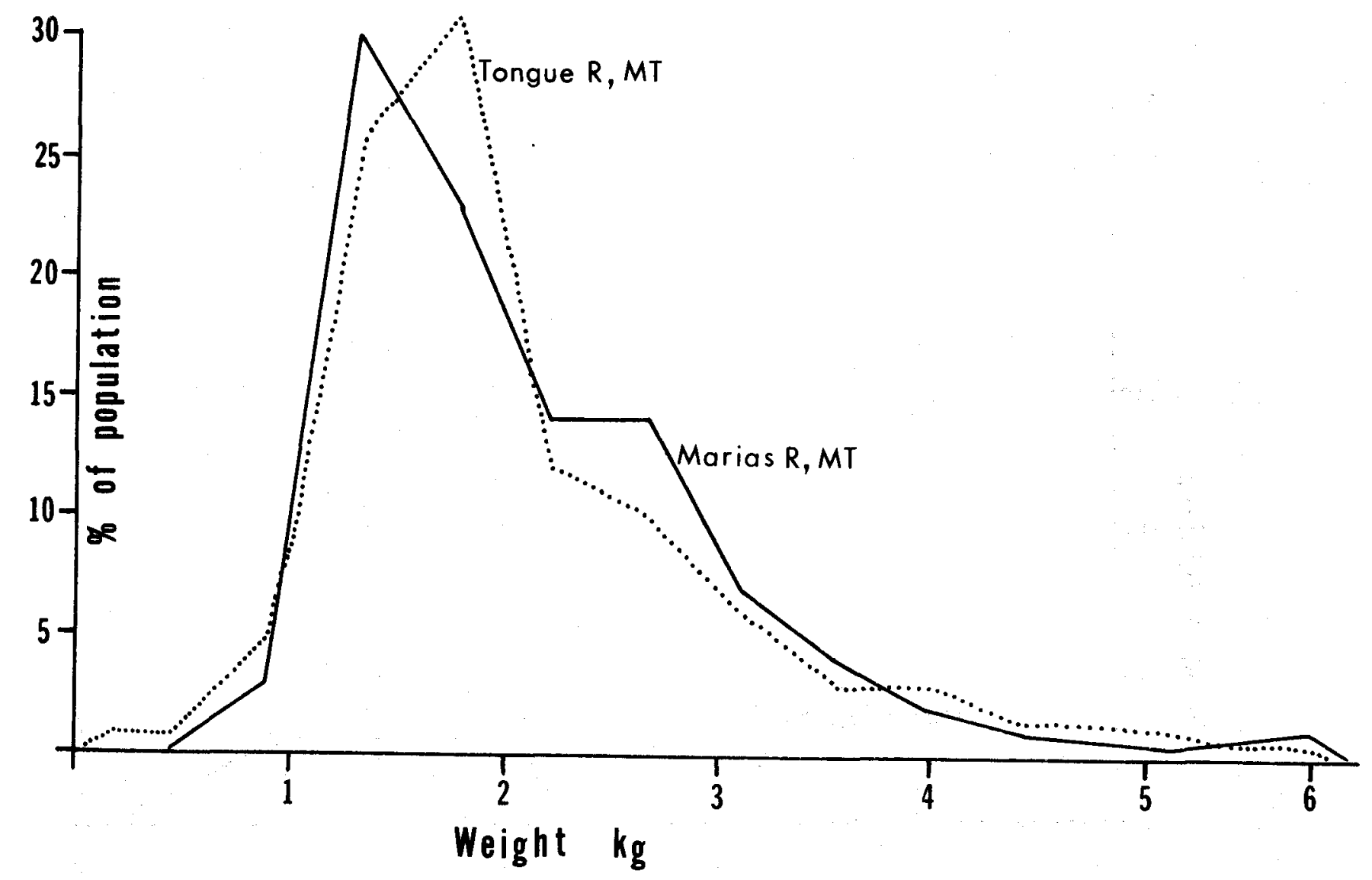

Fiqure 24. A comparison of the weight-frequency distributions of shovelnose sturgeon sampled in the lower Marias and Tongue rivers, Montana. 
Shovelnose sturgeon captured during the spawning period in the lower Marias, Tongue, and Powder rivers, Montana, were considerably larger in both length and weight than those reported in other streams. Even though the sturgeon sampled in the Montana streams were spawning populations, the presence of considerabie numbers of larger fish is significant. Carlander (1969) reviewed numerous research reports on shovelnose sturgeon. The largest shovelnose sturgeon recorded in the studies which he reviewed was a $4.536 \mathrm{~kg}$ (10 1b) specimen reported by Trautman (1957). Eddy and Surber (1943), Pflieger (1975), and Brown (1971) indicate that shovelnose sturgeon rarely exceed 2.3 to $3.2 \mathrm{~kg}$ ( 5 to 7 lbs).

The relatively large size attained by shovelnose sturgeon in the lower Marias, Tongue, and Powder rivers may be related to an abundant food supply available to these fish in the lower Yellowstone and middle Missouri rivers during the summer months. Two mayflies, Rhithrogena and Traverelza, comprised 58 percent of the food volume in the summer diet of shovelnose sturgeon in the middle Missouri River (Gardner and Berg 1981). Traverezla are also abundant in the lower Yellowstone River (Newe11 1976). They accounted for 46 percent of the food volume in the diet of shovelnose sturgeon in the lower Yellowstone from July to September (Elser et al. 1977). Rhithrogena and Traverelza exhibit relatively little tolerance to habitat changes, and the middle Missouri and lower Yellowstone rivers are the only significant reaches of large river habitat in the Mississippi/ Missouri River drainage which have not been extensively altered. Limited findings by researchers studying the food habits of shovelnose sturgeon in other portions of the Mississippi and Missouri rivers indicate that the bulk of the diet is usually comprised of trueflies (Diptera) and caddisflies (Pflieger 1975). The relative scarcity of mayflies in the summer diet of shovelnose sturgeon in these areas could account for the smaller sizes, but this hypothesis requires more supporting evidence.

Shovelnose sturgeon in the middle Missouri and lower Yellowstone rivers may also be a distinct genetic subgroup, and this could explain their larger size. However, genetic studies conducted on shovelnose sturgeon collected in Montana and other states in 1979 failed to confirm this hypothes is (Larry Peterman, DFWP, personal communication).

Channel Catfish and Other Species

Use of the lower Marias River for spawning by migrant channel catfish was studied in 1978 and 1979. An average of 1.06 channel catfish per net-day was captured in 18 net-days on the lower Marias River from August 3 through 9, 1978. By mid-September, spawning was apparentiy completed, and no channel catfish were taken in 12 net-days of sampling, September 23 through 29, 1978. One channel catfish aelvin was sampled in a plankton net on the lower Marias River on June 19, and three were collected on July 28, 1978. Assuming an incubation period of 6 to 10 days and aelvin dispersal after about five days (Brown 1971), spawning occurred between June 4 and July 17. An average of 2.25 channel catfish per net-day were captured in four net-days on the lower Marias River from June 8 through 12, 1979. These data suggest that peak abundance of migrant channel catfish in the lower Marias River occurs during the early portion of the spawning period.

Maximum water temperature in the lower Marias River during the channel catfish spawning periods in 1978 and 1979 ranged from 18.9 to $25.6 \mathrm{C}$ (66 to $78 \mathrm{~F})$ and averaged $22.2 \mathrm{C}(71.9 \mathrm{~F})$. Brown (1971) indicated 
channel catfish spawning usualiy occurs from May into July after water temperatures exceed $23.9 \mathrm{C}(75 \mathrm{~F})$. However, Helms (1975) reported spawning activity of channel catfish in the upper Mississippi River, Iowa, usually began in mid-May at a water temperature of $18.3 \mathrm{C}(65 \mathrm{~F})$. Initial spawning of channel catfish in the lower Marias River appears to occur when the maximum water temperature reaches $18.9 \mathrm{C}(66 \mathrm{~F})$.

Significant spawning runs of blue sucker, smallmouth and bigmouth buffalo, river carpsucker, shorthead redhorse, longnose sucker, and goldeye were observed in the lower Marias River during the spring/summer migration periods from 1976 through 1979. Limited numbers of walleye, northern pike, carp, and several minnow species were also observed spawning in the lower Marias River during the study period. Spawning condition of fish examined during the surveys is shown in Table 18. In genera1, Catostominae (suckers and redhorse) and goldeye spawned primarily in May, while (Ictiobinae/Cyprinidae (river carpsucker, buffalo and minnows) spawned primarily in June.

Table 18. Spawning condition of several fish species sampled in the lower Marias River during the spring/summer spawning periods from 1976 through 1979.

Fish

Species

Gol deye

Northern pike

Carp

Flathead chub

Emerald shiner

W. silvery minnow

Longnose dace

River carpsucker

Blue sucker

Smallmouth buffalo

Bigmouth buffalo

Shor thead redhorse Longnose sucker

Walleye

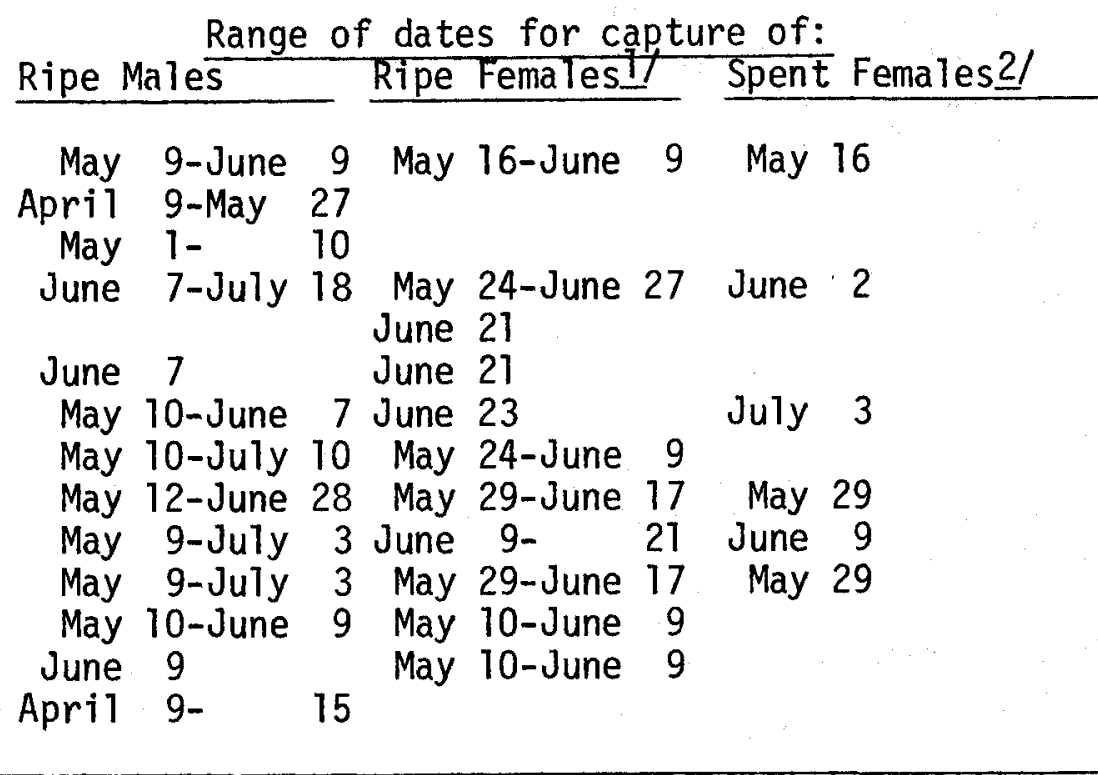

1/ Range of dates for sampling ripe females is equivalent to observed spawning period.

2) Earliest date observed. 


\section{Teton and Judith River Spawning Migrations}

The lower several kilometers of the Teton and Judith rivers were sampled on several occasions during the spring/summer migration periods in 1977, 1978, and 1979 to document possible spawning runs from the Missouri River. Considerably less effort was spent on migrant fish surveys in the lower Teton and Judith rivers than on the lower Marias River. Therefore, the spawning runs found in these areas are probably an underestimate of actual use. Further surveys should be conducted to confirm the presence of spawning runs of additional species.

The lower Teton River was sampled by electrofishing on April 27, 1977, and May 13, 1979. A significant number of migrant sauger were found in the lower Teton River. An average of 10.5 sauger per electrofishing-kilometer were sampled on April 27, and 1.5 per electrofishingkilometer were captured on May 13. This information suggests that peak spawning of sauger in the lower Teton occurs in late April. Sauger spawning on the lower Teton apparently occurs slightly earlier than on the lower Marias. This is probably due to warmer spring water temperatures on the lower Teton River. Sauger found spawning in the lower Teton were significantly less abundant than in the lower Marias.

Numerous migrant goldeye, shorthead redhorse, and Iongnose suckers were collected on both sampling dates on the lower Teton River, and the fish were in a ripe spawning condition. A few migrant carp were also sampled on both dates, but they were not ripe.

A significant spawning run of blue suckers was observed in the lower Teton River on May 13, 1979. An average of 25.0 blue suckers per electrofishing-kilometer were sampled, and all were ripe males and females or gravid females. Most of the blue suckers were found in the lower 2 kilometers of the Teton River, and the run was confined to the lower $15 \mathrm{~km}$ of the river. This run was substantially larger than blue sucker spawning runs observed in the lower Marias River. No blue suckers were found in the lower Teton River in an electrofishing survey conducted on April 27, 1977, indicating that the run probably does not begin until mid-May.

Migrant river carpsucker, smallmouth buffalo, and bigmouth buffalo were conspicuously absent from electrofishing surveys conducted in the lower Teton River. These species usually spawn in larger streams with backwater areas (Brown 1971), and therefore, it is unlikely they spawn in the lower Teton River. As described earlier, significant spawning runs of these three species were found in the lower Marias River. The lower Marias is a substantially larger stream than the lower Teton River, and it contains more slow-moving and backwater areas.

Migrant channel catfish were sampled in the lower Teton River with baited hoop nets in 1978 and 1979. An average of 0.67 channel catfish per net-day were captured in six net-days on the lower Teton River from August 3 through 9, 1978. By mid-September spawning was apparently completed, and no channel catfish were taken in six net-days of sampling from September 23 through 29,1978 . An average of 1.88 channel catfish per net-day were captured in eight net-days on the lower Teton River from June 8 through 12, 1979. Thus, migrant channel catfish are found in the lower Teton River from at least early June through early August.

Largely because of irrigation withdrawals, it is not uncommon for the 
lower 20 to $30 \mathrm{~km}$ of the Teton River to be dewatered by late August to the extent that only large pools remain. In some years, the lower Teton is completely dewatered. Therefore, the spawning fish found there during the spring/summer migration (runoff) period are all migrants.

The lower Judith River was sampled by electrofishing on May 25 and August 13, 1979. A significant number of mature sauger were sampled on May 25. All female sauger were spent, indicating that spawning was completed prior to May 25. Some of the sauger appeared to be migrants from the mainstem of the Missouri River. The recapture of one sauger previously tagged on the mainstem of the Missouri River confirmed this observation.

Shorthead redhorse and longnose suckers in a ripe spawning condition were abundant in the lower Judith River on May 25, 1979. Many were probably spawning migrants from the Missouri River. A few carp and goldeye were also sampled on the lower Judith on May 25, and some of them were ripe. Two ripe male blue suckers were sampled on May 25, and one spent male was taken on August 13. River carpsucker, smallmouth buffalo, and bigmouth buffalo were conspicuously absent.

No effort was made to sample migrant channel catfish in the lower Judith River with baited hoop nets. However, circumstantial evidence indicates that this river is an important spawning tributary for this species. Gardner and Berg (1981) collected 30 channel catfish aelvins in a plankton net fished in the lower Judith River on August 2, 1979. In addition, numerous logs and other instream cover features necessary for catfish nests are found in the lower Judith.

Age and Growth

\section{Paddlefish}

Age Structure of the Population

In 1977 and 1978, 132 paddlefish harvested by anglers from the middle Missouri River were assigned ages ranging from 6 to 29 years (Table 19). The sample included 69 males and 63 females. Males averaged 13.7 years of age and ranged in age from 6 to 25 years. Females averaged 18.7 years and ranged from 11 to 29 years. Forty-four percent of the female paddlefish were 20 years or older, while only 7 percent of the males were this old.

The middle Missouri River paddlefish population is older and probably more stable than most other paddlefish populations in northern waters. In a study of paddlefish in the lower Yellowstone River, Montana, Rehwinkel (1975) found only 0.2 and 3.9 percent of males and females, respectively, were 20 years or older. Twenty-six percent of the paddlefish (male and female combined) harvested by anglers in the Missouri River below Fort Randall Dam, South Dakota, in 1979 were 20 years or older (Unkenholz 1980b). The oldest paddlefish harvested by anglers in the Missouri River below Gavins Point Dam, South Dakota, in 1979 was a 14-year old specimen (Unkenholz 1980a). In 1960, 2.3 percent of the paddlefish collected from the Mississippi River, Iowa, were 20 years or older (Meyer 1960).

Most paddlefish populations in the United States are harvested more intensively by anglers than the middle Missouri population. Since anglers select for larger fish, the older paddlefish experience greater harvest rates than younger fish as fishing pressure increases. The relatively 
small harvest rate of paddlefish in the middle Missouri River probably accounts, in part, for the large percentage of old fish.

Table 19. Age structure and observed growth of male and female paddlefish sampled in the middle Missouri River in 1977 and 1978. The number of fish sampled is shown in parentheses.

\begin{tabular}{|c|c|c|c|c|c|c|}
\hline \multirow{2}{*}{$\begin{array}{l}\text { Age } \\
\text { Group }\end{array}$} & \multicolumn{2}{|c|}{1977} & \multicolumn{2}{|c|}{1978} & \multicolumn{2}{|c|}{ Combined Average } \\
\hline & Male & Female & Male & Female & Male & Female \\
\hline 6 & & & $102(1)$ & & $102(1)$ & \\
\hline 7 & $122(1)$ & & & & $122(1)$ & \\
\hline 8 & $132(1)$ & & $135(7)$ & & $134(2)$ & \\
\hline 9 & $136(2)$ & & $137(1)$ & & $136(3)$ & \\
\hline 10 & & & $137(1)$ & & $137(1)$ & \\
\hline 11 & $139(5)$ & $156(1)$ & & & $139(5)$ & $156(1)$ \\
\hline 12 & $143(11)$ & & $140(4)$ & & $142(15)$ & \\
\hline 13 & $144(5)$ & $156(4)$ & $142(3)$ & & $143(8)$ & $156(4)$ \\
\hline 14 & $147(6)$ & $164(3)$ & $142(2)$ & $168(2)$ & $145(8)$ & $166(5)$ \\
\hline 15 & $148(6)$ & & $144(2)$ & $170(6)$ & $147(8)$ & $170(6)$ \\
\hline 16 & $149(4)$ & $169(1)$ & $149(3)$ & & $149(7)$ & $169(1)$ \\
\hline 17 & & $168(5)$ & $150(1)$ & $175(1)$ & $150(1)$ & $170(6)$ \\
\hline 18 & $149(2)$ & $168(3)$ & & $173(1)$ & $149(2)$ & $170(4)$ \\
\hline 19 & $150(2)$ & $169(7)$ & & $175(1)$ & $150(2)$ & $171(8)$ \\
\hline 20 & $149(3)$ & $171(6)$ & & $173(1)$ & $149(3)$ & $171(7)$ \\
\hline 21 & $155(1)$ & $171(8)$ & & & $155(1)$ & $171(8)$ \\
\hline 22 & & $174(4)$ & & & & $174(4)$ \\
\hline 23 & & $173(5)$ & & & & $173(5)$ \\
\hline 24 & & $177(1)$ & & & & $177(1)$ \\
\hline 25 & $160(1)$ & & & $180(1)$ & $160(1)$ & $180(1)$ \\
\hline 26 & & & & & & $181(1)$ \\
\hline 27 & & $181(1)$ & & & & \\
\hline 29 & & $188(1)$ & & & & $188(1)$ \\
\hline
\end{tabular}

Observed Growth

Since the middle Missouri River paddlefish population is comprised almost entirely of mature, spawning fish, observed annual increments of growth are fairly small (Table 19). Female paddlefish were consistently larger than male paddlefish at all comparable ages. The largest (and oldest) male paddlefish collected for age determination was a $160 \mathrm{~cm}, 28.6$ $\mathrm{kg}$ (62.8 in., $63 \mathrm{lb}$ ) 25-year-old. The largest (and oldest) female was a $188 \mathrm{~cm}, 54.8 \mathrm{~kg}$ (74.0 in., $121 \mathrm{lb}) 29$-year-old. The smallest (and youngest) male was a 6-year-old measuring $102 \mathrm{~cm}(40.0 \mathrm{in}$.$) in total length and$ weighing $7.7 \mathrm{~kg}(17 \mathrm{lb})$. The smallest (and youngest) female was a $156 \mathrm{~cm}$, $22.2 \mathrm{~kg}$ (61.3 in., 49 1b) 11-year-old. 
Observed growth of paddlefish collected from the middle Missouri River is compared to observed growth in other waters in Table 20. Growth of paddlefish in the middle Missouri River is superior to growth in the other waters at all ages. Growth of paddlefish in the middle Missouri River also exceeds growth in all the studies summarized by Carlander (1969). Based on this evidence, it can be concluded that growth of paddlefish in the middle Missouri River and Fort Peck Reservoir is better than in any other known water in the United States.

\section{Shovelnose Sturgeon}

\section{Characteristics of the Annuli}

Annuli appearing on the anterior pectoral fin ray sections of shovelnose sturgeon occurred in belts (Figure 25). Four to eight single annuli preceded the first sub-marginal annuli belt. Sub-marginal annuli belts contained from two to three annuli. Zweiacker (1967) identifed similar annuli belt patterns on shovelnose sturgeon pectoral rays from the Missouri River in South Dakota. Roussow (1957) found annuli belts on pectoral fin ray sections of lake sturgeon. These researchers attributed the belts of annuli to slowed growth during periods of gonadal development.

Single annuli occurring on the sections were more widely spaced than annuli within belts, indicating faster growth of the shovelnose sturgeon in the first years of life before belting of annuli occurred. Belting of annuli probably coincided with attainment of sexual maturity and slowed growth due to channeling energies into gonadal development. Spaces also occurred between each sub-marginal annuli belt, probably indicating faster growth between periods of gonadal development.

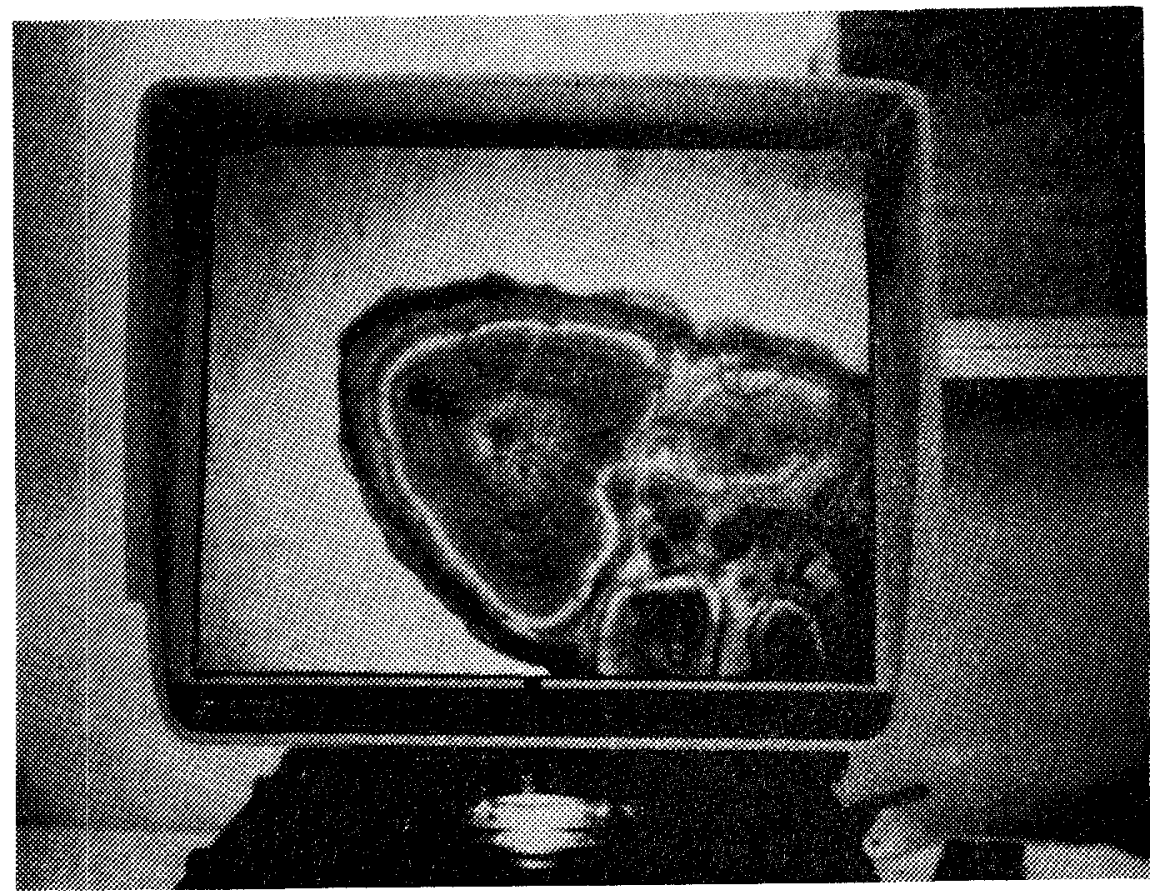

Figure 25. Cross-sections of the anterior pectoral fin rays of shovelnose sturgeon were studied for age and growth determination. The belt patterns of the annuli are probably related to slowed growth during periods of gonadal development. 


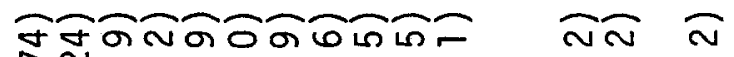

NNㅡ르는

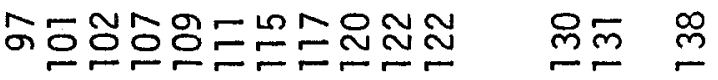

to

읕:-

Eั 4

$0 \div$

$\infty$ 뭄

के ฉ

밈 $\frac{\infty}{\stackrel{0}{E}}$

त

ลิ요

$2=$

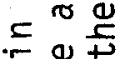

$\therefore \sqrt{\frac{1}{0}}$

$\sum \equiv \frac{1}{\pi}$

$\therefore \leq$

$\therefore \overbrace{4}=$

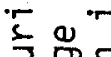

实要

络응

$\cong \frac{\pi}{n}$

$\sum \pi$

$0=n$

뭄

E क

$0 \backsim \pi$

市的

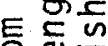

등 둔

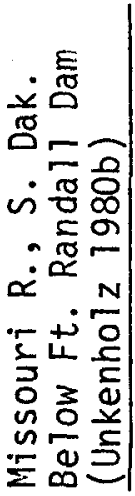

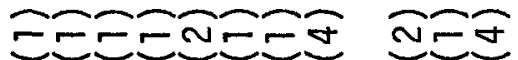

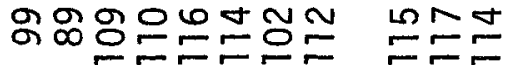

홍

;

ن몽요

a n

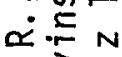

-

50

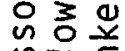

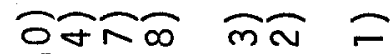

40-N 舟

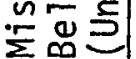

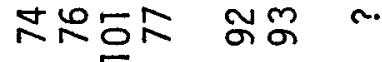

54

\&

$\frac{1}{2} \sum$

葛

in

的市

证药

o

$\frac{1}{0} \frac{1}{d}$

둥

沉苍高

$4=8$

ᄃ욜

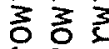

ธัธธ์

잉

o d

之交 n

वे a

号资点

$\dot{\sim}$

$* * * * * *$

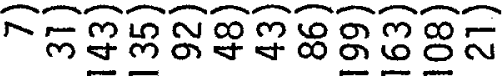

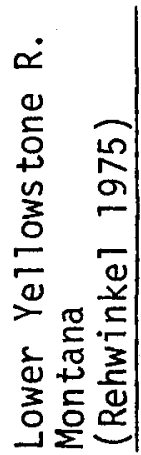

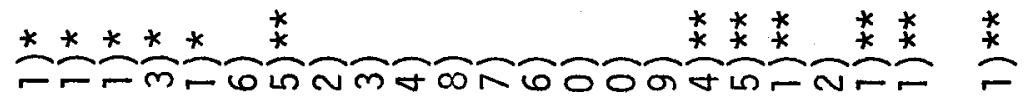
픈

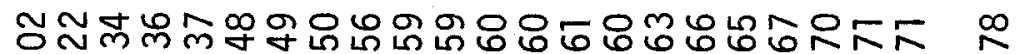

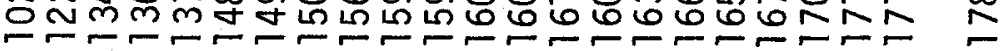


If the interpretation of the single annuli/annuli belt patterns is correct, shovelnose sturgeon in the middle Missouri River become sexually mature at 4 to 8 years and make their first spawning attempt between 6 and 11 years. They spawn every 2 to 3 years after their initial attempt.

Assigned Ages and Observed Growth

In 1978 and 1979,122 shovelnose sturgeon sampled on the middle Missouri River were assigned ages ranging from 8 to 33 years and averaging 21.3 years (Table 21). Ninety-three percent of the sturgeon in the sample were 15 years or older. Zweiacker (1967) reported shovelnose sturgeon in the Missouri River in South Dakota ranged from 8 to 27 years, and 80 percent of the sturgeon were 13 years or older. The oldest shovelnose sturgeon reported by Helms (1974b) in the Mississippi River, Iowa, was a 12-year-old measuring $716 \mathrm{~mm}$ (28.2 in.) in fork length. However, Christenson (1975) seemed to question the rapid growth rates and young ages reported by Heims. Christenson observed a very slow growth rate for tagged and recaptured shovelnose sturgeon in the Red Cedar/Chippewa River system in Wisconsin. Christenson felt his tagging method should have had a negligible effect on sturgeon growth rates. He concluded it was unlikely that shovelnose sturgeon in the Red Cedar/Chippewa River system were only 12 years old at approximately $710 \mathrm{~mm}(27.9 \mathrm{in}$.) in fork length. Schmulbach (1974) also observed a very slow growth rate for tagged and recaptured shovelnose sturgeon in the Missouri River near Vermillion, South Dakota.

Male shovelnose sturgeon sampled from the middle Missouri River averaged 20.6 years of age and ranged from 9 to 29 years. About onethird of the sturgeon 25 years or o1der were males. The youngest ripe male in the sample was a 10-year-old. Female sturgeon averaged 22.6 years and ranged from 14 to 33 years. About two-thirds of the sturgeon 25 years old or older were females. The youngest female with egg development in the sample was a 16 -year-old. The data indicate that female sturgeon mature at an older age and live longer than males.

The aging technique used for shovelnose sturgeon was validated by two forms of evidence. First, there was a highly significant correlation $(r=0.84, P<.01)$ between body length and anterior pectoral fin ray section radius. Second, sturgeon of increasing lengths were generaliy assigned ages of increasing magnitude (Table 21).

\section{Length/Weight Relationship}

Shovelnose sturgeon sampled in 1978 and 1979 ranged from 533 to 945 $\mathrm{mm}(21.0$ to $37.2 \mathrm{in.})$ in fork length and averaged $758 \mathrm{~mm}(29.8 \mathrm{in.}$.). Mean weight of the sturgeon in the sample was $2791 \mathrm{~g}(4.83 \mathrm{1b})$. The length/ weight relationship for sturgeon in the sample is described by the equation: $\log W=3.22 \log L-5.95(r=0.93)$, where $W=$ weight and $L=$ fork length.

Forty-one shovelnose sturgeon sexed as males averaged $739 \mathrm{~mm}$ (29.1 in.) in fork length and $1969 \mathrm{~g}(4.34 \mathrm{lb})$. Fifty females averaged $782 \mathrm{~mm}(30.8$ in.) in fork length and $2472 \mathrm{~g}(5.45 \mathrm{lb})$. The average length and weight of shovelnose sturgeon sampled from the middle Missouri River in 1978 and 1979 equal or exceed the maximum lengths and weights reported for shovelnose sturgeon in samples from the Missouri River in South Dakota (Zweiacker 1967), Mississippi River in Iowa (Helms 1974a), and the Red Cedar/Chippewa River system in Wiscons in (Christenson 1975). Mean lengths and weights of shovelnose sturgeon in the Tongue River, Montana (Elser et a1. 1977), 
Table 21. Age-frequency of shovelnose sturgeon sampled from the middle Missouri River in 1978 and 1979 with mean fork length, weight and condition factor ( $K_{T L}$ ) of each age class.

\begin{tabular}{|c|c|c|c|c|}
\hline Age & No. of Fish & Mean Fork Length $(\mathrm{mm})$ & Mean Weight $(\mathrm{g})$ & Mean KTL \\
\hline 8 & 2 & 579 & 826 & 0.43 \\
\hline 9 & 1 & 566 & 703 & 0.38 \\
\hline 10 & 2 & 655 & 1179 & 0.42 \\
\hline 11 & 0 & - & - & - \\
\hline 12 & 0 & - & - & - \\
\hline 13 & 1 & 686 & 1505 & 0.47 \\
\hline 14 & 3 & 663 & 1442 & 0.49 \\
\hline 15 & 7 & 683 & 1578 & 0.50 \\
\hline 16 & 2 & 711 & 1828 & 0.51 \\
\hline 17 & 5 & 701 & 1683 & 0.49 \\
\hline 18 & 9 & 749 & 1647 & 0.40 \\
\hline 19 & 12 & 749 & 1978 & 0.47 \\
\hline 20 & 13 & 729 & 1896 & 0.49 \\
\hline 21 & 7 & 762 & 2109 & 0.48 \\
\hline 22 & 11 & 754 & 2109 & 0.49 \\
\hline 23 & 7 & 759 & 2127 & 0.49 \\
\hline 24 & 9 & 785 & 2667 & 0.55 \\
\hline 25 & 8 & 813 & 2690 & 0.50 \\
\hline 26 & 6 & 772 & 2495 & 0.54 \\
\hline 27 & 2 & 790 & 2717 & 0.55 \\
\hline 28 & 4 & 820 & 2839 & 0.52 \\
\hline 29 & 3 & 813 & 2930 & 0.55 \\
\hline 30 & 1 & 914 & 3946 & 0.52 \\
\hline 31 & 3 & 874 & 3266 & 0.49 \\
\hline 32 & 3 & 902 & 3878 & 0.53 \\
\hline 33 & 1 & 853 & 3774 & 0.61 \\
\hline
\end{tabular}


Powder River, Montana (Rehwinkel et al. 1976), were similar to the middle Missouri River.

\section{Condition Factors}

Mean condition factors were higher for shovelnose sturgeon over 21 years (the mean age) than for sturgeon younger than 21 (Table 21). Mean condition factors were 0.46 for fish less than 21 years and 0.52 for fish more than 21 .

The average condition factor for all shovelnose sturgeon sampled from the middle Missouri River was 0.503 . Condition factors averaged 0.487 for males and 0.517 for females. Condition factors reported by Carlander (1969) for shovelnose sturgeon in reservoirs on the Missouri River in South Dakota were much lower, ranging from 0.22 to 0.27 . Elser et a1. (1977) reported data which indicated mean condition factors of 0.481 for males and 0.611 for females in the lower Tongue River, Montana, in 1975. Since the shovelnose sturgeon population in the lower Tongue River was comprised almost entirely of mature spawning fish, the high condition factor of female sturgeon is probably related to the presence of a large number of gravid fish. The middle Missouri River sample included a significant number of immature and nonspawning females, which more nearly reflects an average condition factor for female shovelnose sturgeon.

\section{Channel Catfish}

Assigned Ages and Observed Growth

In 1978, 234 channel catfish sampled on the middle Missouri River were assigned ages ranging from 1 to 18 years (Table 22). Age determinations were made by examining cross-sections of the pectoral spine (Figure 26). Since the sampling gear was selective for larger fish, only 4 percent of the channel catfish in the sample were 2 years or younger. Three and fouryear-old channel catfish made up 66 percent of the sample. About 30 percent of the channel catfish were age five or older. Ragland and Robinson (1972) reported that 3 and 4-year-old channel catfish made up 61 percent of a sample of channel catfish from the lower Missouri River in Missouri. They concluded the most likely cause for the dominance of catfish of intermediate size and age was gear selectivity.

In general, the middle Missouri River channel catfish population appears to be older than populations in the lower Missouri River, Missouri (Ragland and Robinson 1972), Lake-of-the-0zarks, Missouri (Marzolf 1955), Grand Lake, Oklahoma (Sneed 1951), and the Salt River, Missouri (Purkett 1957). The channel catfish population in the St. Lawrence River in Quebec (Carlander 1969) appears to be older than the middle Missouri population in Montana. Carlander (1969) reported that channel catfish reach sexual maturity at 303 to $381 \mathrm{~mm}$ (11.9 to $15.0 \mathrm{in}$.) and 4 to 5 years of age in the Mississippi River in Iowa and Missouri. If this is true for the middle Missouri River population in Montana, probably half or less of the sample of 234 channel catfish collected in 1978 were sexually mature.

Growth of channel catfish in the middle Missouri River is superior to growth in the Tongue River, Montana (Elser et a1. 1977), Des Moines River, Iowa (Carlander 1969), and St. Lawrence River, Quebec (Carlander 1969), and similar to average growth in the Mississippi and Missouri 
Table 22. Age-frequency of channel catfish sampled from the middle Missouri River in 1978 with mean length, weight and condition factor

$\left(K_{T L}\right)$ of each age class.

\begin{tabular}{|c|c|c|c|c|c|}
\hline Age & No. of Fish & $\%$ of Sample & Mean Length $(\mathrm{mm})$ & Mean Weight $(\mathrm{g})$ & Mean KTL \\
\hline 1 & 2 & 0.9 & 186 & 61 & 0.93 \\
\hline 2 & 7 & 3.0 & 256 & 148 & 0.88 \\
\hline 3 & 69 & 29.2 & 304 & 227 & 0.80 \\
\hline 4 & 87 & 36.9 & 373 & 417 & 0.79 \\
\hline 5 & 9 & 3.8 & 428 & 641 & 0.81 \\
\hline 6 & 15 & 6.4 & 471 & 869 & 0.82 \\
\hline 7 & 9 & 3.8 & 496 & 1067 & 0.87 \\
\hline 8 & 7 & 3.0 & 542 & 1424 & 0.89 \\
\hline 9 & 4 & 1.7 & 527 & 1325 & 0.89 \\
\hline 10 & 3 & 1.3 & 587 & 2008 & 0.95 \\
\hline 11 & 3 & 1.3 & 582 & 1837 & 0.93 \\
\hline 12 & 3 & 1.3 & 648 & 3007 & 1.11 \\
\hline 13 & 2 & 0.9 & 701 & 4105 & 1.19 \\
\hline 14 & 7 & 3.0 & 669 & 3334 & 1.11 \\
\hline 15 & 5 & 2.1 & 690 & 3656 & 1.11 \\
\hline 16 & 0 & 0 & - & - & $\because$ \\
\hline 17 & 2 & 0.9 & 718 & 4604 & 1.24 \\
\hline 18 & 2 & 0.9 & 658 & 2767 & 0.97 \\
\hline
\end{tabular}

rivers (as calculated by Carlander 1969) through age six (Table 23). For channel catfish 7 years and older, growth in the middle Missouri River is slower than average. However, since channel catfish in the middle Missouri live longer than average, the size structure of the population is nearly identical to that in other portions of the Mississippi and Missouri rivers.

The aging technique used for channel catfish was validated by three forms of evidence. First, there was an increase in ages assigned to catfish of increasing length (Table 22). Second, there was a highly significant correlation between body length and pectoral spine section radius $(r=0.87, P<.07)$. Third, calculated lengths at annuli 1 through 10 showed reasonable agreement with observed mean lengths of assigned age classes.

Length/Weight Relationship

Channel catfish sampled in 1978 ranged from 175 to $787 \mathrm{~mm}(6.9$ to 31.0 in.) in total length and averaged $371 \mathrm{~mm}(14.6 \mathrm{in.})$. Weights ranged from 45 to $5488 \mathrm{~g}(0.10$ to $12.101 \mathrm{~b})$ and averaged $771 \mathrm{~g}(1.70 \mathrm{1b})$. The length/weight relationship for channel catfish in the sample is described by the equation: $\log W=3.187 \log L-5.563(r=0.99)$, where $W=$ weight and $L=$ total length.

\section{Condition Factors}

Condition factors of channel catfish showed a tendency to increase with age (Table 22). Mean condition factors of the various age groups ranged 


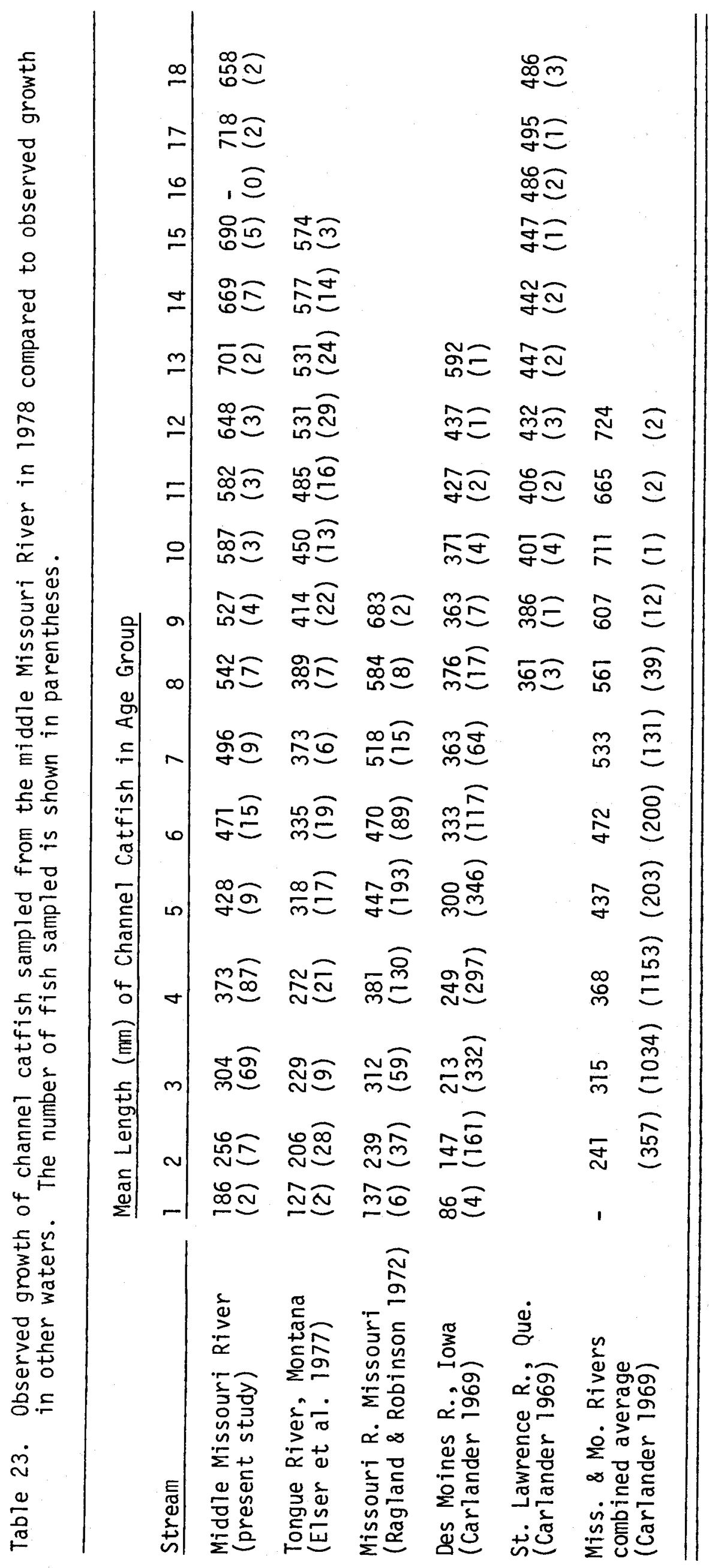




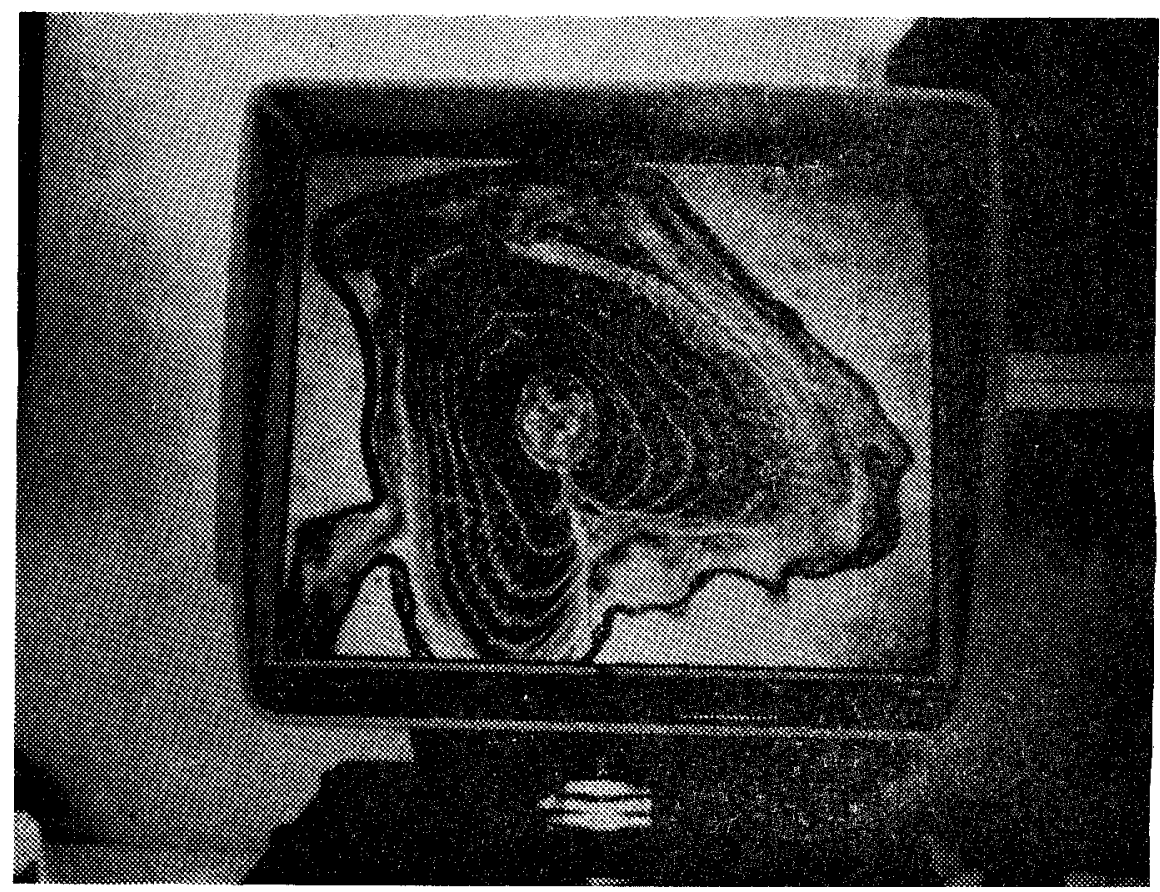

Figure 26. Cross-sections of the pectoral spines of channel catfish were studied for age and growth determination.

from 0.79 to 1.24 . Carlander (1969) reported condition factors of channel catfish populations in five midwestern states ranged from 0.50 to 1.22 .

\section{Calculated Growth}

Calculated lengths of channel catfish at annuli 1 through 10 are presented in Table 24. The calculations were based on 212 channel catfish from the 1978 sample. The Monastyrsky logarithmic equation best fit the data $(r=0.87)$, indicating curvilinear growth. Growth was greatest during the first three years of life, then continued more slowly, but steadily, through the tenth year. Lee's Phenomenon was apparent in the data for most age classes.

Calculated growth of channel catfish in the middle Missouri River is generally equivalent or superior to growth in other northern waters (Table 25). Channel catfish growth in the middle Missouri River also compares favorably with growth in lakes and rivers in southern states, particularly during the first few years of life. 
Table 24. Calculated length at the end of each year of life and average growth of channel catfish sampled from the middle Missouri River in 1978 (Monastyrsky logarithmic method).

Calculated Total Length (mm) at End of Year

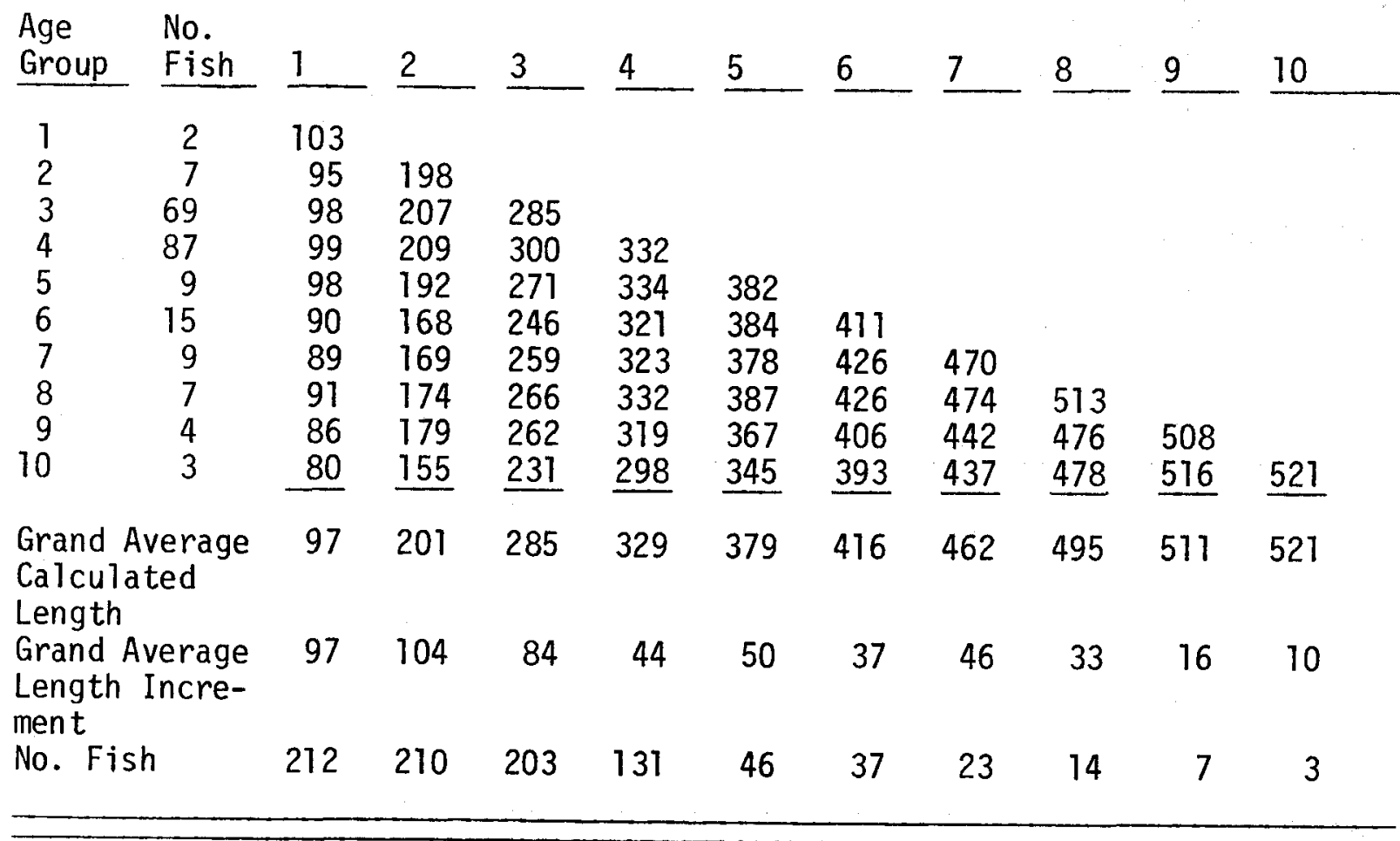

Sauger

Assigned Ages and Observed Growth

In 1978 and 1979, 802 sauger sampled on the middle Missouri River were assigned ages ranging from 0 to 8 years (Table 26). Ages 0,1 and 2 made up 23 percent of the sample. The small percentage of sauger in this age range was due to sampling bias. The boom suspended electrofishing boat was much less efficient for sampling smaller, younger sauger than larger, older sauger. Ages 3, 4, and 5 made up 61 percent of the sample. This percentage would have been even higher if the 1979 sample had contained fish from 305 to $405 \mathrm{~mm}$ (12.0 to $15.9 \mathrm{in.}$ ) in length. Sauger in this size range were not collected in 1979 because an adequate sample was collected in 1978. Ages 6, 7, and 8 made up 16 percent of the sample.

Completion of annuli for sauger in 1978 ranged from June 7 to July 22 and averaged June 29. Time of completion of annuli formation in 1979 ranged from May 19 to July 10 and averaged June 9. Riggs (1978) reported 100 percent completion of annuli formation for sauger in the Tongue River Reservoir by July 11 in 1975 and July 5 in 1976. 


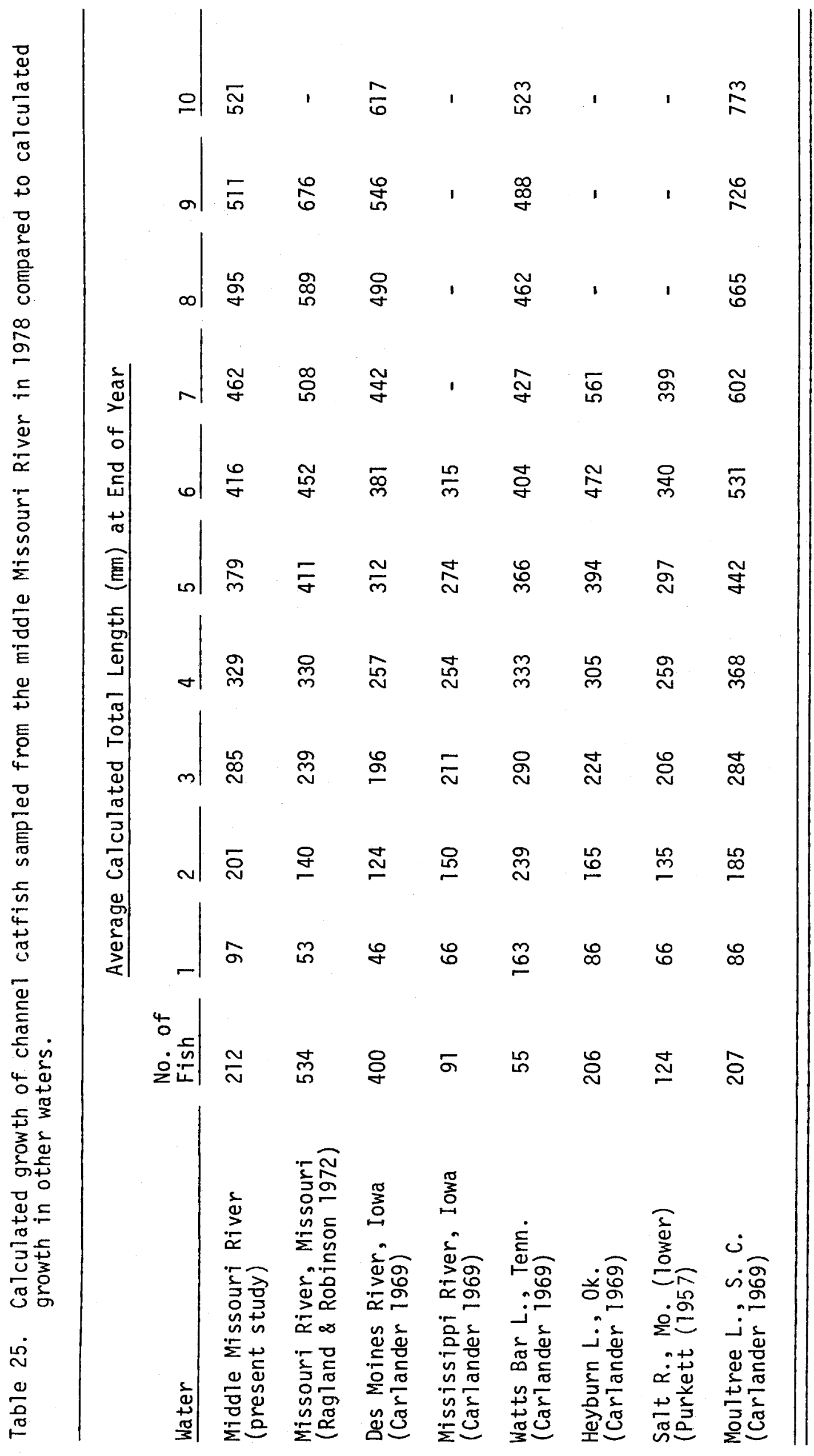


Table 26. Age-frequency of sauger sampled from the middle Missouri River in 1978 and 1979 with mean length, weight and condition factor $\left(\mathrm{K}_{\mathrm{TL}}\right)$ of each age class.

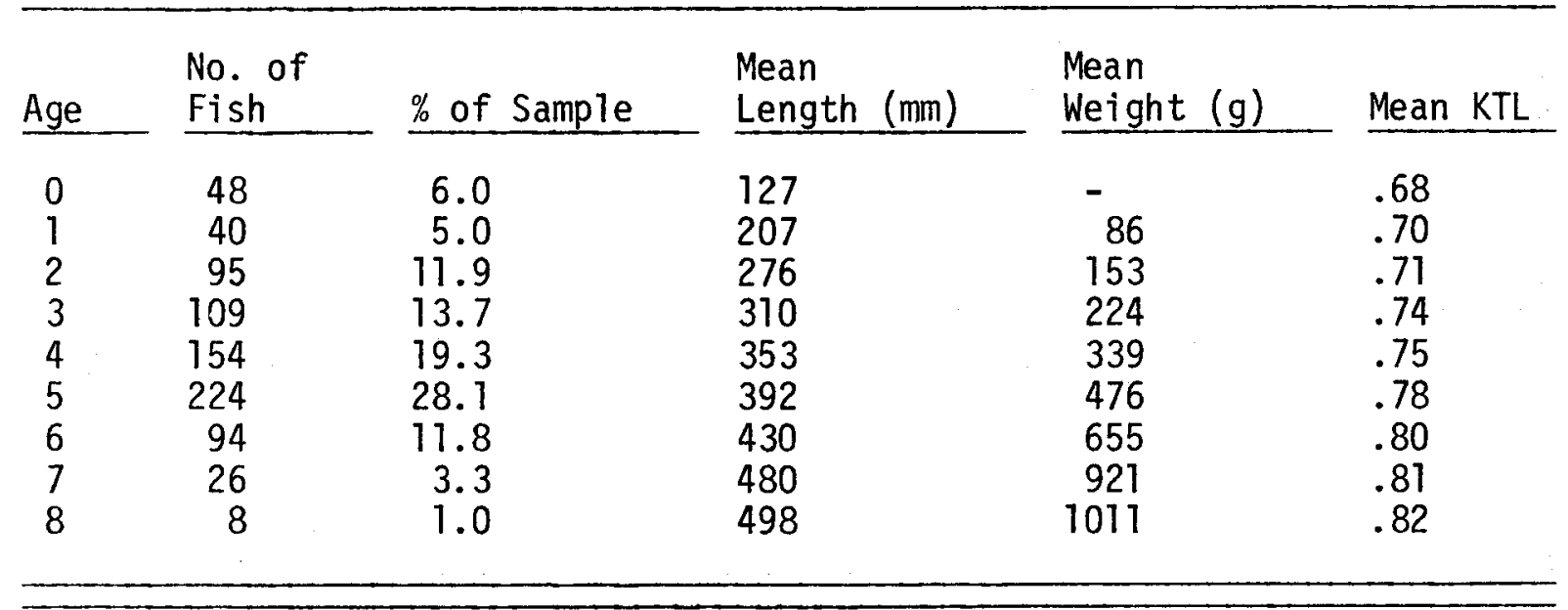

Table 27. Observed growth of sauger sampled from the middle Missouri River in 1978 and 1979 compared to observed growth in other Montana streams. The number of fish sampled is shown in parentheses.

\begin{tabular}{|c|c|c|c|c|c|c|c|c|c|}
\hline \multirow[b]{2}{*}{ Stream } & \multicolumn{9}{|c|}{ Mean Length $(\mathrm{mm})$ of Sauger in Age Group } \\
\hline & $\underline{0}$ & 1 & 2 & 3 & 4 & 5 & 6 & 7 & 8 \\
\hline $\begin{array}{l}\text { Middle Missouri River } \\
\text { (present study) }\end{array}$ & $\begin{array}{l}127 \\
(48)\end{array}$ & $\begin{array}{l}207 \\
(40)\end{array}$ & $\begin{array}{l}276 \\
(95)\end{array}$ & $\begin{array}{l}310 \\
(109)\end{array}$ & $\begin{array}{l}353 \\
(154)\end{array}$ & $\begin{array}{l}392 \\
(224)\end{array}$ & $\begin{array}{l}430 \\
(94)\end{array}$ & $\begin{array}{l}480 \\
(26)\end{array}$ & $\begin{array}{l}498 \\
(8)\end{array}$ \\
\hline $\begin{array}{l}\text { Lower Yellowstone R. } \\
\text { (Haddix and Estes 1976) }\end{array}$ & $\overline{(0)}$ & $\begin{array}{l}217 \\
(44)\end{array}$ & $\begin{array}{l}257 \\
(82)\end{array}$ & $\begin{array}{l}310 \\
(67)\end{array}$ & $\begin{array}{l}356 \\
(85)\end{array}$ & $\begin{array}{l}394 \\
(78)\end{array}$ & $\begin{array}{l}485 \\
(50)\end{array}$ & $\begin{array}{l}574 \\
(7)\end{array}$ & $\overline{(0)}$ \\
\hline $\begin{array}{l}\text { Tongue River } \\
\text { (Elser et al. 1977) }\end{array}$ & $\overline{(0)}$ & $(\overline{0})$ & $(\overline{0})$ & $\begin{array}{l}289 \\
(26)\end{array}$ & $\begin{array}{l}332 \\
(89)\end{array}$ & $\begin{array}{l}374 \\
(62)\end{array}$ & $\begin{array}{l}418 \\
(50)\end{array}$ & $\begin{array}{l}444 \\
(31)\end{array}$ & $\begin{array}{l}478 \\
(12)\end{array}$ \\
\hline $\begin{array}{l}\text { Powder River } \\
\text { (Rehwinkel et al. 1976) }\end{array}$ & $\overline{(0)}$ & $\overline{(0)}$ & $\begin{array}{l}306 \\
(4)\end{array}$ & $\begin{array}{l}378 \\
(20)\end{array}$ & $\begin{array}{l}357 \\
(45)\end{array}$ & $\begin{array}{l}415 \\
(22)\end{array}$ & $\begin{array}{l}421 \\
(15)\end{array}$ & $\begin{array}{l}425 \\
(5)\end{array}$ & $\begin{array}{l}478 \\
(2)\end{array}$ \\
\hline
\end{tabular}

Table 28. Mean monthly condition factors $\left(K_{T L}\right)$ of sauger sampled from the middle Missouri River in 1978 and 1979.

\begin{tabular}{|c|c|c|c|c|c|c|c|}
\hline & April & May & June & JuTy & August & September & October \\
\hline $\begin{array}{l}\text { Mean KTt } \\
\text { No. of Fish }\end{array}$ & $\begin{array}{l}0.83 \\
8\end{array}$ & $\begin{array}{l}0.80 \\
49\end{array}$ & $\begin{array}{l}0.71 \\
88\end{array}$ & $\begin{array}{l}0.73 \\
127\end{array}$ & $\begin{array}{l}0.76 \\
319\end{array}$ & $\begin{array}{l}0.81 \\
135\end{array}$ & $\begin{array}{l}0.74 \\
72\end{array}$ \\
\hline
\end{tabular}


Growth of sauger in the middle Missouri River was similar to growth in the lower Yellowstone, Tongue, and Powder rivers through age five. Beyond age five, sauger from the lower Yellowstone River were larger in average size than on the middle Missouri, while sauger from the Tongue and Powder rivers were smaller.

The aging technique used for sauger was validated by three forms of evidence. First, there was a highly significant correlation between body length and scale radius $(r=0.90, P<.01)$. Second, sauger of increasing lengths were assigned ages of increasing magnitude (Table 26). Third, observed lengths of assigned age classes showed reasonable agreement with calculated lengths at previous annuli.

Length/Weight Relationship

Sauger sampled in 1978 and 1979 ranged from 39 to $579 \mathrm{~mm}(1.5$ to 22.8 in.) in total length and averaged $350 \mathrm{~mm}$ (13.8 in.). Weights ranged from 20 to $1542 \mathrm{~g}(0.04$ to $3.40 \mathrm{lb})$ and averaged $325 \mathrm{~g}(0.72 \mathrm{lb})$. The length/ weight relationship for sauger in the sample is described by the equation: $\log W=3.157 \log L-5.524(r=0.99)$, where $W=$ weight and $L=$ total length.

\section{Condition Factors}

Condition factors of sauger increased consistently with age (Table 26). The condition factors ranged from 0.68 for young-of-the-year to 0.82 for 8-year-olds. Graham et al. (1979) reported condition factors of sauger in the lower Yellowstone River, Montana, ranging from 0.57 to 0.91 .

Mean monthly condition factors of sauger were high in April, decreased in May and June, and increased slowly from July through September (Table 28). The condition factor decreased again in 0ctober. The pattern of seasonal change in condition factors is probably related to spawning, feeding, and recruitment characteristics of the population.

\section{Calculated Growth}

Calculated lengths of sauger at annuli 1 through 8 are presented in Table 29. The calculations were based on 735 sauger from the combined 1978-79 sample. The Monastyrsky logarithmic equation best fit the data $(r=0.90)$, indicating curvilinear growth (Table 30). Calculated growth of sauger in the middle Missouri River is generally superior to growth in other northern waters at the end of the first year of life, similar to other northern waters at the end of the second and third years, and inferior after the third year (Table 31).

\section{Blue Sucker}

Assigned Ages and Observed Growth

In 1978 and 1979,214 blue suckers sampled on the middle Missouri River were assigned ages ranging from 6 to 17 years (Table 32). Over 70 percent of the fish in the sample were 11 years of age or older. The old ages of blue suckers in the sample could be related to sampling bias or differential distribution of the younger blue suckers. The sample was probably comprised almost entirely of mature fish. 
Table 29. Calculated length at the end of each year of life and average growth of sauger sampled from the middle Missouri River in 1978 and 1979 (Monastyrsky logari thmic method).

\begin{tabular}{|c|c|c|c|c|c|c|c|c|c|}
\hline \multirow[b]{2}{*}{$\begin{array}{l}\text { Age } \\
\text { Group }\end{array}$} & \multirow[b]{2}{*}{$\begin{array}{l}\text { No. } \\
\text { Fish }\end{array}$} & \multicolumn{8}{|c|}{ Calculated Total Length $(\mathrm{mm})$ at End of Year } \\
\hline & & 1 & $\underline{2}$ & 3 & 4 & $\underline{5}$ & 6 & $\underline{7}$ & $\underline{8}$ \\
\hline $\begin{array}{l}1 \\
2 \\
3 \\
4 \\
5 \\
6 \\
7 \\
8\end{array}$ & $\begin{array}{r}40 \\
95 \\
109 \\
154 \\
224 \\
94 \\
26 \\
8\end{array}$ & $\begin{array}{l}154 \\
155 \\
147 \\
151 \\
148 \\
152 \\
153 \\
148 \\
\end{array}$ & $\begin{array}{l}250 \\
227 \\
240 \\
236 \\
234 \\
235 \\
228 \\
\end{array}$ & $\begin{array}{l}282 \\
298 \\
296 \\
289 \\
295 \\
280 \\
\end{array}$ & $\begin{array}{l}344 \\
329 \\
336 \\
347 \\
331 \\
\end{array}$ & $\begin{array}{l}377 \\
379 \\
393 \\
381 \\
\end{array}$ & $\begin{array}{r}413 \\
432 \\
422 \\
\end{array}$ & $\begin{array}{r}463 \\
456 \\
\end{array}$ & $\underline{485}$ \\
\hline \multicolumn{2}{|c|}{$\begin{array}{l}\text { Grand Average } \\
\text { Calculated Length } \\
\text { Grand Average } \\
\text { Length Increment }\end{array}$} & 151 & 237 & 293 & 336 & 379 & 417 & 462 & 485 \\
\hline \multicolumn{2}{|c|}{ No. Fish } & 735 & 708 & 615 & 506 & 351 & 128 & 34 & 8 \\
\hline
\end{tabular}

Table 30. Comparison of grand average calculated lengths of sauger at the end of each year of life using a logari thmic method (Monastyrsky) and three linear methods. Calculations are based on 735 sauger sampled from the middle Missouri River in 1978 and 1979.

\begin{tabular}{|c|c|c|c|c|c|c|c|c|}
\hline \multirow[b]{2}{*}{ Method } & \multicolumn{6}{|c|}{ Average Calculated Total Length $(\mathrm{mm})$} & \multicolumn{2}{|c|}{ ) at End of Year } \\
\hline & 1 & $\underline{2}$ & 3 & 4 & 5 & $\underline{6}$ & 7 & $\underline{8}$ \\
\hline $\begin{array}{l}\text { Monastyrsky } \\
\text { Dah1 Lea } \\
\text { Rosa Lee } \\
\text { Rosa Lee (corrected) }\end{array}$ & $\begin{array}{l}151 \\
127 \\
157 \\
157\end{array}$ & $\begin{array}{l}237 \\
210 \\
240 \\
240\end{array}$ & $\begin{array}{l}293 \\
263 \\
292 \\
294\end{array}$ & $\begin{array}{l}336 \\
301 \\
331 \\
337\end{array}$ & $\begin{array}{l}379 \\
341 \\
371 \\
379\end{array}$ & $\begin{array}{l}417 \\
376 \\
406 \\
417\end{array}$ & $\begin{array}{l}462 \\
416 \\
446 \\
462\end{array}$ & $\begin{array}{l}485 \\
439 \\
469 \\
485\end{array}$ \\
\hline
\end{tabular}


Table 31. Calculated growth of sauger sampled from the middle Missouri River in 1978 and 1979 compared to calculated growth in other northern waters.

\begin{tabular}{|c|c|c|c|c|c|c|c|c|c|}
\hline \multirow[b]{2}{*}{ Water } & \multirow{2}{*}{$\begin{array}{l}\text { No. of } \\
\text { Fish }\end{array}$} & \multicolumn{8}{|c|}{$\begin{array}{c}\text { Average Calculated Total Length }(\mathrm{mm}) \text { at } \\
\text { End of Year }\end{array}$} \\
\hline & & 1 & 2 & 3 & 4 & 5 & 6 & 7 & 8 \\
\hline $\begin{array}{l}\text { Middle Missouri River } \\
\text { (present study) }\end{array}$ & 735 & 151 & 237 & 293 & 336 & 379 & 417 & 462 & 485 \\
\hline $\begin{array}{l}\text { Lower Yellowstone River } \\
\text { (Graham et al. 1979) }\end{array}$ & 859 & 157 & 244 & 305 & 365 & 424 & 476 & 534 & \\
\hline $\begin{array}{l}\text { Marias R., Montana } \\
\text { (Peters 1964) }\end{array}$ & 16 & 112 & 203 & 282 & 335 & 384 & 465 & & \\
\hline $\begin{array}{l}\text { Milk R., Montana } \\
\text { (Peters 1964) }\end{array}$ & 5 & 130 & 246 & 323 & 366 & & & & \\
\hline $\begin{array}{l}\text { Fort Peck Res., Mont. } \\
\text { (Peters 1964) }\end{array}$ & 124 & 130 & 224 & 297 & 363 & 429 & 493 & 521 & \\
\hline $\begin{array}{l}\text { Garrison Res., N. Dak. } \\
\text { (Carufel 1963) }\end{array}$ & 378 & 125 & 227 & 310 & 386 & 461 & 587 & & \\
\hline $\begin{array}{l}\text { L. Winnebago, Wisc. } \\
\text { (Priegel 1969) }\end{array}$ & 1741 & 130 & 246 & 310 & 338 & 358 & 378 & 391 & 401 \\
\hline $\begin{array}{l}\text { Upper Mississippi R. } \\
\text { Backwaters (Christenson } \\
\text { and Smith 1965) }\end{array}$ & 42 & 124 & 229 & 302 & 345 & & & & \\
\hline
\end{tabular}

Table 32. Age-frequency of blue suckers sampled from the middle Missouri River in 1978 and 1979 with mean length, weight and condition factor $\left(K_{T L}\right)$ of each age class.

Age №. of Fish \% of Sample Mean Length (mm) Mean Weight (g) Mean KTL

$\begin{array}{rrrrrl}6 & 1 & 0.5 & 556 & 1338 & 0.78 \\ 7 & 2 & 0.9 & 609 & 2043 & 0.91 \\ 8 & 7 & 3.3 & 625 & 2051 & 0.88 \\ 9 & 30 & 14.0 & 670 & 2590 & 0.85 \\ 10 & 21 & 9.8 & 658 & 2551 & 0.90 \\ 11 & 52 & 24.3 & 704 & 2985 & 0.88 \\ 12 & 40 & 18.7 & 734 & 3578 & 0.90 \\ 13 & 34 & 15.9 & 747 & 3774 & 0.92 \\ 14 & 17 & 7.9 & 774 & 4277 & 0.89 \\ 15 & 6 & 2.8 & 799 & 4763 & 0.93 \\ 16 & 3 & 1.4 & 841 & 5053 & 0.89 \\ 17 & 1 & 0.5 & 793 & 5035 & 0.89\end{array}$


Very few studies have been made of the age and growth of blue suckers, probably because of the scarcity of the species. Carlander (1969)

summarized age and growth observations for a few blue suckers collected from the Missouri River in South Dakota and two lakes in Oklahoma. Observed growth of blue suckers in the middle Missouri River is similar to these waters for comparable age groups.

\section{Length/Frequency Distribution}

The length/frequency distribution of blue suckers sampled in 1978 and 1979 is given in Table 33. The fish ranged from 556 to $879 \mathrm{~mm}$ (21.9 to 34.6 in.) in total length, and averaged $714 \mathrm{~mm}$ (28.1 in.). Christenson (1974) collected 181 blue suckers in the Red Cedar/Chippewa River system in Wisconsin. He reported a size range of 470 to $755 \mathrm{~mm}$ (18.5 to $29.7 \mathrm{in.}$ ) total length with a mean size of $625 \mathrm{~mm}$ (24.6 in.). Carlander (1969) reported blue suckers collected from three locations on the Missouri River in South Dakota ranged from 432 to $686 \mathrm{~mm}(17.0$ to $27.0 \mathrm{in.})$ in total length.

\section{Length/Weight Relationship}

Weights of blue suckers sampled from the middle Missouri River ranged from 1338 to $6577 \mathrm{~g}(2.95$ to $14.50 \mathrm{lb})$ and averaged $3305 \mathrm{~g}(7.29 \mathrm{lb})$. Christenson (1974) reported weights for blue suckers which ranged from 1270 to $3992 \mathrm{~g}(2.80$ to $8.80 \mathrm{lb})$ and averaged $2177 \mathrm{~g}(4.80 \mathrm{lb})$ in the Red Cedar/Chippewa River system in Wisconsin. Weights of blue suckers collected from Oahe Reservoir on the Missouri River in South Dakota ranged from 186 to $2504 \mathrm{~g}(0.41$ to $5.52 \mathrm{~Tb})$ (Carlander 1969).

The length/weight relationship for blue suckers sampled in the middle Missouri River is described by the equation: $\log W=2.792 \log \mathrm{L}-4.466$ $(r=0.89)$, where $W=$ weight and $L=$ total length. A length/weight relationship reported for blue suckers in Alabama by Carlander (1969) was described by the equation: $\log W=3.19 \log \mathrm{L}-5.57$. This equation predicts weights similar to those predicted by the middle Missouri River equation.

\section{Condition Factors}

The mean condition factor for the entire sample of blue suckers from the middle Missouri River was 0.88. Condition factors reported by Carlander (1969) for blue suckers collected from three locations on the Missouri River in South Dakota ranged from 0.67 to 0.76 .

Mean monthly condition factors of blue suckers sampled in the middle Missouri River are given in Table 34 . Mean condition factor was lowest in June, probably the result of fish having completed spawning.

\section{Calculated Growth}

An attempt was made to calculate lengths of blue suckers at previous annuli. However, due to the lack of smaller and younger fish, results were very poor and are not included in this report. 
Table 33. Length-frequency distribution of blue suckers sampled on the middle Missouri River in 1978 and 1979.

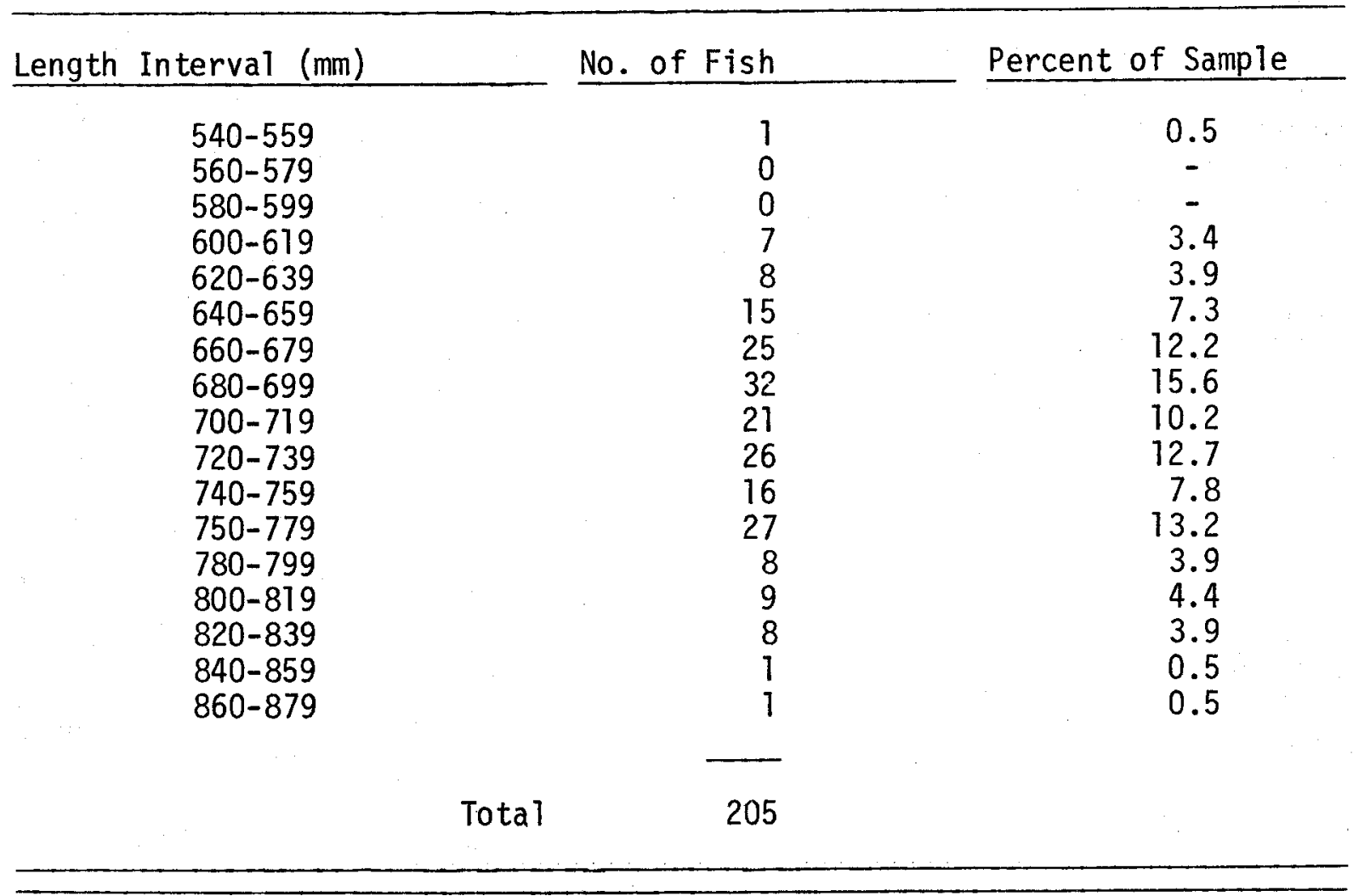

Table 34. Mean monthly condition factors $\left(K_{T L}\right)$ of blue suckers sampled from the middle Missouri River in 1978 and 1979.

\begin{tabular}{|c|c|c|c|c|c|c|}
\hline & May & June & July & August & September & October \\
\hline Mean $\mathrm{K}_{\mathrm{TL}}$ & 0.87 & 0.81 & 0.87 & 0.91 & 0.98 & 0.95 \\
\hline No. of Fish & 25 & 33 & 71 & 68 & 1 & 6 \\
\hline
\end{tabular}




\section{Smalimouth Buffalo}

Assigned Ages and Observed Growth

In 1978 and 1979, 180 smalimouth buffalo sampled on the middle Missouri River were assigned ages ranging from 4 to 16 years (Table 35). About 10 percent were 4 to 8 years old, 73 percent were 9 to 12, and 17 percent were 13 to 16 . Smallmouth buffalo in the Missouri River in South Bakota first reach sexual maturity at age 4. Brown (1971) indicates smallmouth buffalo in Montana usually reach maturity at age three. This indicates that the sample of smallmouth buffalo from the middle Missouri River was probabiy comprised entirely of mature fish, spawners from Fort Peck Reservoir. Immature smal1mouth buffalo rear in the reservoir.

Observed growth of smallmouth buffalo in the middle Missouri is about average when compared to observed growth reported by Carlander (1969) for other waters in the United States.

The aging technique used for smallmouth buffalo was validated by three forms of evidence. First, there was a highly significant correlation between body length and scale radius $(r=0.84, P<.01)$. Second, smallmouth buffalo of increasing lengths were assigned ages of increasing magnitude. Third, observed lengths of assigned age classes showed reasonable agreement with calculated lengths at previous annuli.

Length/Weight Relationship

Smallmouth buffalo sampled in 1978 and 1979 ranged from 404 to 800 $\mathrm{mm}$ ( 15.9 to $31.5 \mathrm{in.)}$ in total length and averaged $576 \mathrm{~mm}$ (22.7 in.). Weights ranged from 975 to $7498 \mathrm{~g}(2.15$ to $16.53 \mathrm{lb})$ and averaged $3120 \mathrm{~g}$ $(6.88 \mathrm{lb})$. The length/weight relationship for smallmouth buffalo in the sample is described by the equation: $\log W=2.96 \log L-4.698(r=0.92)$, where $W=$ weight and $L=$ total length.

Table 35. Age-frequency of smallmouth buffalo sampled from the middle Missouri River in 1978 and 1979 with mean length, weight and condition factor $\left(K_{T L}\right)$ of each age class.

\begin{tabular}{|c|c|c|c|c|c|}
\hline Age & $\begin{array}{l}\text { No. of } \\
\text { Fish }\end{array}$ & $\begin{array}{l}\% \text { of } \\
\text { Sample }\end{array}$ & $\begin{array}{l}\text { Mean } \\
\text { Length }(\mathrm{mm})\end{array}$ & $\begin{array}{l}\text { Mean } \\
\text { Weight (g) }\end{array}$ & $\begin{array}{l}\text { Mean } \\
\text { KTL }\end{array}$ \\
\hline 4 & 1 & 0.6 & 404 & 975 & 1.48 \\
\hline 5 & 0 & 0 & - & - & - \\
\hline 6 & 0 & 0 & - & - & - \\
\hline 7 & 3 & 1.7 & 478 & 1588 & 1.48 \\
\hline 8 & 14 & 7.8 & 513 & 2030 & 1.56 \\
\hline 9 & 39 & 21.7 & 549 & 2564 & 1.53 \\
\hline 10 & 42 & 23.3 & 573 & 2882 & 1.58 \\
\hline 11 & 32 & 17.8 & 597 & 3424 & 1.59 \\
\hline 12 & 18 & 10.0 & 623 & 3724 & 1.62 \\
\hline 13 & 22 & 12.2 & 635 & 4201 & 1.60 \\
\hline 14 & 7 & 3.9 & 685 & 5270 & 1.72 \\
\hline 15 & 1 & 0.6 & 696 & 5557 & 1.71 \\
\hline 16 & 1 & 0.6 & 704 & 5670 & 1.73 \\
\hline
\end{tabular}




\section{Condition Factors}

In general, condition factors of smallmouth buffalo increased with age (Table 35). Mean condition factors for the various age groups ranged from 1.48 to 1.73. Condition factors were high in Apri1, decreased in May and June, and increased from July through October (Table 36). The pattern of seasonal change in condition factors is probably related to spawning, which occurs mainly from late May through late June.

Table 36. Mean monthly condition factors $\left(K_{T L}\right)$ of smallmouth buffalo sampled from the middle Missouri River in 1978 and 1979.

\begin{tabular}{|c|c|c|c|c|c|c|c|}
\hline & April & May & June & July & August & September & October \\
\hline Mean $K_{T L}$ & 1.74 & 1.53 & 1.48 & 1.53 & 1.64 & 1.70 & 1.70 \\
\hline
\end{tabular}

Calculated Growth

Erosion of the edges of the scales and annuli distortions made it difficult to calculate growth increments of smallmouth buffalo at previous annuli. Only 15 scale samples were suitable for age and growth determination by this method. The scales were from fish 10 years of age or younger.

Calculated lengths at previous annuli for this sample of smallmouth buffalo are presented in Table 37. The Monastyrsky logarithmic equation best fit the data and most accurately described the growth increments.

Calculated growth of smallmouth buffalo in the middle Missouri River is similar to other waters (Table 38). Carlander (1969) found no regional trends in growth rates of smallmouth buffalo when he compared growth in various parts of the United States.

\section{Bigmouth Buffalo}

Assigned Ages and Observed Growth

In 1978 and 1979, 72 bigmouth buffalo sampled on the middle Missouri River were assigned ages ranging from 5 to 15 years (Table 39). Onty 12.5 percent of the fish were younger than 10, and 87.5 percent were 10 or older. Carlander (1969) reported bigmouth buffalo in the Missouri River in South Dakota mature at ages 3 to 4 . Brown (1971) indicates bigmouth buffalo in Montana usually reach maturity at age three. This indicates that the sample of bigmouth buffalo from the middle Missouri River was probably comprised entirely of mature fish, spawners from Fort Peck Reservoir. Immature bigmouth buffalo rear in the reservoir.

Bigmouth buffalo in the middle Missouri River appeared to form their annulus mark between late May and mid-June. This is similar to the time of annulus formation reported for bigmouth buffalo in the Missouri River in South Dakota (Carlander 1969). 


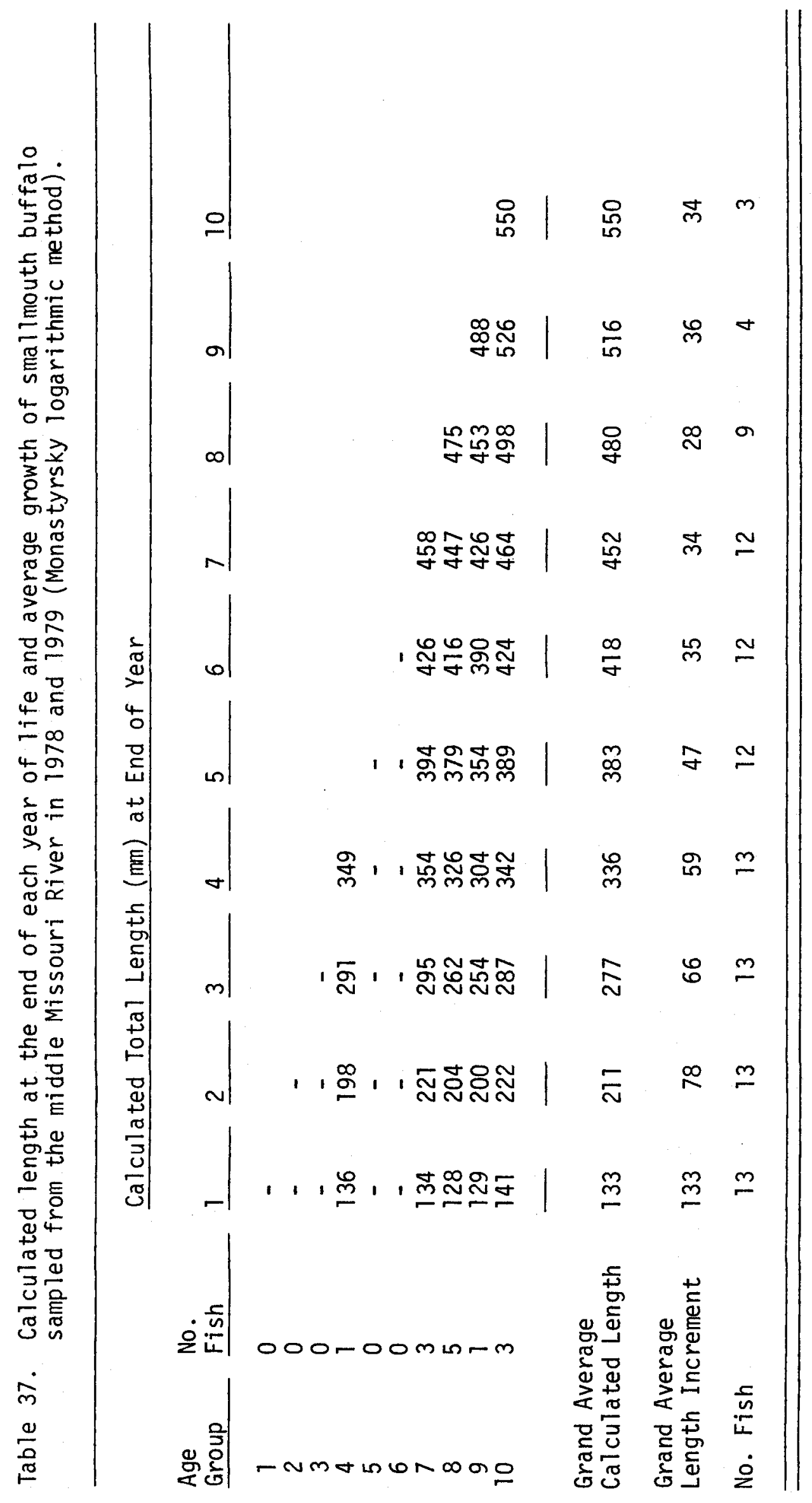




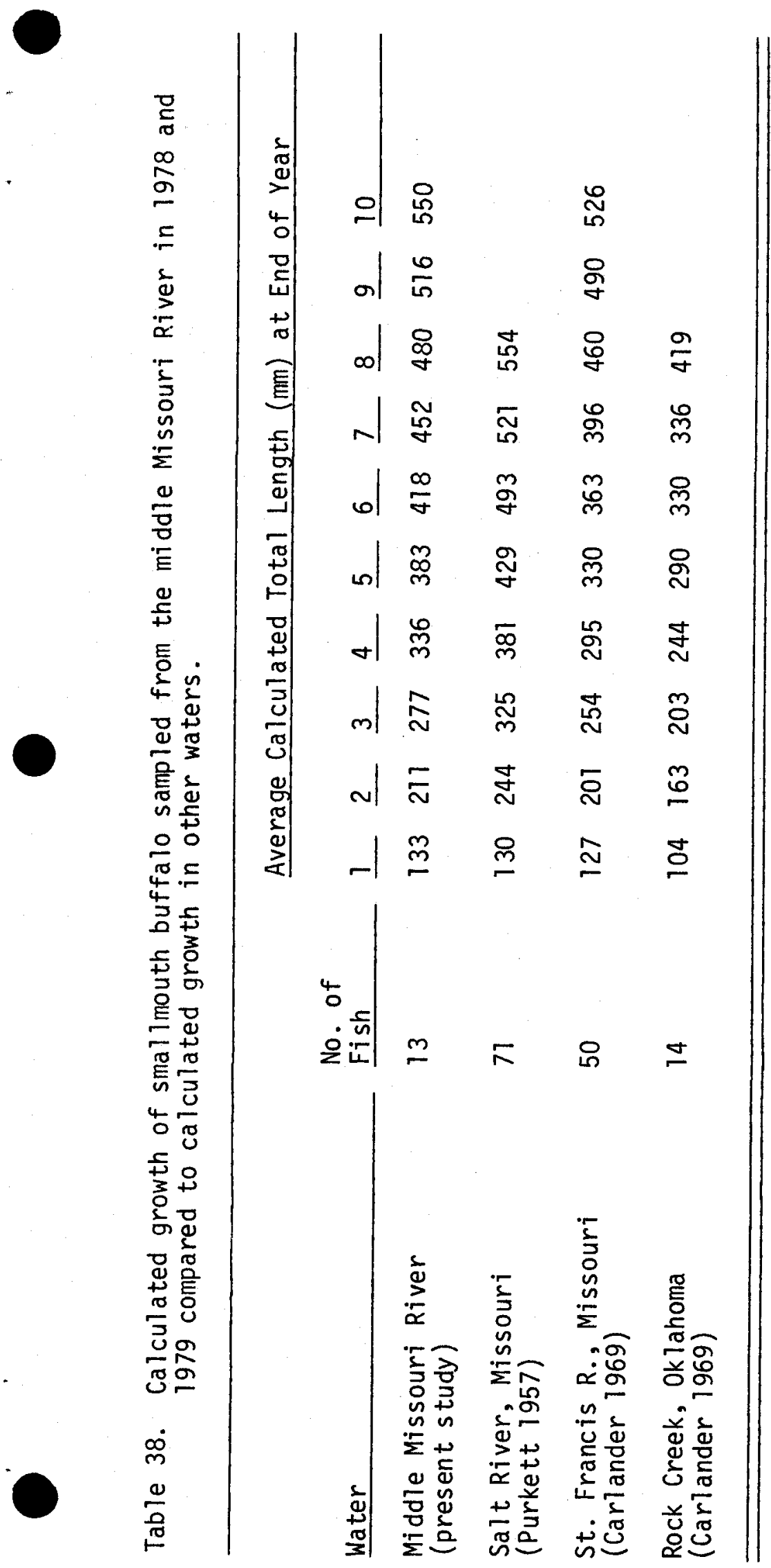


Table 39. Age-frequency of bigmouth buffalo sampled from the middle Missouri River in 1978 and 1979 with mean length, weight and condition factor $\left(K_{T L}\right)$ of each age class.

\begin{tabular}{|c|c|c|c|c|}
\hline Age No. of Fish & $\%$ of Sample & Mean Length (mm) & Mean Weight $(\mathrm{g})$ & Mean KTL \\
\hline 1 & 1.4 & 432 & 1,202 & 1.49 \\
\hline 0 & 0 & - & - & - \\
\hline 1 & 1.4 & 640 & 3,856 & 1.47 \\
\hline 0 & 0 & - & - & - \\
\hline 7 & 9.7 & 707 & 5,811 & 1.64 \\
\hline 12 & 16.7 & 714 & 5,816 & 1.60 \\
\hline 17 & 23.6 & 714 & 5,944 & 1.63 \\
\hline 14 & 19.4 & 801 & 9,593 & 1.87 \\
\hline 14 & 19.4 & 813 & 9,536 & 1.77 \\
\hline 5 & 6.9 & 854 & 10,614 & 1.70 \\
\hline 1 & 1.4 & 790 & 7,824 & 1.59 \\
\hline
\end{tabular}

Table 40. Calculated length at the end of each year of 1 ife and average growth of bigmouth buffalo sampled from the middle Missouri River in 1978 and 1979 (Monastyrsky logarithmic method).

\section{Calculated Total Length (mm) at End of Year}

Age No.

Group Fish

1

$\underline{2} \underline{3}$

$\underline{4}$

$\underline{5}$

$\underline{6}$

$\underline{7}$

$\underline{8}$

$\underline{9} \quad 10$

$\begin{array}{rl}1 & 0 \\ 2 & 0 \\ 3 & 0 \\ 4 & 0 \\ 5 & 1 \\ 6 & 0 \\ 7 & 1 \\ 8 & 0 \\ 9 & 5 \\ 10 & 6\end{array}$

$-$

- -4

$-111 \quad-$

$\begin{array}{lllll}111 & 185 & 245 & 310 & 383\end{array}$

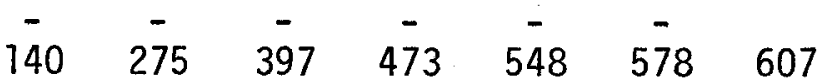

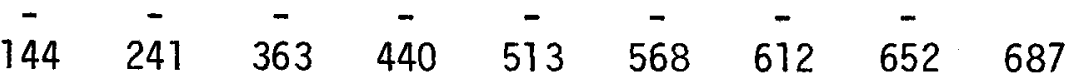

$\begin{array}{lllllllll}133 & 229 & 332 & 415 & 465 & 526 & 578 & 622 & 662\end{array}$

691

Grand Average

Calculated

Length

$\begin{array}{llllllllll}136 & 234 & 342 & 421 & 484 & 548 & 595 & 636 & 673 & 691\end{array}$

Grand Average

Length

Increment

No. Fish

$\begin{array}{lll}136 & 98 \quad 108\end{array}$

$79 \quad 63$

$64 \quad 47 \quad 41$

$37 \quad 18$

$\begin{array}{llllllllll}13 & 13 & 13 & 13 & 13 & 12 & 12 & 11 & 11 & 6\end{array}$ 
Observed growth of bigmouth buffalo in the middle Missouri River is about average when compared to observed growth reported by Carlander (1969) for other waters in the United States.

The aging technique used for bigmouth buffalo was validated by three forms of evidence. First, there was an increase in ages assigned to bigmouth buffalo of increasing length (Table 39). Second, there was a highly significant correlation between body length and scale radius $(r=0.88$, $P<.01)$. Third, calculated lengths at previous annuli showed reasonable agreement with observed mean lengths of assigned age classes.

Length/Weight Relationship

Bigmouth buffalo sampled in 1978 and 1979 ranged from 432 to $914 \mathrm{~mm}$ (17.0 to 36.0 in.) in total length and averaged $756 \mathrm{~mm}$ ( $29.8 \mathrm{in.}$.). Weights ranged from 1202 to $14,061 \mathrm{~g}(2.65$ to $31.00 \mathrm{lb})$ and averaged $7566 \mathrm{~g}(16.68$ 1b). The length/weight relationship for bigmouth buffalo in the sample is described by the equation: $\log W=3.391 \log L-5.898(r=0.96)$, where $W=$ weight and $L=$ total length.

\section{Condition Factors}

In general, condition factors of bigmouth buffalo increased with age (Table 39). Mean condition factors for the various age groups ranged from 1.47 to 1.87 . Carlander reported condition factors of bigmouth buffalo in reservoirs on the Missouri River in South Dakota ranged from 1.39 to 1.88 .

\section{Calculated Growth}

Growth of bigmouth buffalo in the middle Missouri River is best described by the Monastyrsky logarithmic equation. Calculated lengths at annuli 1 through 10 are presented in Table 40 . Growth was very rapid during the first five years of life. Growth continued more slowly through years 6 to 10.

Calculated growth of bigmouth buffalo in the middle Missouri River is similar to other waters (Table 41). Carlander (1969) indicated growth of bigmouth buffalo in Saskatchewan lakes was slower than in southern waters, but other regional differences in the United States and Canada were not distinguishable.

\section{Freshwater Drum}

Assigned Ages and Observed Growth

In 1979, 86 freshwater drum sampled on the middle Missouri River were assigned ages ranging from 2 to 10 years (Table 42). Fish of 4, 5, and 7 years comprised 58 percent of the sample. Six-year-old fish (the 1973 year class) were poorly represented.

The aging technique used for freshwater drum was validated by three forms of evidence. First, there was a highiy significant correlation between body length and scale radius $(r=0.92, P<.01)$. Second, freshwater drum of increasing lengths were assigned ages of increasing magnitude (Table 42). Third, observed lengths of assigned age classes showed reasonable agreement with calculated lengths at previous annuli. 
Table 41. Calculated growth of bigmouth buffalo sampled from the middle Missouri River in 1978 and 1979 compared to calculated growth in other waters.

Average Calculated Total Length (mm) at End of Year

\begin{tabular}{|c|c|c|c|c|c|c|c|c|c|c|c|}
\hline Water & $\begin{array}{l}\text { No. of } \\
\text { Fish }\end{array}$ & 1 & 2 & 3 & 4 & 5 & 6 & 7 & 8 & 9 & 10 \\
\hline $\begin{array}{l}\text { Middle Missouri R. } \\
\text { (present study) }\end{array}$ & 13 & 136 & 234 & 342 & 421 & 484 & 548 & 595 & 636 & 673 & 691 \\
\hline $\begin{array}{l}\text { Missouri R., Iowa } \\
\text { (Carlander 1969) }\end{array}$ & 5 & 135 & 244 & 330 & 368 & 388 & & & & & \\
\hline $\begin{array}{l}\text { Roosevelt L., Ariz. } \\
\text { (Carlander ig69) }\end{array}$ & 490 & 208 & 361 & 455 & 503 & 538 & 569 & 597 & 582 & & \\
\hline $\begin{array}{l}\text { Coralville Res., Iowa } \\
\text { (Carlander 1969) }\end{array}$ & 236 & 175 & 328 & 388 & 432 & 467 & 513 & 584 & 678 & 688 & 703 \\
\hline
\end{tabular}

Table 42. Age-frequency of freshwater drum sampled from the middle Missouri River in 1979 with mean length, weight and condition factor $\left(K_{T L}\right)$ of each age class.

Age №. of Fish \% of Sample Mean Length (mm) Mean Weight (g) Mean KTL

\begin{tabular}{rrrrrr}
1 & 0 & 0 & - & - & - \\
2 & 7 & 8.1 & 276 & 285 & 1.34 \\
3 & 10 & 11.6 & 298 & 342 & 1.29 \\
4 & 16 & 18.6 & 329 & 476 & 1.32 \\
5 & 17 & 19.8 & 352 & 600 & 1.36 \\
6 & 8 & 9.3 & 387 & 816 & 1.39 \\
7 & 17 & 19.8 & 426 & 1203 & 1.49 \\
8 & 8 & 9.3 & 451 & 1406 & 1.52 \\
9 & 2 & 2.3 & 499 & 1996 & 1.59 \\
10 & 1 & 1.2 & 526 & 1973 & 1.38 \\
\hline
\end{tabular}


Observed growth of freshwater drum in the middle Missouri River is shown in Table 42. Growth increased fairly consistently with age and did not appear to slow down in older age groups.

\section{Length/Weight Relationship}

Freshwater drum sampled in 1979 ranged from 267 to $528 \mathrm{~mm}(10.5$ to 20.8 in.) in total length and averaged $362 \mathrm{~mm}(14.3 \mathrm{in}$.). Weights ranged from 227 to $2313 \mathrm{~g}(0.50$ to $5.10 \mathrm{lb})$ and averaged $765 \mathrm{~g}(1.69 \mathrm{lb})$. The length/ weight relationship for freshwater drum in the sample is described by the equation: $\log W=3.295 \log L-5.612(r=0.99)$, where $W=$ weight and $L=$ total length.

\section{Condition Factors}

Condition factors of freshwater drum in the middle Missouri River generally increased with age (Table 42). Mean condition factors for the various age groups ranged from 1.29 to 1.59. All of the freshwater drum in the sample were collected in July and August.

\section{Calculated Growth}

Calculated lengths of freshwater drum at annuli 1 through 10 using the Monastyrsky logarithmic equation are given in Table 43. The calculations were based on 84 freshwater drum from the 1979 sample. The Monastyrsky equation fit the data better than linear equations, indicating growth of freshwater drum was curvilinear.

Calculated growth of freshwater drum in the middle Missouri River is compared with calculated growth in the Salt River, Missouri (Purkett 1957) in Table 44. The calculated growth for the middle Missouri River is slightly inferior to growth in the Salt River. Apparently, very few studies have been made of the age and growth of freshwater drum. The Salt River study by Purkett was the only one located in a brief review of the literature.

\section{Other Species}

Age determinations were made for 15 walleye, 4 brown trout, 2 rainbow trout, 1 mountain whitefish, and 1 northern pike collected on the middle Missouri River in 1978 and 1979 (Table 45). Sample sizes for these species were too small to calculate detailed age and growth statistics.

Forage Fish

Piscivorous game and nongame fish populations depend, in part, on an adequate forage fish base for their food supply. The major fish species in the middle Missouri River which use forage fish for all or part of their diet include sauger, walleye, northern pike, channel catfish, burbot, and goldeye.

Forage fish populations were inventoried from 1976 through 1980 in eleven study sections on the mainstem of the middle Missouri River and in one study area on the lower Marias River. A comprehensive summary of the surveys is given in Appendix Table 56.

The main objective of the sampling was to determine taxonomic composition, longitudinal distribution, and habitat preferences of forage fish populations 
Table 43. Calculated length at the end of each year of life and average growth of freshwater drum sampled from the middle Missouri

River in 1979 (Monastyrsky logarithmic method).

Calculated Total Length (mm) at End of Year

Age No.

Group Fish

$\begin{array}{llll}1 & 0 & - & \\ 2 & 7 & 146 & 226\end{array}$

$3 \quad 10 \quad 138 \quad 216 \quad 266$

$\begin{array}{lllll}4 & 16 & 121 & 200 & 256\end{array}$

$\begin{array}{lllll}5 & 17 & 121 & 196 & 253 \\ 6 & 8 & 115 & 187 & 244\end{array}$

$\begin{array}{lllll}6 & 8 & 115 & 187 & 244\end{array}$

$\begin{array}{rrrrr}7 & 17 & 124 & 196 & 251 \\ 8 & 8 & 117 & 197 & 248\end{array}$

$\begin{array}{lllll}8 & 8 & 117 & 197 & 248 \\ 9 & 2 & 132 & 200 & 251\end{array}$

$\begin{array}{lllll}10 & 1 & 129 & 204 & 258\end{array}$

\section{1}

$295 \quad 330$

$289 \quad 328 \quad 365$

$297 \quad 339 \quad 373$

$\begin{array}{lllll}294 & 332 & 372 & 407 & 435\end{array}$

$\begin{array}{lllll}298 & 349 & 389 & 427 & 452\end{array}$

$\begin{array}{lllll}318 & 362 & 403 & 433 & 467\end{array}$

477

$496 \quad 513$

Grand Average

Calculated

Length

$\begin{array}{llllllllll}125 & 201 & 253 & 297 & 334 & 373 & 408 & 441 & 483 & 513\end{array}$

Grand Average

Length

$\begin{array}{lllllllllll}\text { Increment } & 125 & 76 & 52 & 44 & 37 & 39 & 35 & 33 & 42 & 30\end{array}$

$\begin{array}{lllllllllll}\text { No. Fish } & 84 & 84 & 77 & 67 & 52 & 35 & 27 & 10 & 3 & 1\end{array}$

Table 44. Calculated growth of freshwater drum sampled from the middle Missouri River in 1979 compared to calculated growth in the Salt River, Missouri.

\begin{tabular}{|c|c|c|c|c|c|c|c|c|c|c|c|}
\hline \multirow[b]{2}{*}{ Water } & \multirow[b]{2}{*}{$\begin{array}{l}\text { No. of } \\
\text { Fish }\end{array}$} & \multicolumn{10}{|c|}{$\begin{array}{c}\text { Average Calculated Total Length }(\mathrm{mm}) \text { at End } \\
\text { of Year }\end{array}$} \\
\hline & & 1 & 2 & 3 & 4 & 5 & 6 & 7 & 8 & 9 & 10 \\
\hline $\begin{array}{l}\text { Middle Missouri R. } \\
\text { (present study) }\end{array}$ & 84 & 125 & 201 & 253 & 297 & 334 & 373 & 408 & 441 & 483 & 513 \\
\hline $\begin{array}{l}\text { Salt R., Missouri } \\
\text { Middle Station } \\
\text { (Purkett 1957) }\end{array}$ & 130 & 130 & 229 & 287 & 335 & 378 & 419 & 454 & 483 & 517 & \\
\hline $\begin{array}{l}\text { Salt R. Missouri } \\
\text { Lower Station } \\
\text { (Purkett 1957) }\end{array}$ & 365 & 119 & 211 & 267 & 315 & 351 & 399 & 419 & 449 & & \\
\hline
\end{tabular}


Table 45. Ages of several miscellaneous fish species sampled from the middle Missouri River in 1978 and 1979.

\begin{tabular}{|c|c|c|c|}
\hline Species, Year Collected & Length (mm) & Weight $(g)$ & Assigned Age \\
\hline Walleye, 1978 & $\begin{array}{l}254 \\
318 \\
373 \\
559 \\
658 \\
711 \\
762\end{array}$ & $\begin{array}{r}131 \\
254 \\
431 \\
1538 \\
3538 \\
4627 \\
5965\end{array}$ & $\begin{array}{l}1 \\
2 \\
4 \\
6 \\
7 \\
9 \\
9\end{array}$ \\
\hline Walleye, 1979 & $\begin{array}{l}257 \\
279 \\
292 \\
302 \\
310 \\
693 \\
696 \\
734\end{array}$ & $\begin{array}{r}118 \\
168 \\
181 \\
200 \\
236 \\
3583 \\
3629 \\
3924\end{array}$ & $\begin{array}{r}2 \\
3 \\
2 \\
2 \\
3 \\
7 \\
8 \\
10\end{array}$ \\
\hline Brown Trout, 1979 & $\begin{array}{l}279 \\
287 \\
373 \\
381\end{array}$ & $\begin{array}{l}249 \\
249 \\
658 \\
612\end{array}$ & $\begin{array}{l}2 \\
2 \\
3 \\
4\end{array}$ \\
\hline Rainbow Trout, 1979 & $\begin{array}{l}264 \\
513\end{array}$ & $\begin{array}{r}181 \\
2336\end{array}$ & $\begin{array}{l}2 \\
5\end{array}$ \\
\hline Mountain Whitefish, 1979 & 348 & 386 & 4 \\
\hline Northern Pike, 1979 & 914 & 5216 & 7 \\
\hline
\end{tabular}


in the study area. Most of the forage fish sampling sites were located in confined areas of the river, such as backwaters and side channels, where the presence of forage fish was considered likely. Some forage fish were also taken in the main channel, particularly in shoreline and shallow riffle areas. Forage fish samples were collected with beach seines.

For the purposes of this report, a forage fish is broadly defined as any fish used by another fish as a food source. This definition includes nearly all young-of-the-year (YOY) fish. Some species, such as mottled sculpin, stonecats, mountain suckers, and most of the cyprinids, seldom exceed $150 \mathrm{~mm}$ ( $6 \mathrm{in.}$ ) in length as adults. These species essentially remain as a food source for their entire lives.

Thirty-one forage fish species representing 10 families were collected in the surveys (Table 46). The most common species were flathead chubs, emerald shiners, western silvery minnows, longnose dace, mounta in suckers, stonecats, mottled sculpin, YOY carp, YOY shorthead redhorse, and YOY longnose suckers. Mottled sculpin, longnose dace, mountain suckers, Yoy longnose suckers, and YOY shorthead redhorse were most abundant in the upper portion of the Missouri River above the confluence of the Marias River. Flathead chubs, stonecats, and YOY carp were more common below the confluence of the Marias. Western silvery minnows and emerald shiners were equaliy common above and below the mouth of the Marias.

Stonecats, mottled sculpin, longnose dace, and mountain suckers were found principaliy in riffle habitat. Flathead chubs and YOY longnose suckers were common in both riffles and pools. Emerald shiners, western silvery minnows, YOY shorthead redhorse, and YOY carp were more abundant in pools than in riffles.

For a more detailed discussion of the longitudinal distribution and habitat preferences of forage fish in the middle Missouri River refer to Gardner and Berg (1981).

\section{FINDINGS - SPORT FISHING VALUES}

Paddlefish Creel Census

\section{Background}

Paddlefish are native to Montana waters. However, little angler interest in them occurred until 1962. At that time a number of paddlefish were taken by anglers below an irrigation diversion structure on the Yellowstone River near Intake. This fishery stimulated interest in paddlefishing, and in addition to the Yellowstone River fishery, a good fishery now exists in the Missouri River immediately upstream from Fort Peck Reservoir and in the dredge cut pond complex below Fort Peck Dam.

Fishing pressure on paddlefish reportedly has increased considerably in recent years in the Missouri River immediately upstream from Fort Peck Reservoir (Needham 1973). This created the need for information required to evaluate the effect of angler harvest on the paddlefish population. In response to this need, a creel census study was implemented in 1973 by the Fisheries Division, DFWP (Needham 1973). This study also included tagging of paddlefish and collection of size and sex data. This research was continued by the Fisheries Division in 1974 and 1975 (Needham 1975 and 


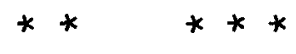

$*$ 


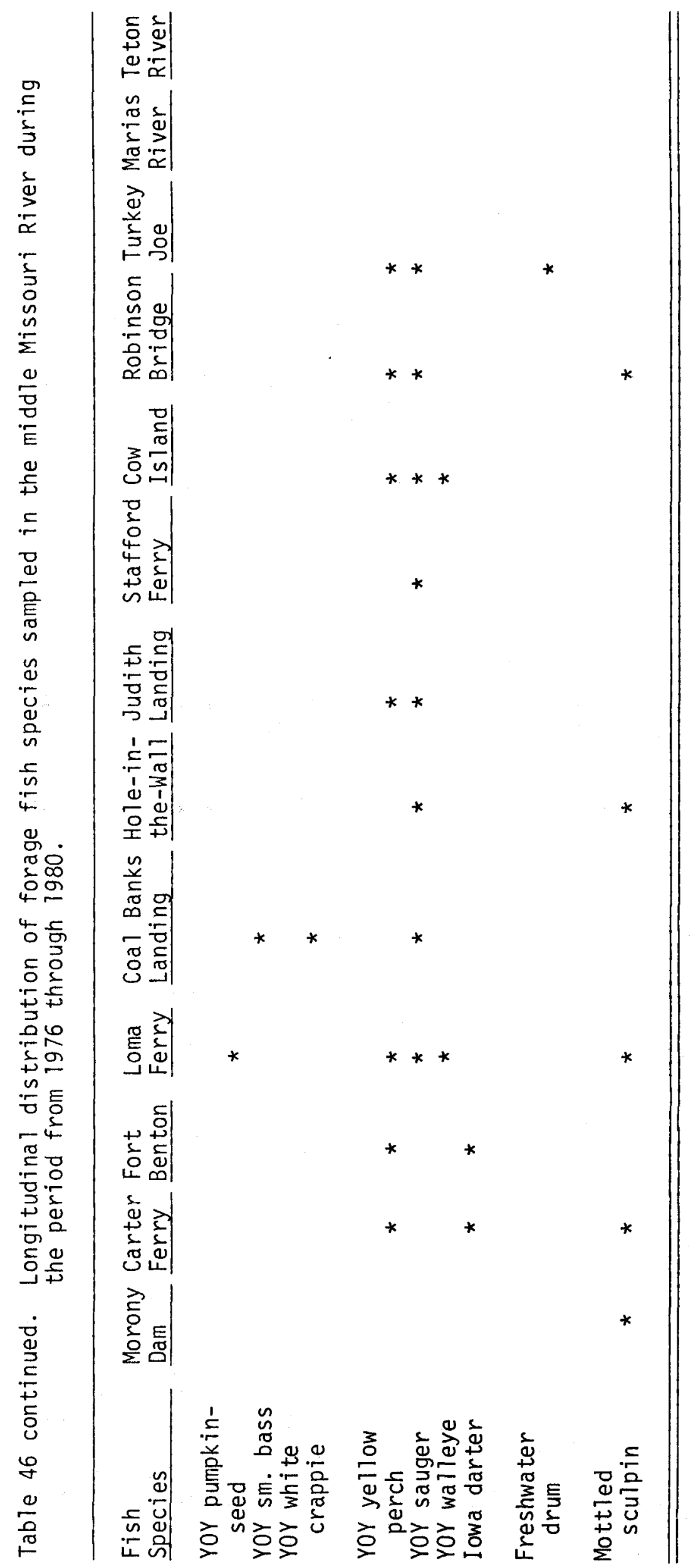


1976). Although the creel census was not repeated in 1976 , general observations suggested that fishing pressure and harvest remained high. Study efforts were, therefore, resumed on the research project in 1977.

The creel census study section consists of a $37-\mathrm{km}$ reach of the Missouri River located immediately upstream from Fort Peck Reservoir. Harvest occurs by snagging, primarily in the spring as paddlefish migrate upstream from the reservoir. Typical snagging gear consists of a heavy surf-casting rod and reel, $13.6-36.3 \mathrm{~kg}(30-80 \mathrm{lb})$ test line, large treble hooks, and heavy weights. 0ccasionally, paddlefish are also caught in the summer and fall, but due to the low number taken in these seasons, only spring harvest was determined.

\section{Creel Period and Coverage}

Creel census efforts in 1977 began when the first paddlefish catch was reported on Apri1 15 and extended through June 12 when most of the fishing activity had ceased and harvest rates dropped to a negligible leve1. Twenty-five (42.4 percent) of 59 days during the creel period were censused. Fishing pressure and harvest were greatest on weekend days and holidays, and 15 (88.2 percent) of 17 of these days were included in the census. During the census in 1979, 1,004 anglers were interviewed. Completed trip data were obtained on 81.3 percent of the anglers.

\section{Fishing Pressure and Harvest}

In 1977, an estimated 1,625 anglers fished 2,526 man-days (8,299 hours) and snagged 900 paddlefish (Table 47). The anglers harvested $666(74.0$ percent) of the fish caught, and the remainder were released. The overall catch rate averaged $0.36 \mathrm{fish} / \mathrm{angler} / \mathrm{man}$-day $(0.11 \mathrm{fish} / \mathrm{angler} / \mathrm{hour}$ ) or $.55 \mathrm{fish} / \mathrm{angler} / \mathrm{trip}$. Harvest rate averaged $0.26 \mathrm{fish} / \mathrm{angler} / \mathrm{man}-\mathrm{day}(0.08$ fish/angler/hour) or $0.41 \mathrm{fish} / \mathrm{angler} / \mathrm{trip}$. The average length of a trip was 1.55 days in 1977, and the average angler spent 3.29 hours per day snagging.

The estimated total weight of the 1977 paddlefish catch in the Missouri River upstream from Fort Peck Reservoir was 21.17 metric tons $(46,676$ Ib), with 15.96 metric tons $(35,195$ 1b) of paddlefish harvested. By comparison the estimated harvest of paddlefish in the spring fishery on the Yellowstone River at Intake averaged 34.55 metric tons $(76,169$ 1bs) annually during a 4-year period from 1972 to 1975 (Elser 1976). Estimated harvest from a fishery in the tailwaters of Big Bend Dam on the Missouri River in South Dakota averaged 47.10 metric tons (103,837 lbs) annual1y in 1970, 1971, and 1973 (Friberg 1974). Paddlefish harvest in a fishery on the Missouri River below Gavins Point Dam in South Dakota totaled 33.69 metric tons $(74,273$ Ibs) in one snagging season (1972-73) during which a creel census was conducted. Prior to 1978, the largest sport fishery for paddlefish in the United States occurred in the Osage River above Lake-of-the-0zarks in Missouri. Harvest during the two-month snagging season averaged about 90.72 metric tons (200,000 1bs) annually (Pflieger 1975). However, the Osage River fishery was drastically reduced with the closing of Truman Dam on the Osage River in 1978.

Bank anglers accounted for 56.6 percent (1,429 man-days) of the estimated fishing pressure during 1977, but they took on $7 y 48.3$ percent of the paddlefish harvested for an average harvest rate of 0.23 paddlefish/ angler/man-day (Table 47). Boat anglers accounted for 43.4 percent 


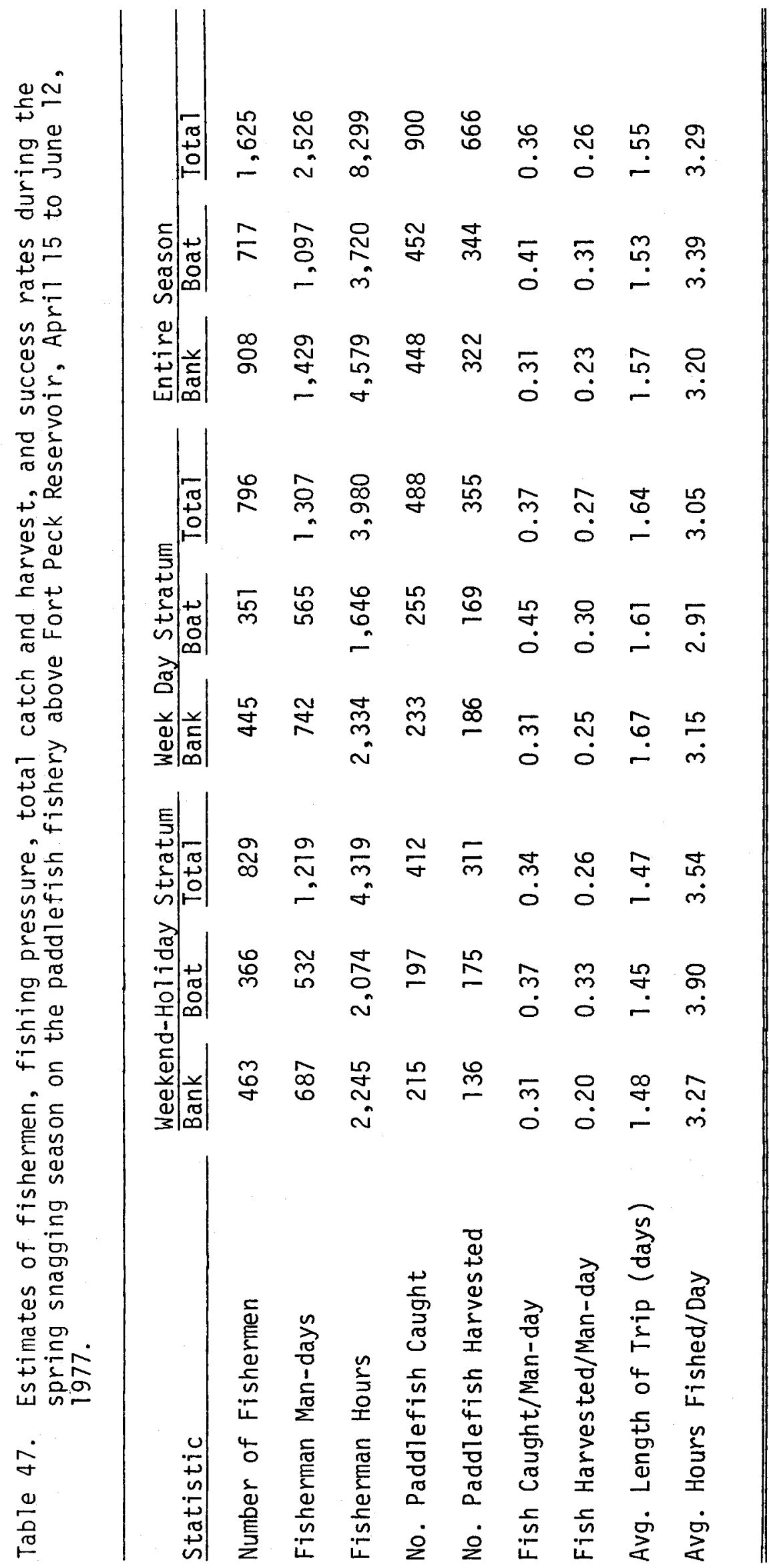


(1,097 man-days) of the pressure and 51.7 percent of the harvest for an average harvest rate of 0.31 paddlefish/angler/man-day.

Weekend/holiday anglers accounted for 48.3 percent $(1,219$ man-days) of the estimated fishing pressure during 1977, but they took only 46.7 percent of the paddlefish harvested for an average harvest rate of 0.26 paddlefish/angler/man-day (Table 47). Weekday anglers accounted for 51.7 percent $(1,307$ man-days) of the pressure and 53.3 percent of the harvest for an average harvest rate of 0.27 paddlefish/angler/man-day.

Estimates of fishing pressure and paddlefish harvest for the 1977 snagging season are compared with 1973, 1974, and 1975 season estimates in Table 48. Fishing pressure and paddlefish harvest were higher in 1977 than during any of the previous creel census periods. Low water levels in the Missouri River during the snaggging season in 1977 may have been partly responsible for the increased angler pressure and harvest. A number of anglers interviewed felt that the low water conditions facilitated snagging of paddlefish. However, the overall angler success rate in 1977, in terms of paddlefish harvested/angler/man-day, was similar to previous years.

\section{Angler Residency}

Angler residence was obtained for 761 fishermen interviewed during the creel census period in 1977. Montana residents accounted for 97.2 percent of the anglers (Table 49). Paddlefish snaggers represented 61 Montana cities and towns with the dominant ones being Billings, Lewistown, and Great Falls. The same three cities dominated during previous creel censuses conducted in the study area (Needham 1973, 1975, and 1976).

\section{Size and Sex Composition of Harvested Paddlefish}

Length, weight, and sex data were obtained from 231 paddlefish harvested during the 1977 snagging season. The paddlefish examined were selected at random throughout the entire creel census period. Average length and weight of paddlefish harvested (males and females combined) was $154.9 \mathrm{~cm}$ (61.0 in.) and $25.2 \mathrm{~kg}(55.6 \mathrm{lb})$ (Table 50). Females averaged $168.9 \mathrm{~cm}$ (66.5 in.) and $35.5 \mathrm{~kg}$ (78.3 1b), while males averaged $145.0 \mathrm{~cm}(57.1 \mathrm{in}$.$) and 17.9 \mathrm{~kg}(39.4 \mathrm{lb})$. The average size of male and female paddlefish harvested in 1977 was similar to the average size of fish harvested in seven previous years (Table 51).

Although the average female paddlefish harvested in 1977 outweighed the average male by a substantial margin, considerable overlap in weight/frequency of the two sexes was observed (Figure 27). Of the 231 paddlefish measured during the spring snagging season in 1977, 43.7 percent occurred in weight intervals which contained both male and female fish. The largest male paddlefish examined in the 1977 harvest weighed $38.1 \mathrm{~kg}(84 \mathrm{lb})$, while the smallest female weighed $22.2 \mathrm{~kg}$ (49 1b). Sex of these two fish was confirmed by autopsy and examination of gonads. Friberg (1974) also observed considerable overlap in weights of male and female paddlefish harvested in the tailwaters of Big Bend Dam on the Missouri River, South Dakota. The largest male in the Big Bend harvest weighed $29.5 \mathrm{~kg}(65 \mathrm{lb})$, while the smallest female weighed $15.9 \mathrm{~kg}$ (35 1b). Conversely, Elser (1976) and Rehwinkel (1975) observed no overlap in weight/frequency of male and female paddlefish harvested on the Yellowstone River at Intake, Montana. 


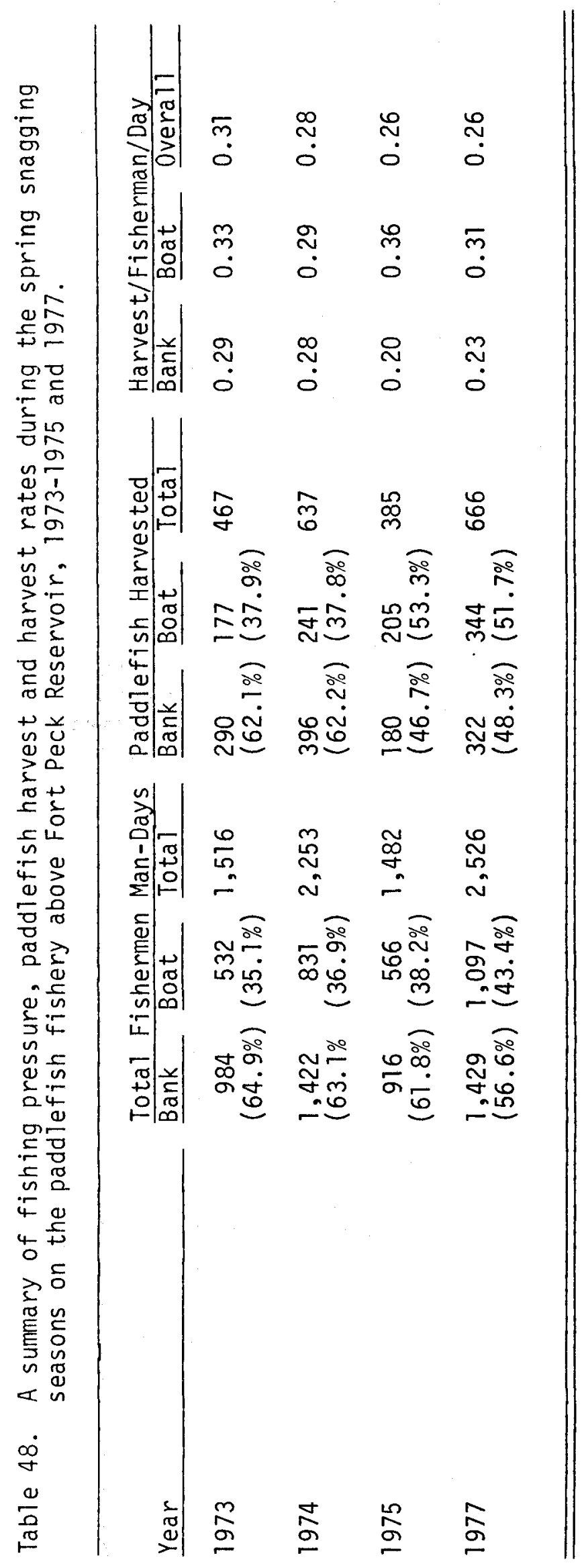


Table 49. Angler residence for 761 fishermen interviewed during the paddlefish creel census period in 1977.

\begin{tabular}{|c|c|c|c|}
\hline $\begin{array}{l}\text { Montana } \\
\text { Res idents }\end{array}$ & $\begin{array}{l}\text { Number of } \\
\text { Fishermen }\end{array}$ & $\begin{array}{l}\text { Montana } \\
\text { Residents }\end{array}$ & $\begin{array}{l}\text { Number of } \\
\text { Fishermen }\end{array}$ \\
\hline Billings & 122 & Helena & 14 \\
\hline Lewis town & 88 & Kalispell & 13 \\
\hline Great Falls & 85 & Winifred & 13 \\
\hline Missoula & 35 & Stanford & 12 \\
\hline Bozeman & 25 & 0ther Cities & 127 \\
\hline Butte & 25 & & \\
\hline Jordan & 25 & Resident Total & 740 \\
\hline Laurel & 23 & & \\
\hline Malta & 22 & Nonresidents & \\
\hline Park City & 22 & Wyoming & 12 \\
\hline Grass Range & 21 & Idaho & 6 \\
\hline Harlem & 20 & Washington & 2 \\
\hline Roy & 19 & California & 1 \\
\hline Havre & 15 & & \\
\hline Deer Lodge & 14 & Nonresident Tota 1 & 21 \\
\hline
\end{tabular}

1/ Cities in this category were each represented by 10 or less fishermen.

Table 50. Size of paddlefish harvested in the Missouri River above Fort Peck Reservoir during the spring of 1977.

\begin{tabular}{|c|c|c|c|c|c|}
\hline & $\begin{array}{l}\text { Number } \\
\text { of Fish }\end{array}$ & $\begin{array}{l}\text { Average } \\
\text { Length } 1 / \\
(\mathrm{cm})\end{array}$ & $\begin{array}{l}\text { Length } \\
\text { Range } \\
(\mathrm{cm}) \\
\end{array}$ & $\begin{array}{l}\text { Average } \\
\text { Weight } \\
(\mathrm{kg})\end{array}$ & $\begin{array}{l}\text { Weight } \\
\text { Range } \\
\text { (kg) }\end{array}$ \\
\hline Female & 96 & 168.9 & $144.8-186.7$ & 35.5 & $22.2-50.3$ \\
\hline Male & 135 & 145.0 & $118.1-174.0$ & 17.9 & $4.5-38.1$ \\
\hline Combined & 231 & 154.9 & $118.1-186.7$ & 25.2 & $4.5-50.3$ \\
\hline
\end{tabular}

If Length measurement is total length 
Table 51. A summary of size data from paddlefish harvested in the Missouri River above Fort Peck Reservoir during eight spring snagging seasons, 1965 to 1977.

\begin{tabular}{|c|c|c|c|c|c|c|}
\hline \multirow[b]{2}{*}{ Year } & \multicolumn{3}{|c|}{ Females } & \multicolumn{3}{|c|}{ Males } \\
\hline & $\begin{array}{l}\text { Number } \\
\text { of Fish }\end{array}$ & $\begin{array}{l}\text { Average } \\
\text { Length!/ } \\
\text { (cm) }\end{array}$ & $\begin{array}{l}\text { Average } \\
\text { Weight } \\
\text { (kg) }\end{array}$ & $\begin{array}{l}\text { Number } \\
\text { of Fish }\end{array}$ & $\begin{array}{l}\text { Average } \\
\text { Length } \\
\text { (cm) }\end{array}$ & $\begin{array}{l}\text { Average } \\
\text { Weight } \\
\text { (kg) }\end{array}$ \\
\hline $\begin{array}{l}1965 \\
1966 \\
1970 \\
1971 \\
1973 \\
1974 \\
1975 \\
1977\end{array}$ & $\begin{array}{r}13 \\
36 \\
7 \\
10 \\
46 \\
58 \\
63 \\
96\end{array}$ & $\begin{array}{l}170.2 \\
162.6 \\
178.3 \\
169.4 \\
168.1 \\
165.9 \\
166.9 \\
168.9\end{array}$ & $\begin{array}{l}37.0 \\
33.7 \\
34.9 \\
38.9 \\
34.5 \\
33.8 \\
33.9 \\
35.5\end{array}$ & $\begin{array}{r}21 \\
30 \\
2 \\
1 \\
50 \\
67 \\
56 \\
135\end{array}$ & $\begin{array}{l}140.7 \\
135.4 \\
148.6 \\
144.8 \\
139.4 \\
139.7 \\
142.0 \\
144.5\end{array}$ & $\begin{array}{l}16.5 \\
14.6 \\
20.0 \\
20.0 \\
15.9 \\
14.9 \\
15.7 \\
17.8\end{array}$ \\
\hline
\end{tabular}

1/ Length measurement is total length.

Table 52. A summary of paddlefish tagging and fisherman tag returns in the Missouri River above Fort Peck Reservoir, 1973 to 1977.

\begin{tabular}{|c|c|c|c|c|c|c|c|c|}
\hline $\begin{array}{l}\text { Year } \\
\text { Tagged }\end{array}$ & $\begin{array}{l}\text { Number of } \\
\text { Fish Tagged }\end{array}$ & 1973 & $\begin{array}{r}\text { Nur } \\
1974 \\
\end{array}$ & $\frac{e r \text { of }}{1975}$ & $\frac{\text { ish Ha }}{1976}$ & $\frac{\text { lested }}{1977}$ & Total & $\begin{array}{l}\text { Percent } \\
\text { Harvested }\end{array}$ \\
\hline $\begin{array}{l}1973 \\
1974 \\
1975 \\
1976 \\
1977\end{array}$ & $\begin{array}{l}45 \\
55 \\
29 \\
23 \\
61\end{array}$ & $\begin{array}{l}0 \\
- \\
- \\
- \\
-\end{array}$ & $\begin{array}{l}1 \\
3 \\
- \\
- \\
-\end{array}$ & $\begin{array}{l}1 \\
0 \\
0 \\
- \\
-\end{array}$ & $\begin{array}{l}0 \\
1 \\
0 \\
1 \\
-\end{array}$ & $\begin{array}{l}1 \\
1 \\
1 \\
1 \\
4\end{array}$ & $\begin{array}{l}3 \\
5 \\
1 \\
2 \\
4\end{array}$ & $\begin{array}{l}6.7 \\
9.1 \\
3.4 \\
8.7 \\
6.6\end{array}$ \\
\hline Total & 213 & & & & & & 15 & 7.0 \\
\hline
\end{tabular}




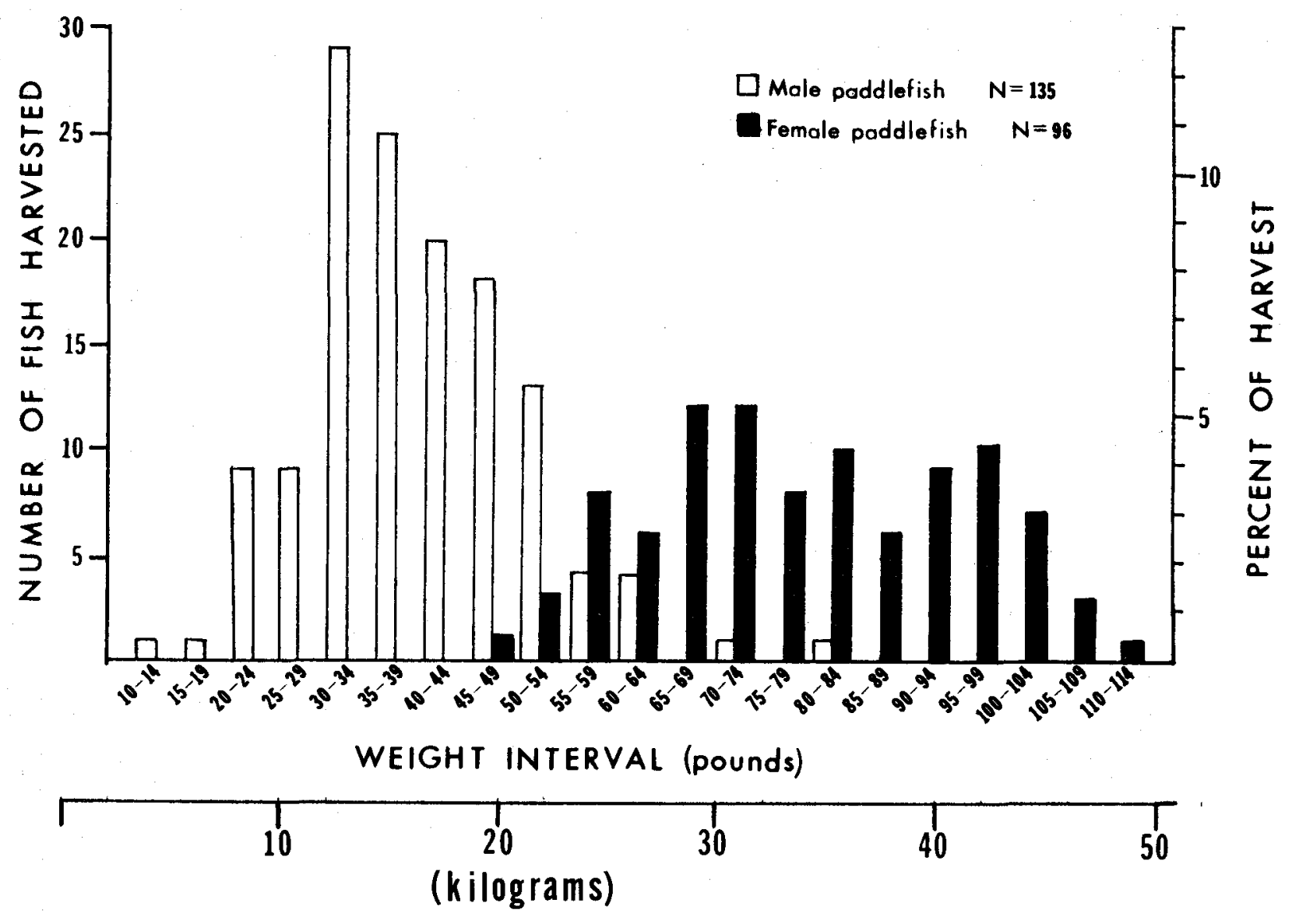

Figure 27. Weight-frequency and sex composition of 231 paddlefish harvested in the Missouri River above Fort Peck Reservoir during the spring of 1977. 
Females accounted for 41.6 percent of the paddlefish examined in the 1977 harvest, while males comprised 58.4 percent. Since anglers often select for larger fish which are predominantly females, the observed sex ratio in the harvest may not be the sex ratio of the population.

\section{Age Structure of Harvested Paddlefish}

Dentary bones were collected from 142 paddlefish harvested during the 1977 snagging season to determine age structure of fish in the harvest. The dentary bones were collected at random throughout the entire creel census period, and the data, therefore, should be representative of the harvest. However, since anglers often select for larger fish which are usually older in age, the observed age structure of paddlefish in the harvest may not be representative of the age structure of the population.

Paddlefish ages were determined by cross-sectioning the dentary bones and "reading" the annuli in the mesial arm. Findings are presented in the age and growth section of this report.

\section{Paddlefish Tagging}

Sixty-one paddlefish were tagged during the spring migration season in 1977 with individually numbered, monel, poultry band tags anchored around the dentary bones to obtain information on angler harvest and movement. Paddlefish tagging assistance was provided by Mike Poore, Fisheries Division, Montana Department of Fish and Game, through Dingel1Johnson Project No. F-5-R-26, Job I-b. Of the fish collected for tagging, 13 were sampled by electrofishing, 44 were taken by snagging, and 4 were captured with large mesh gill nets drifted perpendicular to the current. All of the fish were captured in the Missouri River immediately upstream from Fort Peck Reservoir within the boundaries of the creel census study section. This brings the total number of paddlefish tagged and released since 1973 to 273 . To date, $15(7.0 \%)$ of the tags have been returned by anglers (Table 52). A11 of the recaptured fish were harvested in the creel census study section in the same area where they were tagged.

\section{Discussion}

Data collected in research studies conducted since 1965 suggest that the Missouri River/Fort Peck Reservoir paddlefish population is vigorous, and the current rate of exploitation by anglers does not appear excessive. The overall success rate of anglers in 1977, in terms of the number of paddlefish harvested/fisherman/man-day, was similar to previous years (Table 48). Also, the average size of male and female paddlefish harvested in 1977 was similar to previous years (Table 51). In addition, the total number of paddlefish harvested was higher in 1977 than during any of the previous years when creel censuses were conducted. If over-exploitation does occur in a paddlefish population, females would probably be affected first due to angler selection (Elser 7976).

With only 7.0 percent of the tagged fish returned by anglers, a low rate of harvest is indicated for the Missouri River/Fort Peck Reservoir paddlefish population. By comparison, 13.8 percent of 3,661 paddlefish tagged on the Yellowstone River at Intake since 1964 have been returned by anglers (Elser 1976). In data summarized by Carlander (1969), snagging by anglers brought tag return rates $9.8,12.6$, and 12.4 percent in several studies conducted in the tailwaters of Big Bend Dam on the Missouri River, 
South Dakota. A tag return rate of 24.5 percent in three years following tagging of paddlefish on the Osage River, Missouri, was considered an excessive rate of exploitation (Purkett 1963). Angler harvest rates on the Missouri River/Fort Peck Reservoir paddlefish population do not approach this excessive rate. However, additional tagging of paddlefish and exposure of marked fish to the fishery, and further evaluation of angler success rates and size and sex composition of harvested fish will be necessary to properly evaluate the effects of exploitation rates on the Missouri River/Fort Peck Reservoir paddlefish population.

Potential habitat losses resulting from activities such as dam building or large-scale water withdrawals probably represent a greater threat to the Missouri River/Fort Peck Reservoir paddlefish population than overexploitation by anglers. Every effort should be made to protect the middle Missouri River from this type of habitat alteration so the spawning migration can continue undiminished.

Missouri River Creel Survey

A creel survey was conducted from Apri1, 1977, through August, 1978, on the Missouri River from Morony Dam to Fort Peck Reservoir. The most important game fish species present include sauger, walleye, northern pike, shovelnose sturgeon, channel catfish, burbot, and paddlefish. Since a separate creel census was conducted on paddlefish, this species was not included in this survey.

Results of 312 angler interviews indicated the average length of a fishing trip was 2.13 days, and the average angler spent 2.52 hours per day fishing (Table 53). Sauger comprised the greatest portion of the catch from Morony Dam to the Marias River, shovelnose sturgeon predominated from the Marias River to Robinson Bridge, and channel catfish were the most common species caught from Robinson Bridge to Fort Peck Reservoir. Anglers kept most game fish and released or discarded most nongame fish.

About 90 percent of the anglers interviewed were Montana residents. Only 1 percent of the anglers interviewed in the spring (mid-March to mid-June) were nonresidents compared to 19 percent in the summer (midJune to mid-September). The nonresident anglers came from distant states, including New Jersey, Florida, Texas, Indiana, New Mexico, California, Missouri, and Minnesota, and from nearby states, including North Dakota, South Dakota, Wyoming, Idaho, Washington, Oregon, and the Canadian provinces of ATberta and Saskatchewan.

\section{Angler Harvest as Indicated by Tag Returns}

An indication of angler harvest of fish in the middle Missouri River was provided by angler-returned fish tags. Harvest estimates ranged from 0 percent for several species to 7.5 percent for northern pike and walleye (Table 54). Even though some anglers do not report tagged fish taken in their creel, the data indicate relatively light harvest rates for all species.

Only 0.5 percent of the shovelnose sturgeon tagged in the middle Missouri River were returned by anglers. On the lower Tongue River, Montana, anglers returned 1.1 percent of the shovelnose sturgeon tagged from 1974 through 1976 (Elser et al. 1977). Christenson (1975) reported 2.3 percent of shovelnose sturgeon tagged in the Red Cedar/Chippewa River 
Table 53. A summary of creel survey data collected in three subreaches of the middle Missouri River during the spring and summer of 1977 and 1978.

\begin{tabular}{|c|c|c|c|c|c|c|}
\hline \multirow{3}{*}{$\begin{array}{l}\text { Creel } \\
\text { Survey } \\
\text { Statistic }\end{array}$} & \multicolumn{6}{|c|}{ Subreach of Missouri River } \\
\hline & $\begin{array}{l}\text { Morony } \\
\text { Marias } \\
\end{array}$ & $\begin{array}{l}\text { Dam - } \\
\text { River }\end{array}$ & $\begin{array}{l}\text { Marias } \\
\text { Robinse }\end{array}$ & $\begin{array}{l}\text { R. - } \\
\text { on Br. }\end{array}$ & $\begin{array}{l}\text { Robinso } \\
\text { Ft. Pec }\end{array}$ & $\begin{array}{l}\text { on Br. - } \\
\text { ck Res. }\end{array}$ \\
\hline & Spring & Summer & Spring & Summer & Spring & Summer \\
\hline $\begin{array}{l}\text { No. of Fisherman Interviewed } \\
\text { Avg. Length of Trip (days) } \\
\text { Avg. Hrs. Fished/Day }\end{array}$ & $\begin{array}{r}33 \\
1.61 \\
1.83\end{array}$ & $\begin{array}{r}40 \\
3.06 \\
1.66\end{array}$ & $\begin{array}{r}10 \\
1.70 \\
1.72\end{array}$ & $\begin{array}{l}134 \\
2.41 \\
2.81\end{array}$ & $\begin{array}{r}69 \\
1.54 \\
4.03\end{array}$ & $\begin{array}{r}26 \\
2.46 \\
3.04\end{array}$ \\
\hline $\begin{array}{l}\text { Fish Caught/Man-hour I/ } \\
\text { Sauger } \\
\text { Wal leye } \\
\text { Shovelnose sturgeon } \\
\text { Channel catfish } \\
\text { Northern pike } \\
\text { Burbot } \\
\text { Other species }\end{array}$ & $\begin{array}{l}0.46 \\
0.01 \\
0.04 \\
0.04 \\
0.00 \\
0.01 \\
1.44\end{array}$ & $\begin{array}{l}0.35 \\
0.00 \\
0.01 \\
0.01 \\
0.03 \\
0.02 \\
0.59\end{array}$ & $\begin{array}{l}0.19 \\
0.00 \\
0.26 \\
0.19 \\
0.00 \\
0.04 \\
1.37\end{array}$ & $\begin{array}{l}0.10 \\
0.01 \\
0.12 \\
0.13 \\
0.00 \\
0.01 \\
0.43\end{array}$ & $\begin{array}{l}0.14 \\
0.00 \\
0.03 \\
0.07 \\
0.01 \\
0.01 \\
0.07\end{array}$ & $\begin{array}{l}0.00 \\
0.00 \\
0.00 \\
0.11 \\
0.02 \\
0.01 \\
0.26\end{array}$ \\
\hline $\begin{array}{l}\text { Fish Harvested/Man-hour-2/ } \\
\text { Sauger } \\
\text { Walleye } \\
\text { Shovelnose sturgeon } \\
\text { Channel catfish } \\
\text { Northern pike } \\
\text { Burbot } \\
\text { Other species }\end{array}$ & $\begin{array}{l}0.46 \\
0.01 \\
0.04 \\
0.03 \\
0.00 \\
0.01 \\
0.04\end{array}$ & $\begin{array}{l}0.32 \\
0.00 \\
0.01 \\
0.01 \\
0.03 \\
0.02 \\
0.11\end{array}$ & $\begin{array}{l}0.19 \\
0.00 \\
0.26 \\
0.19 \\
0.00 \\
0.04 \\
0.00\end{array}$ & $\begin{array}{l}0.09 \\
0.01 \\
0.12 \\
0.12 \\
0.00 \\
0.01 \\
0.12\end{array}$ & $\begin{array}{l}0.14 \\
0.00 \\
0.03 \\
0.07 \\
0.00 \\
0.01 \\
0.03\end{array}$ & $\begin{array}{l}0.00 \\
0.00 \\
0.00 \\
0.09 \\
0.02 \\
0.01 \\
0.04\end{array}$ \\
\hline $\begin{array}{l}\text { Percent of Fishermen who } \\
\text { were Montana Residents }\end{array}$ & 100 & 82 & 100 & 96 & 97 & 65 \\
\hline $\begin{array}{l}\text { 1/ Includes fish kept and fis } \\
\frac{2}{2} \text { Includes on } 1 y \text { fish kept. }\end{array}$ & h rele & sed. & & & & \\
\hline
\end{tabular}


Table 54. Summary of tagged fish returned (i.e., harvested) by anglers in the middle Missouri River from October 1, 1975 through October 1, 1980.

\begin{tabular}{|c|c|c|c|}
\hline Species & $\begin{array}{l}\text { No. of } \\
\text { Fish } \\
\text { Tagged } \\
\end{array}$ & $\begin{array}{l}\text { No. of Tags } \\
\text { Returned by } \\
\text { Anglers }\end{array}$ & $\begin{array}{l}\text { Percent of } \\
\text { Tags } \\
\text { Returned }\end{array}$ \\
\hline Pallid sturgeon & 1 & 0 & 0 \\
\hline Shovelnose sturgeon & 814 & 4 & 0.5 \\
\hline Mountain whitefish & 131 & 0 & 0 \\
\hline Rainbow trout & 18 & 0 & 0 \\
\hline Brown trout & 28 & 1 & 3.6 \\
\hline Brook trout & 2 & 0 & 0 \\
\hline Northern pike & 40 & 3 & 7.5 \\
\hline Blue sucker & 423 & 0 & 0 \\
\hline Smallmouth buffalo & 287 & $3 *$ & 1.0 \\
\hline Bigmouth buffalo & 97 & $1 *$ & 1.0 \\
\hline Channel catfish & 1926 & 65 & 3.4 \\
\hline Burbot & 169 & 1 & 0.6 \\
\hline White crappie & 21 & 0 & 0 \\
\hline Yellow perch & 2 & 0 & 0 \\
\hline Sauger & 3950 & 58 & 1.5 \\
\hline Walleye & 40 & 3 & 7.5 \\
\hline Freshwater drum & 216 & 1 & 0.5 \\
\hline
\end{tabular}

* Harvested by commercial fishermen in Fort Peck Reservoir. 
system in Wisconsin were returned by anglers.

The current rate of exploitation of shovelnose sturgeon is not excessive. The shovelnose, like the lake sturgeon, is a slow-growing, late-maturing fish which cannot tolerate high levels of exploitation. Priegel (1973) believed lake sturgeon in the Menominee River, Wisconsin, could sustain a harvest rate of 5.0 percent without harm. The harvest rate for shovelnose sturgeon in the middle Missouri River is well below this level.

Anglers returned 1.5 percent of the sauger tagged in the middle Missouri River. Elser et al. (1977) reported 3.4 percent of the sauger tagged in the lower Tongue River, Montana, in 1976 were returned by anglers. On the lower Yellowstone River, Montana, a minimum harvest of 5 percent, based on angler tag returns, was reported for both walleye and sauger tagged from 1973 through 1977 (Graham et al. 1979).

Anglers returned 3.4 percent of the channel catfish tagged in the middle Missouri River. On the lower Tongue River, Montana, anglers returned 3.6 percent of the channel catfish tagged in 1975 and 1976 (Elser et a1. 1977).

Fishing Seasons and Creel Limits

The fishing season in the middle Missouri River drainage is open from the third Saturday in May through November, with the exception of the Missouri River, Marias River, Judith River below its confluence with Big Spring Creek, Teton River below US Highway 89, Belt Creek below the bridge at Riceville, Big Spring Creek near Lewistown, and Musselshell River below the bridge at Barber which are open the entire year. Most lakes and reservoirs in the drainage are also open year round.

The daily and possession limits for fish in the study area are:

(1) Brown trout, cutthroat trout, rainbow trout, golden trout, lake trout and grayling - 10 pounds and 1 fish or 10 fish, whichever is reached first, in any combination.

(2) Brook trout - 10 pounds, no number limit.

(3) Bass, sauger, walleye - 10 in any combination.

(4) Northern pike - 5 .

(5) Salmon - 10 with some restrictions listed in the regulations.

(6) Whitefish - 30 daily and 60 in possession.

(7) Paddlefish -1 daily and 2 in possession.

There is no numeral limit on catfish, burbot, sturgeon, and nongame fish. However, the maximum weight of a sturgeon (genus Sccphirhynchus) which may be taken is 7.3 kilograms (16 pounds). This regulation was adopted statewide in Montana on May 1, 1980, to protect pallid sturgeon which are rare in the state. All sturgeon larger than 16 pounds are 
assumed to be pallid sturgeon because shovelnose do not grow this large. The pallid sturgeon was designated as a threatened species in the United States in 1979 by the Endangered Species Committee of the American Fisheries Society (Holton 1980). This means the committee believes it "is likely to become an endangered species within the foreseeable future throughout all or a significant portion of its range."

There is no evidence that the fishing regulations outlined above have been detrimental to fish populations anywhere in the study area. In fact, fish populations in the area are lightly utilized, and fishing pressure for most species could probably be increased substantially without harming the populations. Paddlefish are probably an exception, and it is not recommended that harvest be increased substantially above current levels. Statewide limits on paddlefish, formerly two fish per day and in possession, were reduced in 1978 to one fish per day and two in possession to prevent overharvest. The DFWP will continue to monitor paddlefish and will be prepared to further reduce harvest if the future of paddlefish in Montana seems jeopardized (Holton 1980).

\section{POTENTIAL AND EXISTING ENVIRONMENTAL PROBLEMS}

The middle Missouri River and its tributaries support a fishery with substantial recreational value. A major threat to the resource is improper land and water use management. Water quality degradation and stream dewatering have had a detrimental impact on aquatic resources in some portions of the study area. In addition, increased exploitation of fossil fuel and nonfuel mineral resources in the drainage, threatened impoundment of the Missouri River near Fort Benton, and other possible water resource development projects could lead to future environmental problems.

Water Quality Degradation

Water quality in the middle Missouri River and its tributaries is considered generally good (US Congress 1975a). However, there are a few water quality problems in the drainage. A summary of the problems, as determined by the Water Quality Bureau of the Montana Department of Health and Environmental Sciences (DHES), is presented in Table 55.

Sediment is a water quality problem in several tributaries of the middle Missouri River (Kaiser and Botz 1975, Garvin and Botz 1975). The sediment originates largely from nonpoint sources in the Marias River, Judith River, and Arrow Creek drainages. Logging, agricultural, and urbanization practices, as well as natural sources, contribute to the problem.

Logging and urbanization activities in the headwaters of the Judith River and Big Spring Creek drainages near Lewistown have increased the stream sediment load to some extent in almost all portions of the middle Missouri River drainage. Agricultural sediment results mainly from irrigation return flows and erosion related to overgrazing, extensive monoculture, and clearing of vegetation from stream banks. Arrow Creek is the major natural source of sediment in the middle Missouri River basin (Kaiser and Botz 1975). 


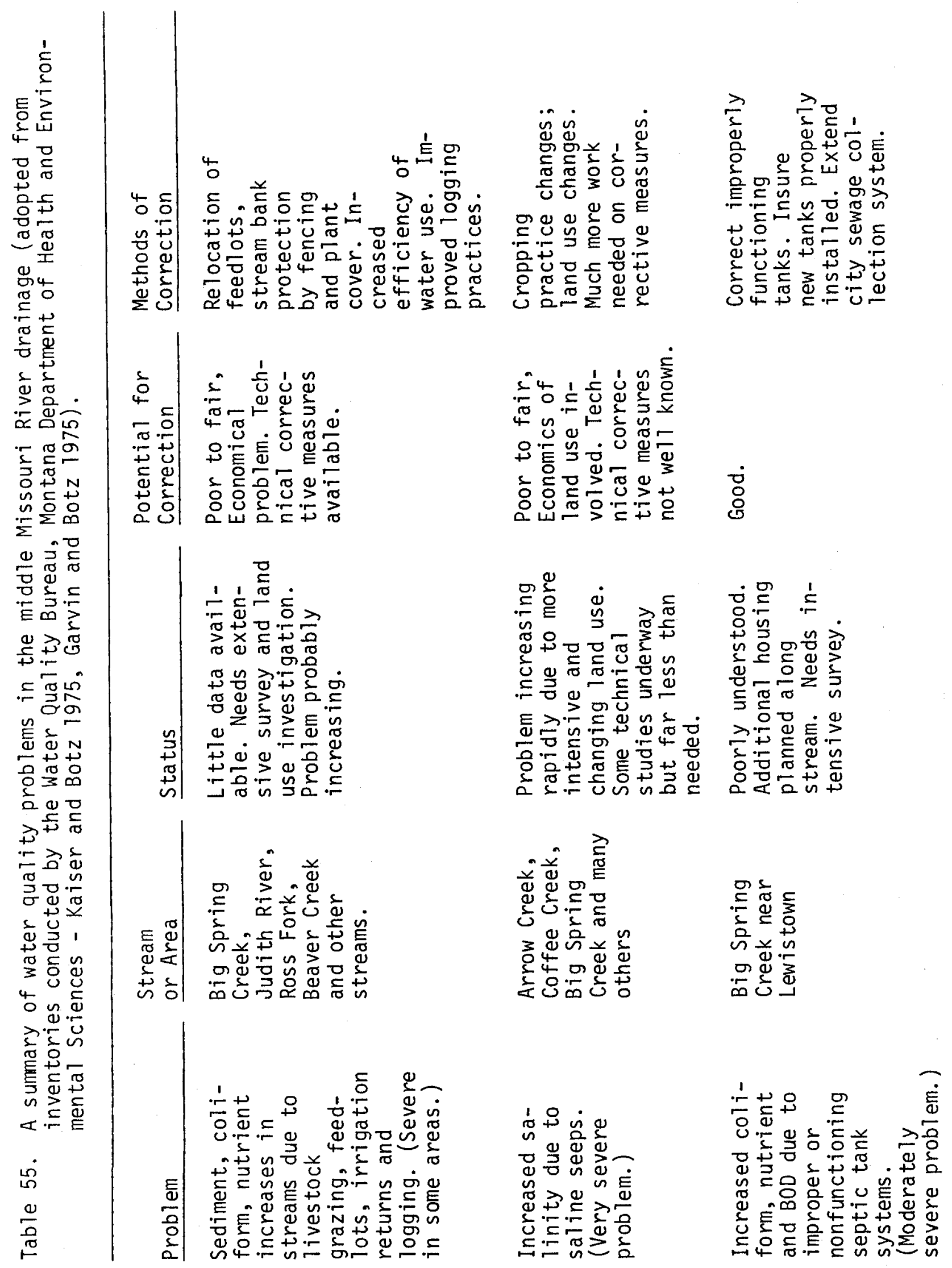




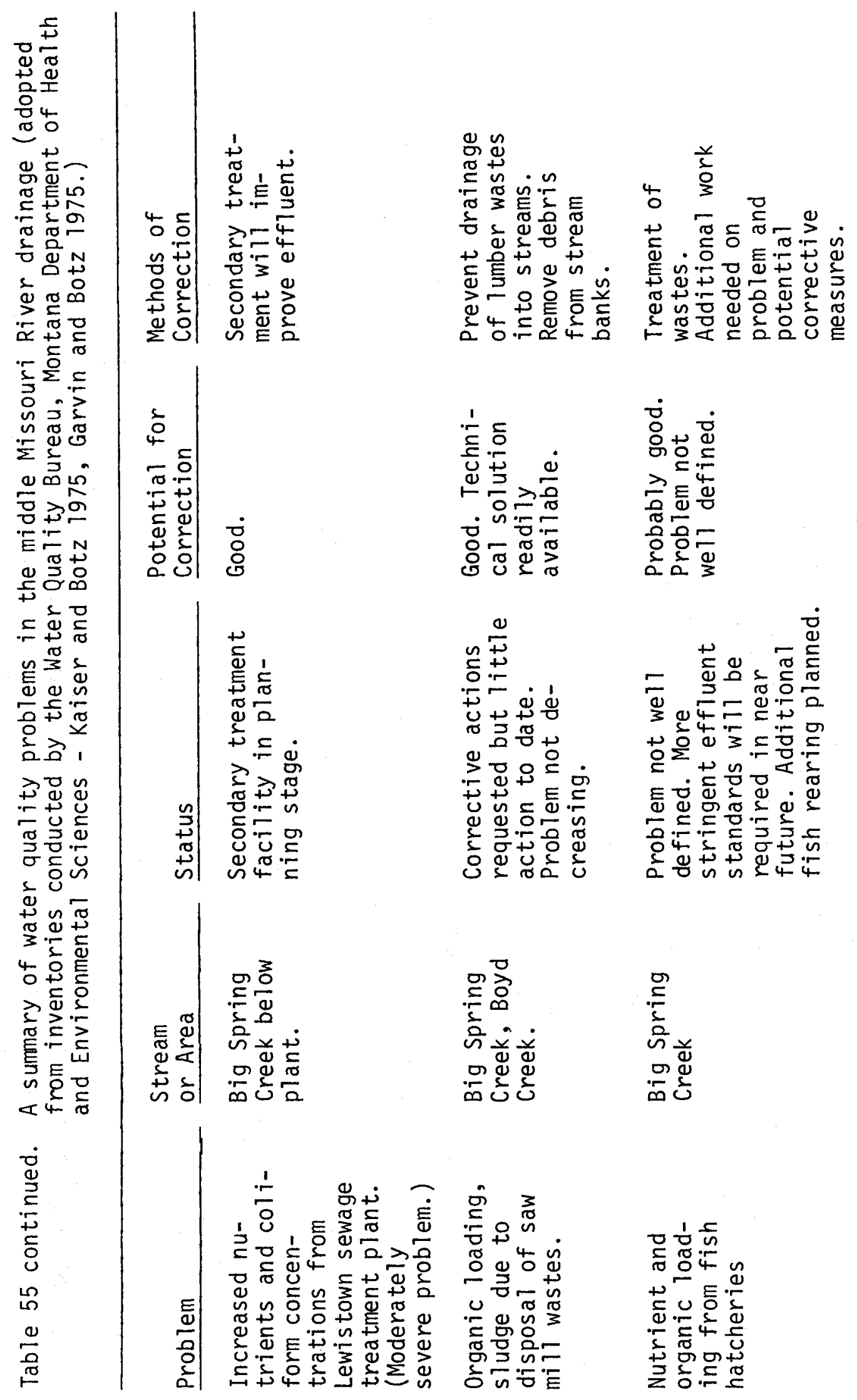




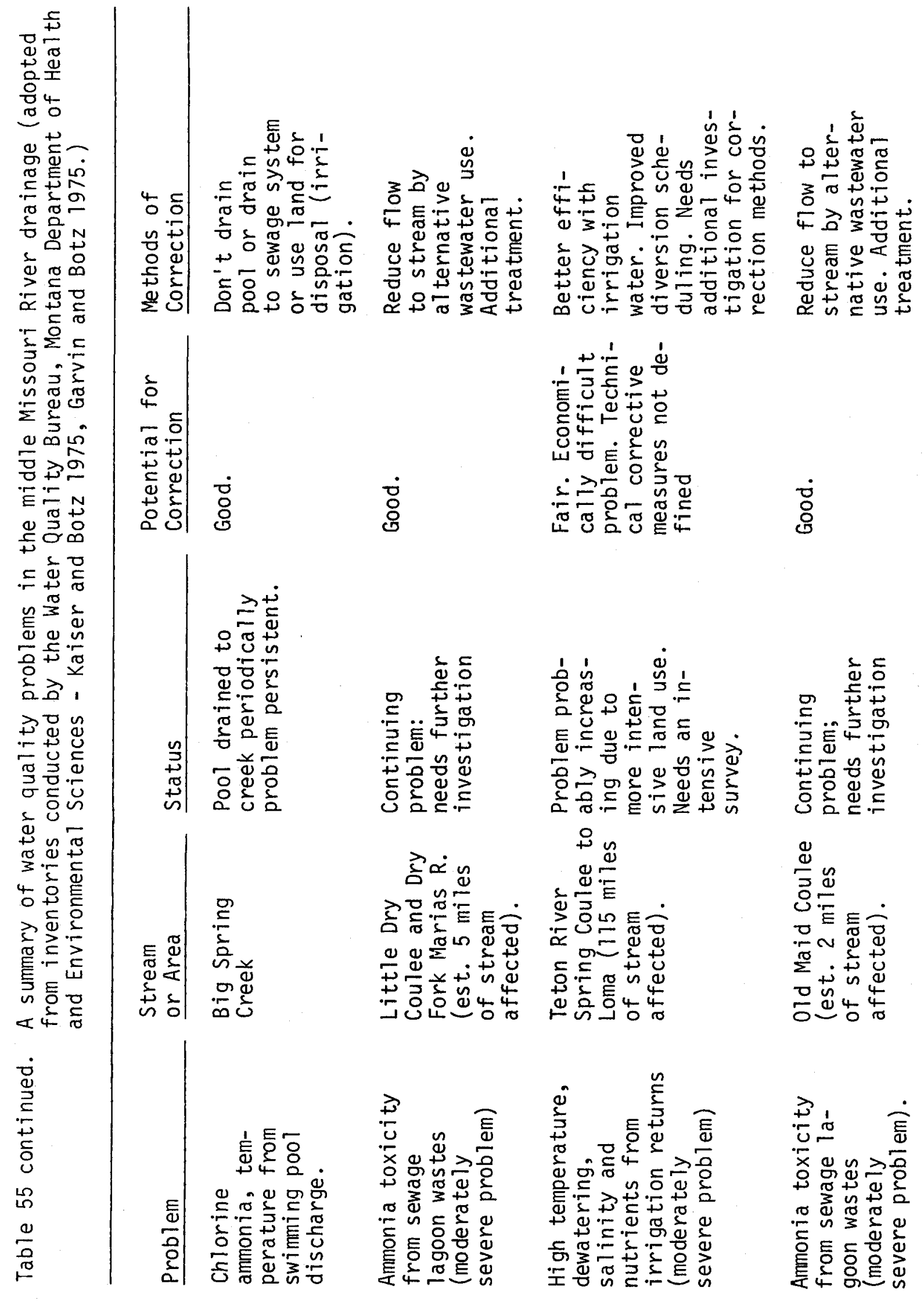




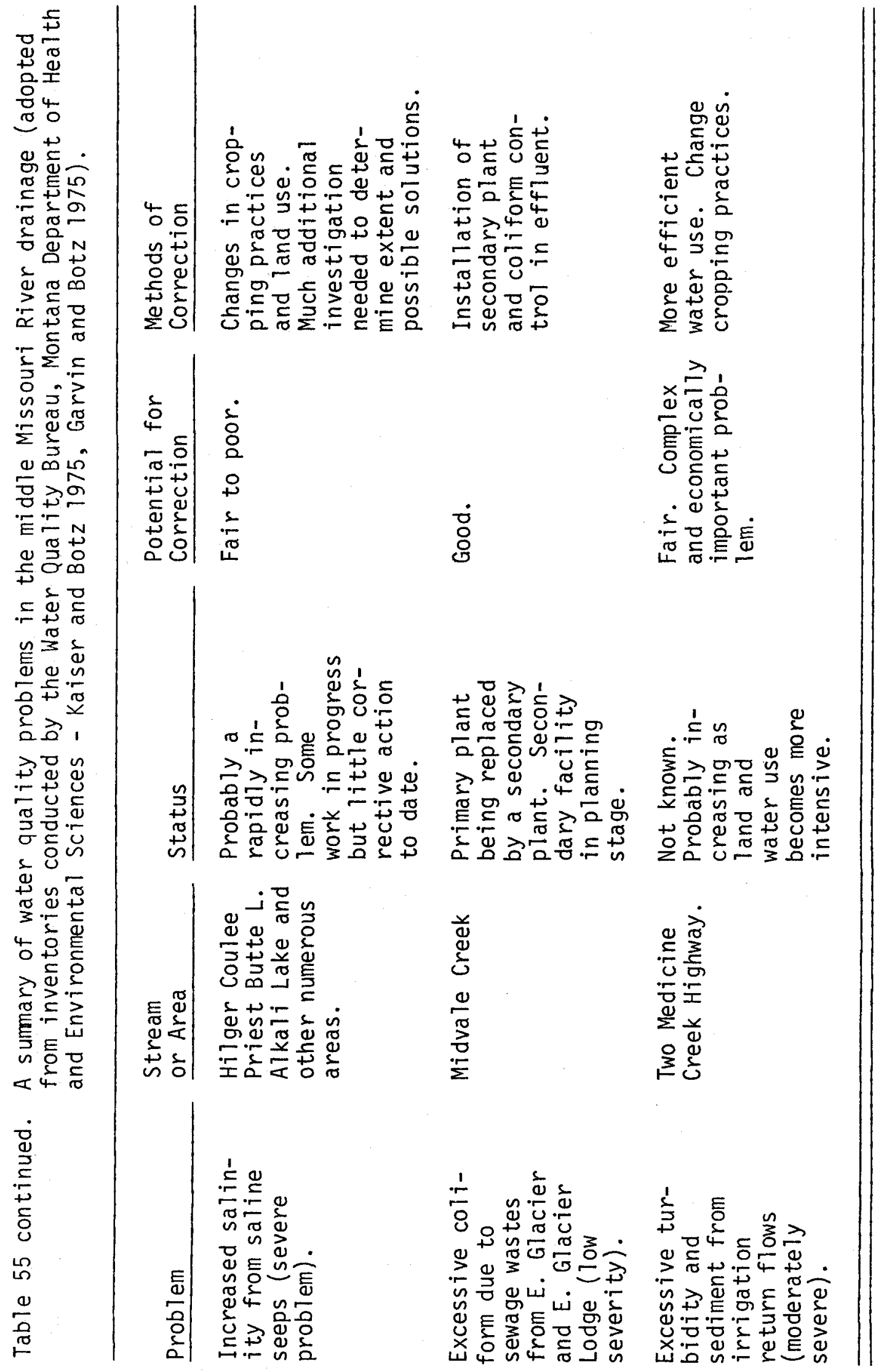


Suspended sediment in the Marias River is a concern in the upper portion of the drainage. The high sediment load in this area is probably due, in part, to natural instability of the streambeds and banks, but irrigation return flows add to the problem (Garvin and Botz 1975).

Nutrient enrichment of streams is a problem in some parts of the drainage. The nutrients enter the streams as a result of drainage from confined livestock yards, runoff from fertilized crop or pasture land, and substandard sewage treatment facilities. High concentrations of nutrients, particularly nitrates and phosphates, have caused serious eutrophication problems and depressed aquatic conditions in isolated portions of the Marias and Judith River drainages (Kaiser and Botz 1975, Garvin and Botz 1975).

Nutrient enrichment of the mainstem of the Missouri River from Great Falls to Coal Banks Landing was a problem prior to improvement of sewage treatment facilities at Great Falls and Fort Benton. A study conducted by the DHES on the Missouri River upstream from Fort Benton over a 3-day period in July, 1959, showed a coliform bacteria count in excess of 1,000/100 ml (US Congress 1975a). The high coliform count was attributed to inadequate municipal sewage treatment in the Great Falls area about $65 \mathrm{~km}$ upstream from Fort Benton. Similar tests near Coal Banks Landing, $70 \mathrm{~km}$ downstream from Fort Benton, still reflected the influence of sewage outfall from both Great Falls and Fort Benton. Both cities have substantially improved their sewage treatment plants since 1959, and a study conducted by the US Geological Survey in 1969 and 1970 revealed coliform bacterial counts within acceptable standards. Precautions should be taken to insure that any outfall released from sewage treatment facilities at Great Falls and Fort Benton remains within acceptable standards.

A great potential for water quality degradation and damage to aquatic life exists from saline seeps (Bahls and Miller 1973). Saline seep generally occurs throughout the middle Missouri River drainage, but it is unknown if any of the seep areas have been detrimental to aquatic life. Streams with saline seep problems in the study area include Bullwhacker, Dog, and Arrow creeks and portions of the Wolf Creek and Marias River drainages (Kaiser and Botz 1975, Garvin and Botz 1975).

0i1 field exploration and development is a major activity in the Marias River drainage. Contamination of surface waters with oil can occur due to leakage at the drilling site or pipeline breaks. 0 il contamination problems are presently confined to seeps from drill holes into some pothole lakes near Cutbank, Montana (Garvin and Botz 1975). Salt water, resulting from deep drilling operations, can also be an important pollutant. Continuous monitoring of oil development projects will be required to prevent increased water pollution.

In summary, water quality problems in the middle Missouri River drainage occur mainly in isolated portions of tributary streams. Water quality of the mainstem of the Missouri River has not been significantly impaired by these problems, and water quality in the drainage as a whole is good. However, efforts should be made to remedy the problems which exist, so that future problems can be avoided. 
Water Use and Stream Dewatering

The largest user of water in the middle Missouri basin is agricultural irrigation, requiring an annual diversion of slightly more than $1.233 \mathrm{~km}^{3} /$ year [one million acre-ft/year (MAFY)]. Net depletion, including crop requirements, delivery loss, and evaporation, amount to about $0.6 \mathrm{~km} /$ year $(0.5 \mathrm{MAFY})$. Slightly more than $0.6 \mathrm{~km} /$ year, or 53 percent of the tota 1 diversion, is eventually returned to the streams.

Municipal water use in the drainage amounts to less than $0.01 \mathrm{~km}^{3} /$ year (0.01 MAFY). Of this amount, about 30 percent is derived from surface water sources, and the remainder comes from groundwater. 0ther uses of water in the drainage (i.e. industrial and stock water) are negligible (Kaiser and Botz 1975, Garvin and Botz 1975).

During late summer and early fall, irrigation withdrawals leave portions of some tributaries dewatered. A comprehensive evaluation of dewatering on major streams was not made during this study; however, severe dewatering was observed in the lower Teton River, and moderately severe dewatering was observed in portions of the lower Judith River.

There are several possibilities for additional water depletion in the middle Missouri River basin. One recent study revealed the possibility of providing irrigation water for lands in the Milk River Valley by means of a $30 \mathrm{~km}$ (100 ft.) pump lift from the Missouri River near Virgelle, Montana. Water withdrawn from the Missouri River would be diverted through the preglacial channel of the Missouri River north of Virgelle and into Fresno Reservoir. Another diversion plan under study to provide irrigation water in the Milk River Valley would pump water from Fort Peck Reservoir through the Beaver Creek drainage in conjunction with the Fort Hawley Waterfow1 proposal (US Congress 1975a).

The Missouri River between Morony Dam and Fort Benton contains several potential sites for hydropower dams. In addition, Montana Power Company has selected a site near Great Falls for a coal-fired generating plant.

The proposed hydropower dam, irrigation, and coal-fired generating plant projects have the potential to significantly alter the natural flow regime of the middle Missouri River. Consequently, detrimental effects on the aquatic ecosystem and existing recreational values may result. The extent of the impact depends on the magnitude and type of development. Impacts could be minimized by establishing a minimum instream flow regime sufficient to protect all existing uses. Instream flow levels required to maintain existing aquatic resources and recreational values of the Missouri River between Morony Dam and Fort Peck Reservoir have been determined (joint BLM/DFWP instream flow study, in press).

Exploitation of Fossil Fuel and Nonfuel Mineral Resources

Exploration and development of oil and natural gas fields in the middle Missouri River drainage has been increasing in recent years. The area lies within a geological province that is favorable for shallow (less than 2,000 ft.) natural gas accumulation. With in the last 6 years, four major natural gas fields have been designated south of the Bearpaw Mountains in the northcentral portion of the drainage. These are the 
Sherard, Bullwhacker, Leroy, and Sawtooth Mountain fields. There are many shut-in wells outside of the four major fields, and there is a high probability that more producible wells will be drilled in other portions of the study area. 0 il field development in the study area is currently confined mainly to the upper portion of the Marias River drainage. However, development of $0 i 1$ wells throughout the study area is possible.

Subbituminous coal deposits extend from the vicinity of Coal Banks Landing to the east boundary of the study area. Early in the century, small quantities of coal were mined and used domestically or sold commercially. Coal mining has been inactive in the study area for the past several decades, but the nation's energy problems could stimulate production (US Congress 1975a).

Bentonite beds 1 ie in three shale formations in the study area. The beds of bentonite are generally less than $50 \mathrm{~cm}$ (18 in.) thick and covered by 15 to $30 \mathrm{~m}$ ( 50 to $100 \mathrm{ft}$.) of overburden. Because of the thick overburden, commercial development is not economically feasible at this time. However, analysis of samples has revealed that some of the bentonite beds are satisfactory for brick, while other are suitable for lightweight aggregate and possibly for foundry sand (USDI 1978).

Metallic minerals are relatively scarce in the study area, but a few known reserves are found in mountainous portions of the drainage. Although present production is negligible, increasing national demand for metallic minerals could stimulate development of the reserves.

Exploitation of the fossil fuel and nonfuel mineral resources described above could have a significant impact on the aquatic resource. Careful scrutiny of this activity will be required to prevent or minimize environmental degradation.

Development of natural gas and oil fields will probably require pipeline crossings of streams in the study area. The crossings must comply with all applicable stream preservation laws and water quality standards and should be routed through established utility and transportation corridors. Pipelines should not be allowed to cross through or in the immediate vicinity of the nine critical paddlefish spawning sites which have been identified.

Potential Hydropower Dams

The Missouri River between Morony Dam and Fort Benton contains several potential sites for hydropower dams ranging in magnitude from a high dam at Fort Benton with a 14.5-km afterbay (which backs water into the Wild and Scenic portion of the Missouri River) to major run-of-river dams (Table 56). Smaller pump-back storage dams on Highwood and Belt creeks, tributaries of the Missouri River between Morony Dam and Fort Benton, have also been studied but are not feasible because benefit/cost $(B / C)$ ratios are presently well below unity. Potential dams on the mainstem of the Missouri River represent the greatest single threat to the aquatic resources of the study area.

The most obvious impact of the proposed dams would be the inundation of 11.3 to $64.4 \mathrm{~km}$ of the Missouri River and several $\mathrm{km}$ 


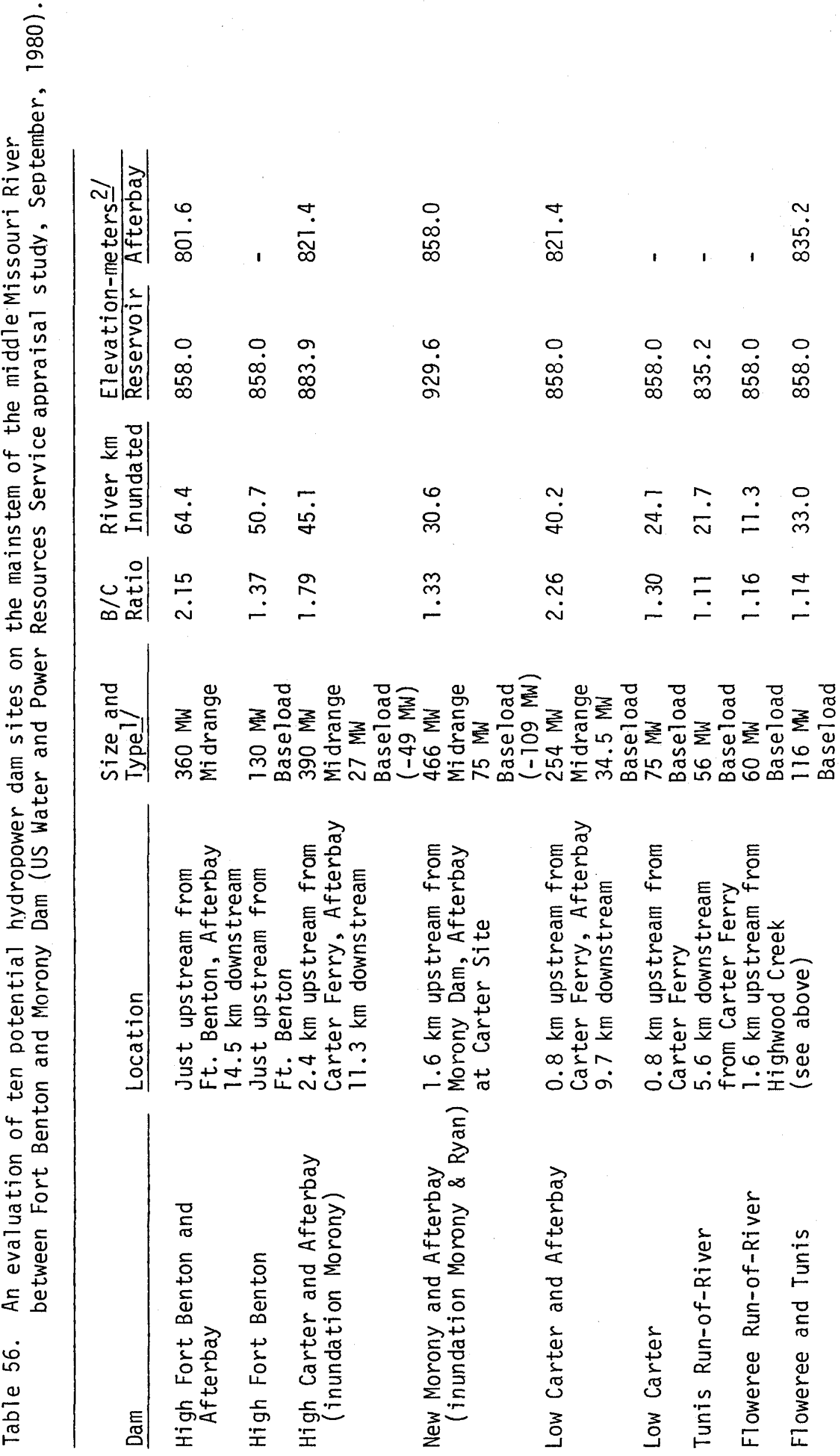




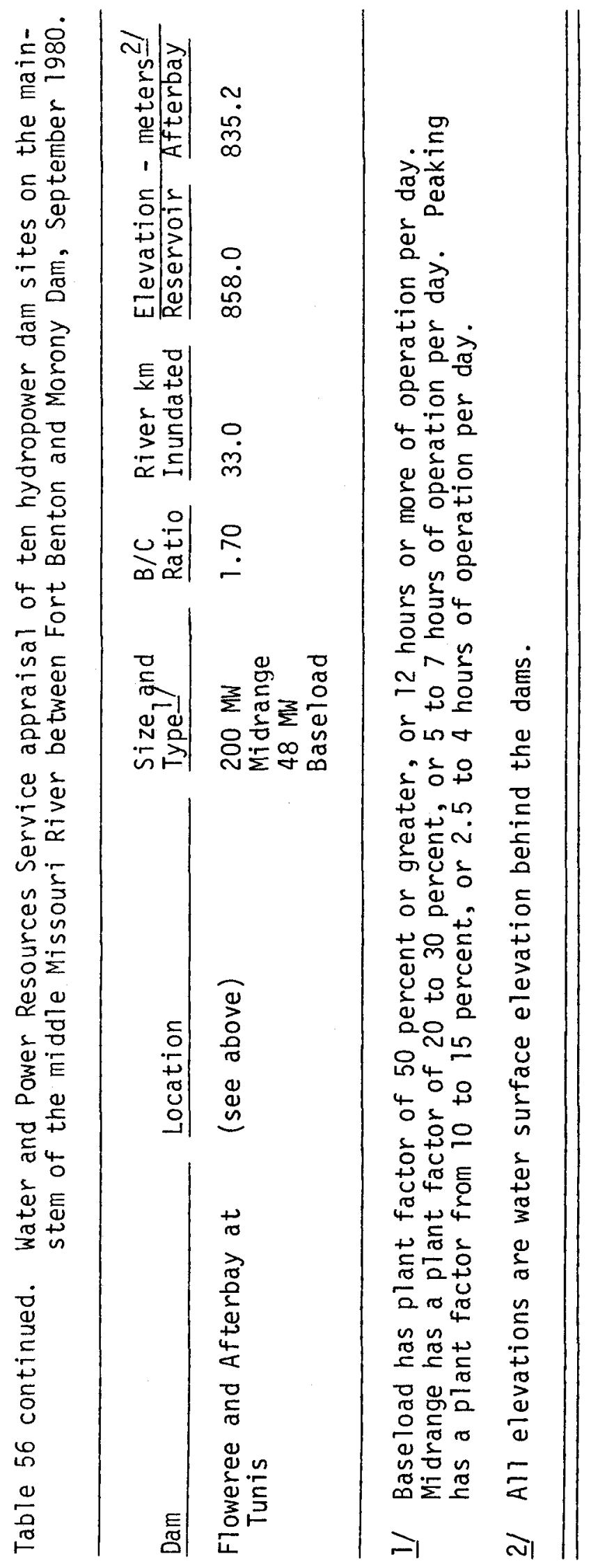


of tributary streams including the lower portions of Highwood Creek, Belt Creek, and possibly Shonk in Creek (Table 56). This irreversible commitment would inundate 3 to 19 percent of the $333-\mathrm{km}$ reach of free-flowing Missouri River which currently remains between Morony Dam and Fort Peck Reservoir. This loss becomes particularly significant in light of increasing national demand for large, free-flowing recreational rivers combined with an everdimishing free-flowing stream resource.

The dams would be a barrier to fish migration. At least eight key fish species (sauger, walleye, shovelnose sturgeon, channel catfish, smallmouth and bigmouth buffalo, blue sucker, and brown trout) spawn in the Missouri River upstream from Fort Benton. In addition, goldeye, carp, and several species of suckers and minnows spawn here. Rainbow trout, mountain whitefish, and burbot probably spawn in this reach, but verification has not been made.

Tag return evidence indicates that fish using the Missouri River upstream from Fort Benton for spawning come for as far downstream as Fort Peck Reservoir, a distance of approximately $280 \mathrm{~km}$. In addition, some species which normally reside in Fort Peck Reservoir also spawn upstream from Fort Benton. Tag return evidence indicates movements of these fish often exceed $300 \mathrm{~km}$.

The fish movement barrier created by the dams would have a negative impact on the existing downstream sport fishery. Walleye, sauger, and brown trout and probably mountain whitefish, rainbow trout, and burbot depend heavily on the river upstream from Fort Benton for spawning. Spawning concentrations of these species were rarely found below Fort Benton, and it can be assumed that most of their spawning area would be inundated by the proposed dams. Since significant spawning concentrations of other species have been located below Fort Benton, their spawning areas would not be reduced as much by inundation. However, spawning of these species could be impacted by regulated flows and modification of habitat characteristics of the river below the dams.

The fish movement barrier created by the proposed dams could also negatively impact the commercial fishery in Fort Peck Reservoir. The three most important commercial fish species in the reservoir, goldeye, bigmouth buffalo, and smallmouth buffalo, spawn in the river above Fort Benton. Large concentrations of goldeye and buffalo were found in the area in electrofishing surveys conducted during the spawning period.

Less obvious, but perhaps even more significant, are possible downstream impacts of the proposed dams. Changes in flow regime, sediment transport, chemistry, and water temperature could cause adverse environmental impacts in downstream areas affecting species composition and abundance, channel configuration, and riparian habitat zones. A major concern about the dams is their possible effect on the paddlefish migration which occurs in the river immediately downstream from the proposed dams. The paddlefish is listed as a "Species of Special Concern - Class A" in Montana (Holton 1980 ), and any major encroachment on its remaining habitat must be avoided if the species is to survive. 
At one time, paddlefish were common throughout much of the Mississippi/ Missouri River system. However, during the last 100 years paddlefish numbers have declined considerably. A variety of man's influences have contributed to the demise of paddlefish, but dams, because they impeded upstream spawning migrations and destroy spawning grounds, have been the single most destructive factor (Pflieger 1975, Rehwinkel 1975, Vasetskiy 1971). Only. six major self-sustaining paddlefish populations remain in the United States today, including the Missouri River/Fort Peck Reservoir population. A seventh major self-sustaining population was lost recently as a result of constructing Harry S. Truman Dam on the Osage River in Missouri. Natural reproduction of paddlefish in the 0sage River was essentially eliminated with the closing of the dam in 1978 (Russell et al. 1980). An attempt is being made to maintain the Osage River population by artificial propagation, but the long-range success of this program is questionable.

Our studies indicate that a spring flow in excess of $396 \mathrm{~m}^{3} / \mathrm{sec}$ $(14,000 \mathrm{cfs})$ downstream from the US Geological Survey gage station on the Missouri River at Virgelle, Montana, is needed by paddlefish to reach critical spawning sites. The flow should exceed $396 \mathrm{~m}^{3} / \mathrm{sec}$ for about 48 consecutive days from May 19 through July 5. Regulation of spring flow below the proposed dams could reduce paddlefish spawning runs. Spring flow in the Missouri River below Fort Benton has already been reduced to some extent by impoundment and storage at Canyon Ferry, Clark Canyon, Hebgen, Gibson, Hauser, Holter, and several other reservoirs in the Missouri River drainage upstream from Fort Benton. If spring flows are reduced further by additional dams, the spawning migration of paddlefish could be reduced or threatened.

Reservoirs behind the proposed dams would act as a sediment trap releasing relatively clear water with a high capacity to erode the streambed and banks. As a result, channel configuration of the river downstream from the dams would be altered. Any alteration of the nine critical paddlefish spawning sites between Fort Benton and Fort Peck Reservoir would be detrimental to paddlefish. Alteration of channel configuration has proven to be a substantial problem below other mainstem dams on the Missouri River.

Other potential impacts of the dams on paddlefish and other species could occur as a result of changes in water temperature, turbidity, and gas concentration. Paddlefish require water temperatures of at least $10 \mathrm{C}$ $(50 \mathrm{~F})$ and moderately high turbidity during the spring runoff period for successful spawning. If the dams significantly alter these parameters, spawning and survival of paddlefish eggs and larvae would be impaired. Gas supersaturation has resulted in substantial kills of paddlefish and other fish species in the Osage River below Truman Dam in Missouri (Kim Graham, Missouri Department of Conservation, personal communication).

It is unlikely that self-sustaining populations of desirable sport fish species would be established in the reservoirs behind most of the proposed dams. Presently, there is a series of five hydropower reservoirs on the mainstem of the Missouri River in the vicinity of Great Falls, Montana, about 60 kilometers upstream from Fort Benton. These reservoirs do not support a substantial recreational fishery, even though they are close to Great Falls, Montana's second largest city. 
Finally, construction of one or more of the proposed dams would result in a loss of recreational opportunities and scenic and aesthetic values, including loss of the last remaining "white water" segment of the Missouri. A study on distribution of recreationists on impounded and unimpounded sections of the lower Columbia and Snake rivers revealed that use of recreational boats per lineal mile of river was greatest on unimpounded reaches. With the addition of each impoundment on the Columbia and Snake rivers in the last several years, use by recreationists has shifted and intensified in the remaining unimpounded sections of river. Distribution data showed that recreationists prefer the unimpounded sections during all seasons (Holubetz and Simons 1975). With recreational use continuing to increase and already extensive on other free-flowing rivers in Montana, such as the Madison, Gallatin, Flathead, and Yellows tone, it becomes imperative to maintain this river in its natural state to continue to provide the unique aes thetic, fishing, and other recreational experiences it provides.

\section{MANAGEMENT RECOMMENDATIONS}

1. Nine paddlefish spawning sites have been identified on the mainstem of the middle Missouri River. The paddlefish is listed as a "Species of Special Concern - Class A" in Montana, and only six major selfsustaining populations remain in the United States. The paddlefish spawning sites are the most critical fish habitat type in the middle Missouri River. Every effort must be made to protect these sites so their use by paddlefish can continue undiminished.

2. Sediment is a water quality problem in portions of the middle Missouri River basin. Contributing factors include logging, agricultural, and urbanization practices as well as natural sources. The sediment problem is most severe in the Marias River, Judith River, and Arrow Creek drainages. Additional study is needed to better define the amount of sediment carried by these streams so that recommendations to control the problem can be formulated.

3. Nutrient enrichment of streams has caused severe eutrophication problems and depressed aquatic conditions in isolated portions of the Marias and Judith River drainages. In some cases, sewage or industrial waste treatment facilities should be upgraded to alleviate the problem. In other cases, confined livestock yards should be relocated to areas where animal wastes (i.e. nutrients) do not run directly into the streams.

4. The study area lies within one of the principal saline seep problem areas in Montana, and potential for water quality degradation exists. More study is needed to define the extent and causes of water pollution caused by saline seep so that recommendations to alleviate the problem can be formulated.

5. Extensive dewatering during the irrigation season seriously impairs fish populations in some streams in the study area. The problem is severe in the lower Teton River and moderately 
severe in the lower Judith River. Since prior water rights are involved, little can be done to enhance or improve stream flows in severely dewatered areas. However, instream flow protection should be sought on streams in the study area to protect the aquatic resource from future dewatering problems. Streams of particular concern are the Marias, Teton, and Judith rivers and Belt and Highwood creeks.

6. There has been an increase in exploration and development of $0 i 1$ and natural gas fields in the middle Missouri River drainage. In addition, increasing national demand could stimulate exploration and production of coal, bentonite, and metallic mineral reserves located in the study area. Continuous monitoring of this activity and establishment of appropriate safeguards, where necessary, will be required to prevent loss of fish and wildlife habitat.

7. Development of natural gas and oil fields will probably require pipeline crossings of streams in the study area. All pipeline crossings should comply with applicable stream preservation laws and water quality standards. Crossings of the mainstem of the Missouri River should be routed through established utility and transportation corridors. Pipelines should not be allowed to cross through or in the immediate vicinity of the nine critical paddlefish spawning sites which have been identified.

8. Man-caused channel alterations are a problem in portions of the study area. Every effort should be made to ensure successful implementation of the Natural Streambed and Land Preservation Act of 1975 and the Stream Protection Act of 1963.

9. Development of one or more of the potential dam sites between Morony Dam and Fort Benton represents the greatest single threat to the aquatic resources of the middle Missouri River. Areas critical for reproduction and recruitment of several important fish species would be inundated. A major dam regulating spring flow could also have detrimental impacts on physical, chemical, and biological characteristics of the river below the dam. This would impair historic, aesthetic, and recreational values in the Wild and Scenic segment of the Missouri River. For these reasons every effort should be made to maintain the Missouri River in its free-flowing state. 


\section{LITERATURE CITED}

Adams, L. A. 1942. Age determination and rate of growth in Polyodon spathula, by means of growth rings of the otiliths and dentary bone. Am. Mid. Nat. 28(3): 617-630.

American Public Health Association. 1975. Standard methods for the examination of water and waste water. New York. 769 pp.

Bahls, L. L. and M. R. Miller. 1973. Saline seep in Montana. Mont. Environmental Quality Council, Second Annual Rept.: 35-44.

Ballard, W. W. and R. G. Needham. 1964. Normal embryonic stages of Polyodon spathula (Walbaum). J. of Morph. 114(3): 465-478.

Barnickol, P. G. and W. C. Starrett. 1951. Commercial and sport fishes of the Mississippi River between Caruthersville, Missouri, and Dubuque, Iowa. Bu11. I11. Nat. Hist. Survey 25(5): 267-350.

Berg, R. K. 1975. Fish and game planning, Upper Yellowstone and Shields River drainages. Job Comp. Rept., Fed. Aid to Fish and Wildl. Rest. Proj. No. FW-3-R. Job Ia. $92 \mathrm{pp}$. - 1980. Spoonbi11. Montana Outdoors 11(3): 11-13, 21-22.

Brown, C. J. D. 1971. Fishes of Montana. Endowment and Res. Found., Mont. St. Uni.v., Bozeman. 207 pp.

Brown, H. P. 1972. Aquatic dryopoid beetles (Coleoptera) of the United States. U.S. Envt. Prot. Agency Proj. No. 18050 ELD. Washington, D. C. $82 \mathrm{pp}$.

Carlander, K. D. 1969. Handbook of freshwater fishery biology. Iowa St. Univ. Press, Ames. $752 \mathrm{pp}$.

Carufe1, L. H. 1963. Life history of sauger in Garrison Reservoir. J. Wi id7. Mgmt. 27(3): 450-456.

Christenson, L. M. 1974. Notes on the blue sucker, Cycleptus elongatus (Lesueur) in the lower Chippewa and Red Cedar Rivers, Wisconsin. Wisc. Dept. Nat. Resc. Research Rept. No. 75.7 pp.

- 1975. The shovelnose sturgeon, Scaphirynchus platorynchus (Rafinesque) in the Red Cedar - Chippewa River system, Wisconsin. Wisc. Dept. Nat. Resc. Research Rept. No. 82.23 pp.

and L. L. Smith. 1965. Characteristics of fish populations in upper Mississippi River backwater areas. Bur. of Sport Fish. and Wild1. Circ. No. 212. $53 \mathrm{pp}$.

Chu, S. P. 1942. The effect of the mineral composition of the medium on the growth of plankton algae. Jour. Ecol. 30: 284.

Cuerrier, J. 1951. The use of pectoral fin rays for determining age of sturgeon and other species of fish. Can. Fish. Cult. 11: 10-17. 
Curry, J. J. and S. L. Wilson. 1955. Effect of sewage-borne phosphorus on algae. Sewage and Industrial Wastes 27: 1262.

Eddy, S. and T. Surber. 1943. Northern fishes, with special reference to the Upper Mississippi Valley. Univ. of Minn. Press, Minneapolis. $276 \mathrm{pp}$.

Elser, A. A. 1976. Southeast Montana fisheries investigations. Job Prog. Rept., Fed. Aid to Fish and Wildl. Rest. Proj. No. F-30-R-12. Job Ia. Paddlefish investigations. $12 \mathrm{pp}$.

, R. C. McFarland and D. Schwehr. 1977. The effect of altered streamflow on fish of the Yellowstone and Tongue rivers, Montana. Tech. Rept. No. 8, Yellows tone Impact Study. Water Resources Div., Mont. Dept. of Nat. Resources and Cons., Helena. 180 pp.

FAO. 1975. Symposium of methodology for the survey, monitoring, and appraisal of fishery resources in lakes and large rivers. $747 \mathrm{pp}$.

Friberg, D. V. 1974. Investigations of paddlefish populations in South Dakota and development of management plans, 1973. Job Prog. Rept., Proj. No. F-15-R-8, S. Dak. Dept. of Game, Fish and Parks. 33 pp.

Gardner, W. M. and R. K. Berg. 1981. An analys is of the instream flow requirements for selected fishes in the Wild and Scenic portion of the Missouri River. Mont. Dept. of Fish, Wildlife, and Parks. In press.

Garvin, W. H. and M. K. Botz. 1975. Water quality inventory and management plan, Marias River basin, Montana. Water Quality Bureau, Mont. Dept. of Health and Envt. Sciences, Helena. 118 pp.

Gieseker, L. F. 1931. Soils of Choteau County. Mont. Agr. Exp. Stat. Bul1. No. 252.

Graham, P. J. and R. F. Penkal. 1978. Aquatic environmental analysis in the lower Yellowstone River. Mont. Dept. of Fish and Game. 102 pp.

, R. F. Penkal and L. G. Peterman. 1979. Aquatic studies of the Yellowstone River. Mont. Dept. of Fish and Game study. US Bur. of Rec. Tech. Rept. No. REC-ERC-79-8. $80 \mathrm{pp}$.

Haddix, M. H. and C. C. Estes. 1976. Lower Yellowstone River fishery study. Final Rept., Mont. Dept. of Fish and Game. 81 pp.

HeTms, D. R. 1973. Progress report on the second year of study of shovelnose sturgeon in the Mississippi River. Annual Prog. Rept., Proj. No. 2-156-R-1, Iowa Cons. Comm. $33 \mathrm{pp.}$

1973. Progress report from the first year study of sub-legal sized channel catfish in the Mississippi River. Job Prog. Rept., Proj. No. 2-178-R-1, Iowa Cons. Comm. 57 pp. 
1974a. Shovelnose sturgeon, Scaphirhynchus platorynchus (Rafinesque), in the navigational impoundments of the upper Mississippi River. Iowa Cons. Comm., Fish. Tech. Series No. 74-3. 68 pp.

- 1974b. Age and growth of shovelnose sturgeon, Scaphirhynchus platorynchus, in the Mississippi River. Proc. Iowa Acad. Sci. $81(2):$ 73-75.

- 1975. Variations in the abundance of channel catfish year classes in the upper Mississippi River and causative factors. Iowa Cons. Comm. Fish. Tech. Series No. 75-1. $31 \mathrm{pp}$.

Hogue, J. J., R. Wallus and L. K. Kay. 1976. Preliminary guide to the identification of larval fishes in the Tennessee River. TVA, Norris, Tenn. $66 \mathrm{pp}$.

Holton, G. 1980. The riddles of existence: Fishes of "special concern." Montana Outdoors 11(1): 2-6, 26.

Holubetz, T. and R. Simons. 1975. Unimpounded river preference. Sport Fishing Inst. Bul1. No. 264. May 1975.

Hornung, C. E. and G. E. Pollard. 1978. Macroinvertebrate sampling techniques for streams in semi-arid regions: Comparison of the Surber method and a unit-effort traveling kick method. Envt. Prot. Agency Rept. No. 600/4-78-040. 21 pp.

Hubley, R. C. Jr. 1963. Movement of tagged channel catfish in the upper Mississippi River. Trans. Am Fish. Soc. 92: 165-168.

Hynes, H. B. N. 1970. The ecology of running waters. Univ. of Toronto Press. $555 \mathrm{pp}$.

Kaiser, J. and M. K. Botz. 1975. Water quality inventory and management plan, middle Missouri River basin, Montana. Water Quality Bureau, Mont. Dept. of Health and Envt. Sciences, Helena. 89 pp.

Kallemeyn, L. W. and J. F. Novotny. 1977. Fish and food organisms in various habitats of the Missouri River in South Dakota, Nebraska, and Iowa. US Fish and Wi 1d7. Ser. Rept. No. FWS/OBS-77/25. 100 pp.

Lagler, K. F. 1956. Freshwater fishery biology. Wm C. Brown Pub. Co., Dubuque, Ia. 421 pp.

Livingstone, D. A. 1963. Chemical composition of rivers and lakes. In Data of geochemistry (6th ed.). US Geol. Survey Prof. Paper 440-G: GT-G64.

Marzolf, R. C. 1955. Use of pectoral spines and vertebrae for determining age and rate of growth of the channel catfish. J. Wildl. Mgmt. 19(2): 243-249.

May, E. B. and C. R. Gasaway. 1967. A preliminary key to the identification of larval fishes of Oklahoma with particular reference to Canton Reservoir, including a selected bibliography. Okla. Fish. Res. Lab., Bul1. 5, Contr. No. 164. Okla. Dept. Wildl. and Cons., Norman. 42 pp. 
Merritt, R. W. and K. W. Cummins. 1978. An introduction to the aquatic insects of North America. Kendall/Hunt Pub. Co., Dubuque, Ia. 441 pp.

Meyer, F. P. 1960. Life history of Marsipometra hastata and the biology of its host, Polyodon spathula. PhD thesis, Ia. St. Univ., Ames. $145 \mathrm{pp}$.

Missouri River Joint Study. 1963. Joint report on water and related land resources development by the US Corps of Engineers and the Bureau of Reclamation. $60 \mathrm{pp}$.

Monson, M. A. and J. Greenbank. 1947. Size and maturity of hackle-back sturgeon. Upper Mississippi R. Cons. Comm. Tech. Commit. Fish Prog. Rept. 3: $42-45$.

Moos, R. E. 1978. Movement and reproduction of shovelnose sturgeon, Scaphirhynchus platorynchus (Rafinesque), in the Missouri River, South Dakota. PhD thesis, Univ. of S. Dak., Vermillion. $213 \mathrm{pp}$.

Morris, L. A. 1965. Sauger and walleye invesigations in the Missouri River. Job Comp. Rept., Proj. No. F-4-R-10, Nebr. Game and Parks Comm. $7 \mathrm{pp}$.

1969. Sauger and walleye investigations in the Missouri River. Job Comp. Rept., Proj. No. F-4-R-15, Nebr. Game and Parks Comm. $9 \mathrm{pp}$.

Morris, J., L. Morris and L. Witt. 1974. The fishes of Nebraska. Nebr. Game and Parks Comm. 98 pp.

Needham, R. G. 1973. Northeast Montana fisheries investigation. Job Prog. Rept., Fed. Aid to Fish and Wild1. Rest. Proj. No. F-11-R-20. Job IIa. $5 \mathrm{pp}$.

- 1975. Northeast Montana fisheries investigation. Job Prog. Rept., Fed. Aid to Fish and Wild1. Rest. Proj. No. F-11-R-22. Job IIa. 6 pp.

- 1976. Northeast Montana fisheries investigation. Job

Prog. Rept., Fed. Aid to Fish and Wildl. Rest. Proj. No. F-11-R-23. Job IIa. $6 \mathrm{pp}$.

- 1978. Missouri River - Fort Peck Reservoir paddlefish

study. Mont. Dept. of Fish and Game. 19 pp.

Nelson, W. R. 1968. Reproduction and early life history of sauger, Stizostedion canadense, in Lewis and Clark Lake. Trans. Am. Fish. Soc. 97(2): 159-166.

Newe11, R. L. 1976. Yellowstone River study. Mont. Dept. of Fish and Game. $97 \mathrm{pp}$.

Novotny, D. W. and G. R. Priege1. 1974. Electrofishing boats - improved designs and operational guidelines to increase the effectiveness of boom shockers. Wisc. Dept. Nat. Resc. Tech. Bull. No. 73.48 pp. 
Pennak, R. W. 1953. Fresh water invertebrates of the United States. The Ronald Press Co., N. Y., N. Y. 769 pp.

Peterman, L. G. 1978. Electrofishing large rivers - the Yellows tone experience. Paper presented at: The electrofishing workshop, St. Paul, Minn., March 9-10, 1978. and M. H. Haddix. 1975. Lower Yellowstone River fishery study. Prog. Rept. No. 1, Mont. Dept. of Fish and Game. 56 pp.

Peters, J. C. 1964. Age and growth studies and analys is of bottom samples in connection with pollution studies. Job Comp. Rept., Fed. Aid to Fish and Wild1. Rest. Proj. No. F-23-R-6. Job I and II. $76 \mathrm{pp}$.

Pflieger, W. L. 1975. The fishes of Missouri. Missouri Dept. of Cons., Jefferson City, Mo. $343 \mathrm{pp}$.

Posewitz, J. A. 1962. A fish population investigation in the Marias River below Tiber Dam. Fed. Aid to Fish and Wildl. Rest. Proj. No. F-5-R-11. Job IIa. 9 pp.

- 1963. Missouri River fish population study. Fed. Aid to Fish and Wildl. Rest. Proj. No. F-11-R-10. Job III. 9 pp.

Priegel, G. R. 1969. The lake Winnebago sauger. Wisc. Dept. Nat. Resc. Tech. Bul1. No. 43. 63 pp.

- 1973. Lake sturgeon management on the Menominee River.

Wisc. Dept. Nat. Resc. Tech. Bul1. No. 67. 20 pp.

Purkett, C. A. 1957. Growth of the fishes in the Salt River, Missouri. Trans. Am. Fish. Soc. 87: 116-131.

- 1961. Reproduction and early development of the paddlefish.

Trans. Am. Fish. Soc. 90(2): 125-129.

- 1963. The paddlefish fishery of the Osage River and Lake of the 0zarks, Missouri. Trans. Am. Fish. Soc. 92(3): 239-244.

Ragland, D. V. and J. W. Robinson. 1972. Dynamics and growth of commercially exploited catfish populations in the lower Missouri River. Final Rept., Nat. Marine Fisheries Ser., Proj. No. 4-3-R, Missouri Dept. of Cons. 39 pp.

Rehwinke 1, B. J. 1975. The fishery for paddlefish at Intake, Montana during 1973 and 1974. M. S. thesis, Mont. St. Univ., Bozeman. $37 \mathrm{pp}$.

, M. Gorges and J. Wells. 1976. Powder River aquatic ecology project. Annual Rept., Oct. 1, 1975-June 30, 1976. Mont. Dept. of Fish and Game. $35 \mathrm{pp}$. 
Reid, G. K. 1961. Ecology of inland waters and estuaries. Van Nostrand Rienhold Company, New York. 375 pp.

Ricker, W. E. 1971. Methods for assessment of fish production in fresh waters. IBP handbook no. 3. Blackwell Scientific Pub., Oxford and Edinburgh, England. $348 \mathrm{pp}$.

Riggs, V. L. 1978. Age and growth of walleye and sauger of the Tongue River Reservoir, Montana. M. S. thesis, Mont. St. Univ., Bozeman. $53 \mathrm{pp}$.

Robinson, J. W. 1973. Missouri River habitat study. Final Rept., Proj. No. 4-3-R-8, Missouri Dept. of Cons. $15 \mathrm{pp}$.

1977. The utilization of dikes by certain fishes in the Missouri River. Final Rept., Proj. No. 2-199-R, Missouri Dept. of Cons. $17 \mathrm{pp}$.

Roemhild, G. 1976. The aquatic Heteroptera (True Bugs) of Montana. Mont. Agr. Exp. Stat. Research Rept. No. 102. 70 pp.

Roussow, G. 1957. Some considerations concerning sturgeon spawning periodicity. J. Fish. Res. Bd. Can. 14(4): 553-572.

Russe11, T. R., L. K. Graham, D. M. Carlson and E. J. Hamilton. 1980. Maintenance of the Osage River - Lake of the Ozarks paddlefish fishery. Missouri Dept. of Cons. $33 \mathrm{pp}$.

Sawyer, C. N. 1948. Fertilization of lakes by agricultural and urban drainage. Water Pollution Abs. 21, Apri1 1948.

Schmulbach, J. C. 1974. An ecological study of the Missouri River prior to channelization. Comp. Rept., Proj. B-024-S. Univ. of South Dakota, Vermillion. $34 \mathrm{pp}$.

Schwehr, D. J. 1977. Temperature related zonation of aquatic insects in the Yellowstone River. Mont. Dept. of Fish and Game. $23 \mathrm{pp}$.

Scott, W. B. and E. J. Crossman. 1973. Freshwater fishes of Canada. Fish. Res. Bd. of Canada, Ottawa. 966 pp.

Sneed, K. E. 1951. A method for calculating the growth of channel catfish, Ietalurus lacustris punctatus. Trans. Am. Fish. Soc. 80: 174-183.

Stuckey, N. P. 1973. Effects of warm water discharges on fish in the Missouri River. Job Prog. Rept., Proj. No. F-4-R-18, Nebr. Game and Parks Comm. $14 \mathrm{pp}$.

Tesch, F. W. 1971. Age and growth. In Methods for assessment of fish production in fresh waters. IBP handbook no. 3. Blackwell

Scientific Pub., Oxford and Edinburgh, England. 348 pp.

Trautman, M. B. 1957. The fishes of Ohio. Ohio St. Univ. Press. 683 pp. 
US Congress. 1975a. Hearings on S. 1506, a bill to amend the wild and scenic rivers act, part 2 - Missouri River, Mont. US Govt. Printing Office, Washington, D. C. $444 \mathrm{pp}$.

- 1975b. Designating a segment of the Missouri River in the state of Montana as a component of the national wild and scenic rivers system. Senate Rept. No. 94-502. 16 pp.

USDI. 1975. Missouri River - A wild and scenic river study. Bur. of Outdoor Rec. $95 \mathrm{pp}$.

1978. Upper Missouri wild and scenic river management plan. Supplemental document (final). Bur. of Land Mgmt. 159 pp.

USGS. 1979. Water resources data for Montana. US Dept. of Interior. $824 \mathrm{pp}$.

- 1980. Flow duration hydrograph for Missouri River at Virgelle, Montana, 39-year period between water years 1940 and 1978.

US Water and Power Resources Service. 1980. Fort Benton reformulation news letter, issue 2, Sept. 1980. 3 pp.

Unkenholz, D. G. 1980A. Investigation of the paddlefish population and recruitment in the Missouri River below Gavins Point Dam. Job Prog. Rept., Proj. No. F-15-R-15, S. Dak. Dept. of Game Fish and Parks. $7 \mathrm{pp}$.

1980b. Paddlefish spawning movements and reproductive success in the Missouri River below Fort Randall Dam, 1979. Prog. Rept. No. 80-3, S. Dak. Dept. of Game, Fish and Parks. 13 pp.

Vasetskiy, S. G. 1971. Fishes of the family Polyondontidae. Jour. of Icthyology 17(1): 18-31.

Ward, H. B. and G. C. Whipple. 1959. Fresh water biology. John Wiley and Sons, Inc., New York, N. Y. 1248 pp.

Wiedenheft, B. 1980. South central fisheries investigation/Musse1shell River study. Job Prog. Rept., Fed. Aid to Fish and Wild1. Rest. Proj. No. F-20-R-24. Job Ia (supplement). $15 \mathrm{pp}$.

Wipperman, A. H. 1973. Smith River drainage inventory and planning investigation. Job Comp. Rept., Fed. Aid to Fish and Wildl. Rest. Proj. No. FW-1-R, Job Ia.

Witt, A. Jr. 1961. An improved instrument to section bones for age and growth determinations of fish. Prog. Fish - Cult. 23(2): 94-96.

Zweiacker, P. L. 1967. Aspects of the life history of the shovelnose sturgeon, Scaphirhynchus platorynchus (Rafinesque), in the Missouri River. M. A. thesis, Univ. of S. Dak., Vermillion. $46 \mathrm{pp}$. 
Appendix Table 1. River distance chart for the middle Missouri River study area. Confluence of the Missouri River with the normal flood pool of Fort Peck Lake is river kilometer 0.0 .

\section{Location}

Morony Dam

Belt Creek

Highwood Creek

Carter Ferry

Fort Benton

Loma Ferry

Marias River

Spanish Island

Virgelle Ferry

Coa1 Banks Landing

Little Sandy Creek

Eagle Creek

Hole-in-the-Wal1

Arrow Creek

Judith River

Judi th Ferry

Stafford Ferry

Bird Rapids

Sturge on Is land

Cow Island

Grand Island

Robinson Bridge

Sl ippery Ann Campground

Rock Creek

Turkey Joe

Fort Peck Reservoir
River Kilometer

333

331

321

307

281

248

245

235

218

213

205

190

177

154

138

136

114

92

85

70

51

37

28

16

1 
Appendix Table 2. Daily maximum and minimum water temperatures (degrees $\mathrm{F}$ ) for the Missouri River near Morony Dam during 1977.

\begin{tabular}{|c|c|c|c|c|c|c|c|c|c|c|c|}
\hline \multirow[b]{2}{*}{$\begin{array}{c}\text { Day } \\
1 \\
2 \\
3 \\
4 \\
5 \\
6 \\
7 \\
8 \\
9 \\
10 \\
11 \\
12 \\
13 \\
14 \\
15 \\
16 \\
17 \\
18 \\
19 \\
20 \\
21 \\
22 \\
23 \\
24 \\
25 \\
26 \\
27 \\
28 \\
29 \\
30 \\
31\end{array}$} & $\begin{array}{r}\text { April } \\
\text { Min.Max } \\
\end{array}$ & $\begin{array}{c}\text { May } \\
\text { Min.Max. }\end{array}$ & \multicolumn{2}{|c|}{$\begin{array}{c}\text { June } \\
\text { Min.Max. }\end{array}$} & \multicolumn{2}{|c|}{$\begin{array}{c}\text { JuTy } \\
\text { Min.Max. }\end{array}$} & \multicolumn{2}{|c|}{$\begin{array}{c}\text { Aug. } \\
\text { Min.Max. }\end{array}$} & \multicolumn{2}{|c|}{$\begin{array}{r}\text { Sept. } \\
\text { Min.Max. }\end{array}$} & \multirow[t]{2}{*}{$\begin{array}{c}\text { Oct. } \\
\text { Min.Max. }\end{array}$} \\
\hline & & & $\begin{array}{l}60 \\
60 \\
63 \\
58 \\
57 \\
56 \\
55 \\
57 \\
57 \\
56 \\
56 \\
56 \\
57 \\
58 \\
59 \\
58 \\
57 \\
59 \\
58 \\
59 \\
63 \\
56 \\
58 \\
53\end{array}$ & $\begin{array}{l}66 \\
67 \\
67 \\
67 \\
61 \\
58 \\
60 \\
62 \\
62 \\
62 \\
60 \\
63 \\
64 \\
63 \\
64 \\
65 \\
64 \\
65 \\
65 \\
67 \\
65 \\
65 \\
60 \\
60 \\
63\end{array}$ & $\begin{array}{l}56 \\
59 \\
55 \\
55 \\
56 \\
58 \\
56 \\
55 \\
56 \\
57 \\
56 \\
58 \\
58 \\
56 \\
63 \\
58 \\
60 \\
61\end{array}$ & 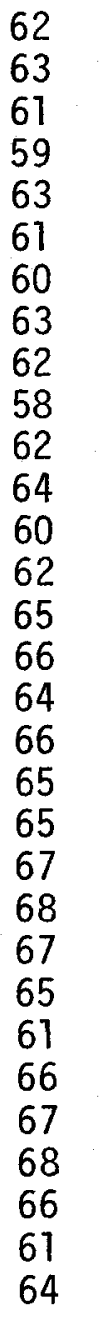 & $\begin{array}{l}61 \\
62 \\
61 \\
59 \\
59 \\
59 \\
59 \\
59 \\
60 \\
58 \\
53 \\
58 \\
60 \\
60 \\
57 \\
57 \\
58 \\
57 \\
59 \\
61 \\
63\end{array}$ & $\begin{array}{l}68 \\
67 \\
64 \\
63 \\
63 \\
63 \\
65 \\
65 \\
62 \\
63 \\
63 \\
64 \\
61 \\
61 \\
60 \\
63 \\
65 \\
65 \\
65 \\
65 \\
65 \\
63 \\
65 \\
64 \\
62 \\
60 \\
59 \\
59 \\
60 \\
58 \\
58\end{array}$ & $\begin{array}{l}54 \\
52 \\
56 \\
56 \\
59 \\
56 \\
55 \\
57\end{array}$ & $\begin{array}{l}59 \\
59 \\
61 \\
63 \\
63 \\
63 \\
63\end{array}$ & \\
\hline
\end{tabular}


Appendix Table 3. Daily maximum and minimum water temperatures (degrees F) for the Missouri River at Fort Benton during 1976.

\begin{tabular}{|c|c|c|c|c|c|c|c|c|c|c|c|c|c|c|}
\hline $\begin{array}{c}\text { Day } \\
1\end{array}$ & \multicolumn{2}{|c|}{$\begin{array}{r}\text { Aprit } \\
\text { Min.Max } \\
\end{array}$} & \multicolumn{2}{|c|}{$\begin{array}{c}\text { May } \\
\text { Min.Max. }\end{array}$} & \multicolumn{2}{|c|}{$\begin{array}{c}\text { June } \\
\text { Min.Max. }\end{array}$} & \multicolumn{2}{|c|}{$\begin{array}{c}\text { July } \\
\text { Min.Max. }\end{array}$} & \multicolumn{2}{|c|}{$\begin{array}{c}\text { Aug. } \\
\text { Min.Max. }\end{array}$} & \multicolumn{2}{|c|}{$\begin{array}{c}\text { Sept. } \\
\text { Min.Max. }\end{array}$} & \multicolumn{2}{|c|}{$\begin{array}{c}\text { Oct. } \\
\text { Min.Max. }\end{array}$} \\
\hline $\begin{array}{r}1 \\
2 \\
3 \\
4 \\
5 \\
6 \\
7 \\
8 \\
9 \\
10 \\
11 \\
12 \\
13 \\
14 \\
15 \\
16 \\
17 \\
18 \\
19 \\
20 \\
21 \\
22 \\
23 \\
24 \\
25 \\
26 \\
27 \\
28 \\
29 \\
30 \\
31\end{array}$ & $\begin{array}{l}49 \\
47 \\
46 \\
45 \\
45 \\
45 \\
45 \\
46 \\
47 \\
47 \\
45 \\
43 \\
42 \\
42 \\
43\end{array}$ & $\begin{array}{l}52 \\
50 \\
49 \\
49 \\
49 \\
49 \\
49 \\
48 \\
49 \\
52 \\
49 \\
47 \\
45 \\
43 \\
46 \\
50\end{array}$ & $\begin{array}{l}46 \\
49 \\
50 \\
51 \\
50 \\
49 \\
48 \\
50 \\
52 \\
54 \\
53 \\
52 \\
52 \\
53 \\
52 \\
52 \\
52 \\
54 \\
54\end{array}$ & $\begin{array}{l}52 \\
53 \\
54 \\
52 \\
51 \\
57 \\
52 \\
53 \\
56 \\
57 \\
56 \\
54 \\
54 \\
54 \\
55 \\
54 \\
56 \\
56 \\
57 \\
57 \\
58 \\
58 \\
59 \\
60 \\
59 \\
59\end{array}$ & $\begin{array}{l}57 \\
58 \\
57 \\
58 \\
57 \\
57 \\
58 \\
57 \\
57 \\
58 \\
61 \\
60 \\
57 \\
57 \\
56 \\
57 \\
57 \\
56 \\
57 \\
60 \\
61 \\
62 \\
58 \\
57 \\
56 \\
55 \\
55 \\
58 \\
60 \\
62\end{array}$ & $\begin{array}{l}61 \\
61 \\
61 \\
60 \\
60 \\
60 \\
50 \\
59 \\
60 \\
62 \\
64 \\
64 \\
64 \\
63 \\
60 \\
0\end{array}$ & 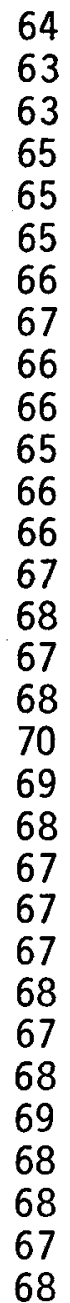 & 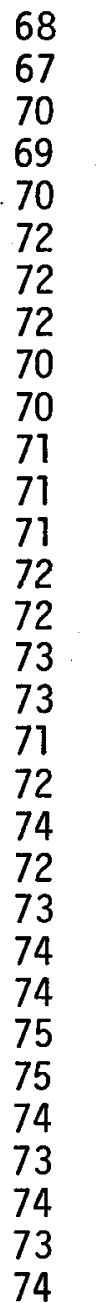 & 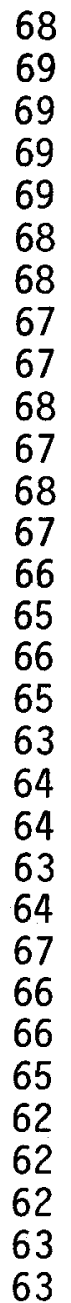 & $\begin{array}{l}73 \\
73 \\
73 \\
74 \\
73 \\
74 \\
74 \\
72 \\
73 \\
72 \\
73 \\
73\end{array}$ & $\begin{array}{l}64 \\
66 \\
65 \\
65 \\
65 \\
63 \\
61 \\
60 \\
59 \\
59 \\
59 \\
60 \\
59 \\
59 \\
60 \\
60 \\
60 \\
62 \\
62 \\
59 \\
59 \\
53\end{array}$ & $\begin{array}{l}70 \\
71 \\
70 \\
69 \\
70 \\
68 \\
64 \\
65 \\
64 \\
64 \\
64 \\
62 \\
63 \\
64 \\
64 \\
65 \\
65 \\
66 \\
65 \\
63\end{array}$ & $\begin{array}{l}59 \\
60 \\
59 \\
57 \\
54 \\
53 \\
52 \\
52 \\
53 \\
53 \\
54 \\
54 \\
54 \\
54 \\
52 \\
50 \\
48 \\
47\end{array}$ & $\begin{array}{l}63 \\
63 \\
67 \\
60 \\
56 \\
57 \\
56 \\
56 \\
57 \\
57 \\
58 \\
58 \\
57 \\
54 \\
52 \\
50 \\
49 \\
50 \\
48\end{array}$ \\
\hline
\end{tabular}


Appendix Table 4. Daily maximum and minimum water temperatures (degrees F) for the Missouri River at Fort Benton during 1977.

\begin{tabular}{|c|c|c|c|c|c|c|c|c|c|c|c|c|c|c|}
\hline Day & \multicolumn{2}{|c|}{$\begin{array}{r}\text { April } \\
\text { Min.Max } \\
\end{array}$} & \multicolumn{2}{|c|}{$\begin{array}{c}\text { May } \\
\text { Min.Max. }\end{array}$} & \multicolumn{2}{|c|}{$\begin{array}{c}\begin{array}{c}\text { June } \\
\text { Min.Max. }\end{array} \\
\end{array}$} & \multicolumn{2}{|c|}{$\begin{array}{c}\text { July } \\
\text { Min.Max. } \\
\end{array}$} & \multicolumn{2}{|c|}{$\begin{array}{c}\text { Aug. } \\
\text { Min.Max. }\end{array}$} & \multicolumn{2}{|c|}{$\begin{array}{c}\text { Sept. } \\
\text { Min.Max. }\end{array}$} & \multicolumn{2}{|c|}{$\begin{array}{c}\text { Oct. } \\
\text { Min.Max. }\end{array}$} \\
\hline $\begin{array}{c}1 \\
2 \\
3 \\
4 \\
5 \\
6 \\
7 \\
8 \\
9 \\
10 \\
11 \\
12 \\
13 \\
14 \\
15 \\
16 \\
17 \\
18 \\
19 \\
20 \\
21 \\
22 \\
23 \\
24 \\
25 \\
26 \\
27 \\
28 \\
29 \\
30 \\
31\end{array}$ & $\begin{array}{l}36 \\
36 \\
36 \\
40 \\
41 \\
42 \\
44 \\
46 \\
49 \\
48 \\
48 \\
47 \\
47 \\
48 \\
47 \\
49 \\
42 \\
43 \\
47 \\
47 \\
45 \\
47 \\
47 \\
46 \\
49 \\
54 \\
54 \\
54 \\
55 \\
55\end{array}$ & $\begin{array}{l}41 \\
41 \\
40 \\
45 \\
47 \\
48 \\
50 \\
53 \\
53 \\
52 \\
52 \\
53 \\
53 \\
51 \\
52 \\
54 \\
53 \\
52 \\
50 \\
51 \\
50\end{array}$ & $\begin{array}{l}54 \\
55 \\
56 \\
58 \\
55 \\
54 \\
52 \\
50 \\
49 \\
49 \\
50 \\
51 \\
54 \\
57 \\
57 \\
56 \\
58 \\
53\end{array}$ & $\begin{array}{l}61 \\
59 \\
61 \\
62 \\
62 \\
56 \\
57 \\
55 \\
53 \\
51 \\
54 \\
55 \\
58 \\
60 \\
59 \\
59 \\
64 \\
60 \\
59\end{array}$ & $\begin{array}{l}62 \\
62 \\
61 \\
63 \\
65 \\
63 \\
67 \\
68 \\
67 \\
69 \\
69 \\
69 \\
68 \\
65 \\
63 \\
62\end{array}$ & $\begin{array}{l}68 \\
67 \\
67 \\
73 \\
70 \\
70 \\
71 \\
74 \\
74 \\
74 \\
73 \\
74 \\
74 \\
72 \\
72 \\
67 \\
74\end{array}$ & $\begin{array}{l}65 \\
64 \\
64 \\
63 \\
63 \\
57 \\
57 \\
63 \\
65 \\
63 \\
61 \\
66 \\
64 \\
64 \\
64 \\
66 \\
66 \\
63 \\
67 \\
63 \\
63 \\
66\end{array}$ & 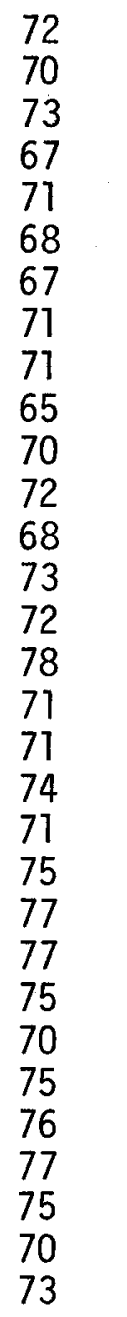 & $\begin{array}{l}68 \\
69 \\
68 \\
66 \\
66 \\
66 \\
66 \\
65 \\
64 \\
62 \\
64 \\
65 \\
65 \\
63 \\
64 \\
64 \\
63\end{array}$ & $\begin{array}{l}75 \\
74 \\
71 \\
70 \\
70 \\
70 \\
72 \\
72 \\
69 \\
70 \\
71 \\
69 \\
68 \\
72 \\
71 \\
68\end{array}$ & $\begin{array}{l}58 \\
57 \\
60 \\
61 \\
63 \\
62 \\
62 \\
61 \\
59 \\
67 \\
60 \\
59 \\
62 \\
60 \\
60 \\
59 \\
59 \\
57 \\
57 \\
57 \\
57 \\
57 \\
56 \\
54 \\
54 \\
55 \\
53\end{array}$ & $\begin{array}{l}63 \\
63 \\
65 \\
68 \\
69 \\
68 \\
68 \\
65 \\
65 \\
67 \\
65 \\
65 \\
65 \\
65 \\
63 \\
61 \\
59 \\
62 \\
62 \\
62 \\
62 \\
60 \\
59 \\
57 \\
58 \\
59 \\
57 \\
56 \\
55 \\
55\end{array}$ & $\begin{array}{l}52 \\
51 \\
51 \\
49 \\
48 \\
48 \\
50 \\
47 \\
47 \\
47 \\
45 \\
45 \\
46 \\
48 \\
47 \\
47 \\
47 \\
49 \\
49 \\
49 \\
50\end{array}$ & $\begin{array}{l}53 \\
56 \\
54 \\
54 \\
51 \\
52 \\
51 \\
51 \\
49 \\
49 \\
49 \\
49 \\
51 \\
51 \\
50 \\
52 \\
54 \\
54 \\
53 \\
53 \\
53 \\
53 \\
52 \\
52 \\
52 \\
53 \\
51 \\
51\end{array}$ \\
\hline
\end{tabular}


Appendix Table 5. Daily maximum and minimum water temperatures (degrees F) for the Missouri River at Fort Benton during 1978.

\begin{tabular}{|c|c|c|c|c|c|c|c|c|c|c|c|c|c|c|}
\hline$\frac{\text { Day }}{1}$ & \multicolumn{2}{|c|}{$\begin{array}{r}\text { April } \\
\text { Min.Max } \\
\end{array}$} & \multicolumn{2}{|c|}{$\begin{array}{c}\text { May } \\
\text { Min.Max. }\end{array}$} & \multicolumn{2}{|c|}{$\begin{array}{c}\begin{array}{c}\text { June } \\
\text { Min.Max. }\end{array} \\
\end{array}$} & \multicolumn{2}{|c|}{$\begin{array}{c}\text { July } \\
\text { Min.Max. }\end{array}$} & \multicolumn{2}{|c|}{$\begin{array}{l}\text { Aug. } \\
\text { Min.Max. }\end{array}$} & \multicolumn{2}{|c|}{$\begin{array}{r}\text { Sept. } \\
\text { Min.Max. }\end{array}$} & \multicolumn{2}{|c|}{$\begin{array}{c}\text { Oct. } \\
\text { Min.Max. }\end{array}$} \\
\hline $\begin{array}{c}1 \\
2 \\
3 \\
4 \\
5 \\
6 \\
7 \\
8 \\
9 \\
10 \\
11 \\
12 \\
13 \\
14 \\
15 \\
16 \\
17 \\
18 \\
19 \\
20 \\
21 \\
22 \\
23 \\
24 \\
25 \\
26 \\
27 \\
28 \\
29 \\
30 \\
31\end{array}$ & $\begin{array}{l}36 \\
37 \\
36 \\
37 \\
38 \\
39 \\
41 \\
42 \\
42 \\
43 \\
43 \\
41 \\
43 \\
43 \\
43 \\
43 \\
43 \\
45 \\
43 \\
44 \\
46 \\
40\end{array}$ & $\begin{array}{l}40 \\
42 \\
41 \\
41 \\
42 \\
42 \\
43 \\
44 \\
48 \\
51 \\
50 \\
49 \\
49 \\
47 \\
48 \\
49 \\
47 \\
48 \\
49 \\
48 \\
48 \\
4\end{array}$ & $\begin{array}{l}50 \\
50 \\
50 \\
49 \\
48 \\
48 \\
47 \\
46 \\
48 \\
49 \\
48 \\
50 \\
50 \\
51 \\
52 \\
53 \\
52 \\
51 \\
51 \\
52 \\
53 \\
55 \\
54 \\
53 \\
52 \\
54\end{array}$ & $\begin{array}{l}56 \\
55 \\
53 \\
53 \\
52 \\
51 \\
50 \\
50 \\
51 \\
52 \\
52 \\
53 \\
54 \\
54 \\
55 \\
56 \\
55 \\
53 \\
55 \\
56 \\
57\end{array}$ & $\begin{array}{l}51 \\
53 \\
56 \\
59 \\
60 \\
60 \\
60 \\
60 \\
60 \\
60 \\
59 \\
56 \\
57 \\
58 \\
59 \\
60 \\
60 \\
61 \\
59 \\
58 \\
59 \\
60 \\
60 \\
62 \\
62 \\
63\end{array}$ & $\begin{array}{l}55 \\
56 \\
58 \\
63 \\
64 \\
64 \\
64 \\
64 \\
63 \\
63 \\
62 \\
60 \\
60 \\
61 \\
62 \\
62 \\
63 \\
64 \\
62 \\
60 \\
62 \\
62 \\
64 \\
66 \\
67 \\
67 \\
68 \\
64 \\
63\end{array}$ & 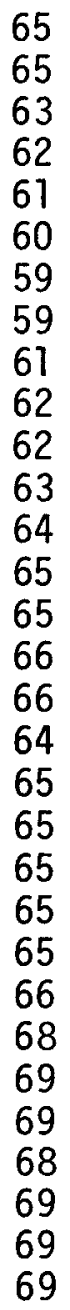 & 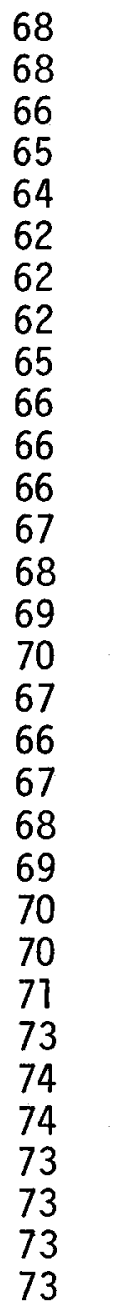 & 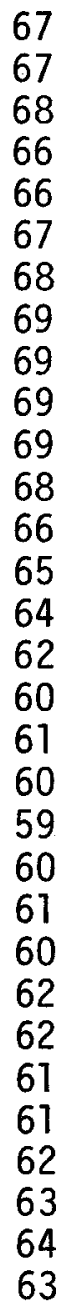 & $\begin{array}{l}69 \\
70 \\
71 \\
70 \\
69 \\
70 \\
72 \\
73 \\
74 \\
74 \\
73 \\
73 \\
72 \\
72\end{array}$ & $\begin{array}{l}63 \\
64 \\
64 \\
63 \\
64 \\
64 \\
63 \\
63 \\
62 \\
61 \\
58 \\
55 \\
53 \\
53 \\
54 \\
53 \\
53 \\
53 \\
51 \\
50 \\
51 \\
50 \\
50 \\
50 \\
52 \\
53 \\
54 \\
54 \\
54 \\
54 \\
53 \\
53 \\
53\end{array}$ & $\begin{array}{l}67 \\
67 \\
68 \\
68 \\
67 \\
68 \\
68 \\
67 \\
66 \\
63 \\
61 \\
56 \\
55 \\
57 \\
58 \\
56 \\
55 \\
53 \\
54 \\
55 \\
56 \\
55 \\
57 \\
58\end{array}$ & $\begin{array}{l}52 \\
52 \\
50 \\
50 \\
51 \\
51 \\
51 \\
50 \\
50 \\
49 \\
51 \\
50 \\
50 \\
48 \\
48 \\
48 \\
48 \\
49 \\
49 \\
49 \\
48 \\
48 \\
47 \\
48 \\
4\end{array}$ & $\begin{array}{l}57 \\
56 \\
54 \\
54 \\
54 \\
56 \\
55 \\
55 \\
56 \\
54 \\
54 \\
53 \\
52 \\
53 \\
52 \\
52 \\
53 \\
52 \\
51 \\
53 \\
50 \\
52\end{array}$ \\
\hline
\end{tabular}


Appendix Table 6. Daily maximum and minimum water temperatures (degrees F) for the Missouri River at Fort Benton during 1979.

\begin{tabular}{|c|c|c|c|c|c|c|c|c|c|c|c|c|c|c|}
\hline $\begin{array}{c}\text { Day } \\
1\end{array}$ & \multicolumn{2}{|c|}{$\begin{array}{r}\text { Apri } 1 \\
\text { Min.Max } \\
\end{array}$} & \multicolumn{2}{|c|}{$\begin{array}{c}\text { May } \\
\text { Min.Max. }\end{array}$} & \multicolumn{2}{|c|}{$\begin{array}{c}\begin{array}{c}\text { June } \\
\text { Min.Max. }\end{array} \\
\end{array}$} & \multicolumn{2}{|c|}{$\begin{array}{c}\text { July } \\
\text { Min.Max. } \\
\end{array}$} & \multicolumn{2}{|c|}{$\begin{array}{l}\text { Aug. } \\
\text { Min.Max. }\end{array}$} & \multicolumn{2}{|c|}{$\begin{array}{r}\text { Sept. } \\
\text { Min.Max. }\end{array}$} & \multicolumn{2}{|c|}{$\begin{array}{c}\text { Oct. } \\
\text { Min.Max. }\end{array}$} \\
\hline $\begin{array}{r}1 \\
2 \\
3 \\
4 \\
5 \\
6 \\
7 \\
8 \\
9 \\
10 \\
11 \\
12 \\
13 \\
14 \\
15 \\
16 \\
17 \\
18 \\
19 \\
20 \\
21 \\
22 \\
23 \\
24 \\
25 \\
26 \\
27 \\
28 \\
29 \\
30 \\
31\end{array}$ & $\begin{array}{l}47 \\
48 \\
50 \\
52 \\
52\end{array}$ & $\begin{array}{l}52 \\
50 \\
55 \\
57 \\
56 \\
57\end{array}$ & $\begin{array}{l}53 \\
52 \\
51 \\
51 \\
52 \\
52 \\
50 \\
49 \\
50 \\
49 \\
52 \\
52 \\
54 \\
55 \\
57 \\
59 \\
57 \\
57 \\
55 \\
54 \\
52 \\
53 \\
54 \\
54\end{array}$ & $\begin{array}{l}55 \\
57 \\
54 \\
53 \\
53 \\
53 \\
53 \\
57 \\
53 \\
56 \\
55 \\
56 \\
58 \\
62 \\
63 \\
63 \\
59 \\
59 \\
57 \\
58 \\
56 \\
57 \\
57\end{array}$ & $\begin{array}{l}52 \\
54 \\
58 \\
57 \\
58 \\
58 \\
55 \\
54 \\
55 \\
56 \\
58 \\
61 \\
66 \\
63 \\
61 \\
61 \\
61 \\
62 \\
62 \\
61 \\
60 \\
50\end{array}$ & $\begin{array}{l}57 \\
59 \\
62 \\
61 \\
61 \\
60 \\
56 \\
57 \\
57 \\
58 \\
65 \\
67 \\
67 \\
67 \\
66 \\
63 \\
67 \\
67 \\
62 \\
63 \\
63 \\
65 \\
67 \\
67 \\
69 \\
69 \\
72\end{array}$ & $\begin{array}{l}63 \\
65 \\
63 \\
64 \\
65 \\
66 \\
67 \\
69 \\
68 \\
71 \\
71 \\
68 \\
66 \\
69 \\
65 \\
65 \\
70 \\
69 \\
70 \\
71 \\
72 \\
73 \\
70 \\
69 \\
65 \\
67 \\
67 \\
67 \\
66 \\
68 \\
68\end{array}$ & $\begin{array}{l}71 \\
70 \\
70 \\
67 \\
71 \\
73 \\
75 \\
73 \\
73 \\
75 \\
72 \\
72 \\
72 \\
72 \\
70 \\
73 \\
72 \\
74 \\
76 \\
77 \\
77 \\
79 \\
77 \\
74 \\
73 \\
03\end{array}$ & $\begin{array}{l}68 \\
69 \\
69 \\
69 \\
69 \\
70 \\
69 \\
69 \\
69 \\
69 \\
68 \\
68 \\
69 \\
69 \\
67 \\
66 \\
63 \\
63\end{array}$ & 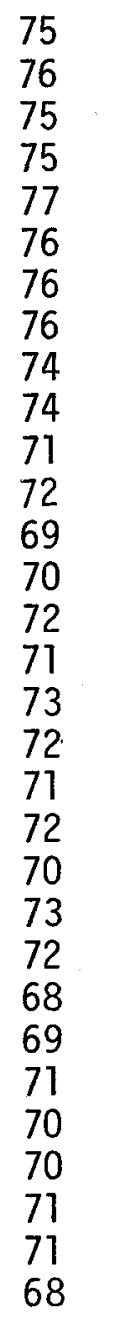 & 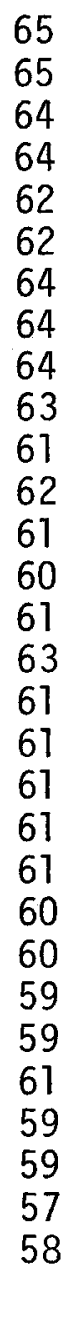 & $\begin{array}{l}68 \\
69 \\
70 \\
67 \\
68 \\
68 \\
68 \\
69 \\
67 \\
64 \\
64 \\
64 \\
65 \\
63 \\
64 \\
64 \\
65 \\
65 \\
66 \\
65 \\
65 \\
64\end{array}$ & $\begin{array}{l}55 \\
56 \\
52 \\
53 \\
54 \\
53 \\
56 \\
54 \\
52 \\
53 \\
55 \\
54 \\
52 \\
53 \\
55 \\
54 \\
53 \\
50 \\
49 \\
45 \\
46 \\
46 \\
46 \\
45 \\
46 \\
47 \\
46 \\
46 \\
46 \\
46 \\
43 \\
43\end{array}$ & $\begin{array}{l}57 \\
57 \\
57 \\
56 \\
57 \\
58 \\
60 \\
55 \\
56 \\
57 \\
57 \\
57 \\
57 \\
57 \\
56 \\
57 \\
55 \\
52 \\
51 \\
47 \\
47 \\
48 \\
49 \\
48 \\
48 \\
50 \\
48 \\
49 \\
48 \\
47 \\
45\end{array}$ \\
\hline
\end{tabular}


Appendix Table 7. Daily maximum and minimum water temperatures (degrees F) for the Missouri River near Coal Banks Landing during 1976.

\begin{tabular}{|c|c|c|c|c|c|c|c|c|c|c|c|}
\hline \multirow{2}{*}{$\frac{\text { Day }}{1}$} & $\begin{array}{r}\text { April } \\
\text { Min.Max } \\
\end{array}$ & $\begin{array}{c}\text { May } \\
\text { Min.Max. } \\
\end{array}$ & $\begin{array}{c}\begin{array}{c}\text { June } \\
\text { Min.Max. }\end{array} \\
\end{array}$ & \multicolumn{2}{|c|}{$\begin{array}{c}\text { July } \\
\text { Min.Max. }\end{array}$} & \multicolumn{2}{|c|}{$\begin{array}{l}\text { Aug. } \\
\text { Min.Max. }\end{array}$} & \multicolumn{2}{|c|}{$\begin{array}{c}\text { Sept. } \\
\text { Min.Max. }\end{array}$} & \multicolumn{2}{|c|}{$\begin{array}{c}\text { Oct. } \\
\text { Min.Max. }\end{array}$} \\
\hline & & & & & & 70 & 74 & 65 & 70 & 59 & 62 \\
\hline 2 & & & & & & 68 & 72 & 66 & 70 & 59 & 67 \\
\hline 3 & & & & & & 70 & 75 & 65 & 70 & 56 & 60 \\
\hline 4 & & & & & & 71 & 73 & 65 & 70 & 54 & 56 \\
\hline 5 & & & & & & 69 & 74 & 65 & 70 & 52 & 54 \\
\hline 6 & & & & & & 69 & 73 & 63 & 67 & 50 & 53 \\
\hline 7 & & & & & & 69 & 71 & 59 & 62 & 50 & 53 \\
\hline 8 & & & & & & 66 & 70 & 58 & 63 & 51 & 55 \\
\hline 9 & & & & & & 67 & 69 & 58 & 64 & 52 & 56 \\
\hline 10 & & & & & & 65 & 67 & 58 & 64 & 53 & 55 \\
\hline 11 & & & & & & 65 & 70 & 59 & 62 & 53 & 56 \\
\hline 12 & & & & & & 67 & 72 & 60 & 63 & 53 & 56 \\
\hline 13 & & & & & & 68 & 71 & 58 & 64 & 53 & 55 \\
\hline 14. & & & & & & 67 & 72 & 60 & 64 & 48 & 53 \\
\hline 15 & & & & & & 67 & 72 & 59 & 64 & 46 & 48 \\
\hline 16 & & & & & & 67 & 70 & 60 & 64 & 44 & 46 \\
\hline 17 & & & & & & 65 & 68 & 63 & 67 & 43 & 45 \\
\hline 18 & & & & & & 65 & 68 & 67 & 64 & 42 & 45 \\
\hline 19 & & & & & & 65 & 67 & 58 & 62 & 43 & 45 \\
\hline 20 & & & & & & 65 & 68 & 57 & 62 & 43 & 46 \\
\hline 21 & & & & & & 63 & 68 & 57 & 63 & 43 & 46 \\
\hline 22 & & & & & & 65 & 71 & 58 & 63 & 43 & 45 \\
\hline 23 & & & & 70 & 74 & 67 & 69 & 58 & 62 & 42 & 44 \\
\hline 24 & & & & 71 & 75 & 66 & 71 & 59 & 63 & 47 & 42 \\
\hline 25 & & & & 69 & 74 & 68 & 73 & 60 & 63 & 41 & 44 \\
\hline 26 & & & & 71 & 76 & 63 & 69 & 60 & 64 & 44 & 46 \\
\hline 27 & & & & 69 & 73 & 61 & 64 & 58 & 62 & 44 & 46 \\
\hline 28 & & & & 69 & 74 & 61 & 66 & 57 & 62 & 45 & 47 \\
\hline 29 & & & & 69 & 74 & 63 & 68 & 57 & 63 & 45 & 47 \\
\hline 30 & & & & 69 & 72 & 65 & 68 & 58 & 62 & 44 & 46 \\
\hline 31 & & & & 68 & 74 & 65 & 70 & & & 43 & 45 \\
\hline
\end{tabular}


Appendix Table 8. Daily maximum and minimum water temperatures (degrees $F$ ) for the Missouri River near Coal Banks Landing during 1977.

\begin{tabular}{|c|c|c|c|c|c|c|c|c|c|c|c|c|c|}
\hline Day & $\begin{array}{r}\text { Apri1 } \\
\text { Min.Max } \\
\end{array}$ & \multicolumn{2}{|c|}{$\begin{array}{c}\text { May } \\
\text { Min.Max. }\end{array}$} & \multicolumn{2}{|c|}{$\begin{array}{c}\text { June } \\
\text { Min.Max. }\end{array}$} & \multicolumn{2}{|c|}{$\begin{array}{c}\text { July } \\
\text { Min.Max. }\end{array}$} & \multicolumn{2}{|c|}{$\begin{array}{c}\text { Aug. } \\
\text { Min.Max. }\end{array}$} & \multicolumn{2}{|c|}{$\begin{array}{l}\text { Sept. } \\
\text { Min.Max. }\end{array}$} & \multicolumn{2}{|c|}{$\begin{array}{c}\text { Oct. } \\
\text { Min.Max. }\end{array}$} \\
\hline $\begin{array}{r}1 \\
2 \\
3 \\
4 \\
5 \\
6 \\
7 \\
8 \\
9 \\
10 \\
11 \\
12 \\
13 \\
14 \\
15 \\
16 \\
17 \\
18 \\
19 \\
20 \\
21 \\
22 \\
23 \\
24 \\
25 \\
26 \\
27 \\
28 \\
29 \\
30 \\
31\end{array}$ & $\begin{array}{ll}39 & 43 \\
39 & 42 \\
37 & 40 \\
40 & 45 \\
43 & 49 \\
45 & 52 \\
47 & 53 \\
49 & 55 \\
52 & 56 \\
52 & 56 \\
51 & 55 \\
51 & 56 \\
51 & 57 \\
51 & 54 \\
50 & 56 \\
52 & 58 \\
51 & 55 \\
49 & 55 \\
50 & 53 \\
50 & 53 \\
49 & 53 \\
49 & 56 \\
52 & 58 \\
53 & 60 \\
55 & 61 \\
56 & 61 \\
56 & 62 \\
57 & 63 \\
58 & 64 \\
58 & 64\end{array}$ & $\begin{array}{l}57 \\
55 \\
58 \\
55 \\
52 \\
53 \\
52 \\
56 \\
57 \\
61 \\
59 \\
58 \\
59 \\
61 \\
56 \\
55 \\
53 \\
51 \\
53 \\
52 \\
54 \\
55 \\
58 \\
59 \\
59 \\
58 \\
61 \\
58 \\
55 \\
56 \\
59\end{array}$ & $\begin{array}{l}61 \\
62 \\
63 \\
59 \\
57 \\
56 \\
59 \\
61 \\
64 \\
65 \\
62 \\
65 \\
66 \\
66 \\
62 \\
58 \\
56 \\
54 \\
54 \\
57 \\
60 \\
62 \\
63 \\
63 \\
61 \\
65 \\
64 \\
62 \\
61 \\
64 \\
67\end{array}$ & $\begin{array}{l}63 \\
64 \\
63 \\
65 \\
67 \\
68 \\
72 \\
72 \\
70 \\
69 \\
65 \\
65 \\
63 \\
65 \\
67 \\
67 \\
65 \\
67 \\
69 \\
67 \\
68 \\
69 \\
70 \\
71 \\
71 \\
71 \\
71 \\
69 \\
67 \\
65\end{array}$ & $\begin{array}{l}69 \\
68 \\
68 \\
72 \\
74 \\
76 \\
78 \\
76 \\
75 \\
72 \\
68 \\
66 \\
68 \\
70 \\
72 \\
69 \\
71 \\
74 \\
75 \\
71 \\
73 \\
75 \\
76 \\
77 \\
77 \\
77 \\
75 \\
73 \\
70 \\
73\end{array}$ & $\begin{array}{l}67 \\
70 \\
66 \\
66 \\
65 \\
67 \\
65 \\
64 \\
65 \\
68 \\
65 \\
67 \\
69 \\
66 \\
69 \\
70 \\
72 \\
71 \\
70 \\
69 \\
68 \\
73 \\
75 \\
74 \\
69 \\
69 \\
72 \\
73 \\
71 \\
68 \\
68\end{array}$ & $\begin{array}{l}74 \\
74 \\
73 \\
70 \\
72 \\
71 \\
69 \\
71 \\
72 \\
70 \\
71 \\
73 \\
71 \\
73 \\
75 \\
77 \\
76 \\
74 \\
75 \\
74 \\
75 \\
79 \\
80 \\
77 \\
73 \\
74 \\
78 \\
79 \\
77 \\
70 \\
74\end{array}$ & $\begin{array}{l}70 \\
71 \\
72 \\
69 \\
65 \\
67 \\
69 \\
69 \\
68 \\
64 \\
65 \\
68 \\
69 \\
64 \\
63 \\
65 \\
67 \\
66 \\
68 \\
67 \\
66 \\
66 \\
65 \\
67 \\
64 \\
62 \\
62 \\
61 \\
60 \\
58 \\
57\end{array}$ & $\begin{array}{l}76 \\
77 \\
74 \\
71 \\
71 \\
72 \\
74 \\
74 \\
73 \\
71 \\
72 \\
72 \\
70 \\
69 \\
67 \\
71 \\
72 \\
73 \\
72 \\
71 \\
72 \\
70 \\
70 \\
70 \\
68 \\
66 \\
65 \\
64 \\
63 \\
60 \\
64\end{array}$ & $\begin{array}{l}60 \\
58 \\
61 \\
61 \\
65 \\
64 \\
64 \\
61 \\
59 \\
60 \\
61 \\
61 \\
60 \\
61 \\
60 \\
58 \\
57 \\
55 \\
58 \\
59 \\
58 \\
56 \\
56 \\
55 \\
53 \\
55 \\
53 \\
54 \\
53 \\
53\end{array}$ & $\begin{array}{l}64 \\
63 \\
65 \\
67 \\
68 \\
69 \\
69 \\
64 \\
64 \\
67 \\
65 \\
65 \\
65 \\
66 \\
64 \\
60 \\
58 \\
61 \\
61 \\
61 \\
60 \\
61 \\
59 \\
57 \\
58 \\
58 \\
57 \\
55 \\
54 \\
54\end{array}$ & $\begin{array}{l}52 \\
50 \\
51 \\
50 \\
48 \\
47 \\
49 \\
49 \\
46 \\
44 \\
44 \\
46 \\
49 \\
48 \\
46 \\
48 \\
49 \\
48 \\
49 \\
49 \\
48 \\
48 \\
48 \\
48 \\
49 \\
47 \\
45 \\
47 \\
49 \\
47 \\
46\end{array}$ & $\begin{array}{l}53 \\
55 \\
53 \\
51 \\
51 \\
51 \\
51 \\
51 \\
50 \\
48 \\
48 \\
50 \\
51 \\
50 \\
50 \\
51 \\
52 \\
52 \\
52 \\
51 \\
51 \\
51 \\
51 \\
51 \\
50 \\
49 \\
50 \\
50 \\
51 \\
50 \\
48\end{array}$ \\
\hline
\end{tabular}


Appendix Table 9. Daily maximum and minimum water temperatures (degrees F) for the Missouri River near Coal Banks Landing during 1978.

\begin{tabular}{|c|c|c|c|c|c|c|c|c|c|c|c|c|c|c|}
\hline$\frac{\text { Day }}{1}$ & \multicolumn{2}{|c|}{$\begin{array}{r}\text { April } \\
\text { Min.Max } \\
\end{array}$} & \multicolumn{2}{|c|}{$\begin{array}{c}\text { May } \\
\text { Min.Max. }\end{array}$} & \multicolumn{2}{|c|}{$\begin{array}{c}\text { June } \\
\text { Min.Max. }\end{array}$} & \multicolumn{2}{|c|}{$\begin{array}{c}\text { July } \\
\text { Min.Max. }\end{array}$} & \multicolumn{2}{|c|}{$\begin{array}{c}\text { Aug. } \\
\text { Min.Max. }\end{array}$} & \multicolumn{2}{|c|}{$\begin{array}{r}\text { Sept. } \\
\text { Min.Max. }\end{array}$} & \multicolumn{2}{|c|}{$\begin{array}{c}\text { Oct. } \\
\text { Min.Max. }\end{array}$} \\
\hline $\begin{array}{r}1 \\
2 \\
3 \\
4 \\
5 \\
6 \\
7 \\
8 \\
9 \\
10 \\
11 \\
12 \\
13 \\
14 \\
15 \\
16 \\
17 \\
18 \\
19 \\
20 \\
21 \\
22 \\
23 \\
24 \\
25 \\
26 \\
27 \\
28 \\
29 \\
30 \\
31\end{array}$ & $\begin{array}{l}45 \\
44 \\
45 \\
44 \\
43 \\
42 \\
43 \\
43 \\
45 \\
44 \\
44 \\
44 \\
47 \\
49 \\
49 \\
50 \\
52 \\
51\end{array}$ & $\begin{array}{l}46 \\
46 \\
46 \\
47 \\
46 \\
44 \\
46 \\
46 \\
46 \\
47 \\
46 \\
49 \\
51 \\
52 \\
51 \\
53 \\
53 \\
54\end{array}$ & $\begin{array}{l}52 \\
53 \\
51 \\
49 \\
48 \\
48 \\
47 \\
46 \\
49 \\
50 \\
52 \\
52 \\
51 \\
53 \\
55 \\
55 \\
53 \\
51 \\
50 \\
52 \\
54 \\
56 \\
56 \\
53 \\
52 \\
51 \\
52\end{array}$ & $\begin{array}{l}55 \\
56 \\
53 \\
51 \\
50 \\
49 \\
48 \\
50 \\
50 \\
52 \\
53 \\
52 \\
53 \\
55 \\
57 \\
57 \\
56 \\
53 \\
54 \\
55 \\
58 \\
58 \\
58 \\
56 \\
54 \\
54 \\
55 \\
56 \\
56 \\
56 \\
55\end{array}$ & $\begin{array}{l}51 \\
53 \\
56 \\
59 \\
62 \\
63 \\
61 \\
62 \\
61 \\
60 \\
58 \\
58 \\
58 \\
60 \\
62 \\
61 \\
60 \\
61 \\
59 \\
59 \\
69\end{array}$ & $\begin{array}{l}54 \\
57 \\
60 \\
62 \\
64 \\
65 \\
63 \\
63 \\
63 \\
62 \\
60 \\
59 \\
61 \\
62 \\
63 \\
63 \\
63 \\
63 \\
63 \\
62 \\
62 \\
62 \\
65 \\
67 \\
68 \\
70\end{array}$ & $\begin{array}{l}68 \\
68 \\
67 \\
65 \\
63 \\
62 \\
60 \\
62 \\
62 \\
64 \\
65 \\
65 \\
66 \\
68 \\
69 \\
71 \\
66 \\
65 \\
63 \\
64 \\
65 \\
67 \\
68 \\
69\end{array}$ & $\begin{array}{l}70 \\
70 \\
68 \\
67 \\
65 \\
63 \\
65 \\
65 \\
66 \\
66 \\
67 \\
68 \\
69 \\
69 \\
71 \\
72 \\
71 \\
67 \\
65 \\
66 \\
69 \\
71 \\
73 \\
71\end{array}$ & $\begin{array}{l}62 \\
60 \\
62 \\
64 \\
62 \\
63 \\
65 \\
65 \\
64 \\
64 \\
65 \\
65 \\
66\end{array}$ & $\begin{array}{l}63 \\
65 \\
67 \\
67 \\
66 \\
67 \\
69 \\
68 \\
67 \\
67 \\
69 \\
69 \\
69\end{array}$ & $\begin{array}{l}65 \\
65 \\
66 \\
66 \\
67 \\
67 \\
67 \\
64 \\
62 \\
63 \\
59 \\
54 \\
54 \\
54 \\
55 \\
54 \\
53 \\
51 \\
50 \\
50 \\
50 \\
52 \\
53\end{array}$ & $\begin{array}{l}68 \\
69 \\
70 \\
69 \\
69 \\
70 \\
69 \\
67 \\
66 \\
65 \\
63 \\
59 \\
54 \\
57 \\
58 \\
56 \\
56 \\
56 \\
55 \\
52 \\
54\end{array}$ & $\begin{array}{l}54 \\
53 \\
52 \\
51 \\
50 \\
50 \\
50 \\
51 \\
51 \\
52 \\
52 \\
50 \\
47 \\
47 \\
48 \\
49 \\
50 \\
49 \\
50 \\
50 \\
49 \\
47 \\
48 \\
46 \\
45\end{array}$ & $\begin{array}{l}57 \\
55 \\
54 \\
53 \\
53 \\
53 \\
53 \\
55 \\
55 \\
55 \\
53 \\
52 \\
50 \\
51 \\
52 \\
51 \\
51 \\
52 \\
53 \\
52 \\
52 \\
49 \\
50 \\
49 \\
49 \\
47 \\
46 \\
45\end{array}$ \\
\hline
\end{tabular}


Appendix Table 10. Daily maximum and minimum water temperatures (degrees

F) for the Missouri River near Coal Banks Landing during 1979.

April May June July Aug. Sept. Oct.

Day Min.Max Min.Max. Min.Max. Min.Max. Min.Max. Min.Max. Min.Max.

$\begin{array}{lllllllllllllll}1 & 36 & 38 & 49 & 51 & 54 & 56 & 66 & 69 & 70 & 74 & 64 & 69 & 55 & 58\end{array}$

$\begin{array}{lllllllllllllll}2 & 37 & 40 & 47 & 52 & 56 & 59 & 65 & 69 & 70 & 74 & 65 & 69 & 54 & 56\end{array}$

$\begin{array}{lllllllllllllll}3 & 38 & 40 & 47 & 51 & 58 & 61 & 64 & 70 & 70 & 74 & 65 & 71 & 51 & 56\end{array}$

$\begin{array}{lllllllllllllll}4 & 37 & 39 & 47 & 48 & 60 & 62 & 67 & 68 & 70 & 74 & 65 & 68 & 52 & 56\end{array}$

$\begin{array}{lllllllllllllll}5 & 35 & 37 & 47 & 49 & 58 & 60 & 65 & 71 & 70 & 75 & 63 & 67 & 54 & 57\end{array}$

$\begin{array}{lllllllllllllll}6 & 35 & 40 & 47 & 49 & 58 & 59 & 68 & 74 & 70 & 75 & 63 & 68 & 53 & 57\end{array}$

$\begin{array}{lllllllllllllll}7 & 41 & 43 & 47 & 48 & 55 & 57 & 69 & 74 & 70 & 74 & 64 & 69 & 55 & 58\end{array}$

$\begin{array}{lllllllllllllll}8 & 41 & 45 & 46 & 47 & 54 & 57 & 71 & 74 & 70 & 74 & 64 & 69 & 53 & 55\end{array}$

$\begin{array}{lllllllllllllll}9 & 44 & 47 & 45 & 48 & 56 & 59 & 69 & 74 & 68 & 73 & 65 & 68 & 50 & 53\end{array}$

$\begin{array}{lllllllllllllll}10 & 42 & 45 & 45 & 50 & 58 & 60 & 70 & 74 & 68 & 73 & 62 & 65 & 51 & 57\end{array}$

$\begin{array}{lllllllllllllll}11 & 41 & 42 & 50 & 51 & 59 & 63 & 70 & 73 & 68 & 71 & 61 & 64 & 54 & 58\end{array}$

$\begin{array}{lllllllllllllll}12 & 40 & 41 & 49 & 52 & 61 & 67 & 68 & 71 & 66 & 69 & 60 & 63 & 55 & 58\end{array}$

$\begin{array}{lllllllllllllll}13 & 41 & 43 & 50 & 54 & 64 & 67 & 67 & 71 & 66 & 69 & 60 & 65 & 53 & 56\end{array}$

$\begin{array}{lllllllllllllll}14 & 41 & 44 & 51 & 56 & 63 & 67 & 67 & 70 & 63 & 67 & 60 & 64 & 53 & 56\end{array}$

$\begin{array}{lllllllllllllll}15 & 43 & 47 & 54 & 59 & 62 & 65 & 66 & 71 & 65 & 71 & 60 & 65 & 55 & 56\end{array}$

$\begin{array}{lllllllllllllll}16 & 45 & 48 & 56 & 58 & 62 & 65 & 67 & 72 & 67 & 72 & 61 & 65 & 53 & 56\end{array}$

$\begin{array}{lllllllllllllll}17 & 47 & 51 & 54 & 57 & 62 & 67 & 67 & 74 & 67 & 72 & 61 & 65 & 53 & 55\end{array}$

$\begin{array}{lllllllllllllll}18 & 46 & 50 & 55 & 56 & 64 & 67 & 70 & 76 & 68 & 72 & 61 & 65 & 50 & 52\end{array}$

$\begin{array}{lllllllllllllll}19 & 45 & 48 & 54 & 57 & 63 & 65 & 72 & 76 & 68 & 72 & 62 & 65 & 49 & 51\end{array}$

$\begin{array}{lllllllllllllll}20 & 45 & 47 & 54 & 56 & 61 & 64 & 72 & 77 & 68 & 71 & 61 & 65 & 47 & 49\end{array}$

$\begin{array}{lllllllllllllll}21 & 45 & 47 & 55 & 58 & 62 & 64 & 73 & 78 & 68 & 70 & 61 & 64 & 45 & 47\end{array}$

$\begin{array}{lllllllllllllll}22 & 44 & 46 & 56 & 58 & 62 & 64 & 73 & 76 & 67 & 70 & 60 & 64 & 44 & 46\end{array}$

$\begin{array}{lllllllllllllll}23 & 42 & 44 & 57 & 59 & 63 & 66 & 70 & 74 & 67 & 72 & 60 & 64 & 46 & 49\end{array}$

$\begin{array}{lllllllllllllll}24 & 47 & 43 & 59 & 60 & 64 & 68 & 69 & 73 & 67 & 71 & 60 & 64 & 46 & 49\end{array}$

$\begin{array}{lllllllllllllll}25 & 42 & 46 & 59 & 62 & 64 & 69 & 65 & 69 & 65 & 67 & 59 & 63 & 46 & 49\end{array}$

$\begin{array}{lllllllllllllll}26 & 45 & 48 & 61 & 63 & 66 & 72 & 63 & 67 & 65 & 70 & 61 & 62 & 47 & 49\end{array}$

$\begin{array}{lllllllllllllll}27 & 45 & 49 & 61 & 63 & 69 & 72 & 66 & 72 & 66 & 71 & 60 & 63 & 46 & 48\end{array}$

$\begin{array}{lllllllllllllll}28 & 48 & 52 & 58 & 61 & 68 & 74 & 68 & 72 & 65 & 69 & 59 & 61 & 46 & 47\end{array}$

$\begin{array}{lllllllllllllll}29 & 50 & 53 & 55 & 58 & 70 & 74 & 68 & 71 & 65 & 70 & 57 & 61 & 46 & 48\end{array}$

$\begin{array}{lllllllllllllll}30 & 50 & 52 & 55 & 56 & 69 & 72 & 68 & 73 & 66 & 71 & 58 & 59 & 44 & 46\end{array}$

$\begin{array}{lllllllll}31 & 54 & 56 & 69 & 74 & 66 & 69 & 43 & 44\end{array}$ 
Appendix Table 11. Daily maximum and minmum water temperatures (degrees $F$ ) for the Missouri River near Robinson Bridge during 1976.

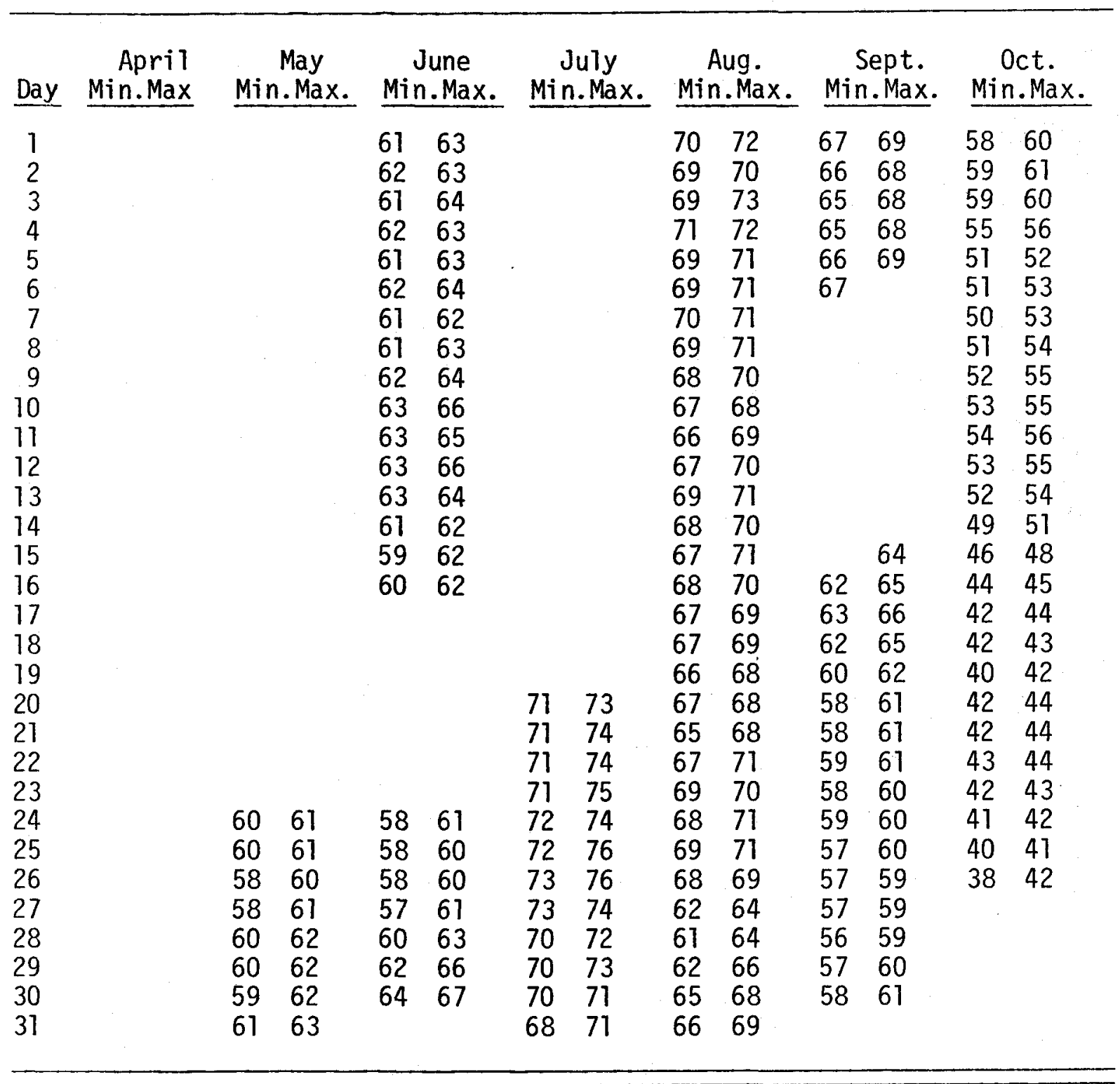


Appendix Table 12. Daily maximum and minimum water temperatures (degrees F) for the Missouri River near Robinson Bridge during 1977.

\begin{tabular}{|c|c|c|c|c|c|c|c|c|c|c|c|c|c|c|}
\hline $\begin{array}{c}\text { Day } \\
1 \\
1 \\
2 \\
3 \\
4 \\
5 \\
6 \\
7 \\
8 \\
9 \\
10 \\
11 \\
12 \\
13\end{array}$ & \multicolumn{2}{|c|}{$\begin{array}{r}\text { April } \\
\text { Min.Max } \\
\end{array}$} & \multicolumn{2}{|c|}{$\begin{array}{c}\text { May } \\
\text { Min.Max. } \\
\end{array}$} & \multicolumn{2}{|c|}{$\begin{array}{c}\text { June } \\
\text { Min.Max. }\end{array}$} & \multicolumn{2}{|c|}{$\begin{array}{c}\text { July } \\
\text { Min.Max. }\end{array}$} & \multicolumn{2}{|c|}{$\begin{array}{l}\text { Aug. } \\
\text { Min.Max. }\end{array}$} & \multicolumn{2}{|c|}{$\begin{array}{l}\text { Sept. } \\
\text { Min.Max. }\end{array}$} & \multicolumn{2}{|c|}{$\begin{array}{c}\text { Oct. } \\
\text { Min.Max. }\end{array}$} \\
\hline $\begin{array}{l}1 \\
2 \\
3 \\
4 \\
5 \\
6 \\
7 \\
8 \\
9 \\
10 \\
11 \\
12 \\
13 \\
14 \\
15 \\
16 \\
17 \\
18 \\
19 \\
20 \\
21 \\
22 \\
23 \\
24 \\
25 \\
26 \\
27 \\
28 \\
29 \\
30 \\
31\end{array}$ & $\begin{array}{l}55 \\
53 \\
54 \\
54 \\
52 \\
52 \\
51 \\
50 \\
52 \\
54 \\
55 \\
57 \\
58 \\
60 \\
59 \\
60 \\
62\end{array}$ & $\begin{array}{l}57 \\
57 \\
57 \\
58 \\
55 \\
55 \\
54 \\
53 \\
53 \\
57 \\
59 \\
60 \\
62 \\
63 \\
63 \\
63 \\
64 \\
66\end{array}$ & $\begin{array}{l}61 \\
59 \\
60 \\
58 \\
54 \\
54 \\
56 \\
60 \\
62 \\
65 \\
65 \\
63 \\
64 \\
64 \\
66 \\
60 \\
57 \\
55 \\
52 \\
52\end{array}$ & $\begin{array}{l}64 \\
62 \\
62 \\
60 \\
57 \\
57 \\
60 \\
62 \\
66 \\
67 \\
68 \\
67 \\
68 \\
68 \\
65 \\
60 \\
58 \\
55 \\
55 \\
56 \\
59 \\
62\end{array}$ & $\begin{array}{l}68 \\
67 \\
67 \\
68 \\
70 \\
71 \\
72 \\
72 \\
72 \\
70 \\
69 \\
65\end{array}$ & $\begin{array}{l}73 \\
69 \\
70 \\
73 \\
75 \\
76 \\
77 \\
77 \\
76 \\
74 \\
71 \\
73\end{array}$ & 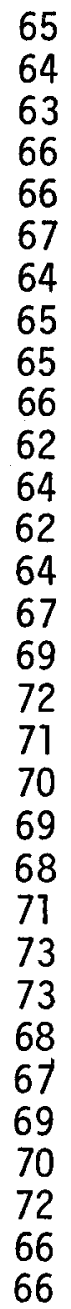 & 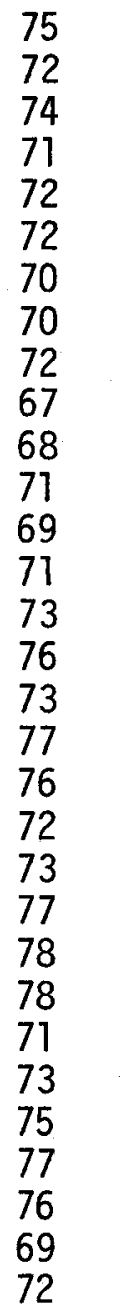 & 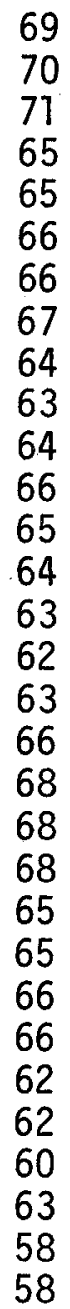 & $\begin{array}{l}75 \\
78 \\
75 \\
70 \\
71 \\
70 \\
69 \\
71 \\
68 \\
69 \\
69 \\
71 \\
68 \\
66 \\
65 \\
66 \\
69 \\
72 \\
71 \\
72 \\
72\end{array}$ & $\begin{array}{l}60 \\
60 \\
61 \\
62 \\
65 \\
65 \\
66 \\
62 \\
61 \\
61 \\
61 \\
61 \\
60 \\
62 \\
60 \\
60 \\
57 \\
56 \\
57 \\
58 \\
56 \\
56 \\
56 \\
55 \\
54\end{array}$ & $\begin{array}{l}64 \\
65 \\
66 \\
68 \\
68 \\
70 \\
71 \\
66 \\
66 \\
66 \\
66 \\
66 \\
66 \\
66 \\
62 \\
63 \\
59 \\
60 \\
60 \\
61 \\
60 \\
59 \\
60\end{array}$ & 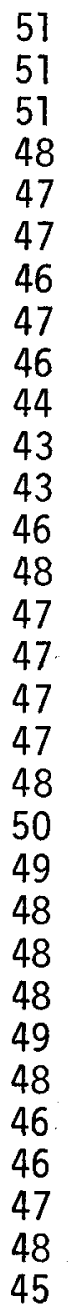 & $\begin{array}{l}53 \\
54 \\
52 \\
51 \\
49 \\
49 \\
49 \\
51 \\
49 \\
46 \\
46 \\
47 \\
48 \\
51 \\
50 \\
50 \\
49 \\
50 \\
51 \\
52 \\
51 \\
51 \\
50 \\
50\end{array}$ \\
\hline
\end{tabular}


Appendix Table 13. Daily maximum and minimum water temperatures (degrees $\mathrm{F}$ ) for the Missouri River near Robinson Bridge during 1978.

\begin{tabular}{|c|c|c|c|c|c|c|c|c|c|c|c|c|c|c|}
\hline $\begin{array}{c}\text { Day } \\
1 \\
2\end{array}$ & \multicolumn{2}{|c|}{$\begin{array}{r}\text { April } \\
\text { Min.Max } \\
\end{array}$} & \multicolumn{2}{|c|}{$\begin{array}{c}\text { May } \\
\text { Min.Max. }\end{array}$} & \multicolumn{2}{|c|}{$\begin{array}{c}\text { June } \\
\text { Min.Max. }\end{array}$} & \multicolumn{2}{|c|}{$\begin{array}{c}\text { July } \\
\text { Min.Max. }\end{array}$} & \multicolumn{2}{|c|}{$\begin{array}{l}\text { Aug. } \\
\text { Min.Max. }\end{array}$} & \multicolumn{2}{|c|}{$\begin{array}{r}\text { Sept. } \\
\text { Min.Max. }\end{array}$} & \multicolumn{2}{|c|}{$\begin{array}{c}\text { Oct. } \\
\text { Min.Max }\end{array}$} \\
\hline $\begin{array}{r}1 \\
2 \\
3 \\
4 \\
5 \\
6 \\
7 \\
8 \\
9 \\
10 \\
11 \\
12 \\
13 \\
14 \\
15 \\
16 \\
17 \\
18 \\
19 \\
20 \\
21 \\
22 \\
23 \\
24 \\
25 \\
26 \\
27 \\
28 \\
29 \\
30 \\
31\end{array}$ & $\begin{array}{l}52 \\
53 \\
53 \\
53 \\
53\end{array}$ & $\begin{array}{l}54 \\
54 \\
54 \\
54 \\
55\end{array}$ & $\begin{array}{l}53 \\
54 \\
57 \\
55 \\
53 \\
51 \\
50 \\
50 \\
51 \\
53 \\
53 \\
53 \\
54 \\
56 \\
57 \\
58 \\
57 \\
54 \\
53 \\
55 \\
57 \\
59 \\
59 \\
59 \\
57\end{array}$ & $\begin{array}{l}55 \\
59 \\
58 \\
57 \\
55 \\
53 \\
51 \\
53 \\
54 \\
56 \\
55 \\
56 \\
57 \\
58 \\
61 \\
60 \\
59 \\
57 \\
56 \\
58 \\
58 \\
60 \\
62\end{array}$ & $\begin{array}{l}55 \\
56 \\
58 \\
61 \\
62 \\
65 \\
65 \\
66 \\
66 \\
64 \\
62 \\
60 \\
61 \\
62 \\
63 \\
63 \\
63 \\
64 \\
64 \\
64 \\
61 \\
63 \\
67 \\
67 \\
68 \\
70\end{array}$ & $\begin{array}{l}58 \\
60 \\
63 \\
65 \\
67 \\
68 \\
68 \\
69 \\
69 \\
67 \\
64 \\
64 \\
63 \\
64 \\
65 \\
63\end{array}$ & 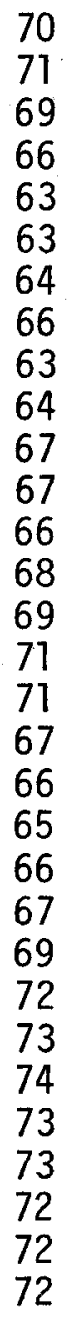 & 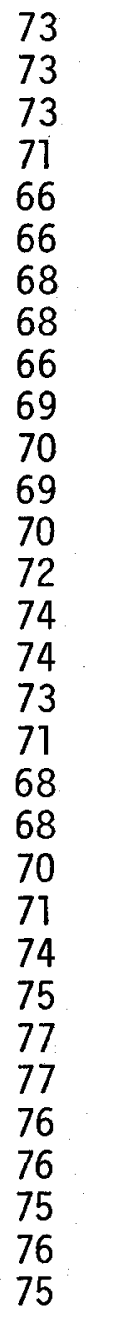 & 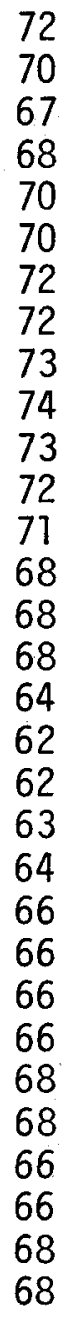 & 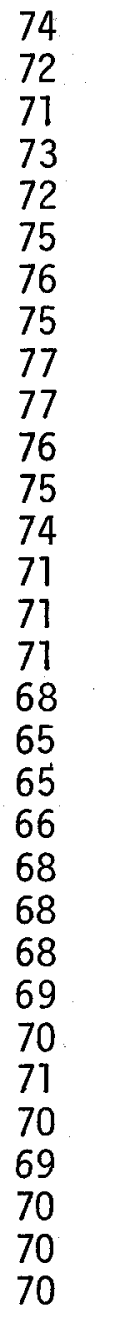 & $\begin{array}{l}67 \\
67 \\
68 \\
68 \\
69 \\
69 \\
70 \\
68 \\
65 \\
65 \\
62 \\
56 \\
55 \\
54 \\
56 \\
56 \\
54 \\
54 \\
52 \\
50 \\
52 \\
54 \\
56 \\
57 \\
58 \\
59 \\
59 \\
59 \\
60 \\
58 \\
57\end{array}$ & $\begin{array}{l}70 \\
70 \\
70 \\
71 \\
71 \\
71 \\
72 \\
71 \\
68 \\
66 \\
65 \\
62 \\
56 \\
57 \\
59 \\
58 \\
56 \\
56 \\
53 \\
53 \\
55 \\
57 \\
59 \\
59\end{array}$ & $\begin{array}{l}58 \\
55 \\
53 \\
53 \\
50 \\
51 \\
51 \\
52 \\
53 \\
53 \\
53 \\
52 \\
50 \\
48 \\
49 \\
50 \\
50 \\
50 \\
50 \\
50 \\
51 \\
40 \\
49 \\
48 \\
48 \\
47 \\
46 \\
45 \\
44 \\
45 \\
43 \\
43\end{array}$ & $\begin{array}{l}59 \\
57 \\
55 \\
54 \\
53 \\
53 \\
53 \\
54 \\
55 \\
55 \\
55 \\
54 \\
52 \\
50 \\
51 \\
57 \\
57 \\
52 \\
52 \\
52 \\
52 \\
51 \\
50 \\
49 \\
49 \\
48 \\
48 \\
46\end{array}$ \\
\hline
\end{tabular}


Appendix Table 14. Daily maximum and minimum water temperatures (degrees F) for the Missouri River near Robinson Bridge during 1979.

\begin{tabular}{|c|c|c|c|c|c|c|c|c|c|c|c|c|c|c|}
\hline$\frac{\text { Day }}{1}$ & \multicolumn{2}{|c|}{$\begin{array}{r}\text { Apri } \\
\text { Min.Max } \\
\end{array}$} & \multicolumn{2}{|c|}{$\begin{array}{c}\text { May } \\
\text { Min.Max. } \\
\end{array}$} & \multicolumn{2}{|c|}{$\begin{array}{c}\text { June } \\
\text { Min.Max. }\end{array}$} & \multicolumn{2}{|c|}{$\begin{array}{c}\begin{array}{c}\text { July } \\
\text { Min.Max. }\end{array} \\
\end{array}$} & \multicolumn{2}{|c|}{$\begin{array}{c}\text { Aug. } \\
\text { Min.Max. }\end{array}$} & \multicolumn{2}{|c|}{$\begin{array}{l}\text { Sept. } \\
\text { Min.Max. }\end{array}$} & \multicolumn{2}{|c|}{$\begin{array}{c}\text { Oct. } \\
\text { Min.Max. }\end{array}$} \\
\hline $\begin{array}{r}1 \\
2 \\
3 \\
4 \\
5 \\
6 \\
7 \\
8 \\
9 \\
10 \\
11 \\
12 \\
13 \\
14 \\
15 \\
16 \\
17 \\
18 \\
19 \\
20 \\
21 \\
22 \\
23 \\
24 \\
25 \\
26 \\
27 \\
28 \\
29 \\
30 \\
31\end{array}$ & $\begin{array}{l}47 \\
44 \\
44 \\
44 \\
46 \\
47 \\
50 \\
50 \\
51\end{array}$ & $\begin{array}{l}50 \\
49 \\
45 \\
45 \\
47 \\
49 \\
51 \\
52 \\
53 \\
54\end{array}$ & $\begin{array}{l}51 \\
50 \\
51 \\
49 \\
49 \\
49 \\
49 \\
48 \\
48 \\
48 \\
48 \\
52 \\
52 \\
54 \\
55 \\
56 \\
60 \\
59 \\
59 \\
58 \\
58 \\
57 \\
58 \\
50\end{array}$ & $\begin{array}{l}53 \\
53 \\
52 \\
50 \\
50 \\
51 \\
50 \\
50 \\
50 \\
53 \\
54 \\
55 \\
57 \\
59 \\
61 \\
62 \\
60 \\
60 \\
60 \\
60\end{array}$ & $\begin{array}{l}57 \\
58 \\
60 \\
62 \\
63 \\
61 \\
59 \\
57 \\
59 \\
60 \\
63 \\
64 \\
66 \\
67 \\
66 \\
65 \\
64 \\
64 \\
65 \\
65 \\
66 \\
64 \\
64\end{array}$ & $\begin{array}{l}60 \\
62 \\
63 \\
65 \\
65 \\
63 \\
60 \\
60 \\
62 \\
65 \\
66 \\
68 \\
70 \\
68 \\
67 \\
67 \\
66 \\
67 \\
69 \\
67 \\
67 \\
67 \\
69 \\
70 \\
70 \\
72\end{array}$ & $\begin{array}{l}70 \\
69 \\
68 \\
70 \\
69 \\
69 \\
71 \\
72 \\
73 \\
73 \\
74 \\
73\end{array}$ & 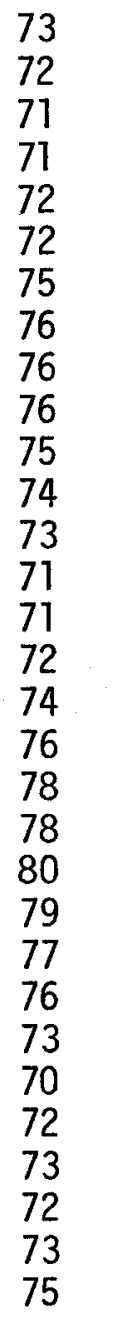 & $\begin{array}{l}73 \\
73 \\
73 \\
72 \\
72 \\
73 \\
74 \\
74 \\
72 \\
72 \\
72 \\
71 \\
70 \\
68 \\
|\mathbf{y}| \mid \\
65 \\
64 \\
68 \\
69 \\
71 \\
71\end{array}$ & $\begin{array}{l}76 \\
76 \\
76 \\
76 \\
75 \\
77 \\
76 \\
75 \\
76 \\
74 \\
73 \\
71 \\
69 \\
67 \\
69 \\
72 \\
73 \\
73 \\
73 \\
73 \\
72 \\
71 \\
72 \\
72 \\
71 \\
69 \\
70 \\
70\end{array}$ & 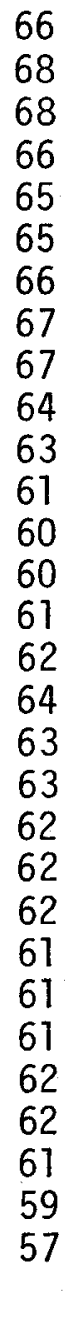 & $\begin{array}{l}69 \\
70 \\
72 \\
69 \\
68 \\
68 \\
69 \\
69 \\
70 \\
66 \\
64 \\
62 \\
63 \\
63 \\
65 \\
66 \\
67 \\
66 \\
66 \\
65 \\
65 \\
65 \\
64 \\
64 \\
64\end{array}$ & $\begin{array}{l}56 \\
54 \\
54 \\
53 \\
55 \\
55 \\
56 \\
53 \\
52 \\
53 \\
54 \\
56 \\
55 \\
55 \\
56\end{array}$ & $\begin{array}{l}58 \\
57 \\
56 \\
56 \\
57 \\
57 \\
58 \\
57 \\
54 \\
55 \\
56 \\
57 \\
57 \\
57 \\
57 \\
\end{array}$ \\
\hline
\end{tabular}


Appendix Table 15. Daily maximum and minimum water temperatures (degrees F) for the Marias River near the mouth during 1977.

\begin{tabular}{|c|c|c|c|c|c|c|c|c|c|c|c|c|c|c|}
\hline $\begin{array}{c}\text { Day } \\
1 \\
2\end{array}$ & \multicolumn{2}{|c|}{$\begin{array}{r}\text { April } \\
\text { Min.Max } \\
\end{array}$} & \multicolumn{2}{|c|}{$\begin{array}{c}\text { May } \\
\text { Min.Max. }\end{array}$} & \multicolumn{2}{|c|}{$\begin{array}{c}\text { June } \\
\text { Min.Max. }\end{array}$} & \multicolumn{2}{|c|}{$\begin{array}{c}\text { July } \\
\text { Min.Max. }\end{array}$} & \multicolumn{2}{|c|}{$\begin{array}{c}\text { Aug. } \\
\text { Min.Max. }\end{array}$} & \multicolumn{2}{|c|}{$\begin{array}{c}\text { Sept. } \\
\text { Min.Max. }\end{array}$} & \multicolumn{2}{|c|}{$\begin{array}{l}\text { Oct. } \\
\text { Min.Max. }\end{array}$} \\
\hline $\begin{array}{r}1 \\
2 \\
3 \\
4 \\
5 \\
6 \\
7 \\
8 \\
9 \\
10 \\
11 \\
12 \\
13 \\
14 \\
15 \\
16 \\
17 \\
18 \\
19 \\
20 \\
21 \\
22 \\
23 \\
24 \\
25 \\
26 \\
27 \\
28 \\
29 \\
30 \\
31\end{array}$ & $\begin{array}{l}37 \\
36 \\
36 \\
39 \\
42 \\
45 \\
48 \\
51 \\
53 \\
52 \\
49 \\
49 \\
50 \\
51 \\
48 \\
52 \\
48 \\
47 \\
47 \\
47 \\
47 \\
47 \\
48 \\
51 \\
53 \\
56\end{array}$ & $\begin{array}{l}43 \\
41 \\
40 \\
46 \\
51 \\
55 \\
58 \\
61 \\
60 \\
58 \\
58 \\
59 \\
60 \\
56 \\
59 \\
60 \\
56 \\
57 \\
53 \\
53 \\
53 \\
59 \\
62 \\
65 \\
65 \\
66 \\
65\end{array}$ & $\begin{array}{l}55 \\
54 \\
57 \\
52 \\
46 \\
49 \\
50 \\
58 \\
59 \\
63 \\
59 \\
58 \\
61 \\
64 \\
54 \\
51 \\
49 \\
47 \\
49 \\
50 \\
54 \\
57 \\
61 \\
61 \\
62 \\
58 \\
60 \\
55\end{array}$ & $\begin{array}{l}63 \\
63 \\
64 \\
59 \\
56 \\
54 \\
64 \\
66 \\
71 \\
71 \\
67 \\
71 \\
73 \\
70 \\
70 \\
64 \\
56 \\
55 \\
51 \\
52 \\
60\end{array}$ & $\begin{array}{l}64 \\
62 \\
66 \\
67 \\
70 \\
74 \\
72 \\
69 \\
66 \\
63 \\
63 \\
61 \\
60 \\
64 \\
65 \\
65 \\
65 \\
64 \\
66 \\
68 \\
65\end{array}$ & $\begin{array}{l}71 \\
72 \\
77 \\
79 \\
83 \\
82 \\
78 \\
79 \\
71 \\
65 \\
64 \\
69 \\
73 \\
72 \\
69 \\
73 \\
78 \\
77 \\
75 \\
75 \\
75\end{array}$ & 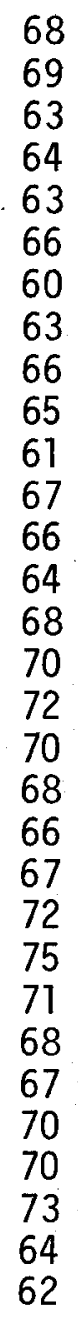 & $\begin{array}{l}76 \\
74 \\
73 \\
68 \\
74 \\
71 \\
71 \\
75 \\
75 \\
70 \\
74 \\
76 \\
70 \\
77 \\
79 \\
81 \\
75 \\
74 \\
77 \\
74 \\
79 \\
83 \\
84\end{array}$ & $\begin{array}{l}66 \\
70 \\
71 \\
68 \\
63 \\
65 \\
67 \\
67 \\
64 \\
60 \\
63 \\
67 \\
68 \\
63 \\
61 \\
62 \\
65 \\
69 \\
70\end{array}$ & $\begin{array}{l}80 \\
81 \\
76 \\
70 \\
74 \\
75 \\
77 \\
78 \\
72 \\
73 \\
75 \\
74 \\
71 \\
68 \\
69 \\
74 \\
77 \\
80 \\
78 \\
76 \\
78 \\
72\end{array}$ & $\begin{array}{l}60 \\
59 \\
62 \\
63 \\
67 \\
65 \\
65 \\
63 \\
57 \\
61 \\
61 \\
59 \\
59 \\
61 \\
61 \\
59 \\
56 \\
54 \\
56 \\
59 \\
57 \\
55 \\
53 \\
54 \\
51 \\
53 \\
51 \\
54 \\
53 \\
54\end{array}$ & $\begin{array}{l}67 \\
67 \\
70 \\
72 \\
74 \\
75 \\
73 \\
70 \\
67 \\
70 \\
68 \\
68 \\
68 \\
69 \\
66 \\
62 \\
59 \\
63 \\
63 \\
64 \\
63 \\
62 \\
61 \\
57 \\
60 \\
60 \\
57\end{array}$ & $\begin{array}{l}52 \\
49 \\
51 \\
47 \\
44 \\
44 \\
47 \\
46 \\
47 \\
41 \\
40 \\
43 \\
49 \\
48 \\
45 \\
48 \\
47 \\
46 \\
48 \\
48 \\
47 \\
45 \\
46 \\
47 \\
48 \\
47 \\
52 \\
44 \\
47 \\
45 \\
42\end{array}$ & $\begin{array}{l}54 \\
56 \\
54 \\
52 \\
49 \\
51 \\
50 \\
51 \\
49 \\
47 \\
48 \\
53 \\
54 \\
53 \\
52 \\
54 \\
52 \\
53 \\
52 \\
52 \\
51 \\
51 \\
52 \\
50 \\
50 \\
50 \\
47 \\
49 \\
49 \\
49 \\
45\end{array}$ \\
\hline
\end{tabular}


Appendix Table 16. Daily maximum and minimum water temperatures (degrees

F) for the Marias River near the mouth during 1978.

\begin{tabular}{|c|c|c|c|c|c|c|c|c|c|c|c|c|c|c|}
\hline $\begin{array}{l}\text { Day } \\
1 \\
2 \\
3 \\
4 \\
5 \\
6 \\
7 \\
8 \\
9\end{array}$ & \multicolumn{2}{|c|}{$\begin{array}{r}\text { April } \\
\text { Min.Max } \\
\end{array}$} & \multicolumn{2}{|c|}{$\begin{array}{c}\text { May } \\
\text { Min.Max. }\end{array}$} & \multicolumn{2}{|c|}{$\begin{array}{c}\begin{array}{c}\text { June } \\
\text { Min.Max. }\end{array} \\
\end{array}$} & \multicolumn{2}{|c|}{$\begin{array}{c}\begin{array}{c}\text { July } \\
\text { Min.Max. }\end{array} \\
\end{array}$} & \multicolumn{2}{|c|}{$\begin{array}{c}\text { Aug. } \\
\text { Min.Max. }\end{array}$} & \multicolumn{2}{|c|}{$\begin{array}{l}\text { Sept. } \\
\text { Min.Max. }\end{array}$} & \multicolumn{2}{|c|}{$\begin{array}{c}\text { Oct. } \\
\text { Min.Max. }\end{array}$} \\
\hline $\begin{array}{r}1 \\
2 \\
3 \\
4 \\
5 \\
6 \\
7 \\
8 \\
9 \\
10 \\
11 \\
12 \\
13 \\
14 \\
15 \\
16 \\
17 \\
18 \\
19 \\
20 \\
21 \\
22 \\
23 \\
24 \\
25 \\
26 \\
27 \\
28 \\
29 \\
30 \\
31\end{array}$ & $\begin{array}{l}40 \\
40 \\
40 \\
41 \\
42 \\
41 \\
40 \\
43 \\
44 \\
44 \\
43 \\
42 \\
42 \\
41 \\
41 \\
40 \\
41 \\
42 \\
44 \\
47 \\
47\end{array}$ & $\begin{array}{l}46 \\
47 \\
47 \\
47 \\
56 \\
47 \\
47 \\
49 \\
50 \\
51 \\
50 \\
50 \\
49 \\
48 \\
48 \\
47 \\
47 \\
47 \\
48 \\
53 \\
54 \\
54 \\
54 \\
53\end{array}$ & $\begin{array}{l}52 \\
52 \\
51 \\
50 \\
48 \\
47 \\
46 \\
49 \\
53 \\
54 \\
54 \\
54 \\
56 \\
55 \\
54 \\
56 \\
53 \\
55 \\
56 \\
57\end{array}$ & $\begin{array}{l}60 \\
57 \\
57 \\
55 \\
54 \\
53 \\
54 \\
56 \\
61 \\
62 \\
64 \\
64 \\
66 \\
66 \\
63 \\
66 \\
62 \\
63 \\
63 \\
63 \\
66 \\
67 \\
67\end{array}$ & $\begin{array}{l}61 \\
62 \\
61 \\
61 \\
62 \\
62 \\
62 \\
61 \\
62 \\
60 \\
61 \\
59 \\
60 \\
59 \\
57 \\
60 \\
61 \\
61 \\
62 \\
63 \\
63 \\
62\end{array}$ & $\begin{array}{l}69 \\
70 \\
71 \\
72 \\
71 \\
71 \\
70 \\
70 \\
69 \\
69 \\
69 \\
69 \\
69 \\
70 \\
69 \\
69 \\
68 \\
67 \\
68 \\
69\end{array}$ & $\begin{array}{l}67 \\
66 \\
66 \\
66 \\
62 \\
62 \\
62 \\
61 \\
64 \\
64 \\
64 \\
64 \\
64 \\
66 \\
68 \\
66 \\
64 \\
63 \\
63 \\
62 \\
62 \\
64 \\
63\end{array}$ & 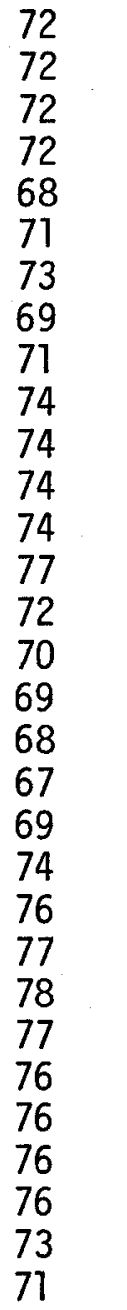 & $\begin{array}{l}63 \\
62 \\
63 \\
63 \\
66 \\
66 \\
67 \\
68 \\
68 \\
69 \\
68 \\
63 \\
62 \\
62 \\
61 \\
58 \\
55\end{array}$ & $\begin{array}{l}70 \\
73 \\
72 \\
72 \\
72 \\
74 \\
74 \\
76 \\
76 \\
77 \\
78 \\
77 \\
77 \\
74 \\
69 \\
69 \\
69 \\
69 \\
64 \\
62 \\
61 \\
65\end{array}$ & $\begin{array}{l}61 \\
62 \\
63 \\
64 \\
60 \\
58 \\
56 \\
56 \\
58 \\
56 \\
54 \\
52 \\
50 \\
51 \\
50 \\
50 \\
50 \\
49 \\
48 \\
47 \\
53 \\
53 \\
53\end{array}$ & $\begin{array}{l}68 \\
69 \\
70 \\
72 \\
68 \\
65 \\
63 \\
63 \\
65 \\
62 \\
60 \\
58 \\
53 \\
58 \\
57 \\
55 \\
54 \\
54 \\
51 \\
54\end{array}$ & $\begin{array}{l}52 \\
51 \\
50 \\
49 \\
48 \\
48 \\
48 \\
48 \\
47 \\
47 \\
46 \\
47 \\
48 \\
49 \\
48 \\
46 \\
47 \\
49 \\
47 \\
48 \\
46 \\
44 \\
42 \\
41 \\
42 \\
40\end{array}$ & $\begin{array}{l}59 \\
58 \\
57 \\
56 \\
55 \\
56 \\
56 \\
55 \\
55 \\
54 \\
56 \\
55 \\
56 \\
56 \\
55 \\
53 \\
55 \\
55 \\
54 \\
55 \\
54 \\
52 \\
51 \\
49 \\
47 \\
46\end{array}$ \\
\hline
\end{tabular}


Appendix Table 17. Daily maximum and minimum water temperatures (degrees

F) for the Marias River near the mouth during 1979.

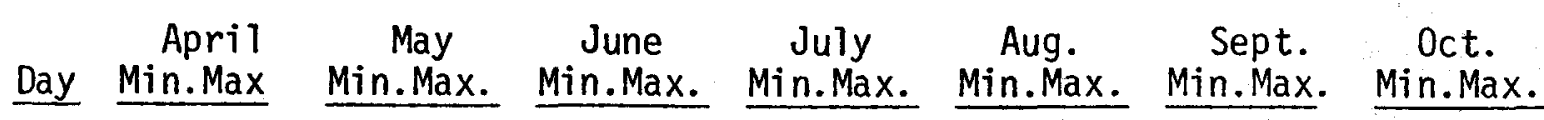

1
2
3
4
5
6
7
8
9
10
11
12
13
14
15

15

16

17

18

19

20

21

22

23

24

25

26

27

28

29

30

31
$51 \quad 58$

5461

5764

5963

$57 \quad 59$

$54 \quad 57$

$57 \quad 54$

$49 \quad 57$

5361

$57 \quad 62$

$58 \quad 64$

$\begin{array}{ll}60 & 67\end{array}$

$62 \quad 67$

54

$51 \quad 57$

$53 \quad 55$

49.54

$50 \quad 54$

$50 \quad 55$

$49 \quad 54$

5158

$52 \quad 59$

$54 \quad 62$

$57 \quad 60$

$56 \quad 63$

$57 \quad 66$

6164

$56 \quad 59$

$52 \quad 57$

$52 \quad 58$

$52 \quad 58$
6166

5864

$58 \quad 64$

$59 \quad 63$

6165

6163

5963

$59 \quad 64$

$60 \quad 64$

$60 \quad 66$

$\begin{array}{ll}61 & 67\end{array}$

6268

6370

$\begin{array}{ll}65 & 69\end{array}$

6370

6370

$65 \quad 69$ $\begin{array}{ll}59 & 63\end{array}$

$\begin{array}{ll}58 & 63\end{array}$

$\begin{array}{ll}58 & 67\end{array}$

.6365

6168

6371

$\begin{array}{ll}65 & 73\end{array}$

6670

6370

$\begin{array}{ll}65 & 72\end{array}$

6470

6268

$60 \quad 68$

$60 \quad 66$

$\begin{array}{ll}60 & 67\end{array}$

6270

$\begin{array}{ll}63 & 72\end{array}$

$\begin{array}{ll}65 & 74\end{array}$

$\begin{array}{ll}66 & 74\end{array}$

$\begin{array}{ll}67 & 75\end{array}$

$\begin{array}{ll}68 & 75\end{array}$

6870

6471

$64 \quad 66$

6162

$57 \quad 63$

5969

6368

6470

6472

$\begin{array}{ll}65 & 73\end{array}$

$$
\begin{array}{llllll}
65 & 73 & 64 & 68 & 54 & 56 \\
65 & 73 & 65 & 69 & 54 & 55 \\
65 & 72 & 65 & 71 & 51 & 55 \\
65 & 71 & 66 & 69 & 51 & 55 \\
66 & 74 & 62 & 68 & 53 & 56 \\
65 & 73 & 62 & 68 & 53 & 57 \\
65 & 72 & 64 & 70 & 55 & 57 \\
65 & 72 & 65 & 70 & 54 & 57 \\
63 & 70 & 65 & 68 & 50 & 53 \\
63 & 70 & 62 & 65 & 50 & 55 \\
64 & 68 & 60 & 62 & 53 & 56 \\
63 & 68 & 59 & 62 & 55 & 57 \\
62 & 67 & 60 & 64 & 54 & 57 \\
60 & 67 & 59 & 64 & 53 & 56 \\
62 & 69 & 59 & 65 & 54 & 56 \\
63 & 70 & 61 & 65 & 52 & 55 \\
64 & 71 & 61 & 65 & 52 & 54 \\
65 & 70 & 61 & 65 & 48 & 53 \\
65 & 69 & 61 & 65 & 49 & 50 \\
64 & 68 & 60 & 65 & 46 & 49 \\
65 & 67 & 60 & 63 & 44 & 46 \\
61 & 66 & 59 & 63 & 42 & 45 \\
62 & 69 & 59 & 63 & 44 & 47 \\
65 & 66 & 59 & 63 & 45 & 47 \\
62 & 65 & 58 & 62 & 46 & 48 \\
61 & 68 & 60 & 61 & & \\
63 & 68 & 58 & 61 & & \\
64 & 70 & 57 & 60 & & \\
62 & 69 & 56 & 59 & & \\
64 & 71 & 57 & 58 & & \\
66 & 68 & & & &
\end{array}
$$


Appendix Table 18. Numbers of aquatic macroinvertebrates collected (per sample period) at the Morony Dam site, late October, 1976, through mid-September, 1977.

Sampling Period

late mid late mid early mid early mid

Oct. Dec. Jan. Mar. May June Aug. Sept.

Mayfly

Tricomythodes

Ephemerelza

Rhithrogena

Stenonema

Baetis

Stonefly

Acroneuria

Truefly

Chironomidae

Diamesa

Monodicamesa

Pot thastia

Chironomus

Dicrotendipes

Microtendipes

Parac Ladope Ima

Phaenopsectra

Polypedizum

Micropsectra

Rheotanytarsus

Tany tarsus

Cardioctadius

Cricotopus

Eukiefferielza

Orthocladius

Hexa toma

Simulizm

Empididae

Muscidae

\section{Caddisfly}

Hydroptiza

Leucotrichia

Hydropsyche

Cheumatopsyche

Psychomyia

Oecetis

Brachycentrus

Amiocentrus
1

$\begin{array}{rr}18 & 5 \\ 2 & 5\end{array}$

19
2

2

$\begin{array}{rr}2 & 1 \\ 296 & 4\end{array}$

376

296

1

121

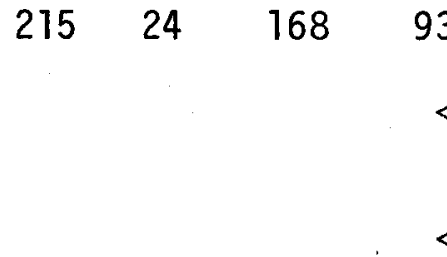

936

$<1$

$<$

$\begin{array}{llll}<1 & 1 & 35 & 39\end{array}$

1

$\begin{array}{rrrr}2 & 1 & & \\ & 28 & 21 & 15\end{array}$

$<1 \quad 4 \quad 35$

$<1$

$\begin{array}{llll}1 & 1 & <1 & 3\end{array}$

3

$\begin{array}{llll}42 & 25 & 1 & 29\end{array}$

$\begin{array}{llll}45 & 36 & 4 & 9\end{array}$

1

$\begin{array}{ll}1 & 2 \\ 1 & 2 \\ & \end{array}$

4

10

$\begin{array}{lllll}315 & 32 & 15 & 39 & 414\end{array}$

91

$2 \quad 10$

$14 \quad 49 \quad 2$

20
2
277
5
1
1
6
2

46

44

30

4 
Appendix Table 18 continued. Numbers of aquatic macroinvertebrates collected (per sample period) at the Morony Dam site, late October, 1976, through mid-September, 1977.

\section{Sampling Period}

late mid late mid early mid early mid

Oct. Dec. Jan. Mar. May June Aug. Sept.

Odonata

Ophiogomphus

1

Heteroptera

Sigara

Trichocorixa

64

4

Coleoptera

Hydrophizus

optioservus

Lepi dop tera

Parargyractis

5

2126

19

1

6. 16

148

Nema tomorpha

14

2

Amphipoda

Hyazleza

Decapoda

Orconectes

1

$\begin{array}{lll}2 & 6 & 4\end{array}$

Total

$\begin{array}{lll}496 & 328 & 62\end{array}$

62

625

1764

15112692

2346

* Chironomidae subordinal taxa expressed as a percentage of the famity's total count. 
Appendix Table 19. Numbers of aquatic macroinvertebrates collected (per sample period) at the Fort Benton site, late October, 1976, through mid-September, 1977.

Sampling Period

late mid late mid early mid early mid

Oct. Dec. Jan. Mar. May June Aug. Sept.

Mayfly

Paraleptophlebia

Tricorythodes

Ephemerelza

Rhithrogena

Stenonema

Heptagenia

Baetis

$\begin{array}{rrrrrrrr}2 & 4 & & & 1 & 20 & 20 & 24 \\ 16 & & 37 & 43 & 111 & 2 & & \\ & & 4 & 20 & 10 & & & \\ 3 & 21 & 2 & 4 & 9 & 2 & 2 & 31 \\ & & 2 & 2 & 10 & & & \\ 1 & 11 & 230 & 4468 & 1767 & 492 & 6 & 109\end{array}$

Stonefly

Acroneuria

Isogenus

Isoperla

Truefly

Chironomidae

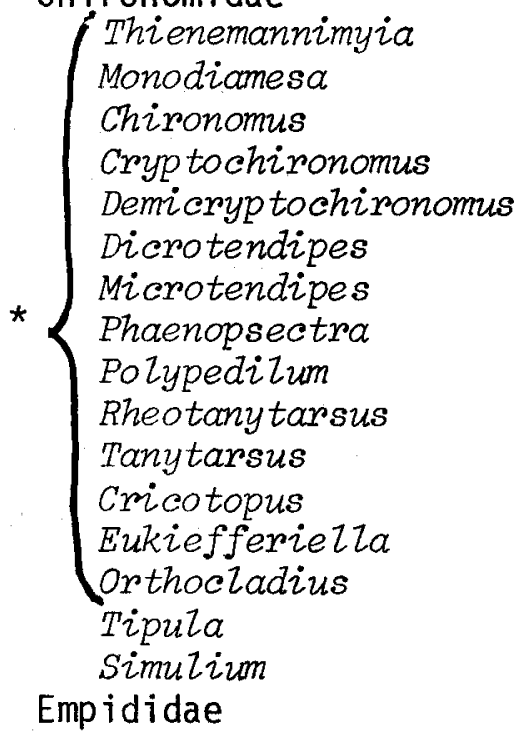

869

$\begin{array}{lllllll}754 & 1133 & 1671 & 787 & 6892 & 392 & 695\end{array}$

$\begin{array}{llll}< & 1 & 11 & 5\end{array}$

$2<1 \quad 4$

$\begin{array}{lll}<1 & 1 & <\end{array}$

$<1<1<1$

$\begin{array}{lll}91 & 1 & \\ 4 & 1 & 61\end{array}$

$\begin{array}{llll}4 & 5 & 15 & 3\end{array}$

$\begin{array}{llll}2 & 90 & 26 & 4\end{array}$

$<\quad 1 \quad 25$

$\begin{array}{lll} & 3 & 3\end{array}$

$<1$

2

2

6
2

Caddisfly

Hydroptiza

Hudropsyche

Chermatopsyche

Oecetis

Brachycentrus

$\begin{array}{rrrrrrrr}46 & 212 & 277 & 396 & 363 & 192 & 1574 & 170 \\ 48 & 103 & 291 & 140 & 117 & 1392 & 30 & 1018 \\ 4 & 22 & 29 & 15 & 6 & 82 & 36 & 644 \\ & 5 & 15 & 6 & 5 & & 22 & 157 \\ & 2 & 2 & 1 & 4 & 38 & 10 & 40\end{array}$

Odonata

Ophiogomphus 
Appendix Table 19 continued. Numbers of aquatic macroinvertebrates collected (per sample period) at the Fort Benton site, late October, 1976, through mid-September, 1977.

\section{Sampling Period}

late mid late mid early mid early mid Oct. Dec. Jan. Mar. May June Aug. Sept.

He teroptera

Trichocorixa

Hesperocorixa

Sigara

$\begin{array}{rrrrrr} & 2 & 1 & & \\ & 1 & 8 & & \\ 18 & & 1 & 128 & 738 & 1\end{array}$

$\begin{array}{rrrrrr} & 2 & 1 & & \\ & 1 & 8 & & \\ 18 & & 1 & 128 & 738 & 1\end{array}$

$\begin{array}{rrrrrr} & 2 & 1 & & \\ & 1 & 8 & & \\ 18 & & 1 & 128 & 738 & 1\end{array}$

$\begin{array}{rrrrrr} & 2 & 1 & & \\ & 1 & 8 & & \\ 18 & & 1 & 128 & 738 & 1\end{array}$

$\begin{array}{rrrrrr} & 2 & 1 & & \\ & 1 & 8 & & \\ 18 & & 1 & 128 & 738 & 1\end{array}$

Coleoptera

Hydropoms

Dytiscus

Pelonomus

Dubiraphia

Ordobrevia

optioservus

1

1

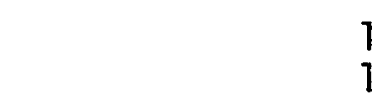

Lepidoptera

Parargyractis

Nema tomorpha

$\begin{array}{lllll}1 & 2 & 1 & 3 & \\ & 2 & 2 & 3 & 2\end{array}$

01 igochaeta

224

142

$22 \quad 94 \quad 92$

$14 \quad 282$

53

Pulmonata

Ferrissia

1

$\begin{array}{lll}1 & 1 & 3\end{array}$

16

Decapoda

Orconectes

2

Total

$\begin{array}{lllll}1237 & 1189 & 2064 & 6901 & 336\end{array}$

$9200 \quad 3128$

2956

* Chironomidae subordinal taxa expressed as a percentage of the family's total count. 
Appendix Table 20. Numbers of aquatic macroinvertebrates collected (per sample period) at the Coal Banks Landing site, late October, 1976, through mid-September, 1977.

\section{Sampling Period}

late mid late mid early mid early mid

Oct. Dec. Jan. Mar. May June Aug. Sept.

Mayfly

Baetisca

Leptophlebia

Traverelza

Tricory thodes

Ephemerella

Rhi throgena

Stenonema

Heptagenia

Baetis

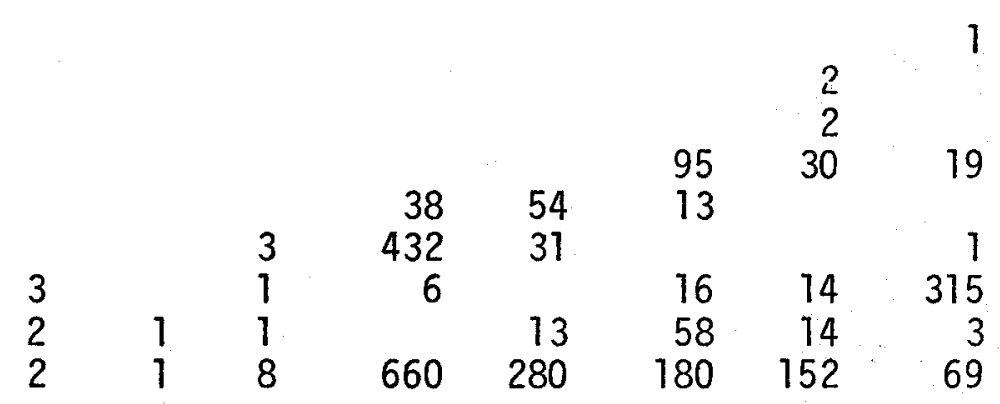

Stonefly

Isogenus

Isoperla

Brachyptera

1

20

$\begin{array}{lll}21 & 46 & 1\end{array}$

Truefiy

Chironomidae

Thienemannimyia

Dicomesa

Monodiamesa

Chironomus

Cryp tochironomus

Dicrotendipes

Microtendipes

*

Phaenopsectra

Polypdilum

Rheotanytarsus

Tanytarsus

Cricotopus

orthocladius

Simulium

Empididae

Caddisfly

Ilydroptila

Hydropsyche

Cheumatopsyche

Decetis

Helicopsyche

Brachycentrus

Odonata

Ophiogomphus $\begin{array}{llllllll}91 & 112 & 44 & 2311 & 44 & 1192 & 1862 & 363\end{array}$

6

$\begin{array}{lll}1 & 9 & 1\end{array}$

$40<1$

50
1

20

392

15

$\begin{array}{rrr}40 & 72 & 1 \\ 4 & 1 & <1\end{array}$

4

$15<1<1<1$

1

$\begin{array}{rrrrrrrr}9 & 7 & 3 & 6 & & 2 & 24 & 5 \\ 5 & 3 & 1 & 19 & 3 & 17 & 60 & 128 \\ & 1 & & 5 & & 6 & 72 & 78 \\ & & & & & & & 72 \\ & & & & & 10 & 8\end{array}$


Appendix Table 20 continued. Numbers of aquatic macroinvertebrates collected (per sampling period) at the Coal Banks Landing site, late October, 1976, through midSeptember, 1977.

\begin{tabular}{|c|c|c|c|c|c|c|c|c|}
\hline & & & & Sampli & ng Peri & & & \\
\hline & $\begin{array}{l}\text { late } \\
\text { Oct. }\end{array}$ & $\begin{array}{l}\operatorname{mid} \\
\text { Dec. }\end{array}$ & $\begin{array}{l}\text { Jate } \\
\text { Jan. }\end{array}$ & $\begin{array}{l}\text { mid } \\
\text { Mar. }\end{array}$ & $\begin{array}{l}\text { early } \\
\text { May } \\
\end{array}$ & $\begin{array}{l}\text { mid } \\
\text { June }\end{array}$ & $\begin{array}{l}\text { early } \\
\text { Aug. }\end{array}$ & $\begin{array}{l}\operatorname{mid} \\
\text { Sept. }\end{array}$ \\
\hline $\begin{array}{l}\text { Heteroptera } \\
\text { Trichocorixa } \\
\text { Sigara }\end{array}$ & 6 & & 5 & & 4 & 2 & $\begin{array}{r}16 \\
330\end{array}$ & 30 \\
\hline $\begin{array}{l}\text { Coleoptera } \\
\text { Gyrinus } \\
\text { Hydroporus } \\
\text { Curcul ionidae } \\
\text { Ordobrevia }\end{array}$ & 1 & 1 & & & $\begin{array}{l}2 \\
1\end{array}$ & & & 2 \\
\hline $\begin{array}{l}\text { Lepidoptera } \\
\qquad \text { Synclita }\end{array}$ & & & & & 2 & & & \\
\hline 01igochaeta & 28 & 34 & & & 85 & 63 & 172 & 43 \\
\hline $\begin{array}{l}\text { Plumonata } \\
\text { Physa }\end{array}$ & & & & & & & & 5 \\
\hline Total & 148 & 161 & 66 & 3538 & 565 & 1692 & 2778 & 1148 \\
\hline
\end{tabular}

* Chironomidae subordinal taxa expressed as a percentage of the family's total count. 
Appendix Table 21. Numbers of aquatic macroinvertebrates collected (per sample period) at the Judith Landing site, late October, 1976, through mid-September, 1977.

\section{Sampling Period}

late mid late mid early mid early mid Oct. Dec. Jan. Mar. May June Aug. Sept.

Mayfly

Leptophlebia

Traverella

Ephoron

Tricory thodes

Ephemerezza

Rhithrogena

Stenonema

Heptagenia

Baetis

$\begin{array}{rrlrrrrr} & & & & & 1 & \\ & & & & & & 160 & 1 \\ 38 & 6 & N & 13 & 162 & 2 & 6 & \\ 33 & 107 & & 156 & 209 & 215 & 41 & 1 \\ 18 & 3 & 0 & 4 & 26 & 19 & 23 & 47 \\ 154 & 49 & & 8 & 92 & 239 & 6 & 30 \\ 2 & 7 & \mathrm{~T} & 79 & 226 & 96 & 84 & 8\end{array}$

Stonefly

Capnia

Acroneuria

Isogenus

Isoperla

$\begin{array}{rrrrrrr} & 32 & \mathrm{~S} & 1 & & & \\ 1 & 1 & & 1 & 4 & & \\ 1 & 1 & \mathrm{~A} & 73 & 17 & & \\ & & & 9 & 34 & 39 & 5\end{array}$

Truef7y

Chironomidae

Thienemannimyia

91

$\begin{array}{lll}57 & \mathrm{P} & 644\end{array}$

$\begin{array}{rrrr}65 & 92 & 24 & 88 \\ & 9 & 50 & 15 \\ 65 & 23 & & \\ & 15 & 15 & 27 \\ 2 & 2 & & 6 \\ & 2 & & \\ 4 & 3 & & 44 \\ 2 & & 20 & 1 \\ 10 & 42 & 10 & \\ & 3 & 5 & \\ 8 & & & 5\end{array}$

Chironomus

Cryptochironomus

Demicryp tochironomus

Microtendipes

Phaenopsectra

Polypedilum

Cladotany tarsus

Rheotanytarsus

Tanytarsus

Cricotopus

Eukiefferiella

Orthocladius

Simulizm

8

2

Caddisfly

$\begin{array}{lll}\text { Hydropsyche } & 40 & 7\end{array}$

Chermatopsyche

Oecetis

Brachycentrus

$\begin{array}{rr}155 & 8 \\ 2 & 1 \\ 91 & 1\end{array}$

$\begin{array}{rr}6 & 26 \\ 1 & 2 \\ 6 & 2 \\ & 1\end{array}$

$\begin{array}{rrr}47 & 48 & 2 \\ 1 & 36 & 7 \\ & 9 & 2 \\ 266 & 384 & 5\end{array}$

Heteroptera

Trichocorixa

Hesperocorixa

Sigara

86

$\begin{array}{rrrrr} & 4 & 1 & & \\ 2 & 120 & 12 & 49 & 15\end{array}$


Appendix Table 21 continued. Numbers of aquatic macroinvertebrates collected (per sampling period) at the Judith Landing site, late October, 1976, through mid-September, 1977.

\section{Sampling Period}

late mid late mid early mid early mid Oct. Dec. Jan. Mar. May June Aug. Sept.

Coleoptera

Carabidae Hydrovatus

Curculionidae

Dubiraphia

Ordobrevia

Stenelmis

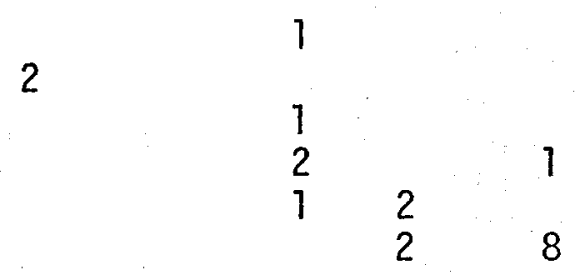

01 igochaeta

2

$157 \quad 17 \quad 88$

Total

$724 \quad 289$

$\begin{array}{lllll}1005 & 1276 \quad 1322 \quad 995 & 358\end{array}$

* Chironomidae subordinal taxa expressed as a percentage of the family's total count. 
Appendix Table 22. Numbers of aquatic macroinvertebrates collected (per sample period) at the Robinson Bridge site, late October, 1976, through mid-September, 1977.

\section{Sampling Period}

late mid late mid early mid early mid oct. Dec. Jan. Mar. May June Aug. Sept.
Mayfly

Lep tophlebia

Traverelia

Ephoron

Ametropus

Tricorythodes

Brachycercus

Ephemerelza

Rhithrogena

Stenonema

Heptagenia

Baetis

Stonefly

$$
\begin{aligned}
& \text { Brachyptera } \\
& \text { Capnia } \\
& \text { Acroneuria } \\
& \text { Isogenus } \\
& \text { Isoperla }
\end{aligned}
$$

Truefly

Thienemannimyia

Monodiamesa

*

Cryptochironomus

Polypedilum

Stenochironomus

Micropsectra

Rheotanytarsus

Eukiefferiella

Simulium

Empididae
Chironomidae

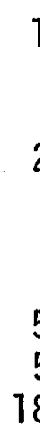

2

5
18

$1 \mathrm{~T} \quad \mathrm{~T}$

$1 \quad S \quad S$

A A

M M

12

$\begin{array}{ll}P & P \\ L & L \\ E & E \\ D & D\end{array}$

18

Hydropsyche

Chermatopsyche

Oecetis

Brachycentrus

$\begin{array}{rrrrr} & & 1 & 8 & 4 \\ & & 22 & & 1 \\ & 1 & 3 & & \\ 1 & 3 & 26 & 17 & 16 \\ & & 6 & 1 & \\ 21 & 58 & 1 & & \\ 30 & 8 & 1 & & \\ 15 & 44 & 33 & 9 & 132 \\ 192 & 248 & 275 & 40 & 39 \\ 28 & 32 & 29 & 30 & 7\end{array}$

8

$\begin{array}{rrr}8 & & \\ 24 & & \\ 1 & 8 & 1 \\ 31 & & \\ 36 & 62 & 8\end{array}$

$\begin{array}{lllll}825 & 10 & 49 & 12 & 7\end{array}$

$85 \quad 12$

$15 \quad 40$

55

25

$20 \quad 25$

$12 \quad 25$

1

27

55

5

$\begin{array}{rr}22 & 1 \\ 1 & 8 \\ & 2 \\ 28 & 16\end{array}$

Odonata

Gomphus

ophiogomphus

13

1

Sigara 
Appendix Table 22 continued. Numbers of aquatic macroinvertebrates collected (per sample period) at the Robinson Bridge site, late 0ctober, 1976, through mid-Sep tember, 1977.

Sampling Period

late mid late mid early mid early mid

Oct. Dec. Jan. Mar. May June Aug. Sept.

Coleoptera

Hydrophizus

Hydrovatus

Dubiraphia

Ordobrevia

Stenelmis

Nema tomorpha

25

2

2

1

$\begin{array}{lll}1 & \\ 2 & 1 & 2 \\ 1 & & 1\end{array}$

01 igochaeta

10

$\begin{array}{llll}81 & 19 & 22 & 65\end{array}$

18

Tota 1

77

1384558

$558 \quad 336$

288

* Chironomidae subordinal taxa expressed as a percentage of the family's total count. 


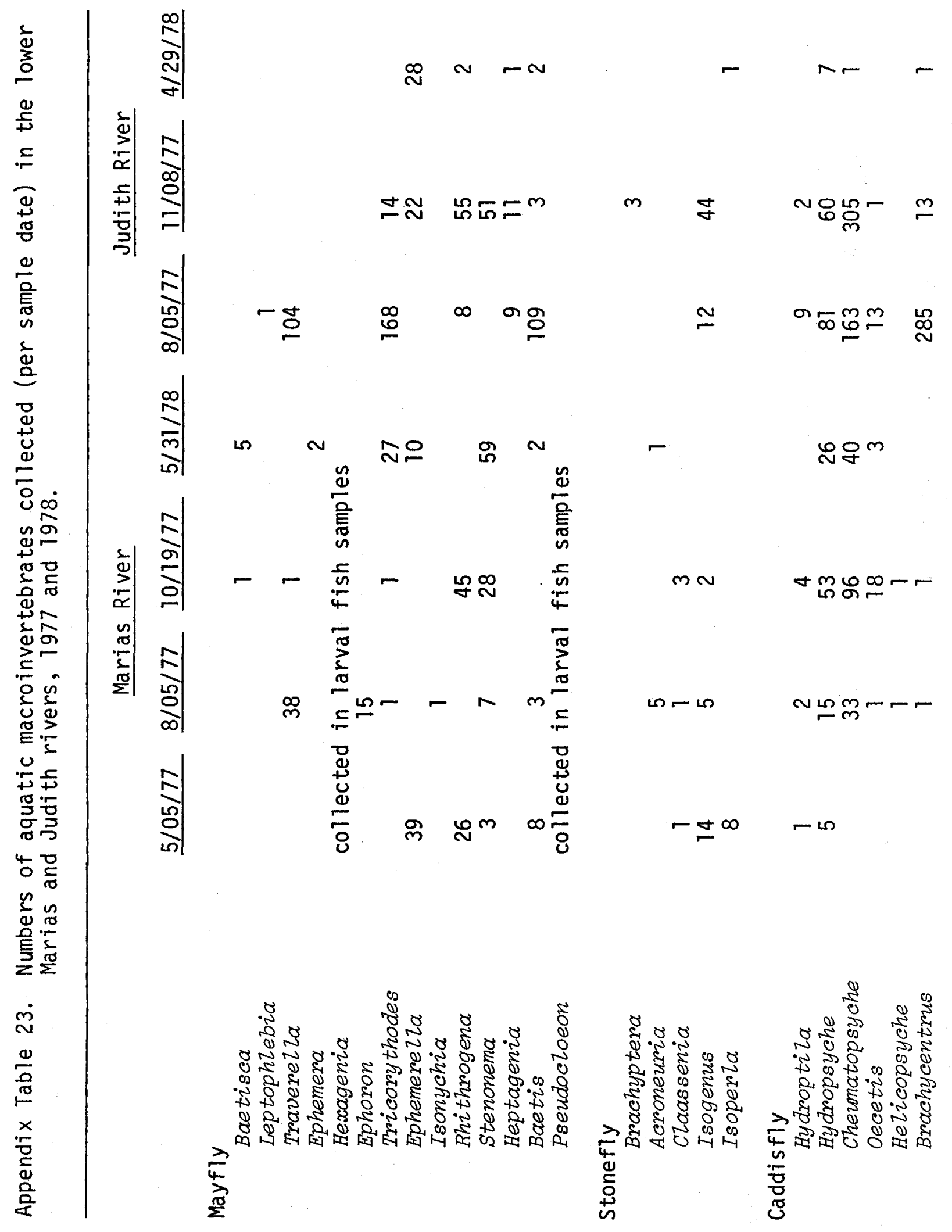




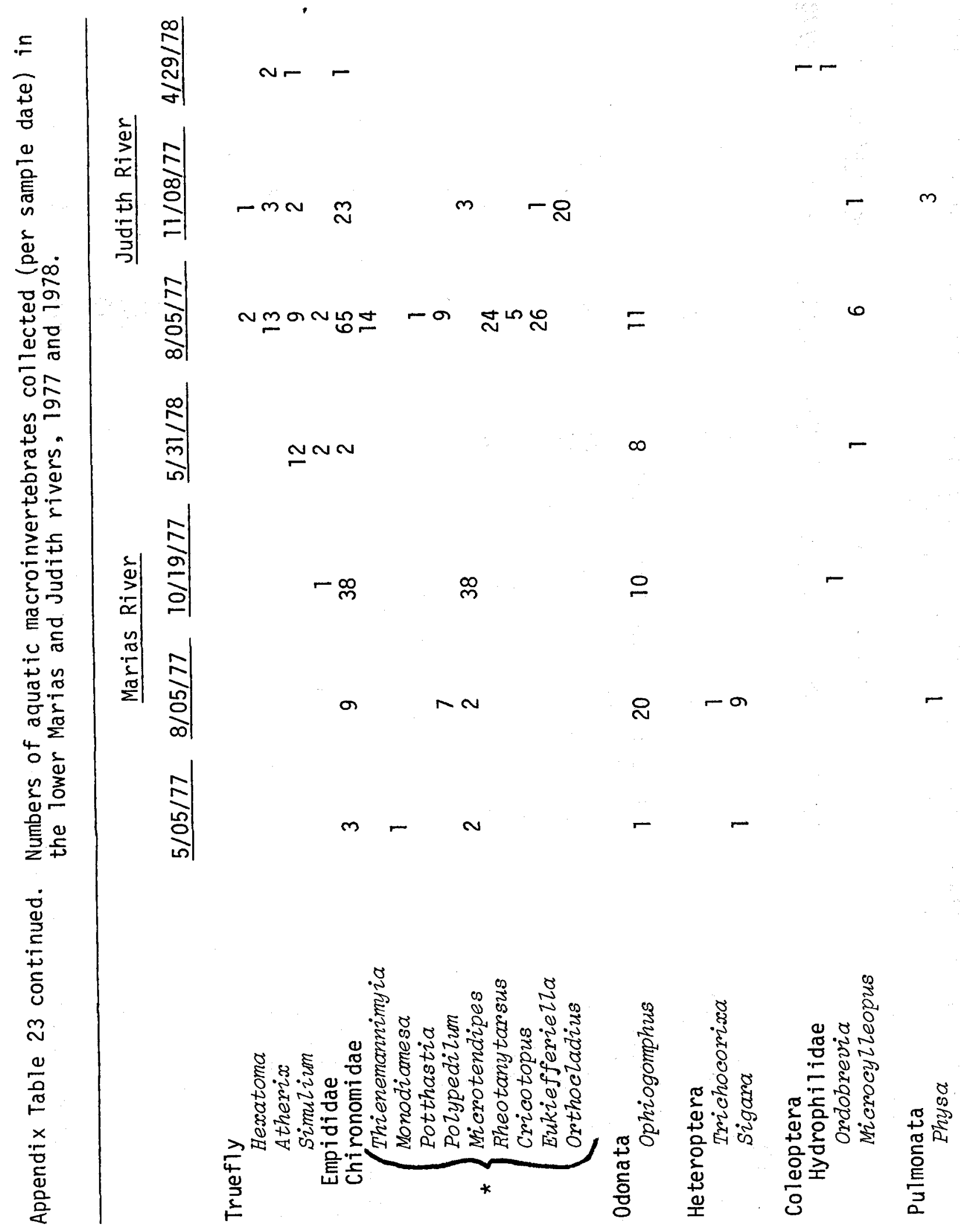




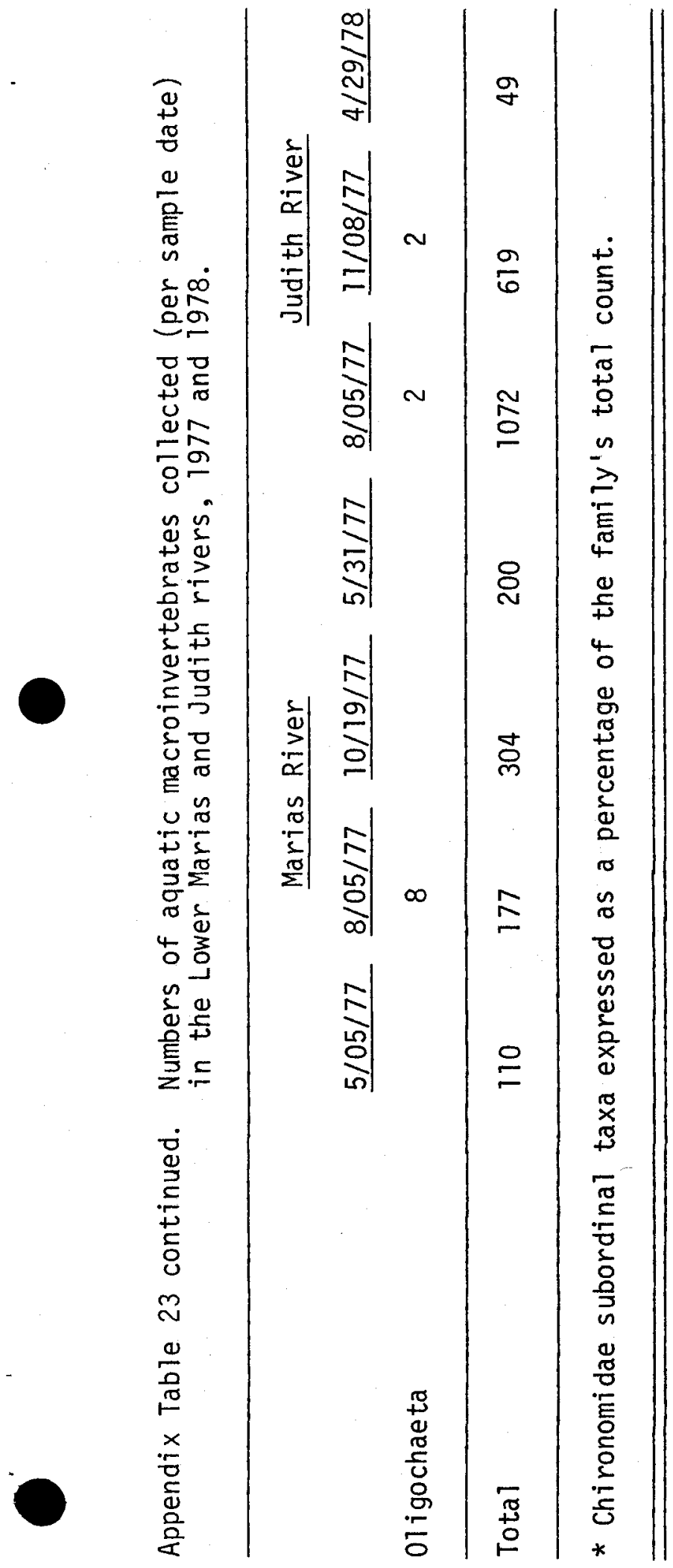




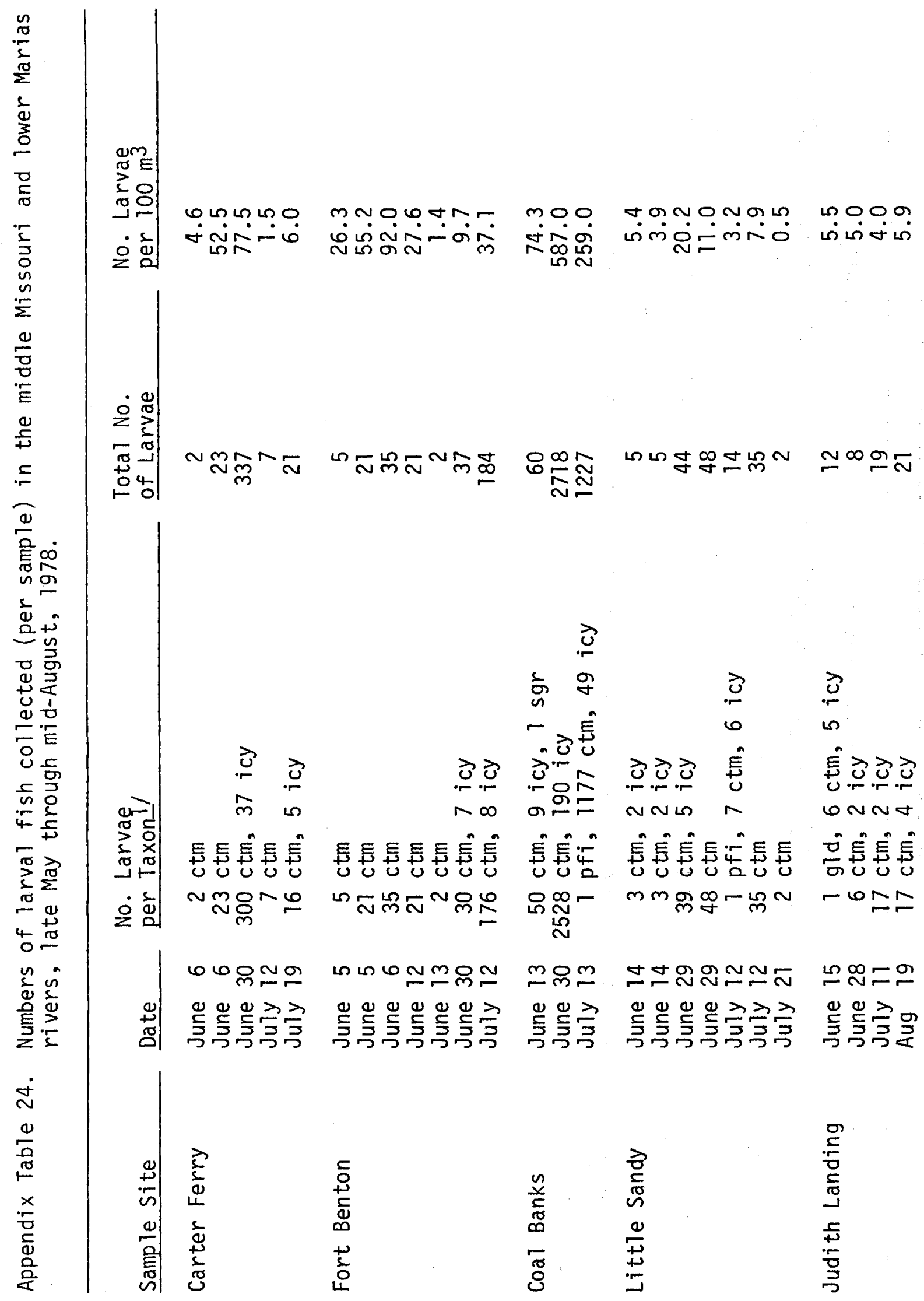


Nommmor

ம் $\dot{0} \dot{0} \dot{0} \dot{0} \dot{0}$

กต.

은

மீஸீர் ஸ்

onto

$\dot{0} \dot{0} \dot{0}$

G $\infty$ MLN $\infty$ N $\infty$

兘吕

$\therefore \underset{n}{n}$

미

$\stackrel{0}{\square}$

을ㅁำ

领

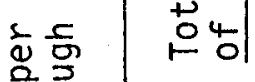

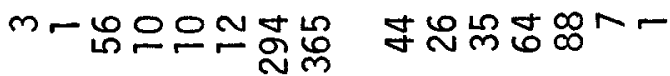

เก- D

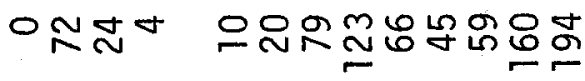

पर

过

ب

远

언

$\frac{1}{n} \stackrel{0}{-}$

$\pi$ is

$=\frac{1}{9}$

$\sum_{i}^{\infty} \frac{1}{i}$

क

-

$4 . \frac{1}{2}$

in

a

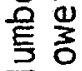

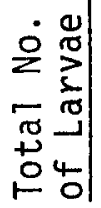

$$
\text { Nd }
$$

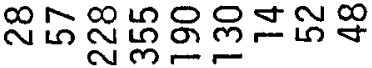
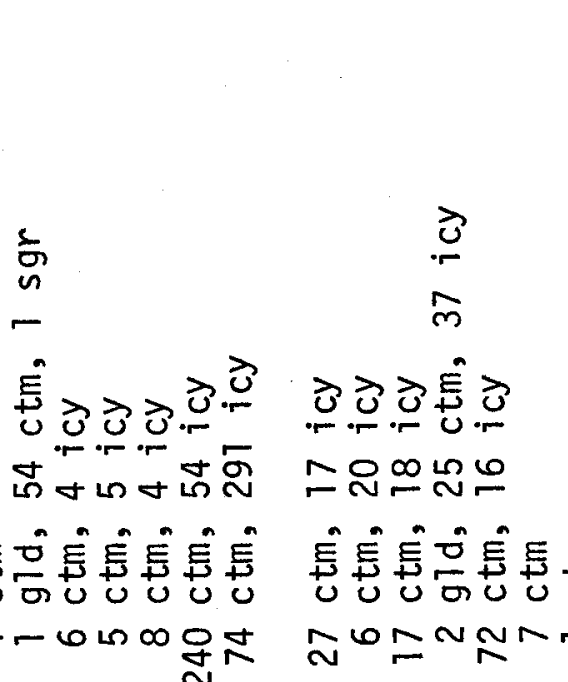

త్ర

$-$

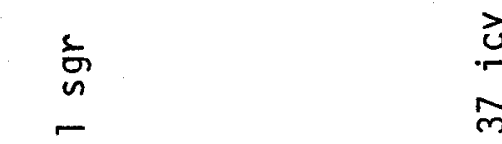

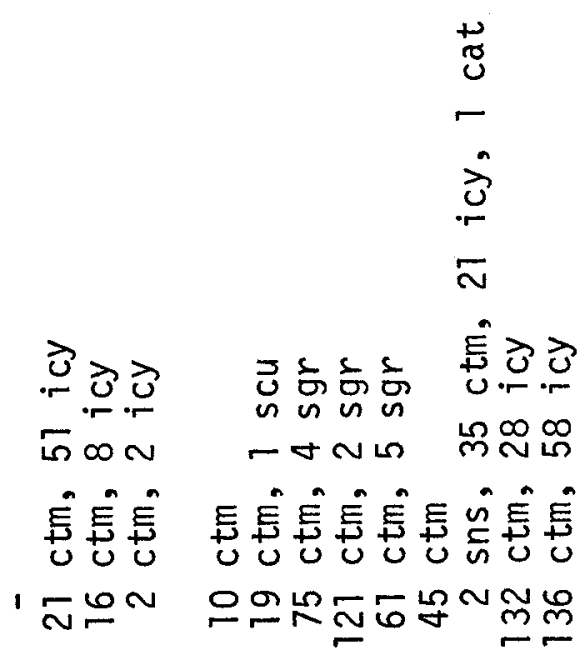

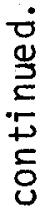

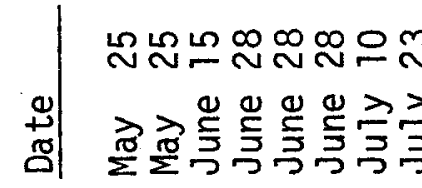

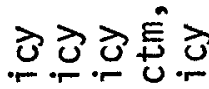

드유묟ㄴ

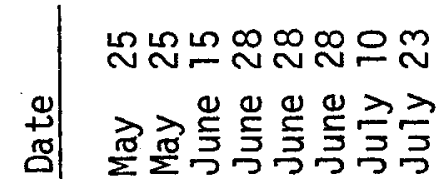

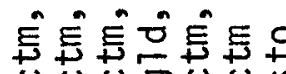

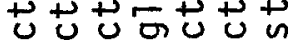

N

'

-

놏ํํㅇํㅇ

ํㅜㅇㅠ

- - N N

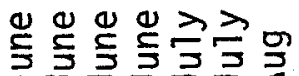

$\stackrel{0}{\stackrel{0}{5}} \frac{2}{3}$

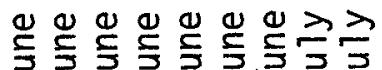

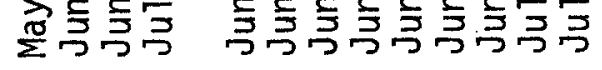

|

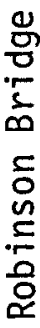

$\frac{1}{10}$
2
0
0
0
0
$\frac{0}{2}$
$\frac{\pi}{2}$ 


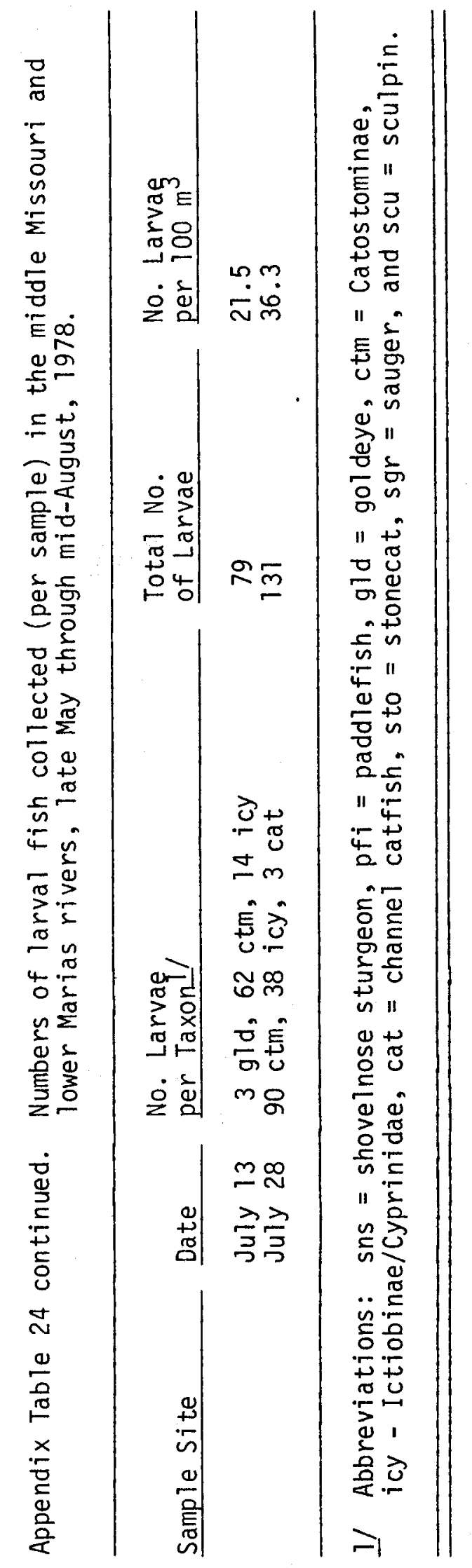


Appendix Table 25. Legal descriptions of boundaries of eleven fishery study sections on the mainstem of the middle Missouri River.

Study Section Boundary

Morony Dam (upper)

Morony Dam/Carter Ferry

Carter Ferry/Fort Benton

Fort Benton/Loma Ferry

Loma Ferry/Coal Banks Landing

Coal Banks Landing/Hole-in-the-Wall

Hole-in-the-Wal1/Judith Landing

Judith Landing/Stafford Ferry

Stafford Ferry/Cow Island

Cow Island/Robinson Bridge

Robinson Bridge/Turkey Joe

Turkey Joe (1ower)
Legal Description of Boundary

$N E \frac{1}{4}, N W \frac{1}{4}, S e c .14, T 21 N, R 5 E$

$N W^{\frac{3}{4}}, N E^{\frac{1}{4}}, \mathrm{Sec}, 27, \mathrm{~T} 23 \mathrm{~N}, \mathrm{R} 6 \mathrm{E}$

$\mathrm{NW}^{\frac{1}{4}}, \mathrm{SW}^{\frac{1}{4}}, \mathrm{Sec} .33, \mathrm{~T} 24 \mathrm{~N}, \mathrm{R} 8 \mathrm{E}$

SW $\frac{1}{4}, S E \frac{1}{4}, S e c .2, T 24 N, R 9 E$

SE $\frac{1}{4}, S^{\frac{1}{4}}, \operatorname{Sec} .20, T 26 N, R 11 E$

SE $\frac{1}{4}, S W \frac{1}{4}, S e c .30, T 26 N, R 13 E$

SW $\frac{1}{4}, E \frac{1}{2}$, Sec. $31, T 23 N, R 15 E$

SW $\frac{1}{4}, S W \frac{1}{4}, S e c .23, T 23 N, R 17 E$

SE $\frac{1}{4}, N E \frac{1}{4}, \operatorname{Sec}, 9, \mathrm{~T} 23 \mathrm{~N}, \mathrm{R} 20 \mathrm{E}$

$\mathrm{SEE}_{\frac{1}{4}}, \mathrm{SW}_{\frac{1}{4}}, \mathrm{Sec} .21, \mathrm{~T} 23 \mathrm{~N}, \mathrm{R} 22 \mathrm{E}$

$N E \frac{1}{4}, N W^{\frac{1}{4}}, \operatorname{Sec} .1, \mathrm{~T} 21 \mathrm{~N}, \mathrm{R} 24 \mathrm{E}$

$\mathrm{NE}_{\frac{1}{4}}^{\frac{1}{4}}, \mathrm{SE}_{\frac{1}{4}}, \mathrm{Sec} .15, \mathrm{~T} 21 \mathrm{~N}, \mathrm{R} 26 \mathrm{E}$ 
Appendix Table 26. Species composition, number, and size of fish sampled by electrofishing in the Morony Dam study section, 1976 through 1979.

\begin{tabular}{|c|c|c|c|c|c|}
\hline Fish Species & $\begin{array}{l}\text { Number } \\
\text { Sampled }\end{array}$ & $\begin{array}{l}\text { Average } \\
\text { Length } \\
(\mathrm{cm})\end{array}$ & $\begin{array}{l}\text { Length } \\
\text { Range } \\
(\mathrm{cm}) \\
\end{array}$ & $\begin{array}{l}\text { Average } \\
\text { Weight } \\
(\mathrm{kg})\end{array}$ & $\begin{array}{l}\text { Wejght } \\
\text { Range } \\
\text { (kg) }\end{array}$ \\
\hline $\begin{array}{l}\text { Goldeye } \\
\text { Mountain whitefish } \\
\text { Rainbow trout } \\
\text { Brown trout } \\
\text { Northern pike } \\
\text { Carp } \\
\text { Flathead chub } \\
\text { Emerald shiner } \\
\text { W. silvery minnow } \\
\text { Longnose dace } \\
\text { River carpsucker } \\
\text { Blue sucker } \\
\text { Smallmouth buffalo } \\
\text { Bigmouth buffalo } \\
\text { Shorthead redhorse } \\
\text { Longnose sucker } \\
\text { White sucker } \\
\text { Mountain sucker } \\
\text { Burbot } \\
\text { Sauger } \\
\text { Walleye } \\
\text { Freshwater drum } \\
\text { Mottled sculpin }\end{array}$ & $\begin{array}{r}75 \\
32 \\
18 \\
16 \\
1 \\
5 \\
1 \\
6 \\
150 \\
9 \\
2 \\
4 \\
31 \\
2 \\
24 \\
65 \\
8 \\
21 \\
6 \\
664 \\
11 \\
85 \\
15\end{array}$ & $\begin{array}{r}31.7 \\
30.8 \\
32.7 \\
41.0 \\
57.9 \\
55.5 \\
8.6 \\
6.9 \\
9.4 \\
8.3 \\
42.0 \\
71.8 \\
55.7 \\
63.0 \\
45.9 \\
38.1 \\
30.8 \\
15.8 \\
59.2 \\
35.6 \\
39.2 \\
37.9 \\
8.6\end{array}$ & $\begin{array}{r}28.4-36.1 \\
9.7-43.4 \\
15.7-40.9 \\
21.6-58.4 \\
- \\
50.3-62.7 \\
- \\
6.4-7.1 \\
8.1-10.7 \\
7.6-8.9 \\
41.9-42.2 \\
66.3-76.2 \\
46.2-69.3 \\
46.5-79.5 \\
33.5-51.8 \\
13.2-50.3 \\
14.5-42.2 \\
8.9-21.6 \\
36.8-66.0 \\
22.6-56.1 \\
27.7-77.0 \\
27.7-52.8 \\
7.9-9.7\end{array}$ & $\begin{array}{l}0.26 \\
0.41 \\
0.36 \\
0.73 \\
1.28 \\
2.31 \\
0.01 \\
0.01 \\
0.02 \\
0.01 \\
0.93 \\
3.10 \\
2.82 \\
5.47 \\
1.13 \\
0.68 \\
0.41 \\
0.06 \\
1.25 \\
0.38 \\
0.86 \\
0.85 \\
0.02\end{array}$ & $\begin{array}{c}0.19-0.43 \\
0.02-1.05 \\
0.15-0.64 \\
0.11-1.95 \\
- \\
1.56-3.72 \\
- \\
- \\
0.01-0.02 \\
- \\
0.86-1.00 \\
2.22-4.31 \\
1.50-6.80 \\
1.50-9.43 \\
0.45-1.81 \\
0.04-1.25 \\
0.04-0.88 \\
0.02-0.11 \\
0.36-1.74 \\
0.09-1.50 \\
0.18-5.35 \\
0.25-2.31 \\
0.01-0.02\end{array}$ \\
\hline Tota 1 & 1251 & & & & \\
\hline
\end{tabular}


Appendix Table 27. Species composition, number, and size of fish sampled by electrofishing in the Carter Ferry study section, 1976 through 1979.

\begin{tabular}{|c|c|c|c|c|c|}
\hline Fish Species & $\begin{array}{l}\text { Number } \\
\text { Sampled }\end{array}$ & $\begin{array}{l}\text { Average } \\
\text { Length } \\
(\mathrm{cm})\end{array}$ & $\begin{array}{l}\text { Length } \\
\text { Range } \\
(\mathrm{cm}) \\
\end{array}$ & $\begin{array}{l}\text { Average } \\
\text { Weight } \\
(\mathrm{kg})\end{array}$ & $\begin{array}{l}\text { Weight } \\
\text { Range } \\
\text { (kg) }\end{array}$ \\
\hline $\begin{array}{l}\text { Shovelnose sturgeon } \\
\text { Goldeye } \\
\text { Mountain whitefish } \\
\text { Rainbow trout } \\
\text { Brown trout } \\
\text { Northern pike } \\
\text { Carp } \\
\text { Flathead chub } \\
\text { Emerald shiner } \\
\text { W. silvery minnow } \\
\text { Longnose dace } \\
\text { River carpsucker } \\
\text { Blue sucker } \\
\text { Smallmouth buffalo } \\
\text { Bigmouth buffalo } \\
\text { Shorthead redhorse } \\
\text { Longnose sucker } \\
\text { White sucker } \\
\text { Mountain sucker } \\
\text { Burbot } \\
\text { Yellow perch } \\
\text { Sauger } \\
\text { Walleye } \\
\text { Freshwater drum } \\
\text { Mottled sculpin }\end{array}$ & $\begin{array}{r}2 \\
175 \\
7 \\
1 \\
5 \\
1 \\
3 \\
1 \\
2 \\
6 \\
6 \\
3 \\
11 \\
21 \\
1 \\
61 \\
68 \\
1 \\
1 \\
4 \\
1 \\
358 \\
1 \\
17 \\
3\end{array}$ & $\begin{array}{r}96.9 \\
31.8 \\
27.2 \\
27.7 \\
35.3 \\
96.5 \\
50.0 \\
16.8 \\
7.1 \\
9.4 \\
6.8 \\
42.5 \\
67.1 \\
57.9 \\
71.4 \\
45.2 \\
42.3 \\
40.6 \\
19.3 \\
58.0 \\
11.4 \\
37.0 \\
31.7 \\
39.8 \\
8.9\end{array}$ & $\begin{array}{c}90.7-103.1 \\
26.7-36.6 \\
15.7-39.6 \\
- \\
28.7-40.9 \\
- \\
49.3-50.8 \\
- \\
6.6-7.6 \\
8.9-9.9 \\
5.8-8.4 \\
38.6-47.2 \\
60.2-78.7 \\
49.0-68.1 \\
- \\
34.0-52.6 \\
22.1-50.3 \\
- \\
- \\
51.8-63.0 \\
- \\
25.7-48.3 \\
28.2-52.6 \\
8.1-9.4\end{array}$ & $\begin{array}{l}4.65 \\
0.27 \\
0.27 \\
0.23 \\
0.52 \\
7.08 \\
1.67 \\
0.05 \\
0.01 \\
0.02 \\
0.01 \\
1.08 \\
2.68 \\
3.21 \\
5.31 \\
1.10 \\
0.93 \\
0.83 \\
0.11 \\
1.03 \\
0.02 \\
0.40 \\
0.25 \\
0.98 \\
0.01\end{array}$ & $\begin{array}{c}3.40-5.90 \\
0.15-0.43 \\
0.03-0.59 \\
- \\
0.25-0.75 \\
- \\
1.48-1.81 \\
- \\
- \\
0.01-0.02 \\
- \\
0.88-1.29 \\
2.09-4.99 \\
1.86-4.58 \\
- \\
0.49-1.47 \\
0.11-1.53 \\
- \\
- \\
0.73-1.39 \\
- \\
0.11-0.91 \\
- \\
0.29-1.97 \\
0.01-0.02\end{array}$ \\
\hline Total & 760 & & & & \\
\hline
\end{tabular}


Appendix Table 28. Species composition, number, and size of fish sampled by electrofishing in the Fort Benton study section, 1976 through 1979.

\begin{tabular}{|c|c|c|c|c|c|}
\hline Fish Species & $\begin{array}{l}\text { Number } \\
\text { Sampled }\end{array}$ & $\begin{array}{l}\text { Average } \\
\text { Length } \\
(\mathrm{cm})\end{array}$ & $\begin{array}{l}\text { Length } \\
\text { Range } \\
(\mathrm{cm}) \\
\end{array}$ & $\begin{array}{l}\text { Average } \\
\text { Weight } \\
(\mathrm{kg})\end{array}$ & $\begin{array}{l}\text { Weight } \\
\text { Range } \\
\text { (kg) }\end{array}$ \\
\hline $\begin{array}{l}\text { Shovelnose sturgeon } \\
\text { Goldeye } \\
\text { Mountain whitefish } \\
\text { Rainbow trout } \\
\text { Brown trout } \\
\text { Brook trout } \\
\text { Carp } \\
\text { Flathead chub } \\
\text { Emerald shiner } \\
\text { W. silvery minnow } \\
\text { Longnose dace } \\
\text { River carpsucker } \\
\text { Blue sucker } \\
\text { Smallmouth buffalo } \\
\text { Bigmouth buffalo } \\
\text { Shorthead redhorse } \\
\text { Longnose sucker } \\
\text { White sucker } \\
\text { Mountain sucker } \\
\text { Stonecat } \\
\text { Burbot } \\
\text { Sauger } \\
\text { Walleye } \\
\text { Freshwater drum } \\
\text { Mottled sculpin }\end{array}$ & $\begin{array}{r}37 \\
198 \\
119 \\
4 \\
14 \\
2 \\
56 \\
34 \\
6 \\
7 \\
12 \\
16 \\
29 \\
57 \\
22 \\
327 \\
180 \\
17 \\
8 \\
1 \\
14 \\
671 \\
7 \\
29 \\
15\end{array}$ & $\begin{array}{r}87.2 \\
31.6 \\
36.8 \\
29.6 \\
40.8 \\
24.0 \\
49.5 \\
15.7 \\
7.4 \\
10.6 \\
7.8 \\
40.7 \\
66.4 \\
58.2 \\
73.7 \\
42.6 \\
37.5 \\
33.1 \\
13.5 \\
14.2 \\
57.0 \\
33.9 \\
58.5 \\
34.5 \\
8.2\end{array}$ & $\begin{array}{r}68.6-101.6 \\
27.9-39.4 \\
9.9-49.5 \\
25.9-39.9 \\
27.9-50.3 \\
23.4-24.6 \\
31.2-61.7 \\
8.4-20.3 \\
- \\
9.7-13.0 \\
4.8-11.7 \\
36.3-44.7 \\
41.4-82.6 \\
46.2-69.9 \\
35.6-83.3 \\
10.9-53.8 \\
15.0-50.3 \\
22.6-44.2 \\
8.6-18.5 \\
- \\
39.1-62.5 \\
18.5-60.2 \\
32.3-74.7 \\
26.7-42.2 \\
5.6-10.4\end{array}$ & $\begin{array}{l}3.03 \\
0.27 \\
0.68 \\
0.37 \\
0.72 \\
0.14 \\
1.59 \\
0.05 \\
0.01 \\
0.02 \\
0.01 \\
0.90 \\
2.66 \\
3.18 \\
7.59 \\
0.91 \\
0.66 \\
0.50 \\
0.04 \\
0.04 \\
1.04 \\
0.33 \\
2.54 \\
0.58 \\
0.01\end{array}$ & $\begin{array}{c}1.66-4.26 \\
0.16-0.51 \\
0.01-1.42 \\
0.18-0.94 \\
0.25-1.27 \\
0.13-0.15 \\
0.51-3.36 \\
0.01-0.11 \\
- \\
0.01-0.03 \\
0.01-0.02 \\
0.59-1.20 \\
0.90-4.54 \\
1.45-5.13 \\
1.20-10.43 \\
0.02-2.16 \\
0.07-1.64 \\
0.15-0.96 \\
0.01-0.09 \\
- \\
0.34-1.56 \\
0.04-2.40 \\
0.32-5.49 \\
0.27-0.98 \\
0.01-0.02\end{array}$ \\
\hline Total & 1882 & & & & \\
\hline
\end{tabular}


Appendix Table 29. Species composition, number, and size of fish sampled by electrofishing in the Loma Ferry study section, 1976 through 1979.

\begin{tabular}{|c|c|c|c|c|c|}
\hline Fish Species & $\begin{array}{l}\text { Number } \\
\text { Sampled }\end{array}$ & $\begin{array}{l}\text { Average } \\
\text { Length } \\
(\mathrm{cm})\end{array}$ & $\begin{array}{l}\text { Length } \\
\text { Range } \\
(\mathrm{cm}) \\
\end{array}$ & $\begin{array}{l}\text { Average } \\
\text { Weight } \\
(\mathrm{kg})\end{array}$ & $\begin{array}{l}\text { Weight } \\
\text { Range } \\
(\mathrm{kg})\end{array}$ \\
\hline $\begin{array}{l}\text { Shovelnose sturgeon } \\
\text { Goldeye } \\
\text { Mountain whitefish } \\
\text { Brown trout } \\
\text { Northern pike } \\
\text { Carp } \\
\text { Flathead chub } \\
\text { Emerald shiner } \\
\text { W. silvery minnow } \\
\text { Longnose dace } \\
\text { River carpsucker } \\
\text { Blue sucker } \\
\text { Smallmouth buffalo } \\
\text { Bigmouth buffalo } \\
\text { Shorthead redhorse } \\
\text { Longnose sucker } \\
\text { White sucker } \\
\text { Mountain sucker } \\
\text { Burbot } \\
\text { Yellow perch } \\
\text { Sauger } \\
\text { Walleye } \\
\text { Freshwater drum } \\
\text { Mottled sculpin }\end{array}$ & $\begin{array}{r}190 \\
170 \\
39 \\
2 \\
5 \\
39 \\
158 \\
32 \\
3 \\
2 \\
32 \\
86 \\
94 \\
23 \\
189 \\
230 \\
5 \\
2 \\
10 \\
7 \\
481 \\
17 \\
55 \\
1\end{array}$ & $\begin{array}{r}82.7 \\
31.0 \\
26.4 \\
34.9 \\
64.2 \\
47.2 \\
13.5 \\
7.3 \\
13.0 \\
7.1 \\
39.6 \\
66.8 \\
57.8 \\
72.2 \\
40.6 \\
38.1 \\
32.0 \\
15.0 \\
46.0 \\
14.1 \\
33.2 \\
51.7 \\
32.4 \\
7.9\end{array}$ & $\begin{array}{r}63.8-100.8 \\
27.9-35.3 \\
9.7-42.4 \\
9.4-60.5 \\
33.3-91.4 \\
25.1-58.4 \\
7.9-24.6 \\
5.1-9.7 \\
12.7-13.5 \\
6.9-7.4 \\
13.5-50.8 \\
55.1-87.1 \\
40.4-72.1 \\
42.4-93.5 \\
14.7-50.8 \\
12.7-52.1 \\
25.7-41.1 \\
12.7-17.3 \\
32.0-55.1 \\
10.9-22.1 \\
15.7-57.9 \\
26.2-76.2 \\
26.4-45.2 \\
-\end{array}$ & $\begin{array}{l}2.53 \\
0.25 \\
0.26 \\
1.09 \\
2.45 \\
1.42 \\
0.03 \\
0.01 \\
0.02 \\
0.01 \\
0.85 \\
3.21 \\
3.12 \\
6.39 \\
0.82 \\
0.73 \\
0.42 \\
0.05 \\
0.50 \\
0.04 \\
0.33 \\
2.15 \\
0.46 \\
0.01\end{array}$ & $\begin{array}{c}0.96-4.67 \\
0.17-0.38 \\
0.01-1.23 \\
0.01-2.16 \\
0.28-5.22 \\
0.22-3.04 \\
0.01-0.15 \\
- \\
0.02-0.03 \\
- \\
0.01-1.68 \\
1.88-8.16 \\
0.98-6.49 \\
5.22-12.25 \\
0.03-1.49 \\
0.04-1.42 \\
0.22-0.72 \\
0.02-0.08 \\
0.17-0.75 \\
0.02-0.11 \\
0.02-1.54 \\
0.11-5.99 \\
0.23-1.27 \\
-\end{array}$ \\
\hline
\end{tabular}

Total

1872 
Appendix Table 30. Species composition, number, and size of fish sampled by electrofishing in the Coal Banks Landing study section, 1976 through 1979.

\begin{tabular}{|c|c|c|c|c|c|}
\hline Fish Species & $\begin{array}{l}\text { Number } \\
\text { Sampled }\end{array}$ & $\begin{array}{l}\text { Average } \\
\text { Length } \\
(\mathrm{cm})\end{array}$ & $\begin{array}{l}\text { Length } \\
\text { Range } \\
(\mathrm{cm}) \\
\end{array}$ & $\begin{array}{l}\text { Average } \\
\text { Weight } \\
(\mathrm{kg})\end{array}$ & $\begin{array}{l}\text { Weight } \\
\text { Range } \\
(\mathrm{kg})\end{array}$ \\
\hline $\begin{array}{l}\text { Pallid sturgeon } \\
\text { Shovelnose sturgeon } \\
\text { Goldeye } \\
\text { Mountain whitefish } \\
\text { Northern pike } \\
\text { Carp } \\
\text { Flathead chub } \\
\text { Emerald shiner } \\
\text { W. silvery minnow } \\
\text { River carpsucker } \\
\text { Blue sucker } \\
\text { Smallmouth buffalo } \\
\text { Bigmouth buffalo } \\
\text { Shorthead redhorse } \\
\text { Longnose sucker } \\
\text { White sucker } \\
\text { Mountain sucker } \\
\text { Channel catfish } \\
\text { Stonecat } \\
\text { Burbot } \\
\text { Sauger } \\
\text { Walleye } \\
\text { Freshwater drum }\end{array}$ & $\begin{array}{r}1 \\
236 \\
276 \\
9 \\
1 \\
62 \\
64 \\
3 \\
9 \\
21 \\
76 \\
69 \\
12 \\
202 \\
67 \\
3 \\
1 \\
1 \\
2 \\
12 \\
358 \\
4 \\
19\end{array}$ & $\begin{array}{r}135.1 \\
83.5 \\
31.1 \\
22.8 \\
80.8 \\
47.3 \\
16.8 \\
7.5 \\
10.8 \\
41.8 \\
70.7 \\
57.0 \\
76.3 \\
38.4 \\
35.6 \\
36.9 \\
6.6 \\
50.3 \\
12.3 \\
44.0 \\
34.3 \\
30.5 \\
32.5\end{array}$ & $\begin{array}{c}57.2-112.3 \\
26.2-37.3 \\
17.0-31.5 \\
- \\
36.6-61.7 \\
9.4-23.6 \\
6.6-8.6 \\
9.7-11.7 \\
37.3-47.2 \\
60.5-87.9 \\
43.4-80.0 \\
69.6-85.1 \\
7.6-50.0 \\
17.8-48.8 \\
36.1-37.8 \\
- \\
- \\
8.9-15.7 \\
26.7-71.1 \\
13.2-52.6 \\
25.4-40.1 \\
27.7-42.9\end{array}$ & $\begin{array}{l}14.52 \\
2.29 \\
0.27 \\
0.13 \\
3.13 \\
1.40 \\
0.06 \\
0.01 \\
0.02 \\
0.94 \\
3.27 \\
3.08 \\
7.59 \\
0.72 \\
0.54 \\
0.58 \\
0.01 \\
1.10 \\
0.03 \\
0.53 \\
0.35 \\
0.26 \\
0.46\end{array}$ & $\begin{array}{r}0.52-5.58 \\
0.17-0.43 \\
0.05-0.21 \\
- \\
0.60-2.95 \\
0.01-0.13 \\
- \\
0.01-0.02 \\
0.72-1.39 \\
1.84-6.58 \\
1.02-7.48 \\
4.94-10.80 \\
0.01-1.62 \\
0.06-1.24 \\
0.54-0.64 \\
- \\
- \\
0.01-0.05 \\
0.11-1.77 \\
0.01-1.36 \\
0.12-0.55 \\
0.26-0.88\end{array}$ \\
\hline Total & 1508 & & & & \\
\hline
\end{tabular}


Appendix Table 31. Species composition, number, and size of fish sampled by electrofishing in the Hole-in-the-Wall study section, 1976 through 1979.

\begin{tabular}{|c|c|c|c|c|c|}
\hline Fish Species & $\begin{array}{l}\text { Number } \\
\text { Sampled }\end{array}$ & $\begin{array}{l}\text { Average } \\
\text { Length } \\
(\mathrm{cm})\end{array}$ & $\begin{array}{l}\text { Length } \\
\text { Range } \\
(\mathrm{cm})\end{array}$ & $\begin{array}{l}\text { Average } \\
\text { Weight } \\
(\mathrm{kg})\end{array}$ & $\begin{array}{l}\text { Weight } \\
\text { Range } \\
(\mathrm{kg}) \\
\end{array}$ \\
\hline Shovelnose sturgeon & 56 & 81.7 & $69.3-97.0$ & 2.52 & $1.54-4.35$ \\
\hline Goldeye & 49 & 32.0 & $27.9-37.6$ & 0.27 & $0.18-0.38$ \\
\hline Carp & 2 & 47.6 & $44.4-50.8$ & 1.32 & $1.07-1.64$ \\
\hline Flathead chub & 11 & 19.9 & $17.4-29.0$ & 0.11 & $0.02-0.29$ \\
\hline River carpsucker & 2 & 44.8 & $43.9-45.7$ & 1.25 & $1.10-1.41$ \\
\hline Blue sucker & 36 & 72.1 & $63.5-79.5$ & 3.50 & $2.04-4.63$ \\
\hline Smallmouth buffalo & 9 & 59.0 & $47.2-65.5$ & 3.24 & $1.63-4.58$ \\
\hline Bigmouth buffalo & 5 & 72.0 & $66.8-81.3$ & 6.70 & $4.94-12.25$ \\
\hline Shorthead redhorse & 12 & 42.4 & $28.7-49.5$ & 0.94 & $0.66-1.43$ \\
\hline Longnose sucker & 3 & 37.3 & $35.1-39.4$ & 0.53 & $0.45-0.59$ \\
\hline Burbot & 3 & 39.0 & $33.5-42.7$ & 0.37 & $0.20-0.49$ \\
\hline Sauger & 23 & 36.6 & $20.3-49.8$ & 0.50 & $0.08-1.05$ \\
\hline Freshwater drum & 1 & 30.5 & - & 0.37 & - \\
\hline Total & 212 & & & & \\
\hline
\end{tabular}


Appendix Table 32. Species composition, number, and size of fish sampled by electrofishing in the Judith Landing study section, 1976 through 1979.

\begin{tabular}{|c|c|c|c|c|c|}
\hline Fish Species & $\begin{array}{l}\text { Number } \\
\text { Sampled }\end{array}$ & $\begin{array}{l}\text { Average } \\
\text { Length } \\
(\mathrm{cm})\end{array}$ & $\begin{array}{l}\text { Length } \\
\text { Range } \\
(\mathrm{cm})\end{array}$ & $\begin{array}{l}\text { Average } \\
\text { Weight } \\
(\mathrm{kg})\end{array}$ & $\begin{array}{l}\text { Weight } \\
\text { Range } \\
\text { (kg) }\end{array}$ \\
\hline $\begin{array}{l}\text { Shovelnose sturgeon } \\
\text { Goldeye } \\
\text { Rainbow trout } \\
\text { Northern pike } \\
\text { Carp } \\
\text { Flathead chub } \\
\text { Emerald shiner } \\
\text { W. silvery minnow } \\
\text { River carpsucker } \\
\text { Blue sucker } \\
\text { Smallmouth buffalo } \\
\text { Bigmouth buffalo } \\
\text { Shorthead redhorse } \\
\text { Longnose sucker } \\
\text { White sucker } \\
\text { Channel catfish } \\
\text { Stonecat } \\
\text { Burbot } \\
\text { White crappie } \\
\text { Sauger } \\
\text { Walleye } \\
\text { Freshwater drum } \\
\text { Mottled sculpin }\end{array}$ & $\begin{array}{r}60 \\
128 \\
1 \\
1 \\
29 \\
47 \\
1 \\
12 \\
28 \\
52 \\
15 \\
11 \\
152 \\
40 \\
6 \\
10 \\
2 \\
12 \\
2 \\
189 \\
1 \\
9 \\
1\end{array}$ & $\begin{array}{r}81.2 \\
30.9 \\
42.7 \\
88.6 \\
47.3 \\
16.2 \\
8.4 \\
11.4 \\
43.4 \\
68.9 \\
59.6 \\
72.6 \\
36.2 \\
32.8 \\
26.9 \\
59.9 \\
16.5 \\
41.0 \\
19.3 \\
30.2 \\
42.9 \\
31.6 \\
5.8\end{array}$ & $\begin{array}{c}66.3-195.0 \\
23.4-34.5 \\
- \\
- \\
40.4-55.6 \\
8.9-26.7 \\
- \\
8.9-12.4 \\
18.5-51.3 \\
61.5-82.8 \\
49.8-67.8 \\
66.3-83.1 \\
17.0-51.8 \\
11.2-46.0 \\
16.5-37.3 \\
47.2-69.3 \\
- \\
24.6-53.3 \\
17.8-20.8 \\
11.7-54.4 \\
- \\
27.9-36.3 \\
-\end{array}$ & $\begin{array}{l}2.43 \\
0.28 \\
0.67 \\
5.31 \\
1.48 \\
0.06 \\
0.01 \\
0.01 \\
1.20 \\
3.53 \\
3.49 \\
6.06 \\
0.59 \\
0.48 \\
0.30 \\
2.63 \\
0.05 \\
0.40 \\
0.10 \\
0.27 \\
0.76 \\
0.40 \\
0.01\end{array}$ & $\begin{array}{c}0.95-4.31 \\
0.14-0.45 \\
- \\
0.89-2.63 \\
0.01-0.22 \\
- \\
0.01-0.02 \\
0.13-1.86 \\
1.95-5.49 \\
1.88-5.99 \\
4.26-9.71 \\
0.07-1.51 \\
0.02-1.10 \\
0.03-0.75 \\
1.08-4.72 \\
0.04-0.05 \\
0.08-0.75 \\
0.07-0.14 \\
0.01-1.40 \\
- \\
0.31-0.55 \\
-\end{array}$ \\
\hline Total & 803 & & & & \\
\hline
\end{tabular}


Appendix Table 33. Species composition, number, and size of fish sampled by electrofishing in the Stafford Ferry study section, 1976 through 1979.

\begin{tabular}{|c|c|c|c|c|c|}
\hline Fish Species & $\begin{array}{l}\text { Number } \\
\text { Sampled }\end{array}$ & $\begin{array}{l}\text { Average } \\
\text { Length } \\
(\mathrm{cm})\end{array}$ & $\begin{array}{l}\text { Length } \\
\text { Range } \\
(\mathrm{cm}) \\
\end{array}$ & $\begin{array}{l}\text { Average } \\
\text { Weight } \\
\text { (kg) }\end{array}$ & $\begin{array}{l}\text { Weight } \\
\text { Range } \\
(\mathrm{kg})\end{array}$ \\
\hline Shovelnose sturgeon & 27 & 80.9 & $68.8-97.8$ & 2.29 & $0.99-3.36$ \\
\hline Goldeye & 51 & 37.0 & $27.2-34.8$ & 0.26 & $0.18-0.38$ \\
\hline Carp & 18 & 49.8 & $45.2-56.1$ & 1.70 & $1.23-2.50$ \\
\hline Flathead chub & 9 & 19.0 & $12.2-24.4$ & 0.08 & $0.02-0.15$ \\
\hline River carpsucker & 5 & 45.0 & $40.6-49.8$ & 1.28 & $0.81-1.64$ \\
\hline Blue sucker & 59 & 71.3 & $63.0-83.3$ & 3.49 & $1.63-5.35$ \\
\hline Smal1mouth buffalo & 3 & 59.0 & $55.9-62.5$ & 3.08 & $2.59-3.67$ \\
\hline Bigmouth buffalo & 5 & 78.5 & $68.6-82.6$ & 9.09 & $5.81-11.20$ \\
\hline Shorthead redhorse & 32 & 40.8 & $17.3-50.3$ & 0.74 & $0.05-1.37$ \\
\hline Longnose sucker & 6 & 36.3 & $22.4-44.4$ & 0.57 & $0.14-0.82$ \\
\hline Burbot & 2 & 37.6 & $31.7-43.4$ & 0.27 & $0.22-0.32$ \\
\hline Sauger & 23 & 37.7 & $29.2-52.1$ & 0.46 & $0.10-1.35$ \\
\hline Total & 240 & & & & \\
\hline
\end{tabular}


Appendix Table 34. Species composition, number, and size of fish sampled by electrofishing in the Cow Island study section, 1976 through 1979.

\begin{tabular}{|c|c|c|c|c|c|}
\hline Fish Species & $\begin{array}{l}\text { Number } \\
\text { Sampled } \\
\end{array}$ & $\begin{array}{l}\text { Average } \\
\text { Length } \\
(\mathrm{cm})\end{array}$ & $\begin{array}{l}\text { Length } \\
\text { Range } \\
\text { (cm) }\end{array}$ & $\begin{array}{l}\text { Average } \\
\text { Weight } \\
(\mathrm{kg})\end{array}$ & $\begin{array}{l}\text { Weight } \\
\text { Range } \\
(\mathrm{kg}) \\
\end{array}$ \\
\hline Pallid sturgeon & one obse & ved, not & aptured & & \\
\hline Shovelnose sturgeon & 78 & 76.2 & $59.7-96.5$ & 1.92 & $0.51-4.58$ \\
\hline Gol deye & 148 & 30.6 & $14.0-35.1$ & 0.29 & $0.04-0.45$ \\
\hline Mountain whitefish & 1 & 15.5 & - & 0.04 & - \\
\hline Carp & 81 & 47.8 & $38.4-62.7$ & 1.42 & $0.77-3.81$ \\
\hline Flathead chub & 22 & 16.0 & $9.9-20.8$ & 0.05 & $0.01-0.12$ \\
\hline W. silvery minnow & 1 & 11.2 & - & 0.01 & - \\
\hline River carpsucker & 15 & 43.1 & $36.1-47.2$ & 1.08 & $0.64-1.61$ \\
\hline Blue sucker & 55 & 73.4 & $61.0-83.3$ & 3.72 & $1.81-5.72$ \\
\hline Smallmouth buffalo & 21 & 56.9 & $49.0-67.3$ & 2.88 & $1.63-6.40$ \\
\hline Bigmouth buffalo & 2 & 76.7 & $75.9-77.5$ & 9.64 & $7.26-12.02$ \\
\hline Shorthead redhorse & 44 & 36.3 & $20.8-48.0$ & 0.58 & $0.10-1.13$ \\
\hline Longnose sucker & 1 & 36.8 & - & 0.53 & - \\
\hline Channel catfish & 1 & 68.6 & - & 4.63 & - \\
\hline Burbot & 2 & 24.1 & $21.6-26.7$ & 0.23 & $0.15-0.32$ \\
\hline Sauger & 33 & 31.2 & $15.2-51.1$ & 0.28 & $0.05-1.07$ \\
\hline Freshwater drum & 3 & 28.8 & $26.9-30.7$ & 0.32 & $0.23-0.36$ \\
\hline Tota 1 & 508 & & & & \\
\hline
\end{tabular}


Appendix Table 35. Species composition, number, and size of fish sampled by electrofishing in the Robinson Bridge study section, 1976 through 1979.

\begin{tabular}{|c|c|c|c|c|c|}
\hline Fish Species & $\begin{array}{l}\text { Number } \\
\text { Sampled }\end{array}$ & $\begin{array}{l}\text { Average } \\
\text { Length } \\
(\mathrm{cm})\end{array}$ & $\begin{array}{l}\text { Length } \\
\text { Range } \\
(\mathrm{cm}) \\
\end{array}$ & $\begin{array}{l}\text { Average } \\
\text { Weight } \\
(\mathrm{kg})\end{array}$ & $\begin{array}{l}\text { Weight } \\
\text { Range } \\
(\mathrm{kg}) \\
\end{array}$ \\
\hline Pallid sturgeon & two obse & ved, not & aptured & & \\
\hline Shovelnose sturgeon & 62 & 74.4 & $62.2-92.5$ & 1.73 & $0.70-3.76$ \\
\hline Gol deye & 326 & 29.2 & $11.2-36.8$ & 0.25 & $0.02-0.50$ \\
\hline Carp & 44 & 46.7 & $32.3-58.9$ & 1.29 & $0.37-2.59$ \\
\hline Flathead chub & 32 & 12.2 & $6.4-24.1$ & 0.06 & $0.01-0.14$ \\
\hline Emerald shiner & 14 & 8.0 & $5.3-9.7$ & 0.01 & - \\
\hline W. silvery minnow & 24 & 10.8 & $9.1-12.4$ & 0.02 & $0.01-0.03$ \\
\hline River carpsucker & 40 & 40.0 & $22.1-48.8$ & 0.99 & $0.16-1.85$ \\
\hline Blue sucker & 20 & 75.6 & $65.0-84.8$ & 4.07 & $2.15-5.72$ \\
\hline Smallmouth buffalo & 2 & 56.6 & $52.1-61.2$ & 2.73 & $2.06-3.40$ \\
\hline Bigmouth buffalo & 1 & 71.4 & - & 5.90 & - \\
\hline Shorthead redhorse & 40 & 34.0 & $22.9-49.5$ & 0.45 & $0.15-1.17$ \\
\hline Longnose sucker & 2 & 23.6 & $20.1-27.2$ & 0.18 & $0.10-0.26$ \\
\hline White sucker & 1 & 21.6 & - & 0.10 & - \\
\hline Channel catfish & 1 & 51.1 & - & 1.07 & - \\
\hline Burbot & 3 & 60.8 & $40.1-78.2$ & 1.37 & $0.32-2.54$ \\
\hline White crappie & 1 & 24.6 & - & 0.24 & - \\
\hline Sauger & 86 & 29.8 & $13.0-50.0$ & 0.25 & $0.01-1.06$ \\
\hline Walleye & 1 & 35.6 & - & 0.34 & - \\
\hline Freshwater drum & 3 & 30.2 & $25.9-33.0$ & 0.36 & $0.22-0.44$ \\
\hline Tota 1 & 703 & & & & \\
\hline
\end{tabular}


Appendix Table 36. Species composition, number, and size of fish sampled by electrofishing in the Turkey Joe study section, 1976 through 1979.

\begin{tabular}{|c|c|c|c|c|c|}
\hline Fish Species & $\begin{array}{l}\text { Number } \\
\text { Sampled }\end{array}$ & $\begin{array}{l}\text { Average } \\
\text { Length } \\
(\mathrm{cm})\end{array}$ & $\begin{array}{l}\text { Length } \\
\text { Range } \\
(\mathrm{cm})\end{array}$ & $\begin{array}{l}\text { Average } \\
\text { Weight } \\
(\mathrm{kg})\end{array}$ & $\begin{array}{l}\text { Weight } \\
\text { Range } \\
(\mathrm{kg})\end{array}$ \\
\hline $\begin{array}{l}\text { Shovelnose sturgeon } \\
\text { Goldeye } \\
\text { Northern pike } \\
\text { Carp } \\
\text { W. silvery minnow } \\
\text { River carpsucker } \\
\text { Burbot } \\
\text { Sauger }\end{array}$ & $\begin{array}{r}1 \\
40 \\
1 \\
16 \\
1 \\
3 \\
4 \\
30\end{array}$ & $\begin{array}{l}68.6 \\
27.2 \\
59.9 \\
36.8 \\
10.7 \\
38.6 \\
52.4 \\
31.9\end{array}$ & $\begin{array}{c}17.3-35.6 \\
- \\
22.4-50.0 \\
- \\
25.7-45.7 \\
48.3-56.6 \\
20.8-42.7\end{array}$ & $\begin{array}{l}1.39 \\
0.23 \\
1.36 \\
0.76 \\
0.01 \\
0.93 \\
0.83 \\
0.27\end{array}$ & $\begin{array}{c}- \\
0.05-0.49 \\
- \\
0.19-1.47 \\
- \\
0.22-1.31 \\
0.49-1.04 \\
0.06-0.69\end{array}$ \\
\hline
\end{tabular}

Total

96

Appendix Table 37. Species composition, number, and size of fish sampled by experimental gill netting in the Carter Ferry study section, 1976 and 1977.

\begin{tabular}{|c|c|c|c|c|c|}
\hline Fish Species & $\begin{array}{l}\text { Number } \\
\text { Sampled }\end{array}$ & $\begin{array}{l}\text { Average } \\
\text { Length } \\
(\mathrm{cm})\end{array}$ & $\begin{array}{l}\text { Length } \\
\text { Range } \\
(\mathrm{cm}) \\
\end{array}$ & $\begin{array}{l}\text { Average } \\
\text { Weight } \\
(\mathrm{kg})\end{array}$ & $\begin{array}{l}\text { Weight } \\
\text { Range } \\
(\mathrm{kg})\end{array}$ \\
\hline $\begin{array}{l}\text { Goldeye } \\
\text { Northern pike } \\
\text { Shorthead redhorse } \\
\text { Longnose sucker } \\
\text { White sucker } \\
\text { Sauger }\end{array}$ & $\begin{array}{l}1 \\
2 \\
2 \\
3 \\
2 \\
9\end{array}$ & $\begin{array}{l}33.5 \\
71.9 \\
45.7 \\
42.2 \\
43.3 \\
34.2\end{array}$ & $\begin{array}{l}- \\
70.1-73.7 \\
45.5-46.0 \\
41.9-42.4 \\
41.4-45.2 \\
31.5-37.8\end{array}$ & $\begin{array}{l}0.36 \\
2.52 \\
1.14 \\
0.89 \\
1.07 \\
0.33\end{array}$ & $\begin{array}{l}- \\
2.20-2.85 \\
1.12-1.15 \\
0.83-0.96 \\
0.93-1.21 \\
0.24-0.43\end{array}$ \\
\hline Total & 19 & & & & \\
\hline
\end{tabular}


Appendix Table 38. Species composition, number, and size of fish sampled by experimental gil1 netting in the Fort Benton study section, 1976 and 1977.

\begin{tabular}{|c|c|c|c|c|c|}
\hline Fish Species & $\begin{array}{l}\text { Number } \\
\text { Sampled }\end{array}$ & $\begin{array}{l}\text { Average } \\
\text { Length } \\
(\mathrm{cm})\end{array}$ & $\begin{array}{l}\text { Length } \\
\text { Range } \\
\text { (cm) }\end{array}$ & $\begin{array}{l}\text { Average } \\
\text { Weight } \\
(\mathrm{kg}) \\
\end{array}$ & $\begin{array}{l}\text { Weight } \\
\text { Range } \\
\text { (kg) }\end{array}$ \\
\hline Shovelnose sturgeon & 3 & 91.7 & $86.6-96.5$ & 3.28 & $2.81-3.90$ \\
\hline Goldeye & 96 & 31.7 & $28.2-38.4$ & 0.28 & $0.18-0.48$ \\
\hline Brown trout & 1 & 47.2 & - & 1.92 & - \\
\hline Carp & 17 & 50.8 & $44.2-57.4$ & 1.76 & $1.18-2.40$ \\
\hline Flathead chub & 5 & 15.7 & $8.4-19.8$ & 0.06 & $0.01-0.11$ \\
\hline River carpsucker & 6 & 47.3 & $37.6-45.2$ & 0.90 & $0.57-1.27$ \\
\hline Blue sucker & 5 & 68.4 & $65.5-70.1$ & 2.72 & $2.27-3.08$ \\
\hline Smal1mouth buffalo & 2 & 60.2 & $58.4-62.0$ & 3.40 & $3.36-3.45$ \\
\hline Bigmouth buffalo & 4 & 61.2 & $47.0-72.1$ & 4.16 & $1.81-6.26$ \\
\hline Shor thead redhorse & 24 & 41.5 & $28.4-49.5$ & 0.86 & $0.27-1.68$ \\
\hline Longnose sucker & 42 & 32.9 & $19.3-46.5$ & 0.47 & $0.08-1.31$ \\
\hline White sucker & 10 & 33.5 & $18.5-43.7$ & 0.53 & $0.08-0.93$ \\
\hline Mountain sucker & 3 & 10.2 & $8.4-13.7$ & 0.02 & $0.02-0.03$ \\
\hline Stonecat & 2 & 14.2 & $13.7-14.7$ & 0.04 & $0.04-0.05$ \\
\hline Burbot & 2 & 48.3 & $38.1-58.4$ & 0.71 & $0.47-0.94$ \\
\hline Sauger & 23 & 31.3 & $24.6-42.9$ & 0.25 & $0.10-0.54$ \\
\hline Walleye & 1 & 62.0 & - & 2.81 & - \\
\hline Freshwater drum & 13 & 31.2 & $26.4-36.6$ & 0.44 & $0.25-0.73$ \\
\hline Total & 259 & & & & \\
\hline
\end{tabular}


Appendix Table 39. Species composition, number, and sizes of fish sampled by experimental gill netting in the Loma Ferry study section, 1976 and 1977.

\begin{tabular}{|c|c|c|c|c|c|}
\hline Fish Species & $\begin{array}{l}\text { Number } \\
\text { Sampled }\end{array}$ & $\begin{array}{l}\text { Average } \\
\text { Length } \\
(\mathrm{cm})\end{array}$ & $\begin{array}{l}\text { Length } \\
\text { Range } \\
(\mathrm{cm}) \\
\end{array}$ & $\begin{array}{l}\text { Average } \\
\text { Weight } \\
(\mathrm{kg})\end{array}$ & $\begin{array}{l}\text { Weight } \\
\text { Range } \\
(\mathrm{kg})\end{array}$ \\
\hline $\begin{array}{l}\text { Shovelnose sturgeon } \\
\text { Goldeye } \\
\text { Northern pike } \\
\text { Carp } \\
\text { Flathead chub } \\
\text { River carpsucker } \\
\text { Smallmouth buffalo } \\
\text { Shorthead redhorse } \\
\text { Longnose sucker } \\
\text { Black bullhead } \\
\text { Stonecat } \\
\text { Burbot } \\
\text { Yellow perch } \\
\text { Sauger } \\
\text { Walleye } \\
\text { Freshwater drum }\end{array}$ & $\begin{array}{r}47 \\
331 \\
1 \\
7 \\
3 \\
19 \\
2 \\
42 \\
23 \\
2 \\
1 \\
1 \\
1 \\
17 \\
1 \\
2\end{array}$ & $\begin{array}{l}78.6 \\
30.7 \\
56.6 \\
42.9 \\
18.7 \\
39.7 \\
57.8 \\
42.2 \\
40.9 \\
19.9 \\
20.1 \\
73.2 \\
20.1 \\
30.2 \\
64.5 \\
33.0\end{array}$ & $\begin{array}{c}58.9-89.9 \\
19.3-35.8 \\
- \\
38.9-57.2 \\
16.5-20.6 \\
31.2-45.2 \\
53.8-61.7 \\
20.8-50.3 \\
22.6-49.5 \\
19.7-20.8 \\
- \\
- \\
- \\
18.0-41.1 \\
- \\
30.5-35.6\end{array}$ & $\begin{array}{l}2.06 \\
0.27 \\
1.24 \\
1.24 \\
0.07 \\
0.83 \\
2.65 \\
0.97 \\
0.87 \\
0.07 \\
0.10 \\
2.05 \\
0.11 \\
0.23 \\
2.90 \\
0.45\end{array}$ & $\begin{array}{c}0.83-3.04 \\
0.05-0.44 \\
- \\
0.78-3.33 \\
0.05-0.09 \\
0.48-1.31 \\
2.36-3.04 \\
0.47-1.58 \\
0.13-1.32 \\
0.06-0.09 \\
- \\
- \\
- \\
0.05-0.67 \\
- \\
0.35-0.54\end{array}$ \\
\hline Total & 500 & & & & \\
\hline
\end{tabular}

Appendix Table 40. Species composition, number, and size of fish sampled by experimental gill netting in the Coal Banks Landing study section, 1976 and 1977.

\begin{tabular}{|c|c|c|c|c|c|}
\hline Fish Species & $\begin{array}{l}\text { Number } \\
\text { Sampled }\end{array}$ & $\begin{array}{l}\text { Average } \\
\text { Length } \\
\text { (cm) }\end{array}$ & $\begin{array}{l}\text { Length } \\
\text { Range } \\
(\mathrm{cm}) \\
\end{array}$ & $\begin{array}{l}\text { Average } \\
\text { Weight } \\
\text { (kg) }\end{array}$ & $\begin{array}{l}\text { Weight } \\
\text { Range } \\
\text { (kg) }\end{array}$ \\
\hline $\begin{array}{l}\text { Shovelnose sturgeon } \\
\text { Goldeve }\end{array}$ & $\begin{array}{r}5 \\
88\end{array}$ & $\begin{array}{l}76.4 \\
30.8\end{array}$ & $\begin{array}{l}65.0-77.5 \\
21-3-34.5\end{array}$ & $\begin{array}{l}1.75 \\
0.28\end{array}$ & $\begin{array}{l}1.18-2.45 \\
0.10-0.40\end{array}$ \\
\hline Carp & 1 & 40.9 & $\begin{array}{c}61.0-34.0 \\
-\end{array}$ & 0.94 & $0.10-0.40$ \\
\hline River carpsucker & $i$ & 40.7 & - & 0.77 & - \\
\hline Shorthead redhorse & 20 & 38.1 & $25.1-48.3$ & 0.65 & $0.19-7.29$ \\
\hline Longnose sucker & 6 & 38.2 & $26.9-41.9$ & 0.67 & $0.27-0.85$ \\
\hline White sucker & 5 & 35.6 & $32.3-42.2$ & 0.57 & $0.40-0.85$ \\
\hline Channel catfish & 2 & 73.7 & - & 5.24 & $4.94-5.53$ \\
\hline Stonecat & 1 & 16.5 & - & 0.05 & - \\
\hline White crappie & 1 & 15.5 & - & 0.06 & - \\
\hline Yellow perch & 1 & 19.6 & - & 0.13 & - \\
\hline Sauger & 65 & 31.2 & $22.6-49.8$ & 0.28 & $0.08-1.36$ \\
\hline Walleye & 2 & 31.7 & $27.4-36.1$ & 0.33 & $0.18-0.47$ \\
\hline
\end{tabular}


Appendix Table 41. Species composition, number, and size of fish sampled by experimental gill netting in the Hole-in-the-Wall study section, 1976 and 1977.

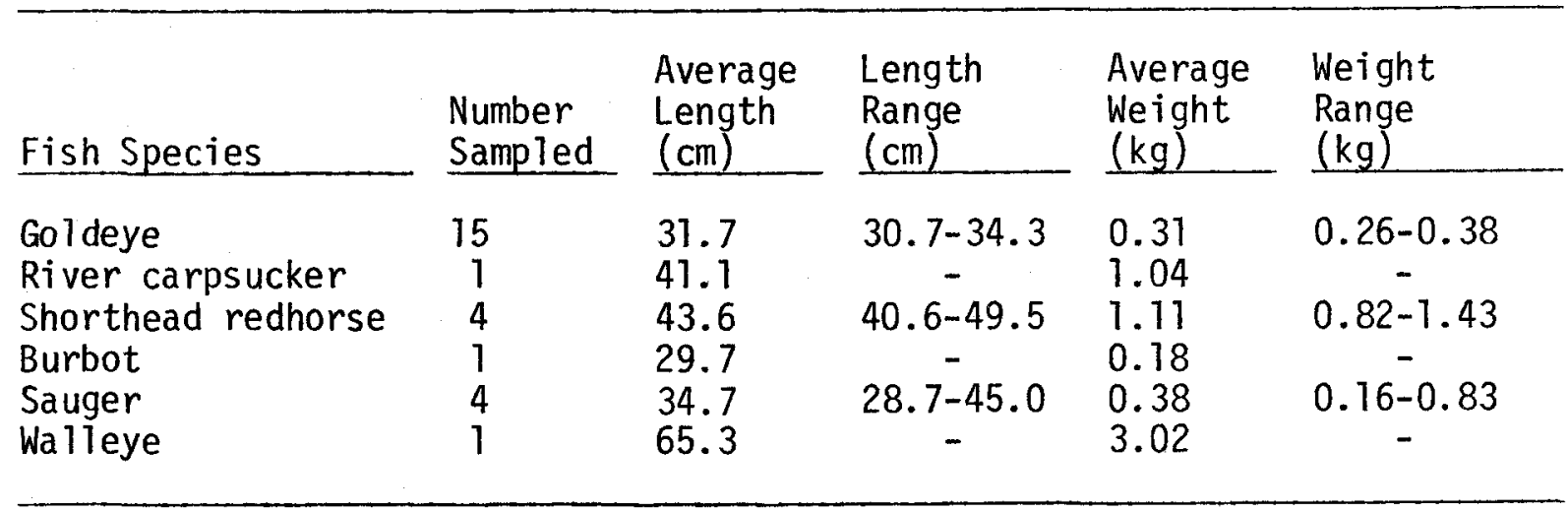

Total

26

Appendix Table 42. Species composition, number, and size of fish sampled by experimental gill netting in the Judith Landing study section, 1976 and 1977.

\begin{tabular}{|c|c|c|c|c|c|}
\hline Fish Species & $\begin{array}{l}\text { Number } \\
\text { Sampled } \\
\end{array}$ & $\begin{array}{l}\text { Average } \\
\text { Length } \\
\text { (cm) }\end{array}$ & $\begin{array}{l}\text { Length } \\
\text { Range } \\
\text { (cm) }\end{array}$ & $\begin{array}{l}\text { Average } \\
\text { Weight } \\
\text { (kg) }\end{array}$ & $\begin{array}{l}\text { Weight } \\
\text { Range } \\
(\mathrm{kg}) \\
\end{array}$ \\
\hline $\begin{array}{l}\text { Shovelnose sturgeon } \\
\text { Goldeye } \\
\text { Carp } \\
\text { Flathead chub } \\
\text { Shorthead redhorse } \\
\text { Longnose sucker } \\
\text { White sucker } \\
\text { Channel catfish } \\
\text { Burbot } \\
\text { Yellow perch } \\
\text { White crappie } \\
\text { Sauger }\end{array}$ & $\begin{array}{r}2 \\
26 \\
5 \\
2 \\
5 \\
11 \\
1 \\
1 \\
1 \\
1 \\
4 \\
25\end{array}$ & $\begin{array}{l}74.7 \\
29.2 \\
47.2 \\
16.8 \\
36.4 \\
29.4 \\
26.2 \\
67.3 \\
37.6 \\
17.8 \\
18.7 \\
29.3\end{array}$ & $\begin{array}{l}73.2-76.2 \\
25.9-32.5 \\
41.4-51.6 \\
15.7-17.8 \\
16.5-47.2 \\
21.8-32.0 \\
- \\
- \\
- \\
- \\
18.0-19.1 \\
19.8-42.2\end{array}$ & $\begin{array}{l}1.79 \\
0.23 \\
1.39 \\
0.05 \\
0.76 \\
0.28 \\
0.19 \\
4.04 \\
0.28 \\
0.09 \\
0.09 \\
0.20\end{array}$ & $\begin{array}{l}1.72-1.86 \\
0.16-0.32 \\
0.92-1.91 \\
0.04-0.06 \\
0.05-1.26 \\
0.10-0.36 \\
- \\
- \\
- \\
- \\
0.08-0.11 \\
0.06-0.59\end{array}$ \\
\hline Total & 84 & & & & \\
\hline
\end{tabular}


Appendix Table 43. Species composition, number, and size of fish sampled by experimental gill netting in the Stafford Ferry study section, 1976 and 1977.

\begin{tabular}{|c|c|c|c|c|c|}
\hline Fish Species & $\begin{array}{l}\text { Number } \\
\text { Sampled }\end{array}$ & $\begin{array}{l}\text { Average } \\
\text { Length } \\
\text { (cm) }\end{array}$ & $\begin{array}{l}\text { Length } \\
\text { Range } \\
(\mathrm{cm}) \\
\end{array}$ & $\begin{array}{l}\text { Average } \\
\text { Weight } \\
(\mathrm{kg})\end{array}$ & $\begin{array}{l}\text { Weight } \\
\text { Range } \\
(\mathrm{kg})\end{array}$ \\
\hline $\begin{array}{l}\text { Shorthead redhorse } \\
\text { Stonecat } \\
\text { Sauger }\end{array}$ & $\begin{array}{l}2 \\
1 \\
2\end{array}$ & $\begin{array}{r}33.9 \\
7.6 \\
37.8\end{array}$ & $\begin{array}{c}16.5-51.3 \\
- \\
34.5-41.1\end{array}$ & $\begin{array}{l}0.84 \\
0.01 \\
0.46\end{array}$ & $\begin{array}{c}0.05-1.63 \\
- \\
0.32-0.60\end{array}$ \\
\hline Total & 5 & & & & \\
\hline
\end{tabular}

Appendix Table 44. Species composition, number, and size of fish sampled by experimental gill netting in the Cow Island study section, 1976 and 1977.

\begin{tabular}{|c|c|c|c|c|c|}
\hline Fish Species & $\begin{array}{l}\text { Number } \\
\text { Sampled }\end{array}$ & $\begin{array}{l}\text { Average } \\
\text { Length } \\
(\mathrm{cm})\end{array}$ & $\begin{array}{l}\text { Length } \\
\text { Range } \\
(\mathrm{cm})\end{array}$ & $\begin{array}{l}\text { Average } \\
\text { Weight } \\
\text { (kg) }\end{array}$ & $\begin{array}{l}\text { Weight } \\
\text { Range } \\
\text { (kg) }\end{array}$ \\
\hline $\begin{array}{l}\text { Goldeye } \\
\text { Sauger }\end{array}$ & $\begin{array}{r}7 \\
15\end{array}$ & $\begin{array}{l}31.8 \\
35.9\end{array}$ & $\begin{array}{l}31.0-34.0 \\
27.9-47.2\end{array}$ & $\begin{array}{l}0.31 \\
0.38\end{array}$ & $\begin{array}{l}0.24-0.34 \\
0.16-0.83\end{array}$ \\
\hline Total & 22 & & & & \\
\hline
\end{tabular}


Appendix Table 45. Species composition, number, and size of fish sampled by experimental gill netting in the Robinson Bridge study section, 1976 and 1977.

\begin{tabular}{|c|c|c|c|c|c|}
\hline Fish Species & $\begin{array}{l}\text { Number } \\
\text { Sampled }\end{array}$ & $\begin{array}{l}\text { Average } \\
\text { Length } \\
(\mathrm{cm})\end{array}$ & $\begin{array}{l}\text { Length } \\
\text { Range } \\
\text { (cm) }\end{array}$ & $\begin{array}{l}\text { Average } \\
\text { Weight } \\
(\mathrm{kg})\end{array}$ & $\begin{array}{l}\text { Weight } \\
\text { Range } \\
\text { (kg) }\end{array}$ \\
\hline $\begin{array}{l}\text { Goldeye } \\
\text { Rainbow trout } \\
\text { Northern pike } \\
\text { Flathead chub } \\
\text { River carpsucker } \\
\text { Shorthead redhorse } \\
\text { White sucker } \\
\text { Channel catfish } \\
\text { White crappie }\end{array}$ & $\begin{array}{r}294 \\
1 \\
3 \\
2 \\
27 \\
1 \\
1 \\
1 \\
1\end{array}$ & $\begin{array}{l}28.6 \\
47.2 \\
65.6 \\
21.7 \\
38.2 \\
27.7 \\
34.0 \\
67.3 \\
18.3\end{array}$ & $\begin{array}{c}16.5-36.8 \\
- \\
65.3-66.0 \\
19.6-23.9 \\
22.7-46.5 \\
- \\
- \\
- \\
-\end{array}$ & $\begin{array}{l}0.23 \\
1.30 \\
1.82 \\
0.11 \\
0.91 \\
0.26 \\
0.40 \\
4.10 \\
0.10\end{array}$ & $\begin{array}{c}0.03-0.40 \\
- \\
1.63-2.04 \\
0.08-0.14 \\
0.16-1.61 \\
- \\
- \\
- \\
-\end{array}$ \\
\hline $\begin{array}{l}\text { Yel low perch } \\
\text { Sauger } \\
\text { Walleye }\end{array}$ & $\begin{array}{r}1 \\
80 \\
3\end{array}$ & $\begin{array}{l}19.3 \\
32.6 \\
39.4\end{array}$ & $\begin{array}{c}- \\
20.6-43.7 \\
34.8-46.0\end{array}$ & $\begin{array}{l}0.09 \\
0.29 \\
0.63\end{array}$ & $\begin{array}{c}- \\
0.07-0.71 \\
0.39-0.71\end{array}$ \\
\hline
\end{tabular}

Tota 1

415

Appendix Table 46. Species composition, number, and size of fish sampled by experimental gill netting in the Turkey Joe study section, 1976 and 1977.

\begin{tabular}{|c|c|c|c|c|c|}
\hline Fish Species & $\begin{array}{l}\text { Number } \\
\text { Sampled }\end{array}$ & $\begin{array}{l}\text { Average } \\
\text { Length } \\
(\mathrm{cm})\end{array}$ & $\begin{array}{l}\text { Length } \\
\text { Range } \\
\text { (cm) }\end{array}$ & $\begin{array}{l}\text { Average } \\
\text { Weight } \\
(\mathrm{kg})\end{array}$ & $\begin{array}{l}\text { Weight } \\
\text { Range } \\
(\mathrm{kg}) \\
\end{array}$ \\
\hline Gol deye & 275 & 30.8 & $19.3-35.1$ & 0.28 & $0.10-0.44$ \\
\hline Northern pike & 1 & 80.8 & - & 3.13 & - \\
\hline Carp & 10 & 41.1 & $28.4-50.3$ & 0.97 & $0.39-1.48$ \\
\hline River carpsucker & 40 & 42.7 & $24.4-46.2$ & 1.08 & $0.20-1.60$ \\
\hline Smallmouth buffalo & 1 & 61.7 & - & 3.90 & - \\
\hline Shorthead redhorse & 10 & 39.8 & $23.9-46.2$ & 0.64 & $0.15-0.97$ \\
\hline Channel catfish & 3 & 39.5 & $31.0-43.9$ & 0.60 & $0.27-0.78$ \\
\hline White crappie & 6 & 23.8 & $19.6-28.7$ & 0.26 & $0.14-0.42$ \\
\hline Sauger & 181 & 35.5 & $22.1-54.6$ & 0.37 & $0.09-1.17$ \\
\hline Freshwater drum & 4 & 28.6 & $25.7-32.7$ & 0.30 & $0.22-0.45$ \\
\hline
\end{tabular}

Total 
Appendix Table 47. Species composition, number, and size of fish sampled with baited hoop nets at the Turkey Joe study site, 1977 through 1979.

\begin{tabular}{|c|c|c|c|c|c|}
\hline Fish Species & $\begin{array}{l}\text { Number } \\
\text { Sampled }\end{array}$ & $\begin{array}{l}\text { Average } \\
\text { Length } \\
(\mathrm{cm})\end{array}$ & $\begin{array}{l}\text { Length } \\
\text { Range } \\
(\mathrm{cm}) \\
\end{array}$ & $\begin{array}{l}\text { Average } \\
\text { We ight } \\
(\mathrm{kg})\end{array}$ & $\begin{array}{l}\text { Weight } \\
\text { Range } \\
(\mathrm{kg})\end{array}$ \\
\hline $\begin{array}{l}\text { Channel catfish } \\
\text { Sauger } \\
\text { Burbot } \\
\text { Freshwater drum } \\
\text { Goldeye } \\
\text { Shorthead redhorse } \\
\text { Smallmouth buffalo } \\
\text { River carpsucker } \\
\text { Carp }\end{array}$ & $\begin{array}{r}1958 \\
15 \\
2 \\
8 \\
2 \\
9 \\
4 \\
1 \\
5\end{array}$ & $\begin{array}{l}38.5 \\
47.8 \\
47.0 \\
35.6 \\
29.5 \\
40.1 \\
57.0 \\
44.2 \\
41.4\end{array}$ & $\begin{array}{c}17.5-91.2 \\
34.3-51.8 \\
44.2-49.8 \\
24.9-46.7 \\
28.4-30.2 \\
39.6-40.9 \\
54.1-59.7 \\
- \\
41.1-41.7\end{array}$ & $\begin{array}{l}0.63 \\
0.57 \\
0.54 \\
0.89 \\
0.25 \\
0.66 \\
2.64 \\
1.15 \\
0.99\end{array}$ & $\begin{array}{l}0.05-10.52 \\
0.31-1.15 \\
0.43-0.66 \\
0.12-1.86 \\
0.21-0.29 \\
0.64-0.67 \\
2.40-2.90 \\
-1.02\end{array}$ \\
\hline Tota 1 & 2004 & & & & \\
\hline
\end{tabular}

Appendix Table 48. Species composition, number, and size of fish sampled with baited hoop nets at the Two Calf Island study site, 1979 .

\begin{tabular}{llllll}
\hline Fish Species & $\begin{array}{l}\text { Number } \\
\text { Sampled }\end{array}$ & $\begin{array}{l}\text { Average } \\
\text { Length } \\
(\mathrm{cm})\end{array}$ & $\begin{array}{l}\text { Length } \\
\text { Range } \\
(\mathrm{cm})\end{array}$ & $\begin{array}{l}\text { Average } \\
\text { Weight } \\
(\mathrm{kg})\end{array}$ & $\begin{array}{l}\text { Weight } \\
\text { Range } \\
(\mathrm{kg})\end{array}$ \\
\hline Channel catfish & 6 & 56.2 & $38.1-77.0$ & 2.53 & $0.40-6.30$ \\
\hline Total & 6 & & & \\
\hline
\end{tabular}


Appendix Table 49. Species composition, number, and size of fish sampled with baited hoop nets at the Judith Landing study site, 1977.

\begin{tabular}{|c|c|c|c|c|c|}
\hline Fish Species & $\begin{array}{l}\text { Number } \\
\text { Sampled }\end{array}$ & $\begin{array}{l}\text { Average } \\
\text { Length } \\
(\mathrm{cm})\end{array}$ & $\begin{array}{l}\text { Length } \\
\text { Range } \\
(\mathrm{cm}) \\
\end{array}$ & $\begin{array}{l}\text { Average } \\
\text { Weight } \\
\text { (kg) }\end{array}$ & $\begin{array}{l}\text { Weight } \\
\text { Range } \\
(\mathrm{kg}) \\
\end{array}$ \\
\hline $\begin{array}{l}\text { Channel catfish } \\
\text { Shovelnose sturgeon } \\
\text { Sauger } \\
\text { Goldeye } \\
\text { Shorthead redhorse }\end{array}$ & $\begin{array}{r}30 \\
1 \\
3 \\
1 \\
1\end{array}$ & $\begin{array}{l}57.4 \\
81.8 \\
47.8 \\
30.5 \\
35.6\end{array}$ & $\begin{array}{c}30.0-82.3 \\
- \\
35.6-53.4 \\
- \\
-\end{array}$ & $\begin{array}{l}2.13 \\
2.31 \\
1.07 \\
0.27 \\
0.58\end{array}$ & $\begin{array}{c}0.28-7.17 \\
- \\
0.43-7.56 \\
- \\
-\end{array}$ \\
\hline
\end{tabular}

Total 36

Appendix Table 50. Species composition, number, and size of fish sampled with baited hoop nets at the Loma Ferry study site, 1978.

\begin{tabular}{|c|c|c|c|c|c|}
\hline Fish Species & $\begin{array}{l}\text { Number } \\
\text { Sampled }\end{array}$ & $\begin{array}{l}\text { Average } \\
\text { Length } \\
(\mathrm{cm})\end{array}$ & $\begin{array}{l}\text { Length } \\
\text { Range } \\
(\mathrm{cm}) \\
\end{array}$ & $\begin{array}{l}\text { Average } \\
\text { Weight } \\
(\mathrm{kg})\end{array}$ & $\begin{array}{l}\text { Weight } \\
\text { Range } \\
(\mathrm{kg}) \\
\end{array}$ \\
\hline $\begin{array}{l}\text { Channe1 catfish } \\
\text { Sauger } \\
\text { Shorthead redhorse } \\
\text { Longnose sucker } \\
\text { Carp }\end{array}$ & $\begin{array}{l}8 \\
3 \\
5 \\
4 \\
1\end{array}$ & $\begin{array}{l}56.7 \\
39.8 \\
\text { not meas } \\
\text { not meas } \\
\text { not meas }\end{array}$ & $\begin{array}{l}41.9-74.2 \\
36.8-43.9 \\
\text { red } \\
\text { red } \\
\text { red }\end{array}$ & $\begin{array}{l}2.22 \\
0.46\end{array}$ & $\begin{array}{l}0.58-4.76 \\
0.36-0.55\end{array}$ \\
\hline Total & 21 & & & & \\
\hline
\end{tabular}


Appendix Table 51. Species composition, number, and size of fish sampled with baited hoop nets in the lower Marias River study section, 1978 and 1979.

\begin{tabular}{|c|c|c|c|c|c|}
\hline Fish Species & $\begin{array}{l}\text { Number } \\
\text { Sampled }\end{array}$ & $\begin{array}{l}\text { Average } \\
\text { Length } \\
(\mathrm{cm})\end{array}$ & $\begin{array}{l}\text { Length } \\
\text { Range } \\
(\mathrm{cm})\end{array}$ & $\begin{array}{l}\text { Average } \\
\text { Weight } \\
(\mathrm{kg})\end{array}$ & $\begin{array}{l}\text { Weight } \\
\text { Range } \\
(\mathrm{kg})\end{array}$ \\
\hline $\begin{array}{l}\text { Channel catfish } \\
\text { Shovelnose sturgeon } \\
\text { Sauger } \\
\text { Northern pike } \\
\text { Burbot } \\
\text { Goldeye } \\
\text { White sucker } \\
\text { Shorthead redhorse } \\
\text { Longnose sucker } \\
\text { River carpsucker }\end{array}$ & $\begin{array}{r}28 \\
14 \\
6 \\
1 \\
2 \\
2 \\
7 \\
5 \\
2 \\
4\end{array}$ & $\begin{array}{l}42.2 \\
79.8 \\
41.1 \\
52.8 \\
44.6 \\
\text { not meas } \\
\text { not meas } \\
\text { not meas } \\
\text { not meas } \\
\text { not meas }\end{array}$ & $\begin{array}{l}29.2-78.7 \\
71.4-91.4 \\
37.6-47.2 \\
- \\
40.9-48.3 \\
\text { red } \\
\text { red } \\
\text { red } \\
\text { red } \\
\text { red }\end{array}$ & $\begin{array}{l}1.39 \\
1.94 \\
0.54 \\
1.12 \\
0.44\end{array}$ & $\begin{array}{c}0.22-6.71 \\
1.27-2.90 \\
0.41-0.87 \\
- \\
0.36-0.52\end{array}$ \\
\hline Total & 71 & & & & \\
\hline
\end{tabular}

Appendix Table 52. Species composition, number, and size of fish sampled with baited hoop nets in the lower Teton River study section, 1978 and 1979.

\begin{tabular}{|c|c|c|c|c|c|}
\hline Fish Species & $\begin{array}{l}\text { Number } \\
\text { Sampled }\end{array}$ & $\begin{array}{l}\text { Average } \\
\text { Length } \\
(\mathrm{cm})\end{array}$ & $\begin{array}{l}\text { Length } \\
\text { Range } \\
\text { (cm) }\end{array}$ & $\begin{array}{l}\text { Average } \\
\text { Weight } \\
(\mathrm{kg})\end{array}$ & $\begin{array}{l}\text { Weight } \\
\text { Range } \\
(\mathrm{kg}) \\
\end{array}$ \\
\hline $\begin{array}{l}\text { Channel catfish } \\
\text { Sauger } \\
\text { River carpsucker } \\
\text { Flathead chub } \\
\text { Goldeye } \\
\text { Shorthead redhorse }\end{array}$ & $\begin{array}{r}19 \\
6 \\
5 \\
2 \\
1 \\
1\end{array}$ & $\begin{array}{l}53.7 \\
41.5 \\
\text { not meas } \\
\text { not meas } \\
\text { not meas } \\
\text { not meas }\end{array}$ & $\begin{array}{l}37.5-80.3 \\
37.3-57.6 \\
\text { red } \\
\text { red } \\
\text { red } \\
\text { red }\end{array}$ & $\begin{array}{l}2.65 \\
0.54\end{array}$ & $\begin{array}{l}0.27-6.94 \\
0.39-0.91\end{array}$ \\
\hline
\end{tabular}




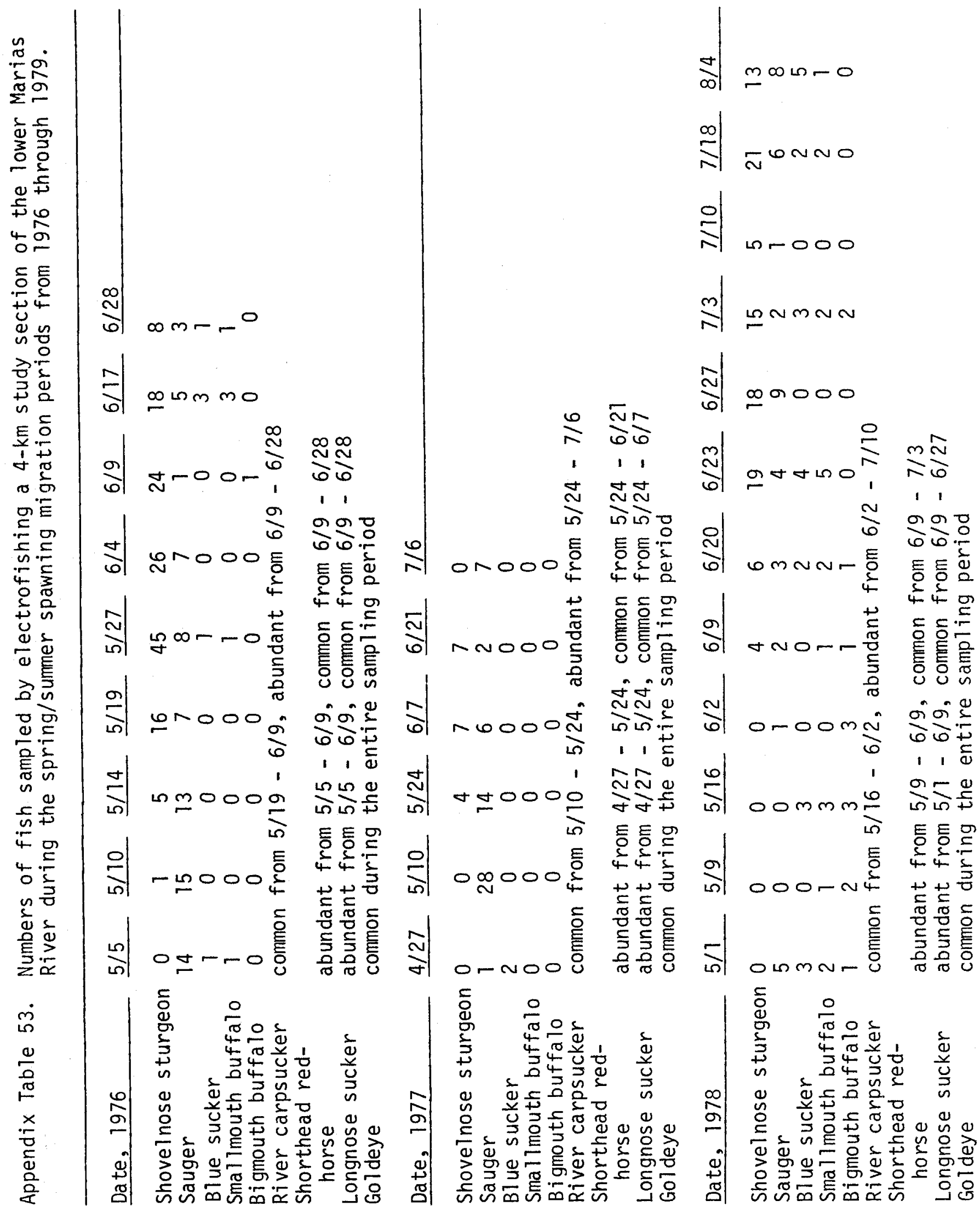




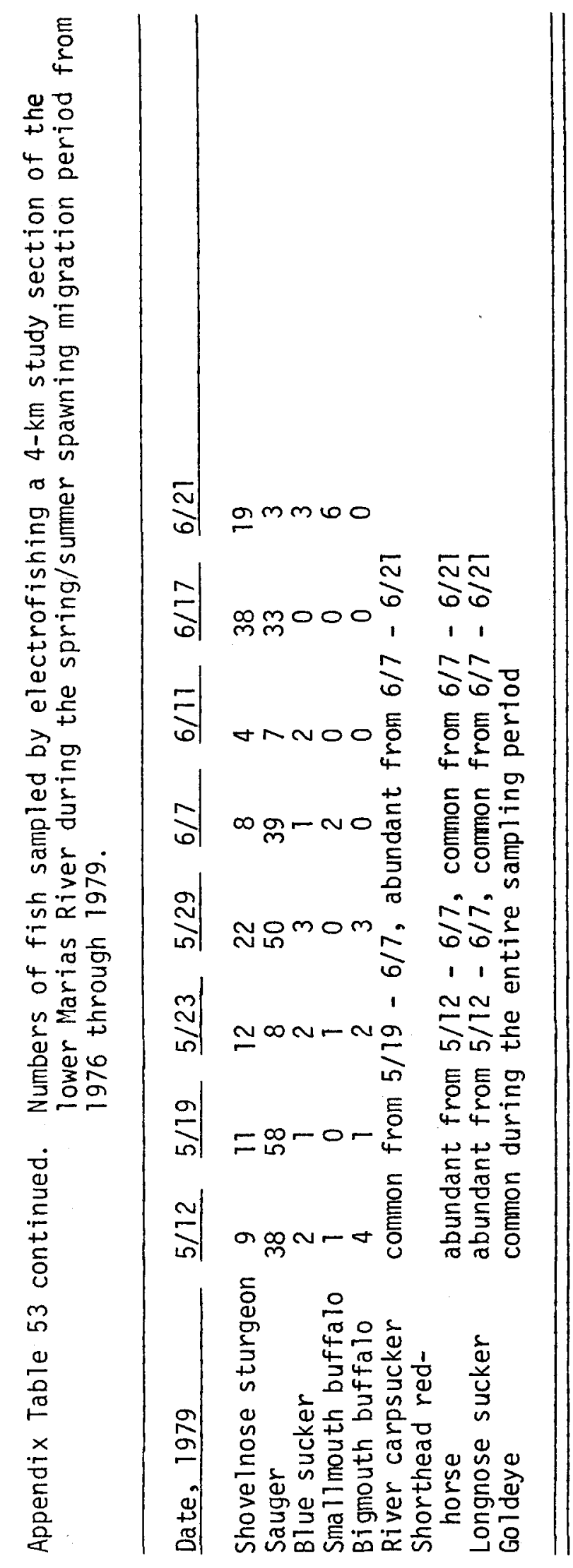


$\stackrel{\frac{1}{t}}{\frac{\alpha}{a}}$

m|

돈

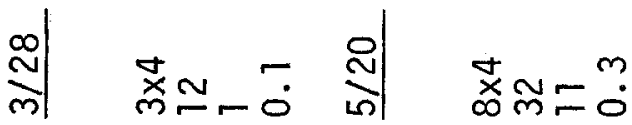

동

$\Phi \pm$

$\frac{2}{2}$

$\sim \infty$

\%

s

든

고

它

$-+$

电

†के

$\therefore \bar{E}$

원

政

응믕

5.을

$+\frac{1}{4}$

$\stackrel{\bigcup}{\varrho}$

ह

$4 \cdot \frac{1}{4}$

ते

0.

으

윹 엉

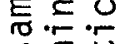

in $\frac{E}{3}$ in

(2) $\frac{3}{0}$

On n

is u

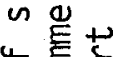

生空

in $थ$

रो व

도

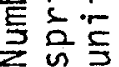

$\frac{1}{2}$

$x$
$\frac{x}{0}$
$\frac{c}{0}$
$\frac{\Omega}{2}$
$\frac{1}{1}$

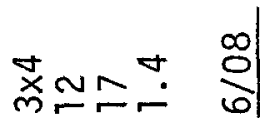

की

区﹎.

$\ddot{x}_{m \sim \tilde{O}} \cong$

艾№m

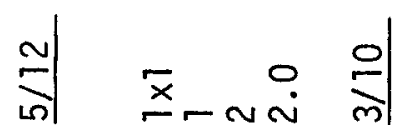

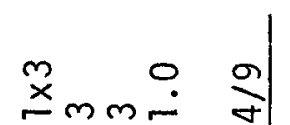

뚱ํํำ

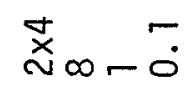

$\frac{7}{5}$

ज|

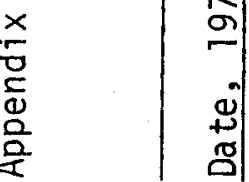
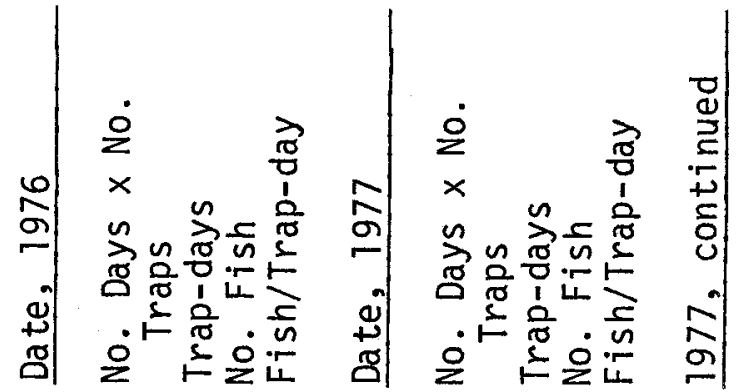

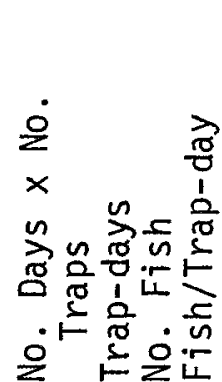

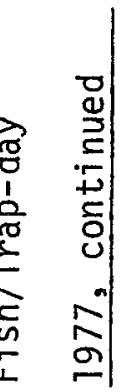

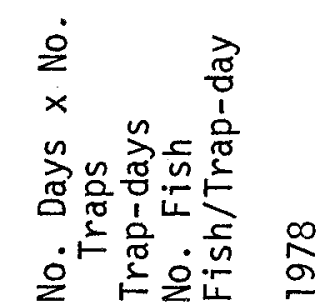




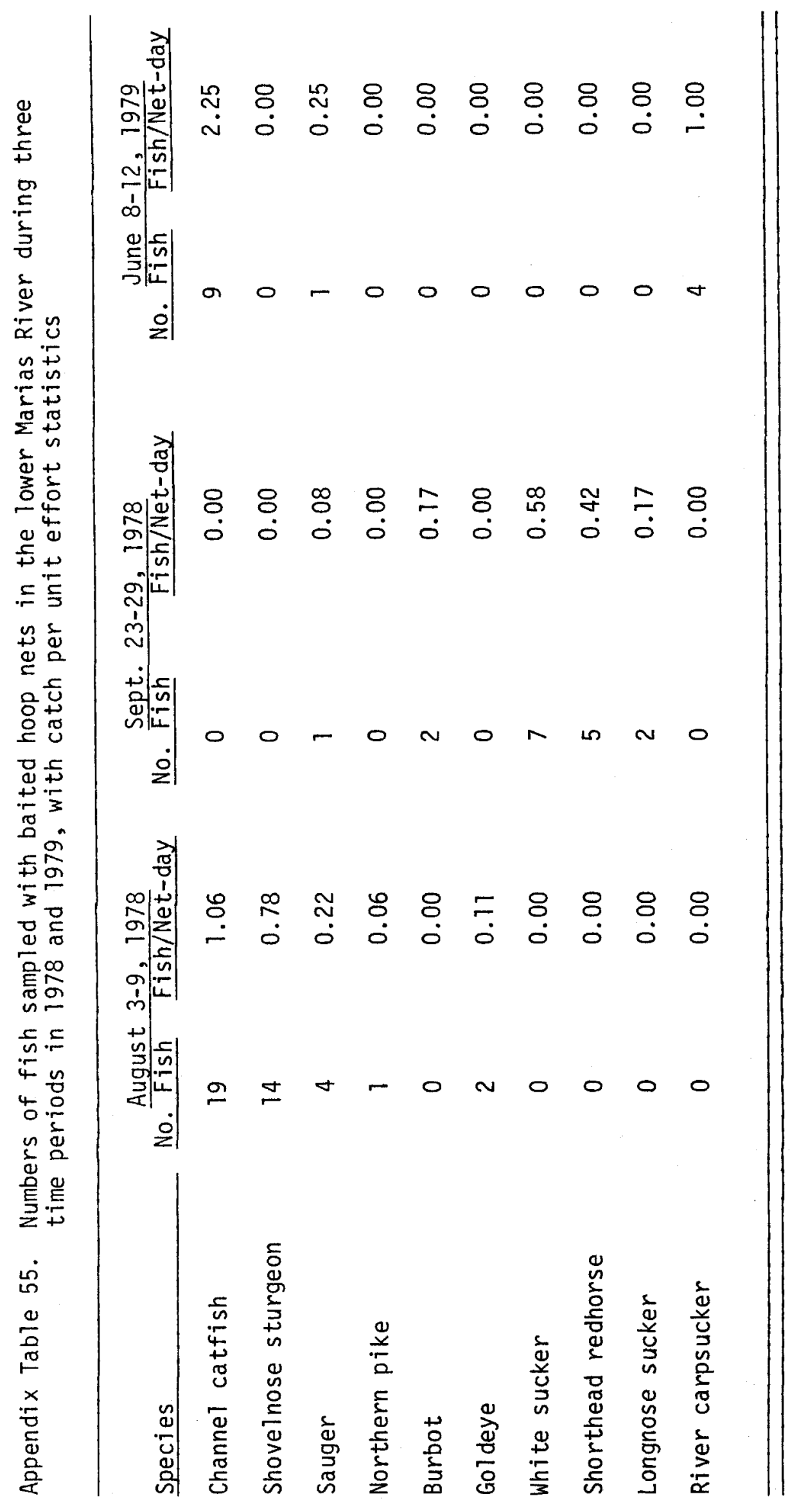




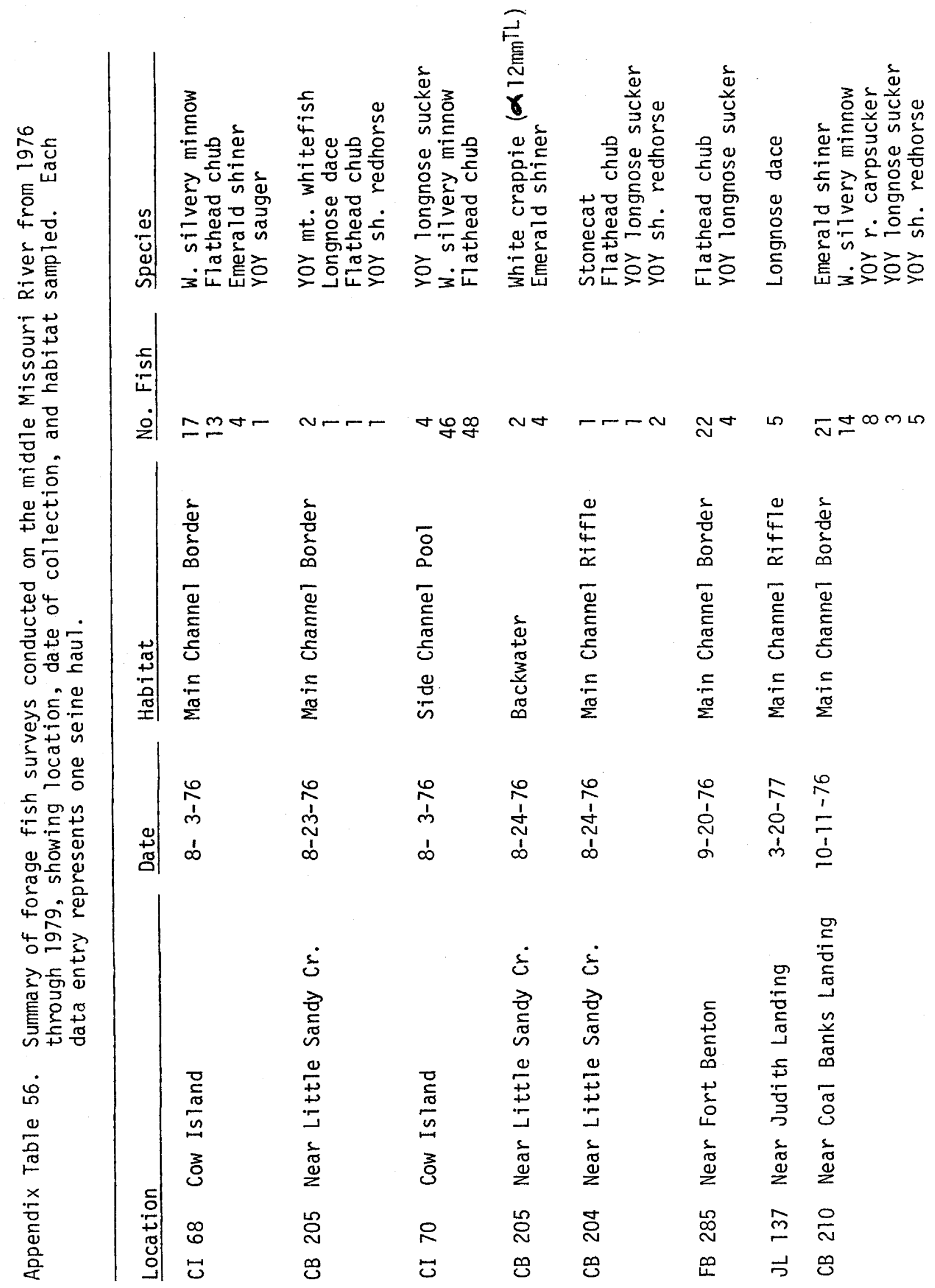




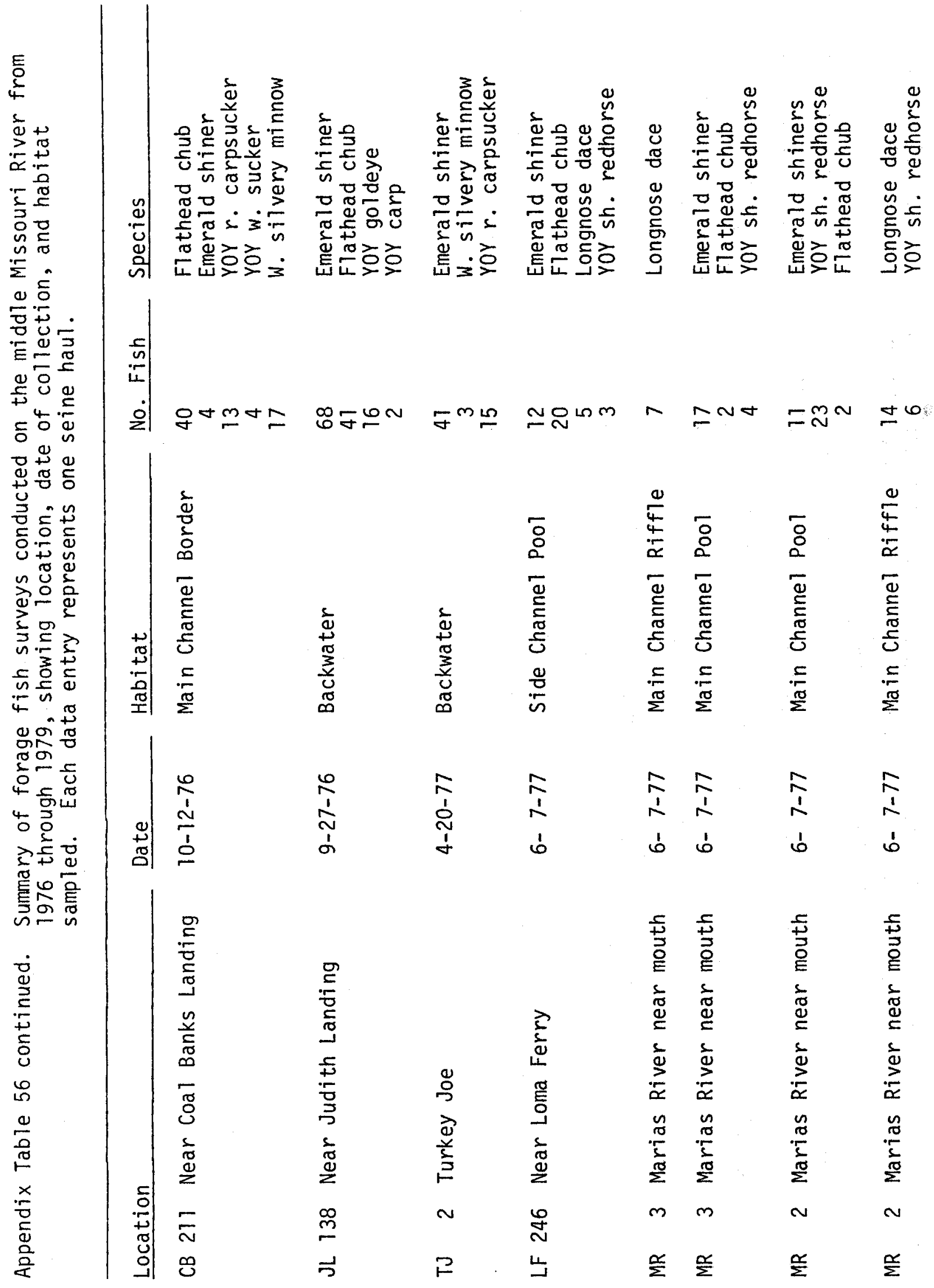




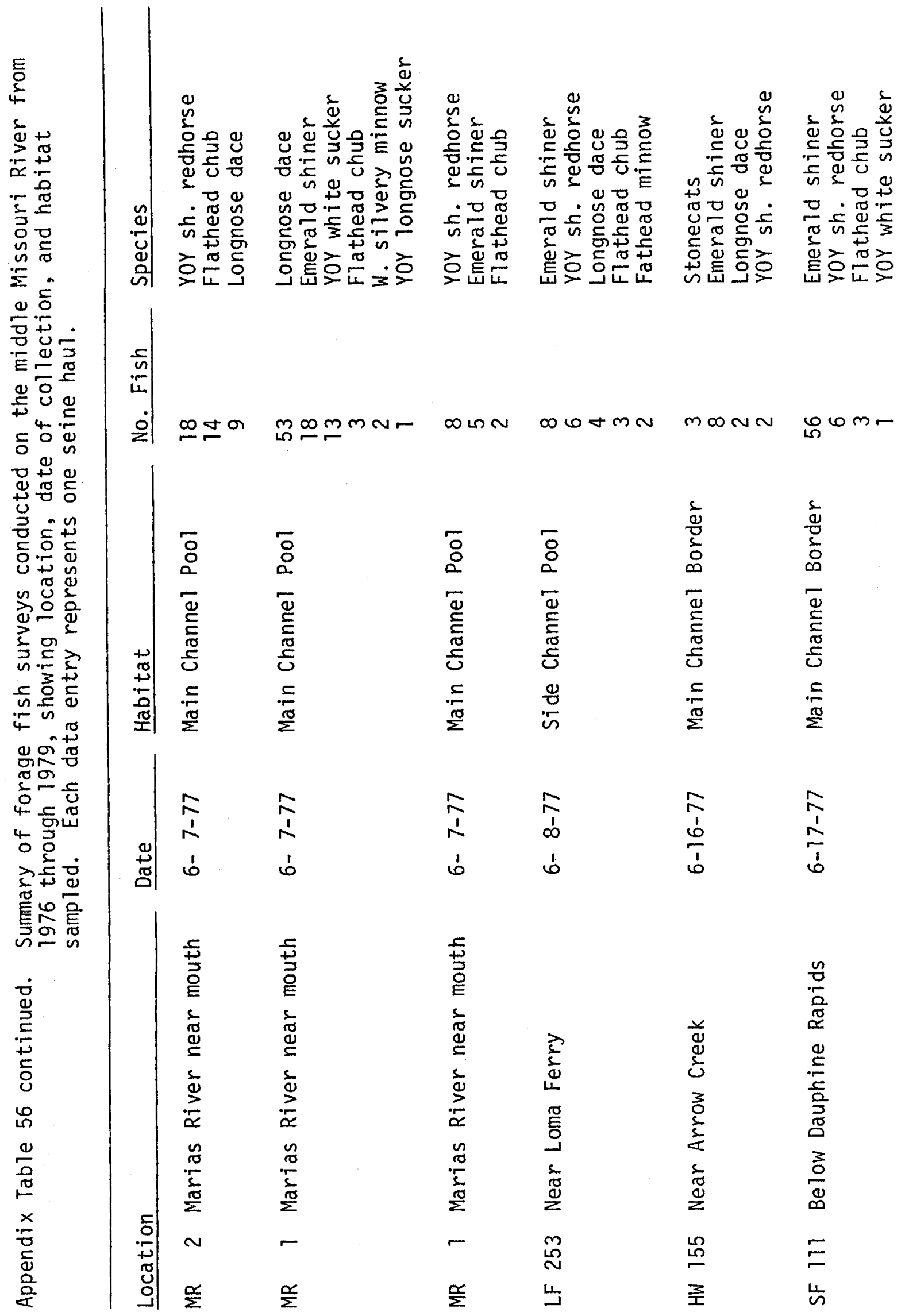




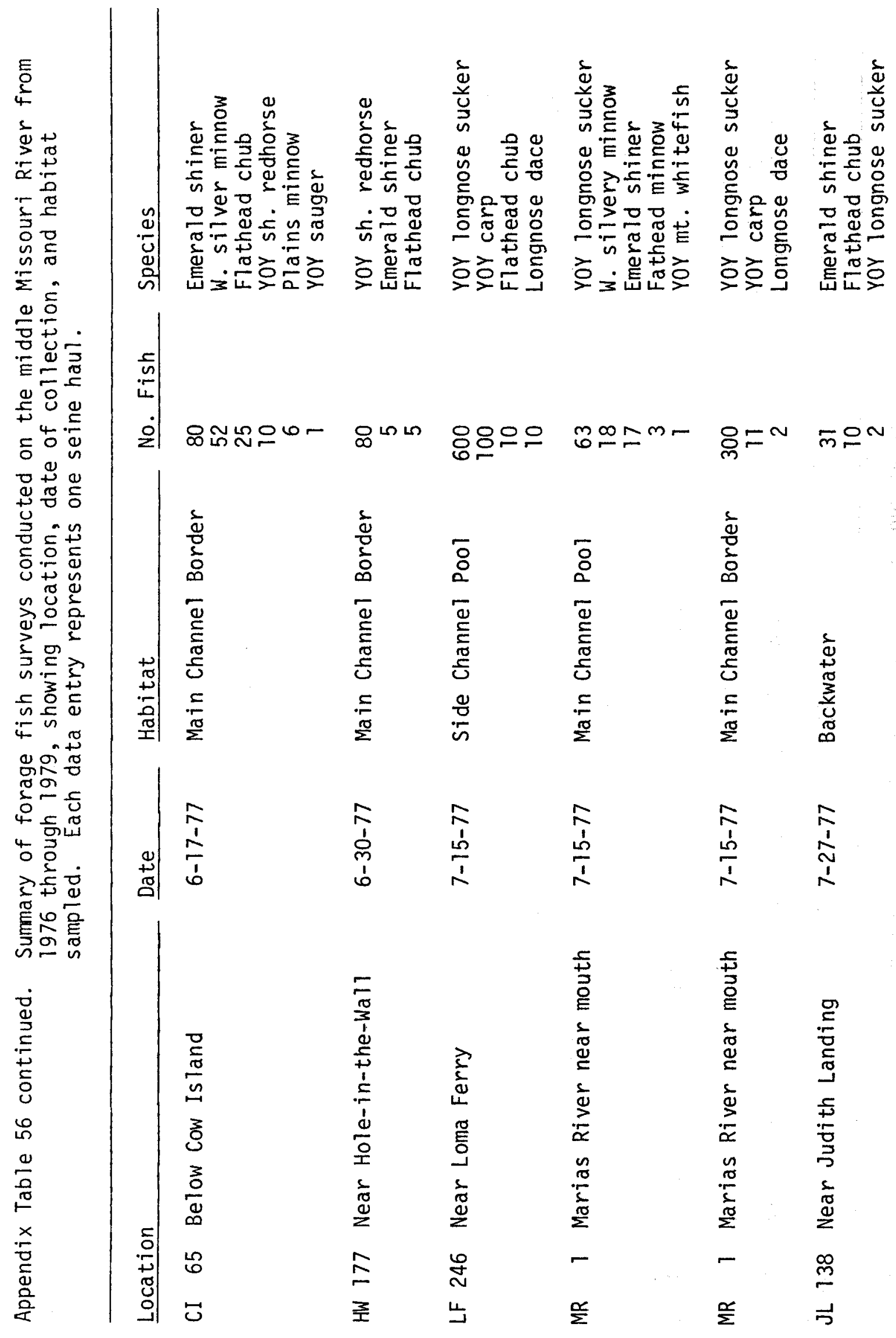




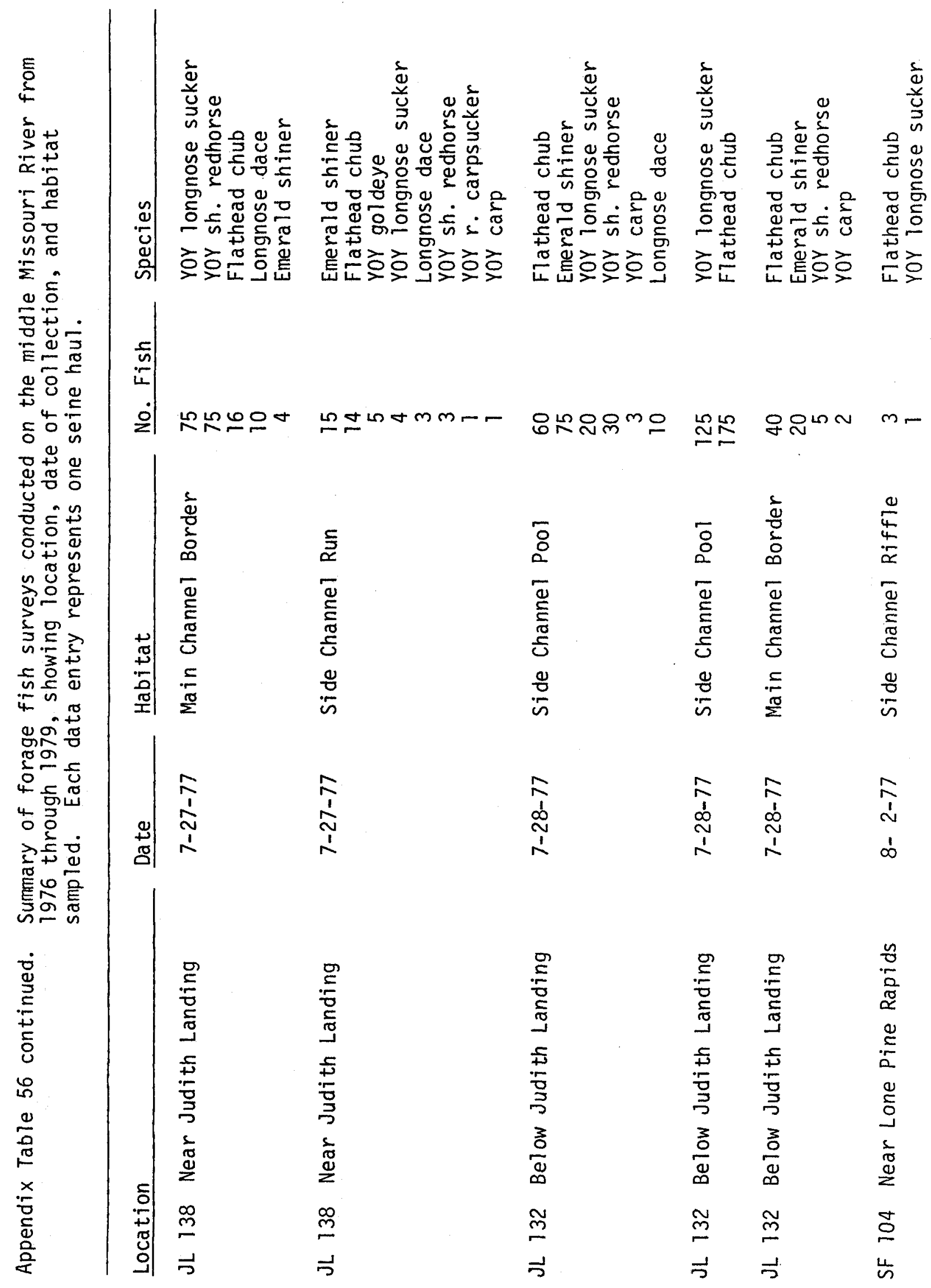




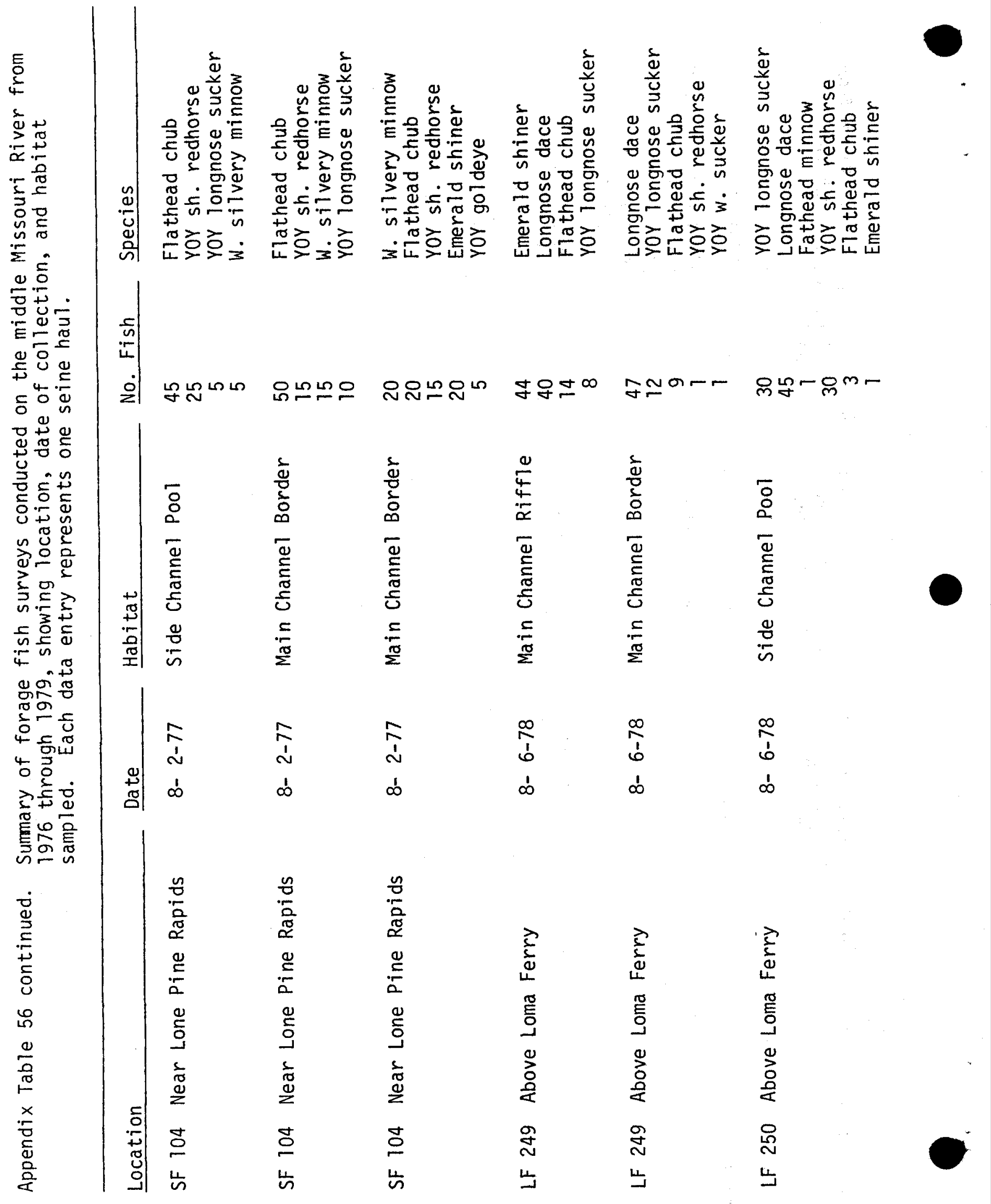




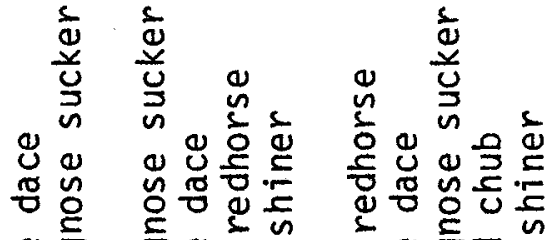

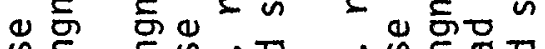

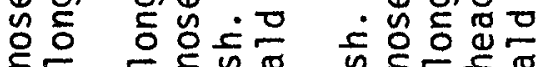

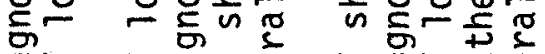

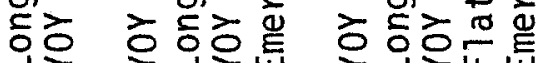

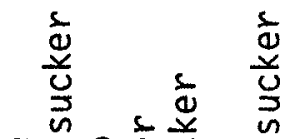

过出呈总总

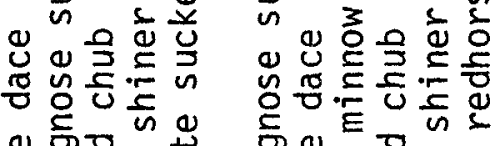

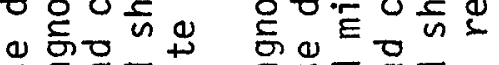

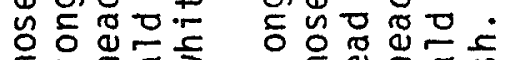

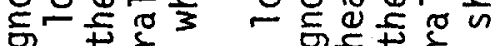

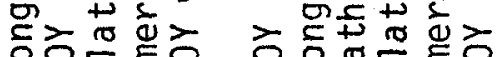

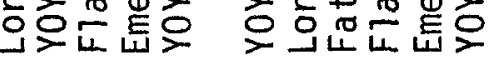

$\frac{\grave{d}}{\stackrel{u}{3}}$

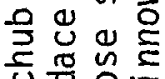

U⿺辶寸

뭉

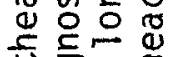

†

$\sum$

$\propto 5$

품.

䠉

$E-\pi$

둥

$\stackrel{5}{+}$

$5 \stackrel{4}{0} \stackrel{8}{4}$

曲

$\underset{+}{9} \frac{\pi}{0}$

u

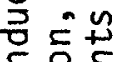

ธ요워

U⿺辶寸

웡응

$\sum \sigma^{2}$

$\sum_{i=1}^{\circ}$

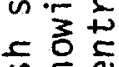

视完

4

a

Gू̃

s.

$4=5$

기

0 :

त产

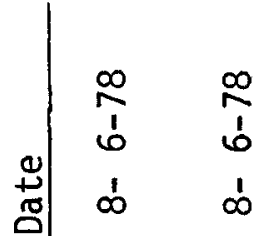

in

E- $-N+N$

-유에 엉ㅁ

암느므은 암으으

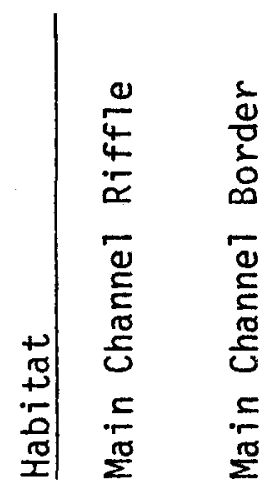

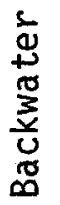

$\frac{1}{0}$
$\frac{1}{0}$
$\frac{\pi}{3}$
$\frac{1}{0}$
$\infty$

$\frac{1}{4}$
+0
$\frac{\pi}{3}$
$\frac{0}{0}$
0

$\frac{0}{4}$

$\frac{\infty}{1}$

$\infty$

$\stackrel{\infty}{1}$

$\stackrel{\infty}{1}$

b́

co

$\infty$

$\infty$

d
$\frac{c}{c}$
$\frac{1}{5}$
$\frac{1}{0}$
$\frac{8}{0}$
in

을을

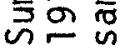

兽

in

$\frac{0}{\frac{0}{\circ}}$

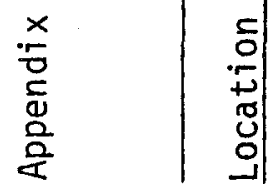

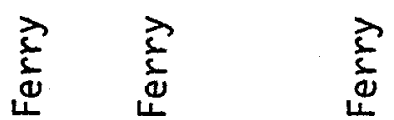

空

放

के

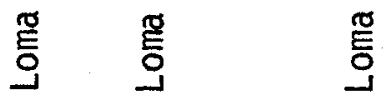

몽

Е్

L

$\begin{array}{ll}0 & 0 \\ \text { 운 } & 8\end{array}$

วั)

客

客

ฮ્ఝ

윤

$\stackrel{9}{\mathbb{N}}$

号

㐫

咅

岃岗

ㄴ

山

山

온 


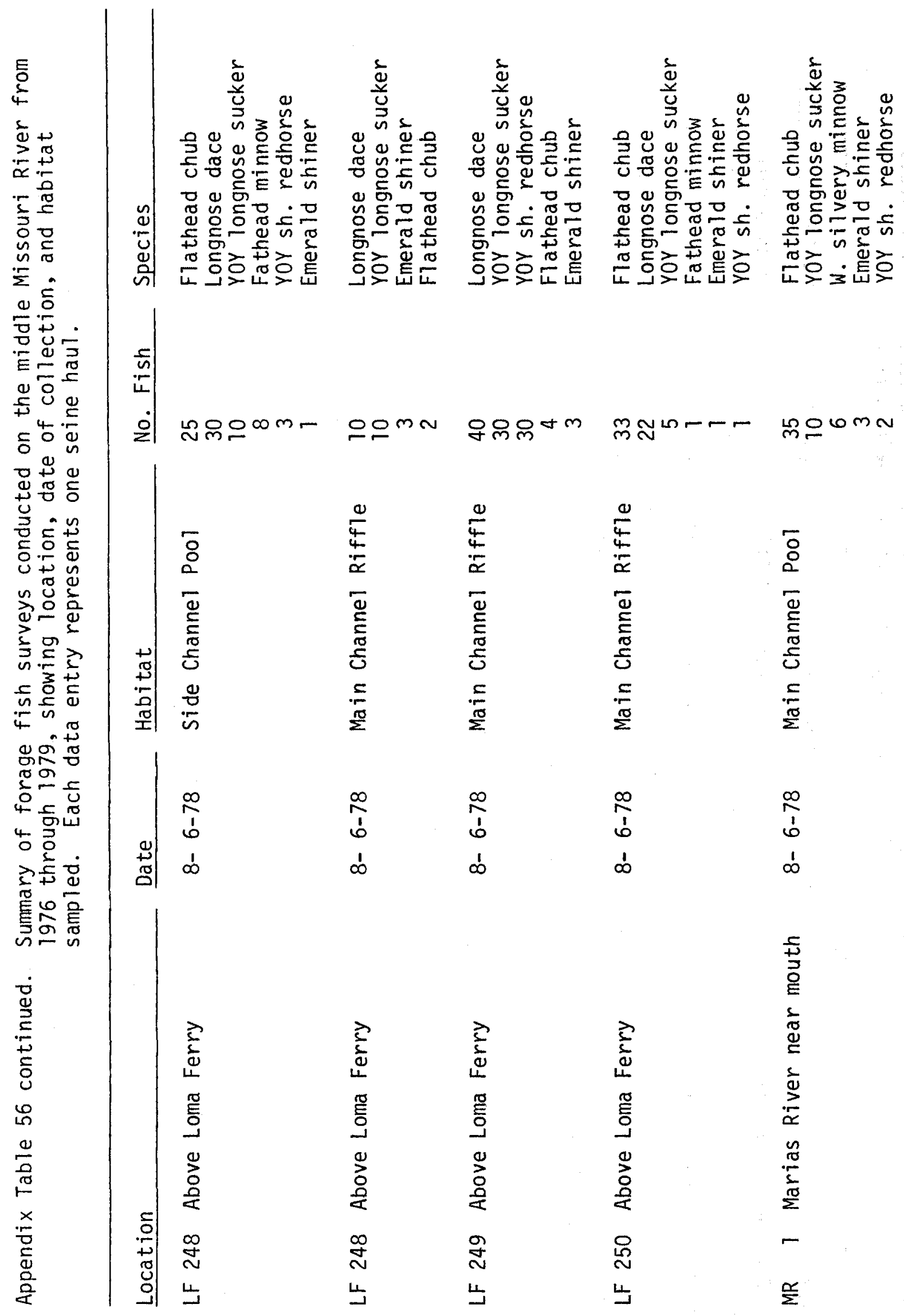




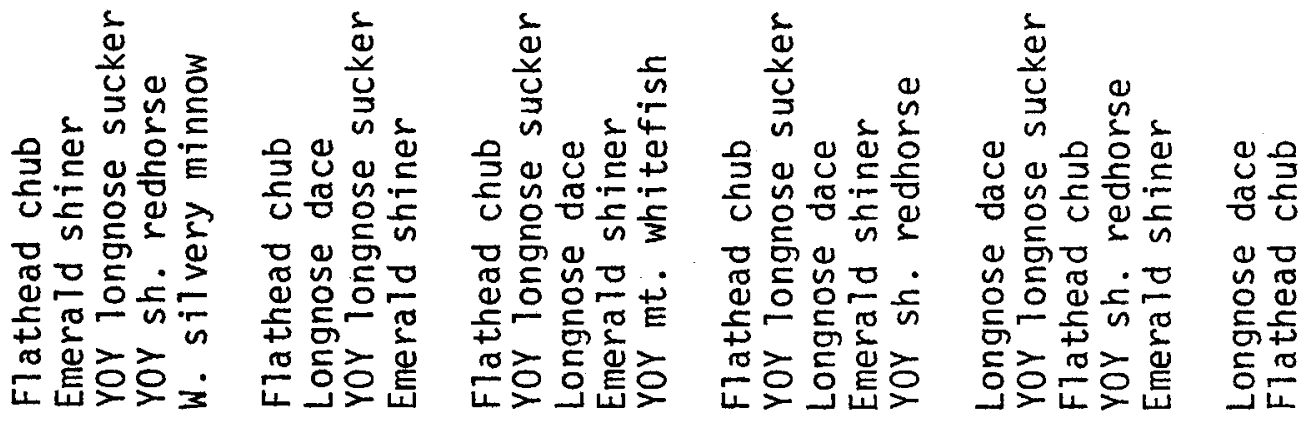

\&

$\frac{0}{0} \div$

음 눅

E定完

0 둥

क⿻

$=40$

o $n$

욤

هั

곰도

등등

U⿻

ऽ

휘으 응

हों

ज.

도응

is

-

똥즁

or

는

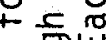

4 号

तो

क्षे

논을

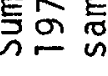

:

in

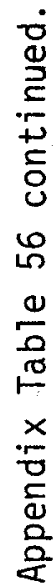

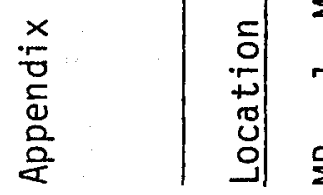

조융으

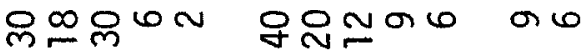
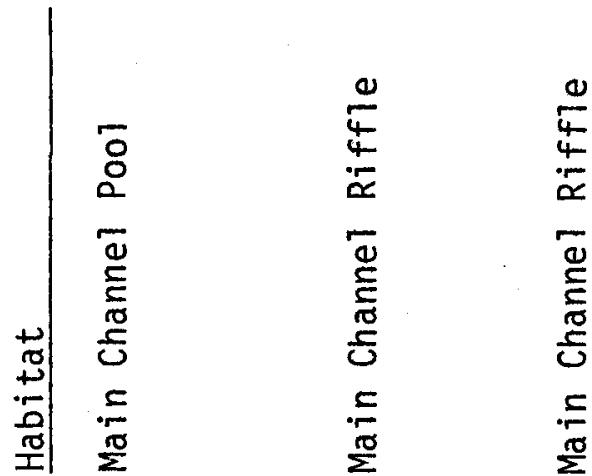

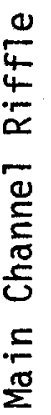

$\overline{8}$

$\overline{8}$

¿

$\therefore$

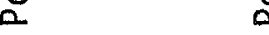

-

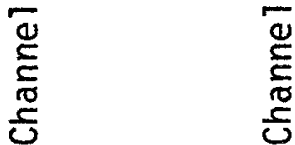

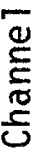

$\stackrel{\infty}{\stackrel{\infty}{E}}$

$\frac{\pi}{2}$

$\stackrel{\pi}{\Sigma}$

$\frac{8}{8}$

0
0
0

$\begin{array}{ll}\infty & \infty \\ 1 & b\end{array}$

$\begin{array}{ll}\infty & 0 \\ 1 & \frac{1}{6}\end{array}$

$\infty$
1
$\infty$

$\frac{\infty}{i}$

$\frac{\pi}{n}$

$\frac{1}{1}$

$\infty$

$\infty$

$\infty$

$\frac{5}{2}$

$\stackrel{5}{5}$

동

동

올

욜

站

5

ฮั

ֻั

范

ฮั

๕ั

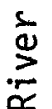

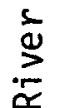

$\stackrel{5}{\infty}$

文

$\infty$

$\infty$

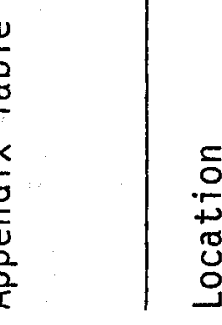

$\frac{n}{\pi}$

$\frac{\pi}{2}$

:

$\frac{\pi}{\pi}$

$\frac{10}{2}$

2

$\sum$

in

$\frac{\alpha}{\Sigma}$

$\frac{\alpha}{\Sigma}$ 


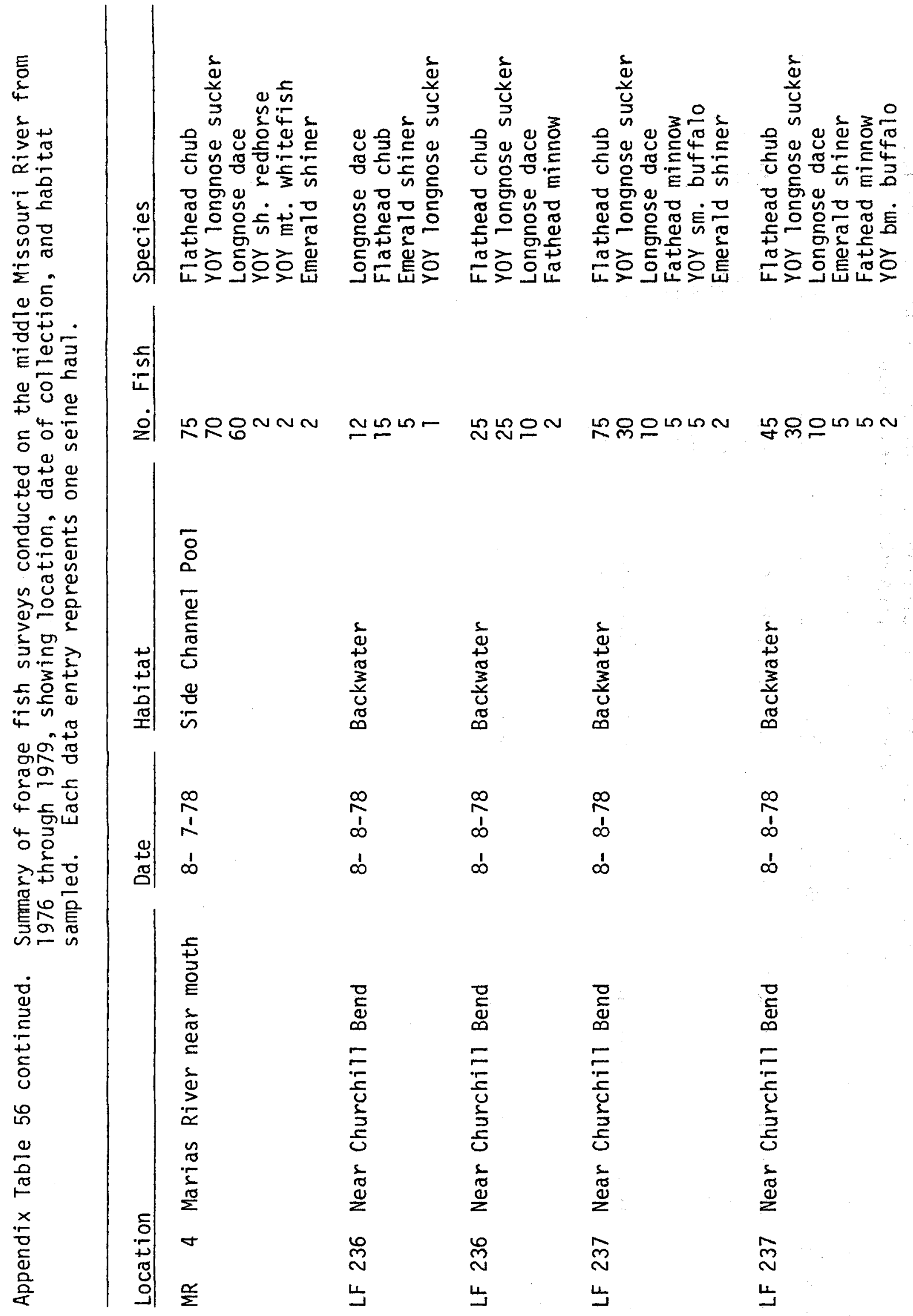




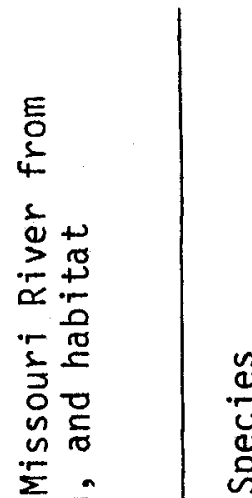

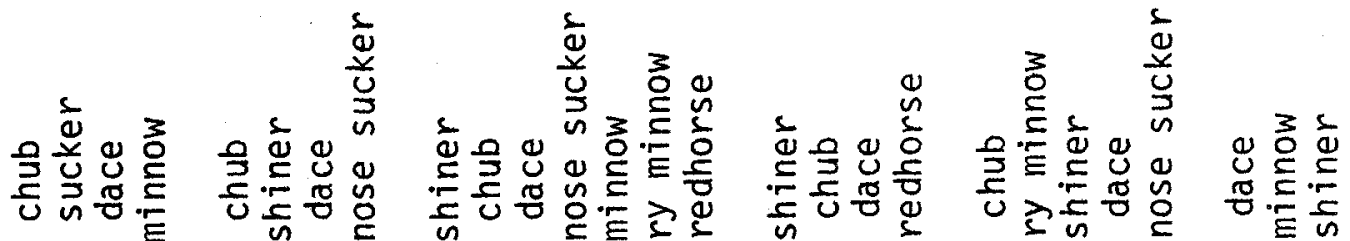

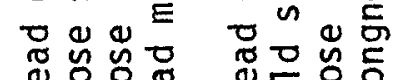

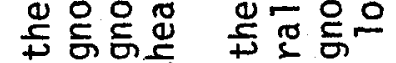
r

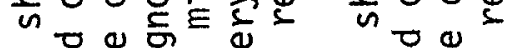
○ す

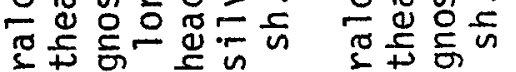

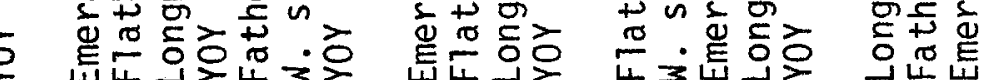
ช O 0 $0>0$ 少

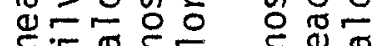

a 동

$7+5$.

두워

$E \frac{\pi}{\mathbb{C}}$

$\stackrel{\circ}{\circ} 0$

$5-\frac{5}{0}$

$0 \underset{+\infty}{0}$

ه

는

등 든

U士

ज บ

ब으뭉

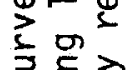

ज.

등 을

in is

(1)

d क त

ro

$5 \div \frac{1}{0}$

+둔

4 ?

운.

空远

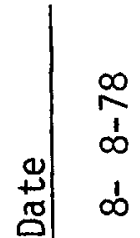

단.

ㄴ山山

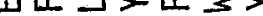

击我

出

율을

5or

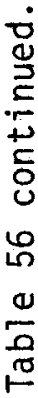

ตூ

a 0 or

$00 N$

윰NㄴN요

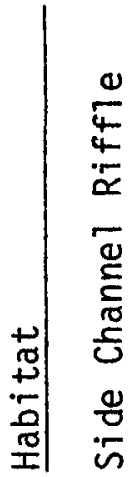

$\frac{0}{4}$

ㄴํํ

$\begin{array}{ll}\frac{1}{0} & \frac{1}{0} \\ \frac{1}{0} & \frac{1}{0}\end{array}$

5
$\frac{1}{0}$
$\frac{1}{0}$
$\infty$

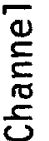

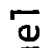

(a)

ह

हू

造

$\frac{\pi}{2}$

$\stackrel{c}{\frac{\pi}{2}}$

$\underset{2}{\infty}$

$\frac{1}{2}$

$\begin{array}{ll}\infty & \infty \\ 1 & 1 \\ \infty & \infty \\ 1 & \infty\end{array}$

$\stackrel{\infty}{1}$

$\frac{1}{\infty}$

$\stackrel{\infty}{\infty}$

$\infty$

$\infty$

$\infty$

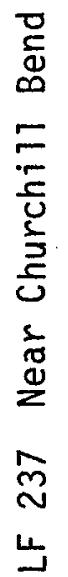

0
$\frac{0}{0}$
$=$
$=\frac{5}{0}$
$\frac{5}{5}$
$\frac{5}{0}$
$\frac{0}{2}$

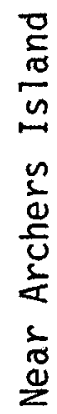

\begin{tabular}{l}
0 \\
$\frac{1}{0}$ \\
0 \\
$\frac{1}{0}$ \\
$\frac{1}{0}$ \\
$\frac{1}{4}$ \\
\hline
\end{tabular}

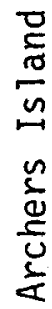

टे

$\stackrel{5}{\stackrel{1}{0}}$

$\stackrel{1}{8}$

옹

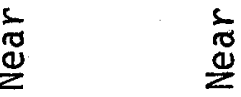

N $\quad \stackrel{m}{N}$

文

$\stackrel{m}{v}$

岃

노

ঊ

는

志

岌 


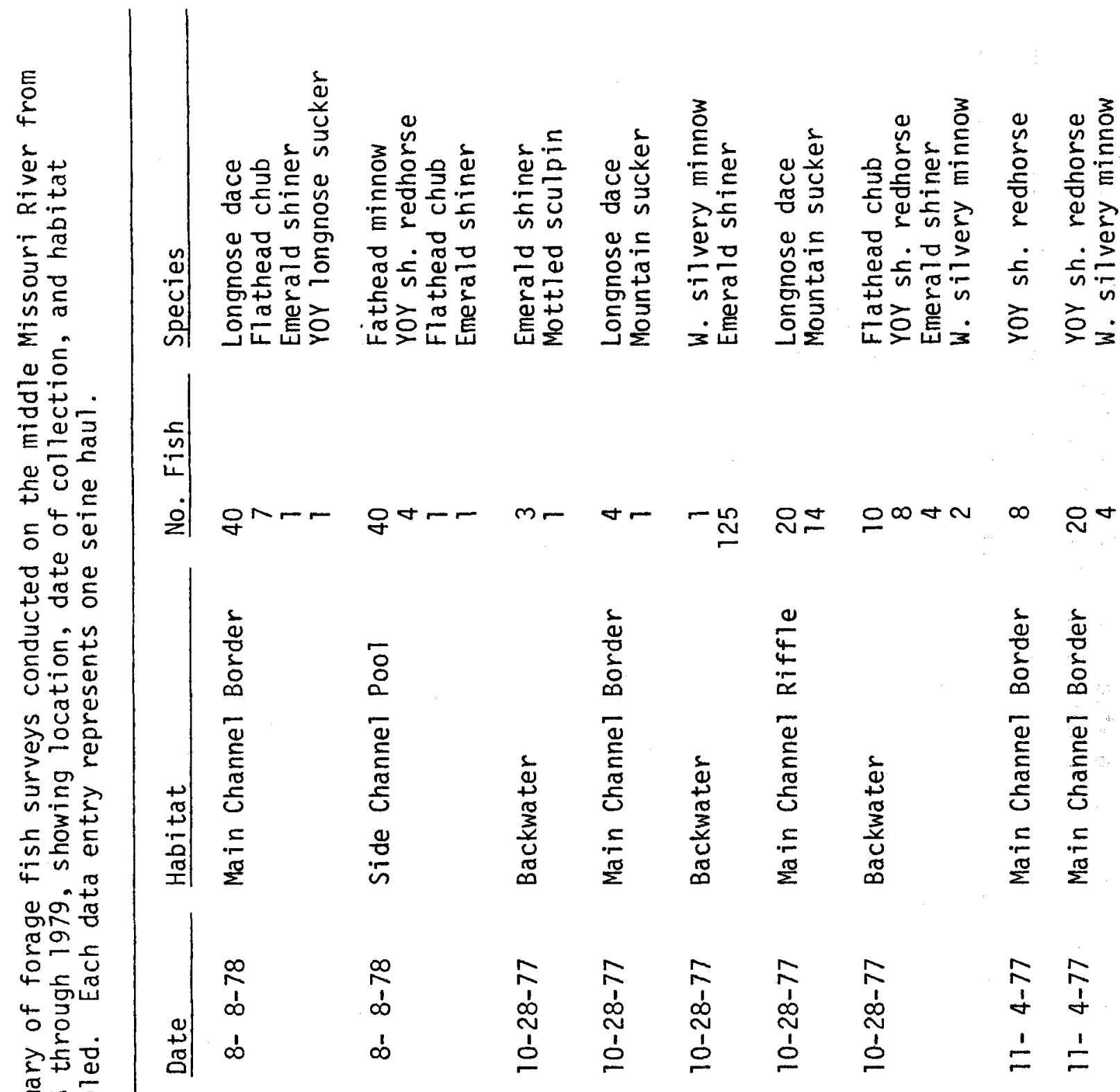

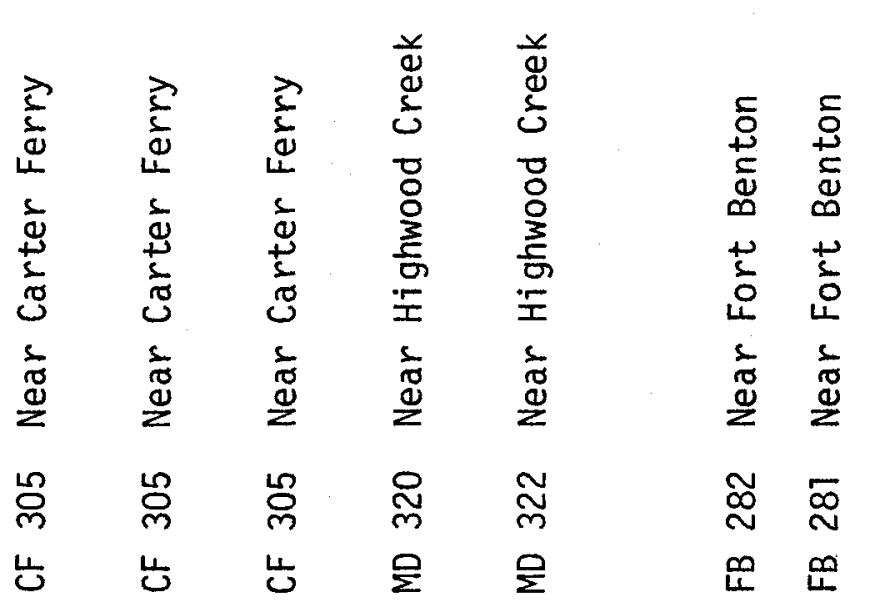




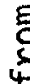

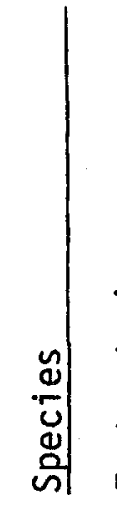

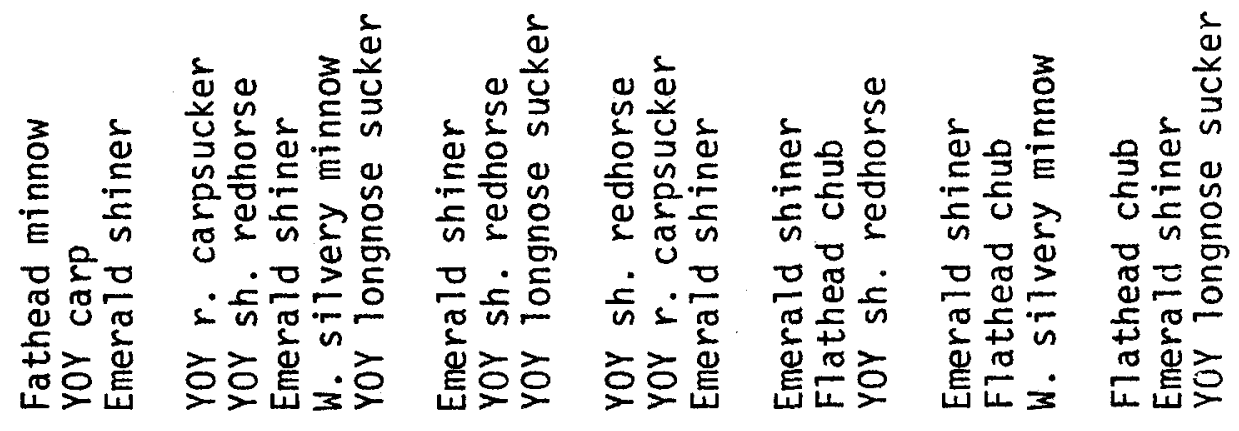
a 훔 E 도 잉 ᄃ告㐫 o 풍 矛东

可题 등음

원 흐음 $\pi^{2}$

ज 론 도옹 훙 in \& का 울웅

4 गे

- 2. 둔 을을 $\frac{c}{n}$

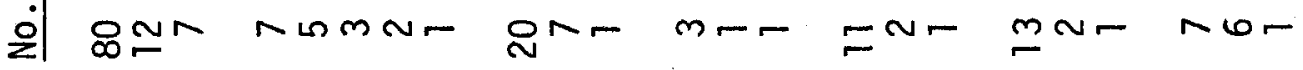

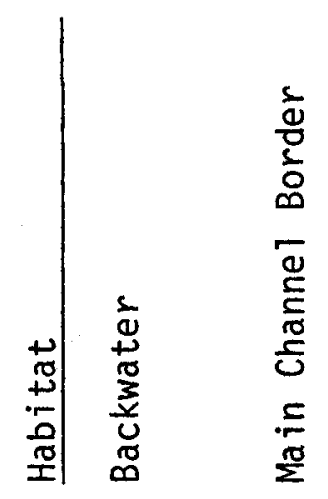

$\frac{5}{8}$

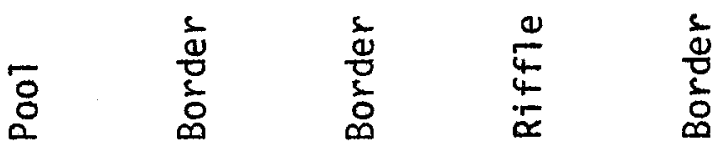

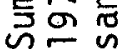

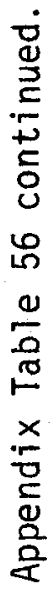
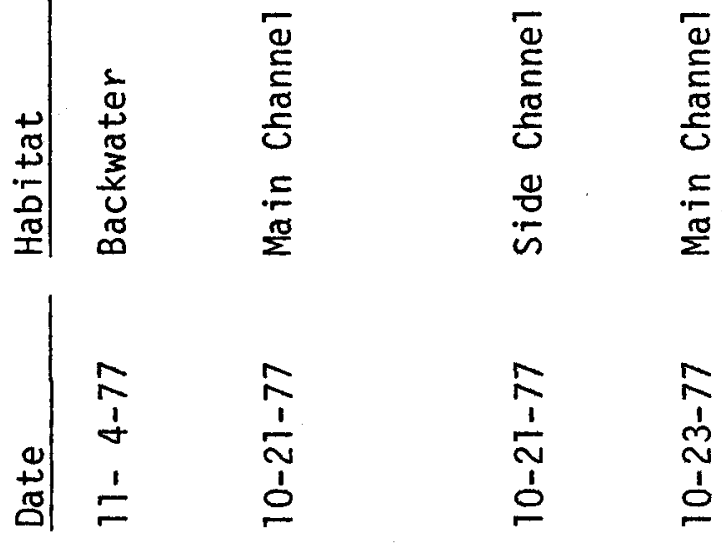

盛

造

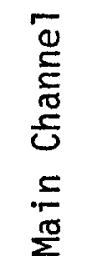

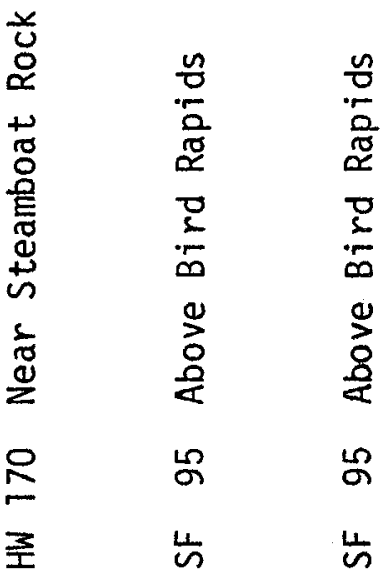




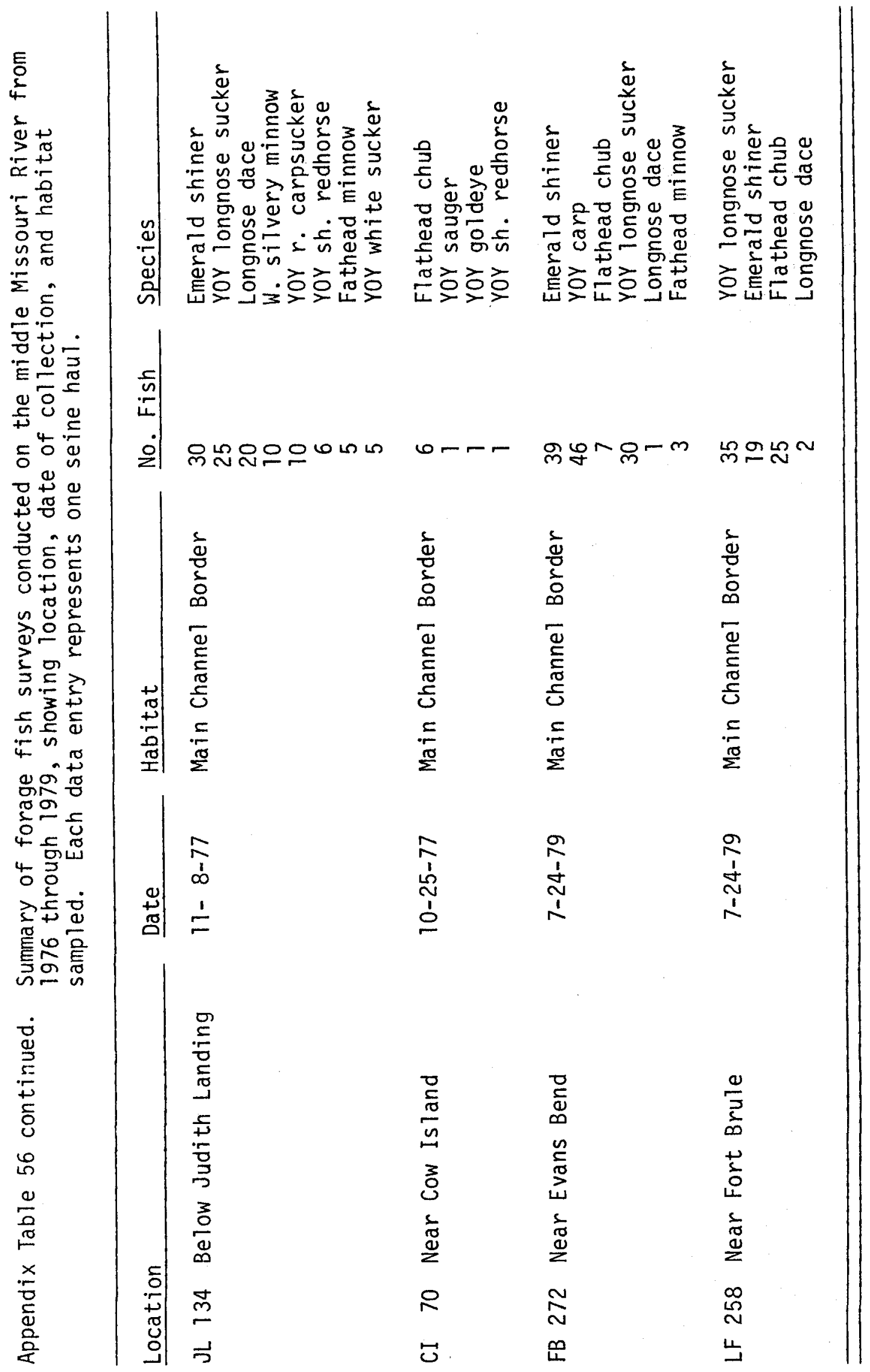




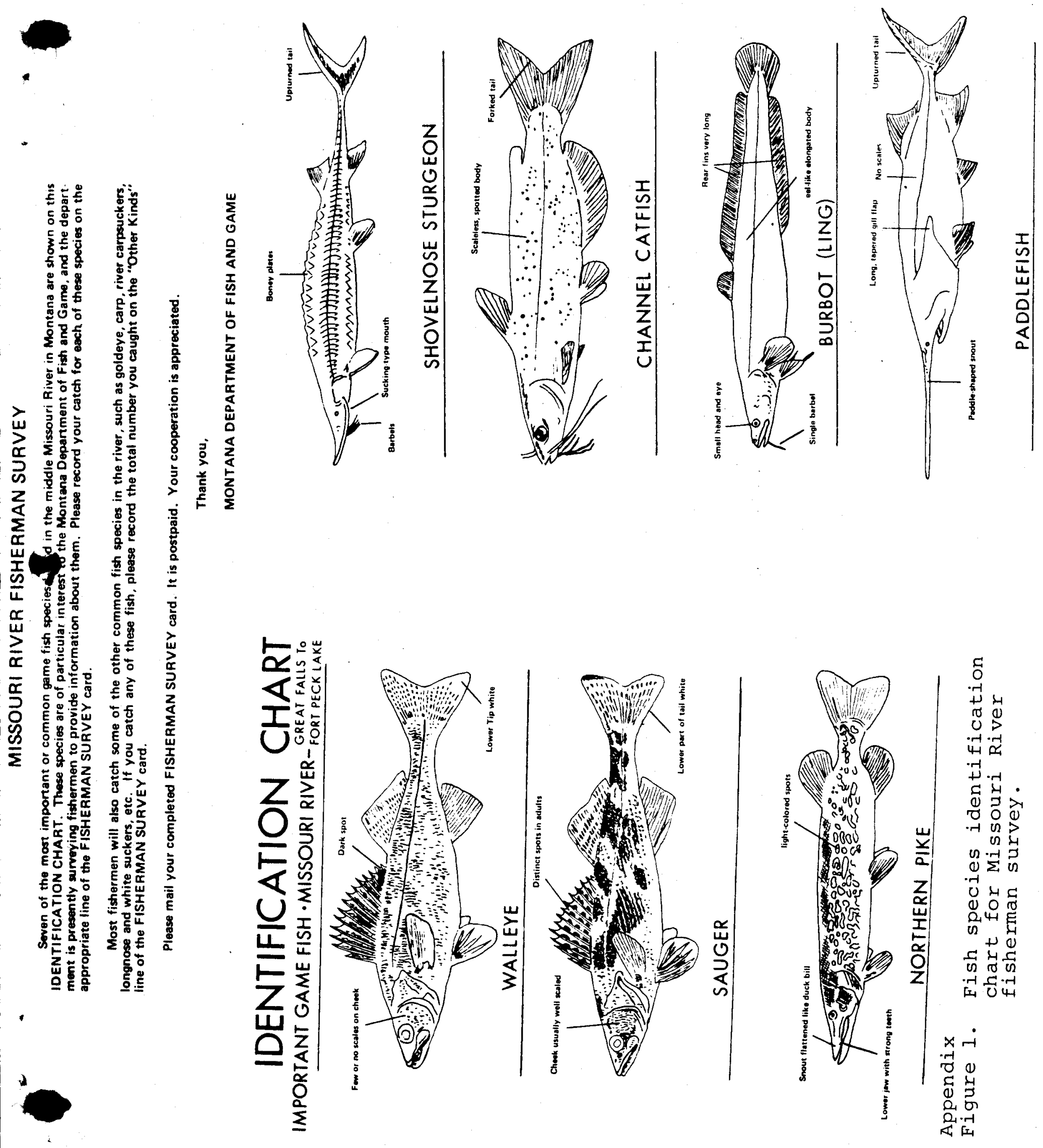


Please answer the following questions as a combined total for all persons in your party who fished during your trip Return the card even if you caught no fish.

Number of anglers in party

Date(s) fished

Total hours spent fishing

Fishing from:

Mothod(s): ( ) Sotline, ( ) Angling (hand hold line with lure), ( I Snagging

Lure(s): ( / Live bait, ( ) Prepared bait, ( ) Artificial lure, other (specify)

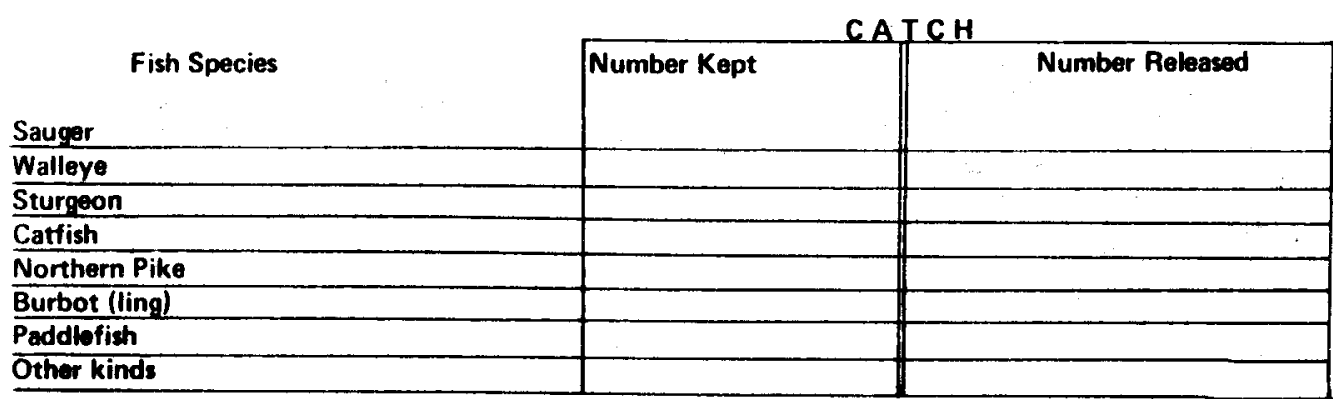

Please mail your completed cerd. It is postpaid: Your contribution will halp to provide a better fisheries resource fer Momtene eportamen.

MONTANA DEPARTMENT OF FISH AND GAME MISSOURI RIVER FISHERMAN SURVEY - ONE ANGLER, ONE TRIP

Angler's residence (city, state)

Date(s) fished

Interview No.

Total hours spent fishing: Section of river fished

Fishing from: ( ) Bank. ( ) Boat, ( ) Combination Trip: ( ) Complete

Method(s): I / Sotline, I / Angling (hand hold line with lure), ( I Snagging

Lure(s): I / Live bait, ( / Prepared bait, ( / Artificial lure, other (specify)

\begin{tabular}{|c|c|c|c|c|}
\hline \multirow[b]{2}{*}{ Fish Species } & \multicolumn{2}{|c|}{ Catch When Interviewed } & \multicolumn{2}{|c|}{ Additional Catch After Interview } \\
\hline & Number Kept & Number Reloased & Number Kept & Number Released \\
\hline \multicolumn{5}{|l|}{ Sauger } \\
\hline \multicolumn{5}{|l|}{ Walleye } \\
\hline \multicolumn{5}{|l|}{ Sturgeon } \\
\hline \multicolumn{5}{|l|}{ Catfish } \\
\hline \multicolumn{5}{|l|}{ Northern Pike } \\
\hline \multicolumn{5}{|l|}{ Burbot (Ling) } \\
\hline Paddlofich & & & & 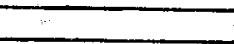 \\
\hline Other kinds & & & & $\therefore$ \\
\hline
\end{tabular}

If your fishing trip was not complete when you were contacted, please record any additional fish caught after the interview in the last columns (above). Answer for yourself only, do not include fish caught by others in your perty. Additional number of hours spent fishing after interview - Additional dote(s) fiethed after interview: . Plaas mail your completed card. It is postpeid. Your contribution will help to provide a better fisheries resource for Montans sportamen.

Appendix Figure 2. "Voluntary" (top) and "interview" (bottom) fisherman survey forms used in Missouri River fisherman survey. 